

El relat en l'àmbit sanitari: els casos clínics sobre afeccions mentals 

Programa de Doctorat en Llengües Aplicades, Literatura i Traducció

Escola de Doctorat de la Universitat Jaume I

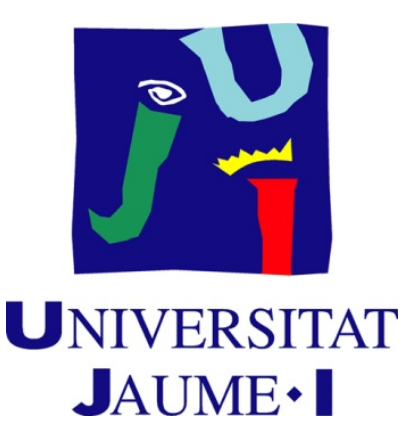

\section{EL RELAT EN L'ÀMBIT SANITARI: ELS CASOS CLÍNICS SOBRE AFECCIONS MENTALS}

Tesi per a optar al grau de doctora per la Universitat Jaume I presentada per Adéla Kotátková

Dirigida per

Dr. Vicent Salvador i Liern

(Departament de Filologia i Cultures

Europees, Universitat Jaume I)
Dr. Manuel Pérez Saldanya

(Departament de Filologia Catalana,

Universitat de València) 



\section{Finançament rebut:}

- Subvenció per a contractes predoctorals del programa Santiago Grisolía (GRISOLIA/2016/055), de la Generalitat Valenciana.

- Subvenció per a estada d'investigació al Fitzwilliam College de la Universitat de Cambridge (BEFPI/2018/064), de la Generalitat Valenciana.

- Projecte d'investigació EXPLORA: «Lenguaje y cultura de la salud» (CSO2014-61928EXP), del Ministeri d'Economia, Indústria i Competitivitat, Govern d'Espanya.

- Projecte d'investigació RETOS: "La construcción discursiva del conflicto: territorialidad, imagen de la enfermedad e identidades de género en la literatura y en la comunicación social» (FFI2017-85227-R), del Ministeri d’Economia, Indústria i Competitivitat, Govern d'Espanya. 

Mámě, babičce, tátovi a dědovi 



\section{AGRAIIMENTS}

Quan em vaig plantejar els estudis de doctorat probablement no era conscient del gran repte que representava escriure una tesi. Han estat tres anys durs, però apassionants, que he volgut acarar sempre amb mentalitat receptiva i voluntat contínua d'aprendre. Arribats en aquest punt, em plantejo un altre desafiament - no menys significatiu-: donar les gràcies en unes poques línies a totes les persones que han contribuït que hagi pogut completar aquest viatge.

El meu pas per diferents universitats - Universitat Carolina de Praga, Universitat de València i Universitat Jaume I- ha fet que em consideri alumna de tres grans mestres.

El meu primer mestre, Petr Čermák, va ser la persona que ho va iniciar tot. Probablement no n'és conscient, però va formar part del tribunal que em va acceptar per als estudis de Filologia Hispànica a la Universitat Carolina de Praga. Complert el meu somni, aquest professor va ser també el culpable de despertar en mi l'interès per la lingüística, especialment per la de corpus, ja des del primer curs de grau. Sempre he trobat el seu suport i la seva confiança. Petr i el professorat de Praga van fornir la meva base filològica que tant els agraeixo avui dia. Entre ells, no puc deixar de mostrar la meva gratitud a Andreu Bauçà, el professor de català que em va introduir en la llengua que ha marcat el meu camí des de llavors. I a Miquel Font, que em va acollir a Mallorca i em va permetre practicar i perfeccionar el meu català amb l'accent que més enyoro.

El meu segon mestre, Manuel Pérez Saldanya, me'l vaig trobar durant el meu any d'Erasmus a la Universitat de València, en les assignatures de Fonètica i de Gramàtica Històrica del Català. Encara que hi venia per continuar amb el meu pla d'estudis d'espanyol, les classes de Manel em van encisar i els meus interessos d'estudi es van 
tornar a ampliar. Ell és qui em va recomanar cursar el Màster de Filologia Catalana a València per així poder venir a viure aquí i centrar-me en l'estudi del català. Sempre m’ha aconsellat bé. De fet, també va ser ell qui em va encoratjar a presentar-me a la beca predoctoral en el marc de la qual s'ha desenvolupat aquesta tesi.

Finalment, Vicent Salvador, amb qui he compartit els darrers tres anys com a doctoranda a la Universitat Jaume I, en els quals ha esdevingut més que un director de tesi: un mestre i un amic. Amb Vicent se m'ha obert un horitzó completament nou -el de l'anàlisi del discurs-, diferent del de la filologia i la lingüística tradicionals, però en el qual he pogut aplicar aquesta base de coneixements. Recordo com va néixer la idea de centrar-me en aquest camp, en un dels nombrosos trajectes en cotxe entre València i Castelló de la Plana. He d'agrair l'acompanyament de Vicent i Manel com a codirectors sempre atents a les meves necessitats acadèmiques en aquesta etapa de la meva formació. En definitiva, és per a mi un gran honor i un plaer que els meus tres grans mestres estiguin presents en aquest treball.

La Universitat Jaume I ha estat un lloc d'aprenentatge, de reflexions, però també un espai de trobada amb grans professionals, avui dia amics. Des del principi, el nostre grup -majoritàriament deixebles de Vicent - hem funcionat com una família. Aquest àmbit de treball ha fet que hàgim compartit les nostres vies de recerca $\mathrm{i}$ ens hàgim ajudat mutualment. Gràcies a Adolf, Enric, Daniel, Josep i els Sergis, els quals sempre m'han ajudat i m'han assessorat mentre ens preníem els mil cafès, poliols i sucs de taronja en el menjador de la nostra facultat.

Tampoc no puc deixar d'esmentar el tutor de l'estada al Fitzwilliam College de la Universitat de Cambrige, Dominic Keown, mercès al qual vaig fer avenços significatius en aquest estudi.

Des del punt de vista més personal, aquesta tesi ha estat un repte ingent. I no únicament per haver decidit redactar-la en una llengua tan diferent del meu txec nadiu com ho és el meu català d'adopció, sinó per la pluridisciplinarietat que exigeix -entre la filologia i les ciències de la salut. Aquesta unió, però, $m^{\prime}$ ha permès connectar amb els àmbits de treball i de recerca d'alguns dels membres de la meva família, la qual, malgrat la distància geogràfica, $m^{\prime}$ ha donat suport des del principi, sabent que aquest treball em tornaria a allunyar d'ells. La tesi va dedicada a ells: a ma mare, infermera; a la meva àvia, metgessa; a mon pare, investigador en neurotecnologies, i també al meu avi. Però de 
què serviria un agraïment si els receptors no l'entenguessin? Heus aquí, doncs, unes paraules per a vosaltres, mare, àvia, pare, avi...: Děkuji ti, mami, babičko, tati, dědo i vám ostatním. Bez vás bych nikdy nedošla až sem. També vull incloure les que m’han fet somriure en els moments més difícils: Eliška i Helča. Finalment, vull donar les gràcies a qui més m'ha animat a afrontar la dedicació tan intensiva que comporta un treball com aquest. A tu, Rafa. 

ÍNDEX

JUSTIFICACIÓ.

CAPÍTOL I. INTRODUCCIÓ: ELS CASOS CLÍNICS I ELS DISCURSOS AL VOLTANT DE LA MALALTIA



1.1. Discurs mèdic vs. discourses in health settings......................................... 23

1.2. Comunitats discursives i comunitats de pràctica.......................................... 25

1.3. Comunitats de pacients $i$ imatge social de les malalties .............................. 29

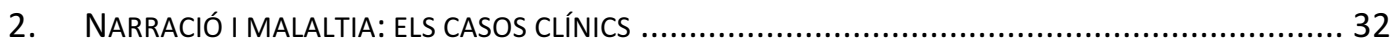

2.1. Caracterització dels casos clínics .............................................................. 35

2.2. Els casos clínics en les revistes mèdiques ................................................. 40

2.3. Els casos clínics en català ........................................................................ 46

2.4. Els casos clínics literaturitzats o contes clínics .......................................... 49

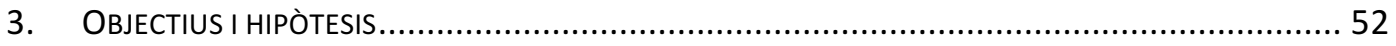



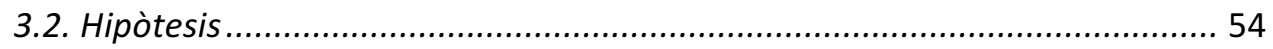



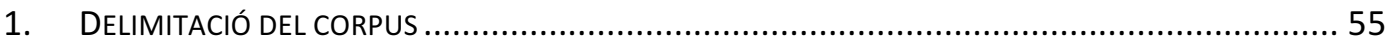

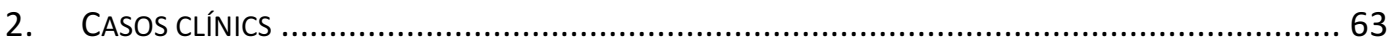

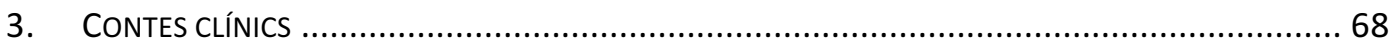

CAPÍTOL III. MARC TEÒRIC: DISCURSOS, GÈNERES I RELATS ................................................. 77

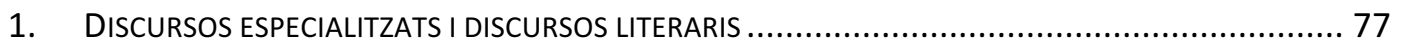

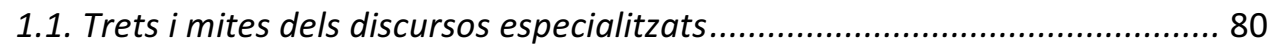

1.2. La divulgació científica i els casos clínics literaturitzats .............................. 89



2.1. Les característiques del gènere discursiu .................................................... 99

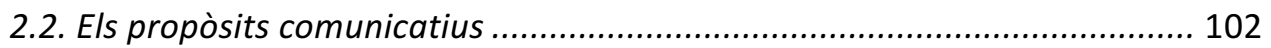

2.3. Els casos clínics entre els gèneres mèdics.................................................. 105

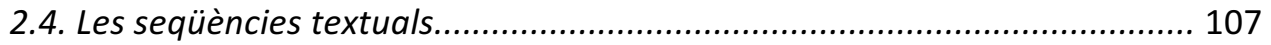

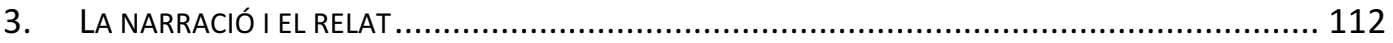

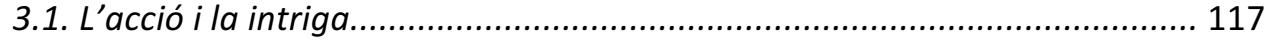

3.2. L'estructura de la narració i del relat .......................................................... 121

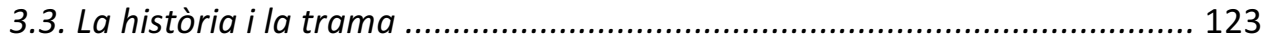




\section{CAPÍTOL IV. LA NARRACIÓ DE LES AFECCIONS MENTALS: DEL CAS CLÍNIC AL CONTE CLÍNIC}

1. CARACTERÍSTIQUES FORMALS DELS CASOS CLÍNICS

1.1. L'autoria 138

1.2. Els títols dels casos clínics 142

1.3. El nucli dels casos clínics. 146

1.4. Els complements visuals 156

1.5. Altres components dels casos clínics 160

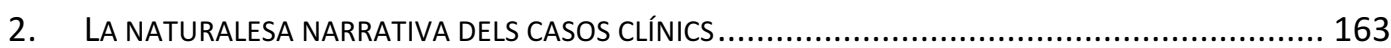

2.1. Les seqüències textuals en els casos clínics ......................................... 163

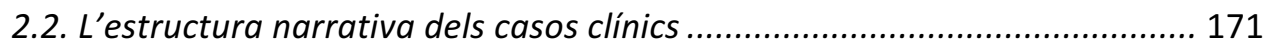

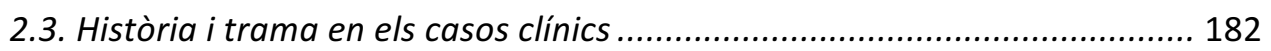

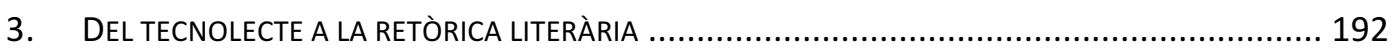

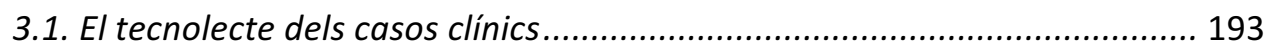

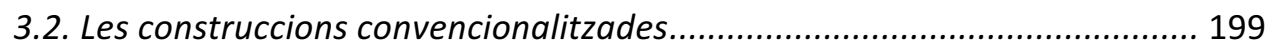

3.3. La recontextualització del coneixement científic en els contes clínics........ 215

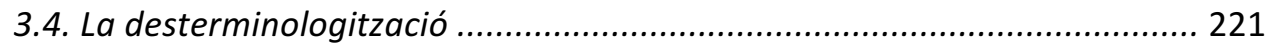

3.5. El tractament de la mort ............................................................. 237

4. POLIFONIA: METGES I PACIENTS; NARRADORS I PERSONATGES ....................................... 248

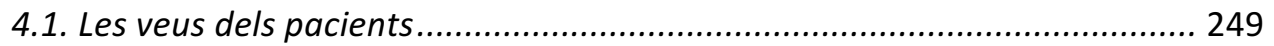

4.2. Quan el pacient sembla fer nosa .................................................. 259

4.3. Entre la despersonalització i la humanització ....................................... 262

4.4. Els espais com a instrument de caracterització....................................... 274



4.6. El professional sanitari com a narrador i personatge............................... 297

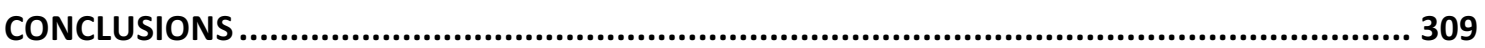



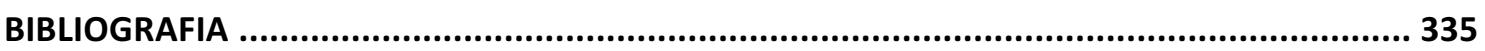

ANNEX I: TAULA DE CODIS DEL CORPUS UTILITZAT ...................................................... 363

ANNEX II: REFERÈNCIES BIBLIOGRÀFIQUES DEL CORPUS.......................................... 375 


\title{
JUSTIFICACIÓ
}

\begin{abstract}
If we wish to know about a man, we ask "what is his story - his real, inmost story?" - for each of us is a biography, a story. Each of us is a singular narrative, which is constructed, continually, unconsciously, by, through, and in us - through our perceptions, our feelings, our thoughts, our actions; and, not least, our discourse, our spoken narrations. Biologically, physiologically, we are not so different from each other; historically, as narratives - we are each of us unique.
\end{abstract}

OLIVER SACKS The Man Who Mistook His Wife for a Hat and Other Clinical Tales

Els humans sentim l'impuls de contar, tant als altres com a nosaltres mateixos, els esdeveniments que experimentem o creiem haver experimentat. Els records, les experiències vivencials, les emocions, no els emmagatzemem d'una manera separada, sinó que els entreteixim i els combinem per bastir un relat, la història de la nostra existència. Aquesta narració interna que construïm i reconstruïm contínuament és la base de nosaltres mateixos, ens ajuda a confegir i a mantenir el nostre jo, la nostra identitat. Podríem dir que, d'alguna manera, les nostres vides són en realitat un gran relat, un Quixot que no està exempt de contenir moltes altres petites històries.

Les malalties constitueixen fites rellevants en la vida de moltes persones i donen peu a capítols sencers en la narració de les seves existències. De vegades, el relat de la malaltia constitueix en si mateix la història de la vida de l'individu. A més de donar sentit a l'existència - i al patiment- dels individus, aquests relats adopten altres finalitats. Pensem ara en les persones que conten les seves dolències per socialitzar-se, per cercar 
l'empatia d'altres malalts o per conèixer altres opinions sobre diferents aspectes de la curació o de la prevenció. $\mathrm{O}$, si ho mirem des de l'altre costat, fixem-nos en els professionals sanitaris que cada dia es converteixen en espectadors d'històries que sovint ni la ficció literària no pot superar.

Precisament, el relat en les ciències de la salut serà l'objectiu d'aquesta tesi doctoral, en la qual ens proposem investigar en el camp de la narrativa mèdica al llarg del seu procés de producció, reproducció acadèmica i recepció, tant en el marc de les revistes especialitzades del l'àmbit sanitari com també en els volums biogràfics que contenen relats de caràcter divulgatiu i, fins i tot, literari. Entre els professionals sanitaris, narrar les experiències clíniques pot tenir diversos objectius: fer progressar la ciència, ensenyar els nous professionals, buscar ajuda dels colllegues del mateix àmbit, mostrar les experiències clíniques als companys de professió o, fins i tot, al públic general. Dos gèneres que responen a aquests propòsits comunicatius de les diverses branques de les ciències de la salut i on es narren aquestes històries vitals són, d'una banda, els casos clínics, i, de l'altra, els contes clínics.

Els casos clínics (CC) són textos altament especialitzats, redactats pels professionals i adreçats als seus col-legues, mentre que els contes clínics o casos clínics literaturitzats, són textos amb un caire divulgatiu i literari - però no de ficció- destinats a un públic general. Els CC, entesos com a modalitat de case study en el camp de les ciències de la salut, han concitat una copiosa bibliografia en els darrers anys. Aquest interès ha estat afavorit, d'una banda, per l'auge de la socionarratologia i, de l'altra, per la recerca orientada a les anomenades comunitats de pràctica. També hi ha hagut intents recents de comparar aquest tipus de relat amb els que s'endinsen en l'àmbit del discurs literari, com són els contes clínics.

Ens interessen els casos clínics, entre altres motius, perquè els considerem un pont entre la biomedicina científica i les humanitats, atès que es tracta d'estudis de base científica, però que no renuncien a una concepció personalitzada del pacient com a subjecte humà (Salvador, 2016). A l'hora de redactar, els professionals de la salut haurien de buscar, per tant, un equilibri entre aquests dos mons, ja que: «En la presentación de un caso clínico no hay que seguir el guión de una telenovela, pero tampoco maquillar la realidad hasta transformarla en la ficción deshumanizada que se pretende "científica” (Camacho et al., 2002: 409). A més a més, els casos clínics tenen 
un especial interès per als analistes del discurs. Des del punt de vista epistemològic, la situació problemàtica d'aquest gènere està motivada per la impossibilitat d'aplicar-ne els resultats a més casos (inducció), per la qual cosa no pot competir amb els articles d'investigació en les revistes especialitzades. Tanmateix, per un altre costat, és un gènere benvingut en les revistes de caire pedagògic. A més, com intentarem mostrar en aquesta tesi, els CC també tenen una dimensió de cohesió dels grups professionals, una funció que dóna rellevància i acceptació a aquest gènere discursiu en nombroses publicacions periòdiques de les ciències de la salut.

La vitalitat del gènere dels CC literaturitzats (contes clínics), parent i tributari dels CC acadèmics, demostra la rellevància de la narració en aquest àmbit. Les històries clíniques dels pacients i les seves malalties s'han revelat com un material de construcció ben aprofitable per fer literatura. El fet que aquest gènere s'haja estudiat des del punt de vista de la narració «leads us to consider the specifity and validity of narrative as a way of thinking about reality, in comparison with the logical, scientific way of constructing discourse and its world view» (Salvador, 2016: 37).

Així doncs, estudiarem i compararem, des del punt de vista de l'anàlisi del discurs, les característiques i peculiaritats d'aquests dos gèneres. Triem per a l'anàlisi aquest gènere del discurs mèdic - malgrat que no sigui tan prototípic d'aquesta comunitat com, per exemple, els articles d'investigació- i la seva versió literaturitzada, oberta al públic general, amb la finalitat d'intentar esbrinar els tipus de relat i els corresponents recursos lingüístics que s'empren en cada cas. Amb aquesta recerca volem contribuir, a més a més, a ubicar els casos clínics dins dels discursos sanitaris i a remarcar i defensar la seva importància com a textos que poden respondre a la demanda creixent de canviar el rumb deshumanitzador de l'atenció sanitària actual, sovint més centrada en les malalties que no pas en les persones que les pateixen. 

CAPÍTOL I.

INTRODUCCIÓ: ELS CASOS CLÍNICS I ELS DISCURSOS AL VOLTANT DE LA MALALTIA

1. El discurs mèdic

2. Narració i malaltia: els casos clínics

3. Objectius i hipòtesis

1. EL DISCURS MÈDIC

La medicina tal com la concebem avui dia - sovint anomenada científica per contrast amb la tradicional, l'alternativa o la complementària - es va desenvolupar entre els segles XVII i XIX (Gotti, 2016). Aquest tipus de medicina, basada en resultats verificables i replicables, va substituir la tradició mèdica anterior, fonamentada principalment en un enfocament en què les afirmacions de les personalitats acadèmiques destacades s'adoptaven sense discussió (Taavitsainen i Pahta, 2004). La font principal d'informació sobre les dolències, fins al segle XIX, procedia de la comunicació entre el metge i el pacient, és a dir de la narració sobre el que afligia el malalt i les preguntes de qui el curava. Aquesta pràctica, però, va començar a canviar des d'aquell moment i aquesta transformació de la relació entre el metge i el pacient encara no s’ha aturat (Kotátková, 2018a).

Un dels avanços científics que erosionen aquesta relació i afavoreixen el distanciament del professional de la salut és, segons Jinich (2013), la invenció de l'estetoscopi l'any 1816 per René Laennec. Els metges s'allunyen cada vegada més dels 
pacients a mesura que necessiten menys la informació verbal, ja que disposen de nombroses màquines que els analitzen objectivament. Però, malgrat tots els progressos científics per poder curar, pal-liar o fer més suportables moltes de les malalties que abans havien estat mortals, l'allunyament entre professionals sanitaris i pacients sovint condueix al descontentament, al conflicte judicial o al recurs a teràpies alternatives sense base científica però amb un contacte humà més estret. Es retreu a la medicina actual el fet de ser massa deshumanitzada i apareixen cada cop més veus des de tots els àmbits - especialment de la medicina mateixa - demanant una praxi més centrada en el malalt i no exclusivament en la malaltia:

Cuando el paciente y el médico se encuentran, el paciente trae consigo un conjunto de síntomas, ideas sobre el significado de los síntomas, emociones y sentimientos causados por todo ello, ideas (conscientes e inconscientes) sobre lo que son la medicina y el médico; expectativas sobre lo que la medicina y el médico harán por él. El médico, a su vez, trae un conjunto de conocimientos sobre modelos teóricos de enfermedades, medicamentos, etc.; un conjunto de habilidades y destrezas para percibir los síntomas y signos que el paciente le entrega; una habilidad (a veces) para percibir el componente emocional y para conocer al paciente como sistema biológico, psicológico y como parte de sistemas más comprensivos cada vez: familia, grupo social, especie humana, biosfera; la capacidad para correlacionar los síntomas y signos del paciente con el modelo teórico que posee intelectualmente; la capacidad (a veces) para captar, a la vez, lo que tiene de única esa persona que está frente a él y que es su paciente. El intercambio que ahora va a ocurrir entre los dos es, en buena parte, hecho a base de lenguaje. (Jinich, 2013: 122)

La proposta de redreçar el rumb de la medicina és clara: que retorni aquell diàleg, que proporcionava tota la informació en altres èpoques, ara combinat o contrastat, això sí, amb les dades dels procediments de la biomedicina científica. Trobem que fins i tot els més destacats professors de medicina solen advertir als seus alumnes: «escolteu el pacient, ell o ella us està dient el diagnòstic» (Greenhalgh i Hurwitz, 1999).

Però mentre debatem sobre la necessitat de recuperar aquell diàleg entre metges $\mathrm{i}$ pacients, d’humanitzar la medicina, el que sí que és indubtable és la consolidació del discurs mèdic. Forma part del que tradicionalment s'anomena discurs científic o especialitzat i correspon a un tipus de textos, majoritàriament en forma escrita, amb unes característiques específiques -terminologia, nominalitzacions, estructures 
impersonals, construccions convencionalitzades, sintaxi condensada, etc. - destinades a garantir l'eficiència en la transmissió de la informació entre els especialistes de l'àmbit corresponent.

\subsection{Discurs mèdic vs. discourses in health settings}

Els textos que s'emmarquen dins del discurs mèdic especialitzat se solen caracteritzar per l'objectivitat (tant en el nivell informatiu com en el lingüístic), la neutralitat, la impersonalitat i la manca de sentiments, emocions, i apreciacions de l'autor' ${ }^{1}$. En el nivell més estrictament lingüístic, hom acostuma a destacar també la configuració textual i la sintaxi, amb formes com ara la veu passiva, les nominalitzacions, les estructures impersonals (per evitar o reduir l'aparició de les marques de primera persona) i l'ús del llenguatge especialitzat (per garantir la claredat, la precisió i la univocitat) (García Negroni, 2008). Aquestes característiques, però, es compleixen en més o menys mesura depenent de cada gènere $\mathrm{i}$, fins i tot, dins de cada gènere podem trobar diferències pel context en què es produeix o publica el text en qüestió. Així doncs, aquest

mite d'un llenguatge científic asèptic, unívoc, explícit, coherent, conformat i formalitzat segons les lleis de la lògica, dóna pas - ja en el decurs del pensament wittgenstanià - a la consideració d'un discurs de la ciència i, més àmpliament, d'uns discursos de la ciència, que inclouen una sèrie de pràctiques de comunicació verbal sense les quals el fenomen científic (és a dir, les descobertes, la transmissió entre especialistes, la divulgació als diversos nivells, la publicitació social o institucional, etc.) no podria produir-se. (Salvador, 2004: 97)

Darrerament, però, ha pres embranzida un altre concepte relacionat amb el discurs mèdic: els discourses in health settings (vegeu Salvador, 2016). Aquest terme es pot emprar com un sinònim de discurs mèdic, és a dir, del discurs especialitzat emprat per a la comunicació entre metges, però també pot abastar un terreny més ampli. Es referiria, en aquest segon cas, a la praxi de la medicina i, per tant, inclouria tots els participants

\footnotetext{
${ }^{1}$ Malgrat aquesta suposada objectivitat, hi ha autors que adverteixen sobre la inevitable subjectivitat del discurs científic i acadèmic (García Negroni, 2008: 9-31). Vegeu també l'apartat 1.1 del capítol III d'aquesta tesi doctoral.
} 
que actuen en contextos relacionats amb la salut, com ara les altres professions sanitàries (infermers), els farmacèutics, els pacients... Se centraria en les produccions discursives que s'originen a l'hora de relacionar-se entre ells, com ara entre el pacient $\mathrm{i}$ el metge o, fins i tot, entre els pacients mateixos, per exemple a la sala d'espera o en els fòrums d'Internet, que podem considerar sales d'espera mediàtiques. Recordem, per tant, que aquest discurs engloba tant la comunicació entre professionals com els vincles comunicatius amb el món no especialitzat.

Els casos clínics són un gènere relativament diferenciat respecte del discurs científic prototípic i, per tant, contenen algunes característiques peculiars. Els contes clínics, en canvi, són històries de l'àmbit sanitari, però escrites per a un públic general, malgrat que els autors sovint siguin professionals de la medicina. Així, la ciència com un «factor imprescindible de la comunicació social contemporània» (Salvador, 2000: 53) ha originat una barreja de discursos que van més enllà d'aquest discurs científic tradicional i, per tant:

resulta més productiu parlar, en plural, dels «discursos de la ciència», és a dir, del conjunt de pràctiques discursives que avui es desenvolupen al voltant del coneixement científic i que no es limiten a la relació professional entre membres d'una especialitat, com en el cas dels articles especialitzats o les comunicacions a congressos, sinó que inclouen un munt de gèneres com els que s'han esmentat suara. Es tracta, en efecte, d'una sèrie de (sub)gèneres discursius que s'han associat, en un grau o altre, amb el coneixement científic, que es poden definir per referència a la comunicació de la ciència i que, al seu torn, contribueixen a definir aquesta com a fenomen social. (Salvador, 2000: 55)

Aquests altres gèneres discursius també formen part dels discursos de la ciència $\mathrm{i}$, malgrat que no s'inclouen dins el discurs científic canònic o prototípic, són una base per a la construcció de l'imaginari social sobre la ciència. En el nostre cas, sobre les ciències de la salut. Des del punt de vista discursiu, la ciència no es caracteritza només per l'ús d'aquest llenguatge idealitzat, sinó, sobretot, per «unes pràctiques sociodiscursives múltiples i multiformes» (Salvador, 2004: 97), com ara un prospecte farmacèutic, una novel-la de ciència-ficció o uns casos clínics literaturitzats amb un llenguatge més propi de la divulgació científica. 
En aquest treball, intentarem aprofundir en el coneixement del discurs mèdic. Analitzarem com és el discurs dels autors dels casos clínics i si hi podem observar alguna reacció davant del repte d'humanitzar la medicina i adreçar-la cap al pacient. D’entrada, el que podem dir és que el gènere dels $\mathrm{CC}$ podria ser apreciablement diferent a la resta dels gèneres, ja que, almenys, parla sobre un o diversos pacients concrets. Veurem, però, de quina manera s'hi fa.

\subsection{Comunitats discursives i comunitats de pràctica}

Quan abordem els gèneres discursius, els quals són una construcció social, és indispensable centrar la nostra atenció en qui els produeix. Cada discurs especialitzat presenta uns trets que responen a l'estructura de la comunitat discursiva corresponent. És a dir, no serà igual el discurs dels metges que el dels físics, per la senzilla raó que els produeixen dues comunitats discursives diferents, amb diferents exigències, regles, hàbits, tradicions, etc.

Un dels autors que més ha contribuït a fixar aquest concepte, dins la teoria dels gèneres del discurs acadèmic, ha estat John M. Swales. Segons Swales, les comunitats discursives estan formades per col-lectius de persones, tant de disciplines acadèmiques com simplement de grups socials, que tenen objectius i metes comuns i utilitzen la comunicació per assolir-los (1990). Swales atribueix la noció de comunitat discursiva al treball de diversos teòrics del constructivisme social, com ara Herzberg (1986):

The use of the term "discourse community" testifies to the increasingly common assumption that discourse operates within conventions defined by communities, be they academic disciplines or social groups. The pedagogies associated with writing across the curriculum and academic English now use the notion of "discourse community" to signify a cluster of ideas: that language use in a group is a form of social behaviour, that discourse is a means of maintaining and extending the group's knowledge and of initiating new members into the group, and that discourse is epistemic or constitutive of the group's knowledge. (Herzberg, 1986: 1, citat per Swales, 1990: 21) 
Alguns autors (Hymes, 1974) distingeixen entre la comunitat discursiva (discourse community) i la comunitat de parla (speech community). Cal remarcar que el terme comunitat de parla ha anat evolucionant en la sociolingüística i, per tant, ha tingut diferents significats que varien segons l'autor. Nosaltres adoptem la definició de Hymes (1974: 51):

A speech community is defined, then, tautologically but radically, as a community sharing knowledge of rules for the conduct and interpretation of speech. Such sharing comprises knowledge of at least one form of speech, and knowledge also of its patterns of use. Both conditions are necessary.

Swales (1990: 23-24) defensa la conveniència d'aquesta diferenciació per distingir una agrupació sociolingüística d’una socioretòrica. En una comunitat de parla sociolingüística, els determinants primordials del comportament lingüístic són socials, atès que les necessitats comunicatives del grup, com ara la socialització o la solidaritat intergrupal, solen ser predominants en el desenvolupament i el manteniment de les seves característiques discursives. En canvi, en una comunitat discursiva socioretòrica, aquests determinants primordials són funcionals. Els membres d'aquest tipus de comunitat es vinculen en funció d'objectius que són anteriors a la socialització i a la solidaritat grupal. Les necessitats comunicatives d'una comunitat discursiva, per tant, són determinades pels propòsits compartits entre els seus membres i predominen en el desenvolupament i el manteniment de les seves característiques discursives. Una altra diferència és la de la proximitat física. Mentre que una comunitat discursiva requereix una xarxa de comunicació i uns objectius comuns sense que importi la distància entre els membres, tant des del punt de vista ètnic com geogràfic, en una comunitat de parla sí que es requereix la proximitat. El darrer motiu exposat per aquest autor és que les comunitats discursives són centrífugues (tendeixen a separar persones en grups d'interès ocupacional o d'especialitat), mentre que les comunitats de parla són centrípetes (tendeixen a absorbir les persones en el teixit general de la societat).

Tal com remarca Borg (2003), en el seu llibre de 1990, Swales va descriure una comunitat discursiva que només estava unida per la comunicació escrita, però uns anys més tard (1998) va tornar a examinar la qüestió i va diferenciar entre comunitats discursives i place discourse communities, que ja estaven unides tant per la comunicació 
oral com per l'escrita. Aquest element és rellevant, ja que afecta la manera com es reprodueix la comunitat i com s'inicia el principiant en les expectatives de la comunitat.

Salvador, Macián i Marín (2013: 80) formulen les condicions perquè els individus pertanyin a una comunitat discursiva dins de la qual es construeix una identitat grupal, col-lectiva o social: a) compartir determinats objectius, valors ètics (o ideològics), interessos i pràctiques socials; $b$ ) disposar de canals de comunicació adequats; $c$ ) activar mecanismes d'informació i participació entre els membres de la comunitat; $d$ ) adoptar o elaborar gèneres textuals adequats per a les diferents finalitats; e) fixar una terminologia pròpia; $f$ ) disposar de vies i models d'instrucció, d'adquisició d'habilitats discursives i d'entrenament pràctic.

L'última condició esmentada és la base d'una altra teoria social sobre l'aprenentatge que defineix les comunitats de pràctica (vegeu Wenger, 1998). Aquest enfocament concep l'aprenentatge com un procés de participació social, és a dir, el compromís en la pràctica social és el procés essencial pel qual aprenem i ens convertirem en qui som. Les comunitats de pràctica es defineixen com:

groups of people who share a concern, a set of problems, or a passion about a topic, and who deepen their knowledge and expertise in this area by interacting on an ongoing basis. Engineers who design a certain kind of electronic circuit called phase-lock loops find it useful to compare designs regularly and to discuss the intricacies of their esoteric specialty. Soccer moms and dads take advantage of game times to share tips and insights about the subtle art of parenting. Artists congregate in cafés and studios to debate the merits of a new style or technique. Gang members learn to survive on the street and deal with an unfriendly world. Frontline managers running manufacturing operations get a chance to commiserate, to learn about upcoming technologies, and to foresee shifts in the winds of power. (Wenger, McDermott i Snyder, 2002: 4)

Segons la visió de Wenger (1998; et al., 2002), les persones que formen part d'aquestes comunitats no han de compartir necessàriament el lloc de treball, però es reuneixen perquè troben un valor en les seves interaccions. Els membres passen el temps conjuntament, parlen de les seves preocupacions vitals, es plantegen temes comuns i això fa que acabin compartint coneixement i informació i que aprenguin junts o també que aprenguin l'un de l'altre. A nivell emocional, senten satisfacció de formar 
part d'un grup així pel sentiment de pertinença, de trobar-se i socialitzar-se amb persones paregudes. Amb el temps, s'hi estableixen determinades maneres d'interactuar entre els membres, els quals solen desenvolupar una opinió i una perspectiva unitària sobre els interessos del grup, així com un conjunt de coneixements, pràctiques i enfocaments comuns. Fins i tot, poden arribar a desenvolupar un sentit d'identitat comuna. Vist així, la majoria de persones forma part d'alguna comunitat de pràctica, conscientment o no.

Així doncs, les comunitats de professionals poden ser definides a partir dels dos conceptes, tant des del punt de vista que posa l'èmfasi en els gèneres discursius (comunitat discursiva) com des del punt de vista de l'aprenentatge pràctic (comunitat de pràctica) (Salvador, Macián i Marín, 2013). Un reflex d'aquests dos conceptes de comunitat discursiva i de pràctica, els quals conviuen i se superposen, el podem trobar en les revistes especialitzades amb enfocament científic o acadèmic $i$ en les professionalitzadores, en les quals podem trobar «una dicotomía aproximativa entre las publicaciones de investigación de punta y las de tipo profesional o gremial, una dicotomía que puede situarse en paralelo con la existente entre comunidad discursiva y comunidad de práctica» (Macián, 2013: 264-265).

Dins del món de les ciències de la salut, doncs, els professionals constitueixen aquestes comunitats discursives i de pràctica, atès que comparteixen les característiques descrites anteriorment. Ens podem trobar diferents comunitats 0 subcomunitats determinades per la professió -com ara metges, infermers, farmacèutics, fisioterapeutes, psicòlegs - o fins i tot per l'especialitat - neuròlegs, pediatres, cardiòlegs, dermatòlegs, oncòlegs-, els membres de les quals comparteixen sistemes conceptuals, coneixements previs de la disciplina en qüestió, rols i distribució del treball dins del sistema particular d'una organització, responsabilitats, codis ètics, estatus social, hàbits de comunicació, preferències terminològiques, etc. (Montalt i García-Izquierdo, 2016: 106). Aquesta construcció de la identitat col-lectiva pot conduir a una sobreidentificació grupal, la qual, al seu torn, pot comportar un risc d'insensibilització i desactivació de la capacitat crítica respecte dels valors compartits pel grup (Salvador, 2012), però també és una base per a la construcció de les comunitats professionals, tant de la seva projecció social com de la seva imatge interna (Macián, 2013). Entre els professionals sanitaris, doncs, els casos clínics contribueixen a 
consolidar una autèntica comunitat de pràctica (Macián, 2013). Per als metges, aquest gènere continua sent, malgrat la seva posició de vegades inestable en les revistes sanitàries, la font preferida d'informació mèdica².

\subsection{Comunitats de pacients $i$ imatge social de les malalties}

Tenint en compte, però, l'enfocament dels discourses in health settings, no podem deixar de costat el grup que en el fons dóna sentit a tota la pràctica sanitària, el dels malalts. Les persones que pateixen alguna dolència també poden conformar una comunitat, ja sigui millor o pitjor definida. Elles també comparteixen moltes característiques comunes, com ara les preocupacions sobre la malaltia o l'objectiu de curar-se, de sobreviure i de tornar a la vida normal. També poden arribar a desenvolupar un argot propi, sovint manllevant lèxic dels professionals de la salut. Aquestes característiques són encara més concretes quan es tracta de pacients d'una mateixa dolència que requereix un procés llarg i específic de curació, com ara el càncer o les malalties rares. A més, els familiars dels pacients, sobretot dels menors d'edat, també poden crear comunitats pròpies. Aquesta mena de comunitats de pacients no és anàloga a la dels metges, ja que la pertinença al grup té raons ben diferents que les que es donen en les comunitats professionals. No es tracta ni de la seva feina ni, òbviament, de cap afició, sinó d'una condició vital, d'una obligació.

Un exemple interessant d'una comunitat de malalts pot ser la unitat de càncer infantil (Clemente, 2015), on la interacció tan freqüent entre els seus membres, que viuen i tracten la dolència conjuntament, fa que parts de les seves vides estiguin entrellaçades. A mesura que avança el tractament, els nens, els progenitors i els professionals de la salut es coneixen millor, i entre els malalts ( $i$ en aquests casos també entre els familiars) es poden crear fortes relacions interpersonals motivades per la necessitat de no sentirse sol i per formar part d'un grup que comparteix espai, preocupacions i objectius. Entre

\footnotetext{
${ }^{2}$ Segons una enquesta publicada el 2010 per la revista Atención Primaria, realitzada a 300 metges de família, un 73 \% dels professionals assenyala els casos clínics com a font preferida d’informació mèdica (Macián, 2013: 125).
} 
els nens, és el patiment del mal físic, però també la frustració d'haver d'estar fora de casa, no poder anar a l'escola, no poder jugar fora; en fi, no poder viure la vida normal d'un nen. Els progenitors (o altres familiars pròxims) comparteixen la preocupació pels seus fills, si guariran o no, com els han de donar suport, com fer perquè els fills no en notin l'estat d'ànim per no posar-los encara més tristos, com conciliar el treball, la vida de parella, amb les visites freqüents a l'hospital. Els pares es donen consells i recomanacions entre ells, atès que cada família està en una fase de curació diferent: hi ha des dels més experimentats fins als més novençans. La llista del que poden tenir en comú podria ser quasi infinita. A part de les preocupacions vitals i els temes de conversa comuns, amb tantes hores d'immersió en qüestions sanitàries, els pacients i els seus familiars es converteixen en experts en la malaltia i cada vegada dominen millor els procediments i també el lèxic mèdic especialitzat. Per tant, el que podem esperar és que, quan parlin, fins i tot entre ells i sense la presència dels metges, incorporin, amb diferents intensitats i freqüències, termes i expressions propis dels professionals de la salut.

A part de les comunitats de pacients i dels seus familiars, també existeixen les comunitats en xarxa dins del que s'anomena la cibersanitat. Moltes vegades es tracta de fòrums en Internet que Salvador (2011) qualifica de sales d'espera mediàtica on les persones en cerquen d'altres amb els mateixos símptomes, problemes, etc. Sovint es tracta de persones que encara no han anat al metge i estan considerant si el que els passa és normal, o d'altres que sí que hi han anat, però el seu problema no s'hi va resoldre satisfactòriament i que, per tant, busquen ajuda en un altre lloc:

Cada vez son más los usuarios, que ya se cuentan por miles de millones, que buscan en los consejos de los 'doctores Google y Yahoo' la esperanza y la solución al problema que su médico no ha sabido proporcionarle, bien porque no existe solución o porque ni siquiera le han preguntado, por falta de tiempo o incluso por falta de credibilidad en el sistema o en sus profesionales. (Sánchez Martos, 2008: 89)

Les revistes mèdiques s'han omplert en els darrers anys d'articles amb diferents opinions sobre com gestionar aquesta nova situació. El major perill no seria el conflicte entre el metge i el pacient perquè aquest no vol seguir les indicacions d'aquell, sinó que aquestes pàgines $\mathrm{o}$ fòrums puguin provocar l'autodiagnòstic $\mathrm{i}$ la consegüent 
automedicació. Aquest pacients informats es converteixen en un problema o repte depèn del punt de vista - per als metges, atès que sovint ja s'han fet una idea de la malaltia que pensen que tenen i quin procediment s'ha de seguir per tractar-la i vénen al metge a fi que segueixi aquests passos. Malgrat no ser professionals de la salut, els pacients poden disposar de moltes informacions - algunes fiables $\mathrm{i}$ altres no tant $\mathrm{o}$ gens-, fins i tot de massa informació i interpretada de manera errònia o no pertinent ${ }^{3}$. Òbviament, el fet que els pacients s'interessin pel que els està passant i es preocupin així per guarir les seves dolències és en principi positiu. L'aspecte negatiu, però, arriba quan el pacient es fia d'informacions falses o mal articulades o, fins $\mathrm{i}$ tot, quan la informació és correcta i ben explicada, però el pacient la malinterpreta. Aquestes situacions afavoreixen l'aparició de prejudicis i predisposen a la desconfiança davant les instruccions dels professionals sanitaris (Salvador, 2011).

Així doncs, la mancança o la falsedat de la informació, com també una interpretació incorrecta de la informació disponible, són terreny adobat per al desenvolupament dels prejudicis. Portats a l'extrem, aquests deriven en els estigmes socials, tan característics d'algunes malalties contagioses - de la lepra a la tuberculosi, passant per la sarna-, però també de les afeccions mentals, agrupades popularment sota el sambenet de la bogeria. Els estigmes socials han estat alhora causa i conseqüència de la reclusió d'aquests malalts en els sanatoris, institucions envoltades sovint per la naturalesa, però, sobretot, allunyades de la resta de la societat (Kotátková, 2018b). Gràcies al desenvolupament científic i tècnic, molts trastorns mentals abans incomprensibles són ara guaribles o almenys contenibles. La majoria de les malalties contagioses es combaten amb antibiòtics o retrovirals i poques representen algun perill epidèmic greu, almenys en les societats occidentals contemporànies. Però malgrat el major nivell cultural general i l'esforç realitzat en el camp de la divulgació, els estigmes socials Iligats a determinades malalties triguen a desaparèixer i fins i tot es generen nous oprobis, com va ocórrer en el cas de la SIDA.

Així doncs, aquests estigmes ens recorden que la imatge social de les malalties no té per què ser objectiva ni unívoca. De fet, les malalties poden veure's des de tres angles o

\footnotetext{
${ }^{3}$ L'accés a les informacions sanitàries s'intenta regular amb el codi ètic internacional HONcode, el qual permet filtrar les adreces fiables.
} 
punts de vista diferents (Lolas, 2015). D'una banda, podem referir-nos a la malaltia com a sensació subjectiva de malestar, és a dir, com a vivència personal de les dolències pròpies (illness). D'altra banda, també podem partir d'una consideració objectivitzant de la malaltia per part dels professionals de la salut, o sigui, una malaltia concreta diagnosticada (disease). Finalment, podem al-ludir a la consideració social de la malaltia per part de profans (sickness).

\section{NARRACIÓ I MALALTIA: ELS CASOS CLÍNICS}

La nostra vida és una narració. Una part del jo es dedica contínuament a seleccionar determinats esdeveniments i vivències i articular-los en forma d'una narració que conforma la nostra consciència (Massimini i Tononi, 2018). La ment no funciona com un dispositiu digital. Els humans no emmagatzemem els records i les experiències de manera separada, sinó que necessitem combinar-los i entrellaçar-los per construir una narrativa que tingui un sentit. Quan ens passen coses noves les integrem amb tota la informació anterior. D’alguna manera, doncs, somiem en narrativa, recordem, anticipem, esperem, desesperem, creiem, dubtem, planifiquem, revisem, critiquem, construïm, xafardegem, aprenem, odiem i estimem a través de la narrativa (Hardy, 1968: 5; Widdershoven, 1993: 3). Els humans sentim, doncs, aquest impuls de contar-nos i repetir-nos - a nosaltres mateixos i als altres - aquells fets que ens han esdevingut, 0 que creiem que ens han esdevingut, de compartir-los i d'interpretar-los.

En aquesta narració que ens fem de les nostres vides, lògicament, hi ha molts aspectes que podem considerar rellevants: les experiències, els aprenentatges i els traumes de la infantesa i la joventut, els amors i els desamors, els èxits i els fracassos socials i professionals, la misèria o la riquesa, la maternitat i, per descomptat, la malaltia i la mort. Pel que fa a la salut, «we fall ill, get better, get worse, stay the same, and finally die by narrative too» (Greenhalgh i Hurwitz, 1993: 48).

Les malalties constitueixen fites rellevants en la vida de moltes persones que donen peu a capítols sencers en la narració de les seves existències. De vegades, la narració de la dolència constitueix en si mateixa la història de la vida de l'individu. A més de donar sentit a l'existència - i al patiment- dels individus, aquestes narracions adopten altres 
finalitats. Pensem ara en les persones que conten les seves dolències per socialitzar-se, per cercar l'empatia d'altres malalts o per conèixer altres opinions sobre diferents aspectes de la curació o de la prevenció.

Si ens centrem en l'àmbit professional de les ciències de la salut, podem distingir tres àrees d'interès per als investigadors del discurs mèdic (Hydén, 2005). En la primera (illness narrative), la narrativa serveix al malalt per contar i articular així les seves dolències en una biografia, que al mateix temps l'ajuda a construir la pròpia identitat; l'escena prototípica seria la del pacient contant a un metge els seus patiments i la seva experiència amb la malaltia. En el segon cas (narrative as a clinical tool), es tracta de la narrativa que s'empra en entorns clínics, com ara en la consulta entre el metge i el pacient, amb la finalitat de negociar la malaltia, i que pot servir per millorar una pràctica mèdica cada vegada més despersonalitzada. Finalment, la tercera (narratives about illness), empra la narrativa per formular i comunicar els coneixements mèdics, sobretot entre els professionals de la salut. En la nostra investigació ens centrem en la darrera àrea, és a dir, en les històries sobre les malalties contades per professionals. No oblidem, però, que el que narren aquests professionals de la salut no són només les seves observacions, sinó que sovint hi incorporen també el discurs dels pacients en qüestió.

Així doncs, podem dir que la medicina «is a narrative art, and physicians are inveterate storytellers» (Mattingly i Garro, 2000: 108). Per això, en els darrers anys ha emergit la medicina narrativa (Segen, 2011), un enfocament clínic que promou la humanització de l'atenció mèdica mitjançant la incorporació de les tècniques narratives en les interaccions entre metges i pacients, però també infermers, treballadors socials, terapeutes i altres especialistes de les ciències de la salut. Un nombre creixent d'autors s'ocupa, doncs, de la narració en la medicina, perquè a més dels interessos per a l'anàlisi lingüística o discursiva, pot millorar la relació terapèutica entre metges i pacients (Goyal, 2013). Així, els professionals de la salut poden oferir una atenció més efectiva i humana als seus pacients, i tenen més probabilitats de resoldre eficaçment les seves dolències si s'hi comuniquen millor, la qual cosa passa per millorar-ne les competències narratives:

If narratives are stories that have a teller, a listener, a time course, a plot, and a point, then narrative knowledge is what we naturally use to make sense of them. Narrative knowledge provides one person with a rich, resonant grasp of another person's situation as it unfolds in 
time, whether in such texts as novels, newspaper stories, movies, and scripture or in such life settings as courtrooms, battlefields, marriages, and illnesses. (Charon, 2006: 9)

La narrativa, per tant, hauria de ser un instrument rellevant en l'exercici mèdic i la podem considerar un mitjà a través del qual els professionals sanitaris poden integrar informació de diverses fonts, articular i comunicar els coneixements clínics. Greenhalgh i Hurwitz (1993: 49) esquematitzen els arguments pels quals s'hauria d'estudiar la narrativa en les ciències de la salut:

In the diagnostic encounter, narratives:

- Are the phenomenal form in which patients experience ill health

- Encourage empathy and promote understanding between clinician and patient

- Allow for the construction of meaning

- May supply useful analytical clues and categories

In the therapeutic process, narratives:

- Encourage a holistic approach to management

- Are intrinsically therapeutic or palliative

- May suggest or precipitate additional therapeutic options

In the education of patients and health professionals, narratives:

- Are often memorable

- Are grounded in experience

- Encourage reflection

In research, narratives:

- Help to set a patient centred agenda

- May challenge received wisdom

- May generate new hypotheses

Taula 1: Raons per les quals s'hauria d'estudiar la narrativa en les ciències de la salut

L'estudi d'aquest camp de la narració en la medicina es pot estructurar, segons Goyal (2013), a partir de tres línies generals: i) la narració en la història del cas mèdic com a base de la cognició mèdica i l'atenció clínica; ii) l'anàlisi formal de les narracions dels pacients sobre la malaltia; iii) la investigació sobre els usos de la narració com a tractament clínic o model d'atenció mèdica. 
Els professionals de la salut, per tant, haurien de disposar de dos tipus de coneixements diferents però complementaris per a la praxi mèdica. D'una banda, el coneixement científic o general, i de l'altra, el narratiu o referent a l'individu particular:

\footnotetext{
Unlike scientific knowledge or epidemiological knowledge, which tries to discover things about the natural world that are universally true or at least appear true to any observer, narrative knowledge enables one individual to understand particular events befalling another individual not as an instance of something that is universally true but as a singular and meaningful situation. Nonnarrative knowledge attempts to illuminate the universal by transcending the particular; narrative knowledge, by looking closely at individual human beings grappling with the conditions of life, attempts to illuminate the universals of the human condition by revealing the particular. (Charon, 2006: 9)
}

En aquest treball, centrarem la nostra atenció en la narrativa dels casos clínics publicats en revistes de les ciències de la salut i escrites per professionals i per a professionals, però també en casos clínics literaturitzats o contes clínics, els autors dels quals igualment poden ser del gremi -encara que no sempre ho són-, però el públic i, per tant, les finalitats i el tipus de discurs haurien de ser diferents en aquest cas. Veurem, llavors, com són aquests dos tipus de CC i en quines característiques divergeixen i en quines s'assemblen, sempre centrant-nos en l'aspecte narratiu.

\subsection{Caracterització dels casos clínics}

El cas clínic (CC) consisteix en la comunicació escrita, per part d'un o diversos professionals de la salut, d'una o més experiències clíniques. En anglès, aquest gènere és conegut sobretot com Clinical Case Report, però també rep altres denominacions, com ara Medical Case Report, Case/Clinical Report, Short Report, Brief Report/Communication, Single-patient Case Report, Single Case Report, Selected Report, Experience \& Reason, Clinical/Scientific Note, Clinical \& Laboratory Observations, Clinical Report Observation (Morales et al., 2007; Nissen i Winn, 2012; Carey, 2006a). El fet que aquest gènere disposi de tants noms diferents podria estar relacionat amb la seva incerta valoració científica, ja que d'aquesta manera els CC es poden presentar «bajo 
otras etiquetas difusas que de alguna manera encubren o disimulan su identidad genérica» (Macián, 2013: 266). En català, predomina clarament la denominació metonímica cas clínic, que fa referència directament al contingut, sense esmentar el text en si mateix, a diferència del que sol ocórrer en castellà, on trobem reporte de caso, reporte de caso clínico, estudio de casos, historia de casos, nota clínica (Morales et al., 2007).

Les definicions dels CC són diverses, però la gran majoria coincideix en unes característiques bàsiques: es tracta d'un resum formal sobre la malaltia d'un o més pacients (el màxim se sol establir en deu casos) que sol incloure el motiu de la consulta mèdica, els símptomes, els diagnòstics, el procés del tractament i els resultats (Venes, 2009). Cal recordar que, tot i que avui dia els CC s'acostumen a publicar en versió escrita, existeix la possibilitat que siguin una producció oral i que, de fet, durant molts segles aquest n'ha estat el costum:

[Clinical Case Report] is a form of verbal o written communication with his own specific rules, which is produced for professional and scientific purposes. It usually focuses on an unusual single event (patient or clinical situation) in order to provide a better understanding of the case and of its effects on improves clinical decision-making. (Jenicek, 2001: 93-94)

Quan un cas reapareix, és a dir, quan l'autor compta amb més casos que giren al voltant de la mateixa problemàtica, sovint s'anomenen també sèries de casos clínics (clinical case series). Abu-Zidan, Abbas i Hefny (2012) analitzen (en anglès) el concepte de «sèrie de casos» (case series) en comparació amb els «casos clínics» individuals (case reports). Segons els seus resultats, la mitjana del nombre de casos d'articles que tenien "sèries de casos» en el seu títol és de set casos i la majoria d'aquests articles contenen deu casos o menys (el $63 \%$ ). Els autors remarquen la falta de concreció dels dos termes quant a la quantitat de pacients que inclouen, atès que es troben amb casos clínics que contenen més subjectes que algunes de les sèries de casos. Proposen, doncs, que a partir de quatre pacients siguin anomenats sèries de $C C$.

Des del punt de vista històric, Hipòcrates és qui va introduir el concepte d'història del cas, una descripció o una representació de la història natural de la malaltia, expressada amb precisió mitjançant el mot patologia (Sacks, 1987a). L'estudi de casos (case study) 
ha perviscut, segons Taavitsainen (2011), com escriptura mèdica a través dels segles amb les arrels en els informes de casos anomenats en llatí consilia i medicina practica, els quals descrivien les malalties i com es podien curar. Es tracta de dos gèneres interconnectats que nasqueren a les universitats europees al voltat del segle XIII i que es convertiren en una valuosa base per a l'estudi i, posteriorment, en una fructífera font d'informació per als historiadors sobre el que es patia en cada època i quines cures hi existien.

Els consilia eren consells mèdics sobre un cas concret, escrits per un reconegut doctor i adreçats a un pacient llunyà i al seu metge (French, 2003: 121-122). Entre els autors més rellevants d'aquest gènere trobem l'occità Bernard de Gordon i el valencià Arnau de Vilanova. Aquest gènere no consistia en exposicions merament teòriques, sinó que abordava casos reals, s'hi oferia un diagnòstic i s'hi suggeria una teràpia. Se n'inferia, per tant, que la medicina no consistia només en l'aprenentatge de coneixements genèrics a partir dels llibres. Els consilia eren recollits i publicats pels metges involucrats o per tercers i servien, a més, com una forma eficaç de publicitat per als autors.

Els practica abordaven els detalls d'una malaltia i del seu tractament. Eren un gènere que va rebre una atenció creixent per part dels intel-lectuals. En la seva forma original -en llatí- els gèneres bàsics d'especialització amb la narració dels casos van ser emprats per un petit grup d'elits de metges i cirurgians a les universitats $i$, per tant, no podem esperar trobar-los com a tals en textos vernaculars (Taavitsainen, 2011) ${ }^{4}$.

En l'actualitat podem distingir, segons Jenicek (2001: 5), tres nivells d'informes clínics, cadascun dels quals té finalitats diferents. En primer lloc hi hauria les presentacions de planta (floor or daily ward presentations), que són informes administratius amb la finalitat de garantir la continuïtat i la compleció dels tractaments de tots els pacients d'una unitat hospitalària. En segon lloc, tindríem els casos seleccionats que es presenten en rondes (rounds), els quals poden ser científicament rellevants, però es presenten, generalment, per assegurar un millor tractament. Finalment, el tercer nivell seria el dels

\footnotetext{
${ }^{4}$ En canvi, durant l'epidèmia de pesta negra que va arribar a Catalunya el 1348, el metge lleidatà Jaume d'Agramunt redacta en català el Regiment de preservació de pestilència, i no pas en llatí, perquè s'adreça a la població en general. Un segle més tard, també el xativí Lluís Alcanyís escriu en català el Regiment preservatiu e curatiu de la pestilència.
} 
casos clínics publicats en la premsa mèdica, els quals representen un esforç científic comparable a altres projectes de recerca de caire experimental o d'observació. En aquest treball ens centrem en aquesta darrera mena de casos clínics.

Aquest gènere és un tipus d'estudi de cas que pertany al discurs mèdic. Està escrit, per tant, per a un públic expert de collegues que comparteixen uns coneixements necessaris per descodificar els significats de l'informe en qüestió. Una de les característiques més notables d'aquest discurs és l'ús d'una terminologia que serveix per a la comunicació entre ells, una marca de cientificitat que remarca la pertinença a una comunitat de professionals. La peculiaritat més notable d'aquest lèxic especialitzat emprat pels professionals, en contrast amb el lèxic comú, és que:

serveix per designar els conceptes propis de les disciplines i activitats d'especialitat. En conseqüència, els termes són coneguts fonamentalment pels especialistes de cada una $d$ 'aquestes matèries i apareixen amb una freqüència molt alta en els documents especialitzats de cada disciplina. (Cabré, 1992: 155)

Des del punt de vista de les macroestructures textuals, el cas clínic és un gènere híbrid o, almenys, heterogeni (Salvador, 2016: 36) que sol contenir seqüències descriptives, expositives i narratives (vegeu el subapartat 2.1 del capítol IV). En l'anàlisi del nostre corpus veurem en quina proporció i en quines parts o apartats apareixen les diverses seqüències i què ens revelen sobre el gènere. Malgrat que els CC continguin diversos tipus de seqüències textuals (Hurwitz, 2000; Morales et al., 2007), la nostra proposta de partida és considerar que es tracta de textos predominantment narratius.

Recordem, d'altra banda, que el relat (mèdic, literari, conversacional...) és un mecanisme eficient per a «configurar discursivamente una experiencia y contribuir a la construcción de identidades individuales o colectivas» (Salvador i Macián, 2004). La complexitat d'aquest gènere no es deu només a la diversitat de seqüències, sinó també a les veus que componen aquest relat (la del metge, de del pacient, les dels familiars...), el qual acaba sent un producte recontextualitzat de comunicació escrita per a la formació i la comunicació en l'àmbit dels professionals.

Els CC s'han estudiat fins ara, sobretot, des del punt de vista mèdic i en l'àmbit anglosaxó, tot i que no exclusivament. En els últims anys han aparegut, sobretot, 
diverses publicacions sobre la política que regula la publicació d'aquest gènere en revistes de les ciències de la salut (Green i Johnson, 2006; Carey 2006a i 2006b; Medeiros Parente et al., 2010; Derman, 2011; Nissen i Wynn, 2012; Wardle i Roseen, 2014; Guimarães, 2015). Majoritàriament, s'hi tracta d'exposar el valor històric dels CC, examinar-ne l'impacte en revistes mèdiques i defensar-ne el lloc en la medicina actual. Trobem també estudis orientats diacrònicament (Taavitsainen i Pahta, 2004; Taavitsainen, 2011) que se centren en l'evolució d'aquest gènere i dels seus antecedents.

També són nombrosos els textos instructius en anglès dedicats a les pautes que s'han de seguir a l'hora de redactar un CC destinat a la publicació (Khan i Thompson, 2002; Green i Johnson, 2006; Cohen, 2006; Hurwitz, 2006) o a la seva estructura (Posteguillo i Piqué, 2007). Montgomery Hunter (1991) i Monroe et al. (1992) presenten suggeriments per millorar els CC perquè se centren més en el pacient i ressalten la importància de la narració per a aquest objectiu. Així, la seva idea és que les dades obtingudes a partir de proves i procediments mèdics es combinarien amb les opinions, els sentiments i també els desitjos relacionats amb el procés de curació tant dels pacients com dels especialistes de l'àmbit sanitari.

Jenicek (2001) és un dels autors que més es fixa en aquest gènere marginat i relativament poc estudiat. En el seu Ilibre Clinical Case Reporting in Evidence-based Medicine, ens ajuda a situar-los en la medicina actual i dóna consells sobre com s'haurien de preparar per a la publicació. És l'obra més exhaustiva sobre els casos clínics. Quasi tots els estudiosos que analitzen algun aspecte d'aquest gènere -i no importa si és des del punt de vista mèdic, pedagògic o lingüístic - la tenen en compte.

Disposem també de diversos estudis des d'un punt de vista lingüístic o discursiu que se centren en l'anàlisi de la pertinença a un gènere discursiu (Helán, 2012), els recursos lingüístics emprats o la traducció i comparació entre diferents llengües (Muñoz Torres, 2011). Hi ha també diversos autors que estudien l'estructura retòrica d'aquest gènere (Burdiles, 2016) i alguns la combinen amb l'anàlisi de les seqüències textuals característiques dels CC (Uribarri, 2004). La tesi doctoral de Sonia Oliver del Olmo (2005) centra la seva atenció en el contrast en l'atenuació en el discurs mèdic en anglès i en castellà en els gèneres del cas clínic i de l'article d'investigació. Una anàlisi d'aquest fenomen la trobem també en la tesi doctoral de Morales (2010), qui es dedica a les 
estratègies d'atenuació (mitigation) en diversos gèneres mèdics, entre ells també el cas clínic. El mateix autor (et al. 2007), anteriorment, també fa una anàlisi retoricodiscursiva dels CC. Alcaraz-Ariza i Salager-Meyer (2002) estudien la controvèrsia acadèmica en el context particular de la funció comunicativa de diferents gèneres del discurs biomèdic escrit en espanyol, inclosos els CC. Zabielska (2014) i Zabielska amb Żelazowska-Sobczyk (2015), (2016) i (2017) es dediquen intensament a l'anàlisi del gènere del cas clínic des d'una perspectiva discursiva en diverses llengües. Estudien, per exemple, la presència del pacient en aquests textos o la tipologia dels CC i fan una revisió crítica de la literatura sobre aquest gènere. Francis i Kramer-Dahl (1991) analitzen des del punt de vista lingüístic, seguint Michael Halliday, dues maneres d'escriure un cas clínic (en la nostra terminologia, fan la distinció entre el CC acadèmic i el CC literaturitzat o conte clínic). Macián (2013) combina la visió de professional sanitari amb la d'analista del discurs per estudiar la construcció discursiva de la professió podològica en les revistes especialitzades, tot analitzant la narració en els CC que contenen. Salvador (2015a i 2016) és dels pocs que estudia també els casos clínics literaturitzats des del punt de vista dels gèneres discursius. A més, el mateix autor analitza la dimensió narrativa dels CC acadèmics i com contribueixen a la construcció de la identitat del pacient.

\subsection{Els casos clínics en les revistes mèdiques}

Des del punt de vista de la classificació de la teoria del gèneres, els CC s'integren en el macrogènere de la revista especialitzada. Els podem considerar un gènere discursiu en si mateix, o bé un subgènere respecte dels estudis de cas (Macián, 2013: 124). Un gènere relativament marginat, poc valorat i perifèric respecte del discurs científic prototípic, però molt útil per als membres d'una comunitat de pràctica. Entronca, a més, amb alguns dels textos més antics del discurs mèdic, precisament per la necessitat que ha tingut la societat, al llarg de la història, de reportar esdeveniments nous o inusuals en el camp de les malalties. Amb arrels evidents en l'Edat Mitjana, en l'actualitat s'ha institucionalitzat com una part de les publicacions científiques en revistes especialitzades, en les quals ha tingut una importància, una representació i una valoració que han anat variant amb el temps. 
A l’Estat Espanyol, la primera publicació periòdica mèdica és de l'any 1820, Décadas médico-quirúrgicas, la qual només va durar vuit anys. En els anys posteriors, apareixen cada vegada més publicacions i butlletins (p. ex. el Boletín del Intituto Médico Valenciano, del 1841 al 1896), en els quals, entre altres gèneres, es presenten els casos clínics (Posteguillo i Piqué, 2007). En el segle xx, amb l'avanç i l'especialització de les ciències de la salut, sorgeix la dificultat, per als professionals sanitaris, d'estar al dia no sols de les novetats mèdiques en general, sinó també dins de la seva especialitat. En aquest context apareixen i prosperen nombroses revistes periòdiques de diferents especialitats, en les quals trobem els casos clínics.

Nissen i Wynn (2012) analitzen les raons de l'evolució de la presència dels CC en algunes de les revistes de prestigi de l'àmbit anglosaxó des dels anys quaranta del segle xx fins a l'actualitat. S'hi pot observar com, al final dels anys setanta i durant la dècada dels anys vuitanta, decau bruscament la presència d'aquest gènere, relegat en molts casos a la secció de Letters to the Editor, mentre que puja el nombre d'articles de recerca, etiquetats com originals. El articles ocupen el Iloc dels CC perquè l'estatus de la revista el marca, cada vegada més, l'anomenat factor d'impacte, calculat en funció de les citacions que es fan de les publicacions. Els casos clínics, en general, se citen molt menys que els altres treballs d'investigació, com ara els articles originals (vegeu Carey, 2006a; Patsopoulos, Analatos i loannidis, 2005). Així doncs, publicar CC pot redundar en una disminució del factor d'impacte de la revista i això fa que aquestes no n'accepten tants i que hi apliquin uns criteris molt més estrictes que anteriorment.

En l'era de la medicina basada en les proves i les dades (en anglès, evidence-based medicine o EBM), l'assaig controlat aleatori (randomized clinical trial o RCT) se situa a la part superior de la jerarquia en les ciències de la salut, gràcies a la fiabilitat i a la possibilitat de repetició dels resultats obtinguts, els quals, per tant, es poden emprar com a base per prendre decisions mèdiques (Green i Johnson, 2006). En canvi, els casos clínics quedarien en la part final d'aquesta jerarquia (taula 2), com a informes descriptius que, segons les crítiques, no ofereixen evidència científicament rellevant.

1. Systematic reviews and meta-analyses

2. Randomised controlled trials with definitive results (i.e. confidence intervals which do not overlap the threshold clinically significant effect) 
3. Randomised controlled trials with non-definitive results (i.e. a point estimate which suggests a clinically significant effect but with confidence intervals overlapping the threshold for this effect)

4. Cohort studies

5. Case-control studies

6. Cross-sectional surveys

7. Case reports

Taula 2: La jerarquia tradicional de l'evidència (Greenhalgh, 2001: 54)

Gopikrishna (2010) descriu la posició dels CC dins d'aquesta jerarquia amb una metàfora de l'escala que representa el seu lloc en l'àmbit de les ciències de la salut: «The single case report occupies a pretty low rung on the ladder of evidence-based medicine, which today's students, investigators and clinicians are admonished to climb diligently in their quest for scientific truth and rational clinical decision-making» (266).

En els anys noranta, tanmateix, es produeix un gir i moltes de les revistes que havien reduït $\mathrm{o}$, fins i tot, deixat de publicar CC, els tornen a demanar. Així doncs, després d'anys en què la literatura mèdica no havia proporcionat gaire espai a les històries dels pacients concrets i donava prioritat a la recerca quantitativa, "a fascination with narratives and qualitative research developed in some fields of medicine, especially in general practice and psychiatry» (Nissen i Wynn, 2012: 3). La psicoteràpia també va contribuir a tornar l'interès per l'estudi qualitatiu de l'individu. El desenvolupament de les publicacions en xarxa, al seu torn, ha afavorit la revitalització dels CC en les revistes, ja que se'n redueix el cost, hi desapareix la limitació de la quantitat de pàgines i es descobreix que, malgrat que se citen poc, solen tenir una gran quantitat de lectors (vegeu Nissen i Wynn, 2012). Gràcies a la possibilitat de publicar en xarxa amb un cost molt més reduït, apareixen pàgines web o revistes online dedicades exclusivament o quasi als $\mathrm{CC}$, com ara: American Journal of Case Reports, Journal of Medical Case Reports, BMJ Case Reports, Case Reports in Neurology...

En l'actualitat, però, la presència d'aquest gènere no està del tot assegurada. Per això, apareixen molts articles que defensen la necessitat de publicar els CC (vegeu Carey, $2006 a$ i 2006b; Neely, 2008). Els arguments principals se centren tant en la utilitat per als professionals que els escriuen com per als col-legues i potencials lectors. Malgrat que 
els CC no poden substituir altres tipus d'estudis quantitatius, atès que representen esdeveniments relatius a una o unes poques persones, els defensors d'aquest gènere adverteixen que, en moltes ocasions, poden donar la primera evidència sobre diagnòstics o teràpies noves o poc freqüents, resultats o pronòstics inusuals, malalties rares i també sobre efectes secundaris que no solen descobrir-se en els assajos clínics (Khan i Thompson, 2002).

El cas clínic conta històries o relats sobre l'aparició, el desenvolupament i el tractament d'una patologia en un sol pacient o en una sèrie de pacients. Els assajos clínics aleatoris, en canvi, són el mètode més convenient per confirmar que una opció de tractament específica és recomanable. Ara bé, no serveixen com a base per conèixer els resultats adversos, perquè cada pacient respon d'una manera diferent al tractament. En aquest cas, se sol recórrer precisament als CC $\mathrm{i}$, en concret, a les sèries de CC. Les altres principals diferències entre els RCT que analitzen grans grups de persones (i que són un pilar fonamental de la investigació mèdica actual) i els CC centrats en pacients individuals, les recull Helán (2012: 64):

Randomised Clinical Trials (RCTs)

- results from RCTs can be further applied to metaanalysis, which can confirm the effectiveness of a treatment

- $\quad$ RCTs require patients only with one disease and with almost no variables

- RCTs involve quantitative research: research concerning effects of treatment in 2 cohorts of patients, one with real treatment, the other with a placebo

- RCTs do not recognize adverse reactions

- $\quad$ statistical methods are applied

- RCTs are based on objective analysis with experimental control and manipulation of variables
Medical Case Reports (MCRs)

- results from individual MCRs can be collected in a case series, which can contribute to a better understanding of adverse events

- comorbidities can be successfully analyzed in MCRs

- MCRs involve qualitative research: research concerning an in-depth understanding of one disease in one patient

- MCRs are the first indications of rare adverse reactions

- no statistical methods applied

- MCRs can be subjective and based on pure coincidence with unreliable description 
- generalizations and approximations of the RCTs results would be used in medical textbooks
- descriptions of real events, which bring the process of learning to a personal level

Taula 3: Les principals diferències entre els assajos clínics aleatoris i els casos clínics (Helán, 2012: 64), el qual es basa en Greenhalgh (2001)

Els CC tenen un altre avantatge, segons Greenhalgh (2001: 53). Si cal, es poden redactar i publicar en pocs dies, cosa que és inviable en el cas dels assajos clínics, que requereixen diversos mesos, i menys encara en les metaanàlisis, el període de gestació de les quals pot durar anys.

Els motius pels quals els professionals de la salut haurien de continuar publicant els CC, els enumeren Green i Johnson (2006: 74) en la taula 4:

- To present an unusual or unknown disorder

- To present unusual etiology for a case

- To present a challenging differential diagnosis

- To describe mistakes in health care, their causes and consequences

- To describe an unusual setting for care

- To present information that can not be reproduced due to ethical reasons

- To illustrate a clinical hypothesis

- To prompt a new hypothesis

- To disconfirm an hypothesis

- To support an hypothesis

- To stimulate further research

- To make an original contribution to the literature

- To offer new insight into the pathogenesis of disease

- To describe unusual or puzzling clinical features

- To describe improved or unique technical procedures

- To describe the historical development of a field or movement

- To report unusual drug-drug, drug-food, or drug-nutrient interactions

- To describe rare or novel adverse reactions to care 
- To study the mechanism of a disease

Taula 4: Motius per a publicar un cas clínic

En la història recent, podem observar casos que han demostrat la gran utilitat dels CC. Per exemple, el virus de la immunodeficiència humana (VIH) no va entrar en la consciència del món mèdic convencional per mitjà d'un seguiment epidemiològic exhaustiu (Wardle i Roseen, 2014), sinó a través de la publicació d'un cas clínic influent: «A preliminary communication on extensively disseminated Kaposi's sarcoma in young homosexual men» (Gottlieb et al., 1981). Un fenomen similar es va produir en el cas de la malaltia de les vaques boges, com també, en l'àmbit farmacèutic, amb el descobriment de la sulfonilurea (Jenicek, 2001).

A més de tots aquests motius de caire mèdic pels quals es cultiva i s'ha de publicar aquest gènere, no n'hem d'oblidar la funció didàctica, tant per als autors com per als lectors. Per als estudiants o practicants novells en les ciències de la salut, els CC són un molt bon material per a l'estudi, ja que s'hi tracten continguts sovint diferents dels que apareixen en les classes tradicionals o en els llibres de text (Jenicek, 2001) i, per tant, solen estimular molt més la discussió. També acostumen a ser de les primeres possibilitats de publicació. L'escriptura sobre la seva praxi mèdica ajuda a millorar l'expressió escrita dels professionals, els fa revisar els estudis actuals sobre el tema i també aprendre a pensar sobre les seves decisions i els seus comportaments d'una manera més crítica (Green i Johnson, 2006).

Una de les funcions més importants dels CC acadèmics té a veure, doncs, amb la formació dels professionals. Però aquesta funció xoca amb la pressió per part de les revistes per publicar CC amb el màxim grau de novetat i originalitat. Es produeix, doncs, un estira-i-arronsa entre la necessitat de disposar de casos clínics nous que ajuden a l'avenç científic i uns altres de més clàssics que serveixin de suport per a l'aprenentatge dels nous professionals sanitaris. Observem, doncs, una diferenciació entre les revistes amb un enfocament acadèmic o científic i les que tenen una tendència més didàctica $o$ professionalitzadora, encara que totes elles comparteixen l'objectiu de cohesionar la comunitat de pràctica i la facilitar la transmissió i l'actualització dels coneixements (Macián, 2013). En el primer cas, parlaríem de les revistes que no solen donar gaire lloc als CC i sovint els releguen o fins i tot els rebutgen. En el segon cas, el tractament seria 
molt diferent, atès que en aquestes revistes els CC són molt llegits, comentats i demandats. A més, pensem que qui més motivat està per escriure els CC són precisament els qui comencen la seva carrera i que, normalment, no disposaran d'exemples de pacients, malalties i curacions revolucionàries que canviïn algun paradigma mèdic.

Hem vist les dificultats dels CC per a trobar lloc en l'àmbit editorial en la biomedicina actual. La realitat d'avui dia dels CC en les revistes de les ciències de la salut continua sent variada i inestable. Segons les observacions d'Alcaraz-Ariza i Salager-Meyer (2002), les revistes biomèdiques generals tenen una tendència de relegar els casos clínics aïllats en forma de notes clíniques, però aquests continuen publicant-se, sobretot en revistes especialitzades. Per a altres estudiosos (Jenicek 2001; Khan i Thompson 2002; Carey, 2006b), els CC conserven el seu lloc en la majoria de les revistes biomèdiques de prestigi, malgrat els obstacles editorials. En les revistes especialitzades, trobem clarament diferències entre les branques de les ciències de la salut. És lògic esperar que, on més proporció hi haurà de $\mathrm{CC}$, és on més poden aportar la comunitat de pràctica. Ja hem mencionat, per exemple, la importància de la descripció de casos aïllats per a l'estudi de les malalties rares i poc freqüents o en psicologia. En general, podem esperar que el paper dels CC en disciplines que s'ocupen de la salut mental sigui més rellevant. És per això que la nostra opció ha estat centrar-nos en els CC que descriuen algun aspecte de la salut mental, entesa en un sentit ampli, tant des del punt de vista de la neurologia com de la psiquiatria i de la psicologia.

\subsection{Els casos clínics en català}

En aquest treball estudiarem els CC en tres llengües: català, anglès i castellà. A la primera d'aquestes llengües, el català, volem dedicar-li una atenció especial, perquè també es tracta de l'idioma de redacció d'aquesta tesi doctoral. Qualsevol persona que pugui llegir aquest text deu saber que la situació del català, tant en l'àmbit científic com fora d'ell, és molt diferent a les altres dues. No es tracta només del nombre de parlants i altres qüestions demogràfiques, sinó de les circumstàncies socials i polítiques que determinen en quina mesura i quan s'empra una llengua. Això, com és obvi, repercuteix 
en el món de la ciència, ja que si una llengua no està normalitzada en tots els altres àmbits d'ús, resulta molt difícil garantir-ne la normalitat en el científic.

La situació actual és que en molts contextos cientificotècnics la llengua catalana té una presència mínima i inestable i en alguns ni tan sols hi és. Així, el discurs mèdic presenta «uns reptes especials per a la normalització del català i uns caires particularment suggestius per a l'analista del discurs que impliquen sovint la construcció social de les diverses professions sanitàries» (Salvador, 2004: 100). Aquí ens trobem amb una anomalia, atès que hi ha molts professionals sanitaris que en la seva comunicació oral habitual, incloent-hi la professional, empren el català i en tenen un bon nivell, però no l'utilitzen a l'hora d'escriure publicacions, ni informes, ni històries clíniques dels pacients (Sans Sabrafen, 2002). La asimetria entre el registre col-loquial oral i l'escrit formal està causada pel fet que no hi ha condicions socials suficientment favorables per a aquests usos (Montalt, 2004).

A part de la creació de textos per part dels professionals, també és necessària la traducció dels diferents gèneres discursius propis de l'àmbit sanitari, com ara els articles d'investigació dels professionals, els prospectes de medicaments, textos divulgatius o els casos clínics. Els especialistes en la traducció científica al català defensen el lloc de la traducció com a eina de garantia perquè l'idioma

puga desenvolupar-se plenament com a llengua apta per a la comunicació cientificotècnica en totes les seues facetes, ja que una part considerable dels textos que s'utilitzen en aquest tipus de comunicació en qualsevol idioma - excepte la lingua franca actual, l'anglès - són, de fet, traduccions. (Montalt, 2004: 104)

Comentem aquí aquesta problemàtica atès que té molt a veure amb el desenvolupament d'aquesta tesi. No pretenem, però, entrar en detalls sobre la situació sociolingüística del català, puix que no és aquest l'objectiu del treball. Sí que creiem convenient, però, esmentar unes quantes qüestions per contextualitzar les condicions de la cerca i la creació del nostre corpus, presentat i descrit en el capítol II. Els CC es publiquen en revistes especialitzades del camp de les ciències de la salut, però no hi ha gaire revistes d'aquesta mena que estiguin en la llengua catalana i que continguin CC. Per això, la recopilació dels CC en català no va ser tan fàcil ni ens va resultar possible ser 
tan selectius com en les altres llengües. Potser per això també ens trobem en el nostre corpus en català alguns CC que contenen més errors dels que esperaríem per poder ser publicats. Generalment es tracta d'errors ortotipogràfics, però també n'hi ha de gramaticals. Per il-lustrar-ho, reproduïm uns fragments d'un CC publicat en la revista Neurologia Catalana:

(1) [...] El mieloma es va diagnostar [sic] l'any 2002, però no va requerir tractament fins l'any 2005, moment en el que [sic] va presentar progressió, indicant-se [sic] quimioteràpia. El 2006, davant nova progressió, es va realitzar autotransplantament [sic] de moll d'ós [sic], que es va haver de repetir l'any 2007. [...] Fins el setembre del 2011, quan una nova recidiva va aconsellar la realització d'un trasplantament alogènic [sic] de donant no emparentat.

$[\ldots]$

El virus de l'herpes humà 6 és la causa más frequent [sic] d'encefalitis en pacients amb trasplantament de moll d'ós [sic], però també és una causa frequent d'encefalitis de causa indeterminada en pacients immunocompetents. Les seves especicitats en quant a [sic] les lesions observables mitjançant ressonància magnètica, així com la necessitat $[\ldots]$.

(20.CAT_Neurologia)

Sense aquesta revista i els autors que hi publiquen ens hauria resultat més difícil analitzar els CC en català en la nostra tesi doctoral, precisament perquè són escassos. Valorem i agraïm, per tant, l'esforç i l'aportació que fan a l'extensió de l'ús de la llengua en aquest àmbit, però considerem que l'ús i la correcció han d'anar de la mà. Aquest és, doncs, un dels reptes per a les revistes científiques en català: garantir la qualitat lingüística amb revisions acurades dels textos, ja que només així es poden crear les condicions òptimes perquè la llengua es desenvolupi en els àmbits científics. En la majoria de les publicacions, en qualsevol idioma, hi ha un percentatge d'errors lingüístics o estilístics, però en les publicacions científiques aquest percentatge sol ser molt baix, negligible. En aquest cas, tanmateix, trobem que massa sovint és excessiu i afecta negativament l'experiència del lector.

Respecte del repertori disponible de casos clínics en cadascuna de les llengües, és obvi que serà molt superior en anglès, la llengua majoritària de la recerca i la publicació científica, utilitzada no únicament pels nadius, sinó per qualsevol professional que aspiri 
a compartir globalment el seu treball. Òbviament, un idioma amb la difusió del castellà també disposarà d'un repertori ben ampli sobre el qual bastir el nostre corpus. Tanmateix, per comprovar si la disponibilitat de casos clínics en català s'ajusta al pes relatiu de la llengua en nombre de parlants -és a dir, si es pot considerar normal - vam fer una recerca de CC en altres llengües europees amb un pes demogràfic comparable al català -això sí, amb un estat darrere- com són el txec o l'eslovac. Van constatar que aquestes dues llengües disposen d'un nombre bastant superior al del català de pàgines i revistes amb casos clínics de diferents especialitats mèdiques.

A més, observem que en moltes revistes txeques apareixen CC escrits íntegrament en eslovac i a l'inrevés, cosa que no hem detectat en les revistes en castellà respecte del català. No entrarem en detalls sobre la intercomprensió, en cadascun dels casos, però cal recordar que el català i el castellà són dues llengües romàniques que conviuen en un mateix estat, mentre que les llengües eslaves esmentades fa ja més de vint-i-cinc anys que no el comparteixen. Amb aquesta comparació com a base, apuntem a la idea que la manca de normalitat del català en la ciència, especialment en medicina i en sector de les revistes que ens ocupa, no està causada perquè sigui una llengua de pocs parlants. Una planificació lingüística normalitzadora, que resolgui aquesta discriminació, podria passar per la inclusió de textos en català en les revistes d'àmbit espanyol, de la mateixa manera que moltes revistes catalanes de diverses matèries inclouen textos en castellà.

\subsection{Els casos clínics literaturitzats o contes clínics}

Els casos clínics literaturitzats, també denominats contes clínics -en anglès, clinical tales-, són un gènere literari híbrid de cas clínic i de narració literària (Salvador, 2015a). No es tracta de textos restringits als professionals de la salut, com en el cas dels CC acadèmics, sinó que aquest gènere obre les portes al públic general. Per això -com veurem més endavant- contenen alguns dels trets característics del discurs científic adaptats per als llecs, tot això dins d'una estructura d'un conte i amb diversos recursos estilístics propis de la literatura. Els autors dels CC literaturitzats converteixen el cas clínic en la història d'un pacient on «ciencia y literatura se dan así la mano a partir de un 
objeto común como es la exploración de enfermos reales, que se convierten en auténticos personajes protagonistas» (Salvador, 2015a).

Atès que aquests casos clínics literaturitzats tracten una temàtica especialitzada, però adaptada per a la seva difusió entre un públic més ampli, els podem classificar dins de la literatura de divulgació científica. Si examinem les obres de divulgació científica en l'àmbit de la salut, observem que n'hi ha moltes que «no han estat compostes per escriptors professionals que fan l'adaptació i la traducció del coneixement científic per a un públic general, sinó directament pels científics mateixos» (Kotátková, 2017: 288), com ara Oliver Sacks (1987), Antonio Damasio (1994) o David Eagleman (2011). Són obres que han sabut guanyar-se el favor d'un públic general molt heterogeni, malgrat la temàtica tan especialitzada, i que avui dia les podem trobar tant als despatxos dels neuròlegs i altres especialistes en la salut mental com també a les llibreries generalistes de les estacions de tren o dels aeroports (Grabowski, 2015: 186-187).

La tradició d'aquests relats clínics es pot traçar en el passat per trobar-ne el punt culminant al segle XIX, a partir del qual es van anar allunyant del centre d'interès a causa dels nous enfocaments científics, basats més en les xifres que en els casos individuals. En l'època d'aquest auge, trobem figures clau com Sigmund Freud, retratat com a mestre de la tradició narrativa amb l'habilitat de "taking pieces of the patient's associations, dreams, and memories and weaving them into a coherent pattern» (Spence, 1982: 21). Freud componia narracions sobre els casos que s'havia trobat en la seva praxi i ho feia amb recursos similars als que es fan servir a les novel/les o històries de suspens (Hydén, 2005), una estratègia que sempre afavoreix que una temàtica tan especialitzada i, en principi, restringida als col-legues de professió, es pugui difondre i tenir èxit entre un públic més general.

La psicoteràpia és una de les disciplines que va contribuir a tornar l'interès per l'estudi qualitatiu de l'individu i que, en l'actualitat, continua fent èmfasi en el paper de la narració per a la descodificació i el replantejament del passat, per donar sentit al present i proporcionar una orientació per al futur (Mattingly i Garro, 2000). El paper de la narrativa ha guanyat reconeixement també en algunes especialitats clíniques com la psiquiatria, una especialitat que, tanmateix, sovint es considera marginal per part de la resta de la biomedicina (Kleinman, 1995: 2). Altres especialitats s'han resistit més, fins fa pocs anys, a emprar aquest discurs connotatiu. Però els canvis, finalment, han 
penetrat en el món de les ciències de la salut i la narrativa "has constituted an alternative mode of representation that is somehow more appropriate to certain aspects of clinical experience» (Mattingly i Garro, 2000: 8).

De quina manera, però, encaixen els professionals de la salut d'avui dia en el món de la narrativa? Mattingly i Garro (2000) expliquen que «the moment one attends to narrative, it becomes clear that stories and storytelling - narratives and narrative practices - have a central role in medical practice» (50). El professionals sanitaris empren històries tant si és per analitzar casos en entorns formals, com ara conferències, com per comentar anècdotes sobre els seus pacients. L'ensenyament dels nous professionals també conté una part que podríem denominar rondallística. Recordem les tradicionals rondes als llits dels pacients, en les qual es presenten i narren casos individuals. La pedagogia clínica també ha tingut com a objectiu revisar la ciència mèdica en el context de les narracions clíniques i la resolució de problemes. Aquest enfocament ja el podem trobar també en l'ensenyament preclínic de les ciències biològiques bàsiques (Mattingly i Garro, 2000). I si tornem a l'àmbit de la literatura, el dia a dia dels professionals sanitaris està farcit d'històries, d'autèntics drames humans, i la narració serveix molt bé per encarnar-los. Així, tenim moltes obres de diferents tipus en les quals els metges conten històries dels pacients que han tractat i reflexionen no sols sobre la fisiopatologia, sinó també sobre el sofriment i la condició humana.

En aquesta línia s'inscriu uns dels representant més rellevants dels metges-escriptors dels contes clínics, el neuròleg Oliver Sacks (1933-2015), el qual critica el discurs mèdic autoritzat:

Such histories are a form of natural history-but they tell us nothing about the individual and his history; they convey nothing of the person, and the experience of the person, as he faces, and struggles to survive, his disease. There is no "subject" in a narrow case history; modern case histories allude to the subject in a cursory phrase ("a trisomic albino female of 21") which could as well apply to a rat as a human being. (Sacks, 1987a: VIII)

Sacks distingeix la història mèdica tradicional de la narrativa pròpiament dita, en la qual el personatge central és el subjecte humà, en lloc de la patologia. És un gran defensor d'una medicina enfocada més cap a les persones i les vivències individuals de les malalties, amb l'objectiu de: 
To restore the human subject at the center-the suffering, afflicted, fighting, human subject-we must deepen a case history to a narrative or tale; only then do we have a "who" as well as a "what," a real person, a patient, in relation to disease- in relation to the physical. (Sacks, 1987a: VIII)

En els textos de Sacks i en la seva praxi mèdica, s'evoca la possibilitat d'unir el científic i el romàntic en allò que Aleksandr Lúria (1902-1977), el seu gran exemple, anomenava la ciència romàntica. Seguint el seu model, Sacks es compromet a una neurologia de la identitat, com a requisit necessari per a poder humanitzar les pràctiques mèdiques en les quals els problemes físics i psicològics del malalt es combinen en una biografia personal (Salvador, 2015a). Els textos de Sacks, els quals han estat etiquetats en diverses categories -estudis mèdics popularitzats, relats curts o anècdotes biogràfiques-, han contribuït a constituir el corpus de contes clínics del nostre estudi.

\section{OBJECTIUS I HIPÒTESIS}

Tant els casos clínics acadèmics com els literaturitzats es basen en la història de la malaltia experimentada per un pacient i de les teràpies que s'hi apliquen. Tanmateix, el fet que un gènere i l'altre es produeixin amb propòsits comunicatius diferents i per a uns lectors diversos comportarà que tinguin trets narratològics també distints: des de les estructures fins al lèxic emprat, passant per l'ús de recursos retòrics. En els CC acadèmics, però, no esperem trobar una situació homogènia, sinó que preveiem detectar i descriure diferències significatives que intentarem correlacionar amb les comunitats de pràctica en les quals es generen.

\subsection{Objectius}

Participem d'un metaobjectiu fonamental: establir un diàleg entre els sabers considerats habitualment científics i els humanístics i, en el nostre cas, entre les ciències de la salut i la lingüística, a través del pont que constitueix l'anàlisi del discurs, tot 
qüestionant les barreres entre les dues cultures (Snow, 2001 [1959]). La tesi doctoral s'adscriu al projecte Explora «Llenguatge i cultura de la salut ${ }^{5}$ », el qual pretén contribuir al creixement d'un moviment que adopta l'etiqueta d'humanitats mèdiques o medicina humanística. Així doncs, en aquesta tesi procurem tenir en compte tant les fonts lingüístiques i de teoria literària com també les mèdiques per dur a terme, així, un treball transdisciplinari.

Els objectius específics d'aquest estudi són els següents:

- Reflexionar sobre el lloc dels CC dins dels gèneres mèdics i en les revistes especialitzades.

- Analitzar els propòsits comunicatius dels CC del nostre corpus.

- Analitzar el pes de la narració en els discursos de la salut i, específicament, en els CC.

- Delimitar els instruments de la teoria narrativa que ens semblen més productius per aplicar-los a l'anàlisi del nostre corpus, el qual inclou, també, textos no literaris.

- Descriure les característiques, l'estructura i les peculiaritats comunes i específiques dels $\mathrm{CC}$, en relació amb les diverses comunitats de pràctica i els propòsits comunicatius.

- Conèixer els recursos estilístics emprats en els CC.

- Examinar quin és el paper que té el discurs dels pacients integrat dins del discurs dels professionals de la salut en els CC.

- Esbrinar quina és la importància textual del pacient en els CC.

- Avançar en l'anàlisi del discurs mèdic en català.

- Reflexionar sobre la situació actual del català com a llengua científica, tot centrant-nos en els CC acadèmics.

- Reflexionar sobre la rellevància dels CC per a l'ensenyament dels futurs professionals sanitaris.

- Valorar l'enfocament de la medicina centrada en les persones i no sols en les proves biomèdiques.

\footnotetext{
${ }^{5}$ Projecte d'investigació EXPLORA: «Lenguaje y cultura de la salud» (CSO2014-61928-EXP), del Ministeri d'Economia, Indústria i Competitivitat, Govern d'España.
} 


\subsection{Hipòtesis}

A continuació exposem les hipòtesis principals d'aquesta tesi doctoral, concretament, les que són d'alguna manera transversals a quasi tot el treball. A banda d'aquestes, al llarg del treball ens en plantejarem d'altres, centrades en aspectes més concrets i limitats.

- Els CC acadèmics tendiran a tenir estructures comunes prefixades i pautades convencionalment, mentre que l'estructura dels CC literaturitzats serà implícita i més flexible.

- En els CC acadèmics es tendirà a utilitzar una terminologia especialitzada, mentre que en els $\mathrm{CC}$ literaturitzats caldrà recórrer a diverses estratègies de desterminologització del llenguatge per fer-lo accessible a un públic més ampli.

- En els CC acadèmics trobarem una sèrie de construccions convencionalitzades molt recurrents, mentre que en els CC literaturitzats aquestes construccions s'evitaran o es minimitzaran.

- En els CC acadèmics trobarem pocs exemples de recursos estilístics propis de la narració literària, a diferència del que passarà amb els CC literaturitzats.

- Tant en els CC acadèmics com en els CC literaturitzats, el professional s'apropiarà del discurs del pacient per construir el seu, però amb estratègies diferents en cada cas.

- En els CC acadèmics els pacients tendiran a aparèixer descrits amb informacions objectives (gènere, edat, antecedents clínics), tot evitant les referències a factors de la personalitat o de la vida social que el professional de la salut no consideri rellevants per al cas. En canvi, en els CC literaturitzats els pacients esdevindran personatges, amb característiques (nom -sovint fictici-, família, professió, aficions) que en principi no serien clínicament rellevants, però que ajudaran a generar interès narratològic en els lectors.

- Dins del camp de la salut mental esperem trobar diferències importants respecte de les característiques esmentades en les hipòtesis anteriors, amb especialitats o comunitats de pràctica on els CC acadèmics seran més explícitament narratius que en altres. 
CAPÍTOL II.

SELECCIÓ I DESCRIPCIÓ DEL CORPUS

1. Delimitació del corpus

2. Casos clínics

3. Contes clínics

1. DeLIMITACIÓ DEL CORPUS

Sempre que s'estudia el llenguatge és convenient realitzar les anàlisis sobre un corpus tan ampli com sigui possible. Tanmateix, l'estudi de discursos professionals o tècnics, com els casos clínics que ens ocupen, resulta més factible a partir d'un corpus d'extensió moderada, atès que no s'hi analitza la generalitat de la llengua, sinó aspectes particulars que resulten característics d'una o diverses especialitats (Paltridge, 1997: 63).

La primera part del nostre corpus consisteix en una sèrie de casos clínics que, per guanyar claredat, sovint adjectivem com CC acadèmics. Es tracta de textos en els quals assumim que no hi ha d'haver cap element ficcional, perquè la informació proporcionada es basa en fets reals tal com van ocórrer -això sí, sempre des del punt de vista dels professionals sanitaris que en són autors. Es publiquen en revistes especialitzades $\mathrm{i}$, en principi, estan adreçats a lectors de l'àmbit de les ciències de la salut, com ara els col-legues d'una mateixa especialitat, amb l'objectiu de fer progressar la ciència o per educar els futurs professionals. 
Òbviament, els CC es poden escriure sobre qualsevol disciplina de les ciències de la salut i no hauria estat un objectiu realista proposar una anàlisi en totes les especialitats. Tampoc no hem volgut limitar la tria, però, a una sola disciplina, ja que perdríem l'oportunitat de fer-ne comparacions. Com hem vist en el subapartat 2.1 del capítol I, el paper dels casos clínics és particularment rellevant en les disciplinis que s'ocupen de la salut mental. Aquest és un dels motius que ens ha conduit a seleccionar el nostre corpus entre aquestes disciplines. L'altre factor que ens hi ha portat han estat els contes clínics de l'escriptor neuròleg Oliver Sacks, el qual narra casos de la seva praxi mèdica. Per un i l'altre motiu, en aquest treball hem restringit la tria del corpus a les disciplines que tracten qüestions relacionades amb la salut mental, entesa en un sentit ampli.

Segons les dades de l'Organització Mundial de la Salut (2005), s'estima que 450 milions de persones arreu del món pateixen simultàniament problemes neurològics, mentals o de conducta. No importa de quin país o de quin continent mirem les dades, el que veurem és que, al llarg de la vida de les persones, quasi tothom ha patit, pateix o patirà algun problema de salut mental més o menys greu. Tot i que les afeccions mentals són les que més discapacitats causen a l'Europa occidental, als Estats Units i al Canadà, i són responsables de gairebé un 13 per cent de totes les malalties del món, la majoria de països encara no en prioritza l'atenció (Cohen, 2008).

Cal tenir en compte que la salut mental s'aborda des de perspectives acadèmiques diverses i amb enfocaments clínics i terapèutics molt diferents. Dins el camp de la medicina trobem les especialitats de la neurologia i de la psiquiatria. La neurologia s'ocupa de la prevenció, el diagnòstic, el tractament i la rehabilitació de totes les malalties que involucren tant el sistema nerviós central com el perifèric o l'autònom. La psiquiatria, al seu torn, se centra més específicament en els trastorns mentals. La psicologia, en canvi, és una disciplina molt àmplia que sovint s'engloba dins de les ciències socials. Tanmateix, existeix una psicologia clínica amb una llarga tradició que considerem que travessa la frontera amb les ciències de la salut i que, atès que s'ocupa també de la salut mental, no podíem deixar de banda als efectes del nostre treball. A l'Estat espanyol, l'especialitat en Psicologia Clínica és un títol que poden assolir els graduats en Psicologia mitjançant un postgrau en forma de residència que es desenvolupa dins el sistema públic de salut, després d'un examen d'accés denominat PIR (psicòleg intern resident). 
Quan ens referim als autors dels CC, generalment tendim a pensar en metges, i cal reconèixer que la major part de textos d'aquest gènere sí que està redactada per aquest sector professional. No hem d'oblidar, però, que no són els únics treballadors de la salut que tenen un contacte amb pacients ni els únics que en fan un seguiment: a més dels psicòlegs ja esmentats, pensem per exemple en els infermers. Per això, el nostre corpus també conté CC redactats per professionals de la psicologia i de la infermeria. Als efectes del nostre treball, doncs, quan ens referim als professionals sanitaris o de la salut, hi incloem tant els metges com els infermers, com també els psicòlegs clínics.

Aquesta part del corpus l'hem seleccionada en tres idiomes: català, castellà i anglès. No pretenem, però, fer aquí un estudi contrastiu entre les tres llengües, sinó analitzar els fenòmens que ens ocupen en un corpus multilingüe. El català és la llengua d'aquest treball $\mathrm{i}$ considerem que és convenient que es facin estudis sobre els CC en aquest idioma, atès que encara no n'hi ha gaires. Ens permet també abordar — d'una manera relativament marginal, ja que no és l'objectiu central d'aquesta tesi-com és la situació del català en l'àmbit de la salut. Ens calia també considerar el castellà, com a llengua pròxima i que en el nostre àmbit lingüístic és emprada per fer publicacions per una gran part dels professionals sanitaris. Finalment, havíem d'incloure-hi l'anglès, puix que, en medicina com en la majoria de disciplines científiques, s'ha convertit en la llengua franca. Com podrem comprovar en el nostre corpus, els CC que es publiquen en anglès -i les revistes mateixes que els inclouen- no provenen exclusivament de països anglòfons, ni els autors n'han de ser necessàriament parlants nadius.

Per seleccionar el corpus hem buscat CC acadèmics que hagin estat publicats en revistes, butlletins o portals especialitzats, sempre amb disponibilitat en format digital, per facilitar-hi l'accés, en cas de desitjar-ho, als lectors d'aquesta tesi. Un problema amb el qual ens hem hagut d'enfrontar és el de la legitimitat acadèmica de les revistes i els portals utilitzats. La xarxa va plena de pàgines que tenen característiques formals d'una publicació científica però que no en tots els casos reuneixen els requisits i les convencions que ens permeten considerar-les com a tals. Ens referim a les publicacions depredadores d'accés obert (Beall, 2018), en les quals els textos publicats no sempre passen per les dobles revisions anònimes, els consells de redacció sovint són totalment o parcialment ficticis, s'apliquen tarifes de publicació als autors que es comuniquen a posteriori i presenten tota una munió de comportaments irregulars que fins i tot han 
estat objecte de diversos processos judicials. Aquestes empreses s'aprofiten tant de les facilitats que forneix Internet com de la necessitat de publicar que experimenten molts professionals en els diversos àmbits acadèmics. Amb aquesta inflació publicadora, separar les fonts legítimes de les fraudulentes planteja dificultats, sobretot per als investigadors que ens acostem a una revista sense ser especialistes en la matèria. En el nostre cas, vam estar revisant durant un temps les característiques dels CC publicats en la revista Acta Psychopathologica, publicada per iMedPub i amb base a Londres. Tot semblava dins de la normalitat fins que vam descobrir que aquesta empresa ha estat demandada per pràctiques depredadores per la Comissió Federal de Comerç dels EUA.

Certament, el fet que una publicació no compleixi totes les convencions o els requisits fixats per les autoritats acadèmiques o administratives no impedeix que els textos concrets que s'hi publiquin circulin en les comunitats de pràctica que estem analitzant, ni que resultin interessants per al seu estudi des del punt de vista del relat. I tampoc no seria correcte qualificar com a depredadora qualsevol publicació pel simple fet de no estar inclosa en uns determinats índexs. Tanmateix, atesa la situació, hem preferit prioritzar les publicacions generades per entitats professionals de prestigi reconegut 0 incloses almenys en un dels índexs amb major nivell de consens: Scopus, Latindex (Sistema Regional d'Informació en Línia per a Revistes Científiques d'Amèrica Llatina, el Carib, Espanya i Portugal) o DOAJ (Directory of Open Access Journals).

En aquest marc, hem prioritzat també aquelles revistes en què els CC tenen una certa vitalitat $\mathrm{i}$ on, per tant, $\mathrm{s}^{\prime}$ hi publiquen regularment. Algunes publiquen quasi exclusivament CC, altres en publiquen un o dos en cada número. Hi ha revistes més enfocades cap a la recerca - descobrir les novetats - i n'hi ha d'altres amb objectius més aviat d'educació dels futurs professionals. Els CC tracten des de nadons, passant per adolescents $\mathrm{i}$ adults, fins a ancians. Disposem de CC orientats més cap a qüestions biomèdiques i dels que se centren en com afecta la malaltia la vida quotidiana del pacient. També volíem que el nostre estudi fos representatiu dels CC actuals i, per tant, en totes les revistes i portals hem procurat seleccionar sempre els CC més recents i ens hem assegurat que la data de publicació no fos anterior a l'any 2000. De fet, la majoria són textos publicats el trienni 2015-2018 (taula 1). En castellà i sobretot en anglès, la quantitat de revistes i de CC disponibles és tan gran que ens ha permès descartar textos 
més antics en benefici dels recents, perquè moltes de les revistes que hem triat publiquen diversos números a l’any amb nombrosos casos clínics.

\begin{tabular}{|ccccc|}
\hline Anys & Català & Castellà & Anglès & Total \\
\hline $2000-2004$ & 3 & 0 & 0 & 3 \\
\hline $2005-2009$ & 7 & 0 & 0 & 7 \\
\hline $2010-2014$ & 11 & 11 & 4 & 26 \\
\hline $2015-2018$ & 14 & 29 & 36 & 79 \\
\hline Total & $\mathbf{3 5}$ & $\mathbf{4 0}$ & $\mathbf{4 0}$ & $\mathbf{1 1 5}$ \\
\hline
\end{tabular}

Taula 1: Nombre de casos clínics per any de publicació i llengua

Partim de la consideració que la narració és l'element fonamental que construeix els CC. En essència, els CC són històries en les quals es narra o conta el cas d'un pacient. Si insistim en la importància de la comunicació, de la paraula, en totes les especialitats mèdiques, entenem que aquesta insistència ha de ser major en l'àmbit de la salut mental. Aquest àmbit té algunes característiques peculiars que fan que difereixi de la resta de les especialitats. Pensem simplement en la transcendència de comunicar el problema al professional sanitari: a diferència de moltes altres disciplines, les proves biomèdiques aquí sovint no poden substituir la paraula. Precisament, en psicologia i psiquiatria, la desil/lusió amb els modes tradicionals de tractament ha portat alguns professionals a adoptar un enfocament narratiu amb els pacients, com una manera de canviar la relació de poder entre el psiquiatre i l'usuari (Cohen, 2008: 1-4).

En aquesta tesi, doncs, reprenem la pregunta formulada per Rishi Goyal (2013): «Are certain medical specialties more narrative-friendly than others?». Sospitem que entre les especialitats que conformen el nostre corpus també trobarem diferències, ja que, per exemple, en la neurologia les proves biomèdiques tenen un lloc més important que en psicologia. Així doncs, esperem que el tractament de la informació en els CC també serà diferent. En alguns casos, la història del pacient i la narració serà més important que en uns altres, amb més descripcions dels processos mèdics o exposicions teòriques sobre una malaltia, un símptoma... 
En resum, els criteris que hem aplicat per seleccionar els CC acadèmics són els següents:

- vinculats a l'àmbit de la salut mental, entesa en un sentit ampli (sobretot neurologia, psiquiatria i psicologia)

- publicats en revistes, butlletins o portals en línia especialitzats (amb disponibilitat i accessibilitat gratuïta en format digital) indexats o avalats per entitats professionals de prestigi

- textos en català, castellà i anglès

- publicacions recents (a partir de l'any 2000)

La segona part del corpus la formen els contes clínics o CC literaturitzats, és a dir, casos mèdics portats al format d'anècdotes o relats literaris, freqüentment per metges escriptors. Recordem que es tracta de narracions basades en experiències clíniques reals, però amb les seves especificitats retòriques, ja que s'adrecen a un públic no especialitzat i amb uns propòsits comunicatius que són alhora divulgatius i literaris: contar una història que sedueixi els lectors per acostar-los a una situació clínica concreta. Hem seleccionat una mostra d'aquests contes clínics que siguin també variats per poder comparar-los també entre ells. Hi ha llibres de contes clínics en els quals cada narració està més o menys aïllada, com els CC acadèmics, i n'hi ha d'altres en què alguns dels pacients reapareixen en diverses històries.

No són pocs els professionals sanitaris que es converteixen en pensadors i escriptors, amb textos oberts al públic general. Ens interessem especialment per determinades publicacions més aviat crítiques que revisen l'estat actual de la medicina i el lloc del malalt, com en el cas del llibre-testimoniatge en català En la pell del pacient (2016), de Salvador Esquena, el qual insisteix en l'aspecte humà i comunicatiu de la professió mèdica, o com What Patients Say, What Doctors Hear (2017), de Danielle Ofri, qui mostra com la reorientació de converses entre metges i pacients pot conduir a millorar els resultats de la salut per a tothom.

En molts d'aquests textos apareixen mencionades algunes històries o anècdotes, tant del personal sanitari com dels pacients, però hi serveixen només com a exemplificació de la crítica o del pensament que hi estan desenvolupant. Sovint no s'hi conta tot el cas clínic, sinó només una part de la història, considerada útil per il/lustrar la línia 
argumental de l'autor. En els CC literaturitzats, en canvi, veiem que la línia principal que es desenvolupa és la narració sobre el pacient. Això no vol dir que els autors d'aquest gènere no puguin fer, de tant en tant, una digressió i tractar també temes teòrics o històrics que tenen alguna relació amb una malaltia o un símptoma.

Un dels majors representants dels casos clínics literaturitzats és, per descomptat, Oliver Sacks (1933-2015), neuròleg i escriptor nord-americà d'origen britànic. Ja hem mencionat la seva defensa de la medicina enfocada més cap a les persones i les vivències individuals de les malalties, en què el personatge central és el subjecte humà en lloc de la patologia. En els seus contes clínics narra, des d'aquest enfocament, les històries dels seus pacients i de les seves dolències. Es va fer conegut mundialment gràcies a aquests llibres, en els quals captiva els lectors amb la narració d'aquests híbrids de cas clínic i conte. Intenta ensenyar a un públic general els retrats humanitzats dels pacients que sofreixen diferents menes d'afeccions neurològiques i també contextualitzar-ne la problemàtica. Els seus llibres de casos clínics literaturitzats han impulsat la reflexió sobre aquest gènere, però també sobre el gènere del qual els considerem tributaris, els CC acadèmics ${ }^{6}$.

Actualment, trobem molts llibres escrits per professionals de la salut que narren històries de la seva praxi i utilitzen el format de contes clínics. Recordem que abans de Sacks ja existia aquest gènere, però és ell qui l’obre al gran públic en les darreres dècades. Així, hi ha nombrosos metges que segueixen els passos de Sacks i escriuen les històries dels seus pacients amb reflexions sobre la medicina actual. Moltes de les publicacions que trobem són de neurologia, l'especialitat de Sacks. També s'hi afegeixen els professionals de la psiquiatria i de la psicologia, ja que aquestes històries tenen un denominador comú: el que abans se simplificava com a bogeria; comportaments que per un costat espanten els lectors, però que al mateix temps els sorprenen $\mathrm{i}$, en alguns casos, els fascinen. Les disciplines que tenen a veure amb la salut i la malaltia mentals semblen ser les més propenses a fornir la base de les històries literàries.

La literatura universal està farcida d'històries que tracten els comportaments humans que es desvien de la norma. Potser és per això que resulta més fàcil literaturitzar casos

\footnotetext{
${ }^{6}$ Un dels factors que ha contribuït a la popularització de l'obra d'Oliver Sacks és la pel·lícula Awakenings (1990), dirigida per Penny Marshall i basada en el llibre de l'autor amb el mateix títol (1973).
} 
sobre malalties mentals que no pas sobre problemes cardíacs o ginecològics, perquè la salut mental afecta amb major mesura el nostre comportament. Així, una disfunció neurològica com l'agnòsia visual pot donar lloc a la història xocant d'un músic, virtuós en el seu ofici però que, paradoxalment, confon la seva dona amb un barret - narració que dóna el títol a un dels llibres més famosos de Sacks.

Així doncs, quant als filtres aplicats per a la constitució del nostre corpus, tal com hem fet en els CC acadèmics, seleccionem publicacions que tractin temes relacionats amb la salut mental, entesa en un sentit ampli. Ens interessen les publicacions redactades per professionals sanitaris i no per escriptors de fora d'aquest àmbit que agafen alguns CC acadèmics i en fan una història. Hem triat llibres amb diversos casos clínics - un o més per cada capítol- i on s'hi vegi present també la figura de l'autor-narrador, el professional sanitari. Cal remarcar que, tot i que els principals autors i obres han circulat traduïts a un bon grapat de llengües, entre les quals s'inclouen tant el català com el castellà, aquest gènere s'ha desenvolupat d'una manera abassegadorament majoritària en anglès. Així doncs, ens hem centrat en publicacions en aquesta llengua, en la qual aquest gènere està ben consolidat, ja sigui per l'àmplia tradició de publicacions mèdiques de divulgació en llengua anglesa com per la influència d'Oliver Sacks mateix. Tots els llibres de contes clínics que hem seleccionat estan disponibles en format electrònic i és aquesta la versió que n'hem fet servir ${ }^{7}$.

\footnotetext{
${ }^{7}$ Com és conegut, la paginació deixa de ser efectiva en aquest format, ja que varia en funció del dispositiu on es visualitza, de la grandària de la lletra i d'altres característiques de presentació en pantalla que pot establir i modificar cada usuari. Per tant, quan en citarem fragments no en donarem la pàgina, sinó únicament la referència del capítol, d'acord amb la codificació que figura en l'annex I d'aquesta tesi doctoral. Quan el context tecnològic $i$ els canvis socials que comporta condueixen a treballar d'una determinada manera - en aquest cas, amb la versió electrònica dels textos-, no té sentit construir a posteriori la ficció que continuem usant-ne la versió en paper, quan no sigui el cas. Per al lector que desitgi contrastar les citacions, l'inconvenient de no disposar del número de pàgina es compensa, amb escreix, amb la disposició, en el format electrònic, de les eines de cerca que permeten localitzar el fragment concret.
} 


\section{CASOS CLÍNICS}

Amb els criteris exposats anteriorment, hem constituït un subcorpus de 115 casos clínics acadèmics en tres llengües (vegeu-ne la llista en l'annex I). La intenció inicial era elegir cinc revistes per cada llengua i seleccionar-ne els vuit casos més recents, és a dir, 40 casos per llengua. Així ho hem fet en els casos de l'anglès i del castellà. En el cas del català hem aplicat un criteri diferent, perquè no hem trobat tantes revistes amb CC en català dels àmbits determinats i que seguissin els nostres criteris. Ja hem comentat que la situació de la llengua catalana en l'àmbit científic i, més concretament, sanitari, no és comparable amb la de l'anglès o el castellà. Així doncs, hem hagut de limitar-nos a 35 casos de tres revistes que encaixen amb el criteris de selecció per al nostre estudi.

La revista o el portal web on es publica el CC influirà molt en la seva forma i contingut, perquè les revistes marquen - algunes amb més rigidesa que altres - els criteris per a poder publicar els casos. No és el mateix publicar un CC en una revista enfocada cap a la recerca que en una de perfil més aviat educatiu. Per això, a continuació presentarem breument les 13 fonts de les quals hem obtingut els nostres textos.

En català hem seleccionat, en primer lloc, la Revista Mèdica Internacional sobre la Síndrome de Down, publicada per la Fundació Catalana Síndrome de Down (FCSD) i indexada en Scopus. Actualment es publica en coedició amb Elsevier i amb versions simultànies també en anglès i en castellà. L'objectiu d'aquesta revista és, per un costat, recollir els coneixements actuals sobre els aspectes mèdics de la síndrome de Down (SD) i, per l'altre, tractar aquells aspectes psicopedagògics que per la seva relació amb el camp mèdic puguin tenir un interès pràctic per a pediatres generalistes $i$ especialistes relacionats amb la síndrome. S'hi publiquen CC pràcticament en tots el números, però no de manera exclusiva. La revista estableix uns criteris de llargària màxima dels CC (8.000 caràcters amb espais inclosos) i també l'estructuració en apartats (resum en català i en anglès, introducció, observació clínica, discussió i bibliografia). Des del punt de vista del nostre estudi, aquesta revista aporta una visió un poc diferent dels CC prototípics, en els quals es tendeix a posar l'èmfasi més en la curació de la malaltia que no pas en el malalt. La finalitat dels casos clínics publicats per aquesta revista no pot ser curar la síndrome de Down - atès que es tracta d'una condició crònica- sinó estudiar com els pacients es veuen afectats per altres problemes relacionats amb la SD. Es tracta 
majoritàriament de CC redactats per professionals que exerceixen als hospitals i altres centres sanitaris de Catalunya.

En segon Iloc, hem triat casos clínics de Neurologia Catalana. Butlletí de la Societat Catalana de Neurologia. Amb molta regularitat, s'hi publiquen casos clínics redactats en català, sobretot en l'apartat «El racó del resident», amb forma d'exercici dividit en diversos números: en un número es presenta un cas clínic sense resoldre; en un número posterior es discuteix el cas per part de residents d'un hospital o d'altres especialistes; finalment, els autors del cas el resolen. D'aquesta manera, el butlletí adopta un enfocament dinàmic i didàctic a l'hora de tractar el CC, ja que es produeix -i es reprodueix - un debat sobre les possibles solucions en el qual participen diversos especialistes. A partir de 2015, el Butlletí inclou també l'apartat «Repte en Neuroimatge», on es presenta una breu exposició clínica i una o diverses neuroimatges que serveixen per plantejar un exercici diagnòstic sobre alguna malaltia. Novament, el diagnòstic es revela al següent butlletí -i també a través d'una newsletter, enviada un mes després de la publicació del repte. En el nostre corpus també hem inclòs quatre d'aquests breus casos clínics visuals.

En tercer lloc, hem seleccionat Desenvolupa: la Revista d'Atenció Precoç, de I'Associació Catalana d'Atenció Precoç. Es tracta d'una publicació en línia que inclou els casos clínics en diversos dels seus números. El seu objectiu és fomentar el diàleg $\mathrm{i}$ l'intercanvi d'idees i experiències entre els professionals de les diferents disciplines que tenen relació amb el desenvolupament infantil i l'atenció precoç. Així doncs, hi trobem CC redactats pels professionals de la psicologia, com també de la logopèdia o la fisioteràpia. Es publiquen amb l'etiqueta «Cas clínic» perquè es puguin distingir dels altres treballs. S'hi accepten treballs tant en català com en castellà, encara que les normes indiquen que "l'idioma oficial de la revista és el català». Només hem pogut seleccionar 5 CC d'aquesta revista que complien amb els criteris que havíem establert. La revista proposa per als CC l'estructura següent: resum (en català o castellà i en anglès), introducció, cas clínic (observació clínica, experiències pràctiques), discussió i referències bibliogràfiques. Curiosament, l'extensió màxima per als CC és la mateixa que per a la resta de publicacions de la revista: unes 20 pàgines, extensió que supera de molt les recomanacions de la majoria de les revistes que publiquen aquest gènere. 
En castellà, hem tingut en compte tres revistes especialitzades i un portal mèdic que inclou una àmplia panòplia d'especialitats. La primera publicació és la Revista de Neurología (neurologia.com), una revista en xarxa, radicada a Barcelona, publicada per Viguera, indexada en Scopus i amb 24 números a l'any. La seva finalitat és fomentar i difondre el coneixement generat en llengua espanyola sobre neurociència, tant clínica com experimental. Regularment hi apareix la secció «Notas clínicas», en la qual es publiquen els CC. Aquests han de tenir els apartats següents: abstract (castellà i anglès), introducció, cas clínic, discussió i bibliografia, amb una extensió màxima de 20.000 caràcters (espais inclosos).

La segona font dels nostres CC en castellà és la Revista Científica de la Sociedad Española de Enfermería Neurológica, amb l'objectiu d'investigar, d'estudiar, de difondre i de desenvolupar la neurologia en l'àmbit de la infermeria, així com també desenvolupar l'atenció i la cura dels pacients neurològics, les seves famílies i els seus entorns. Aquesta revista, indexada en Scopus, ens aporta una visió diferent de la resta, ja que és l'única en el nostre corpus publicada des del punt de vista de la infermeria. Així, aquests CC analitzen l'estat actual del coneixement en aspectes concrets, experiències o intervencions d'infermeria neurològica que siguin de gran interès, no sols de l'àmbit assistencial, sinó també qüestions de contingut docent, d'investigació o de gestió. L'estructura que s'estableix a les normes de la revista és: introducció, desenvolupament, discussió, conclusions, bibliografia i un resum en castellà i anglès, tot plegat amb una extensió màxima de 1.500 paraules.

La tercera publicació en castellà és Adolescere. Revista de Formación Continuada de la Sociedad Española de Medicina de la Adolescencia. Freqüentment s'hi publiquen CC en la secció "Caso clínico» i són de diverses especialitzacions de medicina. Nosaltres $\mathrm{n}^{\prime}$ hem seleccionat els que tenen alguna relació amb la salut mental. Els CC d'aquesta revista destaquen en el nostre corpus per la seva finalitat: millorar l'aprenentatge en el camp de la medicina de l'adolescència. S'hi tracten, entre altres, els problemes psicològics i socials a l'escola, amb els amics o amb la família, la prevenció de les conductes de risc com la violència, els trastorns nutricionals, el consum de tabac, alcohol i altres drogues. És la revista que més se centra en el propòsit de l'aprenentatge. De fet, els CC que conté inclouen al final unes preguntes de tipus test per als lectors i més endavant el solucionari. El CC hi tenen una llargària màxima establerta en deu pàgines i 
una estructura recomanada de: resum, anamnesi, exploració, proves complementàries, evolució clínica, diagnòstic, diagnòstic diferencial i tractament, discussió, tres preguntes de tipus test.

La quarta font dels nostres CC en castellà és el portal PortalesMedicos.com, el qual té registrada una revista electrònica, indexada en Latindex, on es publiquen casos clínics classificats per un total de 39 especialitats. A diferència d'altres revistes en línia, els CC no s'hi publiquen en format PDF, sinó HTML. Nosaltres n'hem seleccionat 8 casos de psiquiatria i 8 de neurologia. Entre les normes de publicació no hi trobem ni l'estructura recomanada ni la llargària màxima.

Pel que fa als casos clínics en anglès, la primera revista que hem triat és Czech and Slovak Neurology and Neurosurgery (CSNN), una publicació indexada en Scopus i amb una llarga tradició. La revista es publica simultàniament en dues versions: una en txec $\mathrm{i}$ eslovac i l'altra en anglès. És, per tant, una revista de matriu txeca i eslovaca però oberta als professionals d'arreu del món, un tret cada cop més comú en la comunitat científica, on l'anglès ja no és la llengua dels anglòfons, sinó la lingua franca. S'hi publiquen habitualment els CC en l'apartat «Case Report». En la versió en línia -la que nosaltres hem utilitzat com a font-, els casos clínics poden tenir una extensió de fins a 3.500 paraules i han d'estar estructurats en apartats, però no s'hi especifica en quins. Cal remarcar que en la versió impresa de la revista, on els CC són acceptats en el format de Letter to the Editor, la llargària màxima permesa és de 1.000 paraules, no poden incloure resum i se'n limiten les referències bibliogràfiques i els annexos. És aquesta una il.lustració paradigmàtica dels avantatges que presenten les publicacions en línia per al desenvolupament d'un gènere com el dels casos clínics, amb un espai tan restringit en les revistes tradicionals.

La nostra segona font en anglès és Case Reports in Neurological Medicine, una revista en línia indexada en DOAJ i publicada per Hindawi, amb base al Caire (Egipte). S'especialitza en els CC centrats en les malalties del sistema nerviós, així com en la funció neurològica anormal. L'estructura que proposen les normes de la revista és: abstract, introducció, presentació del cas, discussió, agraïments, material complementari i referències. No s'hi estableix una llargària màxima.

La tercera font, Case Reports in Psychiatry és del mateix editor que la revista anterior i també està indexada en DOAJ. Així, el format és molt paregut quant als apartats i les 
recomanacions. També es tracta d'una revista que s'especialitza en la publicació dels casos clínics d'una especialitat concreta de la medicina, la psiquiatria, i està oberta a totes les seves àrees. Regularment s'hi publiquen els CC en l'apartat «Case Report».

La quarta font, Frontiers in Psychology, és una revista de recerca en línia, indexada en Scopus, publicada per l'editorial Frontiers Media de Suïssa i dedicada a l'àmbit d'especialització psicològica. Es presenta com un espai interdisciplinari, amb vint-i-vuit seccions segons les diferents subespecialitzacions. Per a la tria dels CC hem emprat la secció «Clinical and Health Psychology». La revista publica diferents tipus de treballs, entre ells també, de manera habitual, els casos clínics, amb l'etiqueta "Case Report». No s'hi proposa l'estructura que han de seguir els autors, sinó la informació que han de contenir els CC: edat, sexe i ocupació del pacient, símptomes, història del pacient i qualsevol informació familiar o social pertinent, resultats clínics rellevants, descripció d'investigacions del laboratori $\mathrm{i}$ de les proves diagnòstiques $\mathrm{i}$ debat sobre la fisiopatologia subjacent i sobre la novetat o la importància del cas presentat. L'extensió màxima són 3.000 paraules i 4 annexos (taules, vídeos...).

Finalment, la cinquena font en línia en anglès ha estat Case Reports in Neurology, una revista publicada per l'editorial suïssa Karger i especialitzada exclusivament en els casos clínics. La revista es presenta com una eina per difondre les experiències dels professionals a un públic més ampli, així com per revisar els casos interessants dels col-legues de tot el món. Quant a les normes, els manuscrits no haurien de tenir més de 2.500 paraules i no s'hi proposen els apartats del text.

Així doncs, el nostre corpus de CC acadèmics està compost per 115 textos en les tres llengües que ens ocupen - català, castellà i anglès-, provinents de 13 revistes de diversos camps que es dediquen a la salut mental, principalment de la neurologia, la psiquiatria i la psicologia, però també d'àrees més especialitzades com l'atenció precoç, l'adolescència o la síndrome de Down. Els autors són principalment neuròlegs, psiquiatres i psicòlegs, encara que també hi hem inclòs altres professionals de la salut que aborden CC de salut mental, com ara infermers o logopedes.

Per facilitar la consulta i la citació del nostre corpus, hem assignat un codi diferenciat a cadascun dels CC. El codi inclou l'idioma: CAT per al català, ESP per al castellà i ENG per a l'anglès. Inclou també un nombre d'identificació específic per a cada text dins del 
conjunt del mateix idioma. Incorpora, finalment, una etiqueta que permet identificar la revista i l'especialitat a les quals pertany. Així, per exemple, el codi 11.CAT_Neurologia ens indica que es tracta del CC en català número onze del nostre corpus i que prové de la revista Neurologia Catalana. En canvi, el codi 16.ENG_Neurology_B fa referència al CC número setze del corpus en anglès i pertany a Case Reports in Neurological Medicine, que és la segona (lletra B) revista de neurologia que hem usat en aquesta llengua. La relació completa de codis i CC es pot consultar en l'annex I i les referències bibliogràfiques detallades en I'annex II.

No és infreqüent trobar errades ortogràfiques, de puntuació, de concordança i, fins i tot, de redacció en el nostre corpus, especialment en els CC acadèmics. En les nostres citacions dels fragments, hem optat per no marcar sistemàticament aquests errors, per no focalitzar l'atenció en un aspecte que seria marginal en la majoria dels casos. Només els marquem en aquelles ocasions en què l'error mateix és l'objecte d'exemplificació.

\section{CONTES CLÍNICS}

En els darrers anys han aparegut nombroses obres que adscriuríem al gènere dels casos clínics literaturitzats o contes clínics. El nostre corpus consta de quatre llibres, amb els quals esperem cobrir un espectre ampli d'estils i d'especialitats dins l'àmbit de la salut mental. No podia faltar-hi, en primer lloc, Oliver Sacks, amb l'obra que considerem més representativa dels contes clínics: The Man Who Mistook His Wife for a Hat and Other Clinical Tales (1987a [1985]) ${ }^{8}$. Estem davant un text produït per un neuròleg i que aborda situacions dels pacients, però el títol mateix ja indica un canvi de perspectiva, una vocació literària. Es basa en un cas real de la praxi mèdica de l'autor, però amb la seva formulació resulta desconcertant per al lector, i alhora invitant, com el títol d'un conte. Tranquil·lament es podria tractar d'un relat de ficció qualsevol. Aquesta «técnica de titulación constituye un reclamo publicitario propio de la literatura» (Salvador, 2015a: 12). En aquesta obra trobem 24 contes clínics organitzats en quatre seccions. Les

\footnotetext{
${ }^{8}$ Traduït al català, entre moltes altres llengües: L'home que va confondre la seva dona amb un barret (Sacks, 1999).
} 
històries varien en extensió, però no acostumen a ser gaire llargues. Sacks sol començar bé presentant el pacient, bé explicant alguna qüestió sobre la malaltia o els símptomes que patirà. A continuació continua narrant la història — sovint amb molts diàlegs entre ell i el pacient - i sol tancar el cas amb un apartat de postscript. Sacks s'hi presenta com un metge savi i empàtic que vol escoltar els seus pacients i ajudar-los, tot contribuint a la humanització de la neurologia. Els contes no estalvien recursos retòrics per captivar els lectors i per assegurar que, malgrat que es tracti de temes especialitzats, els podrà entendre un públic general.

En segon lloc, hem seleccionat un Ilibre del neuròleg Allan Ropper i del matemàtic especialitzat en estadística neurològica- Brian David Burrell. Reaching Down the Rabbit Hole: Extraordinary Journeys into the Human Brain (2014) pretén continuar amb la tradició establerta per Sacks d'explorar la complexa relació entre el cervell i el comportament mental i físic. Els autors són també seguidors de la medicina centrada en la persona i no sols a analitzar els resultats de les proves. Així, en el llibre, quan Ropper orienta uns quants metges en pràctiques o que estan començant la seva carrera, sovint els recomana que s'allunyin del monitor, entrin a l'habitació, s'asseguin al llit, parlin amb el pacient i, així, examinin la persona en lloc dels píxels:

(1) After the bedside visit, the thrombosis suddenly has a name, the glioma has a wife and children, the hydrocephalus writes a column for a well-known business journal. Our coed suffering from psychosis turned out to be a Rhodes Scholarship candidate, the case of multiple strokes became a charming woman who had competed in the Junior Olympics, and the man for whom a smile was a troubling symptom owned a personal empire of six Verizon wireless stores.

(1.LIT_Ropper)

Qualsevol llibre que narri històries de l'àmbit de la neurologia sempre haurà d'enfrontar-se al risc de la comparació amb el gran referent que és Oliver Sacks. Ho podem comprovar en quasi totes les ressenyes de l'obra de Ropper i Burrell, on els acaraments amb Sacks són quasi omnipresents i, en bona part dels casos, amb la conclusió esperable que el Ilibre no assoleix el nivell d'Oliver Sacks. Un dels aspectes criticats és el retrat d'un neuròleg i mestre (Ropper) extraordinàriament talentós, que 
en cada moment és el més savi de la sala. Efectivament, en molts dels contes, Ropper apareix com l'heroi que ho resol tot: «It's too carefully written to be crassly boastful, but it's not exactly an essay in professional humility» (Anthony, 2015). Per als objectius del nostre treball, tanmateix, presenta més interès una obra que, tot i inscriure's en la tradició de Sacks, manifesta característiques diferents del paradigma establert per aquell autor. En el cas que ens ocupa, relacionem aquesta particularitat retòrica -o deficiència, si es vol- amb les peculiaritats de l'autoria plural del text. Ropper és un neuròleg distingit a l'Harvard Medical School i en la seva praxi ha vist casos molt peculiars, però, segons Anthony (2015), qui contaria les històries seria Burrell, atès que ell «is the prose man, turning Ropper's professional stories into tight little homilies of neurological and existential meaning».

Aquest llibre conté 13 capítols, però les històries vitals en són més, ja que un conte sovint inclou més d'un pacient. El narrador va Iligant històries que d'alguna manera es relacionen entre si, tant si és pel que pateixen els pacients com perquè estan simultàniament a l'hospital de Ropper. Aquí doncs, a diferència de Sacks, no es tracta d'històries independents que s'agrupen en un volum, sinó que la narració presenta un encadenament $d$ 'històries.

La primera part del títol del llibre - Reaching Down the Rabbit Hole- va en la línia de Sacks de distanciar-se de títols merament descriptius i de buscar-ne un de literari que atragui l'atenció del públic general pel seu to no especialitzat i per la seva absurditat. En veure la portada del llibre, ens hem de preguntar què té a veure el cau d'un conill amb els viatges extraordinaris al cervell humà (Extraordinary Journeys into the Human Brain). La connexió l'expliquen els autors: el títol fa referència al llibre Alícia al país de les meravelles. Segons Ropper i Burrell, l'obra de Carroll «is an absurdistan story. Beyond fantasy, it's ridiculous. That's neurology in a nutshell. Your patient disappears down a rabbit hole. You've got to do something. You can't just sit there, so you go down the hole after the patient» (1.LIT_Ropper). Per treballar, el doctor Ropper s'endinsa en un lloc on abunden les absurditats, de la mateixa manera com Alícia, en saltar al cau del conill, es troba en un regne estrafolari, on tot té escassa ressemblança amb el món exterior. Al país de les meravelles, la Reina Vermella afirma creure sis coses impossibles abans de desdejunar. Ropper, però, no ho necessita perquè sap que cada dia es trobarà amb sis coses improbables abans de dinar (1.LIT_Ropper). 
En tercer Iloc, hem triat un llibre de contes clínics sobre psicoteràpia: Love's Executioner and Other Tales of Psychotherapy (2013 [1989]), d'Irvin D. Yalom, professor de psiquiatria a la Facultat de Medicina de la Universitat de Stanford. D'aquesta manera, introduïm diversitat d'enfocaments dins de la salut mental. La neurosi i el seu tractament sempre han estat una font de material irresistible per a la narrativa i el drama. Als humans ens inquieten - $\mathrm{i}$ ens atreuen- els reptes que planteja la comprensió de la irracionalitat. Per això també les històries dels casos, com els de Freud, s'han pogut igualar i comparar amb les millors novel-les del segle XIX. Yalom ens demostra que aquest material, recopilat en la seva consulta terapèutica, si es conta bé, pot tenir un gran interès per al públic general.

El llibre ens presenta novament un títol amb una primera part més aviat literària Love's Executioner - i una segona part que reforça el paral-lelisme amb el d'Oliver Sacks: and Other Tales of Psychotherapy. Si comparem aquest llibre de psicoteràpia amb els dos anteriors - de neurologia-, veurem que aquí el pacient té molt més espai i se li dóna més veu a l'hora de narrar els seus problemes. També cal dir que la naturalesa d'aquesta disciplina ho requereix. Aquest llibre, malgrat que s'hagi publicat ja fa uns anys (1989), continua sent un testimoni i una font d'informació rellevant que mostra a un públic general la utilitat de la psicoteràpia en una època en què la medicalització i els tractaments pseudo-alternatius són cada vegada més presents i abundants.

Trobem en el llibre deu relats absorbents, en els quals el psicoterapeuta ens narra els problemes que pateixen els seus pacients. Podem així conèixer-ne els desitjos i les motivacions personals. Però l'autor ens deixa entreveure també la seva lluita personal per reconciliar la manera de tractar el pacient com a psiquiatre amb una resposta més humana. Precisament, dissipar el mite del terapeuta omnipotent i objectiu és una de les finalitats d'aquest llibre - com manifesta Yalom en la introducció. Per això, s'insereix a si mateix en les narracions i ens comenta les seves reaccions amb els pacients, els canvis d'opinió, les seves inseguretats i, fins i tot, hi reconeix els seus errors - una gran diferència amb el llibre anterior, Reaching Down the Rabbit Hole. Així, en el llibre sovint apareixen els seus pensaments o el que voldria dir durant la psicoteràpia, però que no pot expressar per la necessitat de mantenir la distància emocional i, sobretot, la professionalitat: 
(2) Though I had difficulty imagining this shabby old woman having an affair with her therapist, I had said nothing about not believing her. In fact, I had said nothing at all. I had tried to maintain complete objectivity but she must have noticed some evidence of disbelief, some small cue, perhaps a minuscule widening of my eyes.

$$
\text { (1.LIT_Yalom) }
$$

El mite del terapeuta objectiu, Yalom el trenca també amb el reconeixement que no li cauen igual de bé tots els seus pacients. En la psicoteràpia, és més important que enlloc que els pacients estiguin a gust amb el seu metge per poder obrir-s'hi. Malgrat que aquest ha de ser un dels objectius dels terapeutes, i per més entrenats que estiguin per resoldre i reaccionar en situacions crítiques, no deixen de ser persones com tots nosaltres. El doctor Yalom ens ho intenta demostrar, potser amb una honestedat exagerada, per aconseguir trencar tota la idealització que puguem tenir dels psicoterapeutes. Així, veiem en un dels contes clínics, The fat lady, la seva aversió cap a una pacient obesa, ja que troba el seu cos tan repulsiu que li costa, fins i tot, mirar-la:

(3) The day Betty entered my office, the instant I saw her steering her ponderous twohundred-fifty-pound, five-foot-two-inch frame toward my trim, high-tech office chair, I knew that a great trial of countertransference was in store for me.

I have always been repelled by fat women. I find them disgusting: their absurd sidewise waddle, their absence of body contour, breasts, laps, buttocks, shoulders, jawlines, cheekbones, everything, everything I like to see in a woman, obscured in an avalanche of flesh. And I hate their clothes, the shapeless, baggy dresses or, worse, the stiff elephantine blue jeans with the barrel thighs. How dare they impose that body on the rest of us?

$$
[\ldots]
$$

But when I see a fat lady eat, I move down a couple of rungs on the ladder of human understanding. I want to tear the food away. To push her face into the ice cream. "Stop stuffing yourself! Haven't you had enough, for Chrissakes?," I'd like to wire her jaws shut!

Poor Betty, thank God, thank God, knew none of this as she innocently continued her course toward my chair, slowly lowered her body, arranged her folds and, with her feet not quite reaching the floor, looked up at me expectantly.

$$
\text { (4.LIT_Yalom) }
$$


És comprensible que els professionals de la salut tinguin uns pacients amb els quals simpatitzin més que amb altres. Però explicitar-ho en la praxi clínica és, òbviament, un gran tabú, sobretot per escrit i en un context formal. En un cas clínic acadèmic, seria impensable manifestar una opinió subjectiva, sobretot si és negativa, sobre un pacient -tot i que, com veurem en aquest treball, de vegades els textos aparentment més asèptics traspuen aquesta subjectivitat. En la comunicació oral, tanmateix, és molt més habitual que els professionals sanitaris es comentin entre ells quin pacient els molesta i per quines raons. Així, sovint es creen sobrenoms, algunes vegades bastant desagradables $\mathrm{i}$ deshumanitzadors, amb els quals es refereixen als seus pacients. Paradoxalment, quan ens apartem de la fredor del tecnolecte, no sempre acabem en una major humanització, sinó de vegades en la degradació dels pacients (vegeu el subapartat 4.2 del capítol IV).

El quart i darrer llibre seleccionat és Stuff: Compulsive Hoarding and the Meaning of Things (2010), de Randy Frost, professor de psicologia al Smith College (Massachusetts), i de Gail Steketee, professora a l'Escola de Treball Social de la Universitat de Boston. Seleccionem aquest text perquè es pot inscriure en la línia de contes clínics que ens ocupa, però està escrit per un psicòleg i per una sociòloga de formació que s'han especialitzat en l'atenció psicològica clínica. Incloem en el corpus, doncs, un altre text de salut mental que no prové de la neurologia. Frost i Steketee van ser pioners estudiant la síndrome d'acumulació compulsiva (SAC) quan van començar el seu treball, quinze anys abans de la publicació del llibre. Esperaven trobar-ne uns quants malalts, però van acabar tractant centenars de pacients. Van descobrir que aquesta malaltia estava molt més present en la nostra societat del que es pensava (entre el 2 \% i el 5 \%). Frost explica que la idea de dedicar-se a aquesta malaltia va nàixer a partir de l'interès d'una alumna seva a la universitat, amb la qual començà a dedicar-s'hi. Van constatar que hi havia molta recerca feta o en curs sobre els diferents trastorns obsessivocompulsius, com ara la por patològica de la contaminació o la neteja compulsiva, però molt poca sobre l'acumulació compulsiva. Més tard, quan l'alumna va continuar la seva carrera en una altra direcció, Frost començà a col·laborar amb la doctora Steketee, la coautora del llibre. 
Per tant, al contrari del que trobem en altres llibres de contes clínics, aquí estem davant d'unes històries en les quals els professionals no estan mirant d'escatir què afecta els seus pacients, perquè tots pateixen la mateixa síndrome: l'acumulació compulsiva. La seva recerca consisteix a esbrinar quines en són les característiques més habituals, què la pot provocar. Com que es tracta d'un text obert a tothom, els autors ens aproximen a la vida i als drames que han de suportar dia rere dia aquestes persones i els seus familiars i amics. En contra dels prejudicis més estesos, ens ensenyen que no és una malaltia específica d'individus que viuen d'esquena a la societat ni de persones poc intel-ligents o incultes.

Una altra diferència és que les descripcions són molt més presents en aquest text, ja que els investigadors ens recreen les cases dels afectats (exemple 4). És fonamental analitzar quins objectes acumulen, quina és la seva relació amb ells, de quina manera els aconsegueixen, etc. Aquests habitatges sovint estan tan atapeïts que només hi queden estretíssims passadissos entre columnes i més columnes formades per andròmines que els propietaris habitualment no els deixen tocar.

(4) By then, her home was nearly uninhabitable. The entry hallway and first-floor landing were full of children's clothing and toys, shoes, decorations for various holidays, books, Sunday school papers, and lesson plans from her teaching years. Just as we've seen in so many homes, ineffective efforts to organize were evident in the innumerable empty plastic bins and lids stacked elsewhere. The living room and adjacent dining area were waist-high with clutter of a similar sort-lots of clothes and shoes, plus place mats and table decorations, random papers, and assorted knickknacks. The stairwell contained more plastic containers and covers, cascades of newspapers and magazines, and more clothes and shoes. The bedrooms ranged from waist-to ceiling-high mountains of mostly clothes and shoes. The children could still sleep in their beds, but barely.

$$
\text { (4.LIT_Frost) }
$$

Les narracions són potents i ens desvelen o insinuen el passat, sovint traumàtic, dels acumuladors. Tot plegat fa que les vides d'aquests malalts semblen adients per convertir-les en una història que atrapa l'interès dels lectors. Per caracteritzar aquest trastorn, Frost i Steketee trien una pacient, anomenada Irene en el llibre, que ells consideren un cas prototípic. La casa d'Irene està plena de coses aparentment 
aleatòries: periòdics, caixes de cereals buides, jocs infantils o cupons caducats. El seu marit ja no ho ha pogut suportar i se n'ha anat de casa. Irene contacta amb els dos investigadors per buscar ajuda pressionada per la por que el marit demani la custòdia dels fills:

(5) Irene was fifty-three and had just separated from her husband. She had two children, a thirteen-year-old daughter who was away at boarding school and a nine-year-old son who lived at home. Irene worked part-time as a sales associate for a real estate company. She had lived in her house for more than twenty years. Her husband, an engineer, had been after her for years to get rid of the clutter, which waxed and waned but never went away. Finally, he told her to clean it up or he would leave. She couldn't, so he did. Now she was worried that she would lose her children in the upcoming divorce.

(A.LIT_Frost)

El llibre conté 13 capítols i la majoria són històries de diversos pacients. Com en altres llibres del nostre corpus, aquí també poden aparèixer en un mateix capítol diversos pacients que tenen alguna mena de Iligam. Irene n'és la principal. Se'n parla ja en el pròleg, després és la primera que visiten i reapareix en tot el llibre com a exemplificació del que s'explica o per contrastar dos pacients... Però també hi ha uns capítols que són més aviat exposicions teòriques. Així doncs, a més de les històries vitals dels acumuladors, que considerem CC literaturitzats, el llibre també inclou apartats dedicats quasi exclusivament a la revisió del que s'ha investigat sobre aquest trastorn i a contrastar-ho amb el que observen els autors. D'aquesta manera, Frost i Steketee intenten generar noves hipòtesis a partir de les novetats descobertes en el treball de camp, amb els malalts en el seu espai, que abans no havien estat descrites.

Així doncs, pel que fa al corpus de CC literaturitzats, hi hem inclòs quatre llibres. En primer Iloc, l'obra de referència ineludible d'Oliver Sacks, que hem de considerar paradigmàtica d'aquest gènere. A aquesta referència afegim tres llibres més, en els quals hem procurat representar diversos estils narratius $\mathrm{i}$, alhora, les tres especialitats principals de l'atenció a les malalties mentals: la neurologia, la psiquiatra i la psicologia clínica. 
En el conjunt dels quatre llibres hi ha un total de 60 capítols. En el cas d'Oliver Sacks, cada capítol coincideix amb un cas clínic - d'una o més persones. En canvi, tal com ja hem avançat, altres autors inclouen algun capítol de caire més teòric sobre alguna malaltia o, de vegades, un mateix pacient apareix en més d'un capítol. És a dir, que no sempre hi ha una coincidència automàtica entre capítol i cas clínic. En qualsevol cas, per facilitar l'orientació dels lectors d'aquest treball, relacionarem tots els capítols dels llibres inclosos en el corpus, independentment de si constitueixen o no un CC literaturitzat complet, i els citarem sempre d'acord amb la taula (annex I). 
CAPÍTOL III.

MARC TEÒRIC: DISCURSOS, GÈNERES I RELATS

1. Discursos especialitzats i discursos literaris

2. El gènere com acció discursiva

3. La narració i el relat

1. DISCURSOS ESPECIALITZATS I DISCURSOS LITERARIS

En reconèixer la rellevància dels coneixements previs tant a l'hora de generar com de comprendre les produccions orals i escrites, l'estudi del discurs s'ha enriquit amb les contribucions de la psicologia i de la ciència cognitiva. Les paraules, els sintagmes, les oracions no són únicament unitats lingüístiques, sinó que pressuposen uns coneixements socioculturals. Sovint s'empra la metàfora de l'iceberg com a il/lustració que només una diminuta part del significat d'un text és visible i explícita, mentre que la major part queda invisible, implícita. Van Dijk (2003) revisa els diferents tipus de coneixement i mostra com aquests tenen un impacte també diferent en el processament i en l'estructura del discurs. Així, la funció del coneixement és particularment rellevant en el cas dels discursos especialitzats, com ara el científic, ja que la seva producció i comprensió depèn de diversos tipus de coneixements especialitzats: 
This is most obvious in the use of technical terminology, but also extends to many other aspects of specialized discourse, such as its preferred topics, overall formats or text-schemas, style, rhetoric (including its typical metaphors), argumentation patterns, methods of proof and demonstration, the use of tables, figures and other non-verbal aspects of discourse, and so on. (Van Dijk, 2003: 22)

Quan delimitem un concepte solem recórrer a les dicotomies. Així sol passar en el cas del discurs especialitzat, el qual sovint es defineix per contrast amb el discurs general, conegut i dominat per tothom. A nosaltres ens interessa fixar-nos més aviat en una dicotomia un poc diferent: la del discurs especialitzat versus el discurs literari. Aquests són els dos tipus de discursos representats en el nostre corpus. Per un costat, tenim els casos clínics com a exemples de discurs especialitzat i, per l'altre, els contes clínics, que se situen en el camp de la literatura però que podem ubicar a la frontera amb el discurs mèdic.

El discurs especialitzat i el literari podrien semblar les dues cares d'una moneda, perquè a primera vista difícilment trobaríem dues maneres d'expressar els pensaments que siguin tan oposades. Ara bé, encara que ambdós discursos tenen les seves peculiaritats, continua tractant-se d'un mateix llenguatge i ni tan sols el discurs científic més prototípic deixa de tenir una dimensió retòrica ben important (Kotátková, 2017). A més, quan ens referim al coneixement científic, hem de recordar que no és un reflex de la naturalesa, sinó la interpretació que en fa la comunitat humana, mitjançant I'instrument racional del llenguatge (Cassany, López i Martí, 2000: 74).

El discurs científic ha estat objecte d'estudi lingüístic, sobretot per descriure'n les característiques en comparació amb el discurs ordinari, mentre que l'atenció al discurs literari s'ha focalitzat en la delimitació del que és literari respecte del que no ho és. Roman Jakobson (1963) va intentar trobar solució a aquesta problemàtica amb la teorització sobre la funció poètica del llenguatge. Els treballs dels formalistes van definir el llenguatge literari com una varietat més o menys autònoma respecte del llenguatge ordinari o pràctic, al qual s'oposa. Després d'haver esgotat les possibilitats per poder delimitar allò literari que oferien els criteris formals, com ara les estructures lingüístiques objectives, altres autors, com per exemple Genette, es van centrar en conceptes com ara la ficcionalitat, inspirada en criteris clàssics i arrelada en la tradició aristotèlica. Ara bé, com bé apunten Maingueneau i Salvador (1995), no queda clar que 
qualsevol discurs que sigui ficcional necessàriament es converteixi en literari ni tampoc que un discurs no ficcional hagi de ser exclòs de la literatura. En el primer cas, els autors mencionen gèneres com ara els horòscops o els acudits, que són jocs de ficció, i en el segon cas els gèneres testimonials o els històrics. També ho podríem aplicar als contes clínics o casos clínics literaturitzats, un gènere òbviament no ficcional que considerem part de la literatura.

Així doncs, ni els criteris formals, ni la ficcionalitat, no resolen satisfactòriament aquesta delimitació. És pertinent, en aquest cas com en altres, aplicar-hi la visió de l'anàlisi del discurs i de la pragmàtica, les quals tenen en compte, a part de les estructures - que sempre són rellevants - també l'ús. Des d'aquest enfocament, «[u]n text assoleix categoria de literari quan és usat com a literatura» (Maingueneau i Salvador, 1995: 199). Els gèneres discursius, literaris o no, són organitzats amb els diferents trets expressius que fan que els membres de la comunitat els puguin reconèixer i classificar. Cal tenir en compte, però, tant les intencions dels autors com les expectatives dels lectors, emmarcades en una societat concreta, en un espai i en un temps determinats, i recordar que, com deia Umberto Eco, «La literatura no és, sinó que esdevé». I així ens trobem, per exemple, amb unes cròniques dictades per Jaume I o escrites per Ramon Muntaner que potser no pretenien ser literàries en origen, però que ara ho han esdevingut.

Entre els discursos especialitzats i científics hem d'ubicar els casos clínics acadèmics, dels quals ens ocupem en aquesta tesi doctoral. Certament, no es tracta d'exemples prototípics del discurs mèdic com ho podrien ser, per exemple, els articles de recerca, perquè presenten trets molt peculiars. De fet, és un objectiu d'aquesta tesi doctoral apuntar aquestes característiques i veure com és que considerem els CC com un tipus de relat. Parem també atenció als CC literaturitzats, normalment catalogats com a textos literaris, però amb elements característics del discurs científic adaptats per als no especialistes, mitjançant recursos propis de la divulgació científica. Es tracta, en definitiva, d'un gènere en la frontera entre el discurs especialitzat i el literari, ja que els contes clínics contenen trets propis de la ciència, sobretot en les seqüències descriptives i expositives, però també de la literatura, atès que les històries es conten «in a strong narrative vein» (Hoffmann, 2006: 406). Els podem definir com un híbrid de casos clínics i contes $i$, per tant, el que hi esperem és que tinguin trets dels dos gèneres $i$, en 
conseqüència, dels dos tipus de discurs. No sempre ens trobem gèneres que representin prototípicament un discurs determinat $i$, de fet, aquestes fronteres o interseccions que s'han creat per la necessitat de catalogar, de separar per iguals o similars, són els camps d'estudi menys estudiats i, des del nostre punt de vista, més atractius.

\subsection{Trets i mites dels discursos especialitzats}

El concepte de 'discurs especialitzat' rep diverses denominacions, com ara llenguatges d'especialitat, llenguatges especialitzats, llenguatges amb finalitats específiques (Cabré, 1992) o més recentment, en el cas de l'anglès, s'utilitza anglès acadèmic i professional. Si atenem a la manera com els diferents estudiosos han mirat de traçar la línia de demarcació entre la llengua especialitzada i la general, podem parlar de dos enfocaments: per un costat tenim els corrents que intenten trobar un tall nítid entre les dues modalitats i, per l'altre, els que hi veuen una gradació. Al capdavall, com en tantes taxonomies que elaborem els humans, el fet que, per motius pràctics, distingim genèricament entre textos especialitzats i no especialitzats no nega que hi hagi textos amb major o menor grau d'especialització. És a dir que, sense negar la utilitat d'usar aquestes categories, en realitat podríem parlar d'un contínuum, com defensen Ciapuscio, Kuguel i Otañi (2005: 105):

Entre los textos especiales y los no especiales puede haber zonas de transición poco nítidas; por lo tanto, es razonable plantear entre los extremos la existencia de un continuum con transiciones $y$, en todo caso, interrogarse acerca de cómo determinar con fundamento lingüístico-textual grados de especialización.

Nosaltres, doncs, parlarem de textos especialitzats i no especialitzats per motius pràctics, però també tindrem molt en compte aquesta gradació, ja que, per exemple, els CC literaturitzats serien molt complicats de classificar només en una casella, sense considerar l'altra, com també podrem trobar elements retòrics característics del llenguatge literari en els $\mathrm{CC}$ acadèmics.

El llenguatge d'especialitat no és possible definir-lo només en termes estrictament lingüístics, sinó que n'hem de tenir en compte també les característiques pragmàtiques 
o extralingüístiques (Alcaraz Varó, 2000; Pérez Hernández, 2000). Des del punt de vista pragmàtic, el llenguatge especialitzat es pot caracteritzar per les variables de temàtica, usuaris i situació de comunicació, les quals, al seu torn, comporten unes peculiaritats lingüístiques i textuals. Mentre que el llenguatge general presenta una variació formal màxima en tos els seus nivells, restringida només pels límits de comprensió dels interlocutors (Montero Martínez, 2003), els Ilenguatges especialitzats es desenvolupen en funció de temàtiques determinades, ja que són especials pel que fa al contingut del discurs, perquè transmeten uns coneixements específics (Sager, 1993: 40).

El discurs especialitzat és, per tant, un tipus de discurs que conté coneixements especialitzats que produeixen uns determinats usuaris, membres de grups d'investigació o de grups professionals, amb la voluntat de progressar i de trobar respostes a les preguntes que generen sistemàticament (Bach i Martí, 2007). Pel que fa als usuaris i a la funció, els llenguatges especialitzats són sistemes semiòtics complexos i, per això, aquests coneixements són generalment fruit d'un aprenentatge conscient en una situació formativa explícita i són els que asseguren que un tema especialitzat sigui tractat com a tal:

solo será especializado si se representa y se transmite respetando escrupulosamente la estructura conceptual del campo en cuestión; ello significa que cada concepto de una disciplina será transmitido sin sobrepasar los límites de sus características, y además salvaguardando las fronteras nítidas existentes entre los conceptos en el contexto de una especialidad. (Cabré i Estopà, 2005: 69)

Els membres de cada comunitat -en el nostre cas, els professionals sanitariscomparteixen els coneixements sobre la seva matèria i aquests constitueixen un conjunt que se sol anomenar sistema conceptual. Aquests coneixements s'oposen al coneixement comú que adquirim al llarg de la nostra vida en l'àmbit familiar, escolar (educació bàsica no especialitzada), a través dels mitjans de comunicació, etc. Els coneixements especialitzats, com ara els de l'àmbit de les ciències de la salut, a més de requerir la formació professional necessària, són coneixements grupals que es desenvolupen en el si de les comunitats discursives i de les comunitats de pràctica: 
it is acquired, shared and used among members of various kinds of scholarly or other specialized communities, defined not only by their specialized knowledge, but also by their specialized social practices, including their specialized discourse and communication, as well as by a complex network of organizations and institutions such as universities, laboratories and associations. (Van Dijk, 2003: 26-27)

Aquestes comunitats tenen entre els seus objectius el d'innovar, és a dir, produir nous coneixements a partir dels preexistents. Al principi, aquests nous coneixements solen estar restringits a l'àmbit especialitzat, però normalment n'hi ha almenys una part que es transfereix i és compartida per altres persones, com ara professors o periodistes, els quals contribueixen a la divulgació d'aquests coneixements especialitzats (Van Dijk, 2003).

Com s'esdevé amb cada tipus de discurs, l'especialitzat segueix unes regles o pautes i acompleix una sèrie de funcions socials. Quant a les pautes, Bach i Martí (2007) descriuen quatre màximes que es poden aplicar al discurs especialitzat: $a$ ) màxima de quantitat: s'hi hauria de donar la quantitat necessària d'informacions, és a dir, ni massa ni poca; b) màxima de qualitat: només s'hi haurien de proporcionar informacions verificades, de cap manera falses; $c$ ) màxima de manera: s'hi ha d'evitar l'ambigüitat i l'obscuritat del lèxic i de les expressions i cal ordenar les informacions; $d$ ) màxima de relació: s'hi hauria de donar només informació rellevant.

El discurs mèdic és un exemple prototípic de discurs especialitzat. De fet, és un dels més coneguts i dels que més interès desperta -i no sols entre els lingüistes. En la cultura popular, el clixé estès clàssicament sobre els professionals sanitaris, sobretot els metges, és que no se'Is entén ni pel lèxic emprat ni per la seva lletra. És una visió arrelada en uns temps en què l'educació mitjana i superior estava a l'abast d'una minoria i on les receptes $\mathrm{i}$ altres documents mèdics que arribaven a les mans dels pacients es feien a mà, amb lletra de metge. Actualment, però, aquesta percepció podria estar canviant, en bona part perquè els profans entrem més fàcilment en contacte amb el llenguatge especialitzat dels professionals sanitaris, sobretot quan busquem en Internet informacions sobre malalties o símptomes que pensem que estem patint o que pateixen els nostres familiars o amics, però també gràcies a la popularització de les sèries i dels programes televisius de contingut mèdic. 
El discurs mèdic presenta un repte per als analistes del discurs, ja que requereix jutjar textos allunyats de la pròpia especialitat primària. En general, incloem un text dins d'un discurs especialitzat si el seu autor és considerat un especialista en la matèria, és a dir, que domina «el sistema conceptual i de relacions del camp corresponent» (vegeu Bach i Martí, 2007: 182). Així, considerem que els CC acadèmics del nostre corpus -i els CC acadèmics en general- pertanyen a un discurs especialitzat, puix que els autors són professionals sanitaris que publiquen en revistes especialitzades, amb una atenció particular al grau d'exactitud en l'expressió i una selecció de recursos lingüístics tant a nivell gramatical, lexicosemàntic com també textual. Aquest tipus de discurs es pot correlacionar amb un registre del llenguatge. Així doncs, com qualsevol tipus de registre, el cientificotècnic en el qual s'inscriuen els CC acadèmics, compta amb una sèrie de trets lingüístics que responen a les exigències de precisió pròpies de la situació comunicativa (Montero Martínez (2003). Resumirem aquestes característiques breument basant-nos, sobretot, en Bach i Martí (2007) i Cabré (1992 i 2003). Distingirem, per tant, tres grans grups de característiques: les lexicosemàntiques, les gramaticals i, finalment, les textuals.

Quant als trets lexicosemàntics, un dels més característics del llenguatge científic prototípic és l'ús de la terminologia. Amb ella, els professionals de cada branca expressen els conceptes que han creat i assumit com a propis (Bach i Martí, 2007). Aquest tecnolecte, és a dir, el lèxic tècnic d'una professió concreta, a més de ser una de les marques més notables de cientificitat, indica la pertinença a una comunitat de professionals i serveix per a la comunicació entre ells (Kotátková, 2017). Així, en els CC acadèmics, esperem trobar molts termes especialitzats, atès que els textos estan pensats per a altres col-legues del mateix àmbit. La terminologia hauria de facilitar la comunicació dins d'una especialitat científica, garantint la univocitat i l'absència tant d'ambigüitat com de polisèmia. Aquesta ha estat la doctrina imperant durant dècades, tot i que, malgrat aquest ideal científic, el llenguatge especialitzat no deixa de ser un tipus de llenguatge humà i, com a tal, no pot evitar la variació (Freixa, 2005: 111).

En el capítol IV veurem de quina manera s'empra la terminologia en els dos tipus de CC del nostre corpus. Observarem com empren el lèxic els autors (professionals sanitaris) i què implica aquest ús de la terminologia des del punt de vista de la pertinença a una comunitat discursiva o de pràctica determinada, tant dels autors com dels lectors. 
Pressuposem, per tant, que la freqüència d'ús de la terminologia i la manera d'emprarla divergirà en funció del públic al qual s'adreci cada text.

Quant als trets gramaticals, la lingüística de corpus permet comparar la presència major o menor de determinades formes i categories gramaticals entre els discursos especialitzats i el discurs general o comú. Els resultats relativitzen alguns mites, com ara que la primera persona del singular no s'empra en el discurs especialitzat (vegeu Cabré, Bach, Castellà i Martí, 2007). Òbviament, depèn molt de quin tipus de text es tracti, ja que hem d'insistir que no considerem el discurs especialitzat com una categoria homogènia, sinó que és un contínuum, en el qual hi ha textos més prototípics, però pot haver-hi textos de transició cap al discurs general. En qualsevol cas, podem avançar que en el nostre corpus de CC acadèmics sí que trobem casos en els quals els autors empren la primera persona del singular:

(1) Estoy hablando de un varón de 29 años, soltero, que sufrió un accidente hace 10 años, siendo diagnosticado de TCE grave y fracturas múltiples.

$[\ldots]$

Su relato autobiográfico motivó mi necesidad de profundizar en el tema en cuestión de vivencias, y decidí embarcarme en conocer cómo se sentía y/o afrontaba la enfermedad nuestro protagonista.

(13.ESP_Enfermería)

Una altra característica gramatical del discurs especialitzat que el distingeix dels altres és la freqüència de l'expansió adjectival dels noms, condicionada per l'afany d'aconseguir la precisió, sovint amb unitats terminològiques formades per un nom seguit d'adjectiu (Cabré, Bach, Castellà i Martí, 2007). El tecnolecte científic ha creat i està creant contínuament nombrosos adjectius relacionals:

(2) La neurofibromatosis de tipo 2 (NF2; OMIM 101000) es un trastorno genético autosómico dominante causado por mutaciones en el gen que codifica la proteína schwannomina, situado en el cromosoma 22q12.2 [1]. La disminución de schwannomina, que funciona como supresor tumoral, condiciona una predisposición para desarrollar tumores de varios tipos en el sistema nervioso central y periférico [24].

(3.ESP_Neurologia_A) 
Per tant, podem dir que els adjectius tenen una funció clau en el tecnolecte científic, especialment en el camp de les ciències de la salut, ja que formen part de les unitats terminològiques polilèxiques. Els adjectius aporten informació específica al nom, la qual serveix per discriminar semànticament el terme respecte de les unitats de la mateixa classe. Estopà (2000) fa una classificació d'adjectius que en l'àmbit de les ciències de la salut poden formar part d'una unitat terminològica polilèxica amb l'estructura més productiva en textos especialitzats: $\left[\mathrm{N}[\mathrm{A}]_{S A d j}\right]_{S N}$. Així, segons els resultats de la seva I'anàlisi, l'adjectiu que es troba dins d'aquesta unitat terminològica sempre té la funció de classificar el nom que complementa. D'aquesta manera, les unitats terminològiques amb l'estructura esmentada sempre són un hipònim de la classe hiperònima que forma el nucli nominal d'aquesta unitat.



Esquema 1: Classificació dels adjectius (Estopà, 2000: 239) 
En l'esquema 1 podem observar que les dues classes d'adjectius -els qualificatius i els relacionals- exerceixen un paper molt rellevant en la terminologia mèdica. Ara bé, si hem de contrastar aquest llenguatge especialitzat, particularment el de l'àmbit de la salut mental, amb el llenguatge general, clarament hi destaca el nombre i la freqüència de les unitats polilèxiques amb un adjectiu relacional. A més, aquestes unitats són les que causen més problemes de comprensió per als no experts.

Quant als trets textuals dels discursos especialitzats, generalment se'n mencionen quatre de bàsics: la sistematicitat en l'estructura; la impersonalitat o objectivitat en l'estil; la concisió en la forma; la precisió en el contingut (Domènech, 2006: 52). Per aproximar-nos a aquests trets, seguim sobretot Bach i Martí (2007), els quals els analitzen, els revisen i hi aporten una visió crítica.

El primer tret mencionat, la sistematicitat, consisteix que el textos responen a una estructura predeterminada, prototípica d'un cert àmbit, i, sovint, amb uns recursos descriptius i argumentatius recurrents. Ara bé, no es tracta d'una característica exclusiva del discurs especialitzat, ja que la podem detectar en molts altres àmbits del discurs general.

El segon tret és la impersonalitat, per la qual l'autor conscientment no vol mostrarse mitjançant els enunciats ni tampoc no vol implicar el receptor -lector- en el seu discurs. Així, es produeix un distanciament entre el que es diu i qui ho diu. L'autor amaga també tota mena de dubtes o emocions sobre el text mateix. En el discurs especialitzat no s'utilitzen únicament les construccions i formes impersonals, però sí que són molt més freqüents que en altres tipus de discursos.

El tercer tret, la concisió, té a veure amb el contingut del missatge que es transmet. En un discurs concís s'omet tot allò que l'autor considera innecessari i que podria causar que ja no sigui clar el sentit del discurs o obscurir les informacions clau que s'intenten transmetre en el missatge.

El quart tret, la precisió, intenta garantir la bona definició del que s'explica, és a dir, evitar tant com sigui possible l'ambigüitat, l'ambivalència i l'equivocitat. Per tant, es tracta de fer coincidir el significat o el valor del que es vol expressar amb les realitats a les quals es vol referir.

Entre aquests quatre trets, els més definitoris o representatius del discurs especialitzat, segons Bach i Martí (2007: 185-192), serien la concisió i la precisió. Podem 
constatar, tanmateix, que aquesta precisió del discurs especialitzat no queda sempre garantida, com ens mostra Morel (2001) en estudiar el llenguatge jurídic: no és inusual que un text legal o un concepte jurídic sigui interpretat de maneres diferents per experts diversos i que s'acabin dictant sentències segons la lectura pròpia que en faci el jutge en qüestió. A més d'aquestes ambigüitats, diversos estudiosos exposen també l'obscuritat d'alguns discursos especialitzats:

pocs científics d'avui, en el moment d'exposar els seus resultats científics, pensen en aquell terme orsià de redactar. La redacció sembla aliena a la ciència, i el científic, en general, es manté a distància, i evita en els seus articles qualsevol tipus de concessió a la forma literària. En els treballs científics, per exemple, en una tesi doctoral, no hi ha cap tipus d'esforç estilístic: el pensament, en el sentit dels resultats d'investigació, s'exposa en estat químicament pur, sense cap ingredient que ajude a la digestió per part del lector. Hi ha un prejudici, tan absurd com inviolable, en l'ús d'una prosa cultivada, on l'adjectivació siga un recurs vàlid per a dotar de profunditat -i de claredat- l'exposició científica. Més aviat sol esdevindre tot el contrari: el text científic és farcit de tecnicismes i de neologismes dubtosos. I sovint ocorre que aquests treballs de doctorat són publicats posteriorment, i es presenten als lectors en el mateix estat que foren concebuts: obscurs i indestriables. (Domínguez, 2001: 186)

El llenguatge especialitzat de diversos sectors no és sempre, doncs, un exemple de claredat ni sovint de precisió. Pensem ara en els textos que acompanyen les assegurances o els préstecs bancaris, entre altres, i que més aviat solen ser models de la manca d'aquests trets. Quant a la terminologia en aquests textos, sovint s'hi empra amb l'objectiu de fer el text més complicat que no pas per evitar l'ambivalència.

$\mathrm{Hi}$ ha unes altres circumstàncies que fan que els discursos dels membres de les comunitats discursives o de pràctica no sempre compleixin amb els trets exposats anteriorment, com ara la pressió per publicar, la qual fa que s'escriguin textos on es repeteixen les idees o que s'aportin fragments innecessaris per omplir l'extensió establerta. Fins i tot el títol d'algun dels articles dedicats al llenguatge de les publicacions mèdiques pot ser indicatiu del problema: Why are medical journals so badly written? (Albert, 2004). A més, també hem de tenir en compte la pressió interna - des de dins de les comunitats - per diferenciar-se respecte de les altres i de la resta de la societat, en general: «La tasca cognitiva que la societat delega als especialistes fa que els seus discursos siguin concisos i precisos, però només en la mesura que els interessos de 
defensa del territori social i cognitiu de cada grup no es vegin afectades» (Bach i Martí, 2007: 192). Així doncs, que un discurs es decanti més per la claredat - tan reivindicada pel discurs científic - o per l'obscuritat - molt present també, com hem vist- depèn molt de cada comunitat de pràctica, ja sigui per la posició que tingui la comunitat en la societat o pel grau de proximitat de la matèria treballada respecte del públic profà.

En l'àmbit de les ciències de la salut i, per tant, en els discourses in health settings, sovint ens trobem que el llenguatge emprat pels professionals sanitaris sí que s'ajusta a la funció de facilitar la comunicació entre els professionals, fins i tot en contextos internacionals, gràcies a una terminologia profusament desenvolupada i força precisa. Ara bé, malgrat que la comunicació entre professionals del mateix àmbit sí que es produeix majoritàriament sense problemes d'intercomprensió, podem observar també que el sistema de la nomenclatura mèdica tampoc no és perfecte. Per començar, la classificació actual de les malalties no és tan sistemàtica com des de fora de la sanitat esperaríem. S’hi barregen malalties que són definides, segons Gutiérrez Rodilla (2005: 139), seguint criteris diferents, d'acord amb les etapes per les quals va passar la medicina del segle XIX: anatomopatològics, fisiopatològics i etiològics.

Un bon exemple de la imperfecció dels tecnicismes mèdics és l'anècdota que recull aquesta mateixa autora sobre un grup d'uròlegs espanyols que, l'any 1989, va intentar dur a terme un estudi de revisió de conjunt d'un tipus concret de tumor renal (López Aramburo et al., 1989). No van ser capaços d'esbrinar quants casos se n'havien publicat, ja que en els textos apareixien almenys amb una vintena de denominacions diferents: quiste multilocular renal, nefroma quístico multilocular benigno, nefroblastoma quístico benigno diferenciado, linfangioma, adenoma quístico, tumor de Wilms poliquístico bien diferenciado, cistoadenoma renal, enfermedad quística segmentaria del riñón, hamartoma quístico, riñón multiquístico parcial segmentario...

En la comunicació entre metge i pacient, d'altra banda, sovint s'esdevé que el tecnolecte no facilita la comunicació, ans al contrari. Una de les situacions més descrites, criticades i analitzades és, sens dubte, quan el professional usa termes massa arcans per a la comprensió del pacient aliè a l'àmbit sanitari i que no necessàriament aporten més precisió, sinó que generen complicació o incomprensió total del malalt - depenent de l'expressió en qüestió i dels coneixements del pacient. Així, presentem un exemple recurrent d'aquesta tecnicització innecessària: 
Sin duda, decir «tengo el estómago revuelto» es bastante inespecífico, tiene poco grado de precisión. Pero ¿qué grado de precisión puede tener el médico cuando le comunica al paciente: «Tiene usted una gastritis»? ¿Es que le ha practicado una biopsia de la mucosa gástrica y ha visto que allí se está desarrollando un proceso inflamatorio, para afirmar, con propiedad, que la tiene? Desde luego que no. (Gutiérrez Rodilla, 2005: 139)

Els CC acadèmics formen part, doncs, d'aquests discursos especialitzats o científics, atès que corresponen a un tipus de textos amb unes característiques específiques, moltes vegades condicionades, per un costat, per garantir l'eficiència de transmissió de la informació entre especialistes d'un mateix àmbit i, per l'altre, per marcar la pertinença a una comunitat de pràctica. Les característiques d'aquest discurs, del qual formen part els CC, poden desvelar informacions rellevants sobre el model actual de la medicina, com també sobre el caràcter de l'educació mèdica, sovint descrits com a neutrals, econòmics i despersonalitzadors (Zabielska, 2014: 68).

En aquest subapartat hem volgut caracteritzar els discursos especialitzats, veure'n alguns dels trets generals i relativitzar els mites sobre la seva perfecció i precisió, ja que, com tot tipus de discurs, els especialitzats, fins i tot el mèdic, presenten les seves incoherències i ambigüitats. Òbviament, en tenen menys que altres tipus de discursos, puix que una de les seves característiques és que intenten defugir-les, però no sempre amb èxit. De vegades, un llenguatge massa tècnic pot fer més mal que bé per a l'èxit comunicatiu, particularment en la interacció entre els professionals sanitaris i els pacients.

\subsection{La divulgació científica i els casos clínics literaturitzats}

En aquest capítol ens hem referit tant als discursos especialitzats i científics com als discursos literaris i hem apuntat algunes notes sobre la relació que hi tenen els dos tipus de CC. Ens interessa també entendre com es transformen les experiències clíniques reals en contes clínics, revisar de quina manera el discurs literari guanya terreny al científic en els CC literaturitzats. Els trets propis dels dos tipus de discursos hi són presents, en proporcions variables. Els CC literaturitzats continuen sent textos que tracten una temàtica especialitzada, per la qual cosa mantenen molts elements característics del 
discurs científic. Per un altre costat, però, el que motiva aquest trànsit cap al discurs literari que trobem en els contes clínics és la transformació dels objectius principals dels textos: transmetre uns continguts, inicialment especialitzats, a un públic molt variat, sovint no especialitzat, el qual caldrà atreure i aconseguir que s'emocioni amb la lectura. Òbviament, per emocionar-s'hi caldrà que els lectors entenguin bé el relat.

En convertir una sèrie d'experiències clíniques en llibres amb contes clínics, els autors poden tenir intencions molt diverses, però sempre han de seguir els processos de traduir els seus coneixements a un llenguatge accessible no sols als especialistes sanitaris. Per això, en aquest subapartat ens acostarem a les característiques bàsiques de la divulgació científica. Ens centrarem, sobretot, en la desterminologització, és a dir, en el procés de transformació o d'adaptació de determinades unitats lèxiques o termes perquè siguin accessibles a destinataris aliens a l'àmbit especialitzat en qüestió. Així doncs, mirarem d'esbrinar de quina manera els autors de contes clínics troben l'equilibri entre un discurs de base científica i una narrativa adreçada a un públic ampli.

La divulgació científica, és a dir, l'apropament de coneixements especialitzats al públic general, pot estar redactada tant per escriptors professionals que s'encarreguen d'aquesta adaptació i traducció del coneixement científic com, directament, pels científics mateixos. Algunes d'aquestes obres han triomfat en el mercat i s'han convertit en best-sellers, com és el cas del llibre Incognito: The Secret Lives of the Brain (2011), de David Eagleman -el qual va aparèixer en la llista del New York Times dels èxits més grans en vendes de la literatura de no-ficció-, o l'obra Descartes' Error: Emotion, Reason and the Human Brain (1994), d'Antonio Damasio, o també tot un clàssic com els casos clínics literaturitzats del neuròleg Oliver Sacks, entre els quals no podem deixar d'esmentar el seu llibre més conegut -i que, com hem vist, forma part del nostre corpus - The Man Who Mistook His Wife for a Hat: and Other Clinical Tales (1987a).

Els contes clínics del nostre corpus han estat redactats directament per professionals sanitaris amb una llarga trajectòria professional darrere. Cal dir que, en el cas d'aquest gènere, majoritàriament és així. Els autors dels llibres amb contes clínics solen ser metges que narren anècdotes de la seva praxi clínica i que hi aporten la seva visió personal, sovint amb una forta presència d'emocions que havien d'ometre quan publicaven els CC acadèmics en revistes de les ciències de la salut. Les històries que ens presenten sovint són tan peculiars que fins i tot - fent vàlid el tòpic- superen la ficció 
literària. Al llarg dels apartats 3 i 4 del capítol IV d'aquesta tesi doctoral estudiarem, doncs, com els professionals sanitaris es posen en la pell d'un escriptor, d'un narrador, ja que no seria suficient exposar les dades i els fets mèdics, com acostumen a fer en els informes, sinó que els han de transformar en textos literaris comprensibles i interessants per a tothom (Kotátková, 2017).

Els professionals sanitaris que han escrit els contes clínics que hem seleccionat no han començat a publicar llibres abans d'assolir un reconeixement en el seu àmbit professional. Així doncs, han passat per una formació especialitzada i pertanyen a les seves corresponents comunitats de pràctica. Tot això els ha instil.lat unes maneres específiques de redactar i d'expressar-se, i no únicament quant a les formes lingüístiques, sinó també als continguts. Aquests especialistes acostumats als seus gèneres professionals, amb les seves normes externes i internes, amb els seus hàbits sobre com cal proporcionar les informacions, sobre com s'han de veure i tractar els pacients, amb les restriccions d'estil pròpies del seu àmbit, han de fer ara un exercici extraordinari per adaptar-se a un altre món d'escriptura. Tanmateix, pensem que els professionals sanitaris que decideixen transformar la seva experiència científica o professional per convertir-se en escriptors adreçats a un públic general ho fan perquè deuen tenir una relació més estreta, vocacional, amb la literatura, ja sigui perquè hi tenen un do o perquè és el seu lleure.

Així, per tal que aquests escriptors puguin fer accessibles als llecs els seus coneixements especialitzats, xifrats amb recursos lingüístics propis del discurs científic, cal que en transformin divulgativament les xarxes conceptuals, és a dir, que en reelaborin les dades amb altres procediments expressius (Cassany, López i Martí, 2000: 78). Els CC literaturitzats no són l'exemple arquetípic de la divulgació científica, malgrat que també solen fer aquesta funció i en segueixen moltes de les característiques que faciliten la transmissió del coneixement als no iniciats en el discurs d'un àmbit determinat. Els exemples més prototípics de la divulgació podrien ser, d'una banda, els articles de premsa -en els quals els periodistes intenten aproximar els lectors a alguna novetat científica- o, d'altra banda, el material docent dels mestres de les escoles o instituts - en els quals cal condensar tot un corpus de coneixements i adaptar-lo al nivell educatiu corresponent. Cassany, López i Martí (2000) han desenvolupat un esquema (2) 
que representa el procés de transformació del coneixement científic que es verifica en els textos de divulgació prototípics.

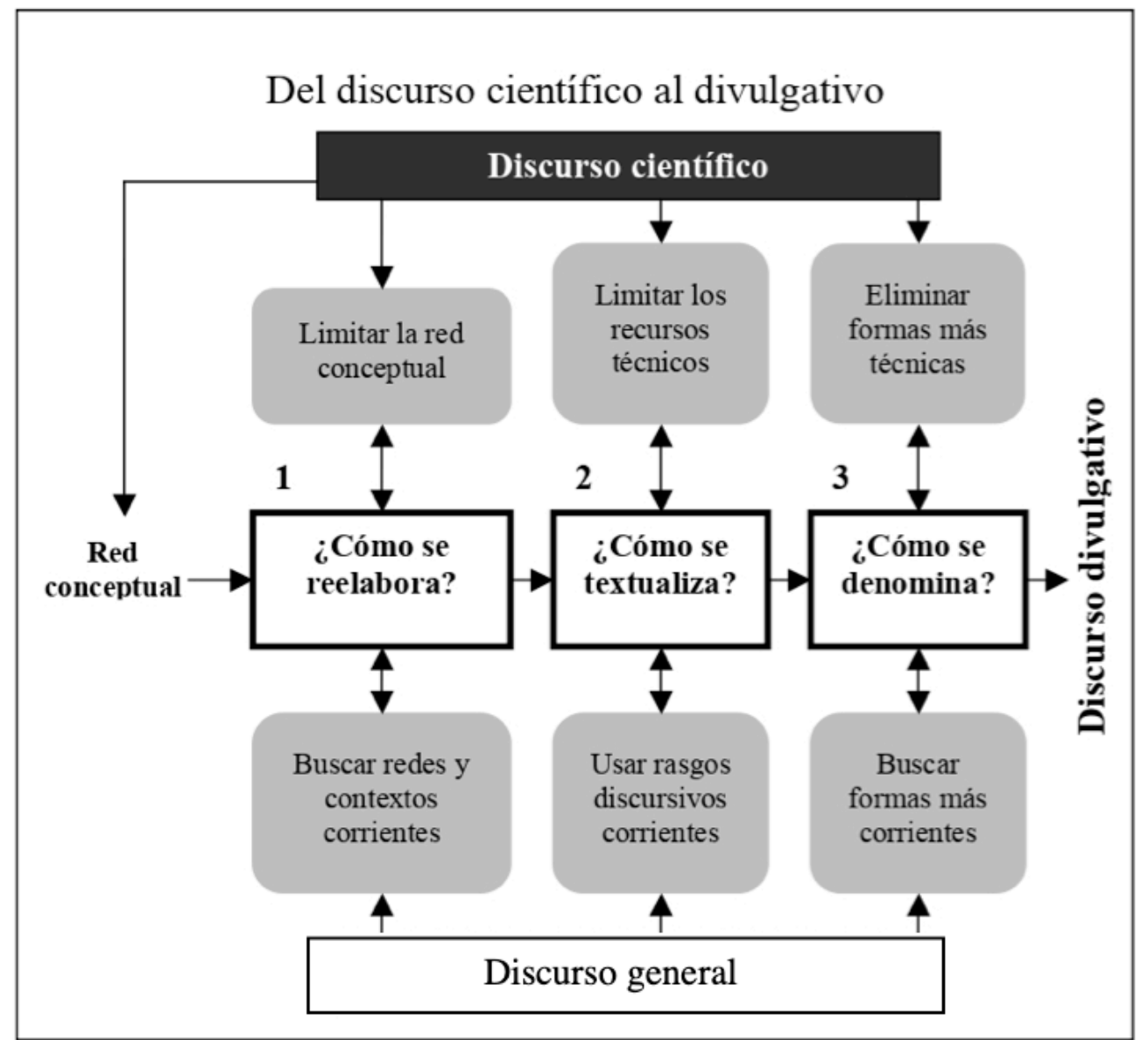

Esquema 2: Procés de transformació del coneixement científic (Cassany, López i Martí, 2000: 79)

Podem observar-hi de quina manera els textos formulats en el registre especialitzat de cada disciplina es transformen per donar forma al discurs divulgatiu, al qual poden accedir públics heterogenis. El discurs científic, objecte de divulgació, hi aporta els coneixements i recursos lingüístics especialitzats, mentre que el discurs general és el marc de referència en el qual podem situar els receptors meta. Així doncs, aquests autors plantegen que hi ha tres procediments bàsics i necessaris que se segueixen a I'hora de processar la informació científica procedent del discurs especialitzat per convertir-la en la divulgació científica accessible per a lectors molt heterogenis: reelaborar, textualitzar i denominar. 
El primer procediment, la reelaboració de la xarxa conceptual del coneixement científic es basa a seleccionar només la informació rellevant que es vol transmetre. Així hi ha, per un costat, continguts que el divulgador elimina i, per l'altre, informacions noves que cal afegir per vincular els coneixements científics amb els no especialitzats del discurs general que el lector suposadament coneix. Cassany, López i Martí (2000: 86) anomenen aquests vincles extradisciplinaris com la porta d'accés que serveix als no experts en la matèria per poder entrar en la xarxa conceptual especialitzada, ja que fan de connector entre els dos mons: l'especialitzat científic i el del saber general. Mentre que la reelaboració se centra més aviat en el contingut, les altres dues operacions tenen a veure amb la forma de presentar el text.

El segon procediment, la textualització, es basa en l'elecció del mode del discurs. En el discurs especialitzat prevalen alguns trets generals, com ara l'ús de les definicions (Salvador, 2009), descripcions i exemplificacions o la restricció del paradigma verbal (és molt menys freqüent l'ús de la 1 a i de la 2 a persona, malgrat que no és inexistent tampoc, com hem vist en el subapartat anterior). En canvi, en el discurs general s'acostumen a emprar més les seqüències narratives o formes plurigestionades, com ara la conversa o el diàleg, entre altres. Així doncs, Cassany, López i Martí (2000) remarquen que els recursos expressius que s'empren en la textualització són el resultat de la negociació entre tres forces: els dos discursos (el general i el científic) i el gènere de sortida al qual s'adapta el text.

Finalment, el tercer procediment, la denominació de conceptes, consisteix a triar unes formes lingüístiques concretes. El que diferencia la textualització de la denominació és que la primera s'aplica a l'àmbit textual —i, per tant, global — i la segona al local, com ara als termes, les expressions, etc. Aquestes estratègies, per tant, són «indicadores de que se toman en consideración lectores más alejados del núcleo de la comunidad discursiva profesional y, en consecuencia, se tiende a reducir la opacidad de discurso» (Salvador, Macián i Marín, 2013: 84).

Tanmateix, aquesta dicotomia entre el discurs científic i la divulgació científica no s’ha d'entendre com una oposició total o absoluta. Al cap i a la fi, és la mateixa llengua, encara que cadascun dels discursos tingui les seves peculiaritats. La divulgació no sempre té el mateix objectiu: algunes vegades es fa una adaptació per a un públic amb més coneixements especialitzats, algunes altres amb menys. Pensem ara en revistes de 
divulgació científica, però amb un públic vinculat amb l'àmbit acadèmic, en les quals, per exemple, un professor de genètica pot redactar un text pensant en collegues d'altres àmbits no gaire pròxims, com ara l'arqueologia o l'economia. Com que el públic no està conformat per biòlegs, però sí per persones amb especialitzacions variades i amb un nivell d'instrucció molt alt, el text resultant no pot ser el mateix que si es concebés per a alumnes d'institut. A més, un tret molt definitori dels textos científics com és la terminologia també continua present en els textos de divulgació. Òbviament, el tractament que se li donarà serà diferent, ja que no s'hi pressuposarà que tots els lectors tenen un coneixement compartit sobre un tema en concret, però sovint apareixeran conceptes clau de cada disciplina o àmbit, perquè així aquest lèxic pot començar a penetrar el llenguatge general, en el fenomen conegut com desterminologització (vegeu el subapartat 3.4 del capítol IV).

Així, trobem molts termes que s'han desterminologitzat i, malgrat que al principi només els empraven els experts de la matèria en qüestió, avui dia ja formen part del cabal lèxic d'una part significativa del públic general. Certament, hi ha àmbits, com ara la nutrició o la cosmètica, en els quals podem trobar més lèxic especialitzat desterminologitzat - sovint i dissortadament, més en benefici d'objectius comercials que no pas d'una millor comprensió ${ }^{9}$. Pensem en tots els anuncis que ens intenten convèncer que el seu producte és millor per al nostre cos, més saludable... ja sigui perquè conté col/lagen, o àcids grassos omega-3, o L-carnitina, o perquè no conté radicals lliures, o colesterol, o greixos saturats, o gluten, o lactosa. Freixa, Solé i Cabré (1998), en un estudi de descripció quantitativa dels neologismes documentats durant l'any 1995 a la premsa en català, constaten que la desterminologització és un recurs molt freqüent i que intervé en el canvi de significat dels neologismes. Com podem veure, hi ha unes àrees temàtiques on es desterminologitza més que en altres:

- tècnica: autoexcitació, cibernètic, desactivar, desactivat, escombratge, minadora, rodatge, quiratar, laminar

- medicina: dosificar, drenar, enquistar-se, menopàusic, radiografiar, ronyonera, vomitori

\footnotetext{
${ }^{9}$ Per referir-se al sentit de pèrdua de valor terminològic, sovint s’empra també el gal-licisme banalització.
} 
- esport: desmarcar-se, fitxatge, pes pesant, tàndem, torejar, tot terreny

- geologia: erosió, erosionar, filó, ignició, juràssic, laminació

- física: per defecte, sedimentar, sideral, sobresaturació, tonatge

- química: clarificació, lisèrgic, oxigenació, triplet

- món militar: detonador, torpedinar

- economia: liquidació, output

- món cultural: orquestrar, reedició

- aeronàutica: posicionament, posicionar-se

- indústria: en sèrie

- electricitat: elèctric

- matemàtiques: maximització

- geometria: polièdric

- fotografia: positivar

- psicologia: negativisme

- tèxtil: ordit

- alimentació: descremar

- antropologia: endogàmic

- biologia: fagocitar

- música: orquestrar

Taula 1: Àrees temàtiques de desterminologització (Freixa, Solé i Cabré, 1998: 23-24)

En el discurs mèdic, com també en les altres especialitzacions de l'àmbit de la salut mental que estudiem, trobem moltes informacions, referències, estructures i expressions que necessàriament s'han de reformular quan el text s'adreça a un públic general. Això haurà de produir-se també a l'hora de publicar casos clínics literaturitzats. Així doncs, a partir del que hem exposat en aquest apartat, en el capítol IV de l'anàlisi del corpus estudiarem l'ús de la terminologia en els CC acadèmics (subapartats 3.1 i 3.2) i quines estratègies s'empren en els CC literaturitzats per transformar aquest tecnolecte perquè sigui comprensible fora d'un àmbit tan especialitzat com és el sanitari (subapartats 3.3 i 3.4). Veurem, per tant, si els metges-escriptors dels contes clínics han sabut renunciar - almenys parcialment-a l'ús d'un tecnolecte que, encara que pugui aportar una major precisió, no sempre és un recurs benvingut en el discurs literari, ja que pot resultar distant, aspre, antiliterari i, sobretot, pot provocar incomprensió del missatge que es vol transmetre. No desapareixerà tot el lèxic especialitzat ni totes les 
característiques del discurs especialitzat, però si s'hi empra, haurà d'haver passat per algun o diversos dels procediments que hem descrit anteriorment, pel conjunt de tècniques anomenades democratització del coneixement (Borja, 2013: 125-198).

Veurem, doncs, com es barregen els trets del discurs científic amb el literari en els CC literaturitzats. També exposarem quins són alguns dels trets bàsics dels CC acadèmics, com per exemple les construccions convencionalitzades (subapartat 3.2) i si tenen alguna relació amb la deshumanització del pacient o amb altres problemes o preocupacions de la medicina actual (subapartat 4.3). En paral.lel amb les anàlisis lingüístiques, mirarem sempre de tenir en compte l'enfocament de l'anàlisi del discurs. Per tant, ens interessarà esbrinar per què s'usen aquests recursos i no pas altres, quins són els propòsits comunicatius dels autors i, òbviament, quina influència poden exercir en els lectors.

\section{EL GÈNERE COM ACCIÓ DISCURSIVA}

Els primers sistemes de distinció entre gèneres registrades en la història occidental es remunten a Plató i Aristòtil. Des d'aleshores, el terme gènere s'ha utilitzat intensament en la teoria literària, però també en altres àrees de coneixement com ara la lingüística aplicada, l'anàlisi conversacional, la sociologia del llenguatge, la retòrica, els estudis folklòrics, l'antropologia lingüística o l'etnografia de la comunicació (Paltridge 1997). Inicialment, els textos no literaris, tant si eren orals com escrits, no eren objecte de teoritzacions ni de classificacions explícites. L'interès dels teòrics per estudiar els gèneres no literaris (la conversa, el debat polític...) no es va estendre fins a l'època contemporània. Des del punt de vista de la lingüística actual, el gènere és una construcció discursiva que pot adoptar formes variades i vehicular-se en diverses modalitats (parlada, escrita, digital, etc.), amb convencions establertes i compartides per la comunitat discursiva, amb o sense aspiracions literàries.

Quan sorgeix l'enfocament de l'anàlisi del discurs, òbviament, aquesta orientació aprofita els estudis anteriors fets sobre els gèneres literaris, però, a més, amplia d'una manera fonamental el camp d'aplicació: 
no sols pel conjunt d'objectes d'estudi a considerar, sinó per l'adopció d'una perspectiva més pragmatista, és a dir, que prenia nota dels contextos de producció i de recepció i no es limitava a l'anàlisi dels productes textuals, sinó que incloïa en el seu horitzó epistemològic els processos mitjançant els quals s'articulaven determinades pràctiques socials comunicatives. (Salvador, 2018a: 73)

Bakhtín (1982) és un dels pioners en la incorporació de les dimensions pragmàtiques a la teoria dels gèneres. Per a aquest autor, la llengua es realitza mitjançant els enunciats, tant orals com escrits. Cada esfera de l'ús de la llengua produeix tipus d'enunciats relativament estables, concrets i singulars, que reflecteixen unes condicions específiques quant al contingut, l'estil verbal (recursos lèxics, fraseològics i gramaticals), però també quant a la composició i l'estructuració. El treball de Bakhtín s'ha d'emmarcar en una àmplia reflexió, a principis dels anys vuitanta, dins la qual hi ha la visió àmpliament compartida que els gèneres es conceptualitzen millor segons la intencionalitat o els propòsits - goal-directed, purposive- (Askehave i Swales, 2001). Martin (1984: 25), per exemple, descriu el gènere com «a staged, goal-oriented, purposeful activity in which speakers engage as members of our culture».

Carolyn Miller (1984) aborda els gèneres retòrics des d'una perspectiva pragmàtica i així connecta els esdeveniments comunicatius - allò que podem considerar gèneres discursius - amb l'acció humana. Per a aquesta autora, el gènere s'ha d'entendre a partir de l'acció que s'efectua amb ell i no del tema que tracta o de la forma que adopta el discurs. D'aquesta manera, el gènere es converteix en un mitjà que serveix per complir determinats objectius en la societat, mitjançant les accions retòriques que realitza el discurs. Per a Miller (1984), doncs, el gènere pren el seu significat no pas per ell mateix sinó pel context, és a dir, per la comunitat discursiva en la qual es desenvolupa i que compta amb unes regles d'interpretació. Amb els gèneres, per tant, duem a terme accions que són reconegudes per aquesta comunitat (Gutiérrez Rueda, 2018).

Podem, doncs, entendre el gènere com una acció social. Dins la tradició dels estudis d'anglès per a fins específics, un dels autors més influents és Swales, el qual proporciona aquesta excel·lent definició:

A genre comprises a class of communicative events, the members of which share some set of communicative purposes. These purposes are recognized by the expert members of the 
parent discourse community and thereby constitute the rationale for the genre. This rationale shapes the schematic structure of the discourse and influences and constrains choice of content and style. Communicative purpose is both a privileged criterion and one that operates to keep the scope of a genre as here conceived narrowly focused on comparable rhetorical action. In addition to purpose, exemplars of a genre exhibit various patterns of similarity in terms of structure, style, content and intended audience. If all high probability expectations are realized, the exemplar will be viewed as prototypical by the parent discourse community. The genre names inherited and produced by discourse communities and imported by others constitute valuable ethnographic communication, but typically need further validation. (Swales, 1990: 58)

Aquesta concepció, formulada des d'un enfocament funcional, planteja que els gèneres no s'han d'entendre tant en termes de categories textuals sinó com esdeveniments socials o comunicatius. Bhatia (1993) observa que Swales subestima els factors psicològics i les intencions individuals i amplia la caracterització dels gèneres:

Most often it [genre] is highly structured and conventionalized with constraints on allowable contributions in terms of their intent, positioning, form and functional value. These constraints, however, are often exploited by the expert members of the discourse community to achieve private intentions within the framework of socially recognized purposes. (Bhatia, 1993: 13)

Bhatia (1993) apunta que els propòsits comunicatius es veuen reflectits en l'estructura interna del gènere i que els grans canvis originen gèneres nous, mentre que els canvis menors donen Iloc a la creació dels subgèneres. El fet d'escriure dins d'un gènere vol dir respectar i seguir determinades pràctiques per estar dins de les línies d'aquest gènere. A mesura que els professionals es converteixen en experts, però, es poden permetre experimentar més amb els límits de cada gènere.

Askehave i Swales (2001: 195) assenyalen les incerteses que envolten el concepte de communicative purposes ('propòsits comunicatius') i que podrien posar en qüestió la seva validesa com a mitjà per a distingir uns gèneres d'uns altres. Tanmateix, en repassar els principals estudis sobre el gènere, remarquen, precisament, que la majoria reconeixen els propòsits comunicatius com un dels fonaments dels gèneres.

La visió hegemònica que s'ha anat consolidant, per tant, és la que entén el gènere com un esdeveniment comunicatiu amb finalitats específiques dins d'una comunitat. 
Una de les definicions més completes en aquest sentit ens sembla la de Montgomery (2007: 26):

A genre is a specific and recognisable configuration of discourse elements realising a particular communicative purpose and usually known amongst a language community by a widely shared label, such as 'advert', 'sermon', 'gossip', 'joke', 'lecture'. 'News' is one such genre. The label is widely understood; and instances of broadcast news are instantly identifiable as such to audiences. However, even within this genre there are generic variations between radio news and TV news... A major source of difficulty in defining and applying the term genre is that some genres, at least, are unstable, in flux, with the boundaries dividing one from another tending to be indeterminate... So, genre describes more than a patterned, recurrent configuration... it may also be considered a process beyond the discourse itself involving a promise, by producers, and recognition, by audiences, of the type of discursive activity being performed.

En definitiva, seguint Morales (2010), quan parlem de gènere discursiu fem referència a unes construccions discursives i socioculturals, emprades per les diferents comunitats discursives per a la seva comunicació, i que es poden definir i caracteritzar tant pel seu context d'ús com per la seva estructura.

\subsection{Les característiques del gènere discursiu}

Com hem vist, els diversos enfocaments a l'hora de concebre els gèneres en realitat tenen molts punts en comú, els quals es poden sintetitzar, seguint Bhatia (2012: 241):

1. Entenem els gèneres com esdeveniments comunicatius recognoscibles, caracteritzats per un conjunt de propòsits comunicatius identificats i compresos pels membres de la comunitat (professional, acadèmica...) en què es produeixen habitualment.

2. Els gèneres són construccions força estructurades i convencionals. A més, tenen restriccions sobre les contribucions permeses en funció de les intencions, de la forma que sovint prenen i també dels recursos lèxics i gramaticals que s'hi poden emprar per donar valors discursius a aquests trets formals. 
3. Els membres veterans d'una comunitat professional acostumen a posseir més coneixements i una major comprensió de l'ús i de l'explotació dels gèneres que aquells que en són aprenents, nous membres o aliens a la comunitat.

4. Tot i que els gèneres se solen considerar com construccions convencionals, els membres experts de les comunitats sovint exploten aquests recursos per expressar les seves intencions privades en relació amb la comunitat.

5. Els gèneres són un reflex de la cultura de cada disciplina o organització i, en aquest sentit, se centren en accions professionals integrades en la disciplina, la professió o la pràctica institucional.

6. Els gèneres de cada disciplina o professió tenen integritat pròpia, la qual sovint s'identifica per una combinació de factors textuals, discursius i contextuals.

Bhatia (2012: 241) conclou que el tret més important que connecta les diferents tradicions teòriques és la convencionalitat. Així, el concepte de gènere discursiu fa referència, fonamentalment, a l'ús del llenguatge en un entorn comunicatiu convencionalitzat per expressar una sèrie específica d'objectius d'una disciplina o d'una institució social. Aquest procés dóna lloc a formes estructurals estables, gràcies a la imposició de restriccions en l'ús tant de recursos lexicogramaticals com discursius.

Seguint Berkenkotter i Huckin (1995), exposarem les cinc característiques bàsiques dels gèneres discursius que ens permetrien integrar la diversitat de models teòrics:

\section{Propietat de la comunitat (community ownership)}

La primera característica que mencionem té a veure amb la delimitació o relació entre el gènere $\mathrm{i}$ les comunitats discursives. En aquest punt ens trobem amb diferents enfocaments, però la diferència bàsica consisteix en qui defineix i selecciona a qui (Martín-Martín, 2003-2004). Si és el gènere qui selecciona els seus usuaris (Mauranen, 1993) o, al revés, és la comunitat discursiva qui determina les condicions per a la identificació dels gèneres (Paltridge, 1997). Per a Berkenkotter i Huckin (1995), les comunitats discursives són les propietàries dels gèneres, és a dir les que marquen les convencions dels gèneres discursius. Aquests autors també argumenten que si es fa un examen detallat dels gèneres, es poden revelar moltes de les pràctiques socials, les normes epistemològiques, la ideologia de la comunitat discursiva en qüestió. 


\section{Dinamisme (dynamism)}

A mesura que es van transformant les comunitats discursives a causa dels canvis tecnològics, socioculturals... també ho fan els gèneres, ja que són dinàmics i es creen per satisfer les necessitats d'aquestes comunitats (Taavitsainen, 2011). És a dir, es desenvolupen nous gèneres per cobrir les noves necessitats, desapareixen els que ja no calen i alguns s'adapten a les noves circumstàncies. Hem parlat de la problemàtica del prestigi dels CC en les revistes especialitzades i com la tecnologia actual -el fet de poder publicar en xarxa amb un cost molt més reduït- està ajudant aquest gènere a trobar el seu lloc entre el discurs mèdic. La possibilitat de publicar CC en Internet també fa que s'hi puguin posar més materials complementaris, com ara fotografies, esquemes, enllaços... Tot això, òbviament, fa que el gènere dels CC hagi canviat (com veurem en l'apartat 1 del capítol IV).

\section{Situació o ubicació (situatedness)}

Els gèneres estan situats. Aquest fet està explícitament expressat en la definició de Miller (1984), on explica que els gèneres són accions socials que responen a situacions retòriques recurrents. A més, el coneixement que tenim sobre els gèneres prové de la nostra participació en les activitats comunicatives de la nostra vida quotidiana. Així doncs, és una cognició situada que es desenvolupa permanentment, gràcies al fet que les persones sempre o quasi sempre participem en alguna activitat.

\section{Forma i contingut (form and content)}

El coneixement sobre els gèneres engloba tant la forma com el contingut. Així, es pot determinar quin contingut i quina forma són adequats per a uns propòsits específics en una determinada situació i en un moment concret. És a dir, per poder emmarcar un text dins d'un gènere específic cal dominar-ne aquests dos trets.

\section{Dualitat d'estructura (duality of structure)}

Es refereix a la relació recíproca entre l'acció humana i les estructures socials. L'ús dels gèneres ajuda a establir i a reproduir les estructures socials en els contextos professionals, institucionals, etc. 


\subsection{Els propòsits comunicatius}

Els textos que classifiquem dins d'un gènere discursiu concret comparteixen uns determinats propòsits comunicatius. Des d'aquest punt de vista, seguint Salvador (2018a) podem afirmar que: 1) un gènere agrupa les realitzacions discursives que s'ajusten a un tipus d'acció social de caràcter comunicatiu; 2) els gèneres produeixen una percepció convencionalitzada pel seu ús que és compartida pels usuaris (tant si existeix una denominació explícita per a un gènere concret com si és una percepció col-lectiva que es basa en la rutina sense emprar cap etiqueta específica; 3 ) els gèneres i les seves regles es distingeixen, s'identifiquen i s'interpreten apropiadament dins de les comunitats discursives, com ara les professionals de personal mèdic o d'infermeria.

Els propòsits comunicatius dels discursos que adscrivim a un determinat gènere condicionen l'estructura compositiva dels textos (l'extensió, el fragmentarisme, el sistematicisme...), els registres lingüístics emprats (col-loquial, estàndard, cientificotècnic...) i els recursos estilístics usats (metàfores, estil telegràfic, nominalitzacions semàntiques...) (Salvador, 2018a).

Neely et al. (2008: 263) identifiquen l'aportació de novetats com a propòsit en els casos clínics: una nova malaltia, una malaltia rara, una complicació nova o inesperada, una nova tècnica de diagnosi o una diagnosi per diferenciar-la d'altres malalties, una nova tecnologia, un nou tractament... La novetat és la idea recurrent que justifica la publicació dels CC i en la qual s'insisteix tant en els diferents manuals com en les directrius editorials. Quan un autor es posa a redactar un CC, doncs, és perquè pensa que podrà aportar una novetat respecte del que hi ha als manuals, una sorpresa, és a dir, una informació que amplia el coneixement:

Surprise means that you the author and/or you the reader are surprised by the case observation because it differs considerably from your prior understanding of the topic. The novel aspect of the case report stands in contrast to the historical control of prior experience or observation. The case is compelling, concise, and is focused on one topic. It describes a new disease, treatment, or mechanism. (Neely et al., 2008: 263)

Vandenbroucke (1999: 159) analitza si -i defensa que- en l'època de la medicina basada en l'evidència encara hi ha lloc per als casos clínics, els quals descriu com «the 
age-old cornerstone of the medical literature». L'autor assigna dues funcions rellevants al nostre gènere: «A case-report teaches us what is 'un-known' or 'unrecognized', either what medicine does not yet know ('progress'), or what individual doctors have not yet recognized ('education') (1999: 160)». Així doncs, aquest autor veu com a finalitats del CC descriure noves malalties, reconèixer noves etiologies i efectes secundaris, estudiar els mecanismes de les malalties, descriure teràpies i pronòstics i, finalment, educar els estudiants i assegurar la qualitat de la praxi mèdica (vegeu també Kunt-Akbaş, 2013).

Green i Johnson (2006) intenten aclarir tots els possibles dubtes sobre el gènere dels CC per als eventuals autors. En el seu article recullen els motius pels quals s'hauria de continuar donant suport als CC i desenvolupen una mena de manual a seguir per redactar un CC profitós i que pugui ser acceptat en les revistes especialitzades. Classifiquen els CC que es publiquen en tres tipus: els de diagnòstic o avaluació, els de tractament o de gestió i els educatius (Green i Johnson, 2006: 73-74). El primer tipus de CC descriu els mètodes diagnòstics o analítics emprats per fer l'avaluació del pacient. Aquest tipus de CC sol presentar una diagnosi poc comuna o difícil d'emetre i no sempre s'hi desenvolupa també la part del tractament. El segon tipus de CC revisa la gestió integral del cas d'un pacient. El tercer tipus de CC - els educatius - se centra a proporcionar als lectors les estratègies de la praxi actual amb una breu revisió de la literatura sobre el tòpic en qüestió, ja sigui una malaltia, un tractament, un procediment... En els tres casos, Green i Johnson (2006) insisteixen que redactar CC per a la publicació és un exercici per practicar la comunicació escrita de l'especialitat de cadascú, per conèixer i actualitzar la literatura o altres CC sobre el mateix i per afavorir el pensament crític. Sense dir-ho expressament, ens donen un bon exemple de com funciona un gènere com a instrument de construcció de la identitat en una comunitat de pràctica.

Tot i que els CC són considerablement diversos, podríem dir que la funció didàctica és un propòsit comunicatiu comú i transversal a tots ells, d'una manera no necessàriament explícita. De fet, trobem revistes que utilitzen els CC com una mena de formació contínua. Ara bé, encara que els CC tinguin un propòsit pedagògic, es recomana, fins i tot si no es tracta d'una experiència completament nova, que la forma en la qual estigui redactat sí que ha d'aportar, almenys, una nova perspectiva sobre el tema d'estudi (vegeu Green i Johnson, 2006: 73-74). 
Segons Kunt-Akbaş (2013), en els casos clínics no es proveeix una resposta a la pregunta «Quin és l’objectiu d’aquest cas?», sinó a «Quina és la lliçó que es pot aprendre a partir d'aquest cas?». Si examinem les frases d'alguns dels nostres CC on es parla sobre la seva contribució i aportació al món mèdic, hi confirmarem el valor educatiu d’aquest gènere:

(1) (Abstract)

After continuing the medication for 2 years he regained a functioning life and remained stable with medication. This case shows the importance of exploring the sexual behavior of the patients and sharing the experience may help in the treatment of schizophrenia patients with incest.

(23.ENG_Psychiatry)

(2) (Resum)

Es revisa la situació nosològica de les malformacions quístiques de fossa posterior, ja que es considera que aquest cas aporta dades favorables pel que fa a la utilitat del concepte de complex Dandy-Walker per situar sindròmicament en un mateix grup les malformacions de fossa posterior (megacisterna magna, síndrome de Dandy-Walker $\mathrm{i}$ variant de Dandy-Walker).

(2.CAT_Down)

(3) (Conclusiones)

La hipotermia leve inducida nos plantea un nuevo reto en el tratamiento del ictus isquémico agudo, pudiendo ser clave para reducir la magnitud del daño cerebral y las secuelas.

Se deberá realizar en una unidad de semicríticos (Unidad de Ictus). Por parte de enfermería, requerirá unos conocimientos y un protocolo de cuidados específicos, así como un control más exhaustivo de estos pacientes.

Tras el inicio del ensayo clínico europeo de hipotermia EuroHYP-1, tendremos más pacientes tratados con hipotermia, donde enfermería tendrá un papel muy importante de control para la seguridad y el bienestar de los mismos.

(12.ESP_Enfermería)

En aquests fragments podem observar la justificació de la raó per la qual es publica el CC, és a dir, el seu propòsit. El perquè es publica un CC sol ressaltar-se o bé en la introducció o, sobretot, en la part final de discussió o conclusió. A més, d'alguna manera 
apareix representat sempre en el resum (si n'hi ha), puix que és el captador d'atenció dels lectors i no exposar-hi la raó per la qual s'ha redactat i publicat el cas seria desaprofitar aquest recurs i córrer el risc que el CC sigui menys llegit.

En els CC, doncs, els autors generalment intenten remarcar l'excepcionalitat del cas i, per tant, sorprendre el lector i compartir la seva experiència amb els col-legues. Ambdós propòsits (sorprendre i ensenyar) els podem associar també als relats com ara els contes o les novel-les, ja que «rather than focusing on general, abstract situations or trends, stories are accounts of what happened to particular people - and of what it was like for them to experience what happened - in particular circumstances and with specific consequences» (Herman, 2009: 1-2).

\subsection{Els casos clínics entre els gèneres mèdics}

L'estatus dels CC entre els altres gèneres sanitaris ha anat variant, malgrat que es tracti, segons Salager-Meyer (1994: 4), d'un dels quatre tipus principals de textos mèdics escrits, juntament amb editorials, articles de revisió i treballs de recerca. La varietat de gèneres en la professió mèdica és tan àmplia com correspon a l'alt grau d’especialització i al desenvolupament de les pràctiques socials de les comunitats professionals de les ciències de la salut (Muñoz Torres, 2011).

Els diferents gèneres mèdics escrits s'han analitzat en contextos acadèmics i professionals des de diversos punts de vista, entre els quals s'inclou la tradició de l'anglès per a fins específics (English for Specific Purposes). Bhatia (2012) aporta una valuosa crítica a aquesta tradició per estar massa centrada en l'anàlisi dels recursos lingüístics interns del text, mentre posa de relleu el paper de la sociopragmàtica en els gèneres professionals, ja sigui escrits o parlats. Així, l'autor planteja el gran repte de l'anàlisi dels gèneres professionals: la part més rellevant d'aquesta anàlisi no són els usos lèxics, gramaticals o la intertextualitat, sinó que aquesta anàlisi s'hauria d'emprar com a eina per investigar i també per comprendre la pràctica professional i, fins i tot, la cultura professional. Només d'aquesta manera, segons l'autor, podem mirar de respondre les preguntes que sovint es plantegen en relació amb el gèneres professionals, com ara: «Per què els membres de les comunitats professionals 
específiques utilitzen el llenguatge de la manera com ho fan?»; «Com gestionen aquests professionals els gèneres per aconseguir els seus objectius corporatius?»; "Com manegen les normes genèriques per assolir objectius privats sense sortir del marc de les convencions dels gèneres?» (Bhatia, 2012: 249-250).

Els gèneres mèdics difereixen molt segons el destinatari i la finalitat. Posteguillo i Piqué (2007: 168) en dibuixen un esquema amb quatre quadrants delimitats per dos eixos (vegeu esquema 1). L'eix horitzontal separa l'oralitat de l'escriptura, mentre que l'eix vertical diferencia la praxi mèdica -inclosa la comunicació metge-pacientrespecte de la recerca - comunicació metge-metge. Malgrat que, històricament, el discurs oral del pacient no sols era la principal, sinó moltes vegades l'única font d'informació sobre el que patia, en l'esquema observem que la diversitat més gran de gèneres actualment no correspon a la comunicació metge-pacient, sinó als quadrants dedicats a la comunicació entre col·legues.

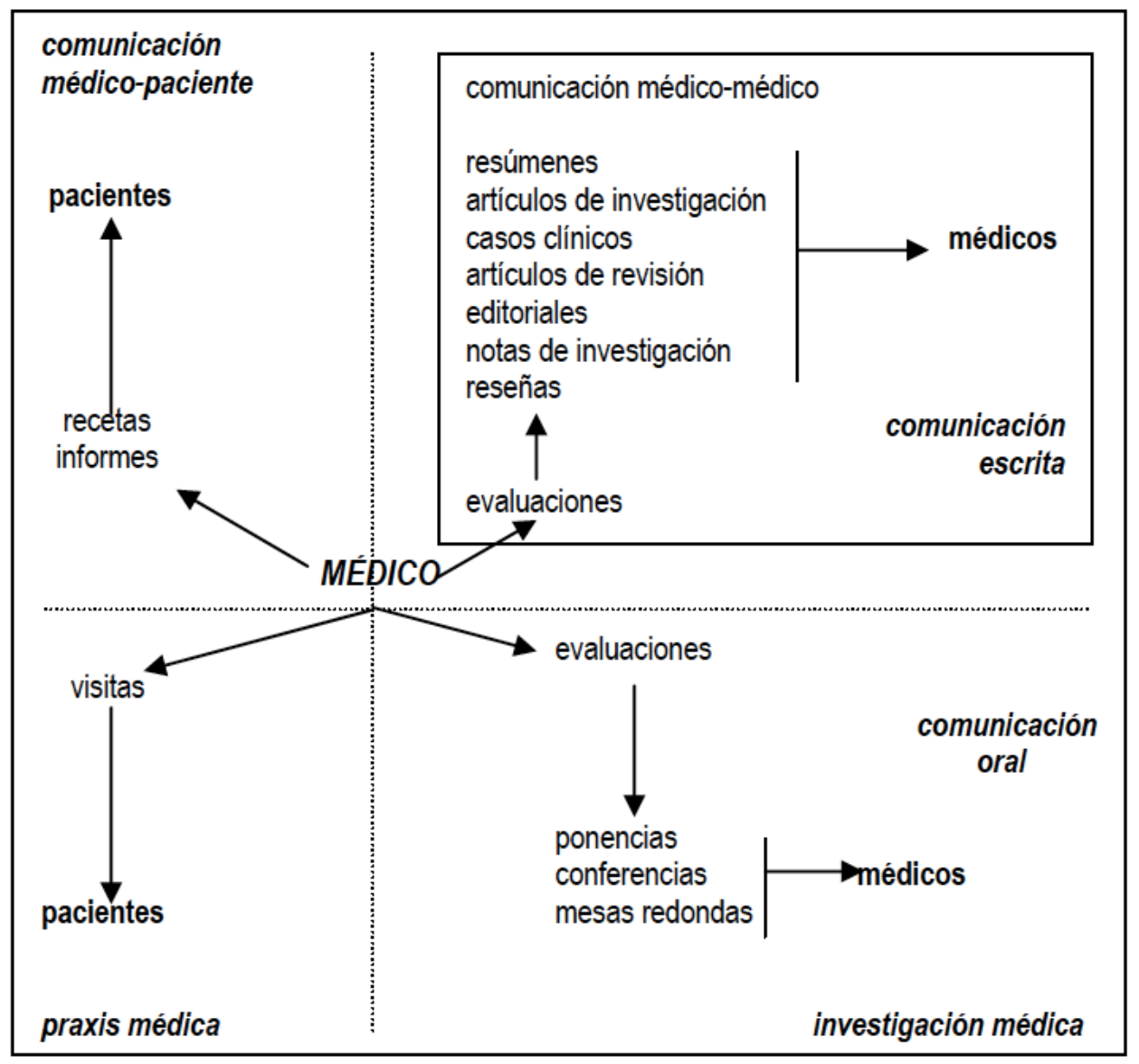

Esquema 1: Mapa dels gèneres mèdics (Posteguillo i Piqué, 2007: 168) 
Com podem veure, aquests autors inclouen el gènere dels casos clínics acadèmics en el quadrant de la comunicació escrita entre metges. En el capítol introductori ja hem caracteritzat els casos clínics com un gènere lligat a les revistes especialitzades de ciències de la salut. També n'havíem repassat la història, amb especial atenció a l'evolució de la valoració d'aquest gènere en comparació amb altres com, per exemple, els articles d'investigació. Per a nosaltres, seguint Macián (2013), aquestes revistes professionals sanitàries formen un macrogènere, tal com el descriuen Eggins i Martin (2003), és a dir, un gènere discursiu compost per seqüències de diversos gèneres que coincideixen amb les diferents seccions que té una revista. En aquest macrogènere que són les revistes professionals, doncs, els textos s'organitzen en seccions que poden variar més o menys: editorial, articles d'investigació, articles de revisió, casos clínics i altres gèneres de caire informatiu (cròniques, pròxims esdeveniments...) o publicitari (Macián, 2013).

\subsection{Les seqüències textuals}

Els gèneres discursius i les seqüències textuals són dos conceptes que han coexistit i que, en algunes ocasions, s'han confós i utilitzat de manera indistinta (vegeu Calsamiglia i Tusón, 1999; Maingueneau 1999 i 2009). Nosaltres entenem la seqüència textual com la unitat constituent del text, la qual, a diferència del gènere, representa una agrupació d'unitats que són similars en termes d'ocurrència d'estructures lingüístiques (Paltridge, 1994: 237).

Els lingüistes dels corrents de la lingüística textual i funcional (o enunciativa) són els qui fan servir, com una de les seves tasques principals, la classificació dels textos segons els seus tipus. El model de les seqüències discursives d'Adam (1992) n'és un del més influents. Descriu les seqüències com realitats lingüisticocomunicatives i també com unitats de composició de textos produïts en àmbits heterogenis de la vida social. Els textos són, per tant, estructures compostes de seqüències. Per adscriure un text a un tipus determinat, Adam empra el concepte de seqüència textual prototípica. És a dir, la seqüència textual és una categoria abstracta concebuda per caracteritzar l'estructura 
principal d'un text en particular o una de les seves parts, d'acord amb les seves propietats dominants.

Com passa sovint amb les categoritzacions, hi ha propostes diverses per caracteritzar i delimitar les seqüències textuals (Aumüller, 2014). Adam (1992) i també Casamiglia i Tusón (1999) en distingeixen cinc tipus: la narrativa, la descriptiva, l'argumentativa, l'explicativa i la dialogal. La narrativa es defineix per la propietat de canvi d'estat d'objectes concrets i assenyala allò verbal, dinàmic, successiu i contingent. La descriptiva tracta els estats d'objectes concrets i es refereix a allò nominal, estàtic, simultani, evident (Genette, 2002). L'argumentativa està definida per relacions logicosemàntiques entre objectes abstractes en Iloc de propietats semàntiques temporals. L'explicativa suposa la possessió d'un coneixement previ i se centra en la proporció de la informació (associada a l'objectivitat i la neutralitat). Finalment, la dialogal, amb la seva estructura de diàleg, es caracteritza per l'alternança de veus.

La majoria de textos no contenen exclusivament seqüències d'un tipus. De fet, cada tipus pot subservir els altres (Chatman, 1990: 2). Habitualment un d'ells el podem marcar com a predominant, però en general són subservits per altres tipus. Així doncs, per exemple, la narració pot estar al servei de la descripció, o viceversa. Pel que fa als CC acadèmics, resulta determinant la dimensió narrativa del gènere, per bé que no sigui gens prototípica dins del discurs científic:

De hecho, el caso clínico se vehicula muy a menudo por medio de secuencias narrativas, en la medida en que comporta la expresión de un proceso que se produce en el tiempo y además está vinculado a actantes que son personajes humanos: el enfermo principalmente, pero también el clínico que plasma en su reportaje de los hechos su propia trayectoria de descubrimiento y de cuestionamiento de las posibles interpretaciones que permiten dar cuenta del caso, y ajustarlo así a un modelo científico de explicación que resulte satisfactoria. (Macián, 2013: 129)

Els CC són un del pocs gèneres sanitaris o mèdics que narren una història. Gràcies a això podem tenir-ne la versió literaturitzada, la qual, òbviament, remarca un altre tipus d'informacions, empra altres recursos estilístics, té una organització estructural diferent, una extensió no tan predeterminada, etc. La base narrativa que defensem en aquesta tesi - a més de les dades que exposarem en el capítol IV, dedicat a l'anàlisi del 
corpus - es pot constatar, per tant, en el simple fet que els CC acadèmics poden convertir-se en històries literàries, en contes clínics. En el cas d'altres gèneres mèdics, com ara els articles d'investigació o els articles de revisió, a dures penes ens podem imaginar com els podríem convertir en la base d'un text literari, per més estratègies de desterminologització i altres recursos literaris que puguem emprar. L'explicació, per tant, podria ser així de simple: aquests altres gèneres que no contenen una història, és a dir, un relat perquè aquest pugui ser desenvolupat, reelaborat i recontextualitzat, difícilment poden esdevenir textos literaris.

Ara bé, no tots els autors adjudiquen un paper tan important a la narració en els CC. Si observem la taula (1) de tipologies de gèneres mèdics segons les funcions i el to, proposada per Gamero (2001: 69) i adaptada per Muñoz Torres (2011), veurem el lloc que s'assigna als casos clínics en relació amb els altres gèneres mèdics. Els CC figuren en la columna de la comunicació especialitzada, classificats com a gènere argumentatiu amb funció secundària expositiva, en un bloc que inclou gèneres tan diversos com els articles d'investigació o les cartes als editors. 


\begin{tabular}{|c|c|c|c|}
\hline $\begin{array}{l}\text { Función } \\
\text { dominante } \\
\text { y secundaria }\end{array}$ & $\begin{array}{l}\text { Comunicación } \\
\text { General }\end{array}$ & $\begin{array}{c}\text { Comunicación } \\
\text { Semiespecializada }\end{array}$ & $\begin{array}{l}\text { Comunicación } \\
\text { Especializada }\end{array}$ \\
\hline $\begin{array}{l}\text { Argumentativo }+ \\
\text { Expositivo }\end{array}$ & $\begin{array}{ll}> & \text { Artículo de } \\
\text { opinión general } \\
> & \text { Editorial médico }\end{array}$ & 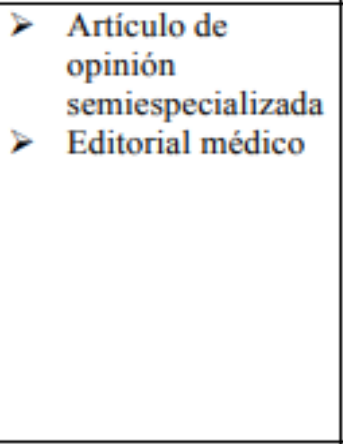 & $\begin{array}{ll}> & \text { Caso clínico } \\
& \text { Artículo de } \\
& \text { investigación } \\
> & \text { Artículo de opinión } \\
& \text { especializada } \\
> & \text { Editorial médico } \\
> & \text { Reseña médica } \\
> & \text { Carta al editor } \\
> & \text { Trabajos de } \\
\text { investigación } \\
\text { académicos }\end{array}$ \\
\hline $\begin{array}{c}\text { Expositivo }+ \\
\text { Argumentativo }\end{array}$ & \begin{tabular}{ll|}
$\begin{array}{l}\text { Artículo } \\
\text { divulgación } \\
\text { general }\end{array}$ \\
\end{tabular} & & $\begin{array}{ll}\text { Artículo } & \text { de } \\
\text { divulgación } \\
\text { especializada }\end{array}$ \\
\hline Expositivo & &  & $\begin{array}{l}\text { Resumen de } \\
\text { investigación } \\
\text { Base de datos } \\
\text { bibliográficos }\end{array}$ \\
\hline $\begin{array}{l}\text { Expositivo } \\
+ \text { Instructivo }\end{array}$ & & $\begin{array}{l}>\text { Cuestionario } \\
\text { médico } \\
>\quad \text { Tratado médico }\end{array}$ & $\begin{array}{l}\text { Historia clínica } \\
\text { Informe médico } \\
\text { anual }\end{array}$ \\
\hline $\begin{array}{l}\text { Instructivo + } \\
\text { Expositivo }\end{array}$ & $\begin{aligned} &> \begin{array}{l}\text { Prospecto de } \\
\text { medicamento }\end{array} \\
& \text { general } \text { Folleto médico } \\
& \text { publicitario } \\
& \text { informativo } \\
&> \text { Anuncio médico } \\
& \text { publicitario } \\
& \text { general }\end{aligned}$ & $\begin{array}{l}\text { Clasificación } \\
\text { médica }\end{array}$ & $\begin{aligned} & \begin{array}{l}\text { Prospecto de } \\
\text { medicamento } \\
\text { especializado }\end{array} \\
& \text { Anuncio médico } \\
& \text { publicitario } \\
& \text { especializado } \\
&> \text { Protocolo clínico } \\
& \text { Normas para } \\
& \text { protocolos }\end{aligned}$ \\
\hline Instructivo & $\begin{array}{l}\begin{array}{l}\text { Recomendaciones } \\
\text { clínicas }\end{array} \\
\end{array}$ & \begin{tabular}{ll|} 
& $\begin{array}{l}\text { Manual de } \\
\text { instrucciones }\end{array}$ \\
\end{tabular} & $\begin{array}{l}\text { Clasificación médico } \\
\text { especializada }\end{array}$ \\
\hline $\begin{array}{l}\text { Heterogeneidad de } \\
\text { funciones }\end{array}$ & $\begin{array}{l}>\text { Página web } \\
\text { médica } \\
>\text { Lista } \\
\text { distribución } \\
>\text { Chat médico }\end{array}$ & $\begin{array}{l}\text { Página web } \\
\text { médica }\end{array}$ & $\begin{array}{l}\text { Página web médica } \\
\text { Foro de discusión } \\
\text { Chat médico }\end{array}$ \\
\hline
\end{tabular}

Taula 1: Tipologia de gèneres mèdics segons les funcions i el to. Adaptat per Muñoz Torres (2011:

179) de Gamero (2001: 69)

Segons Muñoz Torres (2011), doncs, els CC presenten una funció predominantment argumentativa, però que apareix combinada amb alguns trets expositius, com ara: exposició conceptual, descripció o narració. Altres estudis, en canvi, donen més 
importància a les seqüències expositives o descriptives (Jenicek, 2001 i Uribarri, 2004). Finalment, Taavitsainen i Pahta (2004), Morales (2010) i (Salager-Meyer et al., 1989) defensen que les seqüències descriptives i narratives predominen en totes les seccions retòriques dels $\mathrm{CC}$, com també en el raonament mèdic en general. Ara bé, malgrat la importància i la presència d'altres seqüències - sobretot de les explicatives i les descriptives - coincidim amb Salvador (2016) a considerar que la seqüència narrativa és la predominant en els CC i en aquest estudi ho constatem empíricament (capítol IV).

Les reserves dels diversos estudiosos per admetre la preeminència de les seqüències narratives en un dels gèneres mèdics es poden relacionar amb la preferència per l'objectiu (la prova) i l'exclusió del subjectiu (la història), sòlidament consolidats en l'àmbit científic i en la cultura de la pràctica sanitària moderna:

\footnotetext{
Also entrenched is the scientistic bias that history and narrative are inadequate or unreliable modes of communication about the biomedical conditions of patients. Description, especially when buttressed by quantifiable data, is more scientific, somehow more medical, than narrative: description (data) is "hard"; narrative is "soft." This bias is supported by the unexamined assumption that objective data are not only essential but also sufficient for the optimal diagnosis and treatment of an illness. (Monroe et al., 1992: 47-48)
}

Per evitar que les premisses d'objectivitat esdevinguin prejudicis contraproduents, cal doncs recordar i reivindicar la pertinència de la narració, com artefacte comunicatiu particularment efectiu, en l'àmbit de la salut, ja que «la narración de un fragmento de vida, aunque se haga desde una perspectiva de profesional de la salud, permite integrar la actitud del biógrafo y del contador de anécdotas vitales con la actitud del estudioso» (Salvador, 2015a: 13).

En aquest treball, per tant, defensem la idea que el gènere dels CC és principalment narratiu, tot i que també manifesta una presència significativa de les seqüències descriptives i expositives. Comprovarem aquesta hipòtesi en l'anàlisi de les seqüències narratives del capítol IV, on veurem quines seqüències podem detectar en els CC acadèmics del nostre corpus, quines són les més rellevants, en quines parts o apartats apareixen i què ens revelen sobre aquest gènere. 
3. LA NARRACIÓ I EL RELAT

\begin{abstract}
"Well what you really turned out to say was that that's a story. It was interesting logic, but what you're really saying is that that's a story." That's not the point at all. The only thing that's interesting is the logic. That's the whole thing. That it's a story, anybody knows.
\end{abstract}

HARVEY SACKS

Lectures on Conversation

Aquesta tesi doctoral concep els casos clínics com relats i ho manifesta ja des del títol. En aquest apartat, mirarem de desenvolupar les raons teòriques que ho justifiquen, particularment pel que fa als casos clínics acadèmics. En el cas dels literaturitzats, la condició de relats és més evident, ja que els llibres en els quals es publiquen són venuts, de fet, com a relats literaris.

Entenem el relat com una modalitat discursiva que està present més enllà de la literatura. La narració no existeix sols dins les cobertes dels llibres, sinó que impregna les nostres accions diàries, començant per allò que s'ha denominat la narració natural (Labov i Waletzky, 1967: 20-21), a través de la qual recapitulem les experiències en l'ordre dels esdeveniments originals. Per això, lluny de ser una exclusivitat de la literatura, s'ha convertit en un objecte d'investigació en moltes altres disciplines, com ara la sociolingüística, l’antropologia social, la psicologia social... Així doncs, seguint Thornborrow i Coates (2005), tenim la convicció que el discurs narratiu s'entrellaça amb el teixit de la interacció social, ja sigui en les converses casuals, en els mitjans de comunicació, en les interaccions familiars o en els entorns mèdics.

En l'àmbit literari, òbviament, s'han desenvolupat incomptables teories i reflexions sobre el relat. Malgrat que l'interès per la narració es remunta a més d'un parell de mil·lennis, l'estudi sistemàtic es desenvolupa sobretot en el darrer mig segle, amb I'aparició d'una nova disciplina: la narratologia (Frank, 2010). Quan parem esment en alguns filòsofs i crítics literaris que avui dia es consideren pioners de la teoria narrativa, des d'Aristòtil fins a Vladimir Propp, o de Percy Lubbock a Wayne Booth, ens adonem que ells estudiaven els diferents gèneres literaris i no la narrativa com a tal. No és fins a l'estructuralisme francès, amb el seu objectiu de bastir models científics per a les 
disciplines humanes i socials, i els seus exponents Roland Barthes i Claude Bremond, que es comença a abordar «as a semiotic phenomenon that transcends disciplines and media» (Ryan, 2005). Per a Barthes:

el relato puede ser soportado por el lenguaje articulado, oral o escrito, por la imagen, fija o móvil, por el gesto y por la combinación ordenada de todas estas sustancias; está presente en el mito, la leyenda, la fábula, el cuento, la novela, la epopeya, la historia, la tragedia, el drama, la comedia, la pantomima, el cuadro pintado (piénsese en la Santa Úrsula de Carpaccio), el vitral, el cine, las tiras cómicas, las noticias policiales, la conversación. Además, en estas formas casi infinitas, el relato está presente en todos los tiempos, en todos los lugares, en todas las sociedades; el relato comienza con la historia misma de la humanidad; no hay ni ha habido jamás en parte alguna un pueblo sin relatos; todas las clases, todos los grupos humanos, tienen sus relatos y muy a menudo estos relatos son saboreados en común por hombres de cultura diversa e incluso opuesto: el relato se burla de la buena y de la mala literatura: internacional, transhistórico, transcultural, el relato está allí, como la vida. (Barthes, 1970: 9)

Així doncs, el relat es pot entendre com un concepte molt ampli que abasta nombrosos gèneres i situacions comunicatives. Aquesta amplitud mateixa, juntament amb la multiplicitat d'enfocaments teòrics, pot comportar imprecisions i variacions terminològiques ${ }^{10}$. Per exemple, el terme narració tradicionalment denotava la producció verbal (oral o escrita) d'un relat per part d'un narrador, però els estudis actuals ja han ampliat aquesta visió. L'abast d'aquest terme és molt ampli. Encara podríem tenir en compte la visió genettiana, en la qual s'identifica la narració com un dels tres nivells de la narrative, juntament amb histoire i récit (vegeu Genette, 1980 i 1988). L'aplicació d'aquest terme, doncs, és bastant extensa i tant pot correspondre a «unquoted verbal narration by a narrator» com a la interpretació més àmplia que abasta la totalitat del discurs narratiu (Abbott, 2005).

En català i castellà, sovint s'usa indistintament narració o relat per referir-nos al resultat de l'acció de narrar, és a dir, a una successió d’esdeveniments que es produeixen al llarg d'un temps determinat i que, habitualment, causen una transformació de la situació inicial. Tanmateix, és més útil concebre el relat com un tipus

\footnotetext{
${ }^{10}$ En l'ús dels termes més bàsics per a l'anàlisi del nostre corpus, ens hem fixat en els treballs més recents i rellevants, tot seguint, sobretot, Routledge Encyclopedia of Narrative Theory (Herman, Jahn i Ryan, 2005) i Françoise Revaz (1997 i 2009).
} 
específic de narració. En aquest estudi ho entendrem així i n'aplicarem els termes d'acord amb les caracteritzacions que en fa Revaz (2009). Seguint aquesta autora, amb el terme relat (en francès, récit) ens referim als textos narratius que tenen, a més d'una acció, un criteri formal addicional: una mise en intrigue, una disposició dels fets i les accions que genera tensió narrativa, és a dir que desperta en el lector l'interès per conèixer el desenllaç ${ }^{11}$.

L'omnipresència de la narrativa potser és a la base de la dificultat de consens en la seva teorització. Així, depenent del punt de vista, s'entendrà la narrativa com «un mode d'énonciation, un agencement de faits, une structure textuelle, un acte de parole, voire le résultat d'une stratégie de lecture relativement indépendante des propriétés textuelles proprement dites» (Revaz, 2009: 100). Això sí, la narrativa comparteix una sèrie de propietats semàntiques comunes: representació d'accions, desenvolupament cronològic, transformació (inversió) entre l'estat inicial i l'estat final, encadenament causal i desenvolupament inusual o no previsible de l'acció. D'altra banda, si ens fixem en la seva materialitat lingüística, la narrativa té unes característiques tan variades que «semble impossible de fonder son caractère narratif sur le seul relevé de marques linguistiques qui lui seraient propres. En d'autres termes, il n'existe pas de marques linguistiques spécifiques à la narrativité» (Revaz, 2009: 100).

Així doncs, el terme narrativa es pot emprar en un sentit restringit, per designar el gènere del relat literari, però també en un sentit molt més ampli, per abastar un extens ventall de gèneres que inclouen altres relats, com ara les transmissions esportives, els informes, els noticiaris (Ochs, 2000: 277) i també, tal com defensem en aquesta tesi doctoral, els casos clínics. D’altra banda, el terme narratologia es refereix a la teoria de la narrativa, és a dir, a una disciplina de les humanitats que es dedica a l'estudi de la lògica, els principis i les pràctiques de la representació narrativa (Meister, 2014).

La narratologia ha obert el camí a les science studies, una àrea interdisciplinària de recerca sobre la ciència des dels contextos socials, històrics i filosòfics. Es parla, així, de les anomenades narratives of science, un concepte que ens indica que el discurs científic «does not reflect but covertly constructs reality, does not discover truths but fabricates

\footnotetext{
${ }^{11}$ Aquest criteri, agafat d'Aristòtil, és, tanmateix, qüestió de discussions, ja que hi ha autors que es neguen a tenir en compte aquesta distinció (vegeu Ricœur, 1983).
} 
them according to the rules of its own game in a process disturbingly comparable to the overt working of narrative fiction» (Ryan, 2005). En les darreres dècades, doncs, s'ha desenvolupat un camp multidisciplinari d'estudis que es troben en la intersecció de diferents branques de la ciència, en els quals, a més de les anàlisis estructurals, es presta especial atenció a la interpretació de les històries i a l'anàlisi de les seves funcions cognitives i ideològiques (László, 2008: 10). Aquest nou enfocament s'ha anomenat the narrative turn 'el gir narratiu' (McAdams et al., 2001). En aquest context, han aparegut nombrosos estudis de les narratives en les ciències socials i també en l'àmbit de les ciències de la salut, sobretot en el món anglòfon. D’aquesta manera, apareixen etiquetes com ara narrative based medicine (vegeu Greenhalgh i Hurwitz, 2004) o narrative medicine (Charon et al., 2016).

Pel que respecta als aspectes formals del relat, totes les narracions tenen uns trets necessaris perquè puguem classificar-les com a tals. Quant a la forma, hi trobem dos possibles enfocaments àmpliament reconeguts. El primer, formulat per Aristòtil, planteja que les històries són fàcils de reconèixer, ja que tenen un començament, una part mitjana i un final. El segon enfocament és una de les definicions clàssiques de Labov i Waletzsky (1967), els quals van analitzar l'estructura de les narratives orals en entrevistes de recerca sociolingüística. Hi van trobar una sintaxi particular del discurs narratiu, fet que va donar peu a nombroses investigacions en els quaranta anys subsegüents. Una de les conclusions és que una història/narració es compon almenys de dues clàusules amb verbs en temps passat (o en present històric) ordenades seqüencialment, és a dir en l'ordre en què es van produir els esdeveniments explicats (Cheshire i Ziebland, 2005). Si l'ordre d'aquestes clàusules canvia, la història ho fa també. Michael Toolan (2001: 145) dóna suport a aquesta teoria amb un exemple molt citat en tot tipus de publicacions: «John fell in the river, got very cold, and had two large whiskies» és una història ben diferent de «John had two large whiskies, fell in the river, and got very cold».

Ara bé, Ochs (2000: 278) remarca que les narracions també es poden formular en present i en futur, com s'esdevé en els comentaris de les transmissions esportives, en el primer cas, i en les planificacions de qualsevol mena, en el segon $\operatorname{cas}^{12}$. Per a aquesta

\footnotetext{
${ }^{12}$ L'autora hi posa per exemple una noia que elabora un pla per celebrar el seu aniversari.
} 
autora, les narracions retraten una transmissió temporal d'un estat de coses a un altre. Georgakopoulou (2005) hi afegeix que el criteri menys controvertit per distingir la narració d'altres tipus de text és el principi de l'ordenament temporal dels esdeveniments, com ara el de la cronologia doble (Chatman, 1990: 9): perquè un text es qualifiqui com a narratiu, ha d'implicar el moviment a través del temps no sols externament, mitjançant el temps del discurs, sinó també internament, a través de la durada de la seqüència d'esdeveniments que en constitueixen la trama.

Quant a les funcions, la narració és un recurs discursiu emprat pels parlants en diversos contextos socials per dur a terme nombroses accions (Thornborrow i Coates, 2005), com ara: entretenir-se (bromes, anècdotes, rondalles...), justificar i explicar (descripcions d'esdeveniments), instruir (contes morals, faules) o establir normes socials (xafarderies). Ara bé, hi ha una funció que ens sembla encara més important: el relat és a la base de les històries amb què ens diem qui som i amb les quals construïm la nostra identitat social i cultural:

Life is described as a goal-directed chain of events which, despite numerous obstacles and thanks to certain opportunities, has led to the present state of affairs, and which may yet have further unpredictable turns and unexpected developments in store for us. (Fludernik, 2009: 1)

L'estudi de la narrativa, doncs, implica examinar-ne la funció en la construcció de la cultura social però també en la de la identitat personal (Brockmeier i Carbaugh 2001: 16). D'una manera brillant ho il·lustra Oliver Sacks (1987a) quan ens explica el cas d'un pacient que pateix la síndrome de Korsakov i que no té memòria més enllà del que passava uns segons abans. El pacient de Sacks no sap què ha passat en tota la seva vida i, per tant, manca d'identitat pròpia. Els pacients de Korsakov solen trobar una forma diferent d'ajustar-se a l'absència de memòria. Aquest pacient compensa la manca de memòria amb la improvisació de noves identitats, és a dir, es crea a si mateix i al seu món en cada moment. D’aquesta experiència vital, el doctor Sacks treu la conclusió que som la narració que contem sobre nosaltres mateixos:

[...] We have, each of us, a life-story, an inner narrative-whose continuity, whose sense, is our lives. It might be said that each of us constructs and lives, a 'narrative', and that this narrative is us, our identities. 
If we wish to know about a man, we ask 'what is his story-his real, inmost story?' - for each of us is a biography, a story. Each of us is a singular narrative, which is constructed, continually, unconsciously, by, through, and in us-through our perceptions, our feelings, our thoughts, our actions; and, not least, our discourse, our spoken narrations. Biologically, physiologically, we are not so different from each other; historically, as narratives-we are each of us unique.

To be ourselves we must have ourselves-possess, if need be repossess, our life-stories. We must 'recollect' ourselves, recollect the inner drama, the narrative, of ourselves. A man needs such a narrative, a continuous inner narrative, to maintain his identity, his self.

(12.LIT_Sacks)

En aquesta part del capítol, mirarem d'introduir diversos conceptes de la teoria narrativa que ens serveixen de marc per a l'anàlisi del nostre corpus. En el present estudi no pretenem fer un repàs de la teoria del relat, sinó que volem aprofitar alguns dels seus elements per poder interpretar tant els CC acadèmics com els literaturitzats. D'aquesta manera, situem el relat com una modalitat de discurs que pot ser literària o no, ja que el concepte de relat s'arrela en la narrativa literària, però el podem aplicar també a textos no literaris.

\subsection{L'acció i la intriga}

Françoise Revaz (1997 i 2009) es planteja si la presència d'accions en un text implica un veritable criteri de categorització, és a dir, si qualsevol text d’acció és una narració. L'autora analitza textos tan diversos com el reportatge esportiu, la recepta, la publicitat, el conte, la faula o la novel·la. Es basa teòricament en la retòrica antiga (com ara Aristòtil o Quintilià), la clàssica (Du Marsais o Marmontel), la narratologia contemporània (Bremond o Genette) i la filosofia de l'acció de Paul Ricœur.

Seguint aquesta autora, diferenciem els estats i els processos. Els estats són descripcions sense desenvolupament temporal, estàtiques. Els processos, per la seva banda, inclouen dues subcategories: les accions i els esdeveniments. Els esdeveniments són fenòmens que es produeixen en la naturalesa sota l'efecte d'una causa. Es podrien considerar una categoria intermèdia entre l'acció i l'estat, i la major diferència que els separa de les accions és la manca d'agentivitat humana. Com a exemple, podem pensar 
en una descripció de la pluja sense la presència d'agents humans. L'acció és un dels conceptes més rellevants per a aquest treball, perquè és la clau que ens porta a entendre els CC com a relats. Es tracta d'una conducta humana -o d'una entitat antropomorfitzada-, amb una raó per actuar - un motiu-, amb una intenció. Aquesta és la principal diferència amb l'esdeveniment: la presència o l'absència d'agent humà.

Aquesta dicotomia entre esdeveniment i acció també es pot constatar en el fet que l'esdeveniment es pot explicar mitjançant lleis, mentre que l'acció humana només es pot entendre, és a dir, sols la podem interpretar. La comprensió de les accions no és tan transparent, però, com podria semblar a primera vista, puix que sempre és un resultat d'un procés d'interpretació bastant complex. Així doncs, hem de tenir en compte dos elements (Revaz, 2009: 45-46): i) tota conducta humana no ha de ser necessàriament intencional, ja que hi ha graus de motivació i de responsabilitat de l'agent humà; ii) l'acció humana no és pas la producció d'un actor solitari, sinó que s'adscriu a un context cultural, històric i social regit per normes.

Revaz manlleva moltes idees del filòsof Paul Ricœur (1986), qui intenta defugir una categorització estricta entre l'acció i l'esdeveniment, però reconeix que:

ce n'est pas dans le même jeu de langage que l'on parle d'événements se produisant dans la nature, ou d'actions faites par des hommes. Car pour parler d'événements, on entre dans un jeu de langage comportant des notions telles que cause, loi, fait, explication etc. II ne faut pas mêler les jeux de langage, mais les séparer. C'est donc dans un autre jeu de langage et dans un autre réseau conceptuel que l'on parlera de l'action humaine. Car, si on a commencé à parler en termes d'action, on continuera à parler en termes de projets, d'intentions, de motifs, de raisons d'agir, d'agents, etc. (Ricœur, 1986: 169)

Així, podem veure la diferència en els exemples citats: Bayard meurt 'Bayard mor' és clarament un esdeveniment, mentre que tuer Bayard 'matar Bayard' és una acció. En el primer cas, no hi ha agentivitat humana perquè -en principi- pensaríem en una mort natural. Seria, per tant, un esdeveniment. El segon exemple, en canvi, implica la presència i l'actuació d'un ésser animat, amb una raó per actuar d'aquesta manera. Així doncs, per saber si un procés és una acció o un esdeveniment, podem fixar-nos si al darrere hi ha un motiu (una raó per actuar) o una causa (de l'esdeveniment). 
Arribats en aquest punt, cal constatar l'associació de l'acció i el relat (récit) com a fruit de l’oposició literària entre la narració i la descripció, la qual estableix el relat com a lloc textual de les representacions de les accions, mentre que la descripció seria el lloc de representació dels estats:

Il faut observer enfin que toutes les différences qui séparent description et narration sont des différences de contenu, qui n'ont pas à proprement parler d'existence sémiologique: la narration s'attache à des actions ou des événements considérés comme purs procès, et par là même elle met l'accent sur l'aspect temporel et dramatique du récit; la description au contraire, parce qu'elle s'attarde sur des objets et des êtres considérés dans leur simultanéité, et qu'elle envisage les procès eux-mêmes comme des spectacles, semble suspendre le cours du temps et contribue à étaler le récit dans l'espace (Genette, 1969: 59).

En la taula següent (1), podem observar que la dicotomia entre estats i processos (que inclouen les accions i els esdeveniments) es pot traslladar també a la dicotomia entre descripció i narració. Així, Revaz (2009), formalitza aquesta oposició clàssica.

\begin{tabular}{|lll|}
\hline Représentation & ÉTATS & ACTIONS OU ÉVÉNEMENTS \\
Temporalité & SIMULTANÉITÉ & CONSÉCUTION \\
Catégorie textuelle & DESCRIPTION & NARRATION \\
\hline
\end{tabular}

Taula 1: La dicotomia entre la descripció i la narració (Revaz, 2009: 103)

Així doncs, juntament amb l'esdeveniment, l'acció seria un tret característic dels textos narratius, inclosos els relats. Tanmateix, cal recordar que no tots els textos que presenten accions es poden considerar relats. D'altres com els informes, els horòscops, les notícies necrològiques o les receptes poden contenir representacions d'accions, sense que els puguem considerar relats (Revaz, 1997: 8). A més, cal recordar que la narrativitat es pot entendre d'una manera no absoluta, sinó gradual: és a dir, que determinats textos es poden considerar més narratius que altres (Prince, 2012). De fet, Revaz sosté l'existència de categories intermèdies entre la descripció i el relat, tal com podeu veure en la taula 2. 


\begin{tabular}{|c|c|c|c|c|c|}
\hline Représentation & ÉTATS & \multicolumn{4}{|c|}{ ACTIONS } \\
\hline Temporalité & \multicolumn{2}{|c|}{ SIMULTANÉITÉ } & \multicolumn{3}{|c|}{ CONSÉCUTION } \\
\hline Causalité & \multicolumn{3}{|c|}{-} & \multicolumn{2}{|c|}{$A C T I O N$ « UNE » } \\
\hline Composition & \multicolumn{2}{|c|}{ TABULARITÉ } & \multicolumn{2}{|c|}{ LINÉARITÉ } & MISE EN \\
\hline \multirow[t]{2}{*}{ Mise en texte/discours } & DESCRIPTION & TABLEAU & CHRONIQUE & RELATION & RÉCIT \\
\hline & & & & RECETTE & \\
\hline Action langagière & décrire & dépeindre & rapporter & relater & raconter \\
\hline
\end{tabular}

Taula 2: Revaz (1997: 238)

Així, l'autora proposa distingir entre quatre categories de textos d'acció: la categoria del tableau 'quadre' (representació d'accions simultànies); la categoria de chronique 'crònica' (representació d'accions successives, no vinculades per relacions causals); la categoria de recette 'recepta' o relation 'relació' (representacions d'accions successives que formen una unitat); i, finalment, la categoria de récit 'relat' (representació d'accions successives que formen una unitat $i$, a més, presenten una estructura d'intriga). Les quatre categories corresponen a la narrativitat, però cadascuna d'elles s'associa a una manera específica d'introduir el text (o el discurs) que caracteritza una activitat lingüística particular: depeindre 'pintar', rapporter 'informar', relater 'relatar', raconter 'contar' (Revaz, 1997: 238).

Cal parar compte a la terminologia usada per l'autora i a la seva traducció al català: la relació es relata, però no equival al relat. El nostre 'relat' correspon al récit, el qual, com hem vist i a diferència de la relació (o de la recepta), requereix intriga. Per a Revaz, si l'acció defineix la narració, la intriga delimita el relat. En aquest marc conceptual, podríem sentir-nos temptats a classificar els contes clínics, per la seva naturalesa literària, com relats, mentre col·locàvem els casos clínics acadèmics en el calaix d'un altre tipus de narració: les relacions. Nosaltres, però, defensem que tant un gènere com l'altre constitueixen relats, com veurem en el capítol IV. 


\subsection{L'estructura de la narració i del relat}

Els textos que classifiquem en la categoria de relat presenten una sèrie de trets estructurals, com ara el desenvolupament temporal, els enllaços lògics, el nus i el desenllaç (Revaz, 1997: 9). Aquestes característiques no s'han de complir en la seva totalitat ni en aquest ordre jeràrquic. Ara bé, seria estrany imaginar-nos, per exemple, un relat sense cap tipus de desenllaç, ja sigui clarament tancat o més obert. En tot cas, la presència d'una transformació dels fets no hi pot mancar: si no hi ha acció, tampoc no hi ha relat. Cada acció implica una transformació d'un estat de coses a un altre. Aquestes accions s'encadenen les unes amb les altres i constitueixen una seqüència. Per parlar de relat, però, no seria suficient amb un mer encadenament temporal, ja que cal que la seqüència, a més de cronològica, sigui també lògica (Pimentel, 1995: 260-261).

El relat té, doncs, una estructura que segueix una seqüenciació intencionada. D'entre les diferents teories que s'han elaborat sobre la seqüència narrativa ${ }^{13}$, prenem la separació clàssica dels cinc elements bàsics teoritzats per a l'estructura dramàtica en la Poètica d'Aristòtil. Per a aquesta distinció de cinc parts constitutives, adoptem la terminologia d’Adam (1992: 54): la situació inicial, el nus, la (re)acció o avaluació, el desenllaç i la situació final (esquema 1 i 2 ).



Esquema 1: Estructura de la seqüència narrativa (Adam, 2018: 9)

Aquest model ens permet observar una divisió ternària de la seqüència des del punt de vista dels moments del procés: abans del procés (m1), el procés pròpiament dit ( $\mathrm{m} 2$, m3 i m4) i després del procés (m5). Dins del procés pròpiament dit distingim l'inici (m2), la continuació (m3) i el final (m4) (esquema 2).

\footnotetext{
${ }^{13}$ Vegeu més sobre l'estructuració seqüencial en la narrativa en Baroni i Revaz (2015).
} 

-Moment $\mathrm{m} 1=$ BEFORE the process (action is imminent) $\quad=\mathrm{Np} 1$
- Moment $\mathrm{m} 2=$ BEGINNING of the process (beginning to, undertaking) $=\mathrm{Np} 2$
- Moment $\mathrm{m} 3=\mathrm{DURING}$ the process (continuing to) $=\mathrm{Np} 3$
- Moment $\mathrm{m} 4=$ END of the process (ceasing) $\quad=\mathrm{Np} 4$
- Moment $\mathrm{m} 5=$ AFTER the process (recently completed) $\quad=\mathrm{Np} 5$

Esquema 2: Moments del procés dins de la seqüència narrativa (Adam, 2018: 8)

Un cop establerta l'estructura prototípica de la narració, i, per extensió, del relat, cal tenir en compte que la literatura de ficció ha experimentat al llarg dels anys, precisament, amb aquesta estructura:

El cuento literario, nos dice aquélla, consta de los mismos elementos sucintos que el cuento oral, y es como éste el relato de una historia bastante interesante y suficientemente breve para que absorba toda nuestra atención.

Pero no es indispensable, adviértenos la retórica, que el tema a contra constituya una historia con principio, medio y fin. Una escena trunca, un incidente, una simple situación sentimental, moral o espiritual, poseen elementos de sobra para realizar con ellos un cuento.

(Quiroga, 1992: 93)

Pel que fa als casos clínics, l'analogia amb la narració va ser observada per Paul Atkinson (1995), qui va examinar les presentacions de casos i va constatar que la seva estructura era assimilar a una història. Així, l'estructura dels CC acadèmics es pot identificar amb l'ordenació d'una narració, en el sentit de William Labov (1997), qui va dividir la narració en l’orientació, la complicació, l'avaluació i el resultat. Compartim aquesta percepció del paral·lelisme entre l'estructura de la narració —i, en concret, del relat literari- i la del cas clínic, tot i que ens decantem per la visió d’Adam (1992) i Revaz (1997) i hi distingim, per tant, les cinc parts exposades més amunt: la situació inicial, el nus, la (re)acció o avaluació, el desenllaç i la situació final.

Així doncs, considerem que els textos que analitzem en aquest treball, tant si són els $\mathrm{CC}$ acadèmics com els literaturitzats, no trenquen amb les regles estructurals de la narrativa i del relat. Ben al contrari, tendeixen a adaptar-se a l'estructura més tradicional o prototípica de la narració, una estructura culturalment ben difosa i senzilla de seguir per al lector. Si en algun aspecte estructural s'apartaran els CC de les narracions literàries serà precisament en l'evitació d'experimentacions amb l'estructura. En l'apartat 2 del 
capítol IV analitzarem si podem aplicar aquesta estructura dels cinc elements de la narració als casos clínics.

\subsection{La història i la trama}

La major part de les teories narratives estan d'acord amb el fet que hi ha almenys dos nivells en un text narratiu: allò que passa i la manera com es conta. Per a aquests dos nivells (el què i el com) podem trobar noms diferents segons cada tradició teòrica. L'estructuralisme ha estat un dels corrents més influents en aquest àmbit i en la seva terminologia "the what of the narrative is called story, the how is called discourse" (Lethbridge i Mildorf, 2004). Aquesta teoria, per tant, distingeix entre la història, com una seqüència d'accions o esdeveniments independents de la seva presentació discursiva, i el discurs, com a representació narrativa particular d'aquests esdeveniments (Genette, 1980).

Els formalistes russos anomenaven aquesta distinció amb els termes fabula i sujet, tot i que els conceptes no són del tot coincidents amb els genettians d'història i discurs (vegeu-ne més en Pimentel, 1995). En el món anglosaxó, es van traduir els termes del rus per story (fabula) i plot (sujet). Aquesta tria, però, potser no va ser la més encertada (García Landa, 1998), perquè aquests dos termes tradicionals ja existien en anglès i no reflecteixen el mateix tipus de relació com els russos, però al capdavall és la que fet fortuna i trobem, per exemple, en l'estudi clàssic Aspects of Novel, de Forster (1985, 2728):

It [story] is the lowest and simplest of literary organisms. Yet it is the highest factor common to all the very complicated organisms known as novels. [...] A story, by the way, is not the same as a plot. It may form the basis of one, but the plot is an organism of a higher type.

Forster (1985: 86) també és l'autor de l'exemple que més repercussió ha tingut en les obres posteriors, en el qual diferencia aquests dos conceptes. Hi remarca que la història (story) són els successos ordenats seguint una seqüència temporal: «The king died and then the queen died». En canvi, en la trama (plot) també hi ha una seqüencia temporal 
de successos, però l'èmfasi es posa en la causalitat «The king died and then the queen died of grief».

Així doncs, entendrem la història com una seqüència d'esdeveniments en ordre cronològic, en la qual alguna cosa canvia de l'estat A a l'estat B. La trama, en canvi, es refereix a la manera i les etapes en què es configuren i resolen els conflictes cabdals. Així, la trama (plot) designa "the ways in which the events and characters' actions in a story are arranged and how this arrangement in turn facilitates identification of their motivations and consequences» Kukkonen (2014). Aquests patrons causals i temporals poden ser determinats pel discurs narratiu mateix o inferits pels lectors. Per tant, segons Kukkonen (2014), la trama es troba entre els fets d'una narració al nivell de la història i la seva presentació al nivell del discurs. No està subjecta a cap mode particular d'expressió narrativa i es pot observar en una gran quantitat de mitjans i gèneres.

D’alguna manera, la trama de la tradició anglosaxona ens recorda el concepte d'intriga que, segons Revaz (1997), caracteritza els relats respecte de les altres narracions (vegeu subapartat 3.1 d'aquest capítol). Elinor Ochs (2000) remarca que és precisament la trama que distingeix un relat respecte d'una llista d'esdeveniments. Quan un narrador crea una trama, estructura les accions i els esdeveniments en un esquema amb un determinat sentit. Així, podem concebre la trama com una teoria dels fets, entesa com una explicació dels esdeveniments contats des d'un punt de vista particular. Veient-ho així, la trama podria ser un tret distintiu del relat literari, però també del relat científic:

En este sentido, los relatos son afines a las narraciones científicas. Si bien estas últimas quitan todo énfasis a los agentes y motivos, comparten con las narraciones de relatos la propiedad de contar algo que está fuera de lo usual: un enigma, una discrepancia, una rareza, un desafío, un fenómeno que perturba el equilibrio. Además, tanto las narraciones científicas como las personales tratan de esclarecer un problema al colocarlo dentro de una secuencia de sucesos y circunstancias según las leyes de causa y efecto. (Ochs, 2000: 283)

Atesos els fonaments teòrics que hem anat exposant i tal com mostrarem al capítol IV, considerem que els CC acadèmics són narracions científiques, perquè presenten una successió cronològica d'esdeveniments i d'accions. Però, a més, els podem considerar 
un gènere afí al relat, ja que els autors no sempre presenten els processos en un ordre cronològic estricte, sinó que els organitzen en una trama o intriga, a fi palesar millor la seva visió sobre la causalitat de la malaltia:

In case presentations, narratives are used in order to describe the circumstances that resulted in a patient coming to the attention of the medical system. They also describe the nature of the patient's problem or disease, what has been done, and what is planned. These narratives subordinate the chronological chain of events of the patient's life to a plot of relevant medical goals and events. (Hydén, 2005)

Així doncs, la consideració de relats tant els contes clínics com els casos clínics ens permet concebre que hi ha un contínuum entre els dos tipus de textos. Òbviament, la diferència és que els primers tenen una vocació literària i s'adrecen a un públic més ampli, mentre que els segons es presenten com a textos científics, adreçats a un públic més restringit.

\subsection{Personatges i pacients}

Des del punt de vista de la narratologia, el terme personatge es refereix als participants en el món de la història, en contrast amb les persones, que som els individus que vivim i interactuem en el món real. Així doncs, parlem de personatges per referirnos a qualsevol ens, tant individual com col-lectiu, que apareix en una obra dramàtica o narrativa (Margolin, 2005). No es tracta, però, d'entitats autònomes que circulen per la història, sinó que formen part de les estructures significatives que construeixen el món de la història durant el procés de la comunicació narrativa (Jannidis, 2013).

De la construcció d'un personatge -en anglès, character- en diem caracterització -characterization. Mentre que fa uns anys la caracterització s'entenia sobretot com l'assignació de trets psicològics o socials a un personatge (vegeu Chatman, 1980), actualment es posa l'èmfasi en el fet que els textos atribueixen tota mena de propietats als personatges, com ara les espacials i temporals o les fisiològiques. Segons Fotis Jannidis (2013), la caracterització es realitza mitjançant l'associació als personatges d'informacions procedents d'almenys tres fonts: $a$ ) l'assignació explícita de propietats a 
un personatge; $b$ ) les inferències que es poden extreure de fragments del text, com ara: «ella va somriure nerviosament» i c) les inferències que es basen en informacions que no estan vinculades directament als personatges, sinó que són convencions del món real que canvien en diferents èpoques i cultures. Per exemple, una sala ens pot revelar determinades coses sobre els que hi viuen o l'oratge pot expressar els sentiments del protagonista.

La caracterització és un dels mecanismes de la narrativa per crear vincles amb els lectors. La manera com es presenten els personatges en el text condiciona la relació que s'hi estableix amb el lector. Seguint Fotis Jannidis (2013) podem distingir tres factors rellevants en aquesta relació: $a$ ) la transferència de perspectiva; $b$ ) la predisposició afectiva que pot tenir el lector respecte del personatge i $c$ ) l'avaluació dels personatges en el text. La predisposició afectiva, al seu torn, està influïda per: i) les emocions del personatge, tant quan es descriuen explícitament com quan es transmeten implícitament; ii) l'empatia del lector amb les situacions del personatge; iii) l'expressió de les emocions en la presentació. Aquest enfocament cognitiu entén el personatge com el model mental d'un participant en el món de la història. Aquest es va creant pel lector de la història a mesura que va avançant la lectura gràcies a les interaccions constants entre les dades textuals específiques i les estructures del coneixement general que desa el lector en la seva memòria de llarg termini (Margolin, 2005).

Si concebem els $\mathrm{CC}$ acadèmics com un tipus de relat, haurem d'entendre també que els pacients-persona del món real esdevindran pacients-personatge en el món de la història que es desenvolupa en els CC. Els pacients són, de fet, la base dels casos clínics. Sense ells - com també sense els professionals sanitaris - aquest gènere no podria existir, per més que els autors s'esforcin a atenuar-ne la caracterització en els textos. S'han fet nombrosos estudis sobre com els metges parlen amb els pacients, però no són tan freqüents les investigacions sobre com els metges parlen sobre els pacients (Anspach, 1988: 358).

Darrerament han aparegut diversos treballs que analitzen el llenguatge mèdic, especialment l'argot, com a clau per a entendre la subcultura que es desenvolupa entre els estudiants de medicina i els metges residents, sovint com a resposta als problemes causats per l'entorn laboral en què es mouen. En el nostre treball no analitzarem l'argot oral que empren els metges quan parlen entre ells - hi farem algunes referències, això 
sí-, atès que no és l'objectiu d'aquest estudi i no es possible analitzar-lo a partir dels CC. El mencionem perquè és rellevant tenir en compte que el tractament del pacient en els textos que analitzem té uns antecedents en el llenguatge oral del dia a dia en els hospitals i altres institucions sanitàries entre els diversos professionals que hi treballen amb els malalts. En l'apartat 4 del capítol IV estudiarem el tractament i la presència dels pacients en els $\mathrm{CC}$ acadèmics. Es tracta de textos redactats amb temps i preparació i que haurien de passar pel control dels experts de la revista que els publica. L'enfocament que tindrem en compte serà, per un costat, l'anàlisi del discurs mèdic, i, per l'altre, els estudis de socialització professional, ja que la forma en què els metges parlen entre ells, especialment sobre els pacients, és un focus analític d'aquesta segona tradició sociològica mèdica.

Seguint Anspach (1988), l'estudi del discurs mèdic ens permet fer una anàlisi del llenguatge tal com s'empra realment, mentre que els estudis de socialització professional faciliten l'estudi del significat cultural d'aquest llenguatge. L'autora anomena aquest enfocament sociolingüística simbòlica i se centra menys en l'estructura social de la presentació del cas (l'organització jeràrquica i seqüencial de l'intercanvi lingüístic) i més en el contingut simbòlic del llenguatge.

Els CC són un gènere que sovint es descriu com molt estandarditzat quant a l'estructura i els recursos lingüístics. S'hi fa servir un vocabulari estilitzat i una sintaxi que revela creences, hipòtesis i valors tàcits i subtils sobre els pacients, però també coneixements mèdics i pràctiques mèdiques amb els quals els metges en formació se socialitzen (Anspach, 1988: 359). Així doncs, els casos clínics són una molt bona font per a analitzar un aspecte significatiu de la socialització professional i ens deixen entreveure com funciona el món dels professionals sanitaris.

Un dels primers aspectes que ens pot revelar el llenguatge dels CC sobre el tractament dels pacients l'estudia Zabielska (2014: 64-67), qui se centra en la despersonalització de la medicina mitjançant l'atenuació de la presència dels pacients en els CC. Els autors dels CC intenten adoptar un discurs allunyat de la persona que pateix la malaltia que estan estudiant i se centren més aviat en les màquines i els procediments mèdics, que són els que guanyen protagonisme en el text. Així se suposa que les dades obtingudes són objectives i comprovables. Aquesta manera d'emfasitzar el paper de les dades - les que demostren o revelen- és pròpia del discurs científic i té 
a veure amb el desenvolupament històric de les ciències de la salut i la seva especialització. A mesura que avança la medicina i milloren els mètodes de tractament, la malaltia -i no tant el malalt - ocupa un lloc cada vegada més prominent en els textos mèdics.

Un exemple típic de despersonalització es produeix quan es donen els resultats de les proves mèdiques. Aquestes es reporten com a atributs (Atkinson, 1995: 107) dels pacients 0 , fins i tot, sense fer cap referència al pacient. En casos extrems, els pacients es redueixen a portadors d'alguna malaltia o, directament, a la malaltia que pateixen. En els CC acadèmics també podem trobar referències a parts del cos del malalt i a aspectes de la seva salut formulades en uns termes que semblen desvinculats de la persona (Zabielska, 2014: 171-172). Així, per exemple, pot semblar que un ginecòleg només està curant i centrant-se en la vagina, sense veure la dona a qui pertany: «the vagina and the cervix were noted to be clear» (Anspach, 1988: 366). Un lector convencional s'hauria fet la pregunta: «de qui?», ja que aquesta manera d'expressar-se centra tota l'atenció en una malaltia o en un òrgan més que no pas en el pacient.

La despersonalització, però, no és només una qüestió relacionada amb l'escriptura mèdica. Podríem pensar que aquests recursos s'empren només per objectivar el discurs en els textos escrits, inclosos els CC acadèmics. Sembla, però, que fins i tot en el llenguatge oral del dia a dia dels professionals sanitaris - que no es publica enlloci, per tant, no s'hauria d'adaptar a aquestes normes de gènere- es verifica una tendència cap a la despersonalització dels pacients. Així, ens trobem amb la pràctica dels professionals de referir-se als pacient en els hospitals mitjançant el nom de la seva malaltia — «the trisomy in Room 311»- o, en el cas de les sales quirúrgiques, el procediment mèdic que s'hi aplica - «the tonsillectomy in 214»-(Anspach, 1988: 366).

Se sol plantejar la pregunta de si aquest tractament discursiu dels malalts pot provocar que els professionals sanitaris adoptin determinades actituds cap als seus pacients. Darrerament, apareixen moltes publicacions, tant des de dins de la medicina com des de fora, que proposen un nou enfocament en la medicina moderna per canviar l'actual tendència de tractar malalties i no pacients. Els metges que publiquen textos destinats a fora del seu àmbit científic, com ara Oliver Sacks o Arthur W. Frank, els quals escriuen llibres sobre la seva praxi mèdica destinats a un públic general, intenten canviar 
aquest enfocament deshumanitzat del pacient considerat com un cos que exemplifica una malaltia:

\footnotetext{
"I hope to shift the dominant cultural conception of illness away from passivity-the ill person as 'victim of' disease and then recipient of care-toward activity". The ill person who turns illness into story transforms fate into experience; the disease that sets the body apart from others becomes, in the story, the common bond of suffering that joins bodies in their shared vulnerability. (Frank, 2010: $\mathrm{xl}$ )
}

\subsection{El punt de vista}

La caracterització dels personatges i l'encadenament espaciotemporal d'accions i d'esdeveniments que constitueixen la narració d'una història sempre es produeixen des d'una determinada perspectiva o punt de vista (Toolan, 2001). En els CC acadèmics, el narrador -identificat amb l'autor- hauria d'intentar contar els fets i presentar el seu pacient d'una manera objectiva. L'objectivitat total, però, és impossible. El simple fet de dir sobre una persona que és prima, grossa, tímida o tranquil·la ja implica la introducció d'una opinió personal i l'adopció d'un determinat punt de vista, els quals són, òbviament, subjectius. En els CC, no esperarem trobar caracteritzacions subjectives més pròpies de les obres de ficció literària, com ara si el pacient és lleig o simpàtic, però sí que ens en podrem trobar d'altres potser menys evidents que escapen al control de l'esperit científic dels autors.

Per introduir el concepte de perspectiva o punt de vista, recuperem les observacions que en fa Erving Goffman (1974: 504) en relació amb el relat:

A tale or anecdote, that is, a replaying, is not merely any reporting of a past event. In the fullest sense, it is such a statement couched from the personal perspective of an actual or potential participant who is located so that some temporal, dramatic development of the reported event proceeds from that starting point. A replaying will therefore, incidentally, be something that listeners can empathetically insert themselves into, vicariously reexperiencing what took place. A replaying, in brief, recounts a personal experience, not merely reports on an event. 
En un relat no ens importarà només la quantitat d'informació que se'ns ofereix, sinó també la seva qualitat, o millor dit, el nivell de limitació, distorsió i confiabilitat amb el qual se'ns ofereixen els fets. Aquests sempre es presenten des d'una determinada visió o punt de vista. Parlaríem aquí de la manera com es veuen les coses, des de quin angle. En el cas de la narrativa, la seva naturalesa subjectiva és inevitable.

Genette (1972 i 1988) va introduir el terme focalització per substituir els conceptes de 'perspectiva' i 'punt de vista'. El podem definir com una selecció o restricció de la informació narrativa en relació amb l'experiència i el coneixement del narrador, els personatges o altres entitats de la història (Niederhoff, 2013). Genette analitza els models anteriors, els reformula i, així, arriba a tres graus de focalització (zero, intern i extern), és a dir a tres eleccions narratives que es presenten al narrador:

The first term [zero focalization] corresponds to what English-language criticism calls narrative with omniscient narrator and Pouillon 'vision from behind,' and which Todorov symbolizes by the formula Narrator > Character (where the narrator knows more than the character, or more exactly, says more than any of the characters knows). In the second term [internal focalization], Narrator $=$ Character (the narrator says only what a given character knows); this is narrative with 'point of view' after Lubbock, or with 'restricted field' after Blin; Pouillon calls it 'vision with.' In the third term [external focalization], Narrator < Character (the narrator says less than the character knows); this is the 'objective' or 'behaviorist' narrative, what Pouillon calls 'vision from without'. (1980: 188-189)

Així doncs, els diversos tipus de focalització permeten narrar des d'una perspectiva omniscient, des del punt de vista d'un o diversos personatges o, fins i tot, des d'una perspectiva neutra, fora de tota consciència (Pimentel, 1995). Genette separa la veu narrativa i la perspectiva, dos conceptes que tenen molts punts de contacte, però que no són completament intercanviables, ja que no és el mateix qui narra com el punt de vista des del qual ho fa.

Les teories que es desenvolupen després de Genette estan influïdes per la crítica per part de Bal (2009) als models genettians. Així, Bal distingeix dos tipus de focalització: vinculada a personatges o interna (la focalització interna de Genette) i externa (la combinació de la focalització zero i externa genettianes). A més, també diferencia dos 
tipus d'objectes focalitzats: imperceptibles (pensaments, sentiments, etc.) i perceptibles (accions, aspectes, etc.).

Seymour Chatman (1980 i 1990; van Peer i Chatman, 2001) entén la perspectiva com la ubicació des de la qual es presenten els esdeveniments d'una història al lector. Com remarca aquest autor amb van Peer (2001: 5), la ubicació inclou tant el significat literal - amb referència a les coordenades espaciotemporals d'un agent o d'un observador-, com el figuratiu - les normes, les actituds i els valors d'aquest agent o observador. A més, Chatman (1990) considera recomanable fer una diferència entre les experiències mentals del narrador i dels personatges en el món de la història com a tipus d'experiències diferents. Ara bé, això és més que complicat si continuem referint-nos a ambdues amb el mateix terme, ja sigui focalització, punt de vista o perspectiva. Així, suggereix una separació terminològica entre aquests dos loci del punt de vista: el del narrador (slant) i el del personatge (filter).

En contrast amb aquests enfocaments, centrats en preguntes sobre el tipus de perspectiva manifestada en un text en particular, la qual es considerava una característica del producte acabat, els enfocaments posteriors tracten la interacció entre el narrador i el narratari des d'una perspectiva dinàmica. Així, el gir que canvia el model d'investigació consisteix a fer l'anàlisi del procés (How is perspective in the story brought about?) i no exclusivament l'anàlisi del producte textual (What is the perspective in this story?) (van Peer i Chatman, 2001: 7). En el subapartat 4.6 del capítol IV ens acostarem a la problemàtica dels narradors i el punt de vista en els CC. 

CAPÍTOL IV.

LA NARRACIÓ DE LES AFECCIONS MENTALS: DEL CAS CLÍNIC AL CONTE CLÍNIC

1. Característiques formals dels casos clínics

2. La naturalesa narrativa dels casos clínics

3. Del tecnolecte a la retòrica literària

4. Polifonia: metges i pacients; narradors i personatges

En aquest capítol analitzem els casos clínics seleccionats per al nostre corpus, tot comparant-los amb els contes clínics. En revisem les característiques formals, lingüístiques i retòriques, amb especial atenció a aquelles que mostren el caràcter narratiu del cas clínic. En el primer apartat ens centrem en els aspectes formals i estructurals, per tal d'entendre millor com es concreten les convencions d'aquest gènere en el camps de la salut mental. En el segon apartat abordem les seqüències textuals presents i predominants en el gènere i comprovem la presència d'una estructura narrativa que configura el CC. En el tercer apartat repassem el tecnolecte i els trets lingüístics propis d'aquest gènere com també els procediments d'adaptació que s'apliquen en els contes clínics. En el quart apartat estudiem les relacions entre les veus dels professionals sanitaris i dels pacients tal com es reflecteixen en els dos gèneres, especialment en relació a la plasmació textual en els rols de narradors i personatges. Amb tot això, esperem mostrar la naturalesa narrativa compartida pels casos clínics i els contes clínics, comprendre millor les semblances i les diferències entre els dos gèneres i, així mateix, identificar diferents tendències dins de cada gènere respecte de l'enfocament narratiu i del paper dels pacients en els textos. 


\section{CARACTERÍSTIQUeS FORMALS DELS CASOS CLíNICS}

En aquest apartat abordem els aspectes formals dels casos clínics, particularment l'extensió, l'organització formal i les característiques dels diversos apartats. Presentem algunes dades numèriques dels CC acadèmics del nostre corpus trilingüe, les quals poden revelar alguns dels trets $o$ de les tendències d'aquest gènere $i$ de les seves relacions tant amb els propòsits comunicatius com amb les comunitats de pràctica en les quals es desenvolupen. Hi incloem aspectes com la llargària mitjana d'un CC, quants autors hi solen participar i si tendeix a haver-hi més homes o dones.

En el capítol II -on hem presentat les revistes de les quals hem obtingut els nostres textos- havíem mencionat si les publicacions marcaven l'extensió recomanada dels CC. La majoria sí que aconsella als autors una llargària màxima, però aquesta varia considerablement d'una revista a una altra: entre mil paraules i vint pàgines. Els casos clínics del nostre corpus han estat seleccionats pel fet de ser representatius de diferents disciplines de les ciències de la salut i de diverses tipologies de revistes. És comprensible, doncs, que hi hagi variació. En el primer capítol hem mencionat les vicissituds que ha experimentat la presència dels casos clínics en les revistes especialitzades (vegeu capítol I, subapartat 2.2). Ens interessa veure quin espai sol ocupar aquest gènere en les revistes actuals - recordem que els casos seleccionats són força recents. Calculem la llargària en pàgines, ja que són l'espai real que les publicacions permeten que sigui ocupat amb històries clíniques.

Com podem observar en els gràfics 1 i 2 , l'extensió més freqüent dels $C C$ acadèmics és d'entre tres i sis pàgines ( $68 \%$ del nostre corpus), cosa que confirma una de les característiques d'aquest gènere i és que sol ser d'extensió moderada. Les publicacions que es dediquen a les recomanacions sobre com ha de ser un bon CC perquè sigui publicat recomanen que no sobrepassi els 1.500 o 2.000 mots (Cohen, 2006) o que tingui entre quatre i vuit pàgines - això per a l'àmbit de revistes en llengua anglesa. Jenicek (2001) remarca que, si es tracta d'un cas vertaderament excepcional, ni les revistes més estrictes amb la llargària no acostumen a tenir cap inconvenient d'oferir tot l'espai que els autors necessitin. 


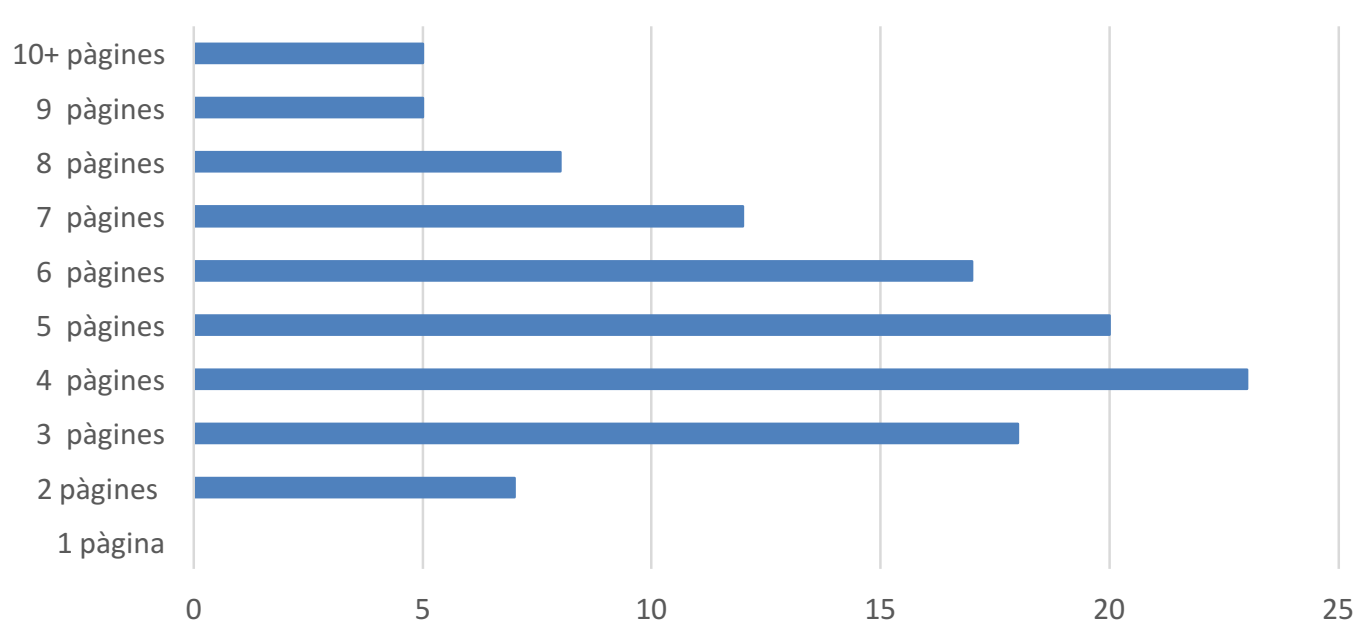

Gràfic 1: Nombre de pàgines dels CC acadèmics

En el gràfic 1 constatem que la Ilargària mínima que trobem són dues pàgines. La majoria d'aquests casos breus provenen de textos en català, concretament d'una variant dels casos clínics més visual, anomenada «repte en neuroimatge» i publicada en la revista Neurologia Catalana. Aquests CC en forma de vinyetes solen ocupar una primera pàgina, en la qual es presenta una breu exposició clínica i una o diverses neuroimatges que plantegen un exercici diagnòstic. En el següent número de la revista, habitualment també en una sola pàgina, es repassa el repte i s'hi revela la solució del cas. Tenim aquí una clara il-lustració de com els propòsits comunicatius de cada revista -en aquest cas, la funció didàctica - poden influir sobre les característiques formals -el suport gràfic, l'extensió, la divisió del cas en dos números de la mateixa revista- que adopta el gènere en cada realització concreta.

Quant a l'extensió màxima, també és en català on en trobem més casos i també aquí podem relacionar aquesta especificitat amb els propòsits comunicatius. Els quatre casos més llargs del nostre corpus pertanyen a la revista Desenvolupa: la Revista d'Atenció Precoç, la qual és la que permet la publicació de CC més extensos: fins a vint pàgines un criteri que aplica a tot tipus de textos. Alguns dels CC del nostre corpus arriben a aquestes vint pàgines - a doble columna, a més-, com és el cas de la «Història d'una nena que jugava a construir-se a si mateixa» (31.CAT_Atenció_precoç). Els CC d’aquesta publicació es diferencien de la resta per la quantitat d'informació teòrica i introductòria 
proporcionada abans de presentar el pacient i també per la descripció detallada dels procediments. La revista Desenvolupa no es dedica als CC únics o innovadors. El seu propòsit, per tant, no són els nous descobriments que justifiquin una extensió no gaire habitual en aquest gènere, sinó que es tracta de compartir experiències i observacions amb una revisió tant del fenomen observat com de la bibliografia sobre ell en l'àmbit de l'atenció precoç.



\begin{tabular}{|l|r|r|r|r|}
\hline Pàgines & Català & Castellà & Anglès & Total \\
\hline 1 pàgina & 0 & 0 & 0 & 0 \\
\hline 2 pàgines & 6 & 0 & 1 & 7 \\
\hline 3 pàgines & 6 & 6 & 6 & 18 \\
\hline 4 pàgines & 10 & 6 & 7 & 23 \\
\hline 5 pàgines & 3 & 11 & 6 & 20 \\
\hline 6 pàgines & 3 & 10 & 4 & 17 \\
\hline 7 pàgines & 2 & 3 & 7 & 12 \\
\hline 8 pàgines & 0 & 3 & 5 & 8 \\
\hline 9 pàgines & 1 & 1 & 3 & 5 \\
\hline $10+$ pàgines & 4 & 0 & 1 & 5 \\
\hline Total & 35 & 40 & 40 & 115 \\
\hline
\end{tabular}

Gràfic 2: Nombre detallat de pàgines dels CC acadèmics

Finalment, no trobem cap cas clínic que càpiga en una pàgina. Hem vist que fins i tot una versió gens prototípica dels CC com són els reptes en neuroimatge n'ocupa dues. Els 
CC tradicionals normalment necessiten almenys tres pàgines, puix que han d'incloure un resum i sovint uns apartats determinats, a més de gràfics o imatges. Seria difícil, doncs, poder reduir tot això a menys de dues o tres pàgines. D'altra banda, recordem que les publicacions en xarxa es poden permetre dedicar un espai virtualment il-limitat a un gènere no tan citat, però molt llegit, com és el dels CC. Això fa possible trobar CC considerablement més llargs del que consideraríem estàndard. Però encara que ja no hi hagi limitacions d'espai real o físic, els experts continuen recomanant no sobrepassar una extensió moderada, perquè es perdria una de les característiques que defineix aquest gènere.

Quant a les diferents especialitzacions incloses en el nostre corpus, podem observar una tendència a publicar CC més llargs en els camps de la psicologia i també en la psiquiatria. Són textos que, com veurem, tendeixen a ser més narratius i on sovint trobem més informacions sobre el pacient com a persona i de quina manera ha afectat o està afectant el problema a la seva vida. En canvi, els CC de neurologia solen ser menys extensos, ja que no hi trobem gaires informacions sobre el pacient, sinó preponderantment taules i gràfics amb resultats, xifres i terminologia altament especialitzada. Aquests recursos fan que els textos siguin més concisos: poden comunicar molt en poc d'espai, però fora del seu àmbit d'especialització resulten quasi indesxifrables. A més, poden transmetre una percepció que el pacient no és el centre del cas en qüestió, sinó que només l’il·lustra.

Pel que fa a l'organització formal dels CC acadèmics, en el capítol introductori aventuràvem la hipòtesi que aquest gènere tendirà a tenir una estructura comuna prefixada i pautada convencionalment, mentre que l'estructura dels CC literaturitzats serà implícita i més flexible. En la presentació del nostre corpus de casos clínics acadèmics hem detallat, per a cada revista, si fixava en les normes de publicació una estructuració en apartats i quina era. En aquesta part de l'anàlisi veurem quins són els apartats més freqüents dels $\mathrm{CC}$, si hi ha una estructura general clara, més o menys fixa per a aquest gènere mèdic, si és comuna a les tres llengües o si en cadascuna d'elles n'hi ha una de particular.

L'estructura, és a dir, els apartats i el seu contingut, han estat i són encara el centre d'atenció tant dels analistes del llenguatge de l'àmbit de la salut com dels professionals 
sanitaris mateixos. Trobem, doncs, publicacions que analitzen de quina manera es distribueix la informació en un CC, sovint com estructura retòrica i moviments discursius (Morales, 2010 o Burdiles, 2016), com també recomanacions de collegues a professionals novells sobre quins apartat ha de tenir un cas perquè sigui publicable. El manual de referència per a redactar un bon CC - Clinical Case Reporting in EvidencedBased Medicine, de Jenicek (2001) - recomana cinc elements: resum; introducció; presentació del cas; discussió i conclusions; referències bibliogràfiques. Les tres parts intermèdies conformen l'estructura retòrica del text (Uribarri, 2004; Morales et al., 2007), mentre que el resum i les referències bibliogràfiques es poden considerar elements paratextuals. Nosaltres hem identificat i quantificat els elements constitutius en el nostre corpus de casos clínics acadèmics (taula 1).

\begin{tabular}{|c|c|}
\hline Parts & Freqüència \\
\hline Títol & $94 \%$ \\
\hline Autoria & $100 \%$ \\
\hline Resum & $76 \%$ \\
\hline Paraules clau & $66 \%$ \\
\hline Introducció & $69 \%$ \\
\hline Presentació del cas & $100 \%$ \\
\hline Figures & $76 \%$ \\
\hline Discussió & $80 \%$ \\
\hline Conclusió & $52 \%$ \\
\hline Agraïments & $22 \%$ \\
\hline Referències & $91 \%$ \\
\hline
\end{tabular}

Taula 1: Freqüència d'aparició dels diversos components dels CC, en l'ordre més habitual d'aparició

\subsection{L'autoria}

Quant al nombre de professionals sanitaris que apareixen com a autors dels CC, el nostre corpus està constituït per textos signats per més de 350 autors -alguns repetits - i tres equips que signen col-lectivament. Observem que hi ha textos redactats -o almenys signats - per un únic autor, encara que la tendència és que en siguin més 
-com a mínim dos. En el gràfic 3a, veiem que el nombre d'autors més comú en el nostre corpus se situa entre un i tres. Aquesta xifra va d'acord amb les recomanacions per part dels experts que han criticat l'excés d'especialistes que presenten —o almenys signenels CC. Un dels màxim referents en el camp, Jenicek (2001), aconsella que no se superin els tres autors. La convenció habitual és que la persona que ha estat al cap del projecte aparegui en primer lloc. Els altres que hi apareixen haurien d'haver-hi col-laborat de manera substantiva. Els abusos que s'han produït i que han estat creixent en els darrers anys, en bona part a causa de la pressió curricular per publicar, han creat una necessitat de criteris clars d'autoria ${ }^{14}$. Atès que «it is unlikely that a single case will be managed by a large team of providers, one would not expect to see more than a few authors on a case report» (Green i Johnson, 2006: 76). Hi ha diversos estudis que demostren que els CC estan signats per massa autors, com ara el d'Har-El (1999), el qual ens pregunta, amb un títol contundent $\mathrm{i}$ irònic, si «Does it take a village to write a case report?».

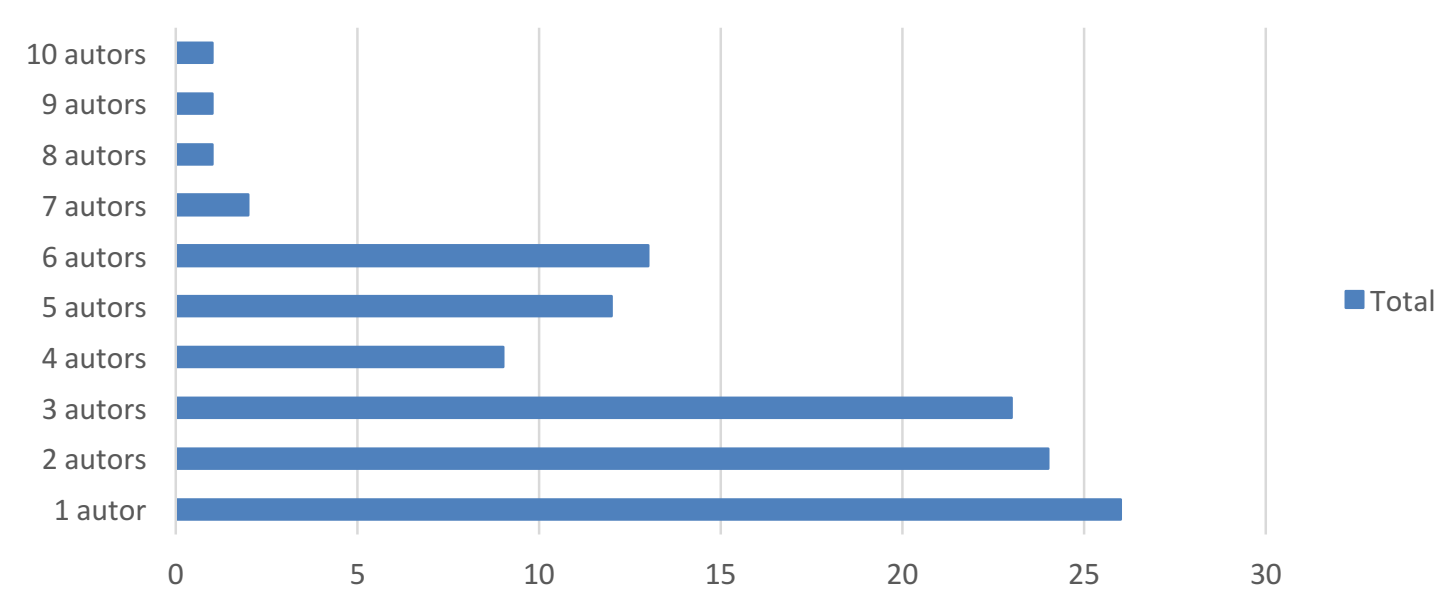

Gràfic 3a: Nombre d'autors dels CC

\footnotetext{
${ }^{14}$ Aquest criteris els va proporcionar l'International Committee of Medical Journal Editors (vegeu-ne més en Johnson, 2005). Segons el Comitè, un professional sanitari només es pot considerar autor si compleix tots els criteris següents «1) has provided substantial contributions to conception and design, or acquisition of data, or analysis and interpretation of data; 2 ) has drafted the article or revised it critically for important intellectual content; and 3) has given final approval of the version to be published" (Green i Johnson, 2006: 76). Els qui no compleixin els tres criteris, però sí que hagin col-laborat a l'estudi no hi han d'aparèixer com a coautors, sinó que se'ls ha d'agrair la contribució en l'apartat de reconeixements de la publicació.
} 
Com es veu en el gràfic $3 b$, no tots han seguit aquestes recomanacions, ja que en el corpus comptem amb CC que tenen més de tres o quatre autors. N'hi ha fins i tot alguns que en tenen vuit, nou i deu. Entre les tres llengües sí que podem veure una petita variació. L'anglès és l'únic idioma en el qual trobem CC amb més de sis signataris. Cal dir que no es tracta sols d'una revista en concret, sinó d'una tendència genèrica. A l'altre extrem tindríem els casos en català, en els quals predomina la presència d'un o dos autors i només hi ha uns quants casos amb cinc o sis signataris. Trobem que aquesta diferència està Iligada amb els tipus de revista en la qual es publica el text. Les revistes de què disposem en anglès estan incloses als índexs amb més prestigi i sovint es paga per poder publicar-hi. Les podríem qualificar de comercials. En canvi, les revistes en català pertanyen a entitats no lucratives i associacions de professionals sanitaris en les quals es publica més per compromisos professionals o fins i tot cívics que no pas per acumular mèrits - algunes no estan indexades. A més, els autors provenen d'un territori ben demarcat i d'àmbits d'especialització restringits, en els quals suposem que es coneixen entre ells. Òbviament, pot haver-hi publicacions de fora del territori catalanoparlant, però el que veiem és que majoritàriament solen ser professionals dels hospitals i centres especialitzats catalans.

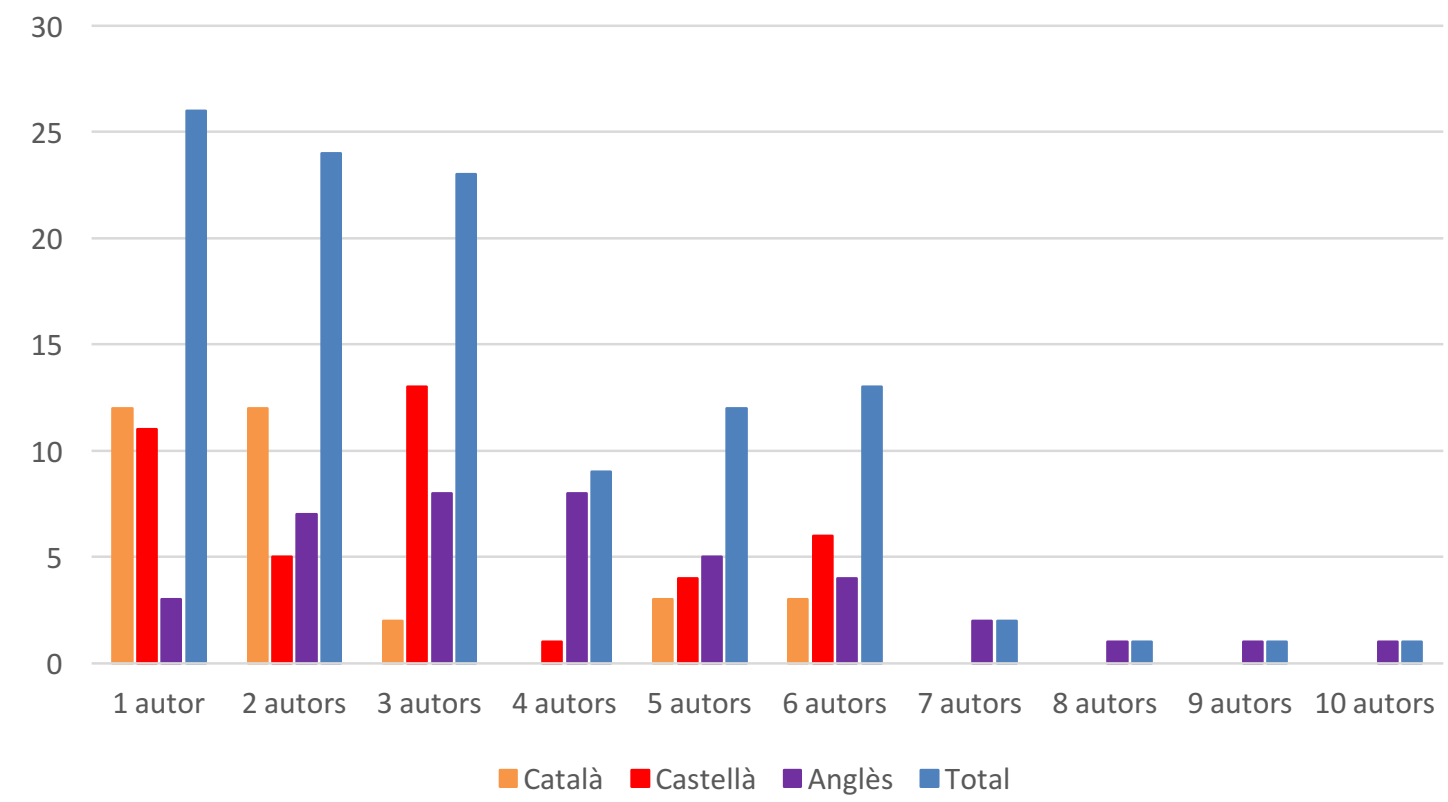

Gràfic 3b: Nombre d'autors dels CC per llengües 
D’aquesta manera, creiem que en les revistes catalanes és més probable que apareguin com a autors únicament els professionals que sí que han participat efectivament en alguna de les parts de l'estudi. Hem de mencionar també que en el nostre corpus disposem de tres CC amb una autoria col-lectiva sense noms dels professionals, només de la unitat hospitalària, com per exemple «Servei de Neurologia. Hospital Parc Taulí, Sabadell (Barcelona)» (11.CAT_Neurologia). Novament, els propòsits comunicatius d'aquesta revista, amb un marcat caràcter institucional, són els que fan possible aquesta peculiar autoria col-lectiva, també institucional. En contrast, les revistes en anglès que hem seleccionat aborden camps més amplis i compten amb autors d'arreu del món. Aquestes revistes grans són les que ens il/lustren els problemes actuals de les publicacions en el món acadèmic. A la qüestió de l'autoria massa nombrosa -o fins i tot fictícia - cal afegir la de les revistes depredadores, com ja hem comentat en el capítol II.

Finalment, entre les diferents especialitzacions no observem una diferència tan clara, però sí que s'hi pot veure en molts casos una determinada tendència. En aquest cas és al revés que en el del nombre de pàgines. Aquí, els $C C$ de psicologia i alguns de psiquiatria tendeixen a comptar amb menys autors que els de neurologia. Ho considerem lògic, ja que mentre que la psicoteràpia la poden conduir una o dues persones, molts dels casos neurològics han requerit tot un equip per poder atendre el pacient. Ara bé, recordem que segons els criteris estàndard no tots els que han tingut contacte amb el pacient i que han col-laborat amb el projecte es converteixen automàticament en coautors d'una publicació.

Un altre aspecte que ens interessa sobre l'autoria és la distribució dels autors per gèneres. En el gràfic $4 a$, podem veure que la proporció entre autors i autores és equiparable, encara que amb una presència un poc major de dones. Aquesta proporció l'apugen els CC en català (gràfic $4 b$ ) i sobretot en castellà (gràfic $4 b$ ), on la presència femenina és palesament superior. En canvi, en els textos en anglès (gràfic $4 b$ ) són els homes els qui prevalen lleugerament. Un factor bàsic d'aquesta diferència és el pes, en el corpus castellà, dels casos clínics d'infermeria, una professió associada tradicionalment a les dones. Vet aquí un dels reptes de l'atenció sanitària actual: el procés de desfeminizació de la infermeria, en el qual s'intenta desvincular la professió d'una adscripció de gènere que ha estat determinant des dels seus orígens (Salvador, 
2017). En les diverses especialitzacions mèdiques, en canvi, no trobem cap predomini destacable.



Gràfic 4a: Distribució dels autors dels CC per gèneres

Català

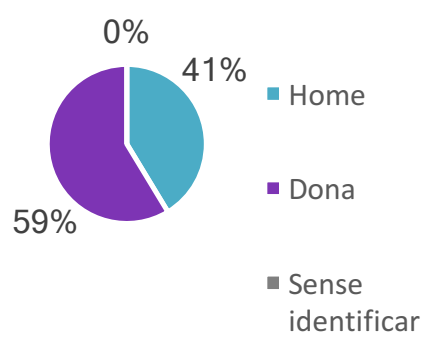

Castellà

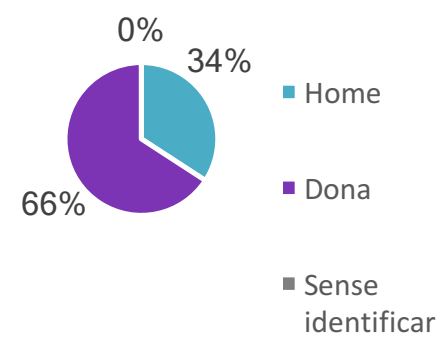

Anglès

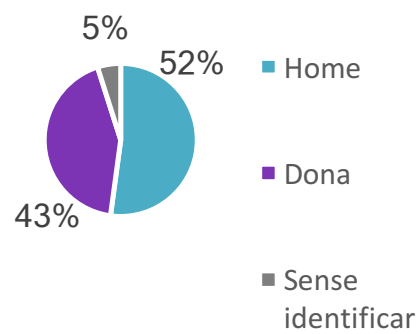

Gràfic $4 b$ : Distribució dels autors dels CC per gèneres i per llengües

\subsection{Els títols dels casos clínics}

Hi ha un element inicial d'enorme rellevància que presenta tot el contingut del CC: el títol. Com en qualsevol altre àmbit, el títol d'una novel·la, el titular d'una notícia, el nom de la pel-lícula... sol ser el primer element del text que arriba al receptor. Un títol pot condemnar a mort el nostre text o catalitzar-ne l'èxit. El contingut d'una publicació, per excel-lent que sigui, no es rendibilitzarà si ningú o massa pocs fan el pas de continuar llegint. Sobretot en la literatura, un títol pot marcar la diferència entre agafar o no una 
obra a les mans quan som en una llibreria o a la biblioteca. Ara bé, els textos científics no tenen per objectiu seduir masses de lectors posant un títol cridaner. En general, en l'àmbit sanitari els títols tendeixen a ser més aviat descriptius. Si algunes vegades tenen la voluntat de sorprendre és pel contingut o per la temàtica tractada, no mitjançant un títol impactant o poètic.

Els CC, com a relats relativament atípics dins de les publicacions sanitàries, presenten dues menes de títols. El primer tipus és el que probablement esperaríem en un text científic, l'informatiu, en el qual es procura incloure informacions sobre el problema i la temàtica abordats per fer saber què tractarà el text. És una mena de síntesi del cas en una o dues frases (exemples 1, 2, 3 i 4).

(1) «Discussió i revisió de la bibliografia a partir del cas d’un home jove amb síndrome de Down i trombosi venosa cerebral» (10.CAT_Down)

(2) «Alteraciones reversibles en la neuroimagen asociadas al tratamiento con vigabatrina en lactantes con espasmos epilépticos» (4.ESP_Neurología_A)

(3) «Favourable Outcome in a 33-Year-Old Female with Acute Haemorrhagic Leukoencephalitis» (33.ENG_Neurology_C)

(4) «Chronic Autoimmune Meningoencephalitis and Periodic Fever Syndrome Treated with Anakinra» (14.ENG_Neurology_C)

Segons Jenicek (2001), un bon títol de CC hauria de contenir quatre elements: intervention, outcomes, population setting i condition of interest. Aquesta mena de títols informatius són els predominants en el nostre corpus, per bé que no sempre compleixen totes aquestes parts. Però entre els casos clínics acadèmics trobem un segon tipus de títol (exemples 5, 6, 7 i 8) que difícilment associaríem amb un text científic i que no podem evitar qualificar de literari:

(5) «Alicia en el país de las maravillas» (25.ESP_Psiquiatría)

(6) «Cuando menos te lo esperas» (33.ESP_Neurología_B)

(7) «Doctora icreo que la veo doble!» (34.ESP_Neurología_B)

(8) «Una demencia como otra cualquiera» (35.ESP_Neurología_B)

Lluny de ser un resum dels continguts que trobarem en el nucli del cas clínic, aquests títols fan ús de recursos poètics - gairebé podríem parlar-hi de publicitaris- per atreure 
el lector cap al text. Si el lector no s'endinsa en el nucli del CC, no podrà determinar res o molt poc sobre el cas. Jenicek (2001: 100-101) detecta aquesta mena de títols amb vocació més aviat artística o simbòlica, en els quals el lector no pot esbrinar quina malaltia, quina complicació ni quin tipus de pacient s'hi tractarà, i els relaciona amb un propòsit comunicatiu ben allunyat dels objectius teòrics d'aquest gènere:

a title like 'The rooster that sang a different song' as an introduction to a case report on an unusual clinical picture of whooping cough may perhaps reflect the author's wit and draw attention. However, the reader might have to read through the whole report in order to understand what it is about. If, as in Agatha Christie's or Sir Arthur Conan Doyle's novels, the mystery is unravelled only at the end of the clinical case report, its reading is often painful. Usually this type of structure suggests that the author wanted to say: 'look how clever I am'. (Jenicek, 2001: 100-101)

Trobem també alguns CC que presenten una combinació dels dos tipus de títol, amb una part més literària barrejada amb la informativa. Si l'autor sent la necessitat de cridar l’atenció del lector mitjançant el títol, aquesta és la solució recomanada tant per Jenicek (2001) com per Green i Johnson (2006): una combinació de títol literari amb títol científic. Els avantatges d'aquesta opció són evidents i l'ordre és pertinent. El títol literari, primer, permet sorprendre i atreure el lector mitjançant la utilització de recursos poètics. Després, el títol científic delimita l'abast del treball, evita confondre el lector o desorientar-lo sobre els continguts:

(9) «Història d'una nena que jugava a construir-se a si mateixa. Desenvolupament de la identitat corporal d'una nena amb trastorn de l'espectre de l'autisme a través d'una psicoteràpia psicomotriu» (31.CAT_Atenció_precoç)

(10) «(Being with a Buddha): A Case Report of Methoxetamine Use in a United States Veteran with PTSD» (17.ENG_Psychiatry)

Arribats en aquest punt, cal parar esment en la similitud que guarden una part dels títols dels casos clínics acadèmics (exemples 5-10) amb els dels contes clínics, on el contingut informatiu sempre cedeix el terreny al propòsit literari i, per tant, als recursos poètics. L'ús d'un títol més poètic que informatiu, o d'una combinació d'ambdós, ens revela que la frontera entre el cas clínic publicat en les revistes científiques i el relat 
literari que constitueix el conte clínic no és un línia divisòria estricta, sinó un territori ampli on els autors mantenen una certa llibertat per combinar els diversos registres $\mathrm{i}$ recursos disponibles i fer-los servir en funció dels seus propòsits.

Pel que fa als CC literaturitzats, si comencem pels noms dels llibres, veiem que sovint combinen una part literària - The Man Who Mistook His Wife for a Hat o Reaching Down the Rabbit Hole - amb una altra que ajuda els lectors a situar la publicació - and Other Clinical Tales o Extraordinary Journeys into the Human Brain - i revela parcialment el contingut i l'adscripció al món sanitari. Dins dels llibres, els títols dels capítols, tant si inclouen un cas clínic sencer, o diversos, o una part - ja que alguns casos se'ns expliquen al llarg de diferents capítols i barrejats amb altres-, veiem com els autors intenten que els títols produeixin curiositat $\mathrm{o}$, fins i tot, desconcert:

(11) «If Rape Were Legal...» (2.LIT_Yalom)

(12) «You Haven't Got a Clue» (9.LIT_Frost)

(13) «A Walking Grove» (22.LIT_Sacks)

(14) «Like a Hole in the Head. Where baseball and neurology converge in a game-saving, over-the-shoulder catch» (2.LIT_Ropper)

A diferència del CC acadèmics, el lector dels contes clínics no necessàriament selecciona els textos per la temàtica que tracten. L'autor no s'adreça a un professional sanitari que està buscant respostes o està aprenent sobre diferents aspectes d'alguna malaltia o símptoma. Al lector prototípic que enceta un conte clínic no li cal saber des del principi de què tractarà, sinó, ben al contrari, agraeix aquesta intriga ja introduïda $\mathrm{i}$ reforçada pel títol.

Encara en l'àmbit dels títols, voldríem fer referència a una particularitat que es troba en alguns dels CC redactats per professionals de la infermeria: la inclusió de la referència a la pròpia professió. En una revistat de neurologia o de psiquiatria, generalment els autors no necessiten remarcar al títol que el CC s'aborda des d'una perspectiva mèdica - de metge-, probablement perquè és la perspectiva per defecte establerta en les convencions del gènere. En canvi, quan els autors són infermers, sembla pertinent explicitar-ne la perspectiva en el títol: «Caso clínico: síndrome de Von Hippel-Lindau, una visión desde enfermería» (9.ESP_Enfermería); «Encefelitis anti-NMDA y enfermería al alta» (11.ESP_Enfermería). Aquest moviment el podem interpretar tant com una 
petició de permís pel que alguns podrien considerar com una intrusió - dels infermers en un gènere de metges-, però també com una reinvindicació del dret d'aquesta comunitat de pràctica d’aportar la seva perspectiva clínica.

Cal dir que trobem també alguns CC sense títol, tots concentrats en la revista Neurologia Catalana (imatge 1). Tot i que la majoria dels CC d'aquesta revista sí que porten títol, en els darrers números la tendència és ometre'l. S’hi destaca la secció -«El racó del resident»-, s'introdueix dades sobre l'autor o els autors i, a continuació, es passa directament a la presentació del cas. Tanmateix, es tracta només de set casos i concentrats en una sola revista. És per això que el 94 \% dels CC del nostre corpus sí que compten amb un títol.

\title{
EL RACÓ DEL RESIDENT
}

\author{
María Ruiz Julián \\ Servei de Neurologia \\ Hospital Arnau de Vilanova, Lleida.
}

Es tracta d'un home de 73 anys, ex-fumador desdel 2005, sense factors de risc vascular. Antecedent d'hemorràgia subaracnoidal no traumàtica en solcs de la convexitat frontal dreta al setembre del 2013. que es va manifestar clínicament com un episodi d'impossibilitat per a expressar-se juntament amb parestèsies a la mà esquerra, d'uns 15 minuts de



alteracions patològiques.

Imatge 1: Fragment del CC 23.CAT_Neurologia

\subsection{El nucli dels casos clínics}

El nucli dels casos clínics està conformat per tres dels cinc elements que recomana Jenicek (2001) -introducció; presentació del cas; discussió i conclusions - i que segons Uribarri (2004) i Morales et al. (2007) constitueixen l'estructura retòrica del text. El primer apartat, la introducció, hauria d'animar el lector a seguir llegint, tot proporcionant una informació inicial sobre l'objecte de l'estudi - problema, malaltia, gestió clínica-, contextualitzar-lo - revisió de la literatura o nombre de casos reportats 
anteriorment-, justificar-lo i explicar-ne els objectius. El repte aquí és limitar la informació i no esplaiar-se amb detalls innecessaris. Els autors només haurien de mencionar les referències que siguin necessàries per a la familiarització dels lectors amb l'objecte de l'estudi (Green i Johnson, 2006). Recordem que la major part dels CC tenen un límit d'extensió i que no es tracta de manuals sobre una malaltia. Segons Jenicek (2001: 103), en la introducció haurien d'aparèixer les informacions següents:

- Definició del tema (problema, malaltia, atenció clínica).

- Context general del tema (coneixement rellevant, situació clínica actual i reptes).

- Les preguntes que aquest cas clínic hauria de respondre o quins buits de coneixement podria omplir.

- Objectius i justificació d’aquest cas clínic.

En aquest apartat és fonamental una bona presentació de l'estat de la qüestió, «como el trasfondo sobre el cual se marcará la figura del avance del conocimiento que la presentación y difusión del caso clínico intenta realizar» (Macián, 2013: 126). S’hi sol presentar la malaltia i el context dels estudis previs (exemple 15).

(15) La síndrome de Down (SD) és el trastorn genètic més freqüent, present en aproximadament 1 de cada 800 naixements vius. Els nens amb SD tenen una estructura de cap i coll alterada que provoca més malaltia otològica, de les vies respiratòries altes i nasosinusal. S'ha informat que entre el $38 \%$ i el $78 \%$ de persones amb SD tenen anormalitats de l'orella externa, mitjana i interna, cosa que contribueix a la hipoacúsia d'aquests subjectes. En aquests, més del $80 \%$ de la hipoacúsia és conductiva i és conseqüència de l'otitis mitjana amb vessament, per tant s'hi pot dur a terme una operació mèdica i quirúrgica. Tanmateix, del $4 \%$ al $20 \%$ de la hipoacúsia en aquesta població és conseqüència de la hipoacúsia neurosensorial. Al principi pensaven que les persones amb discapacitats addicionals $\mathrm{i}$ d'aprenentatge no eren candidats per a l'implant, tot i que gràcies a l'augment dels coneixements i dels bons resultats, els criteris d'inclusió s'han ampliat i cada cop hi ha més candidats que es beneficien de I'implant. Moltes d'aquestes persones, sobretot les que van rebre l'implant molt joves, 
presenten bons resultats pel fet que es conserva el gangli espiral i per la bona habilitació postoperatòria.

(Introducció: 7.CAT_Down)

Moltes de les introduccions acaben amb un avançament sobre els pacients que figuraran d'exemples en el CC. Aquestes parts, en les quals sovint predomina la narració, serveixen com a justificació del CC: una demostració que l'aportació no serà només teòrica, sinó que es basarà en un o més casos concrets. Així, el que trobem més freqüentment en les introduccions del nostre corpus (exemple 16) és una primera part expositiva que ens endinsa en la definició i la caracterització de la patologia en qüestió, de la seva etiologia, classificació... i una segona part de caire narratiu que presenta el pacient amb uns quants fets rellevants del seu historial mèdic, abans de passar a l'apartat «Presentació del cas», en el qual predominarà la descripció del malalt, com veurem més endavant.

(16) El mutismo acinético es un trastorno poco frecuente de la motivación, en el cual el paciente se encuentra en estado de vigilia, pero no presenta actividad motora voluntaria ni del lenguaje, y puede considerarse el caso extremo del trastorno abúlico. Puede aparecer como consecuencia de patología vascular cerebral, cirugía de fosa posterior, infecciones, tumores del tronco cerebral, hidrocefalia y daño traumático cerebeloso.

Presentamos un paciente con mutismo acinético tras una cirugía de fosa posterior por una fístula arteriovenosa, complicada con hemorragia diencefálica e hidrocefalia, que respondió espectacularmente al tratamiento con bromocriptina. También se discuten las causas del mutismo acinético y su posible siopatología mediante una revisión de la bibliografía.

(2.ESP_Neurología_A)

La majoria dels CC del nostre corpus compta amb l'apartat d'introducció (el $69 \%$ ), però la xifra contrasta amb altres estudis en què aquest apartat apareixia en tots o quasi tots els CC (vegeu Morales et al., 2007; Burdiles, 2016). Val a dir que, en aquest aspecte, trobem diferències significatives entre els textos en anglès -que inclouen l'apartat introductori en tots els casos- i els textos en castellà i en català. En el cas del castellà, per exemple, sovint trobem que, en una mateixa revista, un CC conté una introducció i 
un altre no. Com ja hem vist, moltes revistes recomanen una determinada estructura per a les publicacions dels diferents gèneres. Per exemple, la revista Adolescere aconsella una estructura on després del resum ve l'anamnesi, sense cap referència a la introducció, recomanació que segueixen tots els casos que n'hem analitzat excepte un.

En el cas de Neurologia Catalana, els textos comencen directament amb la presentació del cas - l'apartat que, canònicament, hauria de venir a continuació de la introducció. Aquest patró el solem trobar sobretot en CC que es plantegen com exercicis i tenen un propòsit comunicatiu clarament educatiu i no d'investigació. Com que la introducció sol avançar molts detalls sobre la malaltia que pateix el pacient en qüestió, en els CC que es proposen amb finalitats didàctiques resulta convenient ometre-la per evitar donar pistes als lectors que haurien de fer l'esforç de resoldre el cas. Recordem que Neurologia Catalana publica casos dividits entre diversos números: en un número es presenta un cas clínic sense resoldre; en un número posterior es discuteix el cas per part de residents d'un hospital o d'altres especialistes; finalment, els autors del cas el resolen. Aquesta dinàmica en l'ús del text trasllada les informacions pròpies de l'apartat introductori a la discussió sobre el cas -en el número posterior a la presentació- i és allí on se sol fer un repàs informatiu sobre la malaltia. Aquesta estructura permet a la revista transformar el cas clínic en una mena de joc educatiu. Hi podríem veure un paral-lelisme amb la situació en què un pacient arriba a la consulta, el metge encara no sap quin és el seu problema i només disposa del seu relat, dels resultats de les proves i dels seus coneixements especialitzats.

El segon apartat del nucli de text, la presentació del cas, és el nucli més definitori del CC. És on se'ns presenta el pacient que pateix la malaltia o símptoma objecte d'estudi. Així, per exemple, si en el títol i en la introducció se'ns planteja la síndrome de Tourette, en la presentació del cas ens trobarem amb tota la informació rellevant sobre un o més pacients que la pateixen, com també sobre l'atenció prestada per part d'un o diversos professionals sanitaris. La manera concreta com es faci la presentació variarà segons cada revista i cada especialització sanitària, en funció dels propòsits comunicatius i les comunitats de pràctica. Hi ha CC que proporcionen més informació personal sobre el malalt i n'hi ha que se centren quasi exclusivament en les dades objectivables dels resultats de les proves biomèdiques. Però en línies generals podem trobar-hi les informacions següents: 
- Presentació del pacient: identificació i característiques físiques.

- Raó per la qual acudeix al centre sanitari.

- Estat clínic i paraclínic en el qual es troba en el moment de la visita.

- Revisió de l'historial mèdic si s'hi troba alguna informació rellevant.

- Evolució de l'estat del pacient.

- Diagnosi, actes terapèutics, cura i suport.

- Resultats esperats de les accions realitzades.

- Resultats i esdeveniments no esperats.

(Llista adaptada i traduïda de Jenicek, 2001: 105)

En el nostre corpus, trobem aquest apartat de presentació del cas en tots els textos. Com que sense ell no tindríem cas clínic, en nombroses revistes aquest apartat duu precisament el nom de "Cas clínic», cosa que pot resultar confusa, ja que el gènere i un del seus apartats coincideixen en denominació. En els CC en català del nostre corpus observem també les denominacions següents: "Observació clínica», «Exploració clínica», "Presentació del cas», "Descripció del cas», "Participants», "Els infants», «Metodologia». Als textos de la revista Neurologia Catalana, l'apartat apareix sense retolar. Recordem que en aquesta publicació els CC comencen directament per la presentació del cas i no inclouen cap apartat introductori, motiu pel qual es deu haver considerat redundant denotar aquest epígraf.

En els casos en castellà, localitzem les denominacions següents: "Caso clínico», «Metodología», "Metodología/caso clínico», "Método-caso clínico», "Anamnesis», «Motivo de consulta», "Presentación del caso», «Historia clínica: anamnesis», "Historia clínica», «Introducción» i «Presentación del paciente». Finalment, també hi ha alguns casos on l'apartat no està epigrafiat.

En les publicacions en llengua anglesa, també comptem noms ben diversos: «Case report», «Case», «The Case», «Patients and methods», «Methods/Case Report», "Case Description», "Case Presentation», «Clinical Case», «Background», «The case of Sarah», «Background. Case Study: Presenting Problems and Diagnosis», «Clinical Case Presentation: Matilde», «Background. Participants and Setting» i «Presenting symptoms». 
Els casos clínics que usen l'epígraf «Metodologia» per a aquest apartat són presents en diverses revistes del nostre corpus. Aquesta etiqueta és potser la més allunyada de la persona malalta, ja que no parla ni de pacient, ni de cas, ni d'història, ni res paregut. No és coincidència que aquests CC segueixin l'estructura prototípica dels articles d'investigació (introducció, metodologia, resultats i discussió) (vegeu també Morales, 2010). El que hi constatem, doncs, és una voluntat d'importar-hi l'estructura d'un gènere amb validesa consolidada en el món de les ciències de la salut. L'etiqueta «metodologia» automàticament comporta una associació amb «ciència», en comparació amb la majoria de les etiquetes pròpies d'aquest gènere que hem relacionat més amunt i que en ocasions podrien adquirir connotacions anecdòtiques. Significativament, trobem diversos casos amb aquesta etiqueta entre els textos redactats pels professionals d'infermeria. Uns epígrafs que evoquen més cientificitat es podrien interpretar com un altre recurs emprat per demostrar que el treball d'aquesta comunitat de pràctica és igual de vàlid com el dels metges.

La darrera part del nucli del CC està composta per la «discussió» i/o les «conclusions». Els tractem conjuntament com un apartat, seguint Jenicek (2001). Serveixen per avaluar l'atenció al malalt i tancar el cas i els trobem després de l'apartat dedicat al pacient, al final del text — sense comptar les referències bibliogràfiques i altres que no pertanyen al nucli del CC. S'hi comenten els punts més rellevants del cas reportat, inclosa l'atenció clínica i la confrontació amb la literatura relacionada amb el cas. Aquí és el lloc on l'autor pot expressar la seva opinió - la qual, segons les convencions del gènere, no hauria d'aparèixer en cap altre lloc del text. Aquest apartat, per tant, té la mateixa funció que en els articles d'investigació. Quan es tracta de CC orientats a la investigació i no a l'educació, s'hi sol demostrar la singularitat del cas (Morales et al., 2007).

Hem comptabilitzat l'aparició dels epígrafs «discussió» i «conclusions» en el nostre corpus i hem pogut comprovar que la gran majoria dels casos disposen almenys d'un d'ells. En aquests apartats, el epígrafs són força estables i n'hi ha pocs d'alternatius si els comparem amb el segon apartat — «la presentació del cas». De vegades apareix solament un dels dos epígrafs, d'altres els dos combinats, i d'altres també cadascun per separat. Així, el 80 \% dels CC del nostre corpus conté un epígraf marcat com «discussió» i el 52 \% com «conclusió» - o algun sinònim en la llengua corresponent. Veiem que són menys freqüents els epígrafs de "conclusió», perquè en nombrosos casos el darrer 
paràgraf de «discussió» hi fa aquesta funció i comença per «en conclusió...». L'excepció són alguns dels CC educatius, on freqüentment no existeixen les conclusions, i de vegades ni tan sols la discussió, ja que la part final avaluadora del cas l'han de fer els lectors mateixos. Alguns $\mathrm{CC}$ amb aquest enfocament didàctic, per tant, acaben amb preguntes adreçades als lectors. Novament, uns propòsits comunicatius diferents motiven una desviació respecte de l'estructura canònica del gènere.

En nombrosos casos del nostre corpus observem la tendència de tractar en l'apartat de la discussió -o a l'inici de l'apartat «discussió i conclusions»— la malaltia en general. És a dir, s'hi centra l'atenció, sobretot, en les dades objectivables - amb escasses o nul.les referències al pacient concret. $S^{\prime}$ hi sol revisar el que s'ha fet fins ara i de quina manera es podria millorar. Per exemple, s'hi tracta d'on prové la malaltia, a quin segment de població sol afectar més o menys, quins estudis se n'han fet i quins progressos han tingut, com s'hi hauria d'actuar avui dia i si aquesta és la línia que ha seguit amb èxit o no l'autor (exemple 17).

\section{(17) Discussion}

Perilesional brain oedema associated with unruptured brain AVM is an uncommon finding recognized on CT or MRI scans and occurring with incidence of 1.2-3.9\%. In 1985, Kumar et al. first described this phenomenon in their paper published in the American Journal of Neuroradiology. Since then, only a few studies have been concerned with this subject and detailed information is lacking.

The aethiological factor of oedema is supposed to be a venous outflow abnormality. Frequent imaging findings in those cases include varicosity in the major cortical draining vein, dilated venous sac or increased venous pressure secondary to severe stenosis of the draining vein. Several studies suggested that perinidal oedema might be caused by a mass effect due to the AVM itself and also by a local brain parenchymal hypoxia due to the arterial steal phenomenon.

(1.ENG_Neurology_A)

Pel que fa a les conclusions, Jenicek (2001: 112-115) proposa que un bon CC hauria d'integrar-hi tant quina contribució s'hi fa al coneixement fonamental del problema presentat com també les propostes i recomanacions per a la praxi mèdica (decisions clíniques) i per a la recerca (noves hipòtesis generades a partir del cas). Algunes conclusions, però, també se centren a tancar el CC fixant l'atenció més en el pacient en 
concret. Això és més freqüent sobretot en els CC de psicologia o psiquiatria, els quals, per la seva naturalesa, semblen estar més enfocats cap al pacient que no pas els de neurologia, centrats més aviat en les proves i analítiques, però tampoc és infreqüent en aquesta darrera disciplina (18).

\section{(18) Conclusion}

This case report presents a 53-year-old man with unruptured brain AVM surrounded by aubstential parenchymal oedema who was successfully treated with a neurosurgical intervention. This infrequent finding of perilesional oedema in unruptured AVMs significantly influences the rate of nonhaemorrhagic symptoms and increases the risk of haemorrhage. This needs to be takem into account when managing patients with intracranial AVMs.

(1.ENG_Neurology_A)

En la comunitat de pràctica dels infermers, sembla estar ben consolidada la norma de tancar el cas amb les referències als pacients - almenys en el nostre corpus. En alguna ocasió (19), hem trobat que aquesta atenció deriva cap a expressions que podríem qualificar de bastant subjectives, presentades amb unes formes poc habituals en el discurs sanitari prototípic. En aquest cas, la infermera es desvia de l'ús impersonal o de la primera persona del plural per introduir una experiència personal amb la primera persona del singular (me sorprendió...), probablement per remarcar encara més la seva sensació personal ${ }^{15}$. A més, aquesta autora es dirigeix d'una manera directa als lectors en la darrera frase, amb un plural inclusiu de primera persona, un recurs molt poc vist en els CC.

(19) El apoyo psicológico a los familiares es fundamental para garantizar una mejor calidad de vida. Así, tal estudio pone de manifiesto que los familiares y, en concreto, esta madre tienen necesidades sin cubrir y que pasan gran parte del tiempo buscando información, tratamientos y apoyo por parte de los servicios sanitarios y sociales. Me sorprendió su firme creencia de que tras el esfuerzo, todo tenía que salir bien; esa perseverancia y tenacidad por mantener una actitud luchadora y motivación constante por la vida de «X». La utilidad del estudio puede extenderse al ámbito de investigación,

\footnotetext{
${ }^{15}$ Malgrat que la normativa de la revista recomana que els textos siguin impersonals.
} 
de forma que de las conclusiones puedan derivarse nuevos estudios cualitativos que aborden tal patología.

«Brindar apoyo profesional y calidad humana nos acerca cada vez más a la excelencia en los cuidados», reflexionemos sobre esto, queridos lectores.

(10.ESP_Enfermería)

En definitiva i pel que fa a la inclusió del malalt en el tancament del cas, podríem distingir-hi tres graus. En un primer grau, tenim textos que, fora de l'apartat de la presentació del pacient, ja quasi no hi tornen a fer referències i on la part final del CC se centra en la malaltia en general (exemple 20). En un segon grau, el que trobem és que l'apartat pot fer una revisió tan general o més que en el primer, però sempre torna a fer referències al pacient tractat (exemple 21). En un tercer grau, el pacient es converteix plenament en el protagonista de les conclusions de l'estudi (exemple 22$)^{16}$.

(20) Comentarios

Desde el punto de vista práctico es útil conceptualizar los síntomas de ansiedad en la infancia y adolescencia, de forma dimensional. Es muy frecuente que en el tiempo se sucedan diferentes manifestaciones de ansiedad que pueden encuadrarse en categoría diferentes: ansiedad generalizada, de separación, fobia escolar etc.

Por otra parte, la respuesta a los fármacos y la evolución clínica no son tampoco específicas de cada categoría.

El tratamiento abarca el control de los síntomas agudos de ansiedad, el tratamiento de mantenimiento y la terapia conductual que permitirá superar el miedo y conseguir que no haya conductas de evitación.

(24.ESP_Adolescencia)

(21) Discussió

Una anàlisi històrica del desenvolupament de persones amb la SD mostra un canvi de concepció sobre aquesta síndrome, que al principi es basava en supersticions i prejudicis, després en la concepció patològica de la malaltia i actualment en la causa, una alteració genètica compatible amb la vida i la possible adaptació a la societat com a

16 Com podem observar en el fragment 22, aquest darrer tipus de conclusions sol ser predominantment narratiu, ja que ens conta una història dels problemes del malalt, el procés de diagnòstic, la resolució o no del cas concret i, si escau, les informacions que es poden aplicar a altres casos similars. Si ens hi fixem, veurem que l'estil que empra el professional sanitari és quasi telegràfic, amb la supressió d'articles, de preposicions, amb poca atenció a la puntuació, a l'accentuació, a la concordança... 
part de la diversitat humana, amb drets i deures socials. Instal.la un nou model d'interpretació per a la discapacitat en què perd el caràcter d'atribut individual i passa a considerar-se un fenomen contingent que remodela les accions socials i ajusta l'entorn en relació amb la natura de les persones amb discapacitats.

$[\ldots]$

En aquest cas, la premissa fonamental dels pares de la provanda va ser desenvolupar-ne l'autonomia, amb aclariment i assoliment dels seus somnis. Aquesta mateixa actitud segueix present actualment en la conciliació del nét en el sentit de l'educació i el recolzament a la parella.

El cas presentat en aquest article demostra que en un entorn inclusiu poden produirse oportunitats socials i que els temes com el matrimoni i la reproducció en la SD poden avaluar-se en el context de la família.

(9.CAT_Down)

(22) Conclusiones

En este caso, la paciente debutó con manifestaciones articulares, luego manifestaciones vasculíticas, cefalea y posteriormente desarrolló un cuadro de psicosis, Habiéndose descartado razonablemente la etiología infecciosa, se aumentó la dosis de corticoides en espera de una evolución favorable, sin embargo mala evolución con recurrencia que determinan episodio de pérdida de conciencia y posterior fallecimiento de la paciente.

Con relación al tratamiento siempre hubo en cada crisis y exacerbación de sintomatología buena respuesta al tratamiento esteroideo así como también al uso de citostáticos e inmunomoduladores lo que nos hace pensar en la naturaleza autoinmune del cuadro de psicosis presentado.

El caso anterior cumple con el diagnóstico de lupus eritematoso sistémico neuropsiquiátrico, mostro psicosis orgánica, diagnosticada por... [...].

(28.ESP_Psiquiatría)

En el nostre corpus prevalen els CC que situaríem en el segon grau. És un terme mig entre els altres dos, que o bé se centren només en la malaltia sense tenir gaire en compte les persones concretes sobre les quals basen el cas, o bé tanquen les seves observacions centrant-se només en el cas concret analitzat, de vegades sense explicitar gaire l'aportació que pugui tenir el seu exemple per a altres casos. 


\subsection{Els complements visuals}

Sota aquest epígraf incloem les imatges (p. ex. ressonàncies magnètiques), els dibuixos dels pacients, les fotografies, les taules i els gràfics de dades. Són elements paratextuals que poden aparèixer físicament tant dins del cos com al final del CC. La majoria d'aquests elements poden ser interpretables per ells mateixos, amb alguna autonomia respecte del text, i tenen un rol cabdal en els textos del discurs especialitzat, particularment en el de les ciències de la salut. Tots aquests complements visuals -que per abreujar anomenarem figures - fan el text més fluid i ajuden a il/lustrar d'una manera més eficaç els procediments mèdics i les troballes ${ }^{17}$. El $76 \%$ dels nostres CC incorporen almenys una figura. La mitjana és de 2,2 figures per CC, comptant-hi els que no n'inclouen cap. La tendència generalitzada és afegir més o menys tres figures en el text.

Les figures presents en els $\mathrm{CC}$ del nostre corpus tenen bàsicament dues funcions, relacionades amb els propòsits comunicatius dels casos clínics. La primera la trobem en els CC més orientats a la recerca: la imatge proporciona al lector els resultats de les proves perquè ell mateix en pugui fer la pròpia interpretació i no disposi només del comentari que apareix dins del text. A l'autor li serveix per demostrar i reforçar els seus arguments o el seu relat. La segona funció la trobem en els CC amb finalitats educatives: s'hi sol aportar els resultats de les proves biomèdiques amb una o diverses figures i la presentació del pacient amb el seu historial mèdic. Els lectors han d'intentar esbrinar completament pel seu compte - sense ajuda del comentari que ho resol tot- què pateix el malalt i quin en seria el tractament òptim.

Hi ha també diferències destacables entre els diversos àmbits sanitaris que analitzem. D’entre les especialitzacions que componen el corpus, la neurologia és la que es basa més en les proves biomèdiques visuals. No és infreqüent trobar cinc o sis figures en CC de tres o quatre pàgines. Es tracta sobretot d'imatges de ressonàncies magnètiques cerebrals (imatge 2).

\footnotetext{
${ }^{17}$ Per a una anàlisi més detallada dels complements visuals tant en els casos clínics com en general en les revistes especialitzades de les ciències de la salut, vegeu Macián (2011: 230-247).
} 


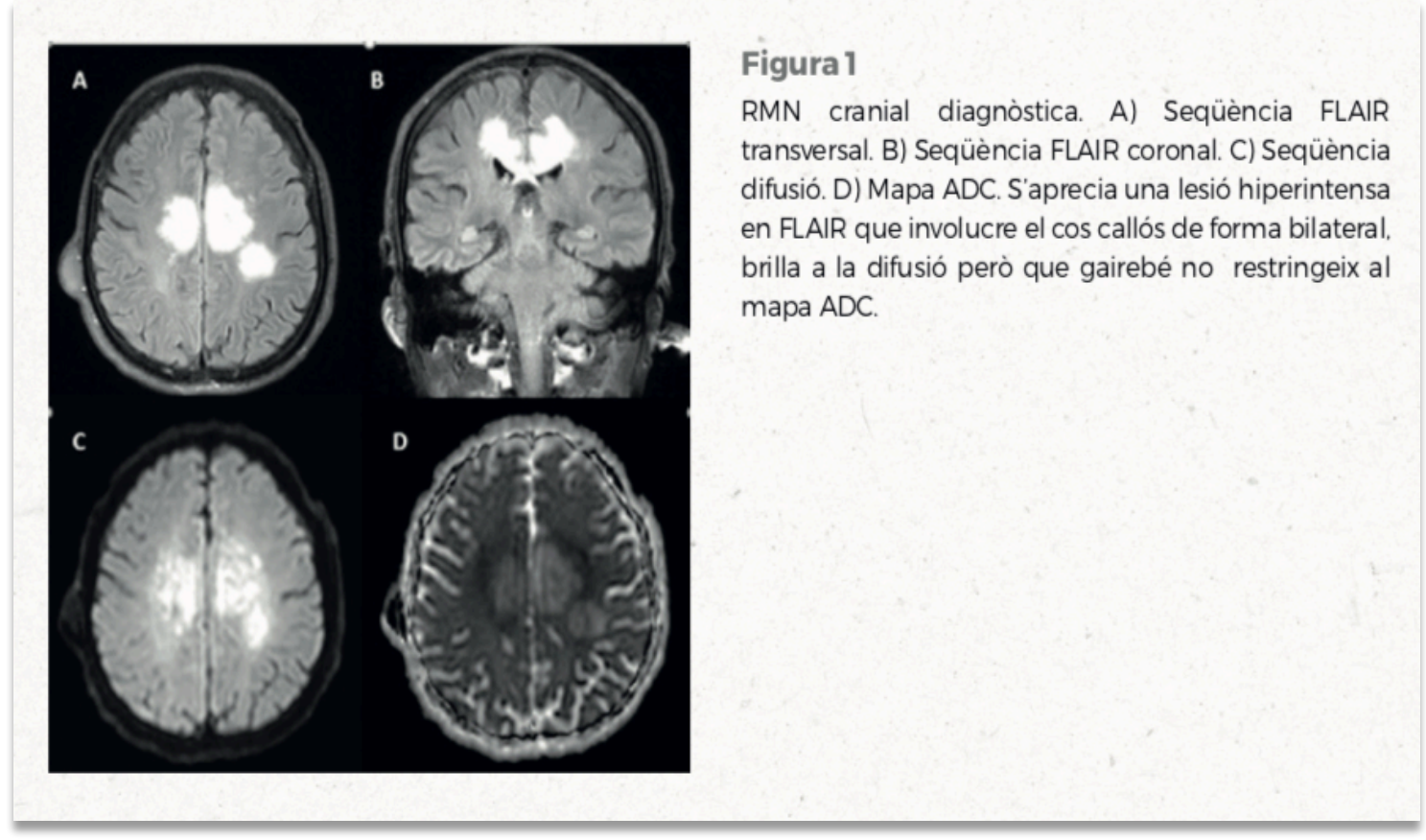

Imatge 2: 29.CAT_Neurologia

Ens trobem fins i tot amb casos en què la limitació imposada per les normes de la revista ha obligat els autors a incloure diverses imatges o gràfics en una sola figura (vegeu imatge 3). 

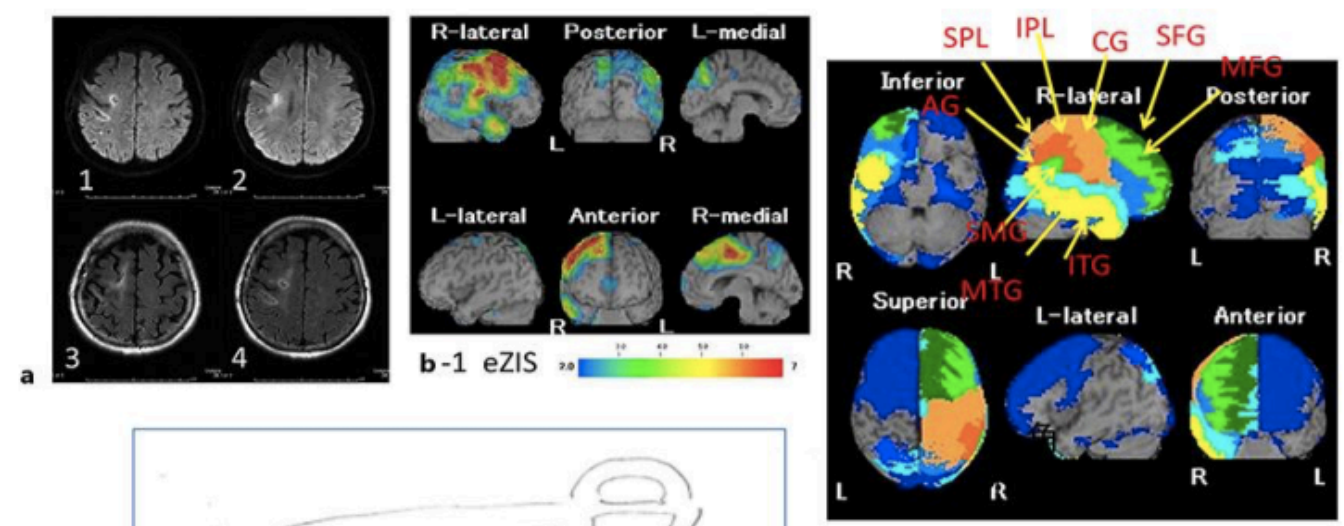

scissors

b-2 vbSEE


Fig. 1. a DWI (images 1 and 2) and FLAIR (images 3 and 4) axial images showing the hyperintense lesions in the right postcentral gyrus, precentral gyrus, and medial frontal cortex. b eZIS image (b-1) showing hypoperfusion in the right frontoparietal areas. vbSEE image (b-2) showing the hypoperfusion regions mainly in the right hemisphere such as the pre-and postcentral gyri (CG), superior and inferior parietal lobules (SPL, IPL), supramarginal gyrus (SMG), angular gyrus, middle and inferior temporal gyri (MTG, ITG), and superior and middle frontal gyri (SFG, MFG). c Figures showing samples of the real objects drawn by the patient after the trials of recognition of real household utensils.

Imatge 3: 39.ENG_Neurology_C

En psiquiatria, en canvi, trobem una mitjana de menys d'una figura per CC. Es tracta, principalment, de taules que ajuden a presentar els resultats clínics o els conjunts d'informació d'una forma més eficient, concisa i organitzada que no pas l'enumeració de la mateixa informació com a text dins d'un paràgraf. I pel que fa als CC de psicologia i els que tracten aspectes socials, com ara alguns dels CC de la síndrome de Down o els que tracten adolescents, de vegades inclouen fotografies - fins i tot de la pacient i la seva família (imatge 4) - o dibuixos traçats pels pacients, indicadors d'uns propòsits comunicatius ben diferents i d'un enfocament que podem qualificar de més humanitzat. 
El casament va ser normal, com el de una parella qualsevol (figura $1 \mathrm{~A}$ ). Es van casar en una cerimònia religiosa i es van traslladar a casa de la família materna, on es dividien les tasques i aportaven una contribució econòmica. Dos anys després del casament, la provanda es va quedar embarassada alhora que la seva cunyada, cosa que va sorprendre tothom, perquè als pares els havien dit que no calia que fessin servir anticonceptius perquè amb la síndrome no hi havia probabilitats que quedés embarassada. L'examen prenatal, efectuat als cinc mesos de gestació, va indicar que estava embarassada d'un nen sense la síndrome, cosa que va alegrar molt tota la família.

Després del naixement del seu fill, la provanda, a qui des del seu naixement només li van fer el diagnòstic clínic de SD, es va sotmetre a l'estudi del seu cariotip, que va mostrar trisomia 21 amb mosaïcisme cromosòmic. Cariotip: 47, $X X,+21 / 46, X X$, amb la majoria de la línia trisòmica present en el $80 \%$ de les cèl-lules examinades. Actualment presenta una salut general bona. Assisteix a un curs d'alfabetització per a adults i participa en activitats educatives sobre la SD. És capac de satisfer les necessitats del seu fill, tot compartint aquesta responsabilitat amb la seva mare, que fou la principal responsable de la seva educació cap a l'autonomia. Després de sis anys de matrimoni, la parella manté una relació estable i afectuosa i dediquen el temps lliure al seu fill (figura $1 \mathrm{~B}$ ).

\section{Discussió}

Una anàlisi històrica del desenvolupament de persones amb la SD mostra un canvi de concepció sobre aquesta síndrome, que al principi es basava en supersticions i prejudicis, després en la concepció patològica de la malaltia i actualment en la causa, una alteració genètica compatible amb la vida i la possible adaptació a la societat com a part de la diversitat humana, amb drets i deures socials. Instal-la un nou model d'interpretació per a la discapacitat en què perd el caràcter d'atribut individual i passa a considerar-se un fenomen contingent que remodela les accions socials i ajusta l'entorn en relació amb la natura de les persones amb discapacitats $^{10}$.

Els avencos en la qualitat de vida, longevitat i mesures d'inclusió han permès l'aparició de nous rols socials, tot $i$ que el tema de la sexualitat s'ha ignorat o subestimat. Brown (1996) ${ }^{11}$ observa que les relacions i els matrimonis es troben dins del context de qualitat de vida en la SD i posa de relleu la necessitat de preparar aquestes persones per a la vida, per tal que puguin donar-se aquestes possibilitats. Denholm (1992) ${ }^{12}$ descriu que els adolescents amb discapacitats intel-lectuals tenen les mateixes expectatives, pel que fa a codis morals, amistats $i$ interessos de moda, que els joves sense discapacitats, i afirma que aquestes tendències poden estendre's, malgrat que tinguin menys oportunitats socials. Conod i Servais $(2008)^{13}$ notifiquen una manca d'estudis sobre persones amb discapacitats intel-lectuals en relació amb el sexe i també les relacions, el matrimoni i la crianç, recordant així que aquestes activitats no només depenen de les expectatives de la gent, sinó també de les oportunitats de socialització oferides.

Les famílies, sobretot els pares, han d'estar més ben preparats per satisfer les necessitats dels seus fills a l'hora de construir la seva personalitat i els canvis evolutius en diversos aspectes de la vida social, i no ha d'haver-hi diferències en relació amb les persones amb SD. Amb tota la independència que pugui assolir una persona amb la SD, sempre hi haurà una consideració, suport, en què la família haurà de ser-hi amb més o menys freqüència ${ }^{14}$.

Actualment, segons el cas, la sexualitat és més acceptada pels parents de les persones amb SD, però el tema de la reproducció es mira amb precaució i es considera inviable per un $70 \%$ dels pares ${ }^{15}$. En homes amb SD, malgrat el desenvolupament normal de característiques sexuals secundàries, la fertilitat és reduïda, possiblement pel comporta-
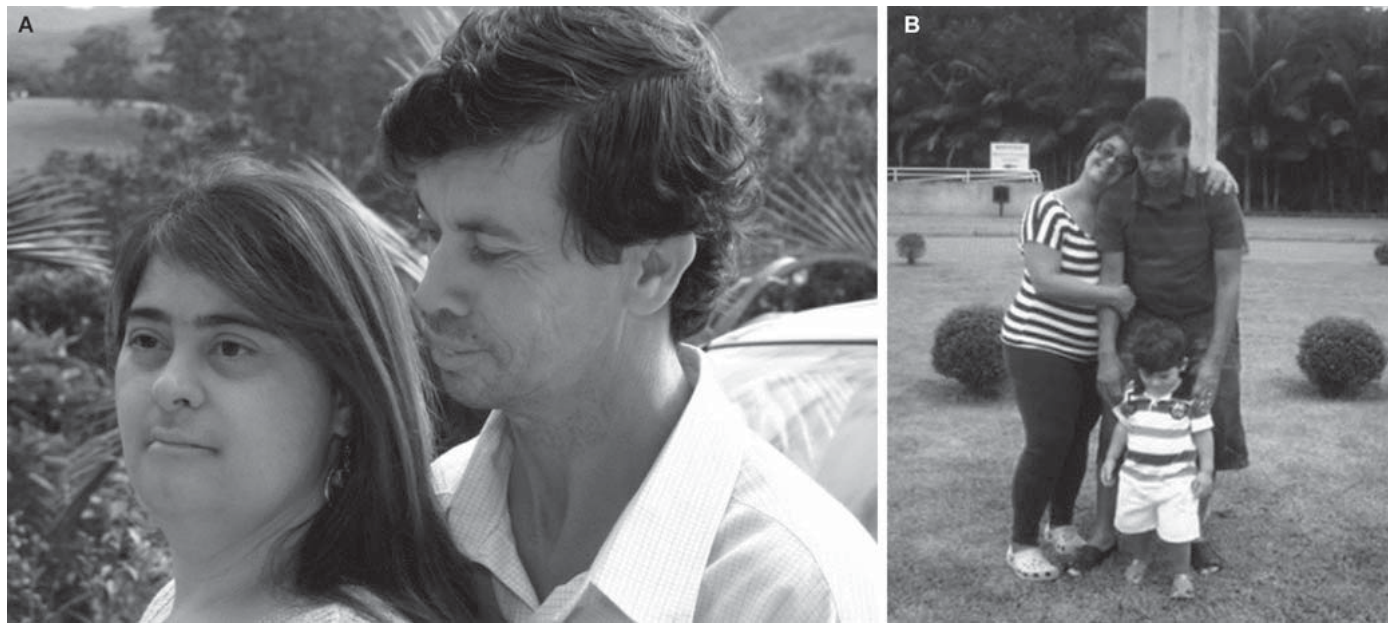

Figura 1 Parella a l'inici de la relació (A) i reunió de la família (B).

Imatge 4: 9.CAT_Down 


\subsection{Altres components dels casos clínics}

El resum és un apartat que apareix en tres quartes parts dels casos del nostre corpus i que està particularment present en els casos clínics en anglès (100 \%), com correspon als requeriments de les revistes i a les recomanacions dels especialistes en la matèria. Cal recordar que, en la interfície de les revistes comercials en xarxa, se sol presentar el resum abans de descarregar el document sencer. Aquest mecanisme sens dubte reforça la convenció d'incloure el resum, sobretot en les publicacions en anglès. Les paraules clau les trobem en un percentatge inferior de casos: un 66 \%. Aquí són les revistes en castellà les que contenen aquest apartat en quasi tots els textos, excepte un.

Els agraïments són un apartat molt breu i que apareix només en el 22 \% dels casos, una freqüència que podríem considerar baixa si tenim en compte que no és possible redactar un cas clínic sense la concurrència, com a mínim, dels pacients, per no parlar de la resta de l'equip professional que fa possible l'atenció sanitària. El fet que les revistes no indiquin, en les seves normes, la disponibilitat d'aquest apartat pot haver-ne reduït la presència als casos en què els autors han manifestat una voluntat explícita d'incloure'l. Una comunitat de pràctica on sí que sembla estar establerta la convenció dels agraïments és la de la infermeria. Així, entre els CC en castellà que hem analitzat, els únics textos que contenen agraïments són redactats per aquests professionals (imatge 5).

\section{Agradecimientos}

A la familia del paciente, a la Dra. Carmen Martínez y a la Dra. Teresa Temprano del Servicio de Neurología del Hospital de Cabueñes de Gijón.

Imatge 5: 16.ESP_Enfermería

Tenint en compte que les revistes no ho requereixen, les motivacions podrien estar relacionades amb les particularitats d'aquesta professió. D'una banda, els infermers acostumen a tenir un contacte més intensiu amb els pacients, un factor que pot contribuir a crear-hi lligams emocionals i a desenvolupar una visió més humana del 
malalt. D'una altra banda, aquesta comunitat de pràctica és una nouvinguda al terreny de la redacció de $\mathrm{CC}$, anteriorment patrimoni exclusiu dels metges. A més, en l'estructura organitzativa de les institucions sanitàries, els infermers solen estar subordinats jeràrquicament als metges. Per tant, els agraïments als pacients i a les famílies es podrien entendre com el fruit de l'empatia, mentre que l'agraïment a la institució o als professionals que hi treballen s'hauria d'interpretar més aviat com una captatio benevolentiae, sense descartar una reivindicació més o menys velada d'igualtat i dignitat professional: al cap i a la fi, tant els metges com els infermers són professionals que treballen conjuntament com un equip pels pacients i les seves famílies (imatge 6).

\section{Agradecimientos}

Nuestro más sincero agradecimiento tanto a la Institución por las facilidades proporcionadas a la hora de la realización de este trabajo, como a todos los profesionales que en ella trabajan y que día a día se esfuerzan para poder proporcionar la mejor atención posible a pacientes y familias.

Imatge 6: 9.ESP_Enfermería

Cap al final del text poden aparèixer eventualment altres apartats molt breus, sobretot en els CC en anglès, com són: les declaracions de contribució de l'autor, el conflicte d'interessos, el consentiment del pacient, la declaració ètica o el finançament rebut.

Finalment, les referències bibliogràfiques solen tancar els CC. A més, són un dels cinc apartats que, com havíem vist anteriorment en aquest capítol, hauria de contenir necessàriament aquest gènere. La bibliografia hauria de cobrir tres aspectes: problema de salut o malaltia que s'estudia; accions clíniques i paraclíniques; decisions i actuacions que cal considerar (Jenicek, 2001: 120). En el nostre corpus, la bibliografia hi és força present. El $91 \%$ dels CC revisats compta amb aquest apartat. La revista en la qual falta la bibliografia en diversos casos és Neurologia Catalana, perquè es tracta de CC força breus i dinàmics. Les cites que remeten a la bibliografia se centren sobretot en la introducció, per basar les explicacions sobre la malaltia en qüestió, comentar-ne els antecedents i fer-ne una revisió de la literatura. També en trobem en l'apartat de 
discussió, on serveixen per contrastar les dades, algunes vegades agafant com a referència un altre estudi o cas clínic (Morales et al., 2007).

Quant al nombre de referències, la majoria de manuals no sol mencionar cap xifra òptima, ja que dependria molt de la temàtica. Moltes revistes, però, sí que estableixen un màxim de referències -les normes sovint marquen que no se'n sobrepassin unes 15. Els màxims, òbviament, solen ser més restrictius en les versions impreses que no pas en les electròniques. Sempre, però, s'insisteix molt que els autors no se'n passin amb la quantitat, perquè en un CC I'objectiu és aportar una bibliografia rellevant, recent, de qualitat i de fons fiables. S'hi dóna preferència, per tant, a articles de revistes amb peer review. La major part de les referències del nostre corpus són articles d'aquest tipus de revistes. A més, observem que les fonts en anglès prevalen clarament, encara que el text estigui en català o en castellà.

Al llarg dels darrers apartats hem detectat i comentat les especificitats estructurals dels CC sovint per llengües i revistes concretes, més que no pas per especialitzacions sanitàries. I és que, excepte en alguns casos, no hi trobem grans patrons estructurals d'especialitat. Veiem que les estructures es relacionen més aviat amb les normes establertes per cada revista i les convencions consolidades en cada llengua. Sí que trobem una correlació entre la quantitat de publicacions en anglès que recomanen com ha de ser l'estructura d'un CC i el compliment d'aquestes característiques en els CC en aquesta llengua. Són els que segueixen uns patrons més estandarditzats i no hi ha tantes diferències entre les diferents revistes. En català, quasi no trobem aquestes publicacions normatives sobre casos clínics. A més, les revistes que hem analitzat tenen una major especialització i un públic més restringit que les altres, i no solament per la quantitat de parlants de català. Són revistes d'associacions de professionals sanitaris i, en alguns casos com el la de la síndrome de Down, també de les famílies dels pacients. 


\section{LA NATURALESA NARRATIVA DELS CASOS CLÍNICS}

En el capítol III hem introduït el concepte de seqüències textuals i hi hem establert una primera relació, per bé que de manera general, amb els casos clínics. En aquest apartat veurem quines seqüències detectem en els $\mathrm{CC}$ del nostre corpus, quines són les més rellevants, en quines parts o apartats apareixen i què ens revelen sobre aquest gènere. Tot seguit, revisarem l'estructura narrativa dels CC acadèmics i la compararem amb els literaturitzats, per contrastar si hi podem detectar i aplicar les parts prototípiques d'un relat: la situació inicial, el nus, la (re)acció o avaluació, el desenllaç i la situació final. Finalment, examinarem si els CC consisteixen només en un cúmul de fets ordenats cronològicament (story) o si hi trobem una trama (plot) que estructura un relat. Així, estudiem de quina manera s’organitza la trama en relació amb la línia temporal -la història- dels casos clínics publicats en les revistes especialitzades.

\subsection{Les seqüències textuals en els casos clínics}

Entenem que la narració és la seqüència textual prototípica dels casos clínics. Sense narració pot haver-hi un article científic, però no hi ha cas. Cal recordar, tanmateix, que aquest és un gènere híbrid (vegeu Salvador, $2015 a$ i 2016), i que, per tant i pel que respecta a les seqüències textuals, és bastant heterogeni i n'hi trobarem de diversos tipus (Salvador, 2016 i Macián, 2013):

a) Seqüències expositives (o explicatives, en termes d'Adam, 1992)

Aquestes seqüències les detectem en l'apartat d'introducció, vinculades sobretot a l'estat de la qüestió (exemple 1) i en les conclusions, on freqüentment s'intenta generalitzar el coneixement derivat de l'estudi de cas (Macián, 2013 i Salvador, 2016) per fer progressar la disciplina o especialitat en qüestió (2).

(1) The grasp reflex is a primitive reflex that may reappear in the presence of lesions in the frontal lobe. Involuntary movements and dystonia are well-known features of neurodegenerative diseases in the basal nucleus. They are both distressing symptoms 
and have specific impacts on the quality of life of patients. There are several effective drugs for involuntary movements, such as L-DOPA, trihexyphenidyl hydrochloride, clonazepam, and botulinum toxin type $A(B T X-A)[1,2]$. However, the need to treat or suppress the grasp reflex has rarely been discussed in the literature.

(Introduction: 9.ENG_Neurology_B)

(2) El meningioma es un tumor de crecimiento lento que surge de la aracnoides. Al menos el $98 \%$ se clasificaron como no malignos o inciertos. Se clasifican en grado I (común), Grado II (atípico), Grado III (anaplásico). Constituyen el tumor intracraneal más frecuente y el primero de los tumores espinales intradurales. Su localización más frecuente es parasagital. El diagnóstico se realiza mediante TAC o RMN. Tienen indicación quirúrgica si existe crecimiento por imagen y/o la presencia de síntomas. La mayoría son curables si se resecan completamente.

(Conclusiones: 35.ESP_Neurología_B)

Les seqüències expositives són molt rellevants per a tot discurs amb propòsits pedagògics, inclosos els CC, en els quals s'empren per situar i delimitar la malaltia, com també per introduir els lectors en els conceptes necessaris per a entendre el cas. Per això, hi trobem amb molta freqüència les definicions, un dels recursos més característics del discurs científic. Aparentment, les definicions s'usen per aclarir un terme (en el nostre cas, la malaltia) que l'autor pensa que podria ser problemàtic d'entendre per al narratari, per al públic que s'imagina. Tanmateix, tenint en compte que els lectors prototípics són membres de la mateixa comunitat discursiva, moltes de les definicions serien supèrflues des d'una perspectiva informativa (exemple 3) i no sempre farien aquesta funció (Macián, 2013), sinó que les podríem entendre més aviat com un recurs per demostrar el domini de la matèria per part dels autors i, doncs, per reforçar la legitimitat professional i la validesa científica del text.

(3) El síndrome de Tourette es un trastorno neurológico caracterizado por movimientos repetitivos, estereotipados e involuntarios y la emisión de sonidos vocales llamados tics. El trastorno lleva el nombre del doctor Georges Gilles de la Tourette, neurólogo pionero francés quien en 1885 diagnosticó la enfermedad en una noble francesa de 86 años. (Introducción: 26.ESP_Psiquiatría) 
El pes de les seqüències expositives en els CC és variable: és més present en els casos en els quals es dedica una part fonamental al repàs i a l'explicació de la bibliografia i dels coneixements anteriors, i molt menys, per exemple, en CC més orientats cap a una descripció exhaustiva dels símptomes del pacient o les analítiques i proves dutes a terme.

b) Seqüències descriptives:

En els CC, aquest tipus de seqüències inclou tant les descripcions verbals com les no verbals, és a dir, les figures (imatges, gràfics, taules). Les descripcions verbals poden aparèixer al llarg de tot el cas clínic. Ara bé, són més freqüents i evidents en la presentació del cas:

(4) Home de 27 anys amb SD, que va acudir al servei d'urgències de l'hospital per cefalea, vòmits i hemiparèsia esquerra. A l'exploració física era conscient, orientat, col·laborador, i tenia una pressió arterial de 150/75 mmHg, una freqüència cardíaca de 68 ppm i no presentava febre. Mostrava una auscultació cardiopulmonar normal. A l'exploració neurològica va destacar una endotropia de l'ull dret en posició basal de la mirada, hemiparèsia esquerra [...].

(10.CAT_Down)

(5) Ms. T was a 64-year-old Caucasian woman with no past psychiatric history and a past medical history of hypertension, hypothyroidism, and Lyme disease who presented with two months of new-onset worsening tremulous jerky movements of her right upper extremity, right-sided numbness, ataxia, headaches, and joint pain. The patient did not exhibit myoclonus or confusion. Her symptoms had occurred in the context of several psychosocial stressors. Ms. T was admitted to a general inpatient medical unit for further evaluation and treatment.

(19.ENG_Psychiatry)

Les descripcions serveixen en aquest apartat per donar al lector una sèrie d'informacions rellevants sobre el pacient (edat, sexe, antecedents, motiu de la consulta o de l'ingrés, símptomes, dades mèdiques), ja que al capdavall és el protagonista de la història. Però tant aquest tipus de seqüència verbal com les figures s'utilitzen també per descriure els resultats de les proves i les analítiques: 
(6) In addition, further laboratory testing revealed inconsistency with the diagnosis of MS: significantly elevated levels of anti-nuclear and anti-double strand DNA antibodies, lowered levels of C3/C4 complements, and decreased white blood cell count. Taken together, these symptoms met the American College of Rheumatology (ACR) SLE criteria, 2012 (meeting 3 of the 11 ACR criteria, 1997) [5]. Her renal function was normal as indicated by the absence of proteins in her urine. The C-reactive protein level was normal $(0.03 \mathrm{mg} / \mathrm{dL})$, and the erythrocyte sedimentation rate was slightly high (21 $\mathrm{mm} / \mathrm{h}$, normal $<15 \mathrm{~mm} / \mathrm{h})$. Anticardiolipin IgG antibody, anticardiolipin/beta 2 glycoprotein inhibitor antibody, protein C, protein S, antineutrophil cytoplasmic antibody levels and routine coagulation tests (prothrombin time-international normalized ratio, activated partial thromboplastin time, and D-dimer) were all within normal limits. The lupus anticoagulant test, which was performed using the dilute Russell viper venom time method and the diluted activated partial thromboplastin time method, was negative. Her cerebrospinal fluid test was also normal with a cell count of $0 / \mu \mathrm{L}$, a total protein count of $48 \mathrm{mg} / \mathrm{dL}$, and negative oligoclonal bands.

(36.ENG_Neurology)

c) Seqüències narratives:

A diferència d'altres gèneres mèdics canònicament més científics, els $C C$ solen representar un procés que es desenvolupa al llarg del temps, una història protagonitzada per personatges humans: els pacients i el professional sanitari. «Narrative appreciation can help clinicians integrate biography and anecdote, life story and case history, with impersonal aspects of medical and scientific knowledge» (Hurwitz, 2000: 2086). Gràcies als personatges i a la seva història, els CC poden resultar més llegidors que altres formes de comunicació científica, ja que l'element humà afegeix un atractiu que sol faltar en altres investigacions. Tots aquest fets i accions dels pacients i professionals sanitaris s'expressen mitjançant la narració, un artefacte retòric susceptible de despertar un major interès pel text i ajudar que el llegeixin no sols els professionals d'una especialització concreta, sinó també d'altres branques més o menys afins $\mathrm{i}$, fins $\mathrm{i}$ tot, sectors del públic general interessats en un tema o una malaltia concreta. Recordem que, malgrat que els $\mathrm{CC}$ no són el gènere mèdic més prestigiós ni citat, freqüentment són el més llegit.

Així doncs, si el llenguatge especialitzat i les parts teòriques expositives són aspectes que assimilen els CC als articles d'investigació, el predomini essencial de les seqüències 
narratives, juntament amb una extensió reduïda, els acosten a la narrativa breu, al conte. Els CC conten històries vitals reals, sovint peculiars, susceptibles d'atreure la curiositat, de captar l'atenció i de despertar empatia en els lectors. L'anàlisi els CC des del punt de vista dels estudis narratius «leads us to consider the specificity and validity of narrative as a way of thinking about reality, in comparison with the logical, scientific way of constructing discourse and its world view» (Salvador, 2016: 37). Els humans hem evolucionat com éssers socials $\mathrm{i}$, tot i que hem desenvolupat una gran capacitat per a comprendre i interpretar dades objectives, continuem entenent millor i interessant-nos més per les històries humanes. És per això que coneixem - o creiem conèixer- més la Història per les novel-les i sèries d'aquest gènere que no pas per les publicacions especialitzades. Tota bona teoria convé, doncs, exemplificar-la amb casos reals -o que semblin reals. Així s'explica l'èxit d'innumerables llibres, pel-lícules, sèries televisives i videojocs ambientats en hospitals, sanatoris i centres mèdics de tota mena on apareixen pacients amb malalties o símptomes singulars $\mathrm{i}$, en molts casos, amb unes històries personals commovedores. I és en aquest context on hem de situar també els casos clínics literaturitzats que formen part del nostre corpus.

Les seqüències narratives, doncs, tenen un paper essencial en els casos clínics. Les podem considerar com seqüències textuals prototípiques o seqüències dominants (Salvador, 2016 i Macián, 2013) en la majoria dels textos que ens ocupen. Els apartats en els quals són més paleses les seqüències narratives solen ser els que conten la vida del pacient per tal de contextualitzar la malaltia. Aquesta informació pot tenir una rellevància determinant en els $\mathrm{CC}$ sobre les afeccions mentals. Així, les seqüències narratives les trobem amb major freqüència en la presentació del cas (conjuntament amb les descripcions) i també algunes vegades en aquelles conclusions que se centren en l'evolució i l'estat del pacient després del tractament i no tant en l'avaluació de la malaltia en general (vegeu el subapartat 1.3 del capítol IV). La narració hi és, encara que adopti algunes característiques pròpies del discurs científic, ja que intenta presentar els fets d'una manera impersonal, perquè no es vegi una involucració de l'autor que seria una marca de subjectivitat incompatible amb les convencions científiques.

(7) La provanda va presentar menarquia als 13 anys d'edat i va demostrar autonomia en la cura del seu cos. Va sortir amb tres amics, un d'ells amb la síndrome, però buscava un 
company per formar una família. Fa vuit anys va conèixer el seu marit actual a l'escola especial on anava. Era un noi orfe amb una història de dèficit d'aprenentatge lleu associat amb esdeveniments gestacionals que vivia i treballava a un centre especialitzat.

El casament va ser normal, com el de una parella qualsevol (figura $1 \mathrm{~A}$ ). Es van casar en una cerimònia religiosa i es van traslladar a casa de la família materna, on es dividien les tasques i aportaven una contribució econòmica. Dos anys després del casament, la provanda es va quedar embarassada alhora que la seva cunyada, cosa que va sorprendre tothom, perquè als pares els havien dit que no calia que fessin servir anticonceptius perquè amb la síndrome no hi havia probabilitats que quedés embarassada. L'examen prenatal, efectuat als cinc mesos de gestació, va indicar que estava embarassada d'un nen sense la síndrome, cosa que va alegrar molt tota la família.

(9.CAT_Down)

(8) The patient was accompanied by a male friend who was casually but neatly dressed and of approximately the same age. The patient provided us with permission to speak with his friend who appeared uncomfortable, saying "I didn't know l'd have to talk!" He reported that he and the patient were work colleagues who had known each other for a few years but refused to reveal where they worked. He provided no further information, other than saying "He's been really depressed and I just know he needs help before something happens." He then quickly left the hospital without saying goodbye to the patient.

Although, the patient initially reported that both parents were deceased, his father was listed as an emergency contact in his medical record. When confronted with this, the patient said that this was his step-father and gave consent for contact. The father reported that, five years ago, his son graduated with poor grades from a university which does not have a Division I football team. He confirmed the patient had played football in high school and had sustained multiple concussions. The year after graduation, the patient had lived with his parents briefly, but because of escalating narcotic use and lack of employment was asked to leave. Since then, he has suffered from severe opioid use disorder and has been homeless and unemployed. He has travelled to various hospitals within the city and even out of state to seek pain medication and care and has told a similarly fictional narrative to other physicians.

(18.ENG_Psychiatry)

A més de les seqüències narratives que ens relaten detalls de la vida habitual del malalt i dels fets relacionats amb el que pateix, també trobem alguns casos que narren amb més detalls del que és comú com es desenvolupa el contacte entre el metge i el 
pacient. Aquesta informació sembla especialment útil per a disciplines com la psicoteràpia, on el comportament del pacient és l'objecte d'estudi i no únicament un element de contextualització. És el cas de «Història d'una nena que jugava a construirse a si mateixa. Desenvolupament de la identitat corporal d'una nena amb trastorn de l'espectre de l'autisme a través d'una psicoteràpia psicomotriu». El fragment que reproduïm (9) apareix com un requadre dins del CC, retolat com «Exemple de registre narratiu realitzat per la psicomotricista», on justament es narra una part de la sessió d'aquesta nena amb la terapeuta.

(9) Entra a la sala amb les sabates posades. No se les vol treure. Finalment aconsegueixo que es tregui les sabates. No es capaç de seure a la cadira. Tira les sabates per la sala i corrent es dirigeix cap als coixins. Tira tots els coixins al terra. Mira com cauen els petits que estan col-locats en un prestatge. Els posa a l'extrem del prestatge i amb delicadesa i lentitud els va apropant al límit fins que cauen al terra. Amb el seu cos realitza moviments en forma de saltirons. Els coixins grans els tira i els barreja. Queda tota la sala plena de coixins al terra. La Jana s'hi tira a sobre. Acaba caient a terra. Es dona cops contra el terra. En un moment donat, es dona un cop fort amb la barana de ferro de la finestra. Segueix movent-se com si res. Durant tota aquesta estona inicial, no em mira i desvia la mirada (girant el cap o tancant els ulls) de forma evident quan busco el contacte ocular. M'aparta davant del contacte corporal. Em situo a una certa distància i poso alguna paraula a les seves accions. Sobretot verbalitzo la sensació de caiguda i de barreja i caos del material. No faig massa menció a la diferenciació self-objecte.

Puja a les espatlleres. És una nena àgil, amb bones capacitats motrius. Gaudeix del moviment i penso que a través d'un treball corporal pot arribar a vivenciar i significar una diferenciació jo-no jo i també a organitzar una estructura i una identitat corporal.

Es queda una estona a dalt de les espatlleres. Mira els coixins escampats per tota la sala.

Passa d'una espatllera a l'altra. Sense recolzar els peus a l'espatllera, de cop i volta, sense cap senyal d'anticipació, es deixa caure. Cau amb els genolls al matalàs. M'espanto per la proximitat amb l'espatllera respecte el lloc on cau. Segurament, mostro i actuo corporalment i verbalment aquest espant. S'estira al matalàs mirant el terra. Va buscant petits borrissols que hi ha per terra, mentre jo li dic que potser està una mica espantada. A mi no em coneix, no coneix la sala... De cop i volta deixa caure la seva saliva al terra. Jo més tranquil.la li explico que $m^{\prime}$ he espantat per si s'havia fet mal. També li vaig posant paraules a les seves maniobres sensorials que realitza amb la saliva. Aquí sí que puc seure al seure costat i no m'aparta. 
Poc a poc vaig anticipant el final de la sessió. Utilitzo una melodia suau i vaig recollint la sala. Torna a ser un moment difícil. Jo recullo i ella ho torna a tirar. S'apropa a les cadiretes i amb tot el seu cos les fa caure (no utilitza les mans). Amb la sala a mig recollir i amb certa dificultat per tornar a posar les sabates, m'acomiado de la Jana remarcant que ens veurem cada dilluns."

(31.CAT_Atenció_precoç)

A diferència d'altres exemples anteriors, en aquest cas la narració representa la interacció entre la professional i la pacient. Per bé que es tracta d'unes notes aparentment internes, destinades a acompanyar la pràctica terapèutica, el fet irrefutable és que s'han publicat dins del CC. En aquest registre narratiu -segons el terme usat per les autores- la psicomotricista no s'intenta amagar darrere de frases impersonals, ans al contrari ens proporciona un relat que permet situar-nos-hi a dins $\mathrm{i}$ entendre millor la tasca que s'hi està desenvolupant. Entre altres recursos retòrics, empra profusament la primera persona del singular, amb la qual cosa esdevé una bona prova que hem de relativitzar alguns mites, com ara que aquesta persona verbal no és pròpia del discurs especialitzat (vegeu el subapartat 1.1 del capítol III). Tot plegat ens condueix a constatar el caràcter especial dels casos clínics en relació amb la literatura científica en general i mèdica en particular, com també els trets que els converteixen en un gènere que, juntament amb el dels contes clínics, connecta la ciència amb el món literari pròpiament dit.

Així doncs, en el nostre corpus constatem que les seqüències prototípiques i dominants, essencials per al gènere dels casos clínics, són les narratives, per bé que les expositives o explicatives hi exerceixen funcions rellevants, com també les descriptives. És possible, així mateix, trobar-hi seqüències argumentatives i, fins i tot, dialogals (10).

(10) A la pregunta de què sap sobre fer l'amor, respon que no en sap res i que, a més a més, està molt refredada. Hi ha un noi i una noia que es besen a la boca i això li fa por (la noia és ella). "I tens por de quedar-te embarassada?" "Sí, sí, això mateix." "Per això l’operació serà la salvació?" "Sí, per això." Al cap de poc temps, comença a caminar bé i diu: "Avui m’he rentat el cul". I s'assenyala els genitals. Li assenyalen la confusió i respon: "Bé, la vagina". "La meva mare se'n va a finals de mes i no em fa por." "Camines 
bé i no t'han operat." Contesta: "A estones camino bé. De vegades em gronxo amb els peus i m'agrada fer-ho" (substitut masturbatori).

(6.CAT_Down)

Algunes seqüències dels $C C$ que hem citat en aquest subapartat tenen tant en comú amb els contes clínics que s'hi podrien transformar sense gaire dificultat. Però cal constatar també que, per bé que les seqüències dominants en els casos clínics acadèmics siguin les narratives, els propòsits comunicatius d'aquest gènere no són literaris, com ens recorda, entre altres elements, el predomini d'un estil auster. Les seqüències narratives dels casos clínics són majoritàriament cadenes de fets redactades d'una manera concisa, sense gaires filigranes retòriques.

\subsection{L'estructura narrativa dels casos clínics}

Els casos clínics acadèmics, com hem comprovat en el subapartat anterior, tenen un caire marcadament narratiu que es manifesta en el fet que la seqüència prototípica n'és la narrativa, per bé que les seqüències descriptives i explicatives també hi siguin rellevants i que fins i tot $n^{\prime}$ hi trobem d'argumentatives o de dialogals. Aquest gènere comparteix patrons amb la narració natural establerta per Labov i Waletzky (1967: 2021) a partir d'enregistraments de relats autobiogràfics de persones en perill de mort (Taavitsainen, 2011: 84). Com a gènere narratiu, situem els casos clínics acadèmics en la frontera entre els gèneres científics i els literaris, a tocar d'un altre gènere germà que n'és tributari i que ja podem considerar plenament literari: els casos clínics literaturitzats o contes clínics.

Amb totes les peculiaritats derivades de la temàtica, dels propòsits comunicatius i de les comunitats discursives en què es produeixen, considerem que els CC acadèmics comparteixen trets amb els relats literaris i que els podem classificar com relats no literaris. Però en quina mesura s'acosten als relats literaris o se n'allunyen? En aquest subapartat revisem l'estructura narrativa tant dels CC acadèmics com dels literaturitzats, per contrastar si hi podem detectar i aplicar les parts prototípiques d'un relat: la situació inicial, el nus, la (re)acció o avaluació, el desenllaç i la situació final. Ho 
fem prenent com a referència, com a prototípics de cadascun dels gèneres, dos textos propers quant a disciplina - els dos s'adscriuen a la mateixa especialitat mèdica- però tan allunyats en termes de lector model, propòsits comunicatius i opcions estilístiques com ho poden estar un àrid cas clínic de neurologia i un conte clínic d’Oliver Sacks.

La situació inicial se sol caracteritzar, en narratologia, per servir d'orientació en el món de la història, sovint amb la presentació d'alguns dels personatges i de les seves relacions. En els CC acadèmics, es correspondria a una presentació -generalment breu- del pacient, amb les informacions més rellevants del seu historial mèdic (exemple 11). En el cas dels CC literaturitzats (exemple 12) trobem més flexibilitat a I'hora d'introduir els lectors a la història, ja que l'estructura no està tan prefixada com en els CC acadèmics.

(11) CC acadèmic:

Niño de 2 años y 3 meses, de origen rumano y de vacaciones en España, sin antecedentes relevantes, calendario vacunal al día y con un desarrollo psico-motor acorde con su edad...

(1.ESP_Neurología_A)

(12) CC literaturitzat:

When I was a medical student many years ago, one of the nurses called me in considerable perplexity, and gave me this singular story on the phone: that they had a new patient-a young man - just admitted that morning. He had seemed very nice, very normal, all day-indeed, until a few minutes before, when he awoke from a snooze. He then seemed excited and strange-not himself in the least.

(4.LIT_Sacks)

En tot cas, la diferència més palesa entre les dues classes de situació inicial és l'estil: en el primer cas, prototípicament molt auster - gairebé telegràfic- i sense cap marca explícita de l'autor/narrador; en el segon, el narrador hi apareix de seguida narrant-nos el cas com una anècdota professional, en primera persona del singular, amb un estil que denota uns propòsits comunicatius marcadament literaris.

Cal recordar, però, que els CC acadèmics tendeixen a començar per l'estat de la qüestió, és a dir, per una seqüència expositiva sobre el tema - que pot ser una malaltia, un símptoma, un procediment curatiu... Aquesta part la considerem també 
configuradora de la situació inicial, perquè ens explica i ens avança les circumstàncies amb les quals ha de conviure el malalt. També la podríem veure, però, com un avançament del nus, ja que si abans d'aparèixer el personatge ens trobem un apartat que comença com l'exemple (13), sabrem o podrem intuir -si no ens n'ha donat prou pistes el títol mateix del $\mathrm{CC}$ - de quina manera es complicarà i cap a on es dirigirà la història del pacient.

(13) El síndrome de Kleine-Levin es una rara enfermedad de causa desconocida que se caracteriza por episodios recurrentes autolimitados de hipersomnia acompañados de alteración cognitiva y conductual. La periodicidad y duración de los episodios es variable y, entre los episodios, los pacientes tienen un patrón de sueño y cognitivo normal [1]. Suele comenzar en la adolescencia y generalmente los primeros episodios son valorados por pediatras, por lo que consideramos que el conocimiento de esta entidad puede llevar a un diagnóstico de sospecha precoz tras descartarse otras entidades.

(7.ESP_Neurología_A)

Així doncs, quan llegim una introducció sobre la síndrome Kleine-Levin, les convencions del gènere ens porten a entendre que el malalt en qüestió la pateix 0 , almenys, s'ha sospitat que la podria patir. També ens imaginem que el pacient podria ser un adolescent - tant pel text presentat com pel títol Síndrome de Kleine-Levin: diagnóstico diferencial en los síndromes encefalíticos recurrentes del adolescente. I, efectivament, aquest CC s'ocupa d'una noia de catorze anys amb aquesta malaltia rara. Però, com hem vist en el subapartat dedicat als títols dels CC, aquests no sempre ens donen tantes pistes sobre la història que els casos narren: comparem per exemple «Demencia rápidamente progresiva y parkinsonismo asociados a múltiples fístulas arteriovenosas durales» amb «Cuando menos te lo esperas».

Els CC literaturitzats també poden començar amb una seqüència expositiva sobre una malaltia o un símptoma, una mena d'estat de la qüestió traslladada al conte clínic (exemple 14). En aquest cas, observem com Oliver Sacks hi transfereix una part de l'estructura dels CC acadèmics (on se sol denominar «introducció»). Òbviament, no pot ser la mateixa presentació que faria en un CC dirigit als seus col-legues, ja que un lector no expert tindria dificultats tal vegada insalvables per entendre una explicació massa tècnica que probablement el desanimaria de la lectura. És per això que Sacks i els altres 
autors dels CC literaturitzats han d'aplicar una sèries d'estratègies (que revisarem en els subapartats 3.3 i 3.4 d'aquest capítol), per intentar fer el text el més llegidor possible per al públic general. Ara bé, malgrat el to divulgatiu, en l'escriptura d'aquest autor no s'amaga mai del tot la seva perspectiva de professional de la neurologia.

(14) A 'phantom', in the sense that neurologists use, is a persistent image or memory of part of the body, usually a limb, for months or years after its loss. Known in antiquity, phantoms were described and explored in great detail by the great American neurologist Silas Weir Mitchell, during and following the Civil War.

Weir Mitchell described several sorts of phantom-some strangely ghost-like and unreal (these were the ones he called 'sensory ghosts'); some compellingly, even dangerously, life-like and real; some intensely painful, others (most) quite painless; some photographically exact, like replicas or facsimiles of the lost limb, others grotesquely foreshortened or distorted ... as well as 'negative phantoms', or 'phantoms of absence'.

(6.LIT_Sacks)

El segon element de l'esquema narratiu, el nus, es caracteritza en la narratologia per la interrupció, és a dir la complicació respecte de la situació inicial. Estableix, així, el moviment del procés narratiu a través d'una acció - ja sigui intencional o no-, un esdeveniment $\mathrm{o}$, fins i tot, a través de la revelació d'un secret. Ja hem vist que en els casos clínics acadèmics la situació inicial no sol ocupar tanta extensió com en els literaturitzats, i és per això que el nus s'hi tendeix a connectar de bon començament. Perquè la complicació de la malaltia o dels símptomes és, precisament, el nus que atraurà els lectors tipus (els altres professionals de la salut). Els personatges -és a dir, els malalts - no són un element d'atracció per a aquest públic. Generalment, no s'hi cerca una empatia (com sol passar quan es llegeix una novel·la o un conte clínic). Com a molt, els professionals que llegeixen un CC poden identificar-ne els malalts amb els seus pacients, res més. Aquesta identificació es podrà produir tenint en compte els símptomes i els resultats de les proves, però en alguns casos també pel seu caràcter 0 comportament -en psicologia i en psiquiatria, especialment.

Tornarem ara als fragments (11) i (12) que citàvem com exemples de situació inicial. El primer fragment correspon a un cas clínic de neurologia sobre un nen petit: «Alteraciones del lenguaje en la cerebelitis aguda: más allá de la disartria». El segon, a 
un conte clínic també de l'àmbit de la neurologia: "The Man Who Fell out of Bed», el qual tracta sobre un pacient que cau del llit a causa d'una cama fantasma, una extremitat que el pacient no reconeix com seva. Els reproduirem novament amb inclusió de la part on comença el nus. En els CC acadèmics, la interrupció o complicació de la història es pot produir ben aviat, entre les primeres frases o al primer paràgraf en què apareix el malalt. Així, en el cas del nen petit amb la cerebel-litis aguda, observem com s'interromp la seva presentació amb l'aparició dels símptomes i el posterior ingrés hospitalari, amb el qual comença a haver-hi una història (exemple 15).

(15) CC acadèmic:

Niño de 2 años y 3 meses, de origen rumano y de vacaciones en España, sin antecedentes relevantes, calendario vacunal al día y con un desarrollo psicomotor acorde con su edad, que comienza con una faringoamigdalitis aguda, acompañada de fiebre de hasta $40,1{ }^{\circ} \mathrm{C}$. Una semana después de su inicio es derivado al servicio de urgencias por presentar cefalea, somnolencia e irritabilidad.

(1.ESP_Neurología_A)

En canvi, en els CC literaturitzats, la situació inicial podrà tenir un paper més important i una extensió major, de manera que el nus serà molt més anàleg al dels gèneres purament literaris, com ara el conte. Freqüentment, la part del nus contindrà la trobada de l'autor-narrador amb el malalt. Aquesta part sol ser on apareix el problema del pacient i la raó per la qual ha acudit a un professional sanitari. Des del punt de vista literari, aquest primer encontre entre els dos davant dels ulls dels lectors és una magnífica oportunitat per endinsar el lector en la història (exemple 16).

(16) CC literaturitzat:

When I was a medical student many years ago, one of the nurses called me in considerable perplexity, and gave me this singular story on the phone: that they had a new patient-a young man - just admitted that morning. He had seemed very nice, very normal, all day-indeed, until a few minutes before, when he awoke from a snooze. He then seemed excited and strange-not himself in the least. He had somehow contrived to fall out of bed, and was now sitting on the floor, carrying on and vociferating, and refusing to go back to bed. Could I come, please, and sort out what was happening? 
When I arrived I found the patient lying on the floor by his bed and staring at one leg. [...]

(4.LIT_Sacks)

Tal com podem comprovar comparant els dos fragments, aquesta trobada entre els personatges principals (professional sanitari i pacient) no serà tan explícita en els CC acadèmics com en els contes clínics, per mor del distanciament objectivador requerit per les convencions del primer gènere. Els propòsits comunicatius dels contes clínics semblen exigir que el narrador esdevingui també personatge de la història, de manera que les seves accions s'incorporin també al nus de manera explícita, enriquint la història, tal com magistralment fa Sacks. En canvi, en el cas del nen de dos anys amb la cerebel-litis aguda, hem de deduir la intervenció del narrador en la història a partir d'una oració tan escarida com «es derivado al servicio de urgencias», la qual en realitat vol dir que des d'aquell moment l'autor-narrador-metge passa a encarregar-se del pacient i entra, en definitiva, a formar part de la seva història.

La tercera part de l'estructura narrativa, la (re)acció o avaluació, és on es continua desenvolupant el procés començat en la part anterior. Recordem que en algunes taxonomies aplicades als contes literaris només hi distingeixen tres parts i, que, des d'aquest punt de vista, la part que ara ens ocupa s'assimilaria al nus. Tanmateix, trobem que, en els dos textos que ens serveixen d'il/lustració, aquesta tercera part és perfectament identificable (exemples 17 i 18).

(17) CC acadèmic:

[...] El hemograma y la bioquímica, así como el estudio de tóxicos en orina, fueron normales, de manera que previa tomografía computarizada craneal para descartar lesiones ocupantes de espacio, se realizó una punción lumbar que mostró una moderada pleocitosis mononuclear (75 leucocitos/mm3, 70\% mononucleados) con leve hiperproteinorraquia $(0,61 \mathrm{~g} / \mathrm{L})$ y cifras de glucosa normales.

$[\ldots]$

La resonancia magnética cerebral mostró una leve hiperintensidad de señal en la corteza cerebelosa, con borramiento de surcos (Fig. 1), que en este contexto clínico apuntaba a una cerebelitis aguda.

(1.ESP_Neurología_A) 
(18) CC literaturitzat:

$[\ldots]$

He gazed at me with a look compounded of stupefaction, incredulity, terror and amusement, not unmixed with a jocular sort of suspicion, 'Ah Doc!' he said. 'You're fooling me! You're in cahoots with that nurse-you shouldn't kid patients like this!'

'I'm not kidding,' I said. 'That's your own leg.'

He saw from my face that I was perfectly serious-and a look of utter terror came over him. 'You say it's my leg, Doc? Wouldn't you say that a man should know his own leg?'

'Absolutely,' I answered. 'He should know his own leg. I can't imagine him not knowing his own leg. Maybe you're the one who's been kidding all along?'

'I swear to God, cross my heart, I haven't ... A man should know his own body, what's his and what's not-but this leg, this thing'-another shudder of distaste-'doesn't feel right, doesn't feel real-and it doesn't look part of me.'

'What does it look like?' I asked in bewilderment, being, by this time, as bewildered as he was.

'What does it look like?' He repeated my words slowly. 'I'll tell you what it looks like. It looks like nothing on earth. How can a thing like that belong to me? I don't know where a thing like that belongs ... 'His voice trailed off. He looked terrified and shocked.

(4.LIT_Sacks)

Novament, cada text manifestarà els trets estilístics propis del gènere corresponent i dels seus propòsits comunicatius, però sempre mantenint la funció narrativa d'aquesta part. Les diferències principals entre la manera com es concreta la (re)acció o avaluació en cadascun dels dos gèneres està - com quasi sempre- condicionada per la finalitat de cada text. El que esperen, a aquestes alçades del text, els col-legues de gremi que Ilegeixen un CC acadèmic com el que citem són les proves i els resultats que els acosten a un diagnòstic. L'avaluació té la funció de remarcar la pertinència i la rellevància del cas exposat per al marc epistemològic i d'interessos professionals dels lectors.

En un conte clínic, en canvi, la (re)acció i l'avaluació es concreten preferentment mitjançant la interacció dels personatges, tant el metge-narrador com el malalt $\mathrm{i}$, quan escau, la resta del personal mèdic o les famílies. En el text de Sacks, el pacient havia desenvolupat una teoria per explicar la presència, en el seu llit, d'una cama que no reconeixia: "one of the nurses with a macabre sense of humor had stolen into the Dissecting Room and nabbed a leg, and then slipped it under his bedclothes as a joke 
while he was still fast asleep» (4.LIT_Sacks.). Ara, però, el veiem parlar amb el doctor Sacks i com s'està adonant, a poc a poc, del seu problema i és que era tot el temps la seva cama, però ell no la notava. El que interessa a l'autor, en aquest conte clínic con en qualsevol text amb propòsits literaris, és continuar capturant l'atenció d'uns lectors que, a priori, poden no tenir cap interès específic en aquesta malaltia. En el fragment citat veiem que s'aconsegueix gràcies a l'ús de les seqüències dialogals, un tret propi de la narració literària i poc comú en els CC acadèmics (com hem vist en el subapartat 2.1 d'aquest capítol). Els diàlegs permeten que l'acció es desenvolupi amb més dramatisme i faciliten l'entrada del lector en la història: com a mínim li permeten sentir-se'n espectador. L'objectiu del CC literaturitzat és arribar a un públic que desitja llegir curiositats mèdiques, conèixer una història vital forta i com reacciona davant d'ella el personatge. Un profà no podria accedir-hi a través dels resultats i les xifres de les proves biomèdiques. Per això veiem que en els CC literaturitzats aquestes informacions apareixen molt poc i sempre contextualitzades, no com en els CC acadèmics, on sovint hi ha cadenes d'oracions amb una successió de dades rònegues.

La quarta part, el desenllaç, permet que el procés narratiu es vagi dirigint cap al seu final (ja sigui definitiu o provisional). Des d'un punt de vista estrictament lògic, les accions no necessàriament han de tenir un final. En canvi, en el relat d'una història, el lector espera un tancament de l'acció. És una part indispensable en un relat, ja que la lògica retòrica ho exigeix. Per tant, els gèneres corresponen a aquesta demanda $\mathrm{i}$ requereixen algun tipus de final.

En els fragments del desenllaç dels dos textos que hem pres com a exemples, podem constatar que hi ha desenllaç en els dos gèneres, però que no hi ha una manera única d'acabar l'acció. En el CC acadèmic, al final de totes les proves i de l'anàlisi dels resultats, el desenllaç arriba en forma de diagnosi de la malaltia (una cerebel-litis aguda parainfecciosa), amb un repàs de l'evolució i, finalment, el comentari sobre l'estat del pacient dos mesos després. En el CC literaturitzat, el pacient s'havia posat molt nerviós per no reconèixer la seva cama esquerra i el metge intenta aclarir per darrera vegada la situació. El fragment que veiem és la part final de la història (a continuació ja només hi trobarem un postscriptum que, com veurem més endavant, forma part de la situació final que és exterior a l'acció). Amb la pregunta que planteja el metge al pacient en el 
diàleg, el lector podia haver esperat que a continuació vingués alguna resposta reveladora del pacient. Com hi observem, Oliver Sacks decideix deixar aquest conte clínic amb un final obert i acaba, fins i tot, amb uns punts suspensius que difícilment trobaríem pertinents en un CC acadèmic.

(19) CC acadèmic:

[...] finalmente se le diagnosticó una cerebelitis aguda parainfecciosa. La grave afectación del lenguaje se consideró un mutismo cerebeloso en el contexto de la enfermedad.

Durante los primeros días de ingreso se asistió a una rápida mejoría de la cefalea, la somnolencia y la irritabilidad. El paciente mantuvo, sin embargo, una situación de mutismo durante dos semanas, presentó un buen nivel de alerta y fue capaz de hacerse entender por gestos, comprender lo que ocurría a su alrededor y obedecer órdenes. Poco a poco comenzó a emitir palabras sencillas, como 'cal' ('caballo' en rumano, su animal favorito), aunque su lenguaje espontáneo seguía siendo escaso y marcadamente disártrico. Por otro lado, el cuadro atáxico había mejorado progresivamente, de manera que en el momento del alta la dismetría había desaparecido, y el paciente era capaz de mantener la sedestación de manera autónoma y deambular con doble apoyo. La recuperación fue gradual, y en una revisión dos meses después únicamente persistía una leve disartria.

(1.ESP_Neurología_A)

(20) CC literaturitzat:

'Listen,' I said. 'I don't think you're well. Please allow us to return you to bed. But I want to ask you one final question. If this - this thing-is not your left leg' (he had called it a 'counterfeit' at one point in our talk, and expressed his amazement that someone had gone to such lengths to 'manufacture' a 'facsimile') 'then where is your own left leg?'

Once more he became pale-so pale that I thought he was going to faint. 'I don't know, he said. 'I have no idea. It's disappeared. It's gone. It's nowhere to be found...

(4.LIT_Sacks)

Aquests només eren dos exemples de desenllaç i dues possibilitats d'acabar la història que es desenvolupa en un CC, tant acadèmic com literaturitzat. D'una banda, un final obert, en el qual no sabem res més del pacient (potser perquè se l'envia un altre especialista o centre). De l'altra, la curació, una millora evident o un avanç en el procés 
de guariment del pacient. La tercera possibilitat és la no curació, que inclou l'empitjorament i, in extremis, la mort (que tractarem en el subapartat 3.5).

La cinquena part, la situació final, és on la tensió inicial o la introduïda pel nus es dissipa -o, en alguns casos, es reactiva per deixar oberta la possibilitat de rebotar, en una mena de cliffhanger que doni peu a una narració futura. En el cas del CC acadèmic que hem triat com a exemple, la situació final és el tancament darrer del cas, amb una valoració i visió del futur, inclosa en el canònic apartat de les conclusions del CC (exemple 21). En el conte clínic de Sacks, que havia quedat amb un desenllaç obert, la situació final seria més creativa, amb un postscriptum que inclou el missatge d'un col-lega de l'autor sobre un altre cas de la mateixa malaltia (exemple 22). Malgrat les diferències estilístiques i retòriques - com ara la cita directa de la carta del col·lega-, els dos fragments comparteixen la mateixa funció narrativa i ho fan d'una manera similar: obrint expectatives i deixant espai per a la recerca sobre la malaltia corresponent i les possibles teràpies.

(21) CC acadèmic:

Casos como éstos expanden las manifestaciones clínicas de la cerebelitis aguda en la infancia y apoyan la hipótesis de la contribución del cerebelo a dominios neurológicos no motores. Pese a que numerosos aspectos siguen siendo especulativos, es de esperar que en el futuro podamos capturar el rico espectro de manifestaciones neurocognitivas en la disfunción cerebelosa, definir mejor los patrones de afectación del lenguaje y su pronóstico, y realizar las intervenciones logopédicas adecuadas.

(1.ESP_Neurología_A)

(22) CC literaturitzat:

Postscript

Since this account was published (in A Leg to Stand On, 1984), I received a letter from the eminent neurologist Dr Michael Kremer, who wrote:

I was asked to see a puzzling patient on the cardiology ward.

$[\ldots]$

He was such an excellent example of this complete loss of awareness of his hemiplegic limb but, interestingly enough, I could not get him to tell me whether his 
own leg on that side was in bed with him because he was so caught up with the unpleasant foreign leg that was there.

(4.LIT_Sacks)

Tant els casos clínics acadèmics com els literaturitzats poden acabar amb la curació del pacient, amb la seva mort o, simplement, amb una clausura provisional o un final en fals que podria consistir, per exemple, en passar el malalt a un altre col-lega. En aquest cas, l'acció real continuaria, però no el relat en si. Pensem ara en els típics finals de les ficcions romàntiques que culminen amb el petó entre els dos protagonistes i de sobte s'acaba la història. Doncs la besada no s'acaba en el moment en què apareixen els crèdits de la pel·lícula ni és el final de la vida dels protagonistes, ja que l'acció real -o imaginària, quan parlem de ficció- continua més enllà del relat.

No sempre és fàcil detectar en tots els CC les cinc parts de l'estructura narrativa, ni on comencen o acaben. Hem de tenir en compte que les seves definicions provenen de plantejaments teòrics pensats sobretot per a textos literaris més tradicionals o per a narracions orals. Hem vist, tanmateix, que en podem aplicar els conceptes a un àmbit no literari com és el dels CC acadèmics. Algunes disciplines com la psicoanàlisi han incorporat explícitament el relat de la història vital del pacient al procés terapèutic i són nombrosos els professionals de la salut mental que fan de la narració el nucli de la teràpia i de la diagnosi. No ens ha calgut, però, recórrer a exemples de casos clínics prolixos en detalls més o menys personals dels pacients - com serien els de psicologia, per exemple. Hem comprovat que aquest gènere segueix l'estructura narrativa del relat, de manera anàloga a com ho fan els CC literaturitzats, salvant totes les distàncies estilístiques i de propòsits comunicatius que diferencien els dos gèneres. Per tant i des d'aquest punt de vista, podem considerar els CC acadèmics com relats no literaris que fan de pont entre altres textos científics i els contes clínics, un pont entre l'escriptura científica i la literatura.

Si els CC acadèmics s'acoblen a l'estructura narrativa del relat, ho fan d'una manera espontània, ja que els seus autors normalment no són escriptors literaris professionals. Així doncs, dins dels apartats convencionals del gènere - moltes vegades preestablerts per la redacció de les revistes - els autors hi encaixen l'estructura d'una narració 
natural, que és el model que tenen en la ment a l'hora de contar una història. Per més que l'expliquin amb un llenguatge altament especialitzat i pensant en un públic restringit, continua sent una història. Les històries les sentim des de petits $i$, per tant, sense cap necessitat d'estudis filològics o discursius, en tenim interioritzada l'estructura més habitual. Així doncs, contar el cas d'un pacient, per moltes normes que fixi la revista on s'hagi de publicar o la comunitat de pràctica on s'inscriu, seguirà d'una manera total o parcial aquesta estructura narrativa àmpliament compartida.

\subsection{Història i trama en els casos clínics}

En el capítol III hem exposat els conceptes d'història (story) i trama (plot) i hem avançat que els podríem aplicar als CC per palesar-ne la condició de relats. A l'hora d'escriure ficció, un dels recursos per captar l'atenció del lector és jugar amb la forma i l'ordre en què se li van presentant aquests esdeveniments. Es pot contar la història seguint un ordre temporal, des de les informacions més antigues fins a les més recents, però en la ficció també és possible i sovint convenient alterar aquesta línia temporal per construir una trama més atractiva, més intrigant. Ara bé, les històries que es reflecteixen en els casos clínics no són ficcions. En aquest subapartat examinem si els CC consisteixen només en un cúmul de fets ordenats cronològicament (story) o si hi trobem una trama (plot) que estructura un relat. Així, estudiem de quina manera s'organitza la trama en relació amb la línia temporal -la història- dels casos clínics publicats en les revistes especialitzades.

Podem concebre la línia temporal com la vida real del pacient, de la qual només coneixerem les parts i els detalls que ens en proporcionarà el professional sanitari en el seu text. La història que s'explica en un cas clínic seria, doncs, el procés lineal de la dolència del pacient. Aquesta malaltia/història comença en algun moment -uns primers símptomes o un esdeveniment desencadenant, per exemple- i té un punt final que pot ser molt divers: pot consistir en el guariment definitiu, en una cronificació o, en

últim extrem, en la mort. Entre aquests dos punts pot haver-hi una sèrie d'esdeveniments diversos, com ara altres símptomes, visites als metges, proves clíniques... 
Ara bé, quan cerquem aquesta línia temporal de la història en els CC, veiem que els professionals de la salut reben els pacients en diferents punts de la malaltia -i en poques ocasions des del seu inici. En la majoria de casos, els pacients no van a la consulta en el moment exacte en què comença la malaltia, ja que encara potser ni n'han aparegut els primers símptomes o, inicialment, no els han donat gaire importància. En el cas de la salut mental és encara més complex que no pas si parlem, per exemple, de braços o cames trencades. Les afeccions mentals tenen també el seu punt de partença -on comença la història - però és complicat d'establir i sovint l'ha d'esbrinar el professional sanitari, tant si l'origen del problema és físic — com veiem en els CC de neurologia - com quan és psicològic.

Així doncs, els CC normalment comencen amb un contacte entre el professional i el pacient, en un moment que no és, des del punt de vista cronològic, l'inici de la història. Freqüentment, el text continua amb l'anamnesi, una mena de flashback clínic, una presentació del pacient amb un repàs - breu en la majoria de casos - de l'historial mèdic i d'altres qüestions pertinents que podrien tenir relació amb les dolències del malalt:

(23) Se trata de una paciente de 18 años de edad que acude al Servicio de Urgencias hospitalario de su zona por dolor abdominal epigástrico de tipo cólico de dos semanas de evolución; asociado a náuseas y sensación diatérmica, sin otro síntoma asociado. Refiere cuadro similar un año atrás, en contexto de situación de estrés. [...] Reconsulta al día siguiente, en el mismo servicio, por persistencia del dolor que ha ido en aumento en las últimas horas, acompañado de sensación nauseosa. [...] Acude por primera vez a su pediatra de atención primaria 19 días tras la consulta al centro hospitalario.

(18.ESP_Adolescencia)

(24) Home de 61 anys que ingresa a l'abril de 2005 per impotència funcional d'extremitats d'instauració progressiva de nou mesos d'evolució. Al juny de 2004, s'inicien rampes a extremitats inferiors de predomini nocturn. Dos mesos després, s'afegeixen parestèsies i hipoestèsia d'inici simètric a mans i peus i debilitat global de les quatre extremitats amb un cert predomini distal.

(15.CAT_Neurologia) 
(25) A thirty-one-year old married male was brought to the psychiatry service due to a suicide attempt after an indecent sexual behavior. He was perplexed, suspicious, and seemed talking with hallucinatory figure.

The patient was brought up in a conservative family and studied in a residential religious institution. His teachers and senior students abused him physically and sexually at the age of eight. Within a few months, this boy started abusing new students sexually and developed sexual relation with multiple boys. At the age of 16 years, his most intimate sexual partner left the hostel. He became suspicious that other students and teachers conspired against him and forced the partner to leave the hostel. Afterwards his suspiciousness spread to every aspect of his life.

(23.ENG_Psychiatry)

(26) Varón de 69 años, ingresado por alteración gradual del estado de conciencia que progresó hasta el coma en alrededor de 24 horas. El cuadro comenzó cinco años antes con pérdida parcial de la visión con predominio en el ojo izquierdo. El paciente fue diagnosticado de neuritis óptica y tratado sin éxito con corticoides e inmunosupresores. Posteriormente, presentó depresión, insomnio y anhedonia, y seis meses antes de su ingreso desarrolló gradualmente inestabilidad postural, rigidez, marcha parkinsoniana, temblor de intención en las extremidades superiores, bradicinesia, episodios de desorientación, amnesia, alucinaciones visuales complejas y deterioro cognitivo, que empeoraron hasta llevarlo al estado de postración. Previamente a nuestra valoración, el paciente había recibido levodopa/carbidopa y memantina, sin obtener respuesta terapéutica. En el momento del ingreso, el sujeto se encontraba en estupor, no emitía lenguaje, sus pupilas eran simétricas y reactivas, y los reflejos oculares de versión cefálica estaban intactos.

(5.ESP_Neurología_A)

Són força habituals, doncs, els CC que comencen in medias res, quan alguna cosa s'agreuja i això fa que el malalt vagi a l'hospital o a la consulta. Però, òbviament, també trobem CC que comencen ab ovo, des del principi o quasi des del principi de la malaltia o dels primer símptomes:

(27) It is about a 50-year-old male patient, native of Cajamarca [...]

Since the age of 13 the patient has presented behavioral changes, with marked isolation due to fearing other people and poor school performance so he repeated third year of high school. [...]

At age 45 the patient was afraid to leave home, as he thought he would be killed. 
$[\ldots]$

At age 49, the patient began to live alone in Cajamarca. He did not care about personal hygiene nor basic needs; he began giving away his belongings. [...]

Three months before the admission to our unit, the patient moved to Lima with his son and started working in the cleaning area of a school. [...]

Twenty days before admission to our unit, the patient refused to eat; he said the food was rotten as he was. [...]

Seven days before admission to our unit, the patient mentioned that he was already dead, his stomach did not work, his liver was decomposed, his brain was paralyzed, and his face lacked blood. [...]

Four days before admission to our unit, the patient's relatives took him to a psychiatric hospital due to persistence of symptoms. He was again diagnosed with schizophrenia and admission was indicated.

The patient remained hospitalized for three days. [...] Since he did not show any improvement, his family decided to bring him to the emergency room of our hospital, before being admitted to the service of General Psychiatry.

The patient was signicantly improved after two weeks of treatment.

(22.ENG_Psychiatry)

(28) Se trata de una paciente de 52 años de edad, que en el año 1999 comienza con dolores a nivel de articulaciones, sequedad de piel y mucosas acudiendo a consulta de inmunología [...] En el año 2002 recurre sintomatología siendo remitida al Centro Nacional de Reumatología con cuadros de dolores articulares y lesiones purpuropetequiales de miembros inferiores [...] Ingresa en abril 2011 al Hospital Camilo Cienfuegos por cefalea [...] En marzo/2011 recurre cuadro neurológico con excitación motora, desorientación, intranquilidad ingresa nuevamente en UCIM [...] Es traída el 13 del mismo mes con toma de conciencia y depresión respiratoria falleciendo a pocas horas de su ingreso.

(28.ESP_Psiquiatría)

Aquests fragments segueixen impecablement una successió cronològica de la malaltia. Tanmateix, encara que el primer text haja començat amb els canvis de comportament del pacient als 13 anys, o que el segon iniciï amb el dolor experimentat en l'any 1999, són uns problemes i uns símptomes molt posteriors els que els han conduït a l'atenció dels professionals que n'estan contant les històries. És per això que el més habitual és que els CC comencin per la presentació del pacient i la raó per la qual 
ha vingut a la consulta o ha estat hospitalitzat i que, a continuació, se'n faci la revisió de l'historial en ordre cronològic.

Tanmateix, també hi ha CC que quasi no remeten als antecedents de la malaltia. En fan el seguiment a partir de la primera consulta i analitzen tots els esdeveniments posteriors (29). En aquests fragments es presenta un CC que es desenvolupa arran de l'ingrés a urgències (excepte una petita referència als fets anteriors a l'entrada a I'hospital: "de horas de evolución») d'un pacient amb mutisme acinètic després d'una cirurgia de fossa posterior per una fístula arteriovenosa, complicada amb hemorràgia diencefàlica i hidrocefàlia, que va respondre espectacularment al tractament amb bromocriptina:

(29) Varón de 43 años, que ingresó con clínica de cefalea y hemiparesia izquierda de predominio crural de horas de evolución. En urgencias presentó una disminución progresiva del nivel de consciencia hasta presentar Glasgow de 6-7 (O1V1M4), con desaturación y posibles crisis tonicoclónicas generalizadas.

$[\ldots]$

Durante su ingreso en la unidad de cuidados intensivos se realizó una arteriografía, donde se objetivó una fístula arteriovenosa dural de tipo III de la clasificación de Cognard (Fig. 2).

Una vez en planta de hospitalización, el paciente sufrió un tromboembolismo pulmonar como complicación más destacada, que precisó ingreso de nuevo en la unidad de cuidados intensivos, tratamiento con heparina y trombectomía, pero que finalmente se resolvió sin más complicaciones añadidas.

Durante todo este período, la exploración física del paciente se mantuvo estable, y destacó un síndrome mesencefálico [...]

Una vez estabilizada su situación clínica, tras la retirada de la cánula de traqueotomía y su traslado a la planta de hospitalización, se comenzó el tratamiento rehabilitador [...]

El paciente fue reevaluado un mes después y se objetivó una clara mejoría de su componente de abulia [...]

$[\ldots]$

El paciente fue dado de alta con traslado a un hospital de daño cerebral para continuar con su rehabilitación. Se reevaluó dos meses después en consultas externas y se observó una clara progresión en su mejoría neurológica global.

(2.ESP_Neurología_A) 
Així, en el cas que no hi hagi historial mèdic o que no hi hagi res rellevant en relació amb el problema pel qual el pacient es troba en la consulta o en l'hospital, la història comença des de la trobada amb el metge i es desenvolupa a partir de les proves i analítiques que se li fan. Aquesta variant sense anamnesi es pot trobar també en els CC dels pacients que arriben a l'hospital sense poder comunicar-se amb el personal sanitari (sigui perquè estan, per exemple, en coma, per alguna deficiència mental o per manca d'una llengua compartida).

Cal dir que alguns CC no comencen ni pel principi de la malaltia ni per cap punt intermedi, sinó directament pel final: per la mort del pacient i la voluntat del professional d'esbrinar el motiu del traspàs. Són els casos de la medicina forense (vegeu subapartat 3.5 d'aquest capítol), encara que no n'hem trobat cap al corpus usat per a aquest estudi, limitat al camp de la salut mental. En els altres CC, si el pacient es mor, el lector sovint no se n'assabenta fins al darrer paràgraf de la presentació del cas clínic (imatge 1).

nopathy (Fig. 3). He underwent endoscopic evaluation for his anemia and weight loss that revealed benign polyps in the stomach, duodenum, descending colon, and sigmoid colon. Further workup with fine needle aspiration of the supraclavicular lymph node revealed a high-grade, diffuse large B-cell malignant lymphoma. Immunohistological staining showed CD20(+), CD79s(+), CD43(+), and BCL-6(+). The patient developed resistant hypercalcemia and tumor lysis syndrome. The family opted for comfort measures and hospice care, hence further workup including onconeural antibodies were not pursued. He continued to deteriorate and subsequently expired.

\section{Discussion}

Evaluation of patients presenting with cranial nerve palsies is challenging as the etiology is very extensive. A patient may present with single or multiple cranial nerve palsies. Mul-

Imatge 1: 40.ENG_Neurology_C

Tornem ara als casos majoritaris, en els quals sí que apareixen les informacions anteriors a la consulta proporcionades per l'historial mèdic i també pel pacient. L'entrevista mèdica és un sistema d'intercanvi de veu socialment estructurat, organitzat jeràrquicament en fases (Drass, 1981) i en el qual la interacció entre pacients i metges 
és asimètrica, ja que aquests darrers controlen els temes que s'hi tracten, fan preguntes i sovint desvien les inquietuds dels pacients (Anspach, 1988). Generalment, els malalts, quan conten la raó per la qual han vingut a la consulta mèdica, tenen diverses possibilitats d'organitzar temporalment la informació: poden començar per algun dels fets més recents que els hi han portat o pels primers problemes o símptomes que han tingut i que pensen que estan relacionats amb el problema actual. També poden anar saltant en la línia temporal a mesura que recorden els possibles símptomes. Així, doncs, els pacients tampoc no acostumen a seguir la línia temporal, malgrat que ho intentin. Sovint el metge pregunta "Quan va començar a fer-li mal...?» i el pacient intenta recordar la primera molèstia o el primer símptoma i es posa a narrar la seva història. Alguns pacients, com que s'esperen aquesta pregunta, ja es preparen a casa o a la sala d'espera la seva versió dels fets. Normalment, però, no aconsegueixen contar-ho tot cronològicament, perquè el metge també els interromp freqüentment amb altres preguntes que poden portar els malalts tant a un passat encara més antic de la seva línia temporal narrativa com, de sobte, a alguna qüestió més recent.

A part de les informacions obtingudes de l'entrevista amb el pacient o els familiars, també hi ha detalls del passat mèdic del pacient que el professional sanitari ha d'investigar, com si fos un detectiu, per poder resoldre el cas, ja que el pacient sovint no pot proporcionar-li tota la informació. El professional de la salut agafa les dades proporcionades pel pacient, en selecciona les rellevant per al CC i hi afegeix els resultats $d$ 'altres procediments mèdics, com ara les analítiques que es van efectuar a partir de la consulta, per detectar quina malaltia tenia el pacient. És a dir, el metge ha de repassar o descobrir els fets rellevants que no controla, anteriors a la consulta. Aquests fets els pot esbrinar mitjançant les proves posteriors a la consulta i la informació que li proporcionen el pacient o els familiars.

A diferència del pacient, qui generalment explica els fets de manera oral i improvisada, el professional sanitari té el temps i la possibilitat de reorganitzar la informació, atès que prepara un discurs en forma escrita, sovint amb una distància temporal, a partir dels seus apunts, dels resultats cínics, etc. A més de la possibilitat de seleccionar la informació pertinent i de canviar l'ordre dels fets, el professional recrea el discurs del malalt i l'eleva a un nivell més alt per integrar-lo dins del seu discurs (com veurem en el subapartat 4.1 d'aquest capítol). 
Amb tot això, constatem que els CC rarament s'organitzen com un simple cúmul de fets ordenats cronològicament, ja que hi ha una selecció dels esdeveniments i de les dades que es mencionen. També es tria quin espai se'ls dóna, en quin moment i com estan relacionats entre ells. Encara que bona part de la informació estigui narrada més o menys cronològicament, els autors avancen o posposen determinades informacions $\mathrm{i}$ amb això donen més o menys importància a determinats fets i creen així el que podem considerar una tensió narrativa o intriga. D'aquesta manera, els CC s'assemblen a una història literària, com ara un conte clàssic en el qual els fets se solen presentar d'una manera més o menys cronològica, però també contenen algunes digressions. En els cas dels contes, n'hi ha molts tipus diferents: des dels més clàssics fins als que intenten trencar les regles narratives. En el cas dels CC, el que trobem són casos de caire més narratiu - sobretot si tracten afeccions psiquiàtriques o psíquiques - i els que es presenten com una sèrie de resultats de proves biomèdiques - un estil freqüent en neurologia.

Així doncs, si bé els CC acadèmics poden seguir una mena de narració natural, és a dir conten una història seguint, a grans trets, l'ordre cronològic -com esperaríem i consideraríem lògic en un informe científic-, això no es verifica sempre ni molt menys de manera escrupolosa. Alguns CC s'assemblen, d'alguna manera, a les narratives lineals dels contes clàssics. Tanmateix, si parlem d'intrigar els lectors, els CC d'algunes especialitats, com ara la psicologia, poden tenir un caire marcadament narratiu $\mathrm{i}$ assemblar-se encara més a un conte literari, ja que narrar l'entorn i la vida del pacient és més rellevant per al cas que en altres especialitats. Els autors, per tant, agafen els esdeveniments que en la vida real passen en una successió lògica (i cronològica) i els reordenen d'acord amb els seus interessos discursius. En el present fragment (30) del $\mathrm{CC}$ «Adolescente con anorexia nerviosa», podem veure que, en la part de l'anamnesi de la noia, no se segueix l'ordre cronològic de cap manera. No hi tenim primerament una presentació de com era l'adolescent de petita i després com van començar a aparèixer problemes amb l'anorèxia, sinó que les informacions passades i les actuals s'hi barregen. Els autors opten per una estructura més dinàmica a l'hora de relacionar els fets entre ells, sense seguir totalment l'ordre cronològic. 
(30) La madre apunta que de pequeña era una niña "algo rellenita". Han notado que Itziar, que siempre ha sido una niña alegre, feliz y dócil, está más irritable, enfadándose con frecuencia y sin motivo, con tendencia a encerrarse en su cuarto. Nunca ha sido una niña muy comunicativa. Ha empeorado el rendimiento escolar, ya que era "una chica de sobresaliente". Tiene una amiga con "problemas en la alimentación".

(20.ESP_Adolescencia)

Òbviament, quan les experiències clíniques es converteixen en un text literari, és a dir en els CC literaturitzats o contes clínics, ja no poden presentar-se com informes asèptics que enumeren els resultats de les proves, sinó que els seus autors han d'explotar al màxim la part més humana de cada història. En els CC literaturitzats, el pacient esdevé obertament personatge. Se sol presentar a través de detalls personals que depassen l'interès merament clínic, amb una atenció a les circumstàncies en què se'l va trobar per primera vegada el professional sanitari, l'autor. A continuació s'hi conta la seva història vital, sovint amb l'ús de diàlegs entre el metge i el pacient perquè el text sigui més dinàmic i la lectura més amena. Certament, en els contes clínics també subjau un ordre cronològic, però amb moltes més digressions que en els CC acadèmics, ja que gràcies a la dimensió literària, a unes convencions més flexibles pel que fa a l'extensió i sense la necessitat d'ajustar-se a un registre tan regulat com és el cientificotècnic, resulta molt més fàcil anar movent-se per la línia temporal. Així, les digressions temporals que més podem observar en els CC literaturitzats són els salts a un passat més remot de la vida dels pacients on sovint es produeixen anècdotes que no serien imprescindibles ni rellevants - ni potser pertinents - en un CC acadèmic.

Els autors dels CC acadèmics no es poden permetre jugar amb la trama com els autors dels contes clínics. Tanmateix, com hem vist i tenint en compte que hi ha importants diferències segons les especialitats, les revistes i els autors, tampoc podem dir que els CC siguin simples acumulacions d'esdeveniments ordenats cronològicament. Des del nostre punt de vista, els CC acadèmics són, doncs, relats. De fet, salvant totes les distàncies d'intencionalitat literària, el CC mostra grans paral-lelismes amb el procediment de la novel·la negra. El desenvolupament prototípic de la novel·la negra sovint comença per un detectiu privat que rep la visita d'un client que li encomana un cas. El client li facilita unes informacions seleccionades sobre la història en qüestió (anamnesi) i posteriorment, al llarg de la novel·la, el detectiu haurà d'investigar el que 
ha passat realment, amb resultats sovint contradictoris als que pretenia el client. D'una manera similar, el CC s'inicia sovint amb una consulta en la qual el pacient explica al professional el que sap -o creu saber o vol comunicar - sobre la història que pretén desentranyar -la malaltia-, i el professional sanitari és el detectiu que haurà de desenvolupar les proves necessàries i revisar els fets del passat per treure l'entrellat d'aquesta història.

(31) The patient is a 28-year-old man... He localized his pain to the right lower quadrant, complained of right lower quadrant pain with palpation of the left lower quadrant (Rovsing's sign), and indicated his pain was reproducible with extension of the right hip (psoas sign).

[...] the patient mentioned that he had been struggling with sadness and suicidality since his pregnant fiancé had recently been killed in an automobile accident. The emergency physicians felt the pretest probability for acute appendicitis was extremely high and asked the psychiatry consult-liaison team to "evaluate him quickly before he goes to surgery." Ultimately, the imaging was negative for acute appendicitis, surgery was cancelled, and his disposition from the emergency department was left to psychiatry.

\section{$[\ldots]$}

We obtained information from a local emergency community outreach agency which indicated that the patient had presented with the chief complaint of suicidality to multiple emergency departments in the city resulting in two previous inpatient psychiatric stays over the past year. We obtained records from his most recent inpatient psychiatric hospitalization about six months ago, where he presented with depression related to his girlfriend's putative recent breast cancer diagnosis. He was discharged on an antidepressant, a mood stabilizer, and oxycodone for chronic back pain.

When gently confronted with these inconsistencies, the patient appeared unperturbed and easily provided further elaborate details to explain them. However when further pressed, he stated he believed he needed a "dramatic" reason for his depression and suicidality to receive help and asked, "Can I just be depressed and suicidal?" He appeared perplexed as to why we attempted to clarify his previous statements or their relevance for his care. Despite this, he continued to state that he felt very depressed and would not be able to maintain his safety in the community.

(18.ENG_Psychiatry) 
Com hem vist en aquests fragments del CC «Pseudologia Fantastica in the Emergency Department: A Case Report and Review of the Literature», les qüestions relacionades amb la salut mental s'ofereixen encara més a l'existència de històries en les quals el personal sanitari ha de tenir en compte les paraules del malalt, però també contrastarles amb altres dades disponibles. És en aquest àmbit on trobem els casos més peculiars i curiosos que fàcilment podrien convertir-se en històries literàries.

\section{DEL TECNOLECTE A LA RETÒRICA LITERÀRIA}

L'experiència clínica d'un professional sanitari es pot manifestar en els casos clínics i en els contes clínics, dos gèneres connectats però alhora diferenciats. En aquest apartat ens acostarem a alguns dels mecanismes mitjançant els quals s'efectua l'adaptació a cadascun d'aquests gèneres: un canvi radical que fa que allò que podrien haver estat unes poques pàgines d'un cas clínic acadèmic es converteixin en el capítol d'un llibre de contes clínics. Francis i Kramer-Dahl (1991) i Kotátková (2017) han estudiat les dues maneres d'escriure els CC -acadèmics i literaturitzats- i un dels trets que comparen és l'ús de la terminologia. Tots dos estudis analitzen els contes clínics d'Oliver Sacks i de quina manera ha renunciat o no al llenguatge científic: «does Sacks really abandon "the narrative of neuroscience" - to adapt Myers' term - for the personal narratives of his encounters with his patients?» (Francis i Kramer-Dahl, 1991: 340). Nosaltres reprenem la qüestió i l'apliquem al nostre corpus, el qual inclou contes clínics de Sacks però també d'altres autors i no únicament de neurologia. Hem de destacar que els nostres CC acadèmics, a més de procedir de diverses especialitzacions mèdiques, també són molt diversos quant a l'estil i que no solament comptem amb els prototípics -com ja hem anat veient.

Revisarem els procediments que han seguit els autors dels CC literaturitzats del nostre corpus, amb especial atenció a l'ús de la terminologia. Òbviament, una simple adaptació dels tecnicismes no seria suficient per fer el text atractiu per a un públic general, ja que continuaria tenint els trets del discurs científic, com ara una sintaxi condensada, no hi trobaríem gaire les formes plurigestionades (diàlegs, converses), contindria menys seqüències narratives que un lector s'esperaria d'un conte - encara 
que hem vist que les seqüències narratives poden ser les predominants en els CC acadèmics. La informació en la qual s'hi farà èmfasi, però, i els detalls que es narraran sovint seran ben diferents.

Veurem, en definitiva, de quina manera els metges-escriptors adapten el seu discurs quan escriuen aquestes històries, en comparació a com ho farien si fos un cas clínic acadèmic per publicar en una revista especialitzada de les ciències de la salut adreçada a col·legues. Comprovarem també si ha hi alguna diferència entre els dos llibres de neurologia i els dos de psiquiatria. En principi, ens esperaríem que en els de neurologia serà més difícil evitar del tot els termes per no recórrer a una banalització completa $\mathrm{i}$ que, en canvi, en psiquiatria serà més fàcil emprar altres recursos per explicar l'estat del malalt.

Per cloure aquest apartat, dedicarem l'atenció al tractament de la mort en els dos tipus de CC, amb especial èmfasi en els acadèmics. Aquest subapartat (3.5) ens servirà de transició cap a l'apartat 4, en el qual ens centrarem en la relació entre metges i pacients, narradors i personatges.

\subsection{El tecnolecte dels casos clínics}

Els textos que pertanyen als discursos especialitzats presenten diverses característiques que els solen distingir del discurs ordinari (vegeu subapartat 1.1 del capítol III). En el cas de les ciències de la salut, destacaríem el compactament semàntic dels textos, una sintaxi sintètica, el recurs a les frases fixades convencionals (col·locacions) i l'ús de la terminologia i de les abreviacions. Encara que els CC no siguin els representats més prototípics d'aquest tecnolecte, sí que comparteixen moltes d'aquestes característiques. Tots aquests trets contribueixen a un estil dels diferents gèneres mèdics que podríem qualificar de condensat i fan que els textos mèdics inclosos els CC- ens semblin xifrats als llecs, esotèrics, en contrast amb el necessari exoterisme que caracteritzarà els contes clínics.

Així, seguint Cabré (1992), en els CC podem trobar els trets estructurals propis del llenguatge científic: $a$ ) estructures morfològiques compostes per formants cultes; $b$ ) 
sinapsis o unitats sintagmàtiques; $c$ ) sigles i símbols especialitzats; $d$ ) nominalitzacions a partir de verbs; i e) frases molt curtes i poca subordinació complexa ${ }^{18}$.

a) immunofenotip, hepatoesplenomegàlia, microvasculopatía, proinflamatorias, neurodegenerative, tachycardia

b) la cerebelitis aguda postinfecciosa, trastorn de conducta, deterioro cognitivo, functional amnesia, central nervous system, nasal mucosa

c) la síndrome de Down (SD), proteïna precursora amiloide (APP), la enfermedad de Marchiafava Bignami (EMB), cerebrospinal fluid (CSF), magnetic resonance imaging (MRI), real-time quaking-induced conversion (RT-QuIC)

d) Iligadura de trompes, diagnosis, detection

e) Es decideix ingrés. Gran intranquilidad motriz. She did not suffer from a headache.

Ara bé, al costat d'una profusió de frases molt curtes, en els nostres CC trobem que hi ha parts, sobretot les narratives, en què abunden les frases més llargues. Això sí, sovint amb un estil mecanogràfic, d'informacions seguides, amb poca presència de connectors i d'altres verbs $(f)$. Sobretot, els símptomes i el procés terapèutic s'hi presenten com cúmuls d’informació.

f) Refereix antecedents familiars de migranya amb aura en la mare i epilèpsia en un germà des de la infància fins als 12 anys i antecedents personals de tabaquisme, hipertensió i migranya sense aura que tracta amb AINE.

(13.CAT_Neurologia)

Hi ha CC amb una tendència narrativa encara més desimbolta $(g)$, a frec de la literaturització o la contística, amb profusió de detalls i informacions que acosten el lector a les accions relatades.

g) Since she started University, her life had been totally busy with studying, leaving no time or desire to engage in social relationships. She did not talk about any actual satisfying relationships. The only "friends" she kept in touch with were schoolmates from high school, with whom she shared school topics. She had never had a boyfriend, and felt very uncomfortable talking about romantic or sexual topics. Matilde moved

${ }^{18}$ Recordem, però, que en anglès la tendència a les oracions curtes no és exclusiva del discurs especialitzat. 
away from her small native town to attend University, and she was sharing an apartment with other students next to the Medical School. She went back home to her family during University vacations. She came from an intact family, which she was very proud of. She had a 10-year-old sister, Sarah, to whom she was very attached. Sarah was described as very different from Matilde: very funny, an ironic with a lot of energy. They spent a lot of time playing together, and Matilde was unconcerned about her worries when she was with Sarah.

(29.ENG_Psychology)

Pel que fa al lèxic, també en els CC del nostre corpus trobem els tres nivells característics dels textos especialitzats (Cabré, 1992): a) lèxic comú a textos generals i especialitzats; $b$ ) lèxic fronterer entre la llengua comuna i l'especialitzada; $c$ ) lèxic clarament específic del text especialitzat.
a) malaltia, desenvolupament, lesió
b) teràpia, síndrome, fàrmac
c) xerostomia, hipercolesterolèmia, limfoma

Bona part del lèxic especialitzat està compost per cultismes d'arrel grecollatina, molts dels quals són de difícil comprensió per a un públic general. Val a dir que en cada idioma hi ha uns cultismes que s'entenen millor que altres, i que entre les diferents llengües també hi ha graus diferents de comprensió de les arrels grecollatines. En el nostre corpus comptem amb dues llengües romàniques, com són el català i el castellà, i una llengua com l'anglès, germànica però fortament romanitzada per tots els gal-licismes i llatinismes que conté en els diversos registres. Així, en les tres llengües que ens ocupen podem constatar una familiaritat amb les arrels llatines, de manera que algunes poden ser reconegudes pels parlants aliens a l'àmbit especialitzat ${ }^{19}$. Malgrat aquesta proximitat relativa, molts dels termes són mots morfològicament complexos que obtenen el seu significat de la combinació de diversos formants -arrels, prefixos i sufixos. Així, per exemple, el mot osteopatia es pot dividir en tres parts: I'arrel osteo,

\footnotetext{
${ }^{19}$ A diferència del que passa, per exemple, amb els parlants de les llengües eslaves, els quals difícilment troben relació entre els cultismes grecollatins i les seves paraules patrimonials (Kotátková, en premsa $b$ ).
} 
que prové del grec osteon 'os', l'arrel path, del grec patheia 'sofrença', amb el sufix llatí -ia, -ium (grec -eia, -ia) 'estat' o 'desordre' (Helán, 2012: 77-78).

A més de la terminologia amb formants cultes ja adaptats a cada idioma i integrats en el seu sistema, un altre tret prototípic del discurs mèdic és l'ús d'expressions grecollatines en les seves versions originals en cursiva (exemple 1). En els CC del nostre corpus no trobem aquest ús amb tanta freqüència com en els d'altres especialitats: en les especialitats que estudiem - sobretot en la psicologia i la psiquiatria - no són tan abundants les referències a organismes com ara els bacteris o els virus, que són els que solen apuntar-se amb la denominació grecollatina.

(1) Cryptococcal meningitis (CM) is a potentially fatal disease caused by infection with Cryptococcus spp. Cryptococcus neoformans ( $C$. neoformans) and Cryptococcus gattii (C. gattii) are the most commonly isolated pathogenic Cryptococcus species, and the taxonomy of their species complexes has been revised [1,2]. CM is a global invasive mycosis associated with significant morbidity and mortality $[3,4]$ from neurological complications [4-6]. C. gattii, formerly known as C. neoformans var. gattii, has been recognized as an endemic pathogen since the 1990s [5-7]. Those infected with C. gattii tend to be younger patients with meningitis but without underlying conditions $[8,9]$. Whether the immune function of the host or different $C$. gattii subtypes contribute more to poor prognoses, pathogenesis is still being debated $[10,11]$.

(2.ENG_Neurology_A)

A banda de l'ús de la terminologia més o menys especialitzada, els gèneres mèdics escrits contenen moltes abreviacions (abreviatures, sigles i símbols). En els CC, la presència n'és particularment freqüent. Recordem que la llargària dels textos d'aquest gènere sovint està limitada i, en aquest context, les abreviacions són un recurs que permet estalviar espai. També fan que no s'hi hagin de repetir blocs llargs de mots que farien més carregosos els textos.

(2) Creutzfeldt-Jakob disease (CJD) is a rare, neurodegenerative, transmissible disorder of the central nervous system (CNS), clinically characterized by progressive dementia and death.

$[\ldots]$ 
CJD occurs in sporadic (SCJD), genetic (gCJD) or iatrogenic (iCJD) forms [3] and as a new variant (vCJD) [4]. While origin of the most common SCJD is still unknown, iCJD is caused by accidental transmission of the disease in the course of diagnostic or therapeutic interventions, and VCJD - the first human prion zoonosis - is related to bovine spongiform encephalopathy.

Genetic CJD is associated with disease- specific mutations (insertions, deletions) of the PRNP. They represent about $10-15 \%$ of all CJD cases $[3,5,6]$. Preventive genetic testing in gCJD-affected families revealed "healthy", asymptomatic carriers of the disease-specific mutations. They represent a "genetic CJD risk group" in the general population.

(4.ENG_Neurology_A)

En el nostre corpus, detectem que sobretot s'abreugen: noms de malalties Creutzfeldt-Jakob disease (CJD), neurofibromatosis de tipo 2 (NF2)-, de trastorns trastorno por déficit de atención e hiperactividad (TDAH) - , de síndromes - síndrome de Down (SD), velocardiofacial syndrome (VCFS)-, d'exàmens o procediments d'investigació o diagnòstic -imatge per ressonància magnètica (IRM) - i de fàrmacs fluconazole (FLC).

La tendència a abreujar conceptes repetits s'estén també als de fora de l'àmbit estrictament sanitari. Així, trobem abreviacions que formen part del coneixement general dels parlants de Ilengua, com ara Mr. per mister, US per United States, $m$. per meses, etc.). Ara bé, també en trobem que no estan gens estandarditzades i que podríem considerar pròpies de la comunitat discursiva. En els CC, quan s'estudia i es repeteix molt algun concepte, els autors se'n poden inventar una abreviació, com en l'exemple del CC «Psychopathology Related to Energy Drinks: A Psychosis Case Report» en el qual l'ús d'energy drinks és tan freqüent que els autors decideixen substituir-lo en la majoria de casos per $E D$ :

(3) To our knowledge this case report is probably the first case of psychosis related to ED abuse in a patient without a previous diagnosis of psychotic disorder. ED abuse likely played the most important role in the pathogenesis of psychosis in this case report; however, other factors, such as cannabis use disorder, genetic factors, and sleep deprivation, were probably relevant and facilitated the process.

ED consumption could represent a global public health problem because of its potential severe adverse events. Few articles have been published on this important 
matter. The general public and potentially vulnerable users, such as adolescents, should be advised that caution is warranted when using these drinks, especially in large quantities over short periods of time or mixed with cannabis, alcohol, or other substances. More research is needed to determine the potential health and mental effects associated with ED consumption.

(21.ENG_Psychiatry)

A part d'aquestes abreviacions a la carta, les que estan estandarditzades poden, òbviament, ser diferents en cada idioma, per bé que n'hi ha que coincideixen en les tres llengües, en els casos en què els mots comencen per la mateixa lletra o en aquells en què les llengües romàniques empren l'abreviació anglesa. Ara bé, quan es tracta d'una abreviació menys coneguda o quan fa referència a una afecció rara o poc freqüent, se'n sol donar el nom complet en l'apartat «introducció», amb l'abreviació entre parèntesis. Després, en la resta del text, es fa servir només l'abreviació. En els casos de procediments, malalties, etc. més coneguts - per als professionals de la comunitat de pràctica concreta, és clar-, ja no es facilita enlloc el desenvolupament de l'abreviació.

(4) The choice for this medication was mainly due to his cyclical fever/rash presentation, despite genetic testing being negative for periodic fever syndromes, including ELANE, LPIN2, MEFV, MVK, NLRP3, PSTPIP1, and TNFRSF1A.

(35.ENG_Neurology_C)

Així doncs, l'alt nivell tècnic del llenguatge dels CC acadèmics es pot constatar en l'ús freqüent de termes mèdics $\mathrm{i}$ abreviacions especialitzades, les quals contribueixen a generar una complexitat encara major. A més, també hi detectem combinacions de mots fixades i convencionalitzades que podríem considerar prototípiques d'aquest gènere (vegeu el subapartat 3.2 d'aquest capítol). En conjunt, el tecnolecte emprat fa que els llecs, aliens a la comunitat d'experts, tinguin més dificultats per entendre'l, de manera que «this 'arcane' specialized terminology of Graeco-Latin origin can often sound complicated and confusing, maintaining the 'status quo' of medicine as an esoteric science reserved only for the dominating groups of medical professionals» (Helán, 2012: 78). Així, la terminologia i les abreviacions que marquen la cientificitat del text remarquen també la pertinença a una comunitat de pràctica. Precisament per això, 
trobem CC que contenen més termes especialitzats que altres i més o menys abreviacions no desenvolupades al Ilarg del text: quan es tracta de CC d'una especialitat concreta, publicats en una revista exclusiva d'aquesta especialitat, és més habitual que els textos tinguin un grau més alt d'especialització lingüística.

\subsection{Les construccions convencionalitzades}

En el subapartat anterior hem vist com fan servir el tecnolecte propi de la seva comunitat de pràctica els autors dels CC acadèmics. L'ús de la terminologia i de les abreviacions encaixa amb els propòsits comunicatius del gènere, ja que la primera té per missió garantir la precisió del que s'explica, mentre que les segones aporten concisió al text. Juntament amb aquests recursos, també hi podem trobar construccions que no necessàriament contenen mots especialitzats, però que també caracteritzen aquest gènere. Es tracta d'estructures que se solen repetir amb unes formes idèntiques o molt similars en nombrosos CC i amb un mateix objectiu. Els CC del nostre corpus són variats quant a la llengua, l'especialització i fins i tot els propòsits comunicatius - que van dels netament investigadors als obertament didàctics. Malgrat aquestes diferències, hem pogut detectar-hi algunes construccions que hi apareixen de manera recurrent $\mathrm{i}$ contribueixen a la construcció $d^{\prime}$ aquest gènere ${ }^{20}$. Ens centrem en les més destacades $i$ presents en el nostre corpus, que giren al voltant de quatre de les mogudes retòriques analitzades per Helán (2012): la justificació del cas; la presentació del cas; la presentació del pacient quant a la raó de la consulta o l’ingrés; la investigació del problema.

El primer context al qual s'associen bona part de les construccions convencionalitzades dels CC és quan s'explica la singularitat del cas, particularment rellevant en els textos amb un caire més marcadament investigador. Quan hom redacta una publicació científica, sovint sent la pulsió de justificar i explicar per què precisament

\footnotetext{
${ }^{20}$ Per poder detectar aquestes construccions convencionalitzades en un corpus tan extens - 115 casos clínics acadèmics - , hem utilitzat Sketch Engine (2019), un programari de gestió de corpus i d'anàlisi de textos. Aquest gestor permet generar corpus propis en diverses llengües, incloses les que estudiem en aquesta tesi doctoral. Així doncs, hi hem creat tres subcorpus, un per cada llengua, i per separat hi hem cercat les construccions convencionalitzades.
} 
el seu text hauria de ser interessant per a algú. En el gènere dels casos clínics trobem també aquesta necessitat, sia perquè es publiqui el text, sia perquè es llegeixi:

(5) Lo que hace singular este caso es el hecho de que el mecanismo causante de la lesión sea una postura forzada mantenida largo tiempo jugando con un ordenador.

(38.ESP_Neurología_B)

En el subapartat 2.2 del capítol III exposàvem els dos grans propòsits comunicatius dels CC: sorprendre presentant una novetat i ensenyar. En els casos clínics més orientats a la investigació, s'intenta remarcar precisament la novetat que, segons les convencions pròpies de la comunitat de pràctica dels professionals sanitaris i d'acord amb les normes de les editorials, hauria d'aportar aquest tipus de CC. Les construccions vinculades a aquest propòsit les podem trobar majoritàriament en els abstracts i dins del cos del text, tant en les introduccions com en la discussió/conclusions (taula 1).

\begin{tabular}{|l|l|c|}
\hline only a few cases & primer caso & pocs casos descrits \\
a rare case of & primera publicación & alguns casos aïllats \\
peculiar case & único caso & patologia/símptoma/malaltia \\
rare and unique presentation & enfermedad infrecuente & poc freqüent/infreqüent \\
unusual presentation & & etiologia desconeguda \\
atypical presentation & & \\
rare complication & & \\
no reports & & \\
\hline
\end{tabular}

Taula 1: Construccions convencionalitzades per a explicar la singularitat del cas

Òbviament, no tots els casos clínics poden descobrir alguna novetat absoluta. Molts, de fet, també comenten els casos similars descrits anteriorment, però sempre intenten aportar almenys algun detall que els diferenciï. Si pensem que cada pacient és un món i pot tenir progressos i reaccions variades, no és tan complicat d'aconseguir -i no ho diem pas des d'un punt de vista mèdic, sinó des de l'anàlisi del discurs. Recordem també que fins i tot els CC més originals fan una revisió dels estudis anteriors, precisament per poder explicar per què el seu text és tan singular. Els autors, com veiem en els exemples, intenten posar en relleu la singularitat del cas que presenten i afegir l'element de novetat, és a dir, una informació que amplia o detecta un buit en el coneixement clínic. 
La majoria dels CC del nostre corpus que inclouen aquestes construccions convencionalitzades són de neurologia, una especialitat mèdica la naturalesa de la qual permet descobrir i també analitzar les particularitats del cervell humà:

(6) S'han descrit pocs casos de pacients amb TIPS que, en el context d'una encefalopatia hepàtica aguda, hagin desenvolupat manifestacions focals cerebrals associades a la presència de lesions corticals a la neuroimage.

(25.CAT_Neurologia)

(7) El paciente presentado es el único caso que hemos hallado en la bibliografía con diagnóstico confirmado de NF2 y TEA. Dado que desconocemos si se trata de una asociación casual o puede existir una etiología común en algunos pacientes, recomendamos que se explore activamente la capacidad de comunicación social en los pacientes con NF2.

(3.ESP_Neurología_A)

(8) Revisamos las publicaciones de casos similares más importantes realizadas hasta la fecha. Para nuestro conocimiento, ésta es la primera publicación en castellano al respecto.

(4.ESP_Neurología_A)

(9) This case is reported due to the rare and unique presentation of CHS in this patient. Currently, there are no clear guidelines for repeat MRI after CAE and larger population studies are required to determine such guidelines.

(13.ENG_Neurology_B)

(10) To conclude, we described a very rare case of occlusion of two different branches of the ophthalmic artery - central retinal artery (supplying the retina) and short posterior ciliary artery (supplying the optic nerve) with two different symptoms at the back of the eye (occlusion of the macular branch of the central retinal artery and the AION).

(5.ENG_Neurology_A)

En els CC en anglès veiem que aquesta característica de destacar la novetat o singularitat del cas és molt més present. Recordem que les revistes en llengua anglesa del nostre corpus tenen un perfil molt marcat com a comercial, estan ben indexades $\mathrm{i}$ pertanyen a grups editorials i no a associacions o agrupacions professionals, com és el 
cas de diverses revistes en castellà i totes les publicacions en català del nostre corpus. Entre les de llengües romàniques, tenim publicacions amb una orientació més didàctica, en les quals no se sol destacar que el cas sigui únic, ni rar, ni res de semblant. Tampoc, però, no s'hi sol mencionar que es tracti d'una malaltia o d'un símptoma força freqüent. El públic de les revistes que publiquen quasi exclusivament aquesta mena de textos Adolescere, Neurologia Catalana- ja sap quins tipus de CC s'hi trobarà. De fet, recordem que les dues revistes tenen elements que els fan diferents pel que fa a l'estructura: en el cas d'Adolescere és el fet d'incloure preguntes de tipus test al final del cas; en el de Neurologia Catalana, la divisió dels casos entre diversos números de la revista i la dinàmica de discutir els casos amb altres experts.

El segon context en què trobem construccions convencionalitzades pròpies d'aquest gènere és la presentació del cas. Aquí podem observar una sèrie de fórmules que s'hi repeteixen (taula 2). Les construccions es componen per un verb (presentar, describir, report...) més la denominació de l’objecte d'estudi (cas, cas clínic, un pacient, dona...).

\begin{tabular}{|c|c|c|}
\hline $\begin{array}{l}\text { we report a/the } \\
\text { case/treatment... } \\
\text { we present a/the } \\
\text { case/patient... } \\
\text { we describe a/the case... }\end{array}$ & $\begin{array}{l}\text { presentamos el caso clínico } \\
\text { presentamos un paciente... }\end{array}$ & $\begin{array}{l}\text { presentem el cas de... } \\
\text { ens trobem davant d'un } \\
\text { cas/pacient... }\end{array}$ \\
\hline our patient is/was... & & se'ns presenta el cas de.. \\
\hline $\begin{array}{l}\text { this paper/case report } \\
\text { describes a patient... }\end{array}$ & $\begin{array}{l}\text { se presenta el caso de/un } \\
\text { caso... } \\
\text { se trata de un/a pacient... }\end{array}$ & $\begin{array}{l}\text { es presenta el cas de... } \\
\text { es tracta d'un home/una } \\
\text { dona... }\end{array}$ \\
\hline
\end{tabular}

Taula 2: Construccions convencionalitzades per a presentar el cas

En aquesta part del text es comença a narrar la història del pacient i se sol situar bé en l'abstract, bé com última frase de la introducció, bé al principi de l'apartat presentació del cas. Recordem que es tracta d'un gènere mèdic i que, per mantenir l'objectivitat, els 
autors poden tendir a difuminar la seva presència textual en els casos (vegeu subapartat 4.3 d'aquest capítol). En la part superior de la taula 2 podem veure exemples on s'explicita la presència dels autors, amb construccions personals en veu activa «presentem el cas de...» (exemples 11A). En la part inferior, en canvi, trobem les construccions impersonals amb passiva reflexa ${ }^{21}$ que difuminen l'autoria - «es presenta el cas de...» (exemples 11B). A més a més, en la part mitjana de la taula incloem alguns casos que detectem en anglès i en català i que podem ubicar a mig camí: encara que el verb no hi aparegui en primera persona del plural, introdueixen un element gramatical (anglès «our», català «ens») que apunta cap als autors (exemples 11C).

A)

Herein we report a case of a young female who was initially suspected of having MS... (36.ENG_Neurology_C)

We report the case of a non-operable super-super obesity - a 37 year old woman with a BMI of $62 \mathrm{~kg} / \mathrm{m} 2 \ldots$ (28.ENG_Psychology)

In this case report, we present a patient with two paroxysms of anti-NMDAR encephalitis... (15.ENG_Neurology_B)

Here we describe a case of ECD with central nervous system (CNS) involvement presenting as unilateral visual field deficit... (11.ENG_Neurology_B)

Presentamos el caso clínico de un hombre de 50 años, aquejado de una depresión grave... (27.ESP_Psiquiatría)

Presentamos el caso de un paciente con diagnóstico de NF2 en edad pediátrica... (3.ESP_Neurología_A)

Presentem el cas d'un home jove amb SD que va presentar signes clínics i radiològics compatibles amb TVC. (10.CAT_Down)

Presentem el cas d'una dona de 20 anys amb hàbit tabàquic de 10 cigarretes /dia i enòlic ocasional... (22.CAT_Neurologia)

Ens trobem davant d'una pacient amb dolor d'extremitats inferiors de característiques mecàniques d'un any de evolució... (13.CAT_Neurologia)

${ }^{21}$ La passiva reflexa no és, estrictament parlant, una forma impersonal des del punt de vista gramatical, però la podem considerar com a tal a efectes discursius. Vegeu més sobre les passives en Bartra (2002). 
B)

Our patient is a 28-year-old non-smoking woman with a history of 13 attacks of hemiplegic migraine since the age of 19 years. (34.ENG_Neurology_C)

Se'ns presenta el cas clínic d'una dona de 47 anys en estudi per haver presentat un ictus isquèmic amb oclusió d'artèria caròtida interna esquerra a nivell intracranial (TICA) d'etiologia indeterminada. (21.CAT_Neurologia)

C)

This case report describes a patient suffering from retrograde episodicautobiographical amnesia for whole life... (20.ENG_Psychiatry)

Se presenta el caso clínico de una mujer de 34 años de edad con debilidad progresiva en ambos miembros inferiores... (39.ESP_Neurología_B)

Se trata de una mujer de 59 años que ingresa con clínica aguda de infarto isquémico completo de la arteria cerebral media izquierda... (12.ESP_Enfermería)

Es presenta el cas d'un pacient amb SD associada a una malformació congènita de fossa posterior... (2.CAT_Down)

Es tracta d'un home de 73 anys, ex-fumador des del 2005, sense factors de risc vascular. (23.CAT_Neurologia)

En diversos casos també ens podem trobar una manera encara més asèptica d'introduir el cas: començar directament des de la referència al pacient, sense cap verb introductori (exemples 12). Amb aquesta solució, els autors desapareixen completament del text.

(12) Home de 61 anys que ingresa a l'abril de 2005 per impotència funcional d'extremitats d'instauració progressiva de nou mesos d'evolució.

(15.CAT_Neurologia)

Pacient de 62 anys, natural de Bolívia que viu a Espanya des de fa més de 10 anys, ex fumador i ex enolisme moderat.

(29.CAT_Neurologia) 
Primer hijo de padres no consanguíneos. Embarazo controlado, parto eutócico a término y perinatológico sin incidencias.

(3.ESP_Neurología_A)

Mujer de 27 años, fisioterapeuta de profesión, que el 28 de febrero del 2011 comienza con alteraciones visuales (distorsiones de los rostros de sus familiares), cefaleas frontales, febrícula de $37,5^{\circ} \mathrm{C}$ y síndrome confusional.

(11.ESP_Enfermería)

Adolescente varón de 12 años que consulta con su pediatra por presentar vómitos persistentes, alimentarios y "acuosos" de 60 días de evolución, hasta 31 episodios en un día.

(19.ESP_Adolescencia)

A 53-year-old man was hospitalized after two generalized tonic-clonic seizures (GTCS) with no history of previous epilepsy or any other neurological disease.

(1.ENG_Neurology_A)

A 63-year-old male with a past medical history of remote facial trauma presented to our hospital with a 1-month long history of fever, headache, and gait instability.

(35.ENG_Neurology_C)

Hi ha casos en el quals sempre es manté el mateix tipus de construcció — sigui personal, impersonal o sense el verb-, però també trobem textos que en un lloc opten per una forma i en un altre per una altra ben diferent. Quan es produeix aquest canvi, la tendència és que les formes personals apareguin al principi del text -abstract o introducció- i les expressions que ometen el verb s'utilitzin en la presentació del cas.

En els textos en llengua anglesa és on trobem més autors que fan servir per a la presentació del cas les formes personals - primera persona del plural: «we report/present/describe». Com ja ha observat Helán (2012) sobre els CC en anglès, aquest sol ser l'únic lloc - o un dels pocs - on els autors es fan una autoreferència, generalment amb l'ús de la ja esmentada primera persona del plural. Els CC en anglès són els que més es publiquen i circulen. També són els que més regles solen tenir per a ser publicats -i més competència. És en aquest context que hem d'entendre que manifestin unes construccions tan generalitzades com ara "we present a/the case» $\mathrm{i}$ 
«we report a/the case», que són les que més es repeteixen en el nostre corpus. Quan recorren a l'omissió, acostumen a fer-ho amb el darrer mecanisme, és a dir, mitjançant la introducció directa del pacient sense cap verb que faci referència a qui escriu el cas.

En castellà, predomina clarament el darrer procediment. De fet, si ens fixem en la taula 2, no hi trobem gaire varietat d'expressions, tant personals com impersonals. La més freqüent, si deixem de banda la introducció directa, és «se presenta el caso de...». En català, encara que trobem més presència de les formes personals que en castellà sobretot, «presentem el cas de...»-, les més freqüents són les que no contenen el verb introductori i les impersonals — «es tracta de...» $\mathrm{i}$ «es presenta un cas de...».

Quant a les especialitzacions dins de les ciències de la salut, no podem treure cap regla general en relació amb l'ús de les construccions que hem qualificat de més personals i determinades especialitats sanitàries ${ }^{22}$. Encara que ens haguéssim pogut esperar que les formes més impersonals tendirien a ser més freqüents en textos de neurologia i les més personals en els que tracten, a part de la malaltia, també algun aspecte psíquic o social, no hem trobat aquesta distinció. De fet, en anglès, observem que la tendència a emprar les formes personals en aquestes construccions és transversal a totes les especialitats incloses en el nostre corpus. Recordem que es tracta de fórmules que estan molt arrelades en aquest gènere i que hi apareixen independentment de si tot el text està enfocat de manera més o menys personalitzada o humanitzada. El fet que un CC comenci amb una presentació amb un verb personal - «presentem el cas de»- no és cap garantia que al llarg del text continuem detectant la presència de l'autor. Moltes vegades és I'única ocasió on se'ns deixa entreveure. A més, fixem-nos que quan apareixen els autors majoritàriament se'ns presenten casos i no pacients. En canvi, quan manca el verb que en marcaria la presència, se sol presentar un home, una dona, un infant...

El tercer context al qual trobem vinculades determinades expressions convencionalitzades és el de la presentació del pacient en relació amb la raó de la consulta o ingrés (taula 3). En aquesta part del CC es descriuen les característiques

\footnotetext{
${ }^{22}$ A diferència del que constatem pel que fa a la despersonalització dels pacients, més palesa en els casos de neurologia del nostre corpus. Vegeu apartat 4.3 d'aquest capítol.
} 
bàsiques del pacient, tot seguint un guió que també està molt convencionalitzat, en el qual adquireix rellevància el relat del professional sanitari sobre com ha arribat fins a ell el pacient $-d$ 'urgències, $d$ 'un altre centre sanitari- i per quina raó. Els símptomes manifestats pel pacient són traduïts al tecnolecte mèdic pel professional sanitari i d'aquesta manera els trobem en els CC (exemples 13).

\begin{tabular}{|l|c|c|}
\hline $\begin{array}{c}\text { was admitted to/with... } \\
\text { because of... }\end{array}$ & $\begin{array}{c}\text { acude a consulta (o un altre } \\
\text { tipus de centre) por/porque... }\end{array}$ & $\begin{array}{c}\text { va ingressar/ingressa al } \\
\text { nostre centre per... }\end{array}$ \\
$\begin{array}{c}\text { was referred to.../[pacient] } \\
\text { referred to... }\end{array}$ & [pacient] ingresado por... & [pacient] consulta per... \\
presented to/with... & motivo de... \\
& consulta con [el professional derivado a... con & \\
& sanitari] por... \\
\hline
\end{tabular}

Taula 3: Construccions convencionalitzades per a presentar el pacient en relació amb la raó de la consulta o l'ingrés

(13) We present a case of a 37-year-old otherwise healthy man. He was admitted to our department because of four-day history of uncontrollable repetitive jerky movements with tonic component and onset on the left lower extremity.

(6.ENG_Neurology_A)

A 45-year-old female referred to our tertiary care hospital complaining of bilateral knee pain associated with swelling, intermittent generalized body pain that affected her daily activity, progressive painless visual loss in the left eye, and mild headache for one year.

(11.ENG_Neurology_B)

A 63-year-old male with a past medical history of remote facial trauma presented to our hospital with a 1-month long history of fever, headache, and gait instability.

(35.ENG_Neurology_C)

Varón sano de 13 años, sin otros antecedentes de interés, que acude al servicio de Urgencias porque desde las 2 horas previas a su llegada había comenzado con el décimo episodio de sensación de giro de objetos...

(21.ESP_Adolescencia) 
Varón de 49 años, derivado a la unidad de neurorrehabilitación con motivo de ingreso: tratamiento rehabilitador por intervención quirúrgica de hemangioblastoma de suelo del tercer ventrículo a causa del síndrome de VHL.

(9.ESP_Enfermería)

Adolescente varón de 12 años que consulta con su pediatra por presentar vómitos persistentes, alimentarios y "acuosos" de 60 días de evolución, hasta 31 episodios en un día.

(19.ESP_Adolescencia)

Home de 63 anys, ingressa el febrer del 2012 de manera programada al servei d'hematologia del nostre hospital per a realitzar transplantament al-logènic de moll d'ós, no emparentat, amb HLA idèntic.

(20.CAT_Neurologia)

El pacient consulta a urgències per haver presentat tres episodis, en dies successius, consistents en hipoestèsia crural, braquiocrural i facio-braquio-crural respectivament, de segons de durada, seguits de contracció tònica de mà i peu drets que cedeix en 2 minuts.

(13.CAT_Neurologia)

En el moment de la consulta presenta una història clínica d'un any d'evolució caracteritzada per ansietat, presa de consciència de la seva discapacitat, permanència durant llargs períodes de temps asseguda al llit, trastorns del son, pors, manca d'atenció en la cura personal i inici d'una deambulació rígida (amb les cames rectes i els punys tancats).

(6.CAT_Down)

En els exemples citats hem volgut representar els models més freqüents en cada idioma. Aquests expressions convencionalitzades, conjuntament amb la presentació del pacient (home de 63 anys...), fan que puguem distingir aquest gènere i, dins d'ell, també l'apartat de la presentació del cas, fins i tot quan no està diferenciat explícitament. No trobem gaires CC que comencin d'una manera molt diferent a les presentades aquí.

Una diferència entre les dues llengües romàniques i l'anglès la trobem quan s'expressa la ubicació de l'ingrés del malalt. Els autors en llengua anglesa tendeixen a optar per incloure el possessiu our («our department, our tertiary care hospital»), amb 
la qual cosa se situen textualment en el lloc dels fets, mentre que en català i castellà aquest possessiu («al servicio de Urgencias, a la unidad de neurorrehabilitación») no sol aparèixer amb tanta freqüència («al servei d'hematologia del nostre hospital»). Sovint podem trobar expressions molt paregudes o fins $\mathrm{i}$ tot iguals en les dues llengües romàniques, per bé que la fórmula més usada en castellà és «acude a consulta por...» i en català aquesta la trobem només en uns pocs casos.

Una vegada es presenta el malalt i la raó per la qual ha acudit a un centre sanitari, l'atenció sol centrar-se en l'historial mèdic i familiar i en els símptomes. Després d'aquestes expressions que acabem de veure i que combinen el lloc on arriba el malalt amb la raó per la qual ho fa, tot seguit solen aparèixer les queixes del malalt. Aquestes les sol comentar el pacient -si està en un estat que ho permeti-, però el discurs el controla el professional sanitari. Per tant, es comenten en un estil indirecte i traduït del llenguatge generalment comú del pacient al llenguatge propi de la comunitat de pràctica del professional corresponent. Així les possibles queixes del pacient són introduïdes en català i castellà amb verbs com ara "referir» i en anglès «complain» (vegeu-ne més en el subapartat 4.2 d'aquest capítol).

El quart context amb forta presència d'expressions convencionalitzades el trobem a I'hora de presentar les troballes significatives de les proves i altres procediments d'investigació. En la taula 4 veiem quines són les expressions més freqüents per informar sobre els resultats. Així, trobem que, en primer lloc, es realitzen - sense agent- els diferents tipus de proves i procediments i, a continuació, aquests mostren - per si solsles troballes ${ }^{23}$. Quant a la primera part, en la qual els metges fan aquestes proves als pacient, totes les llengües analitzades (exemples 14) opten amb molta freqüència per aquesta construcció en passiva - en anglès - o passiva reflexa —en català i castellà-, sense agent i amb el verb en passat: «es va realitzar», "se realizó», "was performed» (vegeu-ne més en el subapartat 4.3).

\footnotetext{
${ }^{23}$ Aquesta manera de redactar ha estat criticada (Anspach, 1988 i Helán, 2012) i la tractem en el subapartat 4.3 .
} 


\begin{tabular}{|l|c|c|}
\hline $\begin{array}{l}\text { [procedure/examination] } \\
\text { showed/showing }\end{array}$ & [procedimiento/examen] & [procediment/examen] \\
revealed & mostró/mostraron & va/van mostrar \\
confirmed & se observó/observaron & va/van demostrar \\
demonstrated & se confirmó & va/van confirmar \\
& & va/van detectar \\
& & es van objectivar/observar \\
\hline
\end{tabular}

Taula 4: Construccions convencionalitzades per a informar sobre els resultats

(14) Plain X-ray of both knees showed multiple sclerotic patches of the distal femur and upper parts of both tibiae (Figure 1) while bilateral tibia magnetic resonance imaging (MRI) showed bilateral lesions replacing the normal fatty signal intensity in the T1 weighted images (Figure 2).

(11.ENG_Neurology_B)

General physical and neurological examinations revealed no pathological findings. Although systematic and complex neuropsychological tests were not performed, his intelligence appeared to be within normal limits.

(20.ENG_Psychiatry)

In the presented case of traumatic etiology, the diagnostic process was complicated by frontal lobe brain injury confirmed by CT from acute care stay.

(10.ENG_Neurology_B)

El hemograma y la bioquímica, así como el estudio de tóxicos en orina, fueron normales, de manera que previa tomografía computarizada craneal para descartar lesiones ocupantes de espacio, se realizó una punción lumbar que mostró una moderada pleocitosis mononuclear...

(1.ESP_Neurología_A)

En el fondo de ojo se observó un defecto coriorretiniano circumpapilar inferior en el ojo derecho, sugestivo de una malformación colobomatosa. En la exploración funduscópica se halló una lesión pigmentada en el borde nasal del nervio óptico del ojo derecho asociada a bandas de fibrosis prerretianianas...

(3.ESP_Neurología_A) 
Por otra parte, dado los antecedentes de nuestra paciente de ansiedad ante el estrés, se pensó en un trastorno psicosomático pero la exploración en la consulta de atención primaria orientaba a organicidad, que se confirmó con la ecografía abdominal.

(18.ESP_Adolescencia)

Donada la persistència del episodis malgrat tractament anticomicial i l'aparició d'afàsia motora es va decidir repetir la IRM cranial amb angio RM (fig 1) que va mostrar la presència de quatre noves lesions isquèmiques agudes per difusió en territori d'ACM esquerra amb angio RM normal.

(13.CAT_Neurologia)

Exploracions complementàries: l'analítica va detectar una anèmia microlítica hipocròmica i una banda de mobilitat restringida a la zona gamma tipus IgM kappa. La bioquímica hepàtica mostrava una persistència del patró de colestasi dissociada (FA de $130 \mathrm{U} / \mathrm{L}$ i GGT de $505 \mathrm{mg} / \mathrm{dl})$.

(15.CAT_Neurologia)

Es va realitzar una TC cranial que va fer palesa una dilatació de la cisterna magna amb hipoplàsia de la porció inferior del cerebel, suggeridora de la malformació de Dandy-Walker. La RNM va confirmar la hipoplàsia cerebel·losa, associada a una fossa posterior de dimensions reduïdes, la qual cosa suggereix la variant de Dandy-Walker (fig. 1 i 2$)$.

(2.CAT_Down)

Aquesta presentació de les troballes sol anar acompanyada de diferents tipus de figures (vegeu l'apartat 1.4 d'aquest capítol) que ajuden a alleugerir el text de xifres i explicacions i que un professional sanitari ha de reconèixer i saber interpretar per formar part d'una determinada comunitat de pràctica. Així doncs, ens podem trobar amb referències a imatges, de les quals només es destacaran unes poques informacions més rellevants, ja que es pressuposa que el lector pot llegir i interpretar directament la resta de la imatge ( $p$. ex. d'una ressonància magnètica). En anglès, aquestes referències es fan, de manera predominant, amb verbs en passat (confirmed), el subjecte dels quals són els procediments o les màquines. El mateix model trobem en català (va confirmar), amb alguns usos també de les passives reflexes ja esmentades. En castellà, aquestes últimes són, en canvi, les predominants (se confirmó). 
Quant a les diferències entre les especialitats, com que es tracta majoritàriament de proves biomèdiques que mostren els resultats, on més presència detectem d'aquest tipus d'expressions que amaguen la presència del professional sanitari és en els CC de l'àmbit de la neurologia. Les altres especialitats, però, també solen seguir aquest patró i, per tant, és un tret propi d'aquest gènere i podem dir que també del llenguatge d'aquestes comunitats discursives i de pràctica. El fet d'allunyar-se - textualment- dels resultats fa que apareguin com més objectius, a més de complir amb els estàndards de redacció d'aquestes comunitats. Així doncs, les accions són realitzades -com si la participació del professional sanitari fos irrellevant- i les màquines i les proves - que sí que fan de subjecte de l'acció- confirmen, mostren, demostren i detecten. Aquest és el patró majoritari en el gènere, però cal recordar que, al capdavall, sempre és la persona -el professional sanitari- qui confirma o detecta les troballes. Per això, com veurem en l'apartat 4.3, els autors no sempre desapareixen del tot dels seus textos.

En aquest apartat hem vist que hi ha diverses parts dels CC en les quals és habitual trobar determinades construccions convencionalitzades. Ens hem centrat en quatre contextos que hem considerat els més establerts. Quan Ilegim un CC podem esperar, doncs, que el contingut específic que se'ns hi presenta vagi introduït sovint per una sèrie d'expressions que és evident que s'han consolidat en aquest gènere. Aquestes construccions, en canvi, no solen aparèixer en els contes clínics, ja que es tracta de textos literaris i la repetició de les mateixes construccions, sovint impersonals i rígides, no s'ajustaria als propòsits comunicatius del gènere: no faria goig als ulls del lector. Òbviament, en l'àmbit de la literatura també existeixen les col·locacions. Hi podem trobar usos d'expressions convencionalitzades per marcar la pertinença a un determinat gènere, començant, sense anar més lluny, per la introducció dels contes tradicionals: "Això diu que era...., "Érase una vez...., "Once upon a time...». Quant als contes clínics del nostre corpus, examinem breument si hi podem detectar algunes de les expressions abans detallades.

Així, pel que fa al primer context - la justificació de l'originalitat que en els CC acadèmics apareixia des del principi o ja en l'abstract-, quan trobem en els contes clínics alguna referència a la raresa o la novetat del que s'observa, generalment no és per tant per justificar-ne la publicació com per mantenir l'interès del lector. A més, 
freqüentment es presenta cap al final del conte i sense construccions particularment convencionalitzades:

(15) Tourette himself, and many of the older clinicians, used to recognize a malignant form of Tourette's, which might disintegrate the personality, and lead to a bizarre, phantasmagoric, pantomimic and often impersonatory form of 'psychosis' or frenzy. This form of Tourette's-'super-Tourette's' -is quite rare, perhaps fifty times rarer than ordinary Tourette's syndrome, and it may be qualitatively different, as well as far more intense than any of the ordinary forms of the disorder. This 'Tourette psychosis', this singular identity-frenzy, is quite different from ordinary psychosis, because of its underlying, and unique, physiology and phenomenology. None the less, it has affinities, on the one hand, to the frenzied motor psychoses sometimes induced by L-Dopa and, on the other, to the confabulatory frenzies of Korsakov's psychosis (see above, Chapter Twelve). And like these it can almost overwhelm the person.

(14.LIT_Sacks)

La presentació del cas en els contes clínics també difereix força respecte dels casos clínics. No hi és gens habitual començar a narrar el cas amb construccions tan àrides com «we report a case of...», sinó que s'hi empren diverses estratègies per començar a parlar-ne, com ara anècdotes, diàlegs, etc. De fet, la presentació del cas i del pacient hi convergeixen. L'ésser humà -el pacient - hi és el protagonista principal i per tant no se sol parlar del cas, sinó, per exemple, de Marge. A més a més, la posada en escena dels personatges es produeix d'una manera molt més variada i literaturitzada. Generalment, no se'ns desvelen gaires informacions al principi de la història, sinó que s'hi crea suspense. Els autors no comencen amb expressions convencionalitzades, sinó amb diàlegs o $\mathrm{amb}$ anècdotes:

(16) "I'm nothing. Garbage. A creep. A cipher. I slink around on the refuse dumps outside of human camps. Christ, to die! To be dead! Squashed flat on the Safeway parking lot and then to be washed away by a fire hose. Nothing remaining. Nothing. Not even chalked words on the sidewalk saying, 'There was the blob that was once named Marge White."'

Another one of Marge's late-night phone calls! God, I hated those calls! It wasn't the intrusion into my life-l'd learned to expect that: it goes with the territory. A year ago when I first accepted Marge as a patient, I knew there'd be calls; as soon as I saw her, I 
sensed what was in store for me. It didn't take much experience to recognize the signs of deep distress. Her sagging head and shoulders said "depression"; her gigantic eye pupils and restless hands and feet said "anxiety." Everything else about her-multiple suicide attempts, eating disorder, early sexual abuse by her father, episodic psychotic thinking, twenty-three years of therapy-shouted "borderline," the word that strikes terror in the heart of the middle-aged comfort-seeking psychiatrist.

(9.LIT_Yalom)

En la presentació de les proves és on sí que podem trobar algunes construccions que s'assemblen més a les emprades en els casos clínics acadèmics. Majoritàriament, però, encara que el verb sigui el mateix showed o confirmed, la situació és ben diferent. Aquí no s'amaga la presència del personal sanitari que fa les proves al malalt, ans al contrari.

(17) Nurses in trauma rooms are brilliant automatons. They're adept at shearing off clothes in one fluid motion from bottom to top. They stripped down Bob's sister, put leads on her, and right off the bat we couldn't get a blood pressure. She was about to die. They slapped on a cardiogram and it showed a very slow sinus rhythm. Tony Cimaranno was my surgical resident. He was a short, square Mafioso-looking guy from New Jersey, with the thickest, blackest, greasiest hair this side of the Rockies, and we were great together.

$$
\text { (7.LIT_Ropper) }
$$

(18) Lau died despite all of our efforts, and despite draining her ventricles. My diagnosis was confirmed at autopsy. But it was because of that experience and others like it, because I had witnessed unusual, extraordinary cases, that I knew what was going on in Mrs. G's head when she went into cardiac arrest.

(7.LIT_Ropper)

Així doncs, en els contes clínics podem trobar algunes expressions semblants a les convencionalitzades dels CC acadèmics, però no s'hi solen repetir gaire ni tampoc podem dir que estiguin associades a una despersonalització o deshumanització. La seva presència hi és anecdòtica. Podem pensar que, com que els autors són professionals sanitaris familiaritzats amb els CC, en alguns llocs se'ls han colat aquestes expressions i en els altres les incorporen expressament per donar un to més científic, més proper al gènere dels $\mathrm{CC}$ acadèmics. 


\subsection{La recontextualització del coneixement científic en els contes clínics}

En els dos apartats anteriors ens hem centrat en el llenguatge científic usat en els CC acadèmics, concretament en la terminologia i les abreviacions especialitzades (apartat 3.1) i en les construccions convencionalitzades (apartat 3.2). Tot seguit veurem què passa quan les històries dels malalts es literaturitzen i es narren en un altre gènere, el dels contes clínics, amb un propòsit comunicatiu ben diferent i per a un públic de no experts que els llegeix majoritàriament com a passatemps.

Tal com hem exposat en el capítol III (veg. apartat 1.2), quan els coneixements d'un àmbit especialitzat, com és el de les ciències de la salut, volen donar-se a conèixer entre un públic general, cal operar una sèrie de transformacions que agrupem sota les etiquetes de reelaboració, textualització i denominació (Cassany, López i Martí, 2000). Només els textos comprensibles per a una gran part de lectors es poden convertir en llibres d'èxit mundial i penetrar en la consciència d'uns lectors que, en principi, no tenien cap relació amb aquest àmbit d'especialització. La divulgació científica no és, doncs, una tasca gens fàcil. En l'àmbit de les ciències de la salut, a part del llenguatge tan específic que té, l'aparició i l'extensió de subdisciplines mèdiques cada vegada fan més complicada la tasca del divulgador. A més, en construir un pont entre l'expert i el profà, cal tenir especial cura amb els efectes que pot tenir una mala adaptació. A l'hora d'explicar qüestions de la salut humana als no especialistes, cal òbviament emprar un llenguatge comprensible i proper, però sense caure en la banalització:

El problema és que sovint no es pot simplificar. Fa temps, la tendència era reescriure el mateix article de forma més senzilla, es concebia la divulgació com una mena de traducció. Traducció intralingüística. Agafaves un text i el feies més simple. Ara, en canvi, la idea és que es tracta d'una recontextualització total. L'article es reescriu i reprodueix per a un nou públic, però això ja no ho fan els experts en aquell àmbit, sinó experts en mitjans de comunicació, per la qual cosa el text té altres objectius, a més del purament informatiu. En ocasions és l'entreteniment, en ocasions és només promocional, i això ha desdibuixat la línia de separació dels dos camps. Ara molta gent ho veu com un avantatge, com una bona oportunitat per a ampliar la seua audiència, vendre més, arribar a més gent. Per això es corre el risc que aquesta segona part, la de l'entreteniment, la promocional, arribe a ser més important que la informativa. I el risc és molt major ara que no hi ha barreres per a la informació.

Entrevista a Maurizio Gotti (Sapiña, 2015) 
Estrictament parlant, els casos clínics literaturitzats no són textos canònics de divulgació científica, però poden exercir aquesta funció. Aborden casuístiques de pacients amb problemes de diverses menes recontextualitzades per a un públic i amb uns objectius ben diferents dels casos clínics acadèmics - $i$, en alguns aspectes, més acostats als dels textos propis de la divulgació científica. A diferència de la literatura de ficció, un dels principals atractius d'aquest gènere és precisament la seva veracitat. Els lectors queden fascinats amb unes històries peculiars vistes, freqüentment, des del punt de vista del metge que narra els successos - o d'algun collega-, esdeveniments que realment va viure a la consulta, a l'hospital... La tasca dels científics-escriptors, per tant, és trobar «un equilibri entre un discurs de base científica i una narrativa adreçada a un públic ampli» (Kotátková, 2017: 288), ja que s'intenten transmetre coneixements especialitzats però amb uns propòsits comunicatius ben diferents dels que hem vist en els CC acadèmics.

El primer propòsit que n'hauríem de deduir seria el de triomfar o almenys funcionar en el mercat: com qualsevol altre autor, quan un professional sanitari publica un llibre, vol que tingui èxit, una determinada quantitat de lectors, encara que no l'escrigui només per convertir-lo en best-seller. També hi haurem de suposar el propòsit de donar a conèixer la seva disciplina, la seva feina en general o alguna malaltia o símptoma concrets per difondre'n més informació. Aquest podria ser, per exemple, el cas del llibre Stuff: Compulsive Hoarding and the Meaning of Things, que gira al voltant de casos del trastorn o la síndrome d'acumulació compulsiva (SAC). En els contes clínics de l'àmbit de la salut mental, és força freqüent el propòsit d'intentar desestigmatitzar determinades afeccions o els comportaments de les persones que les pateixen. És un objectiu encomiable, puix que aquestes persones sovint es queden desateses quan els passa algun problema al carrer: els vianants acostumen a evitar-los pensant que es tracta de persones èbries, boges... Si la gent sap identificar aquestes malalties, potser ja no activarà automàticament els prejudicis quan conegui una persona que les pateix.

Els contes clínics, per tant, ens poden fer veure quina vida tenen els pacients amb determinades afeccions i poden contribuir que, com a societat, les acceptem amb més facilitat. Amb un professional que ens expliqui en què consisteixen, com pateixen els malalts i de quina manera ens hi hauríem d'adreçar, aquest gènere híbrid és l'espai ideal per poder aconseguir-ho. Si l'escriptor és hàbil, fàcilment pot crear un Iligam emocional 
-tan propi de la literatura de ficció- entre el lector i els personatges, tant el metge com els pacients. Tampoc, però, no podem esperar que de sobte desaparegui tot el que estigui relacionat amb el discurs científic, perquè així els contes clínics es convertirien en simples contes d'ambientació sanitària. Ens interessarà, per tant, veure de quina manera han hagut d'adaptar el seu discurs aquests metges-escriptors per poder atreure un públic molt diferent del que normalment llegeix els CC acadèmics.

No hem de pensar que es tracta d'una simple traducció de coneixements especialitzats als no especialitzats, sinó més aviat d'un conjunt d'operacions implicades en un procés de recontextualització. Aquesta transformació consisteix a construir un nou discurs, una nova situació comunicativa dirigida a una audiència massiva i diversa, en la qual es recontextualitzen per a un públic general uns coneixements que han estat prèviament construïts al si d'una comunitat discursiva especialitzada.

Els autors han d'efectuar una reelaboració (vegeu l'apartat 1.2 del capítol III), és a dir una selecció, entre la informació originada en l'àmbit especialitzat, només d'aquella que resulta rellevant per al que es pretén transmetre. També $n$ 'han de fer la textualització, és a dir l'elecció del mode del discurs. Òbviament, els autors del CC literaturitzats s'han d'adaptar al gènere de sortida que volen produir. Si l'exemple prototípic de divulgació científica és l'adaptació d'un article de recerca o un estudi a una notícia de premsa, aquí el gènere de sortida seria el conte clínic, un gènere híbrid que acostumen a publicar els professionals sanitaris i que, per tant, conté característiques tant del discurs especialitzat com del literari. Així doncs, manté alguns trets com ara l'ús de les definicions, descripcions o exemplificacions que solen ser eliminades quan es fa l'adaptació al discurs divulgatiu. En el cas dels CC literaturitzats, no solament no en desapareixeran, sinó que serviran als autors per poder introduir diversos termes dels seus àmbits d'especialització i, així, aclarir-los als lectors. Aquesta no és una tasca gens fàcil, ja que els exemples que donaran o les definicions que redactaran, evidentment, no poden ser les que emprarien en un text per al seus col/legues.

Entre les transformacions més utilitzades per acostar el text als llecs destaquem la reducció i la inclusió. Moltes vegades les informacions que l'escriptor considera irrellevants per al nou propòsit comunicatiu o massa complicades per a un públic general simplement desapareixen dels textos. Altres vegades, podem identificar petjades lingüístiques de la reducció produïda. Cal recordar que els contes clínics tenen una base 
en casos de pacients reals, i per bé que és improbable que trobem els CC acadèmics que hi corresponguin, entenem que els autors en disposen de notes pròpies, concebudes en el tecnolecte propi de la comunitat de pràctica, utilitzades com a base per al procés de recontextualització. No podem reconstruir tot el que s'ha reduït d'aquells apunts, però sí que en podem detectar algunes empremtes.

Un dels procediments més freqüents i compatibles amb la literaturització per prescindir d'alguna informació excessivament especialitzada és substituir-la per referències indefinides (exemples 19-21). Quan l'autor necessita mencionar alguna malaltia, però per a ser específic requeriria una descripció massa llarga o complicada, simplement s'hi refereix d'una manera genèrica com una malaltia, un tipus de trastorn, una determinada:

(19) Inner difficulties and outer difficulties match each other here. It is not only difficult, it is impossible, for patients with certain right hemisphere syndromes to know their own problems-a peculiar and specific 'anosagnosia', as Babinski called it.

(B.LIT_Sacks)

(20) All went well for two years, until she returned to the hospital with sudden right facial drooping and difficulty finding words, sure signs of another stroke, but this time a stroke of a very different kind. A portion of one of the language centers of her brain had been deprived of its blood supply. Her speech was now noticeably impaired. Within a few days, she showed signs of improvement, and was again discharged on a blood thinner.

(1.LIT_Ropper)

(21) Penny's daughter, Chrissie, had developed a rare form of leukemia when she was nine and died four years later, one day before her thirteenth birthday.

(3.LIT_Yalom)

En els exemples dels contes clínics presentats veiem com s'hi simplifiquen determinades informacions. A diferència d'un CC acadèmic, en els contes clínics no sempre cal entrar en tots els detalls mèdics — ni de fet convé, a risc d'atabalar els lectors. En anglès, com podem veure, sovint trobem expressions com certain, sort of, a kind of... Si parem atenció a una expressió com «certain right hemisphere syndromes» (exemple 19), veurem que no és aquesta la manera de descriure el problema que ens trobaríem 
normalment en un CC acadèmic. Es tracta de prescindir d'informacions que resultarien complicades d'entendre per al lectors aliens a l'àmbit sanitari i, a més, irrellevants des del punt de vista dels propòsits comunicatius del conte clínic. Així doncs, en l'exemple (21) el personatge principal és una mare que no ha sabut acceptar la mort de la seva filla. L'esment de la leucèmia que la va causar dóna dramatisme a la història, però els lectors no necessiten saber més detalls sobre el tipus concret de la malaltia. Si es tractés de CC acadèmics, probablement trobaríem en tots aquests exemples una especificació molt concreta, amb la precisió de la terminologia mèdica, de quin problema pateix el pacient, encara que fos d'un historial familiar no necessàriament connectat amb el que pateix el malalt.

El procediment de la inclusió, en canvi, afegeix més informació al text de la que trobaríem en la seva versió especialitzada. El textos de divulgació se solen ampliar amb informacions que fan referència a l'entorn immediat dels lectors. Es tracta de connectar el món de la recerca científica amb qüestions de la vida quotidiana de les persones. Freqüentment, ens trobem que les dades abstractes científiques van acompanyades d'exemples i anècdotes més accessibles per al públic general, o referències amb les quals poden empatitzar (exemple 22).

(22) The world's finest tennis players train five hours a day to eliminate weaknesses in their game. Zen masters endlessly aspire to quiescence of the mind, the ballerina to consummate balance; and the priest forever examines his conscience. Every profession has within it a realm of possibility wherein the practitioner may seek perfection. For the psychotherapist that realm, that inexhaustible curriculum of self- improvement from which one never graduates, is referred to in the trade as countertransference. Where transference refers to feelings that the patient erroneously attaches ("transfers") to the therapist but that in fact originated out of earlier relationships, countertransference is the reverse - similar irrational feelings the therapist has toward the patient. Sometimes countertransference is dramatic and makes deep therapy impossible: imagine a Jew treating a Nazi, or a woman who has once been sexually assaulted treating a rapist. But, in milder form, countertransference insinuates itself into every course of psychotherapy.

(4.LIT_Yalom) 
Aquestes referències no necessàriament han de ser totalment alienes al món especialitzat, ja que hi ha molts conceptes del llenguatge mèdic, com ara alguns noms d'afeccions i altres termes que han penetrat en el cabal lèxic compartit per una gran part de la societat. Així passa en l'exemple (23), en el qual l'aproximació als lectors es fa mitjançant un concepte mèdic - claustro phobia- vastament conegut i emprat en contextos no especialitzats.

(23) It's possible that people who hoard prefer small, enclosed personal spaces-almost the opposite of claustro phobia. Perhaps they close in their living spaces to achieve a cocoon-like feeling of comfort and safety.

(4.LIT_Frost)

Algunes inclusions poden ser força extenses, com en l'exemple (24). Aquí, Ropper i Burrell aclareixen en què consisteix l'activació del codi en un hospital, una explicació que no caldria, òbviament, en un text adreçat a la pròpia comunitat de pràctica. Per fer-ho, els autors recorren a la comparació d'aquest treball clínic en equip, en el qual cadascú s'ocupa d'una determinada tasca, amb una actuació en equip que els lectors poden trobar més familiar: la d’un conjunt de músics en un concert.

(24) A code is a highly choreographed performance executed in a small space measuring approximately eight by twelve feet. Among the dozen people who rushed into the room in the next few minutes, each one had a specific part to play, much like the musicians in an ensemble. The code leader, a senior medical resident, is nominally in charge, but because Mrs. G was my patient, I took up a position at the head of the bed and "directed" the code while the senior resident "ran" it. In a sense, I appointed myself guest conductor. I had to be there to provide my perspective, because for a code team, whatever's going on with the brain is secondary. Their primary focus is to restore respiration and circulation-keep her heart and lungs going.

(2.LIT_Ropper)

A més de la reelaboració i la textualització, la transformació de l'experiència clínica dels professionals sanitaris en contes clínics requereix una atenció a la denominació i, en concret, a la desterminologització, a la qual dedicarem l'apartat següent. 


\subsection{La desterminologització}

La divulgació i la mediatització del coneixement mèdic fan que uns termes que s'han desenvolupat en àmbits altament especialitzats penetrin en el nostre dia a dia i esdevinguin mots d'ús quotidià. A aquesta desterminologització contribueixen, per descomptat, els divulgadors científics, però sobretot les sèries televisives de temàtica sanitària, la Internet on la gent busca els seus símptomes i, fins i tot, la publicitat. Així, cada cop són més els termes de l'àmbit sanitari que pot conèixer un lector aliè a aquesta especialització, perquè senzillament s'han incorporat al cabal lèxic general. Ara bé, aquest fenomen també pot generar distorsions: en les ficcions audiovisuals, per exemple, el metge se sol caracteritzar per l'ús d'un llenguatge complicat, amb mots desconeguts, però els guions no sempre han estat revisats pels experts i no hi ha garanties que els termes que s'hi difonen estiguin ben emprats.

En el cas de la publicitat, la desterminologització pot donar lloc a situacions particularment qüestionables, si no directament perilloses, ja que sovint, com a estratègia comercial, s'hi recorre a l'adaptació o, fins i tot, a l'alteració dels termes. Així, per exemple, un iogurt que es vol vendre com un producte quasimèdic rebateja un microorganisme -el Bifidobacterium animalis sp. Lactis CNCM I-2494- com Bifidus ActiRegularis. Els estudis de màqueting deuen haver demostrat que el públic general no desitja particularment tenir bacteris ni animals vius en el sistema digestiu. Bifidobacterium animalis és el terme adoptat per la ciència per denominar aquest ésser tan útil per a regular el trànsit gastrointestinal. Però com que l'objectiu de la publicitat és vendre i no difondre la ciència, de poc li serviria a l'empresa recordar que, de fet, tots els humans tenim bacteris i els necessitem per viure. Així que, des del punt de vista publicitari, és molt més efectiva una denominació distorsionada com Bifidus ActiRegularis, la qual manté tots els beneficis del prestigi d'un suposat nom científic, després d'haver-se'n desprès de la càrrega més incòmoda. Aquesta estratègia comercial ha fet que, al capdavall, ens trobem amb el mot desterminologitzat bifidus, el qual ja forma part del vocabulari d'una part del públic general -inclosos els metges, en contextos col·loquials.

En l'àmbit de la salut mental també hi ha molta terminologia que ha penetrat en el lèxic dels no experts i s'ha desterminologitzat. Podem trobar paraules que ja ni es 
consideren termes o que no som conscients que ho siguin, perquè el seu ús s'ha normalitzat, estès i adaptat al llenguatge de fora de l'àmbit sanitari. Aquesta incorporació a la llengua general i, de vegades, fins i tot als registres col-loquials pot erosionar la precisió del significat original. Així, en mots com histèria (sobretot parlant d'una persona histèrica), l'esquizofrènia o l'Alzheimer, quan s'empren en un discurs o registre no especialitzat, veiem que sovint no fan referència a una malaltia diagnosticada, sinó que s'utilitzen com a recursos per desqualificar el comportament dels individus. Amb la mediatització de la salut, doncs, els llecs coneixem -o creiem conèixer - molts noms de diverses afeccions o símptomes de la salut mental i sovint també algunes de les seves característiques. Així, una persona aliena a l'àmbit sanitari pot saber - de manera simplificada o fins i tot distorsionada, és clar - en què consisteix, per exemple, la síndrome de Diògenes, la catatonia o l'erotomania. Sovint es tracta d'afeccions que causen algun comportament peculiar o extravagant, com és el cas de la síndrome de Tourette, identificada popularment amb l'articulació de paraules obscenes i comentaris despectius o inadequats al context.

Però a més de ser un resultat de la mediatització del coneixement mèdic i un instrument publicitari aplicat de manera més o menys qüestionable, la desterminologització és també un recurs necessari per a la divulgació científica. El tecnolecte és inseparable de la professió i del discurs mèdics. Per tant, la terminologia està present en els textos de divulgació i, òbviament, també en els contes clínics, perquè forma una part inherent del món sanitari i, per tant, no és possible defugir-la completament. De fet, unes pinzellades del tecnolecte mèdic poden contribuir a donar als contes clínics un aire iniciàtic que atrapa el lector. Però és obvi que la majoria dels lectors dels CC literaturitzats no coneixeran bona part dels termes emprats, ja que seran un grup molt heterogeni que difícilment tindrà un coneixement compartit sobre el tema tractat. Així que, en els contes clínics en què s'opti per incloure termes que no estiguin ja desterminologitzats, els autors hauran d'integrar-los de tal manera que els lectors no es perdin pel camí (Kotátková, 2017).

Amb els exemples presos del nostre corpus, veurem algunes de les estratègies textuals més freqüents que faciliten la comprensió de la terminologia que els autors dels contes clínics consideren desconeguda per als seus lectors. Comprovarem, doncs, com els metges-escriptors dels contes clínics hi despleguen diversos tipus de recursos que 
provenen del discurs científic, com són la definició o l'exemplificació, però també recorren a altres mecanismes més propis de la divulgació científica, com ara les paràfrasis, els sinònims, els símils i les metàfores, per acostar i explicar els termes. Finalment, pararem esment a la manera com aquests autors gestionen les abreviacions, tan característiques del tecnolecte mèdic.

L'exemplificació és un recurs que concreta una idea abstracta o complexa mitjançant un cas o uns casos particulars (Calsamiglia i Tusón, 1999: 310). El que trobem sovint en el nostre corpus és que, després d'un terme que els autors consideren problemàtic d'entendre, el complementen amb uns exemples que, sense definir el terme, permeten una orientació del lector, sovint molt bàsica però suficient. És un recurs molt estandarditzat, fàcil de detectar, atès que sol anar introduït per una sèrie de connectors o entre parèntesis. L'altra cara, però, és que emprar dos o tres exemples que puguin revelar més o menys el significat del terme en qüestió i que permetin que el lector continuï llegint sobre medicina -com en moltes altres disciplines altament especialitzades - no és una tasca gens fàcil.

En el primer fragment (25) podem observar com s'explica als lectors els termes paracinèsia i paragnòsia. L'autor, en aquest cas Oliver Sacks, posa entre guionets alguns dels seus símptomes $\mathrm{i}$, així, els lectors poden seguir què és el que li està passant al malalt. A més, ho reforça tot amb l'ús d'adjectius força expressius (monstrous, perverse aberrations) que també situen el receptor, perquè li anticipen que es tracta d'alguna cosa molt enutjosa. En casos com aquest, ens podem atrevir a dir que paracinèsia $\mathrm{i}$ paragnòsia no formen part del cabal lèxic comú i que deuen ser ben pocs els lectors capaços d'identificar què és el que hi està passant. Així, per als lectors no especialitzats, aquesta part del relat esdevindria un autèntic problema de comprensió i el missatge que llegirien seria que una estranya malaltia tendeix a esdevenir una altra (Kotátková, 2017). Amb les exemplificacions, però, sense haver-ne explicat detalls - que probablement allargarien massa el text i podrien resultar, fins i tot, pedants o avorrits- $s$ 'aconsegueix que qualsevol persona amb un cert grau d'instrucció pugui continuar absorbit per la història.

(25) All the 'hyper' states can become monstrous, perverse aberrations, 'para' states: hyperkinesia tends towards parakinesia -abnormal movements, chorea, tics; 
hypergnosia readily becomes paragnosia -perversions, apparitions, of the morbidly heightened senses; the ardors of 'hyper' states can become violent passions.

(C.LIT_Sacks)

(26) Specific (and pathological) enhancements of smell have indeed been reported as occurring in paraphilia, fetishism, and allied perversions and regressions. (This is well described by A.A. Brill (1932), and contrasted with the overall brilliance, the redolence, of the smell-world, in macrosomatic animals (such as dogs), 'savages' and children.)

(18.LIT_Sacks)

(27) She developed distressing physical symptoms-including headaches (her father died of brain cancer), backaches, and shortness of breath - and was tormented with the obsessive thought that she, too, had cancer.

(4.LIT_Yalom)

Com que es tracta d'un recurs sovint introduït entre parèntesis o guionets, no trenca tant la línia narrativa principal, ja que no cal fer unes grans digressions, sinó que es tracta d'una petita pista per a qui està llegint el text. Tanmateix, resulta molt pràctic per al lector, perquè és menys probable que s'hi perdi, puix que tota la informació necessària la troba dins de la mateixa oració, fet que fa que no hagi de tornar enrere per revisar el que s'hi havia dit. És, per tant, un mecanisme que també permet a l'autor evitar incisos innecessaris que podrien esquerdar la frase.

La definició és un altre dels recursos típics del discurs científic que podem trobar en els textos de divulgació. En els CC literaturitzats no és l'estratègia més habitual, però sí que hi és present. Els nostres autors són científics i, com a tals, estan ben acostumats a recórrer a la definició quan volen explicar amb precisió el sentit d'un mot o d'una expressió (DNV), en una presumpció d'ignorància que es projecta sobre l'interlocutor o I'auditori (Salvador, 2009). En els contes clínics, les definicions no seran tan estrictament precises, ni rigoroses, ni exhaustives com si es tractés d'un article d'investigació mèdica, però sempre hauran de seguir la màxima que «les operacions de definició han de fer el seu definiens molt més explícit que el definiendum, si es vol incrementar la seua intel-ligibilitat» (Salvador, 2011: 92). Comparada amb les altres estratègies, la definició té un major potencial de proporcionar informació sobre el mot o l'expressió en qüestió. 
En els contes clínics del nostre corpus, les definicions s'usen majoritàriament per explicar termes mèdics que són rellevants per a la comprensió de la història. No seria gaire atractiu si tot el tecnolecte emprat en els contes clínics anés acompanyat de les respectives definicions. Els metges-escriptors només hi recorren en alguns casos en què ho consideren imprescindible, sobretot quan un terme esdevé el centre de l'atenció, fins al punt que sovint el podríem considerar un autèntic protagonista de la història (Kotátková, 2017). On més definicions trobem és en els dos llibres de neurologia Reaching Down the Rabbit Hole: Extraordinary Journeys into the Human Brain (exemples 28, 29 i 31) i The Man Who Mistook His Wife for a Hat and Other Clinical Tales (exemple 30), ja que és també on més termes especialitzats s'empren.

(28) A teratoma is an unusual tumor that contains cells from the brain, teeth, hair, skin, and bone. Most teratomas are harmless, but they have the potential to wreak havoc by causing encephalitis. When you see it, the syndrome is unmistakable: an ovarian teratoma stimulates an antibody that will produce the very ensemble of symptoms that were described to me over the phone.

(1.LIT_Ropper)

(29) Status is short for status epilepticus, a state in which a patient is constantly seizing. In this case, without physical convulsions, it would properly be called nonconvulsive status epilepticus.

(3.LIT_Ropper)

(30) A 'phantom', in the sense that neurologists use, is a persistent image or memory of part of the body, usually a limb, for months or years after its loss. Known in antiquity, phantoms were described and explored in great detail by the great American neurologist Silas Weir Mitchell, during and following the Civil War.

(6.LIT_Sacks)

(31) An understanding of confusion has yet to be operationalized in the way that stroke or neuropathy or Parkinson's disease have been. It is not, technically, a disease, but a syndrome, a collection of problems. Clinically, confusion is defined as a loss of the usual clarity, coherence, and speed of thinking, but this description, while accurate as far as it goes, captures only a snapshot of confused behavior.

(3.LIT_Ropper) 
Observem l'estructura prototípica de la definició encapçalada amb el verb «to be» ('ser'). Es tracta, per tant, de la combinació: terme + is/are + explicació. Aquesta estratègia trenca molt més la línia narrativa que, per exemple, l’exemplificació, ja que sovint es tracta d'una o més frases, fins i tot d'un paràgraf que es requereix per a l'aclariment del significat del mot o de l'expressió. En el darrer exemple (31) observem com els autors van definint la confusió. Primerament, se'ns situa per veure com d'evolucionats estan els estudis sobre la confusió en comparació amb altres. Després s'hi constata que no es tracta d'una malaltia sinó d'una síndrome i, finalment, se'ns aclareix en què consisteix amb l'altra fórmula prototípica d'aquesta estratègia: es defineix com...

Tant la definició com l'exemplificació són recursos propis del discurs científic que s'empren també en la divulgació i en els contes clínics. Però els autors també tenen al seu abast altres recursos de desterminologització, més característics de la divulgació, com són els aclariments discursius (les paràfrasis), els sinònims, els símils (la comparació) i les metàfores.

La primera estratègia d'aquest grup i la més emprada per desterminologitzar el llenguatge en els contes clínics és la paràfrasi. Aquests aclariments sovint consisteixen a donar una altra versió del que s'està explicant, més o menys lliure, fent servir altres paraules amb la finalitat que sigui més comprensible. Les paràfrasis, per tant, faciliten la comprensió d'un mot que l'autor pressuposa que podria complicar la comunicació del que vol transmetre al lector, normalment mitjançant unes aposicions no gaire llargues. La frontera entre les paràfrasis i les definicions - que hem tractat més amunt- és borrosa i es pot establir una gradació des de l'una fins a l'altra (Kotátková, 2017). La finalitat d'ambdues és anàloga: aclarir el significat d'un terme o mot que podria causar problemes de comprensió. Una diferència formal que tindrem en compte és que les paràfrasis solen anar inserides amb guionets, parèntesis o comes (Cassany, López i Martí, 2000: 93-94). Majoritàriament, apareixen darrere del mot o terme en qüestió i la seva llargària no sol ser gaire extensa. Seguim aquest criteri i classifiquem com paràfrasis els segments que van introduïts per un connector reformulador o que donen una explicació que es pugui considerar parcial. 
Així, trobem en el nostre corpus tres maneres més freqüents d'incloure els aclariments discursius. En la primera, l'explicació del terme es presenta entre parèntesis (exemples 32 i 33) i formalment s'assembla, per tant, a l'exemplificació, ja que no trenca gaire el text. A més, generalment, sol tractar-se d'explicacions bastant curtes, també perquè estilísticament no és gens recomanable allargar excessivament un parèntesi.

(32) Vincent's form of speech difficulty, known as Wernicke's aphasia, sounds like gibberish, but not pure nonsense. It can include halting phrases that almost make sense, echolalia (repeating someone else's just-used words), perseveration (giving the same answer to a succession of different questions), and play association (cracking wise).

(1.LIT_Ropper)

(33) We could show that he had apnea (that he couldn't breathe on his own), but that's just one of the five elements of the tests for death by brain criteria.

(12.LIT_Ropper)

La segona manera més habitual d'incloure els aclariments discursius que hem trobat en el corpus és amb incisos col-locats entre guions (exemples 34, 35 i 36). En aquests casos, les paràfrasis freqüentment prenen la forma de a/one form of... 'una forma de...' (exemples 34 i 35), però no exclusivament (exemple 36). D’aquesta manera se simplifica l'explicació del terme, puix que els autors consideren que el lector no en necessita més informació, només se'I vol ubicar. Així, en l'exemple (34) se'ns aclareix només que tabes dorsalis és una forma de neurosífilis, sense més detalls. Aquest tipus d'aclariments el trobem especialment en els CC literaturitzats d'Oliver Sacks.

(34) I had one patient, treated with Salvarsan by Ehrlich himself, who developed tabes dorsalis -one form of neurosyphilis- more than fifty years later.

(11.LIT_Sacks)

(35) For a moment Carlos enjoyed my perplexity, and then proceeded to explain that he had been working with visual imaging -a form of self-healing many cancer patients attempt.

(2.LIT_Yalom) 
(36) I know now that retrograde amnesia, to some degree, is very common, if not universal, in cases of Korsakov's. The classical Korsakov's syndrome -a profound and permanent, but 'pure', devastation of memory caused by alcoholic destruction of the mammillary bodies- is rare, even among very heavy drinkers.

(2.LIT_Sacks)

La tercera manera que trobem d'introduir els aclariments discursius és amb un connector reformulador (exemple 37 i 38). En el nostre corpus clarament predominen els connectors in other words i l'abreviació i.e., que té el mateix significat que el primer o també es pot llegir com 'that is' o 'that is to say'.

(37) "She's the lady with the hydrocephalus." In other words, she has too much water in the cavities of her brain, a serious problem.

(1.LIT_Ropper)

(38) Given this history, and her pathetic condition-with spasticity and athetosis, i.e., involuntary movements of both hands, to which was added a failure of the eyes to develop- I expected to find her both retarded and regressed.

(5.LIT_Sacks)

La segona estratègia d'aquest grup és l'ús dels sinònims. Els autors introdueixen un terme i a continuació en donen un sinònim, ja sigui un mot o un grup de mots que no són tan especialitzats i ajudaran a la comprensió (exemples 39-41). En la majoria d'ocurrències del nostre corpus, en primer lloc apareix el terme científic presumptament desconegut (sovint una malaltia o un símptoma) i després, normalment en la mateixa oració, es troba un mot (o uns mots) que més o menys signifiquen el mateix, però es tracta d'una denominació més popular. Els sinònims solen aparèixer darrere d'alguna conjunció, com ara «or» 'o' o entre parèntesis.

(39) His was a unique type of confusion, with speech that approached what my professor, C. Miller Fisher, used to call amphigory, or nonsense speech.

(3.LIT_Ropper) 
(40) There was an absolute 'prosopagnosia', or agnosia for faces. This patient was not only unable to recognize faces, but unable to imagine or remember any faces, but unable to imagine or remember any faces-he had indeed lost the very idea of a 'face', as my more afflicted patient had lost the very ideas of 'seeing' or 'light.'

(2.LIT_Sacks)

En el segon exemple (40) observem que, freqüentment, després de la frase en la qual s'empra la sinonímia, n'hi pot haver una altra que continua aclarint el significat, ja que l'autor considera que l'ús del sinònim, exclusivament, no seria suficient per dibuixar la situació en què es troba el pacient. Se sol fer quan una malaltia o símptoma ocupa un lloc important en la història, com s'esdevé en aquest cas sobre el navegant perdut (The Lost Mariner). En el tercer exemple (41) també ocorre el mateix. En primer lloc s'ofereix als lectors la denominació científica, seguida de la popular valley fever (en català, entre altres noms, 'febre de la vall de San Joaquín') i, a continuació, els autors expliquen també en què consisteix per si hi ha lectors que no coneixen aquesta malaltia endèmica: es transmet per partícules de pols que entren als pulmons i causen una infecció pneumònica que pot esdevenir una inflamació del revestiment del cervell.

(41) At about the same time, when I was an intern in San Francisco, we treated a farmer from the Sacramento area who had coccidioidomycosis meningitis, also known as valley fever. Stockton, California, was ground zero for the disease. It is carried by airborne dust particles that settle into the lungs, causing a pneumonia-like infection that can develop into an inflammation of the brain's lining.

(7.LIT_Ropper)

En aquest recurs a la sinonímia, majoritàriament s'intenta aclarir el significat d'un terme emprant en primer lloc el mot desconegut, com en els exemples anteriors (4244). També hi ha alguns casos, però, en els quals l'ordre és l'invers: primer el sinònim potencialment més conegut, després el terme més desconegut (exemple 42).

(42) In 1969, I gave these sleepy-sickness or post-encephalitic patients L-Dopa, a precursor of the transmitter dopamine, which was greatly lowered in their brains.

(10.LIT_Sacks) 
D’aquesta manera, l'autor parteix de la denominació més popular per intentar ensenyar-ne als lectors el terme científic. Així, en l'exemple (43) Sacks enllaça per als lectors la malaltia de la son (sleepy-sickness) i l'encefalitis letàrgica, una forma atípica d'encefalitis. Encara que sigui només perquè el nom resulti familiar a molts lectors, l'encefalitis és un conjunt de malalties àmpliament conegut. El fet d'ajuntar aquestes dues denominacions fa que molts lectors s'adonin que el que coneixien com la malaltia de la son és, efectivament, una forma d'encefalitis.

(43) The forgetting of sleepy-sickness (encephalitis lethargica) and the forgetting of Tourette's have much in common.

(10.LIT_Sacks)

A més d'assegurar aquesta connexió entre les dues denominacions per al lectors, també hi veiem, sobretot en l'exemple amb el nom científic grecollatí (43), una voluntat per part de l'autor de no renunciar a la precisió en la designació de la malaltia. Ho fa perquè és ben conscient, com a professional, que la malaltia de la son (sleepy-sickness) pot fer referència a diverses afeccions. La malaltia de la qual parla Sacks se sol confondre, entre altres, amb la tripanosomiasis africana humana, també coneguda popularment en anglès com sleeping sickness, un nom força semblant a la sleepysickness del text. És evident que Sacks n'és ben conscient i vol prevenir una possible confusió amb aquesta malaltia o amb qualsevol altra. El nom científic, en aquest cas, és la millor manera de fer-ho ${ }^{24}$.

En els exemples citats fins ara podem entreveure que moltes vegades no s'aplica una sola estratègia de desterminologització, sinó diverses alhora. Quan es tracta de l'afecció que pateix un dels personatges, sovint els diversos recursos de desterminologització es van succeint al llarg de tot el conte clínic. En aquest punt ens centrem en la sinonímia i els seus exemples en el nostre corpus, però cal recordar que hi ha un context molt més ampli del que reproduïm aquí, en el qual se solen continuar aclarint els significats dels termes, tot combinant diverses estratègies. Així, podem comparar casos que han estat

\footnotetext{
${ }^{24}$ En la versió catalana d'aquest llibre, la traductora manté l'estratègia de Sacks, puix que en aquesta llengua la confusió és encara més probable, atès que les dues malalties esmentades - que en anglès, com hem vist, reben noms molt semblants - en català tenen una denominació idèntica: malaltia de la son (Termcat, 2019).
} 
desterminologitzats amb dues estratègies diferents en un mateix text, com ara en el cas de la pacient amb hidrocefàlia, una patologia caracteritzada per una acumulació excessiva de líquid en el cervell. En tractant els aclariments discursius, hem vist de quina manera s'explica aquest terme amb una paràfrasi (exemple 44). En l'exemple (45), en canvi, veiem una desterminologització amb efectes similars, però usant el mecanisme de la sinonímia. És com si els autors ens diguessin hydrocephalus = water on the brain. El fet d'emprar dues estratègies diferents per al mateix terme només demostra una altra vegada la voluntat literària i divulgadora dels autors, ja que volen evitar les repeticions innecessàries, però també explicar bé el que li passa a aquesta pacient.

(44) "She's the lady with the hydrocephalus." In other words, she has too much water in the cavities of her brain, a serious problem.

(1.LIT_Ropper)

(45) Mrs. G was Sofia Gyftopoulos, and her condition-hydrocephalus, also known as water on the brain, accompanied by a history of meningitis-was serious, but not critical.

(1.LIT_Ropper)

La sinonímia ajuda a aclarir el significat dels termes, però també pot aportar efectes humorístics (exemples 46 i 47). En lloc d'evitar uns termes mèdics especialitzats que els lectors podrien considerar pedants, el to irònic, unit al recurs de la sinonímia, permet introduir-los tot acostant-se al públic general.

(46) The Brits call this sort of thing Functional Neurological Symptoms, or FNS, the psychiatrists call it conversion disorder, and almost everyone else just calls it hysteria.

(5.LIT_Ropper)

(47) During the next month, the excitement and delirium died down, but he was left with deep and bizarre memory lapses, or 'deficits,' to use the medical jargon.

(2.LIT_Sacks) 
La comparació o símil és la següent estratègia que tractarem i que es basa a comparar un terme, el significat del qual es considera que podria ser desconegut, amb un concepte més familiar (exemples 48 i 49).

(48) I grabbed the tiny bag of the air reservoir that hangs down from the tracheostomy tube like a piece of spaghetti. It was too easily compressible, indicating that the cuff around the tube wasn't inflated.

(8.LIT_Ropper)

(49) With the low, early morning light from Francis Street running diagonally across her body, it was now evident that virtually every muscle in her body was twitching away like an orchestra of fleas-“widespread fasciculations," as we say.

(8.LIT_Ropper)

Es tracta d'un recurs molt emprat per Oliver Sacks, amb el qual aconsegueix, per un costat, un aclariment molt bàsic del terme — suficient per poder seguir amb la lecturai, per l'altre, un acostament del lector a les sensacions que experimenta el pacient (Kotátková, 2017). Hi trobem exemples com (50 i 51), en els qual se'ns aproxima els termes propriocepció i síndrome de Tourette mitjançant les sensacions dels pacients. Les comparacions que fa aquest autor solen contenir mots populars i situacions ben imaginables per a qualsevol tipus de lector, ja sigui en la comparació amb els ulls del cos (50) o amb l'estat ebri (51).

(50) [Patient:] This "proprioception" is like the eyes of the body, the way the body sees itself. And if it goes, as it's gone with me, it's like the body's blind. My body can't "see" itself if it's lost its eyes, right? So I have to watch it - be its eyes. Right?'

(3.LIT_Sacks)

(51) [Patient:] Having Tourette's is wild, like being drunk all the while. Being on Haldol is dull, makes one square and sober, and neither state is really free...

(10.LIT_Sacks)

Aquesta estratègia requereix un esforç tant divulgatiu com de creativitat literària. Per a un metge, hauria estat més fàcil definir d'una manera canònica el terme propriocepció o donar exemples dels símptomes que poden presentar els qui pateixen la síndrome de 
Tourette. La solució per la qual opta aquest escriptor-neuròleg, tanmateix, és més econòmica, més intel-ligible i facilita la connexió entre els lectors i els personatges. Per tant, des del punt de vista literari, és un recurs molt efectiu. No és el que més detalls explica sobre els termes, però l'exhaustivitat no és un objectiu propi dels contes clínics.

En l'exemple (52), en el qual es descriu la cura per a l'aneurisma cerebral, s'intenta explicar que s'ha de col-locar una espècie de clip al coll de l'aneurisma. Els autors no mencionen cap denominació específica del clip i s'hi refereixen amb una fórmula genèrica - a clip. Perquè els lectors se'l puguin imaginar, s'hi fa la comparació amb un objecte de la vida quotidiana: el clip s'assembla a una pinça de roba en miniatura.

(52) The definitive cure for an anterior cerebral aneurysm is an extremely delicate procedure. It involves the placing of a clip that looks like a miniature distorted clothespin on the neck of the aneurysm.

(6.LIT_Ropper)

Trobem també casos de símil com el de l'exemple (53), en els quals no és ben bé el terme el que s'està aclarint, ja que skull 'crani' és un mot que pertany al lèxic general, sinó que són les seves propietats les que s'intenta acostar als lectors del text. S'hi compara el crani i la pressió intracranial amb un contenidor i l'efecte que hi pot causar un desembossador. La comparació pot resultar xocant, però facilita la comprensió a qualsevol lector aliè a la neurologia.

(53) The bluntness told me that her hydrocephalus was pressing on the frontal lobes from the inside, and winding down the engine that makes the nervous system spin. The pain that caused her to intermittently clutch her head and neck suggested that the pressure inside her skull was not only very high, but rising.

The skull is like a fixed container. If pressures within the skull are unevenly distributed, there is a breaking point at which the entire brain gets squeezed downward like a plunger, compressing the brain stem. This is precisely what happened when Mrs. $\mathrm{G}$ blew her pupil later that afternoon, resulting in the code blue.

(2.LIT_Ropper)

La comparació és un recurs de desterminologització bastant freqüent en el nostre corpus de CC literaturitzats, particularment en el llibre de Ropper i Burrell i en el de 
Sacks. Una vegada més, són els dos llibres de neurologia els que ens aporten més exemples, ja que són els que més terminologia especialitzada contenen. Aquests termes, majoritàriament neurològics, s'hi aclareixen mitjançant la comparació amb expressions populars fàcils de comprendre i d'interioritzar. Cal remarcar que el maneig d'aquest recurs, que sol ser més fàcil d'entendre i més pròxim als llecs que, per exemple, una definició, requereix, per l'altre costat, molta més habilitat. L'autor ha de buscar paral-lelismes amb el món no sanitari i decidir si la seva aproximació serà suficient perquè el lector no es quedi encara més desorientat que quan ha llegit un terme tout court.

Un altre recurs que ajuda a comprendre la terminologia és la metàfora. Les metàfores permeten transmetre una idea o un domini conceptual en termes d'un domini diferent:

Comprendre és precisament això: integrar les noves dades en el motlle del nostre coneixement previ, de manera que troben el seu lloc en l'edifici del coneixement i el desenvolupen amb harmonia. Precisament les metàfores faciliten aquesta integració en la mesura que acomoden les noves dades en un esquema previ. (Salvador, 2008: 9)

Tradicionalment, la metàfora es considerava un artilugi retoricopoètic que no tenia res a veure amb l'essència dels conceptes o del pensament, un mer element decoratiu i ornamental del llenguatge. Avui dia, però, la visió ha canviat i la metàfora ha trobat el seu lloc també com a eina del coneixement:

\footnotetext{
Superada l'època en què la seva funció semblava la de l'ornament preciosista i prescindible amb què s'endiumenjava la paraula literària, la lingüística cognitiva ha proclamat el valor $d$ 'aquest recurs com a eina del coneixement, alhora que la filosofia de la ciència reconeix el seu paper clau en l'activitat científica: des de l'eureka de l'investigador que fa un descobriment fins a la transmissió educativa en el dia a dia acadèmic. (Salvador, 2008: 8)
}

Així, les metàfores són força freqüents en l'àmbit sanitari (vegeu Sontag, 1990; Domínguez i Sapiña 2016; Salvador, 2018b), i tant els professionals sanitaris com els malalts i els seus familiars les empren i desenvolupen contínuament, en comunicacions de tot tipus. Ens hi podem trobar les més prototípiques: la medicina com a art, la malaltia com a guerra (especialment en malalties com ara el càncer), buscant similituds en la 
relació entre el metge i el pacient amb un mecànic i el cotxe (reparació)... (Tajer, 2012). En els CC literaturitzats, òbviament, també és present aquest recurs, fins i tot amb un esment explícit (exemple 54):

(54) Frozen - the metaphor often applied to chronic grief-is apt. The body is stiff; the face taut; cold, repetitive thoughts clog the brain. Penny was frozen. Would our confrontation break the ice jam? I was optimistic it would. While I couldn't guess what would be set free, I anticipated considerable churning during the week and awaited her next visit with much curiosity.

(3.LIT_Yalom)

Majoritàriament, es tracta d'ajudar a comprendre amb la metàfora la malaltia o els símptomes que està patint el pacient. Són les veus mateixes dels pacients les que freqüentment caracteritzen així les seves dolències, tot i que també hi trobem metàfores preses d'altres textos i autors. Aquest seria el cas d'Oliver Sacks, quan reverteix la cèlebre metàfora de John Donne (s. XvI) de I'home i l'illa. Si per al poeta anglès «cap home és una illa», per al seu compatriota neuròleg sí que hi ha homes que en són, d'illes: els autistes. Aquesta metàfora es desenvolupa al llarg de tot el cas clínic sobre un artista autista (The Autist Artist), en el qual el pacient és equiparat amb una illa que està separada del continent, dibuixant precisament l'aïllament del malalt respecte de la resta de la societat. Sacks acosta els lectors al món interior de les persones que pateixen aquest trastorn neurològic $i$, en especial, al protagonista de la història. Podríem considerar aquest text una crítica social, ja que no veu el futur d'aquestes persones dins de la nostra societat, atès el doble aïllament provocat per la malaltia com també pel tractament que reben dels altres (Kotátková, 2017).

(55) The autistic would complain-if they complained-of absence of influence, of absolute isolation.

'No man is an island, entire of itself,' wrote Donne. But this is precisely what autism is -an island, cut off from the main.

$[\ldots]$

Is being an island, being cut off, necessarily a death? It may be a death, but it is not necessarily so.

$[\ldots]$ 
This brings us to our final question: is there any 'place' in the world for a man who is like an island, who cannot be acculturated, made part of the main? Can 'the main' accommodate, make room for, the singular? Can 'the main' accommodate, make room for, the singular? There are similarities here to the social and cultural reactions to genius. (Of course I do not suggest that all autists have genius, only that they share with genius the problem of singularity.) Specifically: what does the future hold for Jose? Is there some 'place' for him in the world which will employ his autonomy, but leave it intact?

For, as the stars stand, he will probably do nothing, and spend a useless, fruitless life, as so many other autistic people do, overlooked, unconsidered, in the back ward of a state hospital.

(24.LIT_Sacks)

Per completar aquest apartat, hem de parar esment a les abreviacions. Com hem vist en abordar el tecnolecte dels casos clínics (apartat 3.1), l'abreviació és un recurs força freqüent en els CC acadèmics, on facilita la concisió. Les abreviatures, les sigles i els símbols sovint s'hi empren sense el seu desenvolupament, de la mateixa manera que els termes s'hi usen sense definir-los, ja que es pressuposa que els lectors - membres de la mateixa comunitat de pràctica- els entendran sense problemes. Tal com s'esdevé amb la terminologia més convencional, les abreviacions continuen presents en els casos clínics literaturitzats, però, òbviament, sempre desenvolupades la primera o les primeres vegades que apareixen en el text. Així, la manera més freqüent d'introduir-les que hi trobem és la següent:

(56) Concluding that it was an episode of transient global amnesia, or TGA, a dramatic but entirely benign condition, the resident came to me to approve a discharge in anticipation of the expected return of the patient's memory.

(4.LIT_Ropper)

(57) A particularly fascinating case of an acute (and mercifully transient) Korsakov's syndrome has been well described only very recently in the so-called Transient Global Amnesia (TGA) which may occur with migraines, head injuries or impaired blood supply to the brain. [...] (Some remarkable videotapes of patients during TGAs have recently [1986] been made by Dr John Hodges, of Oxford.)

$$
\text { (2.LIT_Sacks) }
$$


(58) At first I thought he might have been suffering from Creutzfeldt-Jakob disease, known to us as CJD, and more popularly as the human form of mad cow disease.

(3.LIT_Ropper)

(59) We had reduced, though not annulled, his temporal lobe disorders -his electroencephalograms (EEGs) were never normal; they still showed in these lobes a sort of low-grade electrical muttering, occasional spikes, dysrhythmia, slow waves.

(24.LIT_Sacks)

En alguns casos puntuals, pot passar que sigui més probable que els lectors coneguin millor l'abreviació que el seu desenvolupament, ja que se sol emprar molt més i ja ha penetrat entre els no experts. Així doncs, hi ha algunes abreviacions com la d'EEG que no necessàriament apareixen desenvolupades. De fet, en el llibre Reaching Down the Rabbit Hole no es desenvolupa mai aquesta abreviació (60).

(60) Victor had no previous epileptic history, but we have to admit him to the ICU and take continuous EEG recordings for a day or two just to confirm that nothing shows up on the recordings. Nothing does.

(5.LIT_Ropper)

Aquest és el llibre de contes clínics del nostre corpus on més abreviacions trobem, seguit, en segon lloc, per The Man Who Mistook His Wife for a Hat. Es tracta de textos de neurologia, una especialitat que també és la dels CC acadèmics que contenen més terminologia especialitzada. En canvi, en els dos llibres restants de contes clínics trobem poques abreviacions i quan hi apareixen solen ser conceptes clau que es repeteixen amb molta freqüència al llarg de tot el llibre.

\subsection{El tractament de la mort}

Malgrat totes les nostres prevencions culturals sobre la mort, els humans morim. Els metges ens tracten quan estem malalts, ens atenen en el moment de la mort i en parlen quan n'escriuen els casos clínics, tant els acadèmics com els literaturitzats. Efectivament, 
no tots els CC són exemples de la teràpia perfecta o de la curació del pacient en qüestió, sinó que també n'hi ha que en narren un empitjorament, un estancament de la situació o, fins i tot, la mort (Kotátková, en premsa $a$ ).

Durant mil·lennis, la majoria dels humans hem acceptat la mort com una part natural del procés vital. Hi estàvem reconciliats i celebràvem conjuntament tota mena de rituals que contribuïen a integrar aquest fenomen biològic en la vida col-lectiva (Ariès, 1981). En l'Europa monoteista medieval, per exemple, la mort era un fet quotidià que es tendia a interpretar com un alliberament de les càrregues de la vida física, després del qual la nostra ànima podria accedir a una estadi superior. El declivi de les religions més clàssiques i l'auge de les ideologies humanistes -incloses les diverses variants del liberalisme i del socialisme- han convertit l'individu en l'objecte de culte, en el centre de l'Univers tal i com ara el percebem. En la societat occidental actual, doncs, tendim a veure la mort com una interrupció inesperada - i indesitjada - de tot el que l'ha precedida, més que no pas com una part inexorable i previsible del cicle vital. La mort, sobretot si és sobtada i no es tracta d'una persona molt anciana, sol considerar-se com un esdeveniment tràgic del qual es parla poc o gens i sempre es fa amb una cautela especial.

Durant el segle $x x$, els mateixos canvis socials i culturals que van facilitar un alliberament del llenguatge i de les restriccions comunicatives respecte de les relacions sexuals o el part, paradoxalment van propiciar el desenvolupament del que s'ha denominat pornografia de la mort (Gorer, 1967). I no es tracta únicament d'un fenomen lingüístic: els rituals de sepeli, per exemple, es transformen per allunyar cada vegada més el mort de les persones que li eren properes, sovint amb l'exclusió completa dels més petits. La medicina, la higiene, el desenvolupament científic en general i, sobretot, la sanitat com a institució intervenen decisivament en la nostra percepció del final de la vida. La mort desapareix de la vida quotidiana i s'amaga darrere de les parets de les institucions sanitàries. Moltes persones moren soles i abandonades en els hospitals o altres institucions i, en el millor dels casos, els seus cadàvers fan una breu estada en un asèptic tanatori just abans d'anar al cementiri o al crematori.

Un dels factors que ha contribuït a aquest canvi cultural ha estat el canvi de les taxes de mortalitat (Aiken R., 2000: 230). Els avanços en les condicions de vida, la higiene i la sanitat - almenys als països occidentals - han fet que sovint no experimentem la mort 
de persones properes fins a una edat ja avançada, fins al punt que es parla d'una deathfree generation (Flynn i Philip, 2017). Les malalties, doncs, ja no es veuen necessàriament com l'avantsala d'una mort inevitable, sinó com disfuncions d'un organisme que cal reparar i que podem -o podrem algun dia, després de la recerca adequada- reparar. Ja no morim perquè som mortals, sinó que morim d'alguna cosa (Přidalová, 1998: 351). Si abans, en bona part de les dolències, ens acontentàvem amb pal-liar-ne les conseqüències, els símptomes, avui dia hi esperem diagnòstics acurats, precoços si pot ser, que ens en diguin la causa i la teràpia que les previndrà o eliminarà (Bauman, 1992). Aquesta excepcionalitat, sumada a la concepció humanista de l'individu com a centre de tot, converteix el final de la vida en una catàstrofe inefable tant per a qui està a punt de morir com per als qui l'envolten. No podem assumir la mort ni sabem què dir quan es produeix.

La mort, doncs, ha esdevingut un tabú en moltes cultures, especialment en la civilització occidental (Walter, 1991). Els membres de les societats occidentals ens sentim incòmodes - en diferents graus i de maneres diverses, és clar- a l'hora de parlar-ne i, per tant, tendim a evitar els mots que s'hi relacionen directament (mort, morir...). Així, els parlants de les diferents llengües hem anat desenvolupant -i, probablement, continuem fent-ho- una sèrie de sinònims per referir-nos a la mort. Sovint es tracta d'eufemismes, és a dir, d'una paraula o frase que s'utilitza com a recurs retòric per evitar dir una expressió desagradable o ofensiva. L'eufemisme i el tabú estan estretament lligats amb «the concepts of politeness and face (basically, a person's selfimage)» (Allan i Burridge, 2006: 238), ja que els parlants han de tenir en compte de quina manera el que diu pot danyar o potenciar la pròpia imatge. Per exemple, segons una enquesta realitzada entre el públic general (Smith i Kelly 2012), els mots i les expressions més emprades al Regne Unit per substituir death o dying serien: passed away (57\%), deceased (23\%), kicked the bucket (20\%), passed on (18\%), gone to a better place (17\%).

Aquests canvis socioculturals respecte de la mort tenen un impacte especialment rellevant sobre les comunitats de professionals de les ciències de la salut, sobretot al món occidental. Ni tan sols els àmbits sanitaris, amb una intensa especialització professional i un alt grau de familiarització amb el final de la vida, poden defugir completament la tendència d'atenuar d'alguna manera la mort i de suavitzar l'efecte 
que provoca parlar-ne o escriure'n. Així, ni el fet d'estar exposats amb més freqüència a la mort no fa que s'escapin de recórrer als eufemismes i d'intentar evitar el tabú, the ' $D$ ' Word:

One day, as a medical team was examining a patient, an intern came to the door with information about another patient's death. Knowing that the word "death" was taboo and finding no ready substitute, the intern stood in the doorway and announced, "Guess who's not going to shop at Wal-Mart anymore." Soon, this phrase became the standard way for staff members to convey the news that a patient had died. (Corless et al., 2003: 12)

La majoria dels experts de l'àmbit sanitari defensen que s'hauria de reduir l'ús dels eufemismes, especialment en la comunicació entre el professional i el pacient (Herbert, 2016), ja que poden distorsionar el significat del que es pretén explicar. Un clar exemple en seria la utilització de la metàfora del son, amb la qual es pot provocar una confusió no desitjada, sobretot en la comunicació amb els infants. Prototípicament, es tractaria de dir a un infant que un parent seu se n'ha anat a dormir en lloc de dir-li que s'ha mort. Així, el petit pot esperar que desperti i quan, passat un temps, no sigui així haurà de reviure la situació desagradable. A més, podria començar a associar el son amb la mort i desenvolupar por d'anar-se'n a dormir i no despertar mai més.

Ara bé, tampoc no sembla viable eliminar totalment els eufemismes de la comunicació sanitària, ja que no necessàriament amaguen els significats, sinó que funcionen com una mena de lubricants de les relacions socials que ajuden a reduir la conflictivitat de determinades situacions (Salvador, 2010). Hi ha moments en els quals aquest tipus d'expressions és quasi inevitable, com ara quan el propi pacient o el familiar comencen per emprar un eufemisme. En aquest cas, podria resultar innecessàriament aspre, fins i tot groller, traduir les seves paraules per respondre amb la paraula mort. Sovint és el personal mèdic mateix qui, malgrat la seva formació professional, necessita un llenguatge indirecte per a poder assumir i comunicar a les famílies l'impacte emocional dels pacients que moren estant al seu càrrec. Entre els eufemismes mèdics més comuns en anglès relacionats amb la mort, trobem: not doing very well, declining, failing to respond, might want to consider comfort care, seriously ill, isn't going to make it, treatment is futile, expired (Heerema, 2018). A més dels eufemismes d'ús general, 
que els professionals sanitaris poden usar en la comunicació amb pacients i familiars, en aquest apartat veurem que tenen la possibilitat d'emprar també un lèxic tècnic.

Pel que fa als casos clínics, constatem que és poc freqüent trobar-ne que acabin amb la mort del pacient, i menys encara en les especialitats relacionades amb la salut mental $^{25}$. La finalitat dels CC acadèmics és ensenyar dins d'un col·lectiu o una comunitat de pràctica algun descobriment d'una malaltia, una medicació, un procediment aplicat a un o més pacients i contar quines complicacions s'han detectat en aquell cas, com s'han resolt, com hi reaccionava aquell pacient en concret... Caldria pensar, doncs, que els CC acabats amb la mort podrien aportar dades rellevants per a la comunitat sanitària. Si un equip mèdic no ha estat capaç de resoldre un cas, potser seria interessant compartir-lo amb els col-legues per detectar els possibles errors o veure quina investigació s'ha de fer per poder curar casos similars. Tanmateix, el CC és una de les primeres publicacions que poden fer els metges que comencen la carrera. D'alguna manera, és la seva presentació en societat dins la pròpia comunitat de pràctica. Així, les motivacions per decidir redactar un CC en el qual el seu pacient acaba morint no deuen ser gaire grans.

En Kotátková (en premsa a) revisem en quines circumstàncies s'empren obertament, en els casos clínics en anglès, els mots de la família die i death i en quines se substitueix aquests mots per uns altres, tant sigui per tecnicismes mèdics com per eufemismes. $\mathrm{Hi}$ distingim dos grups de CC acabats amb la mort del pacient: el primer grup seria el dels CC que tenen la mort com a objecte d'estudi; el segon, el dels CC que tenen com a objecte d'estudi una malaltia o un tractament i la mort hi apareix com un esdeveniment més, però no necessàriament el principal. Dins del primer grup, els que tenen precisament la mort com a objecte d'estudi, comprovem que predomina l'ús sense eufemismes dels $D$ words. En aquesta mena de casos, òbviament, no hi ha cap necessitat retòrica d'amagar ni atenuar la mort amb cap altra etiqueta. Són casos que solen portar la paraula death ja en el títol del cas i que sovint provenen de l'especialitat de la medicina forense ${ }^{26}$.

\footnotetext{
${ }^{25}$ És per això que, en aquest subapartat, hem recorregut a alguns casos d'altres especialitats, més enllà del nostre corpus, per il.lustrar aquests fenòmens retòrics.

${ }^{26}$ Com ara "Sudden Death After a Cold Drink" (Burke P. et al., 1999), la mort cardíaca sobtada d'un nen de 12 anys després de la ingestió ràpida d'una beguda granissada. Un altre exemple en seria «Death
} 
En el corpus de CC acadèmics sobre salut mental que hem usat com a base per a aquesta tesi doctoral, en trobem ben pocs que emprin els $D$ words, i cap d'ells en el títol:

(61) Prodromal stage, characterized by visual problems lasting three months, was followed by behavioural changes, progressive mental deterioration, motoric dysfunction and death within four months, corresponding to the course of gCJDs.

$[\ldots]$

The patient died four months after the onset of clinical symptoms, on February 10, 2001.

$[\ldots]$

She died on December 16, 2008, following a rapid progression of the neurological symptoms and mental functions.

(4.ENG_Neurology_A)

Observant atentament aquest cas, veiem que està dedicat a diversos membres d'una família afectats per la síndrome - particularment mortífera ${ }^{27}$ - de Creutzfeldt-Jakob i que s'hi fa un repàs de les circumstàncies en què van morir altres familiars. Amb aquest objecte d'estudi i amb la presència recurrent de la mort en les diverses històries dels pacients i dels seus familiars, l'eufemisme podria haver resultat caricaturesc:

(62) His father died at the age of 54 (of silicosis) while his mother, born in 1918, is still alive.

[...]

He died at the age of 79 in 2009 . Maternal great-grandmother died at the age of 30 during delivery of her third child. Great-grandfather died at the age of 69 (prostatic cancer).

$[\ldots]$

Caused by Honey Bee Stings" (Anolay et al., 2014), el cas d'un home de 49 anys amb antecedents de reacció al-lèrgica a les picades d'abella que va aparèixer mort prop d'uns ruscs. Dins d'aquest grup es troben també altres casos que no pertanyen a la medicina forense però que també tenen la mort com a objecte d'estudi, com per exemple la mort sobtada que pot generar problemes jurídics perquè s'ha produït durant alguna prova mèdica. Seria el cas descrit pels neuròlegs de Taiwan «Sudden Death After Medullary Infarction" (Wang i Hu, 2013), en el qual una pacient amb infart medul-lar pateix una aturada cardiopulmonar sobtada durant un estudi de ressonància magnètica cerebral (MRI).

${ }^{27}$ En la introducció del cas, els autors ja avancen que "Creutzfeldt-Jakob disease (CJD) is a rare, neurodegenerative, transmissible disorder of the central nervous system (CNS), clinically characterized by progressive dementia and death" (4.ENG_Neurology_A). 
Her siblings (not genetically tested) died without any signs of mental deterioration at the age of 76 (pneumonia), 88 and 91 (stroke). Her sister, who was positive for the mutation (grandmother of the E200K homozygous patient), died at the age of 90 (peritonitis) without any signs of mental deterioration.

(4.ENG_Neurology_A)

El segon grup de CC seria el d'aquells que no tenen la mort com a objecte principal d'estudi, ni, per tant, estan redactats amb la finalitat d'analitzar-la, sinó que hi apareix com una circumstància més. Es tracta, més aviat, de casos seguits de ben a prop i durant un temps pels professionals sanitaris, els quals hi han estat fent proves, diagnòstics, medicacions, operacions o altres tractaments. Per tant, és un procés de seguiment i de Iluita per la vida del pacient, durant el qual el seu estat empitjora i, finalment, acaba amb la mort. La majoria dels CC d'aquest grup, encara que continguin un o diversos esdeveniments mortals, tendeixen a evitar l'ús dels mots de la família mort i morir. Dues de les expressions usades en aquests CC per dir que un pacient s'ha mort són the patient expired o the patient passed away (63 i 64). Aquests eufemismes -perquè no són de cap manera mots tècnics propis del discurs especialitzat- no tenen cap significat específic, ni tampoc aporten cap informació extra, a part que el pacient hagi mort.

(63) The patient developed resistant hypercalcemia and tumor lysis syndrome. The family opted for comfort measures and hospice care, hence further workup including onconeural antibodies were not pursued. He continued to deteriorate and subsequently expired.

(40.ENG_Neurology_C)

(64) The patient was eventually transferred to hospice care and passed away two months after her initial arrival to the hospital or four months after symptom onset.

(19.ENG_Psychiatry)

L'expressió to pass away no és exclusiva del món sanitari i s'empra àmpliament com a eufemisme de la mort, però no en qualsevol circumstància. Perquè qui diria: «These flowers have passed away» en lloc de "These flowers have died»? (Allan i Burridge, 2006). En l'àmbit quotidià - no sanitari- hi ha una tendència d'emprar aquesta expressió quan ens referim a la mort d'alguna persona pròxima -o fins i tot una 
mascota - a diferència de died, que es tendeix a reservar per a desconeguts. Podríem, doncs, interpretar l'ús d'aquest eufemisme com un indici d'humanització del pacient, de proximitat del metge amb el malalt. Un equivalent castellà d'aquesta expressió seria fallecer, que trobem en el cas d'una pacient de 52 anys amb la psicosi lúpica (65).

(65) En marzo/2011 recurre cuadro neurológico con excitación motora, desorientación, intranquilidad ingresa nuevamente en UCIM aplicándose tratamiento esteroideo e intacglobin pero además se usa ciclofosfamida evolucionando favorablemente. Es traída el 13 del mismo mes con toma de conciencia y depresión respiratoria falleciendo a pocas horas de su ingreso.

(28.ESP_Psiquiatría)

El verb to expire s'empra tant per escrit en els CC com en la comunicació verbal diària entre el personal sanitari. Danielle Ofri (2017), metgessa que escriu sobre el món hospitalari i la connexió entre el metge i el pacient, conta com es va trobar amb aquesta expressió per primera vegada mentre començava la seva carrera, quan una infermera li va dir que el seu pacient had expired:

Expired? I had no idea what she was talking about. The image that came to mind was of the rubber air mattresses we'd used during family camping trips in the Catskill Mountains. When you opened the valve, the mattress would shake and shimmy as the air whistled out, deflating erratically until it was a flabby rumple of army-green rubber. In physiology, we learned that the lungs inspired and expired. The air mattress-like a set of lungs breathing out-expired as soon as the valve was opened. I tried to envision this poor patient, with some physiologic valve unleashed, exhaling a rush of air until he too was a flabby rumple

But then it slowly occurred to me what the nurse probably meant, and I felt like a complete idiot. "You mean the, uh, patient, umm... died?"

$[\ldots]$

"Yes," the nurse snapped, utterly exasperated with my doltishness. "The patient expired. I need to be reassigned."

$[\ldots]$

Cartons of milk had expiration dates. Yogurts expired. Coupons expired. I guess people could too.

(Ofri, 2017). 
En els CC en català del nostre corpus, l'expressió més recurrent per a representar la mort és un tecnicisme: la paraula èxitus (exemple 66 i 67). Comparada amb altres expressions que solem emprar els profans per referir-nos a la mort, èxitus rarament podrà aparèixer en una conversa ni en un escrit quotidià, ni tan sols en un registre formal no especialitzat.

(66) Es va realitzar tractament amb plasmafèresi ( 5 sessions) i posteriorment tractament amb corticoides i ciclofosfamida, sense resposta clínica. La pacient va empitjorar progressivament fins a presentar una debilitat severa per a la flexió dorsal i plantar amb debilitat proximal de les extremitats inferiors i una atàxia molt marcada. Donada la progressió clínica, conjuntament amb el servei d’Hematologia es va decidir finalment procedir al TPH, però la evolució va ser tòrpida i la pacient va ser èxitus unes setmanes més tard, un any després del diagnòstic de la malaltia.

(28.CAT_Neurologia)

(67) El pacient va progressar amb aparició de tetraparèsia i disàrtria. A les noves proves d'imatge realitzades es va constatar una clara progressió del procés i es va decidir aplicar un tractament amb ciclofosfamida. La resposta tampoc va ser satisfactòria i el pacient va ser èxitus el maig de 2006. Es va procedir a l'estudi necròpsic.

(14.CAT_Neurologia)

A primera vista, referir-se a la mort com èxitus podria semblar únicament un eufemisme sofisticat, sobretot per a un lector aliè al món mèdic. Però, a més de ser una manera d'evitar les paraules «morir» $\mathrm{i}$ «mort», també és un terme de l'àmbit de les ciències de la salut, comú a diverses llengües, que significa: «Mort d’una persona que té lloc dins del recinte d'un hospital, el qual assumeix les responsabilitats legals que se'n deriven» (Termcat, 2019). Per tant, a més de referir-se a la mort, en aquest cas el terme també conté en el seu significat una al-lusió a les circumstàncies (en el decurs d'una malaltia) i l'espai (l'hospital) en què s'ha produït, a més de l'assumpte de les repercussions legals. Quan la mort es converteix en èxitus, doncs, és perquè l'ha presenciada i la descriu un professional sanitari.

Es fa difícil dibuixar la frontera entre l'ús eufemístic dels tecnicismes i la pulsió d'emprar-los per exigències del registre. Els CC són una publicació en la qual s'espera dels metges un registre formal i tècnic. Estan dient èxitus per mort de la mateixa manera 
que diuen cefalea per mal de cap? O hi intervé també el fet que s'hi parli d'una persona concreta, més o menys coneguda, malgrat que en resti amagada la identitat? Els dos factors es combinen en proporció variable per donar com a resultat la pràctica desaparició dels $D$ words en els CC del nostre corpus.

Així doncs, en el nostre corpus veiem confirmada una correlació directa entre els CC que tenen la mort con a objecte d'estudi i la utilització sense eufemismes dels mots de la família die i death. Hi comprovem també que els CC que esmenten la mort sense ser l'objectiu principal d'estudi tendeixen a referir-s'hi mitjançant eufemismes del llenguatge general - to pass away, fallecer-, eufemismes propis del llenguatge mèdic -to expire- o tecnicismes - èxitus.

Quant als CC literaturitzats, l'estratègia emprada hi serà, òbviament, força diferent. Recordem que es tracta de textos literaris. Així, en els contes clínics, els pacients manifestament esdevenen personatges - anònims o disfressats rere noms ficticis-que necessitaran tota mena de caracteritzacions per donar vida a un text literari. I en aquest context, l'autor no pot deixar passar la mort com a element que afegirà dramatisme al text - una finalitat que rarament es busca en els CC acadèmics. En el fragment (68) de Sacks podem veure el cas del personatge Bhagawhandi P., una noia de l'Índia de dinou anys amb un tumor maligne al cervell:

(68) Once, just once, I said, 'Bhagawhandi, what is happening?'

'I am dying,' she answered. 'I am going home. I am going back where I came fromyou might call it my return.'

Another week passed, and now Bhagawhandi no longer responded to external stimuli, but seemed wholly enveloped in a world of her own, and, though her eyes were closed, her face still bore its faint, happy smile. 'She's on the return journey,' the staff said. 'She'll soon be there.' Three days later she died-or should we say she 'arrived', having completed her passage to India?

(17.LIT_Sacks)

Les diferències retòriques entre els $C C$ acadèmics i els literaturitzats pel que fa al tractament de la mort van, doncs, més enllà del lèxic emprat. En el cas del fragment (68) ens trobem davant d'una narració amb profusió de recursos literaris i un estil que 
podríem qualificar fins i tot de poètic. S'hi reprodueix una metàfora de la mort, aparentment emprada per la pacient i continuada isotòpicament pels altres personatges, des dels treballadors del centre a l'autor-narrador mateix. De fet, l'autornarrador conta als lectors explícitament que Bhagawhandi va morir — «she died»-, però de seguida ho complementa amb la metàfora del viatge a l'Índia — «or should we say she 'arrived', having completed her passage to India?». S'hi pot observar el procés de la mort de la pacient contemplat pels professionals sanitaris, inclòs el doctor Sacks. Sens dubte, aquesta manera de contar la mort vol provocar emocions. La mort esdevé un recurs al servei de l'estilística i de literatura, un esdeveniment que es conta per causar un determinat efecte en els lectors.

En els CC acadèmics, en canvi, s'informa quan cal de la mort dels pacients, però les convencions del gènere no hi permeten gaires jocs literaris. No són textos de divulgació científica ni menys encara de diversió o d'entreteniment. Tampoc no hem d'oblidar el compromís ètic dels professionals sanitaris amb els familiars i amics dels difunts. No semblaria gens pertinent que en els $\mathrm{CC}$ acadèmics es dibuixés una escena de la mort tal com hem vist en l'exemple de Sacks. La mort del pacient s'hi sol expressar en una única oració cap al final de la presentació del cas, en la qual es conta la història del pacient en qüestió: des de la raó de la seva visita al metge fins a les circumstàncies que, en determinats casos, duen a la seva mort. S'hi empren expressions que no intenten provocar cap emoció, ans al contrari, sembla com si es busqués la manera més asèptica d'informar sobre la defunció, de constatar la mort, ja que aquí aquest esdeveniment no és cap recurs dramàtic que hagi de provocar cap reacció emocional en els lectors ni res de semblant.

En conclusió, encara que les estratègies retòriques a l'hora d'abordar la mort són ben diferents entre els CC acadèmics i els literaturitzats, hi ha un contínuum discursiu entre els dos gèneres. Els contes clínics poden tractar la mort com un element de desenvolupament dramàtic i literaturització de la història del pacient, mentre que els CC acadèmics tendeixen a informar-ne $a m b$ un to asèptic. Malgrat aquesta suposada objectivació, observem una tendència generalitzada en els CC acadèmics a evitar els $D$ words i substituir-los per eufemismes del llenguatge general o propis de l'àmbit sanitari, i fins i tot per tecnicismes. Com hem vist, aquesta regla es confirma amb l'excepció els CC acadèmics que aborden explícitament casos específics de mort. 


\section{POLIFONIA: METGES I PACIENTS; NARRADORS I PERSONATGES}

En els apartats 3.4 i 3.5 del capítol III hem introduït diversos conceptes relacionats amb la caracterització dels personatges i amb el punt de vista. Hem exposat que distingim les persones - els individus que vivim i interactuem en el món real- i els personatges -els participants en el món de la història. En l'àmbit de la literatura de ficció s'ha estudiat àmpliament l'anomenada caracterització, és a dir el conjunt de mecanismes pels quals s'adscriuen les propietats als personatges. Segons els teòrics del segle XIX, la caracterització pot ser directa -en el cas que els atributs s'assignen explícitament als personatges mitjançant el narrador o un altre personatge - o indirecta -quan s'efectua mitjançant les informacions que el lector extreu del text. Quant a la caracterització directa, és molt freqüent en la literatura l'ús d'adjectius descriptius. En la indirecta, en canvi, els personatges es poden caracteritzar per les seves accions. En aquest cas, els adverbis contribueixen significativament en aquest procés, ja que concreten les accions i les paraules i les avaluen.

Podríem pensar que els pacients són persones del món real que esdevenen personatges en els contes clínics, però no en els CC acadèmics. Tanmateix, en aquesta tesi defensem el caràcter narratiu dels $\mathrm{CC}$ acadèmics, com a relats no literaris, i per tant concebem els pacients que s'hi reflecteixen també com a personatges, ja que no deixen de ser recreacions dels autors d'aquests textos. Cal recordar, en aquest sentit, que els personatges dels contes clínics tampoc no deixen de ser reflexos de pacients que van anar a la consulta del professional sanitari que escriu el llibre. Com en qualsevol relat literari, encara que estigui basat en fets reals, en els contes clínics es poden seleccionar i focalitzar determinats detalls perquè la història funcioni millor com a relat, tal com ens deixa entreveure aquesta nota al final del llibre Reaching Down the Rabbit Hole, de Ropper i Burrell:

Finally, we should acknowledge the role of serendipity, which allowed us to relate these stories more or less as they occurred.

(B.LIT_Ropper) 
El professional sanitari, en escriure un conte clínic, té una certa llibertat i més facilitat per poder acabar d'encaixar els esdeveniments, les descripcions o la caracterització dels personatges, per crear un relat més rodó i una trama més interessant. Les convencions de gènere dels CC acadèmics, en canvi, no permeten que s'hi afegeixin gaires ornaments i menys encara ficcions, però la selecció de la informació que s'hi reflecteix i la manera de presentar-la pot fer que un informe sobre els patiments d'una persona es converteixi en el seu relat. Així doncs, en els dos tipus de textos comptem amb personatges inspirats en unes persones reals.

En aquest apartat mirarem d'aprofundir en tots aquests conceptes amb referències més específiques als gèneres que ens ocupen. Ens acostarem, doncs, als pacientspersonatges dels casos CC acadèmics i literaturitzats. Intentarem entendre de quina manera es presenten, com es caracteritzen, com són presents i tractats en els dos gèneres, tot intentant respondre la pregunta «How do sentences create people?» (Grabes, 1978, citat per Fludernik, 2009). Revisarem, per tant, el punt de vista dels narradors dels casos clínics acadèmics i literaturitzats. A més de quina informació ens presenten sobre els pacients, quins esdeveniments, etc., ens interessa també de quina manera ho fan, és a dir, com es construeix la perspectiva de la història. Cal tenir present que el punt de vista pot ser presentat tant pel narrador (identificat amb el professional sanitari) com per algun dels personatges (els pacients). Atendrem també a aquest factor, doncs, i tractarem d'esbrinar si, en els casos clínics sobre afeccions mentals, els professionals sanitaris cedeixen en algun moment aquesta possibilitat als pacients o més aviat en colonitzen el discurs.

\subsection{Les veus dels pacients}

Els contes clínics ens acosten a les històries, les malalties i les vivències personals d'uns pacients que en són els protagonistes, de manera que ens permeten, als lectors, de veure el món des de la perspectiva dels malalts, poder empatitzar-hi i, fins i tot, imaginar-nos com és viure amb les disfuncions o els problemes que pateixen. Tanmateix, no hem de perdre de vista el caire autobiogràfic que tenen bona part d'aquests casos clínics literaturitzats, on els professionals sanitaris acostumen a aparèixer com a 
narradors, però alhora com a personatges de la història. Al capdavall, quan llegim un conte clínic no coneixem de primera mà la versió ni el punt del vista del pacient, sinó la percepció que ens en trasllada l'autor, el professional de la salut. Com apunta Hydén (2005) en referència a Oliver Sacks, encara que l'autor intenti «convey an 'inside' perspective rather than an 'outside' one [...], his literary case presentation still relies mainly on the medical point of view; it is the voice of the medical doctor attempting to present the perspective of the patient». És a dir, com a lectors no coneixem els fets tal com han passat, ni com els haurien contat els pacients, sinó només a través de la versió que en narren els autors.

Aquesta idea traspua de les paraules de Sacks (1987b: 45), quan reconeix que «there's a part of me that almost has to organize clinical perceptions into a narrative, as well as theoretically... Subsequently, I think, the patient comes to share the story, and the story gets modified». Showalter (1992: 24) coincideix en aquesta perspectiva: les històries dels metges tendeixen a dominar el discurs mèdic, mentre que les històries dels pacients són modificades. Així doncs, un dels trets - i una de les complexitatstant dels contes clínics com dels casos clínics té a veure amb el caràcter narratiu dels dos gèneres: es tracta de la inserció d'un relat, prototípicament originat per un pacient, dins del marc narratiu elaborat pel professional sanitari.

Pel que fa als CC acadèmics, la subordinació del relat del pacient al discurs del professional sanitari es pot il.lustrar amb l'esquema (1) de Salvador (2016: 37), que estudia la macroestructura narrativa prototípica d'aquest gènere. 


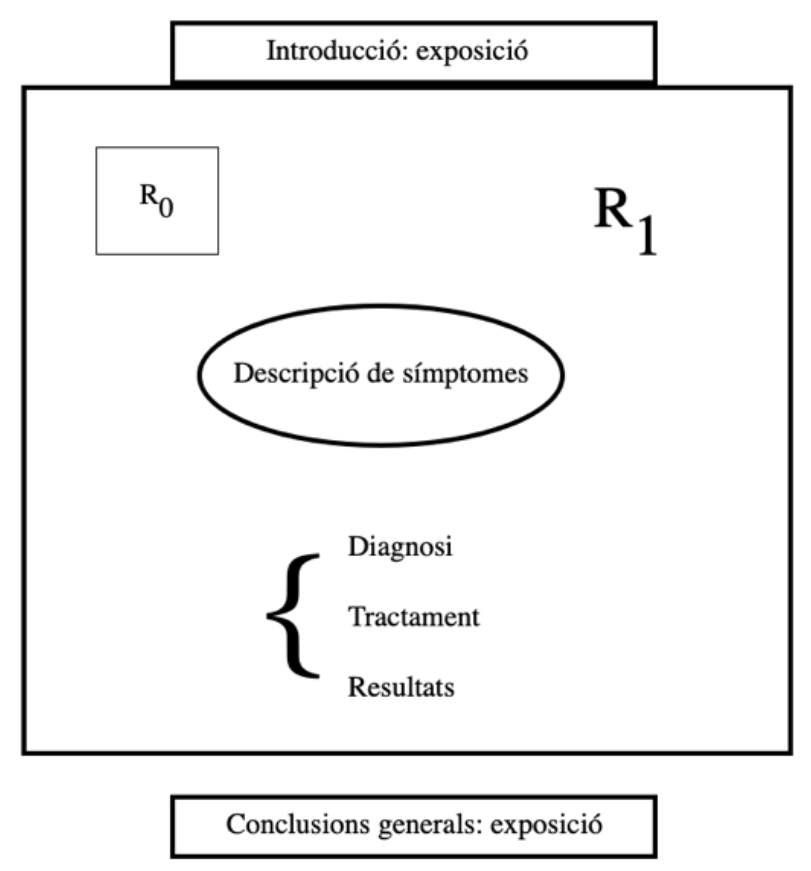

Esquema 1: L'estructura interna prototípica dels CC (traduït de Salvador, 2016)

El CC gira al voltant d'un cas nou, curiós, problemàtic, etc., en el qual el malalt pot tenir més o menys protagonisme, però aquesta decisió la pren qui redacta el CC, ja que, al capdavall, és l'autor qui decideix quina informació ens revelarà sobre el pacient, com també de quina manera ho farà. Cal recordar també que hi ha CC en els quals la concentració en la malaltia és tan intensa que quasi no s'hi veu el pacient. Tot i amb això, el malalt sempre hi és present, ja que el CC es basteix sobre els seus símptomes, els resultats de les seves proves, les seves reaccions als tractaments, etc. La seva presència, a més, es pot entreveure gràcies al seu relat $\left(R_{0}\right)$, el que sol contar el pacient al professional durant les visites. Per descomptat, l'autor pot incorporar al CC informacions de la història clínica del pacient redactades per altres professionals que havien atès aquesta persona prèviament. També hi podem trobar altres fonts d'informació, com ara els acompanyants, especialment en els casos de pacients menors d'edat. Però a la base del CC sol haver-hi una narració oral del pacient al metge (o un altre professional sanitari), el punt central de la qual és l'explicació del motiu de la consulta. Aquest relat $\left(R_{0}\right)$ experimenta una transformació per part del professional que redacta el CC per integrar-lo en el seu relat $\left(R_{1}\right)$. És un procés que resumeix molt bé Hurwitz (2000: 2088): 
This particular narrative genre consists of a story that begins with a succession of events or experiences relating to the patient, which then becomes progressively abstracted from the patient's control and the context of its original telling. The extracted story progresses, transformed by a medicotechnical vocabulary not likely to be understood by the patient.

El professional sanitari no sols transforma el discurs oral en escrit, sinó que també assumeix la responsabilitat enunciativa de $\left(R_{0}\right)$ (Macián, 2013: 273). D'aquesta manera, el pacient perd el control sobre el que, originàriament, era la seva història i així «el paciente y su peripecia clínica no trascienden el anonimato, se convierten en algo anecdótico al servicio del conocimiento científico» (Macián, 2013: 277). Per començar, el professional ha de fer una selecció de les informacions i dels fets per al CC, ja que no tot el que conta el pacient en la seva versió és rellevant per al tema d'estudi. Òbviament, aquestes informacions proporcionades pel malalt són narrades sovint d'una manera caòtica, amb un llenguatge espontani, expressiu, ple d'emocions, pors i hipòtesis sobre allò que el pacient pensa que li està passant (Helán, 2012). El professional ha d'organitzar els fets i establir-hi el màxim possible de relacions causals, freqüentment hipotètiques (Salvador, 2016). També ha de traduir o reformular el discurs del malalt no sols a l'estil indirecte, sinó també a un llenguatge científic, és a dir, més abstracte, més precís, amb l'ús de termes especialitzats. El tecnolecte aporta univocitat i concisió, uns trets cabdals en un gènere sovint molt restrictiu quant a extensió. Amb tot això, «the illness narrative $\left(\mathrm{N}_{0}\right)$ is thereby recontextualised in the medical narrative [...]» (Salvador, 2016).

Aquest nou relat $\left(R_{1}\right)$ que es crea a partir del $\left(R_{0}\right)$ també conté, però, altres parts que desenvolupa el professional, sense la necessitat d'agafar-les del discurs del pacient, com ara el procediment de la diagnosi, el tractament i l'avaluació final dels resultats (vegeu l'esquema 1). D'aquesta manera s'integren en el relat també les altres seqüències textuals, com ara l'expositiva (prototípicament en la introducció i en les conclusions) i la descriptiva (simptomatologia) (vegeu l'apartat 2.1 d'aquest capítol).

Les narracions sobre la vida del pacient les pot presentar el metge, colonitzant completament el discurs del pacient, com veiem en el fragment (1) sobre un pacient amb paranoies i al-lucinacions auditives que, de jove, va ser víctima d'abús sexual per 
persones grans i companys de classe i, posteriorment, va patir esquizofrènia i va abusar de la seva filla biològica. Podem observar que tot el text és un relat en tercera persona sobre el malalt, sense marques evidents de la presència del discurs originari.

(1) The patient was brought up in a conservative family and studied in a residential religious institution. His teachers and senior students abused him physically and sexually at the age of eight. Within a few months, this boy started abusing new students sexually and developed sexual relation with multiple boys. At the age of 16 years, his most intimate sexual partner left the hostel. He became suspicious that other students and teachers conspired against him and forced the partner to leave the hostel. Afterwards his suspiciousness spread to every aspect of his life. He refused to take food and drinks to avoid poisoning and loss of sexual power. Moreover, he started experiencing auditory hallucination (second and third persons) that centered on his poor sexual performance and paranoid delusion of poisoning. He lost his judgment and insight. His disorganized behavior of becoming nude in public places and masturbating warned the family members. He was admitted in the psychiatry hospital and was treated with haloperidol up to $30 \mathrm{mg}$ initially by injectable route then orally. He had to discontinue his study due to his deteriorating mental state. After the discharge from the hospital he started going to brothels. The young man became frustrated and anxious due to lack of rigidity and ejaculation within $20-30$ seconds most of the times. He failed to resist the temptation of touching the private parts of the females in the market, bus stoppage, and other crowded places. He was punished several times; however, the physical punishment by family members or by the angry mobs failed to prevent him from these types of act.

His family assumed that his symptoms might subside after marriage. The couple stayed with the parents and four siblings. However, his sexual problem continued throughout his conjugal life. His psychotic feature fluctuated; however, delusion of infidelity appeared with earlier paranoid delusion and content of auditory hallucination changed over time. He was admitted couple of times in the last five years due to refusal of food and becoming violent towards the family members.

(23.ENG_Psychiatry)

Una manera d'integrar el discurs del pacient en el del professional de la salut pot ser mitjançant el discurs indirecte encapçalat amb el verbs locutius «va dir, refereix que (told, reported)...». Aquesta manera d'introduir la informació pot ser molt útil si l'objectiu és mantenir una certa neutralitat, com veiem en l'exemple (2) d'una pacient jove amb tetraparèsia progressiva. El metge ens acosta als motius de la consulta 
expressats per la pacient. Però, òbviament, en aquest cas tradueix el discurs original, ja que resulta força inversemblant que la pacient digués literalment que patia un dolor lumbosacre o que sentia una debilitat muscular d'inici en extremitats inferiors - excepte potser si la pacient mateixa era una professional sanitària.

(2) La pacient refereix pèrdua d'uns $20 \mathrm{~kg}$ de pes els mesos previs, dolor lumbosacre i sensació de debilitat muscular d'inici en extremitats inferiors.

(22.CAT_Neurologia)

L'autor té també la possibilitat de deixar-nos entreveure el discurs del pacient inserit dins del seu text, amb reproduccions exactes entre cometes de petits fragments del que va dir el malalt, sovint introduïdes per verbs locutius, com ara «el pacient refereix/confirma/nega...». Aquest seria el cas del fragment (3), sobre una adolescent amb anorèxia nerviosa.

(3) Anamnesis

Acude a consulta acompañada por ambos padres. Estos refieren que desde hace 7 meses, desde mayo, comenzó a pedir a su madre que cocinara "más sano", disminuyendo la ingesta y saltándose algunas comidas. Al principio pensaban que era algo "normal para su edad" y la permitieron perder peso, incluso la felicitaron por estar "mejor" pero ahora no saben cómo motivarla para que coma. Está obsesionada con las calorías que ingiere. Itziar refiere que estará tomando $800 \mathrm{cal} /$ día. Desde hace un mes la ingesta se ha reducido a manzanas y agua. Ha perdido unos $11 \mathrm{~kg}$ [de 52 a $41 \mathrm{~kg}$ (21\%)]. Amenorrea desde hace 3 meses. Los padres no refieren conductas purgativas ni ejercicio.

La madre apunta que de pequeña era una niña "algo rellenita". Han notado que Itziar, que siempre ha sido una niña alegre, feliz y dócil, está más irritable, enfadándose con frecuencia y sin motivo, con tendencia a encerrarse en su cuarto. Nunca ha sido una niña muy comunicativa. Ha empeorado el rendimiento escolar, ya que era "una chica de sobresaliente". Tiene una amiga con "problemas en la alimentación".

(20.ESP_Adolescencia)

La incorporació de fragments del discurs literal del pacient en el relat del professional mèdic també es pot produir sense el suport dels verbs locutius, amb una integració sintàctica dels segments entre cometes en les oracions enunciades pel narrador. 
Aquesta pràctica es pot relacionar amb el doble objectiu de mantenir l'expressivitat de l'enunciat original i evitar una traducció al tecnolecte mèdic que podria resultar feixuga (exemple 4).

(4) Gloria had not allowed herself to think about this until she entered treatment and her treatment goal was "to get rid of it." She had a stiff commitment to being strong and carrying on. "I want to function. I will get through this. I want to be able to work. I have worked for many years to wipe out the traumatic event, to get rid of it, to repress it." This perspective had dominated her life and kept her moving forward. She was frightened of not being able to be in control of her symptoms and the prospect of becoming dependent on the pain medication prescribed to combat her severe headaches.

(31.ENG_Psychology)

Així doncs, en determinats CC, sobretot de psicologia i psiquiatria, els professionals sanitaris ens permeten llegir les paraules exactes dels pacients - segons la seva transcripció, això sí. Habitualment, es tracta d'una expressió breu d'alguns sintagmes o poques frases que convé reproduir literalment, com un efecte estilístic que reforça la narració de l'autor. Solen ser, per tant, fragments curts generalment integrats, pels diversos mitjans que hem revisat, dins del discurs del professionals sanitari. Hi ha, però, una variant $d^{\prime}$ aquest gènere, denominada cas clínic interactiu ${ }^{28}$, estudiada per Zabielska i Żelazowska (2017), que s'ha intentat promoure des de diversos àmbits de la medicina. Aquest tipus de CC segueix més o menys l'estructura tradicional o prototípica del gènere, però inclou la perspectiva del pacient. A més, també sol incorporar una part call for readers - en la qual es demana l'opinió dels lectors.

En el nostre corpus també hem trobat algun exemple aïllat de CC que sembla voler trencar amb aquesta colonització del discurs del malalt i li cedeix la veu d'una manera més extensa, fins i tot exhaustiva. Seria el cas del CC «Tengo daño cerebral: relato biográfico de un accidente» (13.ESP_Enfermería), en el qual l'autora, una infermera, decideix centrar el focus de la metodologia qualitativa en les explicacions, les percepcions, els sentiments i les opinions per veure com el pacient afronta la seva

\footnotetext{
${ }^{28}$ Coneguda en les publicacions de llengua anglesa com interactive case report.
} 
malaltia, una lesió cerebral, després d'un accident de trànsit (exemple 5). La professional introdueix la problemàtica dels accidents viaris i les seves conseqüències, tot centrantse en les lesions cerebrals més freqüents. Després ens explica la metodologia emprada i, a continuació — com ja podem observar en el fragment citat-fa la presentació del pacient. Fins aquí, tot seguiria el desenvolupament normal d'un CC. És en el següent apartat, anomenat «Relato biográfico», on la infermera deixa tot l'espai al discurs del seu pacient. Es tracta d'un text preparat anteriorment, a partir del diari del malalt i de les entrevistes amb la professional, que és llegit pel pacient mateix, enregistrat i, posteriorment, transcrit per l'autora. En total, són sis apartats - nosaltres en reproduïm només un- que ocupen una pàgina -més d'una tercera part del cos del text del CC complet. L'única intromissió de l'autora són els comentaris afegits entre claudàtors [sonríe], [suspira]-, acotacions quasi teatrals que faciliten als lectors poder imaginar-se les reaccions emotives més rellevants en cada part del text.

(5) Estoy hablando de un varón de 29 años, soltero, que sufrió un accidente hace 10 años, siendo diagnosticado de TCE grave y fracturas múltiples. Obtuvo una puntuación inicial en la escala de coma de Glasgow de 6. Permaneció en coma durante 36h y sufrió una amnesia postraumática anterógrada de unos 7 días de duración. Un educador con un estilo de vida saludable se enfrenta a una década de sufrimiento a consecuencia de conducir en estado ebrio.

Su relato autobiográfico motivó mi necesidad de profundizar en el tema en cuestión de vivencias, y decidí embarcarme en conocer cómo se sentía y/o afrontaba la enfermedad nuestro protagonista.

\section{Relato biográfico}

En el análisis del relato se han podido identificar 6 categorías temáticas:

La enfermedad

«No me avergüenza reconocerlo: tengo un daño cerebral. Hace 10 años un acontecimiento no previsto en mi agenda cambió mi vida. Tras un accidente de tráfico un extraño dolor en la sien izquierda me despertó de la cama del hospital. No lo recuerdo pero me llevaron a urgencias. Pasé un mes en $\mathrm{UCl}$ en un hospital y después, casi 3 meses más, me derivaron a otro. Dado el alta, continué yendo cada día a rehabilitación.

Cuando me levantaba para tomar un vaso de leche y una aspirina no podía regresar a la cama. Me derrumbaba como un fardo con medio cuerpo paralizado. Tengo secuelas 
irreversibles que me impiden caminar con normalidad, pero he podido ser lo suficientemente autónomo como para seguir trabajando (aunque sea intelectualmente [sonríe]). Evidentemente, hay secuelas y secuelas. EI TCE puede afectar de modo muy diferente a las personas que lo sufren: parálisis en las manos, imposibilidad para hablar, agarrotamiento de las piernas, dolores, pérdida de memoria o de capacidad para razonar. Incluso puede provocar la muerte [suspira]. Cada ser humano reacciona de modo diferente a las eventualidades imprevistas de la vida».

(13.ESP_Enfermería)

Fixem-nos que l'autora empra sovint la primera persona del singular. És evident que aquest $\mathrm{CC}$, ja pel seu plantejament teòric, dóna molta importància a les vivències del malalt i la forma del text hi va en consonància. L'estructura d'aquest cas s'assembla molt a la d'un article de recerca - hi trobem metodologia, resultats, discussió...-, però si mirem més enllà de l'estructura i ens fixem en el contingut, veiem que s'allunya en diversos aspectes del discurs prototípic dels professionals sanitaris. Això no vol dir, però, que aquest fet rebaixi la qualitat de l'estudi, ans al contrari. Creiem que els CC que es decanten per incloure-hi la visió del pacient i que també ens permeten veure algunes reaccions dels autors mateixos poden ser profitosos per als lectors. Aquests CC, més enllà de les dades escarides, permeten acostar als lectors també les reaccions i opinions més personals, tant del professional sanitari com també -i sobretot- del pacient.

Els CC que hem anat citant en aquest apartat són bons exemples de les diferències que poden existir, dins del mateix gènere, entre els textos del camp de la salut mental $\mathrm{i}$ els d'altres àrees sanitàries. La narració és particularment patent en el nostre corpus i el relat del malalt resulta més que rellevant per a la contextualització de molt dels problemes tractats. En psiquiatria i psicologia ens trobem sovint amb narracions que tornen molts anys enrere en la vida del pacient, ja que intenten anar al que se suposa que és l'origen de l'afecció. En altres àrees també trobem la narració, però quan es revisa el passat sovint és quasi exclusivament per referir-se als resultat de les proves biomèdiques. A tot estirar, també es recorda el motiu pel qual va acudir al metge el pacient per primera vegada. I en algunes especialitats, com ara la podologia (Macián 2013: 274), els detalls o les formulacions exactes de l'expressió del pacient són habitualment considerats irrellevants. La majoria de CC, com observa Taavitsainen (2011: 93), «tell the story from the patient's point of view and assume an impersonal 
tone. The emphasis is on the disease and its course, and the natural narrative pattern does not apply as the emphasis has shifted to the non-human facts of test results and laboratory findings». En canvi, en els CC de les especialitats de la salut mental, especialment en els de psiquiatria i psicologia, constatem que, més enllà de les proves de laboratori, la percepció del pacient d'ell mateix i la seva visió dels fets relacionats amb la seva malaltia són, freqüentment, més que rellevants i, per tant, es tracten amb molta més atenció que en altres branques més fisiològiques de la medicina (exemples 6-9).

(6) John reported feeling that these were "blasphemous" acts, and posed the question "Is God punishing me?"

(30.ENG_Psychology)

(7) She reported that she experienced thoughts that her grandmother was in pain and was going "into the unknown, to a scary place." Mary reported feeling afraid of death and that if someone "even closer" to her died she "would not be able to cope" and that she would "lose control completely."

(30.ENG_Psychology)

(8) Although she was a 2-year student at the Medical School with outstanding results, she felt "anxious, confused, and insecure," "I do not know if this Faculty is good for me, maybe Biology would be better, or Pharmacy... I do not know really, I am so confused; I do not understand what is happening to me... I am no more sure about anything."

(29.ENG_Psychology)

(9) The adjectives she chose to describe the relationship with her father were: always affection- ate, playful, formal ("home rules had to be respected, for instance times for lunch and dinner"), respectful ("Nothing escaped from him; his words had always a weight"), and important.

(29.ENG_Psychology)

Tal com remarca Salvador (2016: 41), reproduir les opinions i les paraules del malalt esdevé un recurs necessari, sobretot, quan es tracta d'una malaltia molt greu i que qüestiona la seva identitat, o quan entren en joc els factors psicosomàtics o neurològics, com en els nostres CC de salut mental. En les especialitzacions de la psiquiatria i la psicologia, a més, el fet de preservar les paraules originals del pacient és molt rellevant 
per a l'anàlisi de com es veu a si mateixa aquesta persona o com descriu les seves relacions, els seus problemes... Tot això forma part de la diagnosi en aquestes disciplines, a diferència d'altres que no ho consideren rellevant per al diagnòstic ni per a la cura.

\subsection{Quan el pacient sembla fer nosa}

En una època en què disposem d'una tecnologia que avança amb ritme exponencial -i que sovint tant ens aliena del contacte humà directe-, podria semblar que els professionals de la salut, com a investigadors de la ciència, segons les seves produccions orals i escrites, tendeixen a oblidar que l'objectiu principal de la seva tasca és ajudar la persona, l'individu concret que tenen davant. No són pocs els metges de capçalera que avui ja quasi ni toquen -en el sentit físic- els pacients que arriben a la seva consulta, amagats darrere de l'ordinador, introduint-hi i buscant dades.

Una de les crítiques que reben les comunitats discursives dels professionals sanitaris és l'ús d'un llenguatge parcial i distorsionat (Helán, 2012). En els àmbits especialitzats de la cultura mèdica anglosaxona s'ha tractat a bastament sobre els mots pejoratius ${ }^{29}$, alguns dels quals podríem qualificar de denigrants, com ara gomer ${ }^{30}$-se sol referir a pacients no desitjables: bastant majors, sovint senils, i que tenen moltes malalties- 0 dirtball -sol designar un pacient que entra brut a la sala d'urgències i que fa pudor. Les arrels d'aquest fenomen, segons les publicacions que l'analitzen, serien la frustració dels professionals per l'atenció a determinants pacients, "fostering group solidarity among caregivers under stress, and the alleged "dehumanization" of medical training" (Dans, 2002). Així doncs, més enllà de qualsevol judici de valor sobre aquest fenomen, l'hem

\footnotetext{
${ }^{29}$ Peter E. Dans (2002) va fer una enquesta als estudiants egressats de medicina d'una universitat estatunidenca de diferents cursos. Entre un $8 \%$ i un $13 \%$ dels enquestats no recordaven haver sentit cap terme pejoratiu respecte dels pacients. Només del $2 \%$ al $13 \%$ de determinades classes van considerar que aquest ús era útil, mentre que del $30 \%$ al $50 \%$ el consideraven perjudicial. Aquests termes pejoratius s'utilitzaven amb més freqüència per a referir-se a pacients autodestructius o abusius. Els mots dirtball i gomer eren els més freqüents, segons els enquestats.

${ }^{30}$ Una de les interpretacions més esteses d'aquest mot és que sigui un acrònim de «get out of my emergency room". Vegeu més sobre l'etimologia i l'ús del mot en George i Dundes (1978).
} 
de relacionar amb la necessitat de cohesió de les comunitats de pràctica on es desenvolupa.

Aquestes i altres expressions més o menys barroeres queden normalment relegades a la comunicació oral i són, òbviament, evitades en els CC formals que es publiquen en les revistes. Però n'hi d'altres, menys evidents i bastant freqüents, que Monroe et al. (1992: 46) també classifiquen com ofensives i que debiliten la relació professional entre el metge i el pacient, com ara: "the patient complained of...», "the patient denied...", «the patient admitted...", "the patient is noncompliant» $\mathrm{i}$ "the patient failed therapy» (Monroe et al., 1992: 46). El professional, probablement sense pretendre-ho expressament, pot transmetre la sensació que el pacient és un queixó, un hipocondríac, que no confia en les seves paraules... Així, per exemple, el verb failed ens pot suggerir que el pacient és culpable del fracàs del tractament, en el que podríem interpretar com «an attempt by the physician to avoid or transfer blame, a reluctance to accept the role of comforter as well as healer, and a hubristic refusal to admit that the physician is a catalyst to the healing process rather than the causa sui» (Monroe et al., 1992: 46).

Aquesta mena de fórmules està tan instal-lada en el discurs mèdic (vegeu apartat 3.2 d'aquest capítol) que els professionals sanitaris haurien de reflexionar-hi, a l'hora de redactar un CC, ja que sense adonar-se'n poden construir una imatge del pacient com a poc fiable, no adaptable i, fins i tot, culpable. Així, no és estrany sentir frases del tipus: «Miriam Young has lymphoma. She failed chemo but is refusing radiation. She's noncompliant with her diabetes meds, so her glucose is poorly controlled» (Ofri, 2017). En aquest cas, semblaria com si la pacient, la senyora Young, fos una completa obstruccionista que intenta boicotar totes les recomanacions eminentment prudents dels seus metges. Ofri il/lustra com els pacients poden tenir motius justificats, des del propi punt de vista, per a no seguir les indicacions mèdiques i reclama deixar d'usar aquest llenguatge:

\footnotetext{
"Patients who don't take their medications are labeled "noncompliant," even if they have a perfectly legitimate reason not to: the medication caused sexual dysfunction or they got to the pharmacy and the bill was $\$ 250$ for thirty pills. When patients choose not to do a recommended treatment, doctors typically say the patient refused treatment, a verb choice
} 
that makes me think of a toddler storming away from a plate of broccoli, holding her breath until she turns blue. Why must we use such harsh terminology?"

(Ofri, 2017)

Bona part de les expressions que estigmatitzen el comportament dels pacients es relacionen amb alguns verbs locutius, com ara admetre, confessar, negar... que impliquen una valoració negativa, per part dels professionals de la salut, del que s'ha enunciat. Aquesta mena de verbs es troben sovint en els $\mathrm{CC}$ en relació amb el consum d'alcohol, de tabac o d'altres drogues (Monroe et al., 1992; Salvador, 2016; Helán, 2012) i aporten un biaix negatiu cap al pacient, quasi equiparant-lo amb un delinqüent:

Admittedly, to say "the patient denied having frequent headaches" is quite different from saying "the patient denied having anal intercourse" or "the patient denied heavy alcohol use." The latter statements suggest that the physician doubts the veracity of the patient and may imply that the physician suspects the patient of behavior that is medically or morally objectionable. To eliminate such connotations, the physician ought to substitute neutral expressions for the offending ones: "the patient reported," rather than "complained of"; "the patient stated that he [or she] did not [or does not]," rather than "denied"; the patient's "chief concern" or "worry," rather than "complaint". The term noncompliant, again, suggests an antagonistic relationship between physician and patient and casts the patient as a child or ward and the physician as a domineering parent or sovereign. (Monroe et al.,1992: 46)

En el fragment següent s'examina el cas d'una psicopatologia que pot estar relacionada amb determinades begudes energètiques. Hi podem veure detalls d'una entrevista, probablement la primera que es fa al malalt, en la qual el professional separa quines substàncies el pacient admet haver consumit i quines no. Amb l'ús d'aquest verb i del seu antònim denied, tots dos tan associats al marc i als guions de l'àmbit judicial, el professional sanitari transmet - potser inconscientment- ombres de dubte $\mathrm{i}$ desconfiança sobre la veracitat de les declaracions del pacient i sobre la legitimitat del seu comportament mateix.

(10) The patient was an 18-year-old Spanish male with no relevant medical or psychiatric history. Regarding his substance use, he admitted daily use of tobacco (20 cigarettes/day, meeting criteria for tobacco use disorder), daily use of cannabis (3 cannabis cigarettes/day, meeting criteria for cannabis use disorder), and occasionally 
weekend drinking (no meeting criteria for alcohol use disorder). He denied consumption of other psychoactive substances. As for his family background there was a paternal uncle with an unspecified chronic mental illness.

$$
\text { (21.ENG_Psychiatry) }
$$

Altres verbs com confessar els localitzem sovint, al nostre corpus, introduint comportaments o accions que l'autor del CC considera contraris als valors generalment compartits per la societat o fins i tot a la moral, com en un cas de problemes familiars, en el qual s'escriu sobre el pare que «En alguna ocasión confesó que los niños no le gustaban»(17.ESP_Adolescencia), o el d'un altre pare, en aquest cas esquizofrènic, que confessa l'incest amb la pròpia filla (11):

(11) He was changing topics frequently, sometimes in the middle of a sentence, and there was no logical connection between the different topics. His Brief Psychiatric Rating Scale (BPRS) score was 71. In the subsequent interview he confessed about sexual relation with his biological daughter. The daughter was shy, timid, and anxious; the girl tried to avoid him and she became shy and fearful. The family members noticed his behaviors few weeks before the incident occurred and tried to keep it concealed. They restricted him going close to the girl alone. Unfortunately, the family refused any psychiatric assessment of the girl.

(23.ENG_Psychiatry)

Certament, el professional mèdic és una persona amb els seus valors, les seves preferències i el seus prejudicis. Per més que intenti mantenir sempre la distància i l'objectivitat que exigeixen les convencions de la seva comunitat discursiva, a l'hora d'escriure i de contar un CC com el que acabem d'exemplificar serà molt difícil difuminar el propi punt de vista.

\subsection{Entre la despersonalització i la humanització}

Tant els CC acadèmics com els literaturitzats ens conten històries amb una base real, on es revelen dades molt personals, amb un historial mèdic, amb resultats de les proves i altres informacions sensibles. Des d'un punt de vista deontològic, els autors estan 
obligats a amagar la identitat real del malalt. Ens trobem, doncs, amb diferents solucions per preservar-ne l'anonimat, com ara l'ús del nom sense el cognom, d'un nom fictici (Corinne, Christina, Madeleine J., Daniel M. C.) o l'ús de les sigles (A.Y., Dr P., Mrs S.). En els contes clínics, a més, alguna vegada apareixen també els cognoms dels pacients ( $\mathrm{Mr}$ MacGregor), tot i que probablement es tracta de cognoms també ficticis. En els CC acadèmics, la solució majoritària és elidir totalment el nom del pacient. Així, la presentació prototípica no hi sol començar pel nom o pseudònim - com pot esdevenir en els contes clínics-, sinó mitjançant la fórmula home/dona o pacient masculí/femení, de $\mathrm{X}$ anys d'edat, amb/sense antecedents, que ingressa en un centre per tal raó (exemples 12-14).

(12) Home de 36 anys que consulta el juliol del 2007 per episodis paroxístics d'hemicós dret. Refereix antecedents familiars de migranya amb aura en la mare i epilèpsia en un germà des de la infància fins als 12 anys i antecedents personals de tabaquisme, hipertensió i migranya sense aura que tracta amb AINE.

(13.CAT_Neurologia)

(13) Varón de 69 años, ingresado por alteración gradual del estado de conciencia que progresó hasta el coma en alrededor de 24 horas. El cuadro comenzó cinco años antes con pérdida parcial de la visión con predominio en el ojo izquierdo. El paciente fue diagnosticado de neuritis óptica y tratado sin éxito con corticoides e inmunosupresores.

(5.ESP_Neurología_A)

(14) The patient is a 12-year-old female and was voluntarily admitted to our pediatric psychiatric institute for hospitalization in early 2016 after presenting to an outpatient service with $\mathrm{SI}$, intent, and a plan to overdose on medications and suffocate herself with a plastic bag.

(24.ENG_Psychiatry)

En aquests casos apareixen, en primer lloc, les informacions que el professional sanitari considera oportunes i rellevants perquè un altre col-lega entengui bé el seu estudi. Es tracta d'una caracterització que intenta ser objectiva - edat, sexe, etc.- i també conserva millor l'anonimat del malalt. És un esquema emprat en totes les llengües estudiades i en les diverses especialitats. L'única diferència que trobem és que 
en les revistes en anglès - que recullen CC de tot el món, amb nombrosos professionals dels Estats Units d'Amèrica- en algunes ocasions també apareix la raça o procedència del pacient (exemples 15-17), cosa que no solem trobar en els CC en castellà ni en català.

(15) A 75-year-old Hispanic man with a history of hypertension presented with complaints of left eyelid droop and double vision for 1 day.

(40.ENG_Neurology_C)

(16) The patient is a 57-year-old Caucasian male (May 2015) with a height of $180 \mathrm{~cm}$ and a weight of $82 \mathrm{~kg}$, in whom eosinophilia was first detected in August 2003 and has remained almost constantly present until today (Fig. 1).

(38.ENG_Neurology_C)

(17) It is about a 50-year-old male patient, native of Cajamarca, who had completed high school and lived with his son and daughter-in-law for three months.

(22.ENG_Psychiatry)

Però bona part dels CC acadèmics va bastant més enllà de garantir l'anonimat dels malalts. En molts casos, els autors tendeixen a ignorar textualment els pacients i centren l'atenció en la descripció dels processos biològics que tenen lloc en els seus cossos i els tractaments que experimenten (Anspach, 1988; Kenny i Beagan, 2004). Els pacients s'hi converteixen en actors secundaris, en unes excuses per poder fer una publicació sobre una malaltia, un símptoma, una cura, una tècnica, una medicació..., que són convertits, així, en els protagonistes primaris dels CC. Ens podem trobar amb diverses estratègies retòriques que fan que els pacients, malgrat ser els protagonistes principals de la història que subjau al cas clínic, freqüentment no hi apareguin com a tals. Prenem d'Anspach (1988: 363) tres aspectes relacionats amb la presència dels pacients i dels metges en els CC acadèmics: a) la separació dels processos biològics de la persona (despersonalització); $b$ ) l'omissió de l'agent (per exemple, l'ús de la veu passiva); $c$ ) el tractament de la tecnologia mèdica com a agent de l’acció.

Quan Anspach (1988) parla de la despersonalització, no al-ludeix únicament a l'ús d'un vocabulari impersonal, sinó també a un conjunt més subtil de mecanismes, com ara que hom es refereixi a un nadó com al producte d'una gestació, com si fos 
simplement el procés biològic de la gestació, més que no pas els pares, que va produir el bebè. Aquest llenguatge, doncs, ens podria suggerir que els processos biològics es poden separar de les persones que els experimenten. En els CC acadèmics, la despersonalització es produeix per mitjà de diversos mecanismes. Comença pel fet que els pacients sovint no s'hi presenten amb el nom, sinó com a home/dona o pacient masculí/femení, de $X$ anys d'edat, amb/sense antecedents, que consulta/ingressa al nostre centre per $X$. En el nostre corpus, podem observar com els pacients desapareixen textualment en diferent mesura: la despersonalització és més freqüent i intensa en el CC de neurologia, que solen tenir un enfocament més fisiològic, que no pas en psicologia i psiquiatria, on la persona és necessàriament el centre de l'atenció.

A més de difuminar la identitat personal del pacient, els CC també tendeixen a ometre les del metge, dels infermers $i$ d'altres professionals sanitaris que realitzen procediments o fan observacions (Anspach, 1988: 366). Així, en les oracions en les quals es descriuen els procediments de diagnòstic i el tractament, sovint no s'hi inclou l'agent que realitza aquestes accions (vegeu apartat 3.2 d'aquest capítol). Aquesta omissió se sol efectuar mitjançant l'ús de la veu passiva, un recurs molt utilitzat en el discurs científic -inclòs el mèdic- que serveix per objectivar el text i distanciar-se'n. Aquest ús provoca que la tecnologia hi sigui tractada com si fos ella l'agent de l'acció, mentre s'invisibilitza les persones que fan les observacions, prenen les decisions i duen a terme els procediments.

Els autors dels CC utilitzen freqüentment la veu passiva sense agent en dos contextos. Per una banda, la utilitzen per constatar símptomes o formular diagnòstics (exemples A). Per una altra banda, quan ens informen sobre tractaments i procediments seguits (exemples B). En ambdós casos s'omet no el pacient, sinó els qui van realitzar les observacions, les proves, els diagnòstics o les teràpies. Aquesta omissió té l'efecte d'emfasitzar el que es va fer i no centrar l'atenció en qui ho va fer, fins al punt de passar sovint de puntetes sobre els motius pels quals es va prendre una determinada decisió.

A.

(18) On examination, she was found to have unequal pupils and papilledema.

(11.ENG_Neurology_B) 
(19) Diffusion restriction, which was noted on our patient's MRI, is likely due to cytotoxic oedema.

(33.ENG_Neurology_C)

(20) El paciente fue diagnosticado de neuritis óptica y tratado sin éxito con corticoides e inmunosupresores.

(5.ESP_Neurología_A)

B.

(21) Since at least October 1999, hyperlipidemia has been noteworthy (Fig. 2), which was treated successively with fluvastatin, bezafibrate, atorvastatin, and since March 2015 with ezetimibe (10 mg/day).

(38.ENG_Neurology_C)

(22) Posteriorment, va ser traslladat a un altre centre, on es va efectuar angiografia que no va mostrar lesions vasculars associades. També es va realitzar estudi immunològic bàsic per a descartar vasculitis, amb ANA negatius.

(23.CAT_Neurologia)

L'omissió del subjecte, a més de desviar el focus de l'observador, també implica que allò que s'observa -en anglès s'expressa sovint amb was noted (A.19) - és un fet objectiu que qualsevol persona hauria percebut de la mateixa manera: «using the passive voice while omitting the observer seems to imbue what is being observed with an unequivocal, authoritative factual status» (Anspach, 1988: 367).

Òbviament, no sempre i en totes les oracions s'omet l'agent de l'acció realitzada. En els CC també trobem com s'hi narren les decisions o els processos de tractaments mèdics en veu activa (exemple C.23). Ara bé, hem de constatar que en anglès és molt més freqüent l'ús de la veu passiva sense agent en comparació amb el català o el castellà. A més, les dues llengües romàniques disposen del recurs de la construcció passiva reflexa (exemple C.24), molt més habitual, sobretot en els registres no formals. La veu passiva és molt poc freqüent en les dues llengües, ja que queda restringida per als àmbits molt formals, com ara el científic. Així doncs, la veu passiva hi és present, però no tant com en la llengua anglesa, en la qual sovint ens trobem cadenes de oracions amb verbs sense agent. En les llengües romàniques, més aviat, podem observar combinacions dels dos recursos (exemple C.25). 
C.

(23) [La pacient] Avisa el SEM, que objectiva disminució del nivell de consciència i absència de resposta a estímuls, per la qual cosa decideixen traslladar-la a urgències del nostre centre.

(16.CAT_Neurologia)

(24) El paciente fue dado de alta con traslado a un hospital de daño cerebral para continuar con su rehabilitación. Se reevaluó dos meses después en consultas externas y se observó una clara progresión en su mejoría neurológica global.

(2.ESP_Neurología_A)

En el nostre corpus de CC, doncs, a l'hora de fer les proves i interpretar-ne els resultats trobem, en la majoria de casos, l'ús de la veu passiva i la passiva reflexa. Però també hi ha alguns CC en què s'hi utilitza la veu activa, normalment en primera persona del plural que hem d'interpretar com plural de modèstia en els casos en què l'autor és una única persona (exemple 25), mentre que en els d'autoria múltiple la interpretació restaria oberta (exemple 26). On sí que trobem més freqüent l'ús de la veu activa, sobretot en primera persona del plural, és en l'apartat de "Discussió», en el qual els autors sovint surten de l'omissió textual que han estat aplicant al llarg de tot el text anterior i hi avaluen la seva experiència.

(25) En la figura també mostrem l'atròfia cortical posterior marcada del pacient. Tot i que aquestes atròfies corticals més focals no han estat descrites en estudis previs, hem pogut observar-les en els nostres pacients a nivell posterior (com aquest cas) o anterior (sobretot a còrtex prefrontal medial bilateral), i semblen associar-se amb la presència de dèficits cognitius i conductuals, molt freqüents en el curs evolutiu de l'FXTAS.

(24.CAT_Neurologia)

(26) We performed computed tomography (CT) of the brain and a subsequent lumbar puncture.

$[\ldots]$

We prescribed intravenous AmB $(0.7 \mathrm{mg} / \mathrm{kg} /$ day) and oral 5-FC (100 mg/kg/day) for 2 weeks, followed by 6 weeks of treatment with intravenous FLC ( $6 \mathrm{mg} / \mathrm{kg} / \mathrm{day})$.

(2.ENG_Neurology_A) 
En tercer lloc, a més de la despersonalització del pacient i de l'omissió del subjecte en els procediments sanitaris, en els CC trobem bons exemples del tractament de la tecnologia mèdica com a agent de l'acció. Els professionals sanitaris fan servir en aquest cas la veu activa, però per referir-se als processos realitzats amb una màquina on ella apareix com a agent:

(27) Video EEG showed epileptic activity in the right frontoparietal region.

(15.ENG_Neurology_B)

(28) Una nueva resonancia magnética mostró persistencia de las hiperintensidades con vacíos de señal y dilatación serpentiginosa de los trayectos vasculares en los lóbulos temporales y cerebelosos de predominio izquierdo (Figs. 1c y $1 \mathrm{~d}$ ).

(5.ESP_Neurología_A)

(29) Durant l'ingrés es va completar l'estudi amb RM cerebral i aquesta va revelar àrees hiperintenses en les seqüències FLAIR, T2 i DWI que involucraven principalment les àrees frontal, temporal i parasagital esquerres i en menor extensió, el còrtex temporal dret i la substància blanca subcortical, sense observar-se restricció de la difusió en la seqüència $A D C$ (Figura 1$)$.

(25.CAT_Neurologia)

Aquest tipus d'expressions van un pas més enllà de l'ús de la veu passiva (Anspach 1988: 368), ja que no sols no s'hi menciona la persona a qui es fan els procediments diagnòstics ni qui els realitza, sinó que també s'hi ometen les referències als complicats processos pels quals s'interpreten els resultats d'aquestes proves (27-29). S'hi tracta, per tant, la tecnologia mèdica com si fos l'agent de l'acció. D'altra banda, l'ús dels mots mostrar i revelar - en qualsevol dels temps verbals i en cadascuna de les tres llengües analitzades - suggereix que la informació rebuda de les proves va ser obtinguda per un procés de revelació científica, sense possibilitat d'una interpretació equívoca. Així, aquestes formulacions donen a entendre una visió en la qual els instruments són els que generen i revelen les dades, com si no hi intervinguessin les persones.

En conjunt, els tres mecanismes que observa Anspach i que constatem en el nostre corpus de CC tendeixen a mitigar la responsabilitat del personal sanitari sobre els judicis 
emesos i les decisions preses, com també serveixen per afermar la credibilitat dels resultats que s'hi presenten. Contribueixen, a més, a la integració d'autors i lectors dins d'una comunitat de pràctica que està en construcció permanent, tot familiaritzant-los amb «a culture or world view which may contradict the explicit tenets of medical education» (Anspach, 1988: 357).

Hem vist, doncs, com les convencions del gènere dels CC inclouen una sèrie de mecanismes per minimitzar la identitat del pacient i de la seva experiència subjectiva. El mateix passa amb els professionals sanitaris, els quals en molts casos quasi desapareixen - des del punt de vista lingüístic i textual- com a agents de les històries. Ara bé, no tots els CC intenten amagar la presència del pacient amb la mateixa intensitat. Observem que gran part dels CC neurològics, els quals se centren sobretot en informacions fisiològiques i proves biomèdiques (30), són bastant sistemàtics en l'omissió tant dels pacients com dels metges que realitzen les proves. En canvi, en bona part dels CC de psicologia, de psiquiatria o dels que tracten problemes relacionats amb la síndrome de Down, l'entrevista i les informacions obtingudes del pacient - o dels familiars - són molt més rellevants (31). Per això els pacients d'aquests casos són també més presents textualment, ja que freqüentment s'hi tracta, més que un símptoma o un mal físic, uns comportaments i un mal psíquic. En els exemples 30 i 31 observem una clara diferència, òbviament molt marcada pel tipus de problema que s'hi tracta. En un cas s'ha de resoldre mitjançant una operació quirúrgica i en l'altre per mitjà de la psicoteràpia. Així que, en casos com el segon, resulta molt normal que els autors facin referències a l'estat d'ànims dels pacients, ja que és una part inherent al que tracten. D'aquesta manera, és la naturalesa de la disciplina la que permet - o exigeix, podríem dir- humanitzar els malalts. Sempre parlem, però, d'una tendència i no d'una regla en cada disciplina, ja que també disposem de CC, per exemple, de psiquiatria (32) en els quals el tractament del pacient és més paregut al primer exemple.

(30) Biopsy of the right vocal cord with histopathological examination of squamous cell carcinoma was performed in September 2013. In October 2013, rightsided cordectomy was performed. Subsequently, CT-PET (computed positrone emission tomography) showed increased metabolism of flourine-deoxyglucose in the glottic, subglottic and sacral regions (Fig. 1).

(7.ENG_Neurology_A) 
(31) El tractament s'interromp durant les vacances. Torna després d'haver passat un bon estiu: està simpàtica, s'endreça més i diu que la seva nina es diu Rubí. "És guapa, preciosa. Jugo amb ella a papa i mama. F. és el pare i jo la mare." A la pregunta de si ha pensat en tenir un fill amb F. quan la besa, respon que sí. "Ara que estàs millor potser puguis parlar d'allò que et feia tanta por." "Sí, m'anaven a tallar una cosa de l'estómac." "Quina cosa?" “No ho sé. Un bebè o les cames (fantasia d'embaràs i de castració), i tenia molta por." "Potser el que t'anaven a tallar era la possibilitat de tenir un bebè." "Sí, i tenia por. Mai més no ho tornaré a fer."

(6.CAT_Down)

(32) Paciente ELR masculino de 13 años de edad con antecedentes familiares y personales de salud anterior que acude a consulta por parpadear intermitentemente y emitir un sonido raro de forma involuntaria. Al examen físico se constatan aumento del parpadeo de forma intermitente así como la emisión de sonidos guturales de forma involuntaria. Se interconsulta el caso con el especialista en pediatría, el cual coincide en el diagnóstico y lo remite al especialista en neurología corroborándose el mismo.

(26.ESP_Psiquiatría)

En l'apartat 2.1 hem avançat que els CC que contenen més seqüències textuals narratives solen parlar molt més de la vida i de l'experiència de la malaltia del pacient. Així, podem veure una correlació entre la presència del pacient en el cas clínic i la rellevància de les seqüències narratives. Com més s'hi narra, més presència hi té el malalt, ja que les altres seqüències pertanyen més als apartats que se centren en la malaltia, els símptomes, les proves, etc., sovint de la manera despersonalitzada que hem anat exposant. El que observem, doncs, és que en alguns CC acadèmics els pacients esdevenen uns personatges plens i s'assemblen molt a alguns dels protagonistes dels CC literaturitzats, els quals, al seu torn, comparteixen característiques amb gèneres purament literaris, com ara els contes. Però fins i tot en els casos en què s'intenta difuminar al màxim el pacient els hem de considerar personatges, encara que siguin uns personatges desdibuixats als quals s'intenti regatejar el protagonisme essencial que tenen dins de la història.

De fet, en la presentació dels pacients en els CC acadèmics podríem veure una analogia amb la presentació dels personatges en els textos teatrals. Pensem en les acotacions inicials de les obres dramàtiques, que contenen una descripció quasi esquemàtica dels personatges que podem comparar a les que es fan en els CC: 
home/dona, anys, malalties conegudes o antecedents... Aquestes dades identificatives, certament, no tenen la mateixa finalitat en el CC que en un text literari, però als lectors ens poden servir per imaginar millor a qui li estan passant els esdeveniments. Per exemple, si sabem d'un pacient que és un home que té 70 anys, d'origen asiàtic, podem començar a construir-lo imaginant-nos-en la cara arrugada, el cabell que pressuposem Ilis i canós, la probable condició de jubilat, etc.

En els textos literaris habitualment trobem descripcions detallades dels personatges. Més important que l'edat exacta són altres característiques i atributs: la roba, el comportament, la ubicació dins d'una classe social, en un àmbit laboral o familiar, etc. Tota aquesta informació fa que cada lector s'imagini el personatge d'una manera molt personal, molt seva. De fet, quan els llibres passen a ser pel·lícules, aquesta visió personal dels lectors dels textos -i posteriors espectadors - xoca amb la recreació visual que se $n^{\prime}$ ha fet al film. Al contrari, els que primer veuen la pel-lícula i després llegeixen el llibre normalment perden la possibilitat de desenvolupar lliurement una imatge dels personatges, ja que estan sota la influència del que ja han vist.

En els CC acadèmics, l'essència de compartir les informacions que hem après en els exemples sobre els pacients és poder-les comparar amb altres estudis o integrar-les en anàlisis estadístiques, procediments que podrien revelar la importància prèviament no reconeguda de les dades, com ara l'aparició d'una determinada malaltia entre persones d'un grup d'edat específic, d'un determinat origen ètnic o d'un àmbit laboral concret (Helán, 2012). Així i tot, aquest ús per part dels professionals sanitaris de categories abstractes predefinides en què es classifiquen els pacients en poden comportar la deshumanització:

Instead, they [physicians] often reduce persons to patients or even to instances of diseases and ignore many of the particularities that make each person's illness unique. We hear a person pigeonholed as an "obese black female, diabetic with hypertension" and immediately assume that she has poor health habits, is uneducated, passive, and not motivated to lose weight. Abstract language, used exclusively, abstracts the person out of the case. (Monroe et al., 1992: 49)

Actualment, però, ja no trobem només aquest tipus de casos que tracten malalties i no malalts, sinó que també es publiquen CC en els quals s'opta per introduir el pacient 
d'una manera més humanitzada. Els professionals sanitaris no deixen de ser investigadors científics i, com qualsevol comunitat de pràctica especialitzada, tendeixen a tenir les seves barreres i requisits que de vegades s'imposen ells mateixos. En molts textos de l'àmbit sanitari, com els casos clínics acadèmics, detectem una tendència a objectivar al màxim totes les dades. L'aportació especialment valuosa que pot fer un gènere com els CC rau precisament en la possibilitat d'orientar-se a un o uns quants pacients d'una manera més individualitzada, més personal, ja que, a diferència de molts altres estudis mèdics, no es basa primordialment en dades quantitatives. Així, en aquests textos és on els professionals de la salut haurien de prestar més atenció a allò que és únic i resistir la temptació de definir els pacients com a casos de categories de malalties.

Les històries individuals i, fins i tot, el caràcter, la personalitat i el comportament dels malalts han de formar part dels casos clínics i ser així reconeguts com a rellevants. D'aquesta manera, incloure les observacions i narracions sobre i del pacient aporta dades que altres estudis no poden revelar i és convenient per a l'atenció sanitària moderna. Aquestes dades són, òbviament, particulars i, per tant, majoritàriament no quantificables, però aquest fet — com ja s'ha insistit des del àmbit mateix de la medicina (Jenicek, 2001 i 2018) - no fa que els CC perdin validesa objectiva.

Segons Monroe et al. (1992), un CC no hauria d'excloure determinades dades només perquè l'autor tingui por o senti que no està fent un treball científic, professional i objectiu. A més de no extreure la persona del text, no despersonalitzar-lo i tenir-hi més respecte, aquest enfocament també pot millorar el resultat per al pacient. Així, en els CC acadèmics no necessàriament s'han d'eliminar informacions com ara el comportament del malalt respecte del professional i del tractament, les seves actituds, les creences, els desitjos i les expectatives, entre moltes altres. Òbviament, aquestes informacions s'han de proporcionar sense ironia ni menyspreu cap al pacient. Els autors citats més avall ens il-lustren un exemple de per què un CC és l'espai ideal on tenir en compte els aspectes esmentats:

Consider the case of a man with groin pain who believes that his illness is a punishment from God for committing adultery. His version of the etiology, however unscientific, will almost certainly play a role in his recovery. Therefore, his beliefs and his narrative ought to be included, 
without condescension, in the case report. Many physicians exclude beliefs they regard as superstitions when rendering an illness; instead of describing the illness of a particular person, they use pseudoscientific, abstract-as-concrete language to shape and define the patient. (Monroe et al., 1992: 49)

En el nostre corpus trobem CC amb caracteritzacions com les que hem vist més amunt, amb molt poca informació personal sobre uns pacients despersonalitzats (exemple 33) i moltes dades sobre els seu cos, però també altres CC més humanitzats, que desvelen més sobre els malalts (exemples 34-37). No hi ha dues categories estrictament definides, sinó més aviat tendències cap a un costat més despersonalitzat, més merament descriptiu, i cap a l’altre més narratiu i més humanitzat.

(33) M.M. is a high functioning child with ASD (American Psychiatric Association, 2013) who came to consultation in a clinical center on developmental disabilities when he was 8 years and 10 months and was diagnosed with Asperger Syndrome based on DSM IVTR (American Psychiatric Association, 2000) criteria.

(25.ENG_Psychology)

(34) Daniel M. C. tiene 13 años y ha sido un buen estudiante hasta hace 1 año. Desde entonces sus profesores comentan que se encuentra muy distraído y parece "ausente", quedándose dormido algunas veces en clase. Un día su tutora le pregunta si ha dormido bien y Dani responde que sí pero, habitualmente, cuesta quedarse dormido por la noche.

(23.ESP_Adolescencia)

(35) Sarah was a 3-year-old Italian child who was referred by her parents. Sarah came from an intact family with middle socioeconomic status. Her mother had graduated and worked as an employer; her father was a teacher at an elementary school. They came from intact families and did not report any specific traumatic events in their life.

(26.ENG_Psychology)

(36) This case pertains to a 32-year-old woman, referred to as Susan (a pseudonym), who had a lifelong history of anxiety and depression, had been in the health system since early adulthood and was described as a treatment resistant case by the general 
practitioner who referred her. Susan gave full informed consent to the writing of this article.

(27.ENG_Psychology)

(37) L'Ignasi: Va iniciar el grup amb 4 anys i pocs mesos. Era un nen despert, amb bones capacitats mentals. Reclamava intensament l'atenció de les terapeutes i dels seus companys, necessitant ser mirat contínuament. Feia poc contacte ocular i li costava acceptar les propostes dels altres. Mantenia una expressió seria, d'empipament, amb poc control de les pulsions agressives, que reflectia un malestar intern molt important.

(32.CAT_Atenció_precoç)

Com veiem en els exemples anteriors, emprar el nom o un pseudònim pot conservar l'anonimat del pacient $\mathrm{i}$, al mateix temps, ajudar a no despersonalitzar tant el cas, si ho contrastem amb l'opció de dir pacient, dona de 40 anys... Ara bé, no es tracta únicament de no deixar el malalt sense nom, sinó també de no reduir-lo ja des de les primeres oracions a uns trets tan generals com són el sexe, l'edat, la raça o el pes. Es tracta d'aportar detalls que no desvelin necessàriament la identitat, però que facin que l'home de 50 anys mantingui la naturalesa de persona per al lector.

Evidentment, hi ha especialitats en les quals és més fàcil fer aquest tipus de presentació del pacient, ja que centrar-se en aspectes més personals o socials forma part de l'especialitat sanitària: és el cas de la psicologia i de l'atenció a la millora de la qualitat de vida de les persones afectades per alguna afecció crònica, com per exemple, la síndrome de Down. En canvi, la major part dels nostres CC de neurologia se centren en aspectes en els quals les intervencions i el diagnòstic no depenen majoritàriament del que diu el malalt ni com és ni per quines situacions ha hagut de passar, sinó que són molt fisiològics, centrats en dades i proves mèdiques en què la intervenció del pacient es considera negligible.

\subsection{Els espais com a instrument de caracterització}

En qualsevol relat, la descripció dels espais pels quals es mou un personatge determinat ajuda els lectors a entendre'l millor: els espais contribueixen a caracteritzar els personatges. Bona part dels CC, com hem vist, presenten els pacients d'una manera 
austera. Se'ns hi comunica l'edat, el sexe i algunes vegades la raça. La caracterització, més que no pas a través dels trets personals del malalt, es fa mitjançant els detalls relacionats amb la malaltia: els antecedents, els símptomes i els tractaments. En coherència amb aquests trets discursius, aquests CC tendeixen també a una omissió completa o gairebé completa dels espais en els quals es desenvolupen les accions. S'hi mencionen quasi exclusivament quan tenen o podrien tenir alguna rellevància per al cas clínic, per exemple per al diagnòstic (exemple 38). Ens trobem, per tant, amb uns relats en els quals s'intenta narrar només allò estrictament pertinent i que tendeixen a ometre o minimitzar qualsevol circumstància que no sigui significativa per al diagnòstic o per al tractament de la malaltia.

(38) Refereix manca de destresa amb les mans, més enllà del tremolor, que li dificulta fer tasques motores fines. És enginyer, i nota lleus dificultats pel càlcul i per mantenir l'atenció. Fa 3-4 mesos nota sensació de desequilibri quan camina per la muntanya, al pujar escales, o si hi ha molta gent al carrer. No ha patit caigudes, però la inseguretat al caminar és el que li ha portat a consultar al metge.

(24.CAT_Neurologia)

Aquesta mena de CC, doncs, es desenvolupa com una narració dels símptomes i de les teràpies, on els espais es difuminen o fins i tot desapareixen. En aquests relats, doncs, se'ns presenten uns personatges que el lector sovint té dificultats per a ubicar espacialment. Els espais als quals s'hi fa referència majoritàriament són les instal·lacions sanitàries en les quals es fan les proves biomèdiques (exemple 39).

(39) Ingressa a un hospital comarcal per quadre d'abdominàlgia i estrenyiment, amb exploració física anodina, TC abdominal que descarta patologia intrabdominal aguda, i destacant a l’analítica anèmia macrocítica, augment de bilirubina, alteració del perfil hepàtic i hiponatrèmia.

(22.CAT_Neurologia)

Aquests espais, però, tampoc no vénen acompanyats de descripcions que els acostin als lectors. Es tracta d'unes referències escarides a través de les quals el lector, aplicant-hi la pròpia imaginació, haurà d'evocar els espais referits, ja que no en disposa 
de cap descripció. Per als autors, serien dades innecessàries, ja que no serveixen per al diagnòstic. A més a més, els destinataris dels textos són els seus col·legues, que coneixen massa bé com són aquestes instal·lacions. Els espais, aquí, no ens ajuden a conèixer millor com és el pacient, sinó per quin tractament ha hagut de passar per la seva malaltia.

(40) Home de 27 anys amb SD, que va acudir al servei d'urgències de l'hospital per cefalea, vòmits i hemiparèsia esquerra. A l'exploració física era conscient, orientat, col·laborador, i tenia una pressió arterial de $150 / 75 \mathrm{mmHg}$, una freqüència cardíaca de 68 ppm i no presentava febre.

(10.CAT_Down)

La parquedat dels autors d'aquests CC en les referències espacials és proporcional, en definitiva, a la intenció d'ometre les referències a la personalitat dels pacients. Ara bé, ja hem avançat que constatem almenys dos estils diferenciats en els $\mathrm{CC}$, pel que fa tant al tractament dels pacients com dels espais. Detectem, per tant, que el primer enfocament, representat sovint en els CC de neurologia, se centra més aviat en la descripció de la simptomatologia física i en aspectes de l'anatomia interna, com també en xifres de determinades substàncies trobades a la sang. Hi trobem una tendència a fer desaparèixer el màxim possible d'informacions personals dels pacients $\mathrm{i}$ així assolir el nivell d'objectivitat que s'espera dels textos científics. El distanciament respecte d'aspectes personals i la pressuposada objectivitat es conjuminen amb la hipertecnicitat de la terminologia emprada, en uns textos en què l'espai queda reduït a les meres referències a un servei o una unitat d'un hospital o d'una clínica especialitzada (exemple 41).

(41) Posteriorment la pacient ha tingut seguiment ambulatori a CCEE de Neurologia, Cardiologia, Oftalmologia, Hematologia i Medicina Interna.

[...]

Actualment la pacient continua el seguiment a cardiologia a la unitat de miocardiopaties donada la existència d'una miocardiopatia obstructiva severa.

$[\ldots]$ 
Al març del 2015, el pacient ingressa al servei de Neurologia, des d'urgències per cefalea intensa frontal de 4 dies d'evolució, amb empitjorament nocturn, acompanyada de sensació de mareig i hipoestèsia distal en extremitats esquerres.

(21.CAT_Neurologia)

Per contra, en altres CC, com els dedicats a l'atenció als pacients amb síndrome de Down, trobem enfocaments més centrats en les persones i en la manera com, tant elles com el seu entorn social, s'encaren amb la malaltia. En aquests textos se'ns proporciona més informació personal, sobre problemàtiques socials, fins i tot sobre aspectes com ara la sexualitat o el matrimoni. L'especialització de la revista que publica aquestes històries clíniques, conjuntament amb el fet que parlem de CC que no pretenen cercar un utòpic guariment de la síndrome, sinó abordar altres malalties o problemes que poden afectar les persones amb aquesta condició crònica, fan que els autors se centrin molt més en la manera com es veu afectada la vida i la identitat dels pacients (exemple 42).

(42) El casament va ser normal, com el de una parella qualsevol. Es van casar en una cerimònia religiosa i es van traslladar a casa de la família materna, on es dividien les tasques i aportaven una contribució econòmica.

Era comunicativa, agradable i simpàtica. Va fer fins al 6è curs de Primària en una escola ordinària i després, a l'institut, va dividir l'horari entre l'educació ordinària i l'educació especial (2 dies a la setmana). L'entrada a l'escola especial l'enfronta amb la discapacitat: "no m'agraden els de l'escola perquè estan malament», manifestant un rebuig important de la síndrome.

(9.CAT_Down)

Més que descripcions dels llocs, aquests CC ens ofereixen unes pinzellades sòbries que ens permeten evocar els espais. Novament ens hem d'imaginar com són, però ja no es tracta d'espais clínics asèptics, sinó d'entorns quotidians, propers a l'experiència vital de qualsevol lector. Els espais hi serveixen per contextualitzar una evolució en la vida del malalt. Així, per exemple, tenim el cas d'una noia amb síndrome de Down que pateix un episodi psicòtic abans d'una operació de lligadura de trompes (exemple 43). Podem veure-hi que els espais com ara la universitat o el taller signifiquen la tornada a la 
normalitat d'aquesta noia: encara que rebutgi la seva condició, la pacient accepta l'operació i es veu capaç de seguir una vida normal tant en l'àmbit educatiu com en la feina.

(43) Apareixen idees delirants relacionades amb la seva sexualitat i embaràs: sota el seu Ilit hi ha una dona que vol fer-li mal. Es tracta de la mare del protagonista d'una sèrie de la televisió del qual n'està enamorada.

$[\ldots]$

Així mateix, totes les seves companyes es sotmeten a una operació de lligadura de trompes i es programa que la pacient també s'hi sotmeti, però no arriben a dur-la a terme perquè agafa una depressió. La pacient explica que les persones amb SD tenen un cromosoma de més, però que no són ximples malgrat les seves limitacions. Renega de ser com és i vol anar a la universitat.

[...]

Respon bé als tractaments: accepta rentar-se les dents (no ho feia des de feia mesos) i a dormir en el seu llit. A poc a poc es reincorpora al taller, però no vol veure les seves amigues i insisteix que caminarà bé quan s'operi. Accepta dutxar-se i també va remetent l'agressivitat i el rebuig cap al pare.

(6.CAT_Down)

Des d'un punt de vista canònic, doncs, els CC procuren la supressió dels trets identitaris dels malalts per assegurar-ne l'anonimat i la validesa de les conclusions més enllà del cas concret. En consonància, i a diferència del que s'esdevé en els relats literaris convencionals, tendeixen també a l'omissió completa o quasi completa dels espais en què es desenvolupen les accions. Hem pogut observar que, efectivament, hi ha CC notablement els de neurologia-que centren l'atenció quasi exclusivament en allò considerat objectivable: la descripció dels símptomes, de les proves i dels resultats. Els espais, com també la identitat del malalt, s'hi difuminen i de vegades s'hi genera la sensació que els processos biològics es poden separar de les persones que els experimenten i de les seves circumstàncies vitals i espacials. En els casos prototípics de neurologia, els personatges i els espais estan molt més esquematitzats que en altres que també trobem en el nostre corpus, en els quals sí que apareixen més referències sobre els pacients i els espais pels quals es mouen i condicionen les seves vides, les malalties i, per descomptat, les identitats. Aquest seria el cas dels CC dedicats a l'atenció a les 
persones amb síndrome de Down. En molts d'aquest textos, a banda de tractar complicacions fisiològiques o psíquiques relacionades amb la síndrome, els autors també dediquen l'atenció a les circumstàncies i als espais en els quals s'esdevenen.

Després de revisar de quina manera es tracta la identitat dels pacients i els espais i com aquests dos factors es correlacionen, podem constatar que els CC són un gènere variat, que pot presentar característiques estilístiques molt diferents en funció dels autors, com també i sobretot segons l'especialitat sanitària en què s'inscriuen. Algunes especialitats, com la neurologia, es presten a la consolidació d'un estil més asèptic, amb una alta càrrega de terminologia hiperespecialitzada. Els CC d'aquesta especialitat són uns textos amb poques probabilitats de difusió fora de la comunitat de pràctica i on, per tant, els aspectes socials i la personalitat del pacient -inclosos els espaisdesapareixen quasi completament. En canvi, altres casos clínics com ara, per exemple, els relacionats amb la síndrome de Down, generats en una comunitat on -poc o moltparticipen els familiars dels pacients, són més susceptibles d'adoptar un enfocament més humanitzat, on el pacient no és un conjunt de símptomes i dades fisiològiques, sinó una persona amb necessitats, relacions socials i uns espais per on transcorre la seva vida.

\subsection{Els pacients en els contes clínics}

El tractament dels pacients en els contes clínics no pot ser el mateix que en els casos clínics, atès que els propòsits comunicatius dels dos gèneres són ben diferents. En els CC acadèmics, el pacient serveix al professional de la salut com a exemple de la seva tasca mèdica, del seu descobriment d'alguna novetat. És clar que els especialistes no llegeixen les històries clíniques només per investigar, sinó també per curiositat, plaer o compromisos, però les motivacions principals que fan que un lector - prototípicament, un altre professional sanitari- s'interessi per un CC acadèmic i no deixi de llegir-lo sovint es relacionen amb la recerca d'informació, com per exemple la reacció a un fàrmac determinat, la diagnosi d'una malaltia... En canvi, en els CC literaturitzats, el pacient té un paper molt més important i central, ja que és el personatge amb qui l'autor vol que 
empatitzin el lectors. És un dels elements clau que fan que el lector continuï llegint i que s'endinsi en la història.

En els CC literaturitzats del nostre corpus, poques vegades hi trobem pacients introduïts sense cap nom o amb fórmules del tipus «dona de 43 anys», com succeeix en els CC acadèmics. La tendència dels autors que analitzem és usar un pseudònim o malnom. Entre els quatre llibre de contes clínics també hi ha algunes diferències. En el llibre de Ropper i Burrell se'ns diu que han contat els esdeveniments més o menys com han passat i no queda del tot clar si els noms han estat canviats per conservar l'anonimat dels malalts. Aquests hi reben per regla general nom i cognom (44a), encara que en algun cas els autors ens presenten primer una tal senyora «Mrs. G», de la qual pàgines més endavant se'ns revela el nom complet - Sofia Gyftopoulos. En el text de Yalom, s'avisa els lectors que tots els noms, les característiques $\mathrm{i}$ altres detalls han estat canviats. S'hi refereix als personatges exclusivament amb el nom de pila (44b). També Frost i Steketee, en les seves històries centrades exclusivament en la síndrome d'acumulació compulsiva, fan referència als personatges com en el cas anterior, amb el nom de pila (44c). Novament, en el text apareix que els noms han estat canviats per protegir els pacients. En aquests tres casos, l'única cosa que ens pots desvelar el nom sense altres característiques és la procedència del personatge. Pensem que «Carlos» es diu així perquè el pacient real que representa era un home d'origen hispànic, "Cindy Song» una dona amb arrels coreanes i «Sofia Gyftopoulos» era una senyora grega o d'antecedents grecs. Finalment, en el llibre d'Oliver Sacks, veiem una estratègia molt més variada a l'hora d'anomenar els personatges (44d).

(44)
a) Cindy Song, Arwen Cleary, Mrs. G (més endavant «Mrs. G was Sofia Gyftopoulos»)
b) Thelma, Carlos, Penny
c) Irene, Billie, Bernadette
d) Dr P., Christina, young man, Madeleine J., a sailor, Mr MacGregor, Mrs S.

En tot cas, els noms que empra Sacks sempre estan modificats, però mirant de transmetre-hi la personalitat dels pacients: 
As in Awakenings, names and some circumstantial details have been changed for reasons of personal and professional confidence, but my aim has been to preserve the essential 'feeling' of their lives.

(A.LIT_Sacks)

Sacks és l'únic autor que en alguns casos evita posar als seus personatges un nom de pila o cognom - encara que sigui alterat- i s'hi refereix, per exemple, com a young man o a sailor. Sol fer-ho bé quan introdueix un segon pacient dins d'una història, per esmentar un cas que té alguna relació amb el personatge principal, sense entrar en gaires detalls, bé en històries breus o parts d'històries que no tenen una trama tan complexa i serveixen més aviats com minicontes il-lustratius de determinats fenòmens neurològics:

(45) Phantom Finger

A sailor accidentally cut off his right index finger. For forty years afterwards he was plagued by an intrusive phantom of the finger rigidly extended, as it was when cut off. Whenever he moved his hand toward his face-for example, to eat or to scratch his nose- he was afraid that this phantom finger would poke his eye out. (He knew this to be impossible, but the feeling was irresistible.) He then developed severe sensory diabetic neuropathy and lost all sensation of even having any fingers. The phantom finger disappeared too.

It is well known that a central pathological disorder, such as a sensory stroke, can 'cure' a phantom. How often does a peripheral pathological disorder have the same effect?

(6.LIT_Sacks)

Cal recordar que, mentre que els CC acadèmics segueixen estructures formalitzades relativament rígides, els CC literaturitzats disposen de més flexibilitat. Així doncs, també la introducció del pacient en la història es pot esdevenir en punts diferents: en alguns casos apareix des del principi, en altres al mig. En el nostre corpus hem comprovat, a més, que la història d'un mateix pacient es pot narrar al llarg de diversos capítols, barrejada amb altres històries vitals. Les diferències, però, van més enllà de l'ús o no d'un nom, de l'estructura o del punt del text on es presenta els pacients, i s'estenen a quines informacions se'ns desvelen del malalt i amb quins recursos lèxics i estilístics. Els 
autors d'aquest gènere aprofiten l'ampli marge de maniobra que els permeten les convencions literàries per emprar-hi mecanismes que reforcen la intriga i l'interès per la història que s'hi conta.

Així, en l'exemple (46) tenim una presentació d'un pacient radicalment allunyada de la que esperaríem trobar en un CC acadèmic, en la qual Oliver Sacks narra en primera persona com va ser la primera cita. La diferència la veiem des del principi, ja que no hi trobem la prototípica presentació en primera línia (home de 93 anys d'edat acudeix a...), sinó que les dades biogràfiques del malalt apareixen a poc a poc, barrejades amb altres de caire més personal. Perquè els lectors entenguin quin problema té el senyor MacGregor i de quina manera fa el diagnòstic el doctor Sacks, s'empra el diàleg entre ells dos. Aquest recurs, que apareix en molt pocs CC acadèmics i que és més propi del discurs literari, dóna la veu als pacients, contribueix a construir-ne els personatges i proporciona dinamisme a la història.

(46) It is nine years now since I met Mr MacGregor, in the neurology clinic of St. Dunstan's, an old-people's home where I once worked, but I remember him-I see him-as if it were yesterday.

'What's the problem?' I asked, as he tilted in.

'Problem? No problem-none that I know of ... But others keep telling me I lean to the side: "You're like the Leaning Tower of Pisa," they say. "A bit more tilt, and you'll topple right over."

'But you don't feel any tilt?'

'I feel fine. I don't know what they mean. How could I be tilted without knowing I was?'

'It sounds a queer business,' I agreed. 'Let's have a look. I'd like to see you stand and take a little stroll-just from here to that wall and back. I want to see for myself, and I want you to see too. We'll take a videotape of you walking and play it right back.'

'Suits me, Doc,' he said, and, after a couple of lunges, stood up. What a fine old chap, I thought. Ninety-three-and he doesn't look a day past seventy. Alert, bright as a button. Good for a hundred. And strong as a coal-heaver, even if he does have Parkinson's disease. He was walking, now, confidently, swiftly, but canted over, improbably, a good twenty degrees, his centre of gravity way off to the left, maintaining his balance by the narrowest possible margin.

(7.LIT_Sacks) 
És notori que Oliver Sacks és un escriptor summament creatiu, de manera que les seves presentacions dels pacients en els diversos contes clínics no són iguals, sinó que varien força. En el fragment anterior n'hem vist una de ben allunyada dels CC acadèmics, però en algunes ocasions recorre també a presentacions més lineals, similars a les que podríem trobar en un CC acadèmic (47 i 48).

(47) Christina was a strapping young woman of twenty-seven, given to hockey and riding, self-assured, robust, in body and mind. She had two young children, and worked as a computer programmer at home. She was intelligent and cultivated, fond of the ballet, and of the Lakeland poets (but not, I would think, of Wittgenstein). She had an active, full life-had scarcely known a day's illness. Somewhat to her surprise, after an attack of abdominal pain, she was found to have gallstones, and removal of the gallbladder was advised.

(3.LIT_Sacks)

(48) Bhagawhandi P., an Indian girl of 19 with a malignant brain tumor, was admitted to our hospice in 1978. The tumor-an astrocytoma-had first presented when she was seven, but was then of low malignancy, and well circumscribed, allowing a complete resection, and complete return of function, and allowing Bhagawhandi to return to normal life.

(17.LIT_Sacks)

En el fragment (47) observem una presentació més pareguda estructuralment a la dels CC literaturitzats, almenys molt més que en l'exemple anterior, que es basava en un diàleg. Ara bé, el recursos emprats per Sacks en aquest segon exemple tampoc no serien gaire propis d'un text mèdic prototípic. Fixem-nos que l'autor hi fa una sèrie de valoracions personals sobre el caràcter $\mathrm{i}$ els trets de la pacient «a strapping young woman», "robust, in body and mind», "She was intelligent and cultivated», etc. A més, entre guionets i parèntesis, Sacks afegeix comentaris encara més personals com ara «but not, I would think, of Wittgenstein» o descriu la reacció davant de la malaltia «Somewhat to her surprise...». En el fragment (48), en canvi, la presentació de la pacient podria semblar bastant asèptica per a un conte clínic. Però a continuació Sacks va canviant cap a un discurs més pròxim a la malalta (49). 
(49) She was, at first, remarkably cheerful, seeming to accept fully the fate which lay in store, but still eager to be with people and do things, enjoy and experience as long as she could. As the tumor inched forward to her temporal lobe and the decompression started to bulge (we put her on steroids to reduce cerebral edema) her seizures became more frequent-and stranger.

(17.LIT_Sacks)

Continua sent una història de temàtica neurològica, plena de termes i de descripcions tècniques, però fixem-nos que, a diferència del que podria succeir en un CC acadèmic, Sacks no recorre a les passives per dir que a la pacient «se li ha aplicat un determinat tractament o fet alguna prova», sinó que empra la primera persona del plural «we». A més, comenta l'estat d'ànims de la pacient, cosa que rarament trobem en els CC acadèmics.

Per acabar d'il/lustrar com juga Sacks amb la introducció dels seus pacient en la història, presentem el cas d'un artista autista, Jose (50), la història del qual comença de manera sobtada. Ens trobem en la cita dels dos ja començada i la primera oració del conte clínic és «dibuixa això». Aquesta manera brusca de submergir el lector en la història va acompanyada pel dibuix del rellotge de butxaca del doctor Sacks. L'autisme i altres afeccions mentals desperten curiositat en la societat i poques vegades els llecs tenim l'oportunitat d'observar les persones que les pateixen amb el comentari explicatiu d'un expert. El mateix ocorre amb els dibuixos: encara que per Internet puguem trobarne nombrosos exemples, si no sabem en quina situació es van dibuixar i un expert no ens explica què hi podem observar, la majoria dels profans no sabríem com interpretar les línies fetes amb el llapis. 


\section{The Autist Artist}

'Draw this,' I said, and gave Jose my pocket watch.

He was about 21 , said to be hopelessly retarded, and had earlier had one of the violent seizures from which he suffers. He was thin, fragile-looking.

His distraction, his restlessness, suddenly ceased. He took the watch carefully, as if it were a talisman or jewel, laid it before him, and stared at it in motionless concentration.
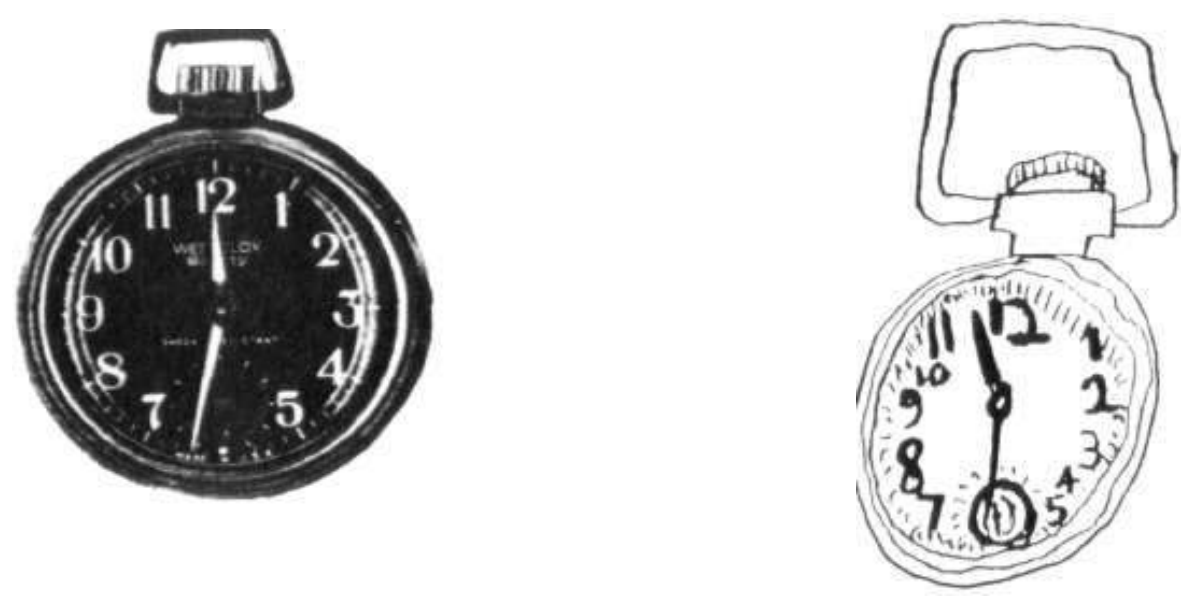

Veiem, doncs, que Sacks juga amb diferents maneres de presentar els seus pacients. Unes vegades els introdueix des del principi del conte clínic, unes altres ens conta abans una altra història o comença per l'explicació d'un trastorn o símptoma curiós que a continuació experimentarà el protagonista del cas. En tots els textos que n'hem analitzat, aquest autor combina hàbilment les seves competències com a professional de la neurologia amb el maneig dels nombrosos recursos literaris propis del gènere. Les històries no es converteixen mai en exemples d'afeccions il-lustrades en uns quants malalts despersonalitzats, sinó que el pacient hi té un lloc destacat, com a protagonista - podríem dir- principal, o almenys al mateix nivell del narrador.

En el Ilibre Reaching Down the Rabbit Hole, de Ropper i Burrell, cada capítol no es correspon amb un cas clínic. Els pacients van apareixent al llarg del llibre d'acord amb l'època en la qual van passar per l'hospital on treballa el doctor Ropper. En aquest text, per tant, els contes clínics dels diferents pacients s'entrellacen. Algunes vegades podem 
observar com els comparen, com dos d'aquests pacients es coneixen o com els autors van canviant del relat d'un pacient al d'un altre. A diferència de Sacks, aquest llibre ens ofereix una orientació temporal de tots els casos, almenys pel que fa a saber qui era a I'hospital abans, qui al mateix temps i hi ha pogut coincidir i qui després.

(51) By the time Vincent Talma and Cindy Song had settled in at the Brigham, Arwen Cleary had been there for four days. She came by ambulance on the morning of July 1 , and was admitted to neurological intensive care from the Emergency Department later that evening. Of the three cases, hers was the least clear-cut, the most troubling, and one that had the potential to become an absolute shambles. According to her medical records, her problems had begun two years earlier, when she showed up at a central Massachusetts hospital with disabling nausea, difficulty walking, and vomiting.

Arwen Cleary had been a professional figure skater as a teenager, had retired from the Ice Capades upon its dissolution in 1995, had then raised three children, gotten divorced, and moved with her two younger children to a ranch house in Leominster, a distant suburb, where she worked part-time at a local health club. Her medical history was unremarkable: once a smoker, she had quit ten years earlier. Her travels had taken her no place more exotic than Bermuda and no more distant than Orlando. Her only hospitalizations to that point had been in maternity wards. She was remarkably fit and in seemingly good cardiovascular health, if judged only by her appearance and vital signs. But shortly after a visit to a chiropractor, she had suffered a vertebral artery dissection, a form of stroke.

(1.LIT_Ropper)

Aquests autors tendeixen a introduir els personatges seguint l'esquema dels CC acadèmics. A més, s'hi infiltren expressions pròpies d'aquell gènere, com «was admitted to», "According to her medical records» $\mathrm{i}$ "Her medical history was unremarkable», barrejades amb informacions o observacions més característiques d'un estil o d'una vocació més literària, ja que entren en més detalls personals. Ara bé, tampoc en aquest cas no hi ha una única manera de presentar els pacients. A part de la que s'assemblaria més a un cas clínic, els autors n'empren una altra, més literària, més contística. Aquesta no comença per l'ingrés del malalt a l'hospital sinó per la situació en la qual es desencadena el problema que el porta a les instal-lacions sanitàries, com podem il.lustrar amb el cas de Vincent Talma (52): 
(52) On the third of July, a day after a routine colonoscopy, Vincent Talma was playing right field in a company softball game. A short, intense man with thick gray hair and a perpetual scowl, he did not look as though he was having fun, or even capable of having any fun. Whenever a teammate said something amusing or cracked a joke, Vincent would laugh without smiling, as if to say, "funny, funny, ha, ha." When he disagreed with a call by the umpire, he would throw up his arms in disbelief, kick the dirt, and swear under his breath, not for show or for the approbation of his teammates, but out of real anger and disgust. No one called him Vinnie, few called him Vince, and when he stood at the plate, none of his teammates dared to cheer him on by name.

As the game wound into the late innings, Vincent's behavior began to change, subtly at first, then dramatically. By the time he was dropped off at his house, his wife was startled to see a bemused look on his face, an air of innocence in place of his usual gruffness. He gave one-word answers to her questions, avoided eye contact, and seemed quite unlike himself. He was smiling too much.

"Are you okay?" she asked.

"Sure, fine," he replied.

“Did you win?"

"Fine, yes."

“Did something happen?"

"Fine."

The more she persisted, the more Vincent perseverated.

"Did anything happen at the game?"

"Fine, yeah fine," he mumbled with a sheepish smile.

She called their primary care physician, who told her to get him to the emergency room immediately.

(1.LIT_Ropper)

Aquesta presentació evoca un guió detectivesc, al principi del qual coneixem uns personatges a qui no passa res d'especial. Hi ha un ambient de tranquil.litat $\mathrm{i}$ es dediquen a coses de la vida quotidiana: en aquest cas, a jugar softball. I el focus de la càmera - o de l'escriptor, en el nostre cas - se centra en un determinat personatge, el qual comença a tenir un comportament que no és normal i la situació esdevé inquietant. En aquest punt de les històries detectivesques sol morir algú: o el personatge enfocat mor o troba un cadàver. Llavors el pla es fon a negre i en la següent escena ja apareix la policia o els forenses. En el nostre cas, veiem com el comportament de Vincent és cada vegada més estrany, fins que la seva dona truca al metge. Aquí és quan comença el CC 
de Vincent Talma i el doctor Ropper haurà d'esbrinar - quasi com un detectiu- què li ha passat.

En Love's Executioner and Other Tales of Psychotherapy, de Yalom, els contes clínics sí que es corresponen amb els capítols del llibre. Al principi de cada capítol se'ns introdueix el pacient que tractarà aquest psiquiatre. L'autor opta per presentacions amb l'objectiu palès d'enganxar el lector amb declaracions d'una honestedat potser exagerada i en uns termes sovint épatants. S'hi intenta xocar el lector perquè continuï llegint. En el capítol introductori d'aquesta tesi ja havíem mencionat el cas d'una senyora obesa i l'aversió de Yalom cap a ella, ja que troba el seu cos tan repulsiu que li costa, fins i tot, de mirar-la. Aquest, però, no és un cas ailllat. Yalom comença sovint la seva narració amb la demonització o ridiculització dels seus pacients (53). És el cas d'una dona que refereix mal d'amors per una relació amb el seu anterior psicoterapeuta. És aquí on les històries de Yalom divergeixen més dels CC acadèmics, ja que amb molta freqüència narra els pensaments que ell mateix tenia al cap durant la teràpia, pensaments segons ell no censurats i que comporten una humiliació dels pacients (54).

(53) Yet Thelma, in the opening minutes of our first interview, told me that she was hopelessly, tragically in love, and I never hesitated, not for one moment, to accept her for treatment. Everything I saw in my first glance-her wrinkled seventy-year-old face with that senile chin tremor, her thinning, bleached, unkempt yellow hair, her emaciated blue-veined hands-told me she had to be mistaken, that she could not be in love.

(1.LIT_Yalom)

(54) Though I had difficulty imagining this shabby old woman having an affair with her therapist, I had said nothing about not believing her. In fact, I had said nothing at all. I had tried to maintain complete objectivity but she must have noticed some evidence of disbelief, some small cue, perhaps a minuscule widening of my eyes. I decided not to protest her accusation that I did not believe her. This was no time for gallantry and there was something incongruous in the idea of a disheveled seventy-year-old infatuated, lovesick woman. She knew that, I knew it, and she knew I knew it. I soon learned that over the last twenty years she had been chronically depressed and in psychiatric treatment almost continuously.

(1.LIT_Yalom) 
Quan no és ell qui, en la seva exagerada sinceritat, malparla dels pacients, deixa que ho faci algun altre col·lega que col·labora amb ell, com en el cas probablement més controvertit de tot el Ilibre, «If Rape Were Legal...» (55). Amb aquesta introducció del pacient es crea una intensa intriga que s'anirà desplegant al llarg de la narració. Fixemnos que els detalls personals no hi figuren: I'únic de què disposem és el nom, que en aquest cas serveix per conèixer el sexe del pacient i pressuposar-ne una procedència hispana.

(55) "Your patient is a dumb shit and I told him so in the group last night-in just those words." Sarah, a young psychiatric resident, paused here and glared, daring me to criticize her. Obviously, something extraordinary had occurred.

$[\ldots]$

Struggling to keep her composure, Sarah began, "Carlos is the grossest, most despicable human being I have ever met! "

$[\ldots]$

Well, as you know, he's been generally obnoxious-sniffing the women as though he were a dog and they bitches in heat, and ignoring everything else that goes on in the group.

(2.LIT_Yalom)

Generalment, però, després d'una presentació que pot resultar ofensiva, massa rònega i freqüentment fins i tot deshumanitzadora, Yalom coneix els problemes dels seus pacients i aconsegueix empatitzar-hi i deixar de banda els prejudicis personals. Així, al Ilarg de les històries, observem com ell aprèn dels seus pacients, ja que també és simplement una persona normal que jutja els altres i sovint s'equivoca. Al final, no totes les històries acaben bé des del punt de vista de la salut del malalt, però sí que hi ha una tendència al final feliç quant a la relació amb el psicoterapeuta. Si no fos així, amb molta probabilitat no podríem llegir-ne el conte clínic, ja que el pacient en qüestió no hauria donat el permís per a la seva publicació.

Allò que diferencia aquest llibre de CC de psicoteràpia està estretament relacionat amb el caràcter de la seva especialització. El pacients reben aquí més espai per expressar-se, si ho comparem amb els dos llibres anteriors, que són de neurologia. És 
clar que aquí el centre d'atenció són els fets esdevinguts des del punt de vista del pacient, mentre que en altres especialitzacions el professional sanitari es pot permetre més llibertats a l'hora de resumir o ometre algunes parts de la història del malalt.

La darrera obra de contes clínics del nostre corpus, Stuff: Compulsive Hoarding and the Meaning of Things, de Frost i Steketee, se centra només en una síndrome concreta. En aquest llibre no hi ha una distribució clara entre CC i capítols. En alguns casos apareix un pacient el cas del qual s'explica en un sol capítol, però generalment el comparteix amb altres pacients que reapareixen al llarg del llibre. A diferència de les obres anteriors, en aquest text podem destacar un personatge-pacient principal. Es tracta d'Irene -ja n'havíem introduït una mica el cas en la descripció del corpus. És una pacient-exemple que Frost i Steketee trien com a cas prototípic i que els serveix per il-lustrar aquesta síndrome. Irene, per tant, és present en quasi tots els capítols i serveix de comparació i exemplificació de molts dels problemes que tenen els altres pacients.

Per la naturalesa del trastorn que s'hi aborda, en aquests contes clínics és particularment important l'espai en què habiten els pacients. Així doncs, són presentats juntament amb sa casa, fins al punt que sovint és més aviat la casa la que se'ns presenta (56). Fixem-nos que s'anteposa completament la descripció de la casa a la de Chris.

(56) Chris lived in a small bungalow on the edge of Berkeley, California.

Overgrown trees and shrubs hid her house from the street. Potted plants covered most of her porch. She had an eye for Persian rugs and hung them from ceiling to floor along her hallway. There were eight or nine of them on top of one another, narrowing the hallway by at least a foot and giving her home a cavelike feel. Goat paths threaded through the waist-high piles of books, clothes, magazines, and other stuff filling the house-certainly enough clutter to impair her quality of life. She told us her refrigerator had broken recently, but she couldn't remove it through the maze of stuff, nor could she get the new one in. So the new refrigerator ended up in the basement, adding one more inconvenience to her already complicated life.

Like so many of the people we've met, she was very intelligent. It was clear that she had read most of the hundreds of books that were strewn throughout her home. Chris was a nurse who had found me through an online hoarding support group, and we corresponded for quite a while before we met. Though she was a great resource for others, she had trouble controlling her own passion for collecting. 
"I have pioneered a method of spotting hoarder houses from the street," she wrote to me once. "I just drive slow and look for front yards that look like mine, a jungle of hundreds of plants. Porches are often full too." She offered to make a study of it, taking pictures and sneaking by when a door or window opened to get confirmation. "I estimate the incidence of $\mathrm{H}-\mathrm{C}$.

(4.LIT_Frost)

Ja hem vist com els espais poden esdevenir un instrument de caracterització dels pacients en els CC acadèmics (apartat 4.4 d'aquest capítol). En aquest llibre, com que es tracta de la síndrome d'acumulació compulsiva, els objectes que amunteguen els protagonistes són en realitat el seu món. Com ens expliquen al principi de l’obra, la gent que pateix aquesta síndrome generalment coneix cada fòtil que té apilat a casa $\mathrm{i}$ cadascun d'aquests objectes té un significat particular per a ells. Així doncs, per conèixer-los millor, també hem de percebre l'espai en què habiten. També és per això que els investigadors es veuen obligats a desplaçar-se per tots els Estats Units per poder visitar i entrevistar aquests malalts en els seus entorns i per analitzar-los.

En els quatre llibres podem observar, d'una banda i com resulta esperable en uns textos literaturitzats, estils diferents en cada autor, però també una sèrie de trets conjunts que fan que conformin un gènere, el dels contes clínics. En tots els textos veiem que no deixen de ser casos clínics. En la presentació dels pacients freqüentment detectem reminiscències del gènere dels $\mathrm{CC}$ acadèmics. Ara bé, aquesta presentació es fa amb una combinació de recursos procedents de l'àmbit especialitzat i que ens podríem trobar en un CC acadèmic, però també i sobretot amb recursos més aviat literaris i amb informacions no tan asèptiques i despersonalitzades sobre els pacients, el seu entorn social i els espais en què es mouen.

La caracterització dels pacients -és a dir la seva conversió en personatges- és més explícita en els CC literaturitzats. Per això hi observem una major freqüència en I'ús d'adjectius. S'hi empren tant per descriure la personalitat i el físic dels pacients com també les situacions en què apareixen implicats. A diferència dels CC acadèmics, aquí no es tracta d'adjectius purament descriptius amb un valor més o menys objectiu o almenys amb aquesta pretensió, sinó tot el contrari. En la descripció dels personatges, els autors usen els adjectius perquè els lectors notin i s'imaginin de quina manera veu el 
metge al pacient. Recuperem aquí dos fragments d'exemples citats anteriorment (57 i 58) on ja hem pogut observar la clara diferència entre el tractament de respecte $i$ admiració de Sacks cap a la pacient Christina (57) en contrast amb el distanciament i la sornegueria de Yalom.

(57) Christina was a strapping young woman of twenty-seven, given to hockey and riding, self-assured, robust, in body and mind.

(3.LIT_Sacks)

(58) Though I had difficulty imagining this shabby old woman having an affair with her therapist, I had said nothing about not believing her.

(1.LIT_Yalom)

N'afegim dos exemples més (59 i 60) per il-lustrar la riquesa de presentacions i recursos emprats en els CC literaturitzats. En l'exemple 59, reproduïm un fragment de la introducció del llibre Reaching Down the Rabbit Hole, en la qual se'ns introdueix el pacient Gary amb un to irònic que no hem detectat en els CC acadèmics. En el segon fragment (60), reproduïm una presentació del principi del conte The Lost Mariner, de Sacks, la qual podríem qualificar de molt subjectiva, ja que s'hi fan valoracions del físic i del caràcter del pacient. Òbviament, no totes aquestes informacions són indispensables per al diagnòstic - com solen ser-ho les facilitades en els CC acadèmics - i, per tant, l'objectiu aquí és ben diferent: crear una imatge del pacient al lector perquè aquest pugui empatitzar amb ell -en alguns casos perquè el pugui odiar o menysprear. Per provocar, al capdavall, les emocions que ajuden amb la continuació de la lectura.

(59) His name is Gary, and he is one unhappy customer. He is thirty-two years old and has spent more time in hospitals than he cares to recall.

$[\ldots]$

Gary is a computer programmer who has so immersed himself in Star Trek that he knows the Starship Design Specifications by heart. He has the body of a Buddha, the eyes of a koala, and an air of resignation that is probably his baseline. He might as well be wearing a T-shirt emblazoned with the motto: IT IS WHAT IT IS. He has had epilepsy since childhood, culminating in the surgical removal of part of his brain when he was seventeen years old. A U-shaped scar stands out prominently on the left side of his close- 
cropped scalp. He has enough experience with his condition to know when he needs to go to the hospital, although he would rather not go.

(A.LIT_Ropper)

(60) It immediately made me think of a patient of mine in whom these questions are precisely exemplified: charming, intelligent, memoryless Jimmie G., who was admitted to our Home for the Aged near New York City early in 1975, with a cryptic transfer note saying, 'Helpless, demented, confused and disoriented.'

$[\ldots]$

Jimmie was a fine-looking man, with a curly bush of grey hair, a healthy and handsome forty-nine-year-old. He was cheerful, friendly, and warm.

(2.LIT_Sacks)

Els humans som uns éssers complexos. Dins nostre, la racionalitat que dóna lloc a la ciència conviu amb les emocions, una capacitat ancestral que compartim amb altres animals i que ens permet processar grans volums de dades i prendre decisions ràpides $i$ intuïtives $-\mathrm{i}$, val a dir, sovint equivocades. Els textos literaris i, en general, la creació artística, apel-len a les emocions dels lectors d'una manera més eficient que la realitat documentada. I aquest és un dels seus objectius. Pensem ara en els telenotícies o els documentals en què podem veure imatges de guerres, genocidis, etc. Pocs de nosaltres ens posem a plorar en veure aquestes imatges, per crues que siguin -o precisament perquè són crues. En canvi, quantes vegades plorem llegint una novel·la o mirant una pel-lícula en què mor algun dels protagonistes, sabent racionalment que no és una mort real? Un bon relat, amb una tristesa ben construïda, sovint pot assolir un efecte emocional molt més intens que mostrar els cossos dels morts reals.

Així doncs, l'ús d'adjectius en els contes clínics, juntament amb altres recursos propis de la literatura, fan que la narració no sigui tan esquematitzada i telegràfica com s'esdevé en la majoria dels CC acadèmics. Les oracions solen ser més llargues i desenvolupades i millor entrellaçades entre elles. La progressió del text també és més fluïda si ho comparem amb alguns CC acadèmics que eren apartats quasi aïllats i reblerts de contingut. Cal recordar que l'extensió dels contes clínics no té límits preestablerts i s'hi sol centrar quasi tota l'atenció precisament en el personatge, i no tant a explicar les malalties i els processos curatius en seqüències expositives i descriptives, encara que aquestes tampoc no desapareixen del tot. 
En general, els CC literaturitzats ens proporcionen més informació personal, familiar i espacial sobre els protagonistes. Aquestes dades no són necessàriament pertinents per el diagnòstic, però ajuden els lectors a imaginar millor els personatges i contribueixen a crear-hi vincles emocionals. Aquest és un dels objectius del relat literari: crear una història amb una trama en la qual es pugui submergir el lector. Així, els personatges se'ns van presentant a poc a poc també en els contes clínics, sobretot quan es tracta d'històries més llargues o repartides entre diversos capítols. Els autors van subministrant aquests detalls sobre els personatges entre les dades clíniques, amb les quals no sempre tenen una relació directa. El que fan és humanitzar encara més el malalt. S'hi parla de la família, de la infantesa, dels lloc que els agrada visitar, de les activitats que acostumaven a practicar abans de la malaltia, etc. En alguns contes també es poden destapar alguns plats bruts per incrementar la curiositat dels lectors. Els personatges dels pacients, en definitiva, es van creant progressivament.

Com els pacients dels CC acadèmics, els personatges dels contes clínics també passen per proves i teràpies. Però com que aquests textos no són un material d'estudi, sinó lectures més o menys edificants però, al capdavall, d'entreteniment, quasi no hi apareixen xifres dels resultats de les proves. Els metges - els narradors- hi són molt presents i narren en primera persona com han realitzat les proves (exemple 61) o com les efectuen alguns dels membres de l'equip (exemple 62). També se centren en les reaccions dels seus pacients, en el procés de la prova o del que passa abans o després d'ella. Veiem com els metges expliquen als seus pacients quins procediments hauran de seguir i per què, com també quan els donen els resultats i les males o incertes notícies (exemple 63).

(61) By the time I came to do an EEG, she heard only occasional brief snatches of music, a dozen times, more or less, in the course of a day. After we had settled her and applied the electrodes to her head, I asked her to lie still, say nothing and not 'sing to herself, but to raise her right forefinger slightly-which in itself would not disturb the EEG-if she heard any of her songs as we recorded. In the course of a two hour recording, she raised her finger on three occasions, and each time she did this the EEG pens clattered, and transcribed spikes and sharp waves in the temporal lobes of the brain.

(15.LIT_Sacks) 
(62) The residents want to get her downstairs immediately for a CT scan and a CT angiogram to see if she's had a stroke. I suggest they may want to slow down and see what happens, but they feel the stroke issue has great time value. They prevail, and she heads off the floor to get a big dose of radiation. She'll be gone for a good hour.

(5.LIT_Ropper)

(63) 'What's the verdict?' Christina asked, with a faint voice and fainter smile, after we had checked her spinal fluid.

'You've got this inflammation, this neuritis ... ' we began, and told her all we knew. When we forgot something, or hedged, her clear questions brought us back.

'Will it get better?' she demanded. We looked at each other, and at her: 'We have no idea.'

(3.LIT_Sacks)

Probablement, una de les majors diferències dels contes clínics respecte dels CC acadèmics és poder veure-hi la comunicació entre el metge i el pacient, tant si és en estil indirecte - «l asked her to...»- com en indirecte lliure i en forma de diàlegs, molt habituals en CC literaturitzats (61). Aquest és un recurs molt freqüent en la narrativa literària, ja que permet dramatitzar la història, fer que avanci i que els lectors puguin conèixer millor la personalitat dels personatges. Els diàlegs ens permeten sentir la veu dels pacients i ens ajuden, com a lectors, a viure la història de més a prop. Els fragments dedicats al diagnòstic $o$ al tractament estan intensament lligats al pacient 0 , quan són exposicions més teòriques, se simplifiquen, s'escurcen i sovint esdevenen anècdotes, precisament per no avorrir el lector i no despenjar-lo de la història.

En els CC literaturitzats els pacients no són tractats, sinó que el metge els tracta. Al contrari del que s'esdevé en nombrosos CC acadèmics, aquí sovint els professionals sanitaris que en són els autors-narradors no dubten a penjar-se les medalles pels èxits aconseguits. Al capdavall, aquest tipus de llibres és el mitjà ideal per narrar els propis mèrits professionals i guanyar reconeixement també fora de la pròpia comunitat de pràctica. Podem dir que, a diferència del que constatem en alguns CC acadèmics, on es pot percebre una malaltia com un fenomen quasi aliè a l'individu que l'experimenta, aquí els autors intenten trobar un equilibri entre la malaltia i la persona. Encara que els casos individuals poden servir per il-lustrar les teories, la visió o el treball dels autors i professionals sanitaris, en major o menor mesura - segons cada text- també hi 
observem la voluntat de demostrar als lectors com és d'important escoltar primer el pacient i després posar-se a fer les proves pertinents, sempre combinant les dues facetes de la praxi sanitària: la humana i la tècnica. Veiem com cada cas - cada persona - pot ser únic i pot requerir un tractament personalitzat.

Hem cercat i trobat semblances, però també diferències, entre els contes clínics i els CC acadèmics. Recordem, però, que els CC acadèmics no són un bloc monolític. En el nostre corpus, com hem anat veient al llarg d'aquesta tesi, trobem una varietat d'enfocaments, des dels textualment més asèptics fins als que desenvolupen el relat fins a fregar un estil literari. Podem establir un contínuum que comença en els casos clínics més despersonalitzats -els més descriptius i els més carregats de dades biomèdiquesi acaba en els contes clínics més creatius i literaris, tot passant per diverses modalitats de CC acadèmics amb pretensions més humanitzadores.

Els contes clínics no deixen de ser una font d'informacions especialitzades dels àmbits d'exercici dels seus autors, però sense perdre de vista els protagonistes principals, els pacients, com en algunes ocasions passa en els CC acadèmics. Òbviament, no podem demanar als professionals sanitaris que converteixin els CC acadèmics en històries literaturitzades, però sí que en podrien aprendre a veure el pacient com una persona que prové d'un entorn familiar i social, que té unes característiques úniques, unes preocupacions, uns coneixements determinats, i que reacciona davant de la malaltia d'una manera molt concreta. En diversos CC acadèmics del nostre corpus hem vist que és possible fer una redacció que conservi l'anonimat, que compleixi amb els estàndards de redacció de textos especialitzats, però on el pacient no sembli una màquina que cal arreglar, un altre cos més que analitzem amb una sèries de proves i reparem amb uns medicaments o unes intervencions quirúrgiques.

Hem constatat que els contes clínics no tenen els mateixos propòsits comunicatius que els CC acadèmics, però tampoc no podem dir que siguin uns textos exclusivament d'entreteniment i que no serveixin per educar els futurs professionals ni per fer progressar l'atenció sanitària. Òbviament, no ho fan de la mateixa manera que els CC acadèmics. Però, si pensem en l'educació dels metges, hi ha CC literaturitzats en els quals els autors reconeixen els seus errors, potser per humilitat, potser perquè volen ajudar a humanitzar la professió mèdica o, precisament, perquè també volen animar els nous metges a fi que no tinguin por de reconèixer quan fan malament alguna cosa. 
Habitualment, els autors que decideixen narrar els casos de la seva praxi, solen tenir ja molta experiència en el món sanitari. Aquests metges, que s'han fet famosos per publicar fora del seu àmbit estricte, s'erigeixen en models per als que s'estan formant $\mathrm{i}$ per als que exerceixen. El valors i pensaments que intenten transmetre en els seus llibres poden resultar, per tant, molt importants per a la formació dels futurs professionals. Aquests textos poden obrir els ulls als qui comencen sobre quines són les qüestions criticades de la sanitat i dels comportaments dels metges, com també sobre quin seria el model ideal d'atenció sanitària cap al qual hauríem d'avançar. Així, un dels aspectes en els quals més s'insisteix en els llibres de contes clínics que formen part del nostre corpus és canviar el rumb de la medicina actual, massa centrada en les malalties, sovint quasi aïllades de les persones que les pateixen. Aquestes - i moltes altres- són les qüestions que sovint no es tracten - o no es poden tractar de la mateixa manera- en cap gènere mèdic especialitzat i que la literatura pot acollir i acompanyar amb unes històries que animen a continuar llegint i a aprendre d'elles.

\subsection{El professional sanitari com a narrador i personatge}

Al llarg d'aquesta tesi hem anat mostrant que els casos clínics i els contes clínics són dos gèneres amb molts elements en comú, però alhora ben diferenciats des del punt de vista dels destinataris, dels propòsits comunicatius, de les convencions que els constrenyen i dels recursos que s'hi apliquen. Pel que fa a la caracterització dels pacients, hem vist que hi ha diferències significatives entre els CC acadèmics i els literaturitzats, però també dins de cadascun dels gèneres. En els dos tipus de textos del nostre corpus trobem autors que donen més o menys protagonisme als seus pacients. La seva presència sol ser major en els contes clínics, ja que s'hi dedica més espai i temps a la construcció del personatge que no pas a l'exposició teòrica sobre la malaltia o els símptomes en qüestió. Dins dels contes clínics, però, tampoc no hi ha un comportament del tot homogeni, ja que detectem textos en els quals els autors, a part de narrar la història del pacient, centren bona part de l'atenció en els processos diagnòstics o en les reunions que mantenen amb els col·legues. D'altres, en canvi, prefereixen centrar-se en els seus èxits o errors o en la seva experiència com a metges. Recordem que, malgrat 
que es tracti d'històries de pacients, l'autor-narrador -el professional sanitari- és qui ens proporciona tota la informació, sovint només des del seu punt de vista. En aquesta darrera característica, els contes clínics no divergeixen dels CC acadèmics, però els estils emprats per proveir-nos les informacions sí que és diferent, com hem anat veient.

La relació que podem observar entre el professional i el pacient sol ser molt més explícita i s'hi dedica molta més atenció en els contes clínics. Sovint, el narrador -el professional - fins i tot ens deixa veure què pensa sobre un pacient. En els CC acadèmics no resulta admissible que els professionals manifestin obertament opinions subjectives sobre qüestions personals dels seus pacients, tot i que ja hem vist que aquestes opinions s'hi poden entreveure de manera més o menys subreptícia (vegeu l'apartat 4.2). En general, en els CC acadèmics trobem poques marques que ens facin veure la relació que hi ha entre el pacient i qui el tracta. No se'n parla gaire, perquè dins del propòsit d'aquests textos no entra evidenciar si el pacient ha caigut simpàtic al professional sanitari ni tampoc què en pensava, de manera que explicitar-ho s'interpretaria, en aquesta comunitat discursiva, com poc professional i abusiu.

En els dos tipus de CC, són els professionals sanitaris els qui decideixen quines informacions proporcionaran, com caracteritzaran el personatge del malalt, en quina mesura dibuixaran la seva relació i també de quina manera se'ns hi presentaran ells mateixos. Recordem que en els casos clínics acadèmics es difumina al màxim la presència del professional de la salut, fins al punt que sovint ens pot semblar que les proves es fan soles i que els resultats s'interpreten per ells mateixos. En canvi, els llibres de contes clínics els solen escriure un o dos autors que apareixen ben visibles a la portada de l'obra: es tracta de la seva presentació davant d'un públic que transcendeix la pròpia comunitat de pràctica.

Ens fixarem ara en el nostre corpus de contes clínics, per veure com els autors s'hi autopresenten i com s'hi construeixen com a narradors i personatges. Comencem per la col-lecció de CC literaturitzats de Frost i Steketee, la qual divergeix de la resta pel fet que els autors no hi figuren amb la missió principal de curar els pacients, sinó d'investigarlos. Aquests autors són investigadors que entren en les vides i en les cases de les persones amb la síndrome d'acumulació compulsiva per fer recerca. Òbviament, l'objectiu últim és ajudar-los, però no es dediquen a una teràpia individualitzada amb ells, sinó que se n'encarreguen altres persones que en el text coneixem com el seu 
terapeuta. A més, les persones sobre les quals fan la recerca viuen lluny i necessiten un seguiment de ben a prop. En aquest llibre veiem molts detalls sobre les vides dels pacients tant en el passat com en el present, visitem les seves cases, es parla de la seva feina, de les relacions familiars, etc. Probablement, és el llibre del nostre corpus on més informació se'ns dóna sobre els malalts, sobretot des del punt de vista espacial, però també quant a les històries familiars. A més, l'autopresentació, tant dels autors com de la seva recerca, la fan explícita des del principi: la primera història que ens conten, amb la veu de Frost, és com van arribar a estudiar junts la síndrome d'acumulació compulsiva (64).

(64) Until we began our research, the scientific literature contained few studies and scant mention of hoarding. I (Randy Frost) began that research almost by accident.

$[\ldots]$

Up to this time, my research had focused on OCD and the trait of perfectionism. As part of that work, I came to know Dr. Gail Steketee, a well-established scholar of OCD at Boston University. We were already collaborating on several OCD projects when hoarding began to capture my interest. Her reaction mirrored my early response to Rachel's queries: hoarding seemed to be a narrow, fringe aspect of OCD and a dubious area of research. Why study something so rare and esoteric-who would care?

But gradually, as I had before her, Gail came to appreciate that hoarding was a substantial and intriguing phenomenon, far more widespread and problematic from a public health perspective than she or I had ever imagined. In our collaboration for this book, I've done the bulk of the fieldwork, investigating and interviewing cases. Hence, the interviews and cases herein are mainly mine, recounted in the first person. The conceptual work, however, has been fully collaborative, and both of us have spoken to and seen more people who compulsively hoard than we could possibly recount. We have experienced awe, the excitement of discovery, and empathy for those caught in the web of hoarding.

(A.LIT_Frost)

En aquesta obra, el narrador freqüentment adopta la primera persona del plural (65) per incloure la seva companya Steketee o altres col·laboradors. Ara bé, quan es tracta de donar opinions o apuntar observacions sovint es passa a la primera persona del singular (66). També hi ha pacients que probablement només van visitar un dels dos. Quan va ser només la professora Gail Steketee, Frost se'n distancia (67) i ho conta des 
del punt de vista d'un narrador que no intervé com a personatge en aquesta història, un narrador heterodiegètic que fa que vegem les escenes des de fora, com mitjançant una càmera que enfoca les dues dones -la pacient i la professora Gail Steketee.

(65) We knocked on the front door but got no answer. We found a side door and knocked. Something stirred inside the house. Behind us, a door to the garage opened, and out stepped Irene, slightly overweight and rumpled, with straight brown hair and a friendly smile.

(1.LIT_Frost)

(66) In Irene I'd found an extraordinarily articulate and insightful subject. I agreed to work with her as she tried to clear her home. In exchange, she agreed to describe everything she felt and thought during the process and not to filter out any reactions, positive or negative.

(1.LIT_Frost)

(67) Gail accompanied a woman who was addicted to books-cookbooks, do-it-yourself craft books, mysteries, novels, and, although her own children were grown, children's books.

$[\ldots]$

At Gail's suggestion, she pulled one out and opened it.

$[\ldots]$

At Gail's request, she closed the book and dutifully put it back, looking disappointed and tearful as she did so.

$[\ldots]$

The woman and Gail walked toward the entrance to the department store, which took a couple of minutes. At the entrance, Gail paused and asked how she felt. Her discomfort rating was down to 75 . They walked to the entrance to the mall. Again she rated her discomfort, and this time, after not more than ten minutes, the rating was less than 20. Gail asked if she remembered the title of the cookbook she had perused in the bookstore. She didn't. Nor could she recall what recipe she'd found so appealing. She couldn't even remember the color of the book jacket. She was shocked. "That's really amazing. I always give in. I would have bought it if you hadn't been here. I can't believe how fast I forgot the book. Wow! I feel fine now. I can't believe it!" Like Irene and her treasured art history book, the woman had avoided the experience of distress for so long that she no longer knew how little value most books really had for her.

(8.LIT_Frost) 
A diferència del que hem pogut observar en els casos clínics acadèmics, aquí el narrador no intenta amagar-se, ans al contrari, la seva narració és un testimoni explícit de les visites a les cases dels malalts per aquesta síndrome. Encara que en alguns apartats els autors fan explicacions teòriques - fins i tot hi trobem un capítol teòric-, el conjunt no deixa de ser majoritàriament narratiu. En els relats sobre les diferents persones que pateixen aquesta síndrome, el narrador apareix amb molta freqüència. De fet, observem les cases mitjançant els seus ulls i escoltem els malalts per les seves orelles.

En el llibre de Sacks, també hi ha una autopresentació al principi de l’obra, però ben diferent del prototípic relat autobiogràfic de Frost (vaig estudiar, vaig fer classes, vaig conèixer una alumna, vaig començar a col/laborar amb la professora Steketee, etc.). Quan va sortir aquest llibre, Sacks ja havia publicat textos per a un públic general i era un personatge relativament conegut ${ }^{31}$. En el pròleg i en la resta de l'obra, òbviament, fa algunes referències a la seva trajectòria professional o personal, però l'objectiu principal és reflexionar sobre el curiós món dels trastorns neurològics i insistir en la importància d'una medicina més humanitzada i centrada en les persones i no solament les malalties. Així comença el seu llibre:

(68) The last thing one settles in writing a book,' Pascal observes, 'is what one should put in first.' So, having written, collected and arranged these strange tales, having selected a title and two epigraphs, I must now examine what I have done-and why.

The doubleness of the epigraphs, and the contrast between them- indeed, the contrast which Ivy McKenzie draws between the physician and the naturalistcorresponds to a certain doubleness in me: that I feel myself a naturalist and a physician both; and that I am equally interested in diseases and people; perhaps, too, that I am equally, if inadequately, a theorist and dramatist, am equally drawn to the scientific and the romantic, and continually see both in the human condition, not least in that quintessential human condition of sickness - animals get diseases, but only man falls radically into sickness.

(A.LIT_Sacks)

\footnotetext{
${ }^{31}$ Encara que serà sobretot amb la pel-lícula basada en el seu llibre Awakenings, presentada uns anys després de la publicació del llibre del nostre corpus, quan es convertirà en una persona famosa per a àmbits no especialitzats.
} 
Des del primer pacient que dóna el nom a tot el llibre, "L'home que confonia la seva dona amb un barret», Sacks és present com un narrador en primera persona i com un personatge sempre amb una cara simpàtica, comprensiva i humana. Ens dibuixa una imatge d'ell mateix com a persona sincera amb els pacients i, quan no entén alguna de les coses que els estan passant, no dubta a reconèixer-ho davant d'ells. També ens conta obertament quan són els pacients mateixos els qui l'ajuden a descobrir alguna mena de solució per als seus casos. Sovint mostra les seves emocions, com ara la perplexitat, l'entusiasme o el temor.

(69) What a lovely man, I thought to myself. How can there be anything seriously the matter? Would he permit me to examine him?

'Yes, of course, Dr Sacks.'

(1.LIT_Sacks)

En un altre llibre de neurologia del nostre corpus, Reaching Down the Rabbit Hole, de Ropper i Burrell, és el doctor Ropper qui fa de narrador, com podem veure des de les primeres línies de la introducció:

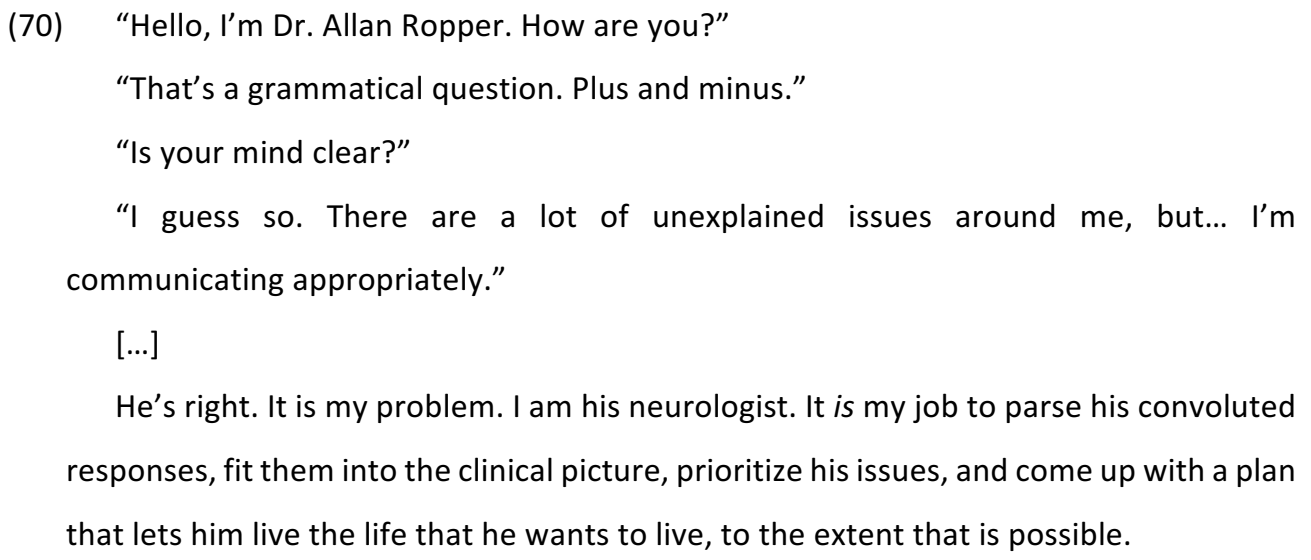

(A.LIT_Ropper)

Ropper es presenta com a metge neuròleg. A continuació es dedica, mitjançant els seus pacients, a explicar-nos el títol del llibre, que està relacionat amb la raresa dels casos que es troba. L'autor apareix en els contes clínics amb un equip de treballadors, ja que fa la seva feina en un hospital. Aquests treballadors hi tenen una presència forta 
encara que no signin com a autors - com en el cas de Frost i Steketee. En els casos de Sacks alguna vegada es menciona alguns treballadors, però no s'hi veu gaire la relació que hi ha entre ells ni més informacions personals: de fet, en la majoria dels casos no se'ns en proporciona ni el nom. En canvi, en Reaching Down the Rabbit Hole, el rol del metge Ropper ens recorda al del Dr. House de la coneguda sèrie televisiva nordamericana. És a dir, ell és el cap que té un equip de residents al darrere, els va formulant preguntes i criticant les decisions que prenen com si ell sabés des del principi totes les respostes: "He had a bad headache from the beginning," she told me, "and a fever.» The residents had neglected to mention this, but it was important». Oliver Sacks, per contra, no sol remarcar l'autoritat ni exhibir la seva saviesa davant dels residents i d'altres collegues, sinó que les poques vegades que hi apareixen són col·laboradors igualment de vàlids que ell no vol alliçonar: "'I'm not testing you,' I added. 'I'm as bewildered as you are. I've never seen or imagined anything quite like this before... ' I thought, and they thought, we thought together.» (3.LIT_Sacks).

Ropper, a part d'emprar els altres professionals sanitaris - sobretot els joves- per Iluir els seus coneixement, també reconeix la feina d'una de les seves col-laboradores, la resident sènior Hannah. Curiosament, quan en parla se centra en alguns detalls més personals d'aquesta noia. En el primer conte clínic Ropper la presenta i ens narra com ha estat la seva incorporació en el seu equip, amb detalls sobre què pensava ell sobre ella (exemple 71).

(71) My colleagues and I had some doubts about Hannah when she first came to the program three years earlier. The most superficial of these doubts focused on her style of dress. In a profession where sartorial flair is an unexpected and somewhat suspect concept, Hannah's clogs, leggings, and wraps seemed needlessly exotic, and sowed uneasiness among the Dockers, Skechers, and scrubs crowd. Perhaps even more alienating was the fact that Hannah did not drive a car, and instead rode her bike from her apartment in Boston's North End to the Brigham, usually well before the sun rose or long after it had set, in any kind of weather short of a blizzard. Such stoicism flew in the face of the unhealthy lifestyle adopted by most of the residents and teaching faculty, who tend to favor pastries over granola, Coke over water, and elevators over stairs.

I could see that over the course of the previous week, Hannah had begun the transition from resident to full-fledged physician. I could see it in her bearing, in the assertive physicality with which she carried out her examinations, in the firmness of her 
tone with some of the more difficult patients, and in the controlled sympathy she adopted in family meetings when she had to deliver bad news. She had turned out to be one of our strongest clinicians.

$$
\text { (1.LIT_Ropper) }
$$

S'hi nota molt com Hannah és la seva collaboradora preferida. És també un personatge que serveix a Ropper per mostrar-se com un educador de futurs professionals, ja que Hannah creix al seu costat. Ella apareix al llarg de tot el llibre i sovint és la que interactua amb els pacients conjuntament amb el doctor Ropper (exemple 72). També hi ha parts de les històries que són presenciades per ella, ja que són diàlegs entre Hannah i els pacients o els seus familiars. Així, podem seguir el cas des d'una perspectiva un poc diferent gràcies als continus diàlegs entre Ropper i Hannah (exemple 73) o un altre metge en pràctiques.

(72) “Hello, there. I'm Dr. Ropper. I'm one of the neurologists. And you've met Hannah Ross, our chief resident. Do you mind if we visit with you?"

(A.LIT_Ropper)

(73) “Did we get a family history for Wally?" I asked Hannah."

"More or less. We talked to the son."

"Which one?"

"He has more than one?"

"Yes."

Wally did indeed have two sons. The first one who visited had provided the family history that the residents had relied on: no history of psychoses, no similar events in the past. His confusion had come out of the blue. Except that it hadn't. We had talked to the wrong son. The other son, Wally's bipolar son, who showed up a week later, painted a very different picture, one in which a history of psychosis ran deep in the family, deep in his own past, and deep in his father's past. Wally had snapped under the pressure. He'd had a nervous breakdown, something, as we would discover, that had happened before. That's when we knew he would probably be okay.

(3.LIT_Ropper)

En el llibre de Yalom, l'objectiu que es planteja és dissipar el mite del terapeuta omnipotent (fragment 74). Ho fa amb el seu exemple, per mostrar als lectors que, a part 
de ser un professional, també és humà i, per tant, no sempre pot mantenir la distància emocional ni veure tots els seus pacients per igual. Amb alguns aconsegueix empatitzar més, amb uns altres gens - recordem el cas The fat lady, sobre la pacient obesa (4.LIT_Yalom). En els seus contes clínics no se centra només en les històries vitals dels seus pacients, sinó també en l'anàlisi de les relacions que s'hi estableixen.

(74) Indeed, the capacity to tolerate uncertainty is a prerequisite for the profession. Though the public may believe that therapists guide patients systematically and surehandedly through predictable stages of therapy to a foreknown goal, such is rarely the case: instead, as these stories bear witness, therapists frequently wobble, improvise, and grope for direction. The powerful temptation to achieve certainty through embracing an ideological school and a tight therapeutic system is treacherous: such belief may block the uncertain and spontaneous encounter necessary for effective therapy. This encounter, the very heart of psychotherapy, is a caring, deeply human meeting between two people, one (generally, but not always, the patient) more troubled than the other. Therapists have a dual role: they must both observe and participate in the lives of their patients. As observer, one must be sufficiently objective to provide necessary rudimentary guidance to the patient. As participant, one enters into the life of the patient and is affected and sometimes changed by the encounter.

(B.LIT_Yalom)

Així, aquest psicoterapeuta comenta les seves reaccions amb els pacients, els canvis de pensament, les seves inseguretats i, fins i tot, reconeix els seus errors i les seves limitacions - una gran diferència amb el llibre anterior, de Ropper i Burrell.

(75) I do not like to work with patients who are in love. Perhaps it is because of envy-I, too, crave enchantment. Perhaps it is because love and psychotherapy are fundamentally incompatible. The good therapist fights darkness and seeks illumination, while romantic love is sustained by mystery and crumbles upon inspection. I hate to be love's executioner.

(1.LIT_Yalom)

Per això, s'insereix com a narrador en els relats i així trobem en els seus textos comentaris sobre el que hauria volgut dir durant la psicoteràpia (fragment 76) o quins eren els seus pensaments més íntims respecte d'una pacient (fragment 77). 
(76) I immediately thought, Not "than $m e$ "; it's "than I." Your only real crime is using the wrong form of the first-person pronoun. Then I noticed how critical I became whenever Saul got feisty. Fortunately I kept all this to myself-where I should as well have kept my next comment.

(8.LIT_Yalom)

(77) This new Marge was vivacious and outrageously, but enjoyably, flirtatious.

$[\ldots]$

She was savvy, willful, very sexy. What a relief to have a break from Marge's droning voice and relentless whining. But I was beginning to feel uneasy; I enjoyed this lady too much. I thought of the Lorelei legend, and though I knew it would be dangerous to tarry, still I visited awhile.

$[\ldots]$

Perhaps I was staying longer with her than I should. It was wrong to talk to her about Marge. It was not fair to Marge. Yet this woman's appeal was strong, almost irresistible. (9.LIT_Yalom)

Yalom és un narrador que deixa més espai als relats del seus pacients i el que el diferencia de la resta de textos del nostre corpus és precisament que no sembla reservar-se cap comentari, cap opinió ni cap crítica. D'una manera molt oberta, es declara imperfecte com a psicoterapeuta. Els lectors es poden sentir escandalitzats llegint com un professional pot pensar i després publicar alguns dels seus comentaris. Però, d'altra banda, també poden posar-se en la seva pell i veure que no és possible mantenir la professionalitat en tots els casos. Qui es mantindria fred davant de declaracions d'un pacient com ara: «l'll tell you the truth, if rape were legal, I'd do itonce in a while» (2.LIT_Yalom).

Els contes clínics, com a relats literaris, permeten que els autors emprin estratègies que no serien admissibles en la majoria dels casos clínics, com hem pogut observar. Hem vist que el narrador té un rol clarament molt més destacat en aquest gènere. Aquí no s'amaga, ans al contrari, destaca. És el professional qui ens acompanya explícitament durant tot el relat. Podem veure amb més detalls com interactua amb els pacients i algunes vegades també les seves emocions i opinions personals. Cada Ilibre de contes clínics té les seves peculiaritats quant a la manera com hi intervenen els narradors. $\mathrm{Hi}$ 
ha obres com la de Sacks, on la base és la interacció entre ell -autor, narrador i personatge Dr. Sacks - i els seus pacients. Sacks insisteix en la part humana de la medicina i en les particularitats de cada pacient. En altres, com el de Ropper i Burrell, s'hi afegeixen detalls sobre com interactua Ropper amb la resta del personal sanitari i s'hi potencia l'autoimatge d'un metge que resol eficientment els casos i, de camí, intenta ensenyar i donar lliçons als residents. El psicoterapeuta Yalom, a diferència de l'anterior, remarca les seves limitacions, relacionades sobretot amb la relació amb els seus pacients. Finalment, en el llibre dels dos investigadors sobre la síndrome d'acumulació compulsiva, la voluntat del narrador és mostrar la seva recerca i proporcionar una imatge viva d'aquesta malaltia encara no prou coneguda. Darrere d'aquestes característiques que destaquem estan els propòsits comunicatius amb els quals els autors van redactar aquests contes clínics: humanitzar la medicina; lluir la seva carrera brillant; fer veure que els metges també són humans i per tant éssers amb emocions i defectes, encara que estiguin treballant; donar a conèixer els resultats, però sobretot l'experiència de com és viure amb una malaltia determinada. No hauríem de caure, però en una simplificació excessiva: cada text dels que hem analitzat en el nostre corpus pot combinar diversos propòsits, ja que els uns no descarten els altres. El que volem remarcar és que la manera en la qual se'ns presenta el narrador i es construeix a si mateix com a personatge, en relació amb els altres professionals sanitaris i els pacients que s'hi retraten, revela el missatge integral que pretén transmetre el conjunt dels casos. 



\section{CONCLUSIONS}

En aquesta tesi doctoral ens hem proposat estudiar els gèneres dels casos clínics (CC) acadèmics i dels contes clínics o casos clínics literaturitzats, com una contribució al diàleg entre els sabers científics - les ciències de la salut - i els humanístics -els estudis lingüístics i literaris - mitjançant el pont de l'anàlisi del discurs. Així doncs, amb un enfocament transdisciplinari, hem integrat informacions extretes tant de la literatura biomèdica i sanitària com de la lingüística i literària. Hem triat aquest gènere del discurs mèdic i la seva versió literaturitzada, oberta al públic general, amb la finalitat d'esbrinar els tipus de relat i els corresponents recursos lingüístics que s'empren en cada cas. Amb aquesta recerca esperem haver contribuït, a més, a ubicar els casos clínics dins dels discursos sanitaris i a remarcar i defensar la seva importància com a textos que poden respondre a la demanda creixent de canviar el rumb deshumanitzador que pot prendre la praxi sanitària actual, sovint més enfocada cap a les malalties que no pas cap a les persones que les pateixen. Ens hem centrat en l'àmbit de les afeccions mentals, atès que bona part de les publicacions de contes clínics pertanyen a aquest camp (neurologia, psiquiatria, psicologia). Hem seleccionat un corpus de $115 \mathrm{CC}$ acadèmics en tres idiomes — català, castellà i anglès - i quatre llibres amb nombrosos capítols de contes clínics, tots en anglès, la llengua en què s'ha desenvolupat majoritàriament aquest gènere.

La tesi s'ha estructurat en quatre capítols. En el primer, de tipus introductori, hem exposat les característiques del discurs mèdic i dels discourses in health settings i hem desenvolupat els conceptes de comunitat discursiva i comunitat de pràctica, sense oblidar les comunitats de pacients i la imatge social de les malalties. Hem caracteritzat 
els CC acadèmics en el context de les revistes mèdiques, amb una referència específica a les problemàtiques que hem trobat en els casos clínics en català. Hem descrit també els contes clínics i hem formulat els objectius i les hipòtesis d'aquest treball. En el segon capítol, hem delimitat i descrit el corpus. En el capítol tercer, hem desplegat el marc teòric en el qual s'insereix el nostre estudi: $a$ ) els discursos especialitzats i els literaris; b) la divulgació científica i la literaturització; c) els gèneres des del punt de vista discursiu; $d$ ) els propòsits comunicatius; $e$ ) les seqüències textuals; $f$ ) els trets de la narració i del relat; $g$ ) els personatges; $h$ ) el punt de vista. Finalment, en el capítol quart, hem analitzat el nostre corpus partint de les hipòtesis formulades i del marc teòric exposat en els capítols anteriors. Hem revisat i) les característiques formals dels CC acadèmics; ii) la seva naturalesa narrativa; iii) el tecnolecte i les construccions convencionalitzades que els configuren i que, en els contes clínics, s'han de recontextualitzar per a un públic més ampli; iv) els eufemismes en el tractament de determinats temes com ara la mort; $v$ ) la polifonia de metges i pacients, en els rols de narradors i personatges, tant en el gènere dels CC acadèmics com en el dels contes clínics.

Entre les nostres hipòtesis inicials plantejàvem que, mentre que l'estructura dels contes clínics seria implícita i més flexible, els CC acadèmics tendirien a una estructura comuna prefixada i pautada convencionalment, la qual cosa hem vist confirmada en la majoria dels textos del nostre corpus. Hem identificat una estructura bàsica comuna per als CC més orientats cap a la investigació (títol, resum, introducció, presentació del cas, discussió i referències) i una estructura simplificada i un mica més variable per als CC d'educació, en els quals es reforça, sobretot, la presentació del cas. A més, en els CC de neurologia hem constatat la presència regular de complements visuals, sobretot d'imatges de ressonàncies magnètiques. Dins de cada gènere també hem trobat, però, diferències formals significatives, per exemple, en la llargària dels textos, en els apartats que contenen o en el tipus de títol emprat. Les semblances i les diferències en els trets formals dels CC acadèmics i dels contes clínics es poden relacionar amb els propòsits comunicatius de cadascun dels gèneres, com també de cada text concret i dels seus autors.

Podem dir, doncs, que el gènere dels CC acadèmics és perfectament recognoscible entre el conjunt dels gèneres mèdics, encara que no assoleix l'homogeneïtat que ens 
esperàvem al principi -ni tan sols si analitzem per separat els CC d'investigació i els més educatius. Les característiques formals estan condicionades per les normes establertes per cada revista, emmarcada dins d'alguna especialitat de les ciències de la salut i, per tant, també pels patrons de la seva comunitat discursiva, a més de les convencions consolidades en cada llengua. Dins d'aquestes normatives, hem detectat que les revistes en anglès que, al mateix temps, podem qualificar de més comercials - revistes de grans editorials que sovint exigeixen que s'hi pagui per publicar - són les que tendeixen a seguir uns patrons més estandarditzats i no hem trobat tantes diferències entre si.

Altres trets dels $\mathrm{CC}$ acadèmics que també prevèiem entre les nostres hipòtesis i que hem confirmat en l'estudi del corpus són l'ús de les construccions convencionalitzades, les quals s'acostumen a repetir-se amb unes formes idèntiques o molt similars, com també la presència del tecnolecte específic de cada professió. La veu del narrador sol ser la del professional sanitari, que colonitza el discurs primari del pacient, el tradueix al tecnolecte esmentat, distribueix, reorganitza i selecciona la informació proporcionada pel malalt en els apartats del CC.

Quant a les característiques estilístiques, encara que hem trobat i mostrat desviacions particularment interessants, globalment podem dir que els CC acadèmics segueixen determinades normes comunes, com ara l'estil auster - fins i tot en els textos més narratius - o la tendència del narrador a no mostrar-se, mitjançant enunciats amb frases impersonals, a amagar qualsevol expressió emocional o els dubtes generats, com també a no implicar el receptor en el seu discurs per mantenir la suposada objectivitat. A la poca informació que sol donar el text sobre l'autor/narrador, s'hi afegeix també la sobrietat en la descripció dels pacients. La caracterització s'hi fa, no tant mitjançant els trets personals del malalt, sinó a través dels detalls que corresponen a la malaltia, com ara els antecedents, els símptomes o els tractaments rebuts. En conseqüència, altres informacions com ara l'espai on es desenvolupen les accions - que solen tenir una presència rellevant en els relats més convencionals- s'hi esmenten quasi exclusivament quan tenen o podrien tenir alguna rellevància per al diagnòstic. L'excepció l'hem trobada en els CC amb una orientació més social, com ara els que tracten els problemes dels pacients amb síndrome de Down.

Entre les desviacions que trenquen amb alguns dels trets propis del discurs científic prototípic, hem trobat en el nostre corpus: a) la presència de primera personal del 
singular per representar la veu de l'autor 0 , fins i tot, la veu del pacient en un relat biogràfic; b) l'ús de la primera persona del plural -aquesta vegada per incorporar el lector al discurs-; c) l'aparició de seqüències dialogals entre el professional i el pacient; d) construccions marcadament personals i subjectives - com ara valoracions personals o la veu activa en lloc de la passiva o la passiva reflexa.

Els casos clínics no estan, per tant, exempts d'una certa heterogeneïtat, de manera que hi hem pogut trobar des dels textos més descriptius i asèptics als francament narratius, és a dir, amb un clar predomini d'aquestes seqüències, amb uns títols que poden arribar a fer servir recursos poètics o gairebé publicitaris, amb una presència considerable de la veu del pacient i, per tant, amb una vocació de contar una història atractiva, llegidora i, fins i tot, intrigant. Hem pogut constatar, però, que fins i tot en els textos amb menys pes de la narració, aquesta continua tenint-hi una funció imprescindible per poder presentar el pacient, les seves circumstàncies i els fets que li han ocorregut. Podem, doncs, concebre els casos clínics acadèmics com un relat no literari altament especialitzat, és a dir, com un gènere narratiu que se situa entre els gèneres científics, vora la frontera amb els gèneres literaris. Aquest comparteix trets amb un gènere germà que ja considerem plenament literari, tot i que de no-ficció: els casos clínics literaturitzats o contes clínics.

Els contes clínics han estat qualificats com un híbrid entre el cas clínic i la narració literària, no restringit als professionals sanitaris, sinó obert a un públic general. Per això hi hem pogut trobar, en simbiosi, característiques pròpies dels dos tipus de discursos. Sense renunciar a l'entreteniment i l'oci dels lectors, aquestes històries literàries de noficció, basades en pacients reals, sovint plasmen les preocupacions i les crítiques sobre l'atenció sanitària actual, com també s'hi donen a conèixer malalties o símptomes rars o curiosos perquè un públic més ampli les conegui i s'hi familiaritzi. En l'àmbit de la salut mental és especialment important que les persones alienes a aquests àmbits sàpiguen almenys algunes dades bàsiques sobre aquestes afeccions per prevenir que les persones que les pateixen siguin estigmatitzades com a boges. I cap altre recurs pot ser més efectiu per a aquest propòsit que unes històries reals que ens fan empatitzar amb els personatges, que ens conten els detalls de la seva vida, els seus problemes i les seves preocupacions. 
Hem verificat la presència i la rellevància de les seqüències narratives en els CC acadèmics. També hem comprovat que hi podem detectar les parts prototípiques d'un relat, és a dir, una estructura narrativa anàloga, per exemple, a la d'un conte. Precisament per contrastar de quina manera s'hi desenvolupen o apareixen les diferents parts, les hem comparades amb els contes clínics, uns textos literaris amb una temàtica similar, salvant totes les distàncies estilístiques i de propòsits comunicatius que els diferencien. Hem exemplificat i comprovat que la narració que es desenvolupa al llarg del CC s'acobla a aquesta estructura del relat i ho fa d'una manera espontània, ja que els autors d'aquest gènere no són escriptors literaris professionals. Així doncs, dins dels apartats convencionals d'aquest gènere els autors encaixen l'estructura d'una narració natural, ja que aquest és el model que tenen en la ment a l'hora de contar una història. Encara que es tracti d'un gènere altament especialitzat quant a la forma i al contingut, no deixa de ser la narració d'una història. Els relats, els sentim des de petits i, per tant, sense cap necessitat d'estudis filològics o discursius, en tenim interioritzada l'estructura més habitual. Així doncs, hem comprovat que, per moltes normes que estableixin les revistes on es publiquen o les comunitats de pràctica en les quals s'inscriuen, els professionals sanitaris que conten els casos dels seus pacients en el nostre corpus tendeixen a seguir completament o parcial aquesta estructura narrativa àmpliament compartida.

Una de les característiques que hem estudiat per poder confirmar la naturalesa narrativa dels $\mathrm{CC}$ acadèmics ha estat l'organització temporal dels fets i la presència de la trama. Hem pogut constatar que els $\mathrm{CC}$ acadèmics rarament s'organitzen com un mer cúmul d'accions i esdeveniments ordenats cronològicament, ja que hi podem detectar una selecció dels fets. Malgrat que una bona part de les informacions se sol narrar seguint l'ordre cronològic -com esperaríem i consideraríem lògic en un informe científic-, els professionals sanitaris també empren el recurs d'avançar o posposar determinades dades. D’aquesta manera, assignen a alguns fets més o menys importància que a altres i així també poden crear una espècie de tensió narrativa o intriga. Els fets que han seguit una successió cronològica en la vida real del pacient passen a ser narrats per aquest -o els seus familiars - en un ordre alterat normalment des dels fets que més els preocupen- i són agafats pel professional sanitari, el qual els selecciona i reordena d'acord amb els seus interessos discursius. 
Aquest és un altre tret que ens permet concebre aquest gènere com a relat: si pensem en els contes clàssics, la major part dels fets s'hi narra seguint un ordre més o menys cronològic, però amb algunes digressions. Quan aquestes informacions han de bastir un conte clínic, la selecció i la reordenació es fan amb uns propòsits de crear intriga encara més potents. Mentre que en els casos clínics sol ser més subtil aquesta intenció d'intrigar el lector, en els contes clínics aquest factor és l'eix vertebrador del text. És més fàcil moure's per la línia temporal i fer digressions gràcies a la major flexibilitat de les convencions d'aquest gènere literari, el qual no necessita ajustar-se a un registre tan regulat com el cientificotècnic.

Encara que els CC acadèmics no sempre continguin totes les parts de l'estructura prototípica del relat, hem trobat que $\mathrm{n}^{\prime}$ hi ha unes d'essencials sense les quals els autors difícilment aconseguirien l'èxit comunicatiu. Així, una de les parts que considerem imprescindible és el nus, on es crea la intriga de la història i es desperta l'interès en el lector. El mateix efecte és necessari per als professionals sanitaris: si desperten la curiositat dels seus collegues, més el llegiran el CC i major reconeixement podran obtenir en la pròpia comunitat de pràctica. Una altra part seria el desenllaç, indispensable tant en un relat literari com en un $\mathrm{CC}$, ja que sense ell la història quedaria només en el plantejament del problema i no satisfaria les expectatives dels lectors. En els $\mathrm{CC}$, els lectors també voldran saber què va passar amb el pacient. Si no, no tindria gaire sentit llegir un cas així, ja que no és una lectura primàriament lúdica, sinó d'aprenentatge i d'adquisició d'experiència amb el seguiment del treball d'un col-lega.

Ara bé, hem de remarcar que els trets narratius no apareixen amb la mateixa mesura en tots els casos clínics, sinó que n'hi ha de diferents graus: des dels que minimitzen el pes de la narració i, per tant, en segueixen menys l'estructura i presenten menys reorganització temporal - una tendència dominant entre els $\mathrm{CC}$ de neurologia - fins als que compleixen aquestes característiques en major mesura i s'acosten als contes clínics -notablement en els camps de la psicologia i la psiquiatria. Així doncs, podem concebre que hi ha un contínuum entre els dos gèneres estudiats en aquesta tesi, en el qual hem trobat casos clínics acadèmics que s'acosten més cap als contes clínics i d'altres que se n'allunyen. Hem citat diversos exemples dels CC que quasi podríem confondre amb fragments d'una novel·la o d'un conte. Tanmateix, sempre continuen contenint també aquelles altres parts - per exemple, les expositives - que expliquen els detalls de 
l'objecte d'estudi, sia una malaltia concreta, sia un símptoma, i que difícilment serien compatibles amb un text literari.

Podem considerar, doncs, els CC acadèmics com relats no literaris que fan de pont entre altres textos científics i els contes clínics, un pont entre l'escriptura científica i la literatura. A més de comparar les estructures d'aquests dos gèneres connectats però alhora diferenciats, en aquesta tesi també n'hem revisat els mecanismes mitjançant els quals es dirigeixen als dos tipus de públic: el professional i especialitzat de col-legues i el general. Ens hem fixat en el tecnolecte dels CC acadèmics, els quals formen part dels discursos especialitzats. L'ús de recursos com ara la terminologia o les abreviacions distingeix aquests textos respecte del discurs ordinari i fa que, per als lectors aliens a aquest àmbit d'especialització, els textos puguin semblar condensats i xifrats. Així doncs, aquest tipus de llenguatge marca i reforça la cientificitat del text, com també la pertinença a una comunitat de pràctica. Els $\mathrm{CC}$ acadèmics tindrien un caire més esotèric -és a dir, dirigits a una comunitat més tancada-, enfront del caràcter necessàriament exotèric - o divulgador, si es vol-dels contes clínics.

A més dels mots tècnics, en els CC també hem trobat construccions que se solen repetir amb unes formes idèntiques o molt similars amb un mateix objectiu o per referirse a la mateixa realitat. Aquestes construccions convencionalitzades es relacionen amb els propòsits comunicatius compartits pels autors dels diferents textos, ja que els autors tenen la necessitat de destacar la singularitat del cas, presentar-lo, introduir-hi el pacient i també comentar les troballes significatives de les proves i d'altres procediments. I tot això ho fan amb unes construccions convencionalitzades $\mathrm{i}$ consolidades entre els membres de la comunitat discursiva. Aquestes construccions, en canvi, no acostumen a aparèixer en els contes clínics, ja que es tracta de textos literaris i la repetició d'unes estructures, sovint rígides i impersonals, no s'ajusta als seus propòsits comunicatius: fer goig als ulls del lector.

La característica provinent dels CC que sí que hem observat amb molta freqüència en els contes clínics és l'ús de la terminologia. Hem defensat que els tecnicismes no es poden defugir del tot ni en la versió literaturitzada, ja que formen una part inherent al món sanitari i contribueixen a donar a aquest gènere un aire iniciàtic que atrapa el lector. A més a més, perquè aquests textos puguin comunicar eficientment el seu contingut no n'hi hauria prou amb una mera adaptació d'aquests termes, ja que 
continuaria havent-hi molts dels altres trets del discurs especialitzat. Tampoc no pot desaparèixer tot allò relacionat amb el discurs científic, ja que així els textos es convertirien en simples contes d'ambientació sanitària. Els autors dels contes clínics, doncs, han de trobar l'equilibri entre el món científic i el literari, és a dir, entre un discurs de base sanitària i una narrativa adreçada a un públic ampli i heterogeni. No es tracta de textos canònics de divulgació científica, però també poden exercir aquesta funció. Els conceptes de recontextualització, reeleboració i textualització, provinents de l'estudi de la divulgació científica, ens ajuden, doncs, a entendre de quina manera es fa el procés de transformació del coneixement científic per adaptar-lo al gran públic.

Hem revisat particularment l'ús de la terminologia i la desteminologització. Molts dels termes que s'han desenvolupat en uns àmbits especialitzats han penetrat en el nostre dia a dia i han esdevingut mots comuns en la semiosi social. Els de l'àmbit de la salut mental no en són una excepció, ans al contrari: molts noms d'aquestes afeccions són coneguts per persones que no són ni especialistes ni les han patides. Com hem vist en el nostre corpus, els autors bé poden emprar alguns dels termes que ja estan desterminologitzats, bé els han d'integrar en el seu discurs sense perdre els lectors profans pel camí. Hem comprovat que els autors dels llibres del nostre corpus fan servir diferents estratègies de desterminologització, com ara: a) la definició, $b$ ) l'exemplificació, $c$ ) les paràfrasis, $d$ ) els sinònims, $e$ ) els símils i $f$ ) les metàfores, per introduir els termes específics de l'àmbit de la salut mental. Paral-lelament amb els CC acadèmics de neurologia, són també els dos llibres de contes clínics d'aquesta especialitat -el d'Oliver Sacks i el d'Allan Ropper i Brian David Burrell- els que més termes empren i, per tant, més quantitat i varietat d'estratègies de desterminologització han d'emprar.

Ens hem fixat també en l'ús dels eufemismes en el moment de l'atenció sanitària que ens ha semblat més procliu: el de la mort. No tots els CC poden acabar amb la perfecta curació del pacient, sinó que també n'hi ha que en narren un empitjorament o, fins i tot, la mort. Parlar de la mort ha esdevingut, almenys en les societats occidentals, un tabú. Els professionals sanitaris són -o haurien de ser- les persones més acostumades a la presència de la mort $\mathrm{i}$, per tant, podríem esperar que no evitessin gaire els mots que designen el final de la vida, els anomenats ' $D$ ' words en la tradició anglòfona. En el nostre estudi, però, hem constatat que ni en aquests àmbits tan familiaritzats amb la mort, no 
s'hi defuig completament l'eufemisme. Hi hem detectat una tendència d'atenuar l'efecte que provoca parlar de la mort -o, en el nostre cas escriure'n. Hem trobat que els CC que analitzen la mort com a objecte del seu estudi - com ara, els casos forenses, s'hi refereixen directament, sense eufemismes. En canvi, els que l'esmenten sense que sigui el seu objectiu tendeixen a emprar un repertori d'eufemismes, provinents tant del llenguatge general com del mèdic o tecnicismes. Així doncs, malgrat la suposada objectivació de les dades que es presenten en els CC, detectem una tendència generalitzada a evitar els ' $D$ ' words. En els contes clínics, la mort no és gaire freqüent, però, quan hi apareix, el seu tractament té repercussions més enllà del lèxic emprat, ja que es converteix en un element que s'aprofita i s'explota per afegir dramatisme al text.

En aquesta tesi hem analitzat també la polifonia, és a dir, de quina manera són presentades i representades les veus dels diferents participants en els casos clínics i en els contes clínics, tant si es tracta dels professionals sanitaris com a autors, dels seus col-legues, dels pacients o dels seus familiars. Atès que hem defensat el caràcter narratiu del cas clínic acadèmic, també hem concebut els pacients - protagonistes de les històries - com a personatges, ja que no deixen de ser recreacions elaborades pels autors dels textos. En els contes clínics, com a relats literaris, és encara més evident que es tracta de personatges d'un relat, malgrat que siguin reflexos dels pacients que acudeixen a la consulta.

Ens hem centrat, en primer lloc, en les veus dels pacients, per veure de quina manera s'integra el seu relat original en el marc narratiu que construeix el professional sanitari quan redacta el CC per a la publicació. En aquest procés veiem com els autors seleccionen les informacions d'acord amb els seus propòsits comunicatius, reformulen el discurs del malalt -majoritàriament en estil indirecte-, i el tradueixen al tecnolecte de la seva especialitat. A més a més, els autors poden afegir al seu relat informacions d'altres fonts, com ara dels procediments de la diagnosi, del tractament i de l'avaluació final dels resultats. Hem trobat CC acadèmics els autors dels quals han volgut preservar algunes paraules tal com les havien expressades els seus pacients i les introdueixen en el seu text entre cometes. Aquest recurs resulta especialment freqüent i rellevant en les especialitats de psicologia i psiquiatria o en casos amb un matís social, ja que contribueix a construir la imatge del malalt i de l'afecció mental que pateix. 
En segon Iloc, hem estudiat el llenguatge que pot afavorir la despersonalització i també la deshumanització de l'atenció sanitària. Hem vist que determinades expressions que s'empren en els escrits sanitaris poden ajudar a construir una imatge del pacient com a queixós, hipocondríac, poc fiable o, fins i tot, culpable. Aquest llenguatge que estigmatitza el comportament dels pacients apareix en alguns dels nostres CC, encara que la major presència correspon al discurs oral entre col-legues, el qual no passa per cap filtre ni està subjecte a normes com les que regeixen les publicacions que ens ocupen.

En tercer lloc, hem analitzat un altre factor que està relacionat amb la despersonalització i la deshumanització dels malalts: la seva presència textual. És clar que, tant en els CC com en els contes clínics, s'han de protegir i s'han d'amagar determinades dades personals per conservar l'anonimat, però en molts CC els autors van més enllà d'això: tendeixen a ignorar textualment els pacients i centren quasi tota l'atenció en els processos biològics que tenen lloc en els seus cossos, en les proves biomèdiques i els tractaments. Així, hem vist que hi ha pacients que es converteixen en actors secundaris, en simples excuses per a publicar el text sobre un símptoma, una malaltia o una medicació, els quals esdevenen protagonistes primaris del cas. En aquests $\mathrm{CC}$, també s'acostuma a ometre les persones que realitzen el diagnòstic i els processos curatius, mentre es tracta la tecnologia mèdica com si fos el subjecte de les accions. Aquests mecanismes poden servir per consolidar la credibilitat dels resultats presentats, com també per mitigar la responsabilitat del personal sanitari sobre les decisions preses. Ara bé, no tots els CC acadèmics intenten minimitzar la presència dels malalts amb la mateixa intensitat. Mentre els CC de l'àmbit de la neurologia se centren sobretot en informacions fisiològiques $\mathrm{i}$ proves biomèdiques, molts dels casos de psicologia, psiquiatria o els que tracten problemes relacionats amb la síndrome de Down donen més espai textual als pacients. Podem dir que la naturalesa d'aquestes disciplines d'alguna manera exigeix humanitzar els malalts.

En quart lloc, ens hem fixat en la presència d'espais en els casos clínics. Com en qualsevol relat, la descripció dels espais pels quals es mouen els personatges contribueix a caracteritzar-los. Així, hem trobat una correlació entre els $\mathrm{CC}$ amb un estil més asèptic amb la minimització de la presència dels personatges i la quasi desaparició dels espais en què actuen. En canvi, altres CC més centrats en aspectes socials, generats en 
comunitats on poden participar els pacients o els seus familiars, són més propensos a adoptar un enfocament més humanitzat i que inclou una major presència textual dels espais per on transcorre la vida dels pacients.

En cinquè lloc, hem parat atenció al tractament dels pacients en els contes clínics. Com que ni els propòsits comunicatius ni el format d'aquest gènere no són iguals, la presència i la presentació dels pacients tampoc no ho és. Els autors aquí també han d'amagar determinades dades personals, ja que els protagonistes no deixen de ser pacients reals que han passat per la consulta. A part d'una diferència tan essencial com és el fet de posar un nom - convencionalment, un pseudònim - al protagonista de la història en els contes clínics, són sobretot els recursos lèxics i estilístics els que marquen les divergències entre els gèneres. Els autors poden aprofitar tots els recursos literaris per reforçar la intriga i dissenyar el personatge, això sí, basat en el seu pacient real. Encara que hi hagi una variació de recursos en els quatre llibres estudiats, no deixen de ser casos clínics - literaturitzats - amb uns trets conjunts. Així doncs, en aquest gènere hem trobat molta més informació personal, familiar i per conseqüència també espacial. No totes les dades són estrictament necessàries per al diagnòstic, sinó que s'empren per ajudar els lectors a imaginar-se millor els pacients i poder crear-hi un vincle emocional, necessari per a assolir els seus propòsits comunicatius. La creació literària i, en general, artística cerca apel·lar a les emocions dels lectors. Freqüentment ho aconsegueix, fins i tot d'una manera més eficient que la realitat documentada.

Finalment, ens hem acostat als professionals sanitaris com a narradors i personatges en els contes clínics. A diferència dels $C C$ acadèmics, en aquest gènere constatem una gran presència textual dels professionals, ja que són els qui ens acompanyen en tot el text sense amagar-se, ans al contrari, sovint destacant la pròpia figura. El gènere dels contes clínics permet emprar estratègies que no serien admissibles en els CC. Podem veure-hi no tan sols com els professionals interactuen amb els malalts - amb seqüències dialogals que poden ser extenses i freqüents-, sinó també les seves emocions i els seus pensaments. Cada llibre té les seves peculiaritats quant a la manera com intervenen els narradors, ja que cada autor segueix uns propòsits comunicatius diferents, però que en molts punts convergeixen: humanitzar la medicina; lluir la seva carrera; fer veure que els metges també són humans; donar a conèixer algunes malalties i l'experiència de viure-les per desestigmatitzar-les. 
Els contes clínics són, per tant, un gènere en què els autors acostumen a reflexionar sobre el rumb actual de l'atenció sanitària i, com a referents en els respectius àmbits professionals, intenten transmetre determinats valors. Alguns, fins i tot, miren de donar exemple als futurs professionals. A part del tractament del pacient, també s'hi reflexiona sobre la figura del professional sanitari. Pensem ara en Yalom, qui reconeix al llarg de tot el llibre les seves debilitats i els seus errors a l'hora de jutjar els pacients. En els CC acadèmics, per la seva banda, avui dia hi ha diverses tendències a l'hora de tractar textualment el pacient. Des dels que intenten objectivar al màxim totes les dades obtingudes fins als que deixen veure l'experiència de la malaltia en la primera persona del pacient. Evidentment, hi ha especialitats sanitàries en les quals és més fàcil centrarse en aspectes personals o socials, ja que aquesta atenció conforma una part nuclear de la disciplina. En tot cas, sigui quina sigui l'especialitat, recordem que un dels trets específics del gènere dels CC és que analitzen un o uns pocs casos $i$, per tant, el que els distingeix dels estudis quantitatius és precisament el fet de poder estar pendents $\mathrm{d}^{\prime}$ aquests pacients que són únics i que poden ajudar a progressar les ciències de la salut i l'atenció sanitària. Aquest gènere ha sobreviscut fins a l'actualitat perquè no totes les respostes les podem obtenir de grans estudis, perquè no tothom reacciona igual, ja que els humans, en definitiva, som diversos. Els CC literaturitzats que majoritàriament descriuen peculiaritats remarquen aquesta singularitat de les persones, especialment els casos d'Oliver Sacks, els quals sovint passen per solucions poc o gens vistes en l'atenció sanitària, com és el cas de l'home que caminava inclinat com la torre de Pisa i es va haver de fer unes ulleres amb un nivell de bombolla per poder mantenir-se recte. Els professionals sanitaris potser haurien de prestar més atenció a allò que és únic en cada malalt i defugir la definició genèrica com a casos de categories de malalties.

Amb tot el que hem trobat i exposat en aquesta tesi doctoral, podem constatar que la narració i el relat tenen un lloc rellevant -imprescindible des del nostre punt de vista- en l'àmbit sanitari, no només en uns textos literaturitzats com són els contes clínics o en la interacció oral entre el professional sanitari i el pacient, sinó també en textos tan especialitzats com són els casos clínics acadèmics, majoritàriament publicats per a col-legues de la pròpia comunitat de pràctica, amb la qual comparteixen uns propòsits comunicatius conjunts. Hem pogut aplicar conceptes de la teoria del relat per analitzar els dos gèneres dels $\mathrm{CC}$, en suport d'una concepció dels $\mathrm{CC}$ acadèmics com $\mathrm{a}$ 
relats. Hem defensat aquest gènere no prototípic del discurs sanitari, l'interès del qual va més enllà dels seus trets peculiars per als analistes del discurs: constitueix un gran recurs de formació per als futurs professionals i una font inestimable d'informació per a la recerca en les ciències de la salut. El gènere dels CC acadèmics ofereix una oportunitat única per a reorientar la perspectiva dels professionals sanitaris, a l'hora de tractar cada malalt, en la seva individualitat i humanitat, més que no pas malalties. Aquest gènere pot esdevenir, si les comunitats de pràctica implicades així ho decideixen, un recurs per a ajudar els professionals a no desconnectar de les persones en un context on la tecnologia facilita, cada vegada més, estalviar-se de tocar el pacient i parlar-hi. En definitiva, pot ser un instrument útil per a millorar la naturalesa i la qualitat de l'atenció sanitària: per a humanitzar-la. 



\section{RESUMÉ A ZÁVĚRY}

\section{Příběhy ve zdravotnictví: kazuistiky o duševních poruchách}

V této disertační práci jsme se zaměřili na studium dvou žánrů: klinické kazuistiky a klinických přiběhů, které přispívají k dialogu mezi poznatky vědeckými - zdravotnické vědy - a humanistickými - lingvistika a literatura - prostřednictvím mostu, který vytváří diskurzivní analýza. S tímto transdisciplinárním př́stupem jsme tedy zahrnuli informace získané jak z biomedicínské a zdravotnické literatury, tak z té jazykové a literární. Vybrali jsme si tento druh lékařského diskurzu - klinické kazuistiky - a jeho literární verzi klinické příběhy -, otevřenou široké veřejnosti, abychom zjistili, jaké typy př́běhů a jaké jazykové prostředky se zde používají. Tímto výzkumem chceme navíc přispět k tomu, abychom zasadili klinickou kazuistiku do rámce zdravotnických diskurzů a také zdůraznili a obhájili její význam jako text, který může přispět ke změně směru současné zdravotní péče, která je často více zaměřená na nemoci než na ty, kteří jimi trpí. Soustředili jsme se na duševní poruchy, protože většina publikací klinických příběhů patří do této sféry (neurologie, psychiatrie, psychologie). Sestavili jsme korpus 115 klinických kazuistik ve třech jazycích - katalánština, španělština a angličtina - a čtyři knihy s početnými kapitolami klinických př́běhů, všechny v angličtině, jelikož se jedná o jazyk, ve kterém se tento žánr vyvinul.

Práce je rozdělena do čtyř kapitol. V té první uvádíme charakteristické rysy lékařského diskursu a také diskurzů ze zdravotního prostředí (discourses in health setting) a uvádíme pojmy komunity praxe a diskurzivní komunity, aniž bychom pominuli komunity pacientů a sociální obraz nemocí. Charakterizujeme klinické kazuistiky v 
kontextu lékařských časopisů s konkrétním odkazem na problémy, se kterými jsme se setkali $v$ prrípadě kazuistik $v$ katalánštině. Dále se věnujeme klinickým příběhům $a$ formulujeme cíle a hypotézy této práce. Ve druhé kapitole vymezujeme a popisujeme náš korpus. Ve třetí kapitole rozvíjíme teoretický rámec naší studie: a) odborné a literární diskurzy; $b$ ) popularizace vědy a literarizace; $c$ ) žánry z hlediska diskurzu; $d$ ) komunikační záměry; $e$ ) textové sekvence; $f$ ) charakterizace vyprávění a příběhu; $g$ ) postavy; $h$ ) narativní perspektiva. Nakonec, ve čtvrté kapitole, analyzujeme náš korpus na základě formulovaných hypotéz a teoretického rámce uvedeného $\mathrm{v}$ předchozích kapitolách. Přezkoumáváme i) formální vlastnosti kazuistik; ii) jejich narativní charakter; iii) terminologii a konvenční slovní spojení; iv) eufemismy $\vee$ určitých př́padech, jako je smrt; v) polyfonii hlasů lékařů a pacientů, at' už v roli vypravěčů nebo samotných postav, a to jak v žánru klinických kazuistik, tak i př́běhů.

V našich počátečních hypotézách jsme nastínili, že by struktura klinických příběhů mohla být implicitnější a pružnější, zatímco u klinických kazuistik by byla tendence ke společné prefixované a konvenčně plánované struktuře, což se ostatně potvrdilo ve většině textů z našeho korpusu. Identifikovali jsme společnou základní strukturu pro kazuistiky zaměřené na výzkum (název, souhrn, úvod, prezentace př́padu, diskuse a zdroje) a zjednodušenou a trochu více proměnnou pro ty vzdělávací, ve kterých je posílena především část prezentace případu. Kromě toho v kazuistikách z neurologie zjištujeme pravidelnou přítomnost grafických doplňků, zejména snímků magnetických rezonancí. V obou žánrech však také nalézáme významné rozdíly ve formátu textu, například $v$ délce, $v$ typu použitého názvu nebo $v$ př́itomnosti či naopak absenci určitých oddílů. Tyto podobnosti a rozdíly souvisí s komunikačními záměry každého žánru, ale i s každým konkrétním textem a jeho autory.

Můžeme tedy ř́ci, že klinické kazuistiky Ize jednoznačně rozeznat mezi ostatními lékařskými žánry, ačkoli nedosahují takové stejnorodosti, jakou jsme očekávali na počátku, a to ani když samostatně analyzujeme kazuistiky zaměřené na výzkum a na výuku. Formální charakteristiky jsou podmíněny jak normami stanovenými každým časopisem, který patří do určité specializace $v$ rámci zdravotních věd, tak i standardy dané diskurzivní komunity, stejně jako konvencemi konsolidovanými v každém jazyce. $V$ rámci těchto pravidel zjištujeme, že časopisy $v$ angličtině, které mohou být označeny jako komerční - jedná se o časopisy velkých vydavatelů, kteří často požadují, aby autoři 
platili za publikování svého príspěvku -, jsou ty, které mají tendenci více dodržovat dané standardy a není mezi nimi tolik rozdílů.

Další rysy klinických kazuistik, které jsme předpokládali v našich hypotézách, a které jsme potvrdili při analýze korpusu, jsou použití konvenčních slovních spojení, která se obvykle opakují ve stejných nebo velmi podobných tvarech a také př́itomnost odborné terminologie. Hlas vypravěče je obvykle také hlasem zdravotnického pracovníka, který kolonizuje primární projev pacienta, jelikož vybírá jen pro sebe podstatné informace, které následně překládá a převádí do výše uvedené terminologie a rozděluje je do různých oddílů svého textu.

Co se týká stylistických rysů, celkově můžeme konstatovat, že ačkoliv jsme odhalili a ukázali některé obzvláště zajímavé odchylky, klinické kazuistiky se obvykle řídí určitými společnými pravidly, jako je např́klad: strohý styl, dokonce i v těch nejvíce narativních textech, nebo tendence vypravěče skrývat se prostřednictvím neosobních frází, aby tak zakryl jakýkoliv projev emocí či vzniklé pochybnosti, nebo také za účelem zachování domnělé objektivity. Tyto texty obvykle poskytují jen velmi málo informací o autorovi/vypravěči a popisy pacientů bývají spíše střízlivé. Charakterizace postav se nevytváří na základě osobních vlastností pacienta, ale prostřednictvím detailů o dané nemoci, jako je anamnéza, příznaky nebo léčba. S tímto také souvisí další informace, které se mohou vyskytnout v kazuistikách, jako je prostor, ve kterém se odehrává děj, a který mívá významnou prítomnost ve většině běžných příběhů. $V$ kazuistikách se ale objevuje téměř výlučně, pokud má, nebo by mohl mít nějakou souvislost například pro diagnózu. Výjimkou jsou zde př́pady se sociální orientací, jako jsou ty, které řeší problémy pacientů s Downovým syndromem.

Mezi odchylkami od prototypického vědeckého diskurzu jsme v našem korpusu našli: a) výskyt sloves $v$ první osobě čísla jednotného, která představují hlas autora nebo dokonce pacienta v životopisném vyprávění; $b$ ) použití první osoby čísla množného tentokrát pro začlenění čtenáře do diskursu; $c$ ) přítomnost dialogu mezi odborníkem a pacientem; $d$ ) užití značně osobních a subjektivních konstrukcí, například pro vyjádření osobních úsudků nebo také využití rodu činného místo trpného ( $v$ katalánštině a španělštině také tzv. passiva reflexa).

Klinické kazuistiky tedy nejsou zcela stejnorodými texty. Můžeme mezi nimi nalézt od těch nejpopisnějších až $\mathrm{k}$ těm nejvíce narativním, tedy $\mathrm{s}$ jasnou převahou těchto 
sekvencí; s názvy, které mohou využít některých básnických nebo i reklamních prostředků; se značnou přítomností hlasu pacienta, a tedy i s účelem vyprávět poutavý a čtivý příběh, dokonce i se zápletkou. Zjištúujeme také, že vyprávění je nepostradatelné i v textech, kde má nejmenší váhu a to proto, že slouží k představení pacienta a toho, co se mu stalo. Můžeme tedy chápat klinické kazuistiky jako vysoce specializované neliterární př́iběhy - jako narativní žánry -, které stojí na hranici mezi žánry vědeckými a literárními. Kazuistiky sdílí rysy s přibuzným žánrem, který považujeme za zcela literární, ačkoli nepatří mezi beletrii: klinickými přiběhy.

Klinické příběhy se označují jako hybrid mezi klinickou kazuistikou a literárním příběhem, který se neomezuje pouze na čtenáře z řad zdravotních pracovníků, ale je otevřený široké veřejnosti. Proto u něj můžeme nalézt v symbióze rysy typické pro oba typy diskurzů. Tyto literární př́běhy bez fikce, o skutečných pacientech, často vyjadřují obavy, ale i kritiku současné zdravotní péče, aniž by ztrácely roli zabavení čtenáře. Také se $v$ nich představují vzácné a pozoruhodné nemoci nebo symptomy, aby je veřejnost poznala a seznámila se s nimi. V oblasti duševního zdraví je obzvláště důležité, abychom všichni znali alespoň některé základní údaje o těchto nemocech, a tímto zabránili stigmatizaci lidí, kteří jimi trpí. Žádný jiný prostředek by nemohl být účinnější než skutečné příběhy, které nás nutí vcítit se do postav, jež nám sdělují podrobnosti o svých životech, problémech i starostech.

Potvrdili jsme př́tomnost a význam narativních sekvencí v klinických kazuistikách. Ověřili jsme také, zdali obsahují prototypické části př́běhu, tj. narativní strukturu podobnou například povídce. Právě proto, abychom dokázali, jak se rozvíjí a objevují tyto různé části narativní struktury, porovnali jsme je s klinickými př́běhy, literárními texty s podobnou tématikou, i když lišíci se jak jazykovým projevem, tak komunikačními cíli. Ukázali jsme a také ověřili, že vyprávění, které se rozvíjí v celé kazuistice, se přizpůsobuje této struktuře př́běhu, a to zcela spontánně, protože autoři tohoto žánru nejsou žádní profesionální spisovatelé beletrie. $V$ rámci konvenčních částí tohoto žánru tak autoři dodržují strukturu přirozeného vyprávění, protože je to model, který mají na mysli, když vypráví svůj př́běh. Ačkoli se jedná o vysoce specializovaný žánr z hlediska formy i obsahu, stále se jedná o vyprávění přiběhu. Příběhy slyšíme už od mala, a proto i bez filologických či diskurzivních znalostí, považujeme za vlastní jejich nejobvyklejší strukturu. Zjistili jsme tedy, že i přes normy stanovené časopisy, ve kterých jsou tyto 
texty publikovány, i přes pravidla komunit, ke kterým patří jejich autoři, mají zdravotničtí pracovníci tendenci dodržovat zcela nebo částečně tuto široce sdílenou narativní strukturu.

Jednou z vlastností, které jsme studovali, abychom potvrdili narativní povahu klinických kazuistik, je časová organizace děje a přítomnost dějového napětí - intriky. Zjistili jsme, že klinické kazuistiky se zrrídka kdy uspořádávají jako pouhý shluk chronologických událostí, vzhledem k tomu, že jsme u nich zaznamenali výběr těchto informací. Ačkoliv podstatná část událostí je obvykle vyprávěna chronologicky (tak, jak bychom očekávali a bylo by to i logické ve vědeckém textu), zdravotničtí pracovníci také využívají prostředky $\mathbf{k}$ přiblížení nebo odložení určitých údajů. Tímto způsobem přidělují některým skutečnostem větší či menší význam než ostatním, a takto také mohou vytvořit jakési narativní napětí nebo i zápletku. Události, které následovaly chronologickou posloupnost $v$ reálném životě pacienta, vypráví on sám nebo jeho př́buzní ve změněném pořadí (obvykle od těch, které ho nejvíce znepokojují). Následně zdravotnický pracovník vybere a přeorganizuje tyto informace podle svých diskurzivních zájmů. Toto je další vlastnost, která nám umožňuje chápat tento žánr jako př́běh: pokud se zamyslíme nad klasickými příběhy, většina událostí je v nich vyprávěna více či méně v chronologickém pořadí s některými odchylkami. V okamžiku, kdy mají tyto informace sloužit ke stvoření klinického příběhu, se jejich výběr a uspořádání provádí se záměrem vytvořit ještě silnější zápletku. Zatímco v klinických kazuistikách je záměr zaujmout čtenáře obvykle jen subtilní, v klinických príbězích se z něj stává jeden z hlavních cílů. V těchto textech je snazší pohybovat se volněji po časové ose a dělat odbočky díky jeho větší flexibilitě, a protože se nemusí přizpůsobovat tolika pravidlům jako vědeckotechnické texty.

Ačkoliv klinické kazuistiky ne vždy vykazují všechny části prototypické struktury př́běhu, zjištúujeme, že existují některé nezbytné, bez kterých by autoři sotva dosáhli komunikačního úspěchu. Jedna z těchto částí je zápletka, ve které se vytváří napětí celého příběhu a probouzí se zde zájem čtenáře. Stejný efekt potřebují vyvolat i zdravotničtí pracovníci: čím větší vzbudí zvědavost svých kolegů, tím více z nich si jejich text přečte a většího uznání dosáhnou ve své komunitě praxe. Další částí je rozuzlení, které je nepostradatelné jak v literárních př́bězích, tak v kazuistikách, protože bez něj by příběh jen nastínil daný problém, a tudíž by nesplnil očekávání čtenářù. I v 
kazuistikách se čtenáři chtějí dozvědět, co se s pacientem stalo. Pokud by tomu tak nebylo, ani by nemělo cenu takový text číst, jelikož se nejedná jen o čtení pro zábavu, ale především o poučení se a získání zkušeností ze sledování postupů a metod ostatních kolegů.

Musíme však zdůraznit, že narativní rysy se neobjevují ve stejné míre ve všech klinických kazuistikách, nýbrž existují různé stupně: od těch, které minimalizují váhu vyprávění, odchylují se méně od chronologického uspořádání a nedodržují tedy tolik narativní strukturu (hlavně u kazuistik z neurologie) až po ty, které plní tyto vlastnosti ve větší míře a blíží se až ke klinickým príběhům (zejména ty z psychologie a psychiatrie). Můžeme si tedy představit, že existuje kontinuita mezi oběma studovanými žánry. Nacházíme zde klinické kazuistiky, které se více přibližují klinickým příběhům, ale také ty, které se jim vzdalují. Uvedli jsme několik př́kladů kazuistik, které bychom mohli téměř zaměnit s fragmenty nějakého románu nebo príběhu. Stále však obsahují další části, např́iklad ty, které vysvětlují detaily předmětu studia, at' už se jedná o specifickou nemoc nebo symptom, a které by se jen sotva mohly objevit v literárním textu.

Můžeme proto považovat klinické kazuistiky za neliterární př́iběhy, které vytváří most mezi ostatními vědeckými texty a klinickými příběhy, a tudíž jsou také mostem mezi vědeckým psaním a literaturou. Kromě srovnávání struktur těchto dvou propojených, ale zároveň odlišných žánrů, se v této práci také zabýváme tím, jak se jejich autoři obrací na oba typy čtenářů: na kolegy z řad odborníků a na širokou veřejnost. Nejprve se zaměříme na terminologii klinických kazuistik, které raadíme mezi specializované diskurzy. Využití prostředků, jako jsou odborné pojmy nebo zkratky, odlišuje tyto texty od běžného diskurzu a způsobuje, že čtenářům mimo tento specializovaný obor mohou připadat jako kondenzované a zašifrované. Tento typ jazyka tedy označuje a posiluje vědecký charakter textu, jakož i př́slušnost ke komunitě praxe. Klinické kazuistiky by měly mít esoteričtější povahu ve srovnání s nezbytně exoterickými klinickými príběhy.

Kromě terminologie nalezneme v kazuistikách také konstrukce, které se obvykle opakují ve stejných nebo velmi podobných tvarech a slouží pro dosažení stejného cíle. Tyto konvenční konstrukce souvisí s komunikačními záměry sdílenými autory různých kazuistik. Slouží k tomu, aby mohli zdůraznit jedinečnost svého případu, prezentovat jej, představit pacienta a také okomentovat významné nálezy zjištěné v testech a dalších 
analýzách. Všechny tyto cíle prezentují konvenčními konstrukcemi, které jsou konsolidované mezi členy diskurzivní komunity. Tyto konstrukce se na druhou stranu obvykle nevyskytují v klinických př́bězích, protože se jedná o literární texty, a opakování stejných slovních spojení, často strnulých a neosobních, neodpovídá jejich komunikačním záměrům: potěšit oči čtenáře.

Jedním z rysů kazuistik, který pozorujeme v klinických příbězích velmi často, je použití terminologie. Považujeme za velmi nepravděpodobné, že by se dalo zcela vyhnout odborným výrazům v klinických příbězích, vzhledem $\mathrm{k}$ tomu, že tvoří nedílnou součást zdravotnictví a přispívají $\mathrm{k}$ tomu, aby tento žánr měl jakýsi zasvěcující nádech, jenž polapí čtenáře. Navíc, aby tyto texty mohly efektivně sdělovat jejich obsah, nestačilo by pouhé přizpůsobení těchto termínů, protože by v nich i nadále existovalo mnoho dalších rysů specializovaného diskurzu. Rovněž ovšem nemůže zmizet vše, co souvisí $s$ vědeckým diskurzem, protože by se tyto texty staly jen pouhými příběhy, jejichž děj se odehrává ve zdravotnické sféře. Autoři klinických příběhů tedy musí nalézt rovnováhu mezi vědeckým a literárním světem, tj. mezi zdravotnickým diskurzem a vyprávěním pro širokou a různorodou veřejnost. Nejedná se o kanonické texty popularizace vědy, ale mohou také hrát tuto roli. Pojmy jako rekontextualizace, reeelaborace a textualizace, které pochází právě ze studia popularizace vědy, nám pomohly pochopit, jakým způsobem se koná proces transformace vědeckých poznatků pro širokou veřejnost.

Soustředili jsme se zejména na použití terminologie a její determinologizaci. Mnoho termínů, které se vyvinuly v odborných oblastech, pronikly do našeho každodenního života, a stala se z nich běžná slova. Oblast duševního zdraví zde není výjimkou, ba naopak: je zcela běžné, že lidé, kteří nejsou ani specialisté ani těmito poruchami nijak netrpěli, znají některá jejich jména. Jak jsme mohli pozorovat v našem korpusu, autoři bud' mohou využít některé z termínů, které jsou již determinologizované, nebo je musí začlenit do svého diskurzu, aniž by při této cestě ztratili své laické čtenáře. Ověřili jsme, že autoři knih v našem korpusu používají různé determinologizační strategie, jako je $a$ ) definice, $b$ ) exemplifikace, c) parafráze, $d$ ) synonyma, e) přirovnání a f) metafory, aby uvedli konkrétní odborné pojmy z oblasti duševního zdraví. Nejvíce termínů, a tedy i největší množství a rozmanitost determinologizačních strategií, nalézáme paralelně v kazuistikách z neurologie a ve dvou knihách klinických príběhů ze stejného oboru (jedna od Olivera Sackse a druhá od Allana Roppera a Briana Davida Burrella). 
Kromě terminologie jsme se také zaměřili na eufemismy, a to v okamžiku, kdy je největší pravděpodobnost se $s$ nimi ve zdravotnictví setkat: $v$ momentu smrti. Ne všechny kazuistiky mohou skončit dokonalým uzdravením pacienta, existují i ty, které vypráví o jeho zhoršení nebo dokonce i o smrti. Mluvit o smrti se stalo přinejmenším v západních společnostech tabu. Zdravotničtí pracovníci jsou - nebo by měli být - lidé, kteří jsou nejvíce zvyklí na její přítomnost, a proto bychom mohli očekávat, že se nebudou přiliš vyhýbat slovům, která označují konec života, takzvaná "D“ words v anglofonní tradici. V naší práci jsme však poznali, že ani v těch kruzích, které jsou natolik obeznámeny se smrtí, eufemismy zcela nezmizely. Zjištúujeme tendenci zmírňovat účinek, který způsobuje mluvit o smrti nebo, v našem případě, o ní psát. Objevili jsme, že kazuistiky, které analyzují smrt jako předmět svého studia -např́klad forenzní kazuistiky - se o ní vyjadřují přímo, bez eufemismů. Na druhou stranu, ty, které se o ní zmiňují, aniž by byla cílem jejich studia, mají tendenci využívat repertoáru eufemismů jak z obecného jazyka, tak z lékařského (dokonce i termínů). Proto i přes domnělou objektivitu údajů prezentovaných v kazuistikách, zjištujujeme obecnou tendenci vyhýbat se „D“ words. V klinických př́bězích smrt není přiliš častá, ale když se objeví, má dopady i mimo rámec používaného lexikonu, protože se stává prvkem, který je použit a využit

\section{k přidání dramatismu textu.}

$V$ této disertační práci jsme také analyzovali polyfonii, tj. jakým způsobem se prezentují hlasy různých účastníků v klinických kazuistikách a v klinických příbězích, at' už se jedná o zdravotnické pracovníky jako autory, jejich kolegy, pacienty anebo jejich příbuzné. Vzhledem k tomu, že obhajujeme narativní charakter klinických kazuistik, chápeme i pacienty -protagonisty př́běhů - jako postavy, jelikož se jedná o výtvory autorů textů. $V$ klinických př́bězích, jakožto v literárních formách, je ještě více zřejmé, že se jedná o postavy vyprávění, ačkoli jsou to odrazy skutečných pacientů, kteří přišli do ordinace.

Na prvním místě jsme se zaměřili na hlasy pacientů, abychom zjistili, jak je jejich původní príběh začleněn do narativního rámce, který vytváří zdravotnický pracovník při psaní kazuistiky. V tomto procesu vidíme, jak autoři vybírají informace v souladu s jejich komunikačními záměry, přeformulovávají řeč pacienta - většinou v nepřímé řeči - $a$ převádějí ji do odborné mluvy své specializace. Autoři mohou navíc doplnit do svého příběhu informace z jiných zdrojů, např́iklad z diagnózy, léčby anebo výsledků. Nalezli 
jsme klinické kazuistiky, jejichž autoři chtěli zachovat doslovně některé výrazy a uvedli je tedy $v$ textu $v$ uvozovkách. Toto řešení je obzvláště časté a podstatné v odborech jako psychologie a psychiatrie nebo $v$ prípadech se sociální tématikou, protože pomáhá vytvořit obraz jak pacienta, tak i duševní poruchy, kterou trpí.

Za druhé jsme studovali výrazy, které mohou způsobit depersonalizaci a také dehumanizaci zdravotní péče. Viděli jsme, že určité slovní obraty, které se používají ve zdravotnických spisech, mohou dopomoci k vytvoření obrazu pacienta jako stěžovatele, hypochondra, nedůvěryhodné nebo dokonce provinilé osoby. Tyto výrazy, které stigmatizují chování pacientů, se objevily i v některých našich kazuistikách, i když je nutné podotknout, že jejich největší přitomnost je v ústní rozpravě mezi kolegy, která ovšem na rozdíl od publikací neprochází žádným filtrem ani nepodléhá žádným pravidlům.

Za třetí jsme analyzovali další faktor, který souvisí s depersonalizací a dehumanizací pacientů: jejich př́tomnost v textu. Je samozřejmé, že jak v kazuistikách, tak i v klinických příbězích musí být chráněny a skryty určité osobní údaje, aby byla zachována jejich anonymita. $\mathrm{V}$ mnoha kazuistikách, jdou ale autoři ještě dál: mají tendenci pacienty $\mathbf{v}$ textu ignorovat a zaměřují téměř veškerou svou pozornost na biologické procesy, které probíhají v jejich tělech, a na biomedicínské testy a léčby. Shledali jsme tedy, že se jedná o pacienty, kteří se stávají druhotnými aktéry, pouhými záminkami pro zveřejnění textu o nějakém př́znaku, nemoci nebo léku, kde se tyto stávají primárními protagonisty případu. $V$ těchto kazuistikách je také běžné vynechat ty, kteří provádějí diagnostické $a$ léčebné procesy a technologie se zde chová, jako by byla činitelem daného děje. Tento postup může sloužit ke konsolidaci důvěryhodnosti předložených výsledků a také ke zmírnění odpovědnosti zdravotnických pracovníků nad svými rozhodnutími. Ne všichni odborníci se však snaží minimalizovat př́tomnost pacientů se stejnou intenzitou. Zatímco $v$ kazuistikách $z$ oblasti neurologie se zaměřují především na fyziologické informace a biomedicínská vyšetření, v mnoha textech z oblasti psychologie, psychiatrie nebo těch, které se zabývají Downovým syndromem, dávají pacientům více prostoru. Můžeme říci, že povaha těchto disciplín jakýmsi způsobem vyžaduje humanizaci nemocných.

Za čtvrté jsme obrátili naši pozornost k výskytu prostorů v klinických kazuistikách. Stejně jako v každém příběhu, popis míst a prostorů, ve kterých se pohybují postavy, 
dopomáhá k jejich charakterizaci. Našli jsme korelaci mezi kazuistikami s aseptičtějším stylem s minimalizací př́tomnosti postav a téměř zmizením prostorů, ve kterých se pohybují. Na druhé straně nalézáme i jiné kazuistiky, více zaměřené na sociální aspekty a vytvořené v komunitách, kde se jich mohou účastnit pacienti nebo príbuzní, a u kterých je pravděpodobnější, že si osvojí lidštější přístup, zahrnující i větší přítomnost popisu prostorů, kde se odehrávají životy těchto pacientů.

Za páté jsme věnovali pozornost pacientům z klinických příběhu. Protože ani komunikační záměry, ani formát tohoto žánru nejsou stejné, předpokládali jsme, že tomu tak bude i u prítomnosti a prezentace pacientů. Autoři zde také musí skrývat určité osobní údaje, protože protagonisté jsou stále skuteční pacienti, kteří prošli jejich ordinací. Kromě takového zásadního rozdílu jako je pojmenování protagonisty př́iběhu - at' už konvenčně nebo pseudonymem - jsou to především lexikální a stylistické prostředky, které vyznačují rozdíly mezi oběma žánry. Autoři zde mohou využít všech řečnických figur k posílení napětí příběhu a vytvoření postavy, ovšem vždy na základě svého skutečného pacienta. Ačkoliv je $v$ našich čtyřech knihách př́běhů velká rozmanitost těchto prostředků, stále se jedná o klinické - zliterárnělé - př́pady se společnými rysy. $V$ tomto žánru tedy najdeme mnohem více osobních, rodinných, a tedy i prostorových informací. Ne všechna tato data jsou nezbytně nutná pro diagnózu, ale slouží k tomu, aby si čtenáři mohli lépe představit daného pacienta a vytvořili si s ním emocionální pouto, které je nezbytné $\mathrm{k}$ dosažení komunikačních cílů tohoto žánru. Literární tvorba a obecně i ta umělecká se snaží apelovat na emoce čtenářů. Často toho dosahuje mnohem efektivněji než zdokumentovaná realita.

Nakonec jsme se zaměřili na zdravotnické pracovníky jako na vypravěče a postavy $v$ klinických příbězích. Na rozdíl od klinických kazuistik, jsou v tomto žánru profesionálové do značné míry prítomní $v$ textu. Jsou to totiž ti, kteří nás provázejí celým textem, aniž by se schovávali. Naopak často zdůrazňují svou přítomnost. Žánr klinických příběhů umožňuje použití strategií, které by nebyly v kazuistikách přípustné. Vidíme zde nejen to, jak odborníci komunikují s pacienty - dialogy mohou být časté a rozsáhlé -, ale také jejich emoce a jejich myšlenky. Každá kniha má své zvláštnosti, pokud jde o to, jak v ní vystupují vypravěči. Každý autor se řídí jinými komunikační účely, ale na některých se shodují: humanizovat medicínu; nechat vyniknout svou kariéru; ukázat, že lékaři jsou 
také jenom lidé a poukázat na některé nemoci a na to, jaké to je s nimi žít a snažit se tak o jejich destigmatizaci.

Klinické př́iběhy jsou tedy žánrem, ve kterém autoři obvykle zvažují současný stav a směr zdravotní péče, a jako vzory $v$ příslušných oborech usilují o předání určitých hodnot. Někteří se dokonce snaží být příkladem pro budoucí odborníky. Kromě léčby pacienta se zde také hloubá nad postavou lékaře. Jedním z př́kladů může být Yalom, který ve své knize přiznává své slabiny a také chyby v úsudcích o pacientech. Na druhé straně, v klinických kazuistikách současně existuje několik tendencí pro zobrazení pacienta $v$ textu. Od těch, které se snaží objektivizovat na maximum všechny získané údaje, až po ty, co nás nechávají si vyslechnout v první osobě pacienta jeho zkušenosti s onemocněním. Je zřejmé, že existují zdravotní obory, ve kterých je snazší zaměřit se na osobní nebo sociální aspekty, nebot' tyto informace jsou středem této disciplíny. $V$ každém prípadě, bez ohledu na obor, připomínáme, že jednou ze specifických vlastností žánru klinických kazuistik je to, že se soustředí na jeden nebo na několik málo případů. To je odlišuje od kvantitativních studií, právě tím, že se mohou zaměřit na každého pacienta zvlášt' a ten se tudíž stává jedinečným a může napomoci pokroku jak v lékařství, tak ve zdravotní péči. Tento žánr přežil do dnešních dnů, protože ne všechny odpovědi Ize získat z velkých studií, ne každý se uzdravuje stejně, a protože my, lidé, jsme rozdílní. Klinické př́běhy, které popisují především zvláštnosti, zdůrazňují tuto naši jedinečnost, zejména př́pady spisovatele a neurologa Olivera Sackse, které často končí málo známými nebo zcela prvotními řešeními ve zdravotní péči, jako je případ muže, který chodil šikmo jako věž v Pise a musel si nechat zhotovit brýle s vodováhou, aby se udržel rovně. Zdravotničtí pracovníci by měli věnovat větší pozornost tomu, co je u každého pacienta ojedinělé, a neodvracet se jen k zobecňování a kategorizaci nemocí.

Můžeme tedy konstatovat, že vyprávění př́běhů má ve zdravotnictví podstatné místo - nepostradatelné z našeho pohledu - a to nejen v literárních textech, jako jsou klinické př́běhy, nebo v ústní komunikaci mezi zdravotnickými pracovníky a pacienty, ale i v odborných textech, jako jsou klinické kazuistiky. Tyto se většinou publikují pro kolegy stejné komunity praxe, se kterými sdílí společné komunikační záměry. Dokázali jsme zde využít pojmy z naratologie pro analýzu obou žánrů, abychom podpořili jejich narativní ráz, obzvláště v př́padě klinických kazuistik. Obhájili jsme tento neprototypický žánr zdravotnického diskurzu, jehož hodnota sahá nad rámec jeho zvláštností pro 
analytiky diskurzu: je to skvělý prostředek pro školení budoucích odborníků a neocenitelný zdroj informací pro výzkum ve zdravotnických vědách. Žánr klinických kazuistik nabízí ojedinělou př́ležitost přeorientovat perspektivu zdravotnických pracovníků při jednání s pacienty jako s jedinečnými a lidskými bytostmi, a ne jako s pouhými nositeli nemocí. Tyto texty by se mohly stát - pokud se tak rozhodnou implikované komunity praxe - prostředkem, který pomůže odborníkům, aby nepřerušili své spojení s lidmi, v době, kdy technologie usnadňuje, čím dál častěji, aby na své pacienty ani nepromluvili ani se jich nedotkli. Stručně řečeno, mohou být užitečným nástrojem ke zlepšení povahy a kvality zdravotní péče: k její humanizaci. 


\section{BIBLIOGRAFIA}

Аввотт, H. Porter (2005): «Narration», en David HeRman, Manfred JaHn i Marie-Laure RYAN (eds.) (2005): Routledge Encyclopedia of Narrative Theory, Abingdon/Nova York: Routledge.

Аввотт, H. Porter (2007): «Story, Plot, and Narration», en David HeRman (ed.): The Cambridge Companion to Narrative, Cambridge: Cambridge University Press, p. 39-51.

Abu-Zidan, Fikri, Alaa Abbas i Ahmed Hefny (2012): "Clinical "Case Series": A Concept Analysis», African Health Sciences, desembre, 12(4), p. 557-62.

ADAM, Jean-Michel (1992): Les textes: types et prototypes, París: Armand Colin.

AdAM, Jean-Michel (2018): «The Narrative Sequence: History of a Concept and a Research Area».

<https://www.unil.ch/files/live/sites/fra/files/shared/The narrative sequence.pdf> [Consulta: 28 de novembre de 2018]

AdAM, Jean-Michel i Clara-Ubaldina LORDA (1999): Lingüística de los textos narrativos, Barcelona: Ariel.

AIKEN, Lewis R. (2000): Dying, Death, and Bereavement, Mahwah: Lawrence Erlbaum Associates. 
AlBerT, Tim (2004): "Why Are Medical Journals So Badly Written?», Medical Education, 38, p. 6-8.

AlCARAz VARÓ, Enrique (2000): El inglés profesional y académico, Madrid: Alianza.

Alcaraz-Ariza, María Ángeles i Françoise Salager-Meyer (2002): «Género y crítica en la prosa médica escrita en español: función comunicativa y relación de poder», Hermes, 29, p. 163- 186.

AlLAN, Keith, and Kate BURRIDGE (2006): Forbidden Words: Taboo and the Censoring of Language, Cambridge/Nova York: Cambridge University Press.

Anolay, Nezih, M. Nihat Arslan, Bahadır Kumral i Yalçın BüYüK (2014): «Death Caused by Honey Bee Stings: Case Report», Medicine Science, 3(2), p. 1305-1314.

ANSPACH, Renee R. (1988): "Notes on the Sociology of Medical Discourse: The Language of Case Presentation», Journal of Health and Social Behavior, 29, p. 357-375.

Anthony, Andrew (04/01/2015): " "Reaching Down the Rabbit Hole" Review Fascinating Tales the Brain» < https://www.theguardian.com/books/2015/jan/04/reaching-down-the-rabbit-holereview-neurologist-brain-tales> [Consulta: 1 de maig de 2018]

ARIÈs, Philippe (1981): The Hour of Our Death, Nova York: Vintage Books.

ASKeHAVE, Inger i John SWALES (2001): «Genre Identification and Communicative Purpose: A Problem and a Possible Solution», Applied Linguistics, 22(2), p. 195-212.

AtKInson, Paul (1995): Medical Talk and Medical Work, Londres: Sage Publications.

AumüLleR, Matthias (2014): "Text Types», en Peter HüHN et al. (eds): The Living Handbook of Narratology, Hamburg: Hamburg University Press. < $\underline{\text { https://www.Ihn.uni- }}$ hamburg.de/> [Consulta: 12 de juny de 2017] 
Bach Martorell, Carme i Jaume Martí (2007): «Revisió crítica de les característiques del discurs especialitzat: el pes de la llei del mercat», en Mercè LORENTE, Rosa EsTOPÀ Bagot, Judit Freixa, Jaume Martí i Carles Tebé (eds.) (2007): Estudis de lingüística i de lingüística aplicada en honor de M. Teresa Cabré Castellví, Barcelona: Universitat Pompeu Fabra/Institut Universitari de Lingüística Aplicada, p. 179-195.

BAKHTín, Mikhaïl (1982): «El problema de los géneros discursivos», en Estética de la creación verbal, Buenos Aires: Siglo XXI.

BAL, Mieke (2009): Narratology: Introduction to the Theory of Narrative, Toronto/Buffalo/Londres: University of Toronto Press.

BAÑos, Josep E. (2015): «Oliver Sacks: un extraordinario médico-escritor, un escritormédico irrepetible», Revista de Medicina y Cine, 11(3), p. 127-129.

Baquero Goyanes, Mariano (1998): ¿Qué es la novela? ¿Qué es el cuento?, Múrcia: Universidad de Murcia.

BARONI, Raphaël i Françoise Revaz (2015): Narrative Sequence in Contemporary Narratology, Ohio: Ohio State University Press.

BARTHES, Roland (1970): «Introducción al análisis estructural de los relatos», en Roland BARTHES et al. (ed.): Análisis estructural del relato, Buenos Aires: Editorial Tiempo Contemporáneo, p. 9-44.

BARTRA KAUfMAnN, Anna (2002): «La passiva i les construccions que s'hi relacionen», en Joan SolÀ, Maria Rosa Lloret, Joan Mascaró i Manuel Pérez Saldanya (eds.): Gramàtica del català contemporani, Barcelona: Empúries, vol. 2, cap. 16.

BaUman, Zygmunt (1992): "Survival as a Social Construct», Theory, Culture and Society, 9, p. 1-36.

BEALL, Jeffrey (2018): «Predatory Journals Exploit Structural Weaknesses in Scholarly Publishing», 4OPEN, 1(1), p. 1-3. <https://www.4opensciences.org/articles/fopen/full html/2018/01/fopen180001s/fopen180001s.html> [Consulta: 11 de setembre de 2019] 
BERGE, Kjell Lars (2003): «The Scientific Text Genres as Social Actions: Text Theoretical Reflections on the Relations between Context and Text in Scientific Writing», en Kjersti FLøTtUm i François Rastier (eds.): Academic Voices, Oslo: Novus Press, p. 141-157.

Berkenkotter, Carol (2008): Patient Tales. Case Histories and the Uses of Narrative in Psychiatry, Columbia: University of South Carolina Press.

Berkenkotter, Carol i Thomas N. Huckin (1995): Genre Knowledge in Disciplinary Communication: Cognition/Culture/Power, Hillsdale: Lawrence Erlbaum Associates.

BHATIA, Vijay (1993): Analysing genre: Language use in Professional Settings, Londres/Nova York: Longman.

Bhatia, Vijay (2012): «Professional Written Genres», en James Paul Gee i Michael HANDFORD (eds.): The Handbook of Discourse Analysis, Londres/Nova York: Routledge, p. $239-251$.

BORG, Erik (2003): «Discourse Community», ELT Journal, 57(4), p. 398-400.

BORJA i SANZ, Joan (2013): Els discursos de la ciència. Joan Fuster i la democratització del coneixement, València: Publicacions de la Universitat de València.

BRIGGS, Charles L. (ed.) (1996): Disorderly Discourse: Narrative, Conflict and Inequality, Oxford: Oxford University Press.

Brockmeier, Jens i CARbaugh, Donal (eds.) (2001): Narrative and Identity: Studies in Autobiography, Self and Culture, Amsterdam: John Benjamins.

Brown, Gillian (1983): Discourse Analysis, Cambridge: Cambridge University Press.

BuRdiles, Gina (2016): "Género Caso Clínico: Organización retórica de su macromovida Relato del Caso en publicaciones médicas chilenas», Revista Signos, 49(91), p. 192-216.

Burke P., Allen, Muhammad Nasir Afza, Muhammad Nasir AfZal, Diane Scala Barnett i Renu VIRMANI (1999): "Sudden Death After a Cold Drink: Case Report», American Journal of Forensic Medicine \& Pathology, 20(1), p. 37-39. 
Cabré Castellví, M. Teresa (1992): La terminologia: la teoria, els mètodes, les aplicacions, Barcelona: Empúries.

Cabré Castellví, M. Teresa (2003): «Theories of Terminology - Their Description, Prescription and Explanation», Terminology, 9(2), p. 163-199.

Cabré Castellví, M. Teresa i Rosa Estopà Bagot (2005): «Unidades de conocimiento especializado, caracterización y tipología», en M. Teresa CABRÉ CASTELLVí i Carme BACH MARTORELl (eds.): Coneixement, llenguatge i discurs especialitzat, Barcelona: Institut Universitari de Lingüística Aplicada, p. 69-94.

Cabré Castellví, M. Teresa, Carme Bach Martorell, Josep M. Castellà lidon i Jaume MARTí LLOBEt (2007): «La caracterización lingüística del discurso especializado,» en Ricardo MaIRAL et al. (ed.): Aprendizaje de lenguas, uso del lenguaje y modelación cognitiva: perspectivas aplicadas entre disciplinas (Actas del XXIV Congreso Internacional de la Asociación Española de Lingüística Aplicada-AESLA), Madrid: Universidad Nacional de Educación a Distancia/AESLA.

CALSAMigliA, Helena i Amparo Tusón (1999): Las cosas del decir. Manual de análisis del discurso, Barcelona: Editorial Ariel.

Calsamiglia, Helena i Daniel CASSANy (2001): «Voces y conceptos en la divulgación científica», Revista Argentina de Lingüística, 11-15, p. 173-208.

CAREY, John C. (2006a): «A Species Not Extinct: Publication of Case Reports and Scientific Knowledge», American Journal of Medical Genetics, 140A(8), p. 801-803.

CAREY, John C. (2006b): «Significance of Case Reports in the Advancement of Medical Scientific Knowledge», American Journal of Medical Genetics, 140A(19), p. 2131-2134.

CASSANY, Daniel (2003): «Análisis de la divulgación científica: modelo teórico y estrategias divulgativas», Lingüística y cultura. XIV Congreso de la Sociedad Chilena de Lingüística, Osorno: Editorial Universidad de Los Lagos, p. 57-80. 
CASSANY, Daniel, Carmen LóPEZ i Jaume MARTí (2000): «La transformación divulgativa de redes conceptuales científicas. Hipótesis, modelo y estrategias», Discurso y sociedad, 2(2), p. 73-103.

ChARON, Rita (2006): Narrative Medicine. Honoring the stories of illness, Nova York: Oxford University Press.

Charon, Rita, Sayantani DasGupta, Nellie Hermann, Craig Irvine, Eric R. Marcus, Edgar Rivera Colón, Danielle Spencer, Maura Spiegel (2016): The Principles and Practice of Narrative Medicine, Nova York: Oxford University Press.

Chatman, Seymour (1980): Story and Discourse, Narrative Structure in Fiction and Film, Ithaca: Cornell University Press.

Chatman, Seymour (1990): Coming to Terms: The Rhetoric of Narrative in Fiction and Film, Ithaca: Cornell University Press.

CheshiRe, Jenny i Sue Ziebland (2005): «Narrative as a Resource in Accounts of the Experience of Illness", en Joanna THORNBORROW i Jennifer COATES (eds.): The Sociolinguistics of Narrative, Amsterdam: John Benjamins, p. 17-40.

CIAPUSCIO, Guiomar (2005): «Las metáforas en la creación y recontextualización de la ciencia», Signo y Seña, 14, p. 183-211.

Ciapuscio, Guiomar Elena, Inés Kuguel i Isabel OtañI (2005): «El conocimiento especializado: el texto de especialidad y los criterios para su tipologización», en M. Teresa Cabré Castellví i Carme Bach Martorell (eds.): Coneixement, Ilenguatge i discurs especializat, Barcelona: Institut Universitari de Lingüística Aplicada, p. 95-110.

Clemente, Ignasi (2015): Uncertain Futures: Communication and Culture in Childhood Cancer Treatment, Chichester: Wiley-Blackwell.

COHEN, Bruce (2008): Mental Health User Narratives. New Perspectives on IIIness and Recovery, Hampshire/Nova York: Palgrave Macmillan. 
CoHen, Henry (2006): "How to Write a Patient Case Report», American Journal of Health-System Pharmacy, 63, p. 1888-1892.

Corless, Inge, Barbara B. Germino, and Mary A. Pittman (eds.) (2003): Dying, Death, and Bereavement, Nova York: Springer.

DAMASIO, Antonio (1994): Descartes' Error: Emotion, Reason and the Human Brain, Nova York: Avon Books.

DAMASIO, Antonio (1994): Descartes' Error: Emotion, Reason, and the Human Brain, Berkley: Putnam.

Dannenberg, Hilary P. (2005): «Plot», en David Herman, Manfred Jahn i Marie-Laure RYAN (eds.) (2005): Routledge Encyclopedia of Narrative Theory, Abingdon/Nova York: Routledge.

DANS, Peter E. (2002): "The Use of Pejorative Terms to Describe Patients: "Dirtball" Revisited», Proceedings (Baylor University. Medical Center), gener 15(1), p. 26-30.

DAsCa BAtAlla, Maria (2017): Entenebrats. Literatura catalana i bogeria, Barcelona, Publicacions de l'Abadia de Montserrat.

DemuÉn, Zsófia i Elena Semino (2017): «Using Metaphor in Healthcare: Physical Health», en Elena SEMINo i Zsófia DeMJÉN (eds.): The Routledge Handbook of Metaphor and Language, Abingdon: Routledge.

DeRMAN, Wayne E. (2011): «Clinical Case Reporting in Sports and Exercise Medicine», South African Journal of Sports Medicine, 23(3), p. 98-99.

DOMÈNECH BAGARIA, Ona (2006): Textos especialitzats $i$ variació vertical: la diversitat terminològica com a factor discriminant del nivell d'especialització d'un text (tesi doctoral), Universitat Pompeu Fabra.

Domínguez, Martí (2001): «L'estil fa la ciència», Treballs de la SCB, 51, p. 185-188. 
Domínguez, Martí i Lucía SAPIÑA (2016): «Cancer Metaphors in Sports News: The Match that Must Be Won», en Pilar Ordóñez-López i Nuria Edo-MarzÁ (eds.): Medical Discourse in Professional, Academic and Popular Settings, Bristol: Multilingual Matters, p. $149-175$.

Drass, Kris A. (1981): The Social Organization of Mid-Level Provider-Patient Encounters (tesi doctoral), Indiana University.

EAgleman, David (2011): Incognito: The Secret Lives of the Brain, Nova York: Penguin Random House.

EGgINS, Suzanne i James Robert MARTIN (2003): «El contexto como género. Una propuesta de lingüística funcional», Revista Signos, 36(54), p. 185-205.

EsquenA, Salvador (2016): En la pell del pacient, Barcelona: Ara Llibres.

ESTOPÀ BAGOT, Rosa (2000): «Los adjetivos en las unidades terminológicas poliléxicas: un análisis morfosemántico», Organon, 14(28/29), p. 233-246.

FLUDERNIK, Monika (2009): An Introduction to Narratology. Londres/Nova York: Routledge.

FLyNN, Eleanor i Jennifer PHILIP (2017): «How Doctors Are Taught to Deal with Death», The Conversation, 22 d'octubre. <https://theconversation.com/how-doctors-aretaught-to-deal-with-death-84429> [Consulta: 23 de març de 2018]

FORSTER, Edward Morgan (1985): Aspects of the Novel, Harmondsworth: Penguin Books.

FrancIS, Gill i Anneliese Kramer-Dahl (1991): «From clinical report to clinical story: Two ways of writing about a medical case», en Eija VENTOLA (ed.): Functional and Systemic Linguistics: Approaches and Uses. Berlín/Nova York: Mouton de Gruyter, p. 339-368.

FRANK, Arthur W. (2010): Letting Stories Breathe: A Socio-Narratology, Chicago/Londres: University of Chicago Press. 
FreIXA, Judit (2005): «La variació denominativa a través de la variació vertical», en M. Teresa Cabré Castellví i Carme Bach Martorell (eds.): Coneixement, llenguatge i discurs especializat, Barcelona: Institut Universitari de Lingüística Aplicada, p. 113-131.

FreixA, Judit; Elisabet Solé i M. Teresa CABré CAStellví (1998): Descripció quantitativa dels neologismes documentats durant l'any 1995 a la premsa en català, Barcelona: Observatori de Neologia, Universitat Pompeu Fabra.

FRENCH, Roger (2003): Medicine before Science: The Business of Medicine from the Middle Ages to the Enlightenment, Cambridge: Cambridge University Press

Fundació Catalana Síndrome de Down (FCSD): <https://www.fcsd.org/ca/sd-revistamèdica_30575> [Consulta: 23 d'abril de 2018]

Gamero Pérez, Silvia (2001): La traducción de textos técnicos. Descripción y análisis de textos (alemán-español), Barcelona, Ariel.

Garcia LANDA, José Ángel (1998): Acción, Relato, Discurso: Estructura de la ficción narrativa, Salamanca: Ediciones Universidad de Salamanca. <https://ssrn.com/abstract=2480262> [Consulta: 6 de setembre de 2017]

García NegronI, María (2008): «Subjetividad y discurso científico-académico. Acerca de algunas manifestaciones de la subjetividad en el artículo de investigación en español», Revista signos, 41(66), p. 9-31.

GenETTE, Gérard (1969): Figures II, París: Seuil.

GenETTE, Gérard (1972): Figures III, París: Seuil.

GenetTe, Gérard (1980): Narrative Discourse. An Essay in Method, Oxford: Blackwell.

GENETTE, Gérard (1988): Narrative Discourse Revisited, Ithaca: Cornell UP.

GenetTE, Gérard (2002): «Fronteras del relato», en Roland BARTHES et al. (eds.): Análisis estructural del relato, México: Ediciones Coyoacán, p. 204-213. 
Georgakopoulou, Alexandra (2005): "Text-Type Approach to Narrative», en David Herman, Manfred Jahn i Marie-Laure Ryan (eds.) (2005): Routledge Encyclopedia of Narrative Theory, Abingdon/Nova York: Routledge.

GeORGE, Victoria i Alan Dundes (1978): «The Gomer: A Figure of American Hospital Folk Speech», The Journal of American Folklore, 91(359), p. 568-581.

Gérvas Camacho, Juan, Mercedes Pérez Fernández, Vicente Albert Cuñat i José Antonio Martínez Pérez (2002): «El caso clínico en medicina general», Atención Primaria, 30(6), p. $405-410$.

GoffMAN, Erving (1974). Frame Analysis: An Essay on the Organization of Experience, Nova York: Harper and Row.

GoPIKRISHNA, Velayutham (2010): «A Report on Case Reports», Journal of Conservative Dentistry, 13(4), p. 265-271.

GORER, Geoffrey (1967): Death, Grief and Mourning, Garden City: Doubleday.

GotTI, Maurizio (2016): «Variations in Medical Discourse», en Pilar OrdóÑEZ-LóPEZ i Nuria Edo-Marzá (eds.): Medical Discourse in Professional, Academic and Popular Settings, Bristol: Multilingual Matters, p. 9-30.

GotTI, Maurizio i Carmen Sancho GuIndA (eds.) (2013): Narratives in Academic and Professional Genres, Bern: Peter Lang.

Gottlieb, Geoffrey J., Anna Ragaz, Joseph V. Vogel, Alvin Friedman-Kien, Arkadi M. Rywlin, Edward A. Weiner i A. Bernard ACKerman (1981): «A Preliminary Communication on Extensively Disseminated Kaposi's Sarcoma in Young Homosexual Men», American Journal of Dermatopathology, 3(2), p. 111-114.

Goyal, Rishi (2013): «Narration in Medicine», en Peter HüHN et al. (eds): The Living Handbook of Narratology, Hamburg: Hamburg University Press. < https://www.Ihn.unihamburg.de/> [Consulta: 21 de juliol de 2017] 
GRABES, Herbert (1978): «Wie aus Sätzen Personen werden...: Über die Erforschung literarischer Figuren», Poetica, 10, p. 405-8.

GrabowskI, Michael (ed.) (2015): Neuroscience and Media: New Understandings and Representations, Nova York/Oxon: Routledge.

Green, Bart N. i Claire D. Johnson (2006): «How to Write a Case Report for Publication», Journal of Chiropractic Medicine, 2(5), p. 72-82.

Greenhalgh, Trisha (2001): How to Read a Paper: The Basics of Evidence, Londres: BMJ Books.

Greenhalgh, Trisha i Brian Hurwitz (1999): «Narrative Based Medicine. Why Study Narrative?», British Medical Journal, 318(7175), p. 48-50.

Greenhalgh, Trisha i Brian Hurwitz (2004): Narrative Based Medicine. Londres: BMJ Books.

Grimes, David A i Kenneth Schulz (2002): «Descriptive Studies: What They Can and Cannot Do», Lancet, 359, p. 145-149.

GuARDIOlA, Elena i Josep E. BAÑos (2014): "Oliver Sacks y la neurología literaria», Revista de Neurología, 58(6), p. 277-283.

GUIMARÃES, Carlos Alberto (2015): «Evidence Based Case Report», Revista do Colégio Brasileiro de Cirurgiões, 42(5), p. 280.

GutiérRez Rodilla, Bertha M. (2005): «La medicina, sus mundos y sus lenguajes», en M. Teresa Cabré Castellví i Carme Bach Martorell (eds.): Coneixement, llenguatge i discurs especializat, Barcelona: Institut Universitari de Lingüística Aplicada, p. 131-140.

GutiéRrez RuedA, Carlos Ramiro (2018): «El género discursivo como acción social: un análisis de un artículo de investigación en Filosofía desde la perspectiva socio-retórica» < $\underline{\text { https://www.academia.edu/31337693/El_Género_Discursivo_como_Acción_Social_u }}$

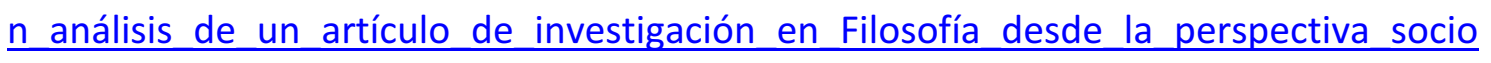
-retórica> [Consulta: 8 de març de 2019] 
HAR-EL, Gady (1999): "Does It Take a Village to Write a Case Report?», Otolaryngology-Head and Neck Surgery, 120, p. 787-788.

HARDY, Barbara (1968): «Towards a Poetics of Fiction», Novel, 2, p. 5-14.

HARVEY, Lee (2018): Researching the Real World. <http://www.qualityresearchinternational.com/methodology/RRW6pt3Genreanalysis. php - pt6311> [Consulta: abril de 2018]

HeEREMA, Esther (2018): «Euphemisms for Dead, Death, and Dying: Are They Helpful or Harmful?», Verywell Health, 12 de febrer. <https://www.verywell.com/euphemismsfor-dead-death-or-dying-1131903> [Consulta: 16 d'abril de 2018]

HeLÁN, Robert (2012): Analysis of Published Medical Case Reports: Genre-Based Study (tesi doctoral), Brno: Masarykova univerzita.

Herbert, Anthony (2016): "The Role of Euphemisms in Healthcare Communication», Journal of Healthcare Communications, 1(2:14), p. 1-2.

HERMAN, David (2009): Basic Elements of Narrative, West Sussex: Wiley-Blackwell.

HeRman, David, Manfred JAHn i Marie-Laure RYAN (eds.) (2005): Routledge Encyclopedia of Narrative Theory, Abingdon/Nova York: Routledge.

Herzberg (1986): «The Politics of Discourse Communities», comunicació presentada a la Conference on College Composition and Communication, Nova Orleans.

HoffMANN, Roald (2006): «The Metaphor, Unchained», American Scientist, 94, p. 406407.

HURWITZ, Brian (2000): «Narrative and the Practice of Medicine», Lancet, 356, p. 20862089.

HURWITZ, Brian (2006): «Form and Representation in Clinical Case Reports», Literature \& Medicine, 25(2), p. 216-240. 
HuRWITZ, Brian i Rita CHARON (01/06/2013): «A Narrative Future for Health Care», The Lancet, 381(9881), p. 1886-1887.

HydÉN, Lars-Christer (2005): «Medicine and Narrative», en David Herman, Manfred JAHN i Marie-Laure RYAN (eds.) (2005): Routledge Encyclopedia of Narrative Theory, Abingdon/Nova York: Routledge.

HyMES, Dell (1974): Foundations in Sociolinguistics: An Ethnographic Approach, Filadèlfia: University of Pennsylvania Press.

JAKOBSON, Roman (1963): Essais de linguistique générale, París: Les Éditions de Minuit.

JANNIDIS, Fotis (2013): «Character», en Peter HüHN et al. (eds): The Living Handbook of Narratology, Hamburg: Hamburg University Press. <https://www.Ihn.uni-hamburg.de/> [Consulta: 22 de maig de 2017]

Jefferson, Tom (2008): «More Cases, Doctor? Yes Please!», Cases Journal 38(1). <https://casesjournal.biomedcentral.com/articles/10.1186/1757-1626-1-38>

[Consulta: 12 d'octubre de 2018]

Jenicek, Milos (2001): Clinical Case Reporting in Evidenced-Based Medicine, Londres: Arnold.

JeNICEK, Milos (2018): How to Think in Medicine: Reasoning, Decision Making, and Communication in Health Sciences and Professions, Abingdon/Nova York: Routledge.

JINICH, Horacio (2013): "Algunas notas sobre el discurso médico», Medicina Interna de México, 2(29), p. 121-127.

JOHNSON, Claire (2005): «Questioning the importance of authorship», Journal of Manipulative and Physiological Therapeutics, 28, p. 149-150.

Kenny, Nuala P. i Brenda L. Beagan (2004): «The Patient as Text - A Challenge for Problem-Based Learning», Medical Education, 38, p. 1071-1079. 
KHAN, Khalid S. i Peter J. Thompson (2002): «A Proposal for Writing and Appraising Case Reports», International Journal of Obstetrics \& Gynaecology, 109(8), p. 849-851.

KleInMAN, Arthur (1988): The Illness Narratives: Suffering, Healing and the Human Condition, Londres: Harper Collins.

KLEINMAN, Arthur (1995): Writing at the Margin: Discourse between Anthropology and Medicine, Berkeley/Los Angeles: University of California Press.

KoŤÁTKovÁ, Adéla (2017): «Neurologia científica i divulgació literària: estratègies de desterminologització en L'home que va confondre la seva dona amb un barret, d'Oliver Sacks», eHumanista/IVITRA, 11, p. 288-299.

KOŤÁTKOVA, Adéla (2018a): «Un puente entre las ciencias médicas y las humanidades: aproximación a los discursos de la salud», Studia Iberica et Americana (SIBA), Monograph 5, p. 37-54.

KoŤÁTKOVÁ, Adéla (2018b): «El sanatori en la novel·lística contemporània: ‘El mar’ de Blai Bonet», Mètode, 96, p. 85-90.

KoŤÁTKOvA, Adéla (en premsa $a$ ): «Rhetoric of Death In Clinical Case Reports and Clinical Tales», en Vicent Salvador, Adéla KoŤÁtKova i Ignasi Clemente (eds.): Discourses on the Edges of Life, Amsterdam: John Benjamins, p. 97-110.

KoŤÁTKOVA, Adéla (en premsa $b$ ): «Las huellas de la dominación: traduciendo el léxico de la salud», en Anna KUKUŁKA-WoJTASIK (ed.): Translatio et Histoire des Ideés / Translatio and History of Ideas, Berlin: Peter Lang, p. 21-32.

KUKKONEN, Karin (2014): «Plot», en Peter HüHN et al. (eds): The Living Handbook of Narratology, Hamburg: Hamburg University Press. <https://www.Ihn.uni-hamburg.de/> [Consulta: 25 de juny de 2017]

Kunt-AKBAŞ, Semra (2013): A Genre Analysis of Medical Case Reports: <https://www.academia.edu/2452076/A_Genre_Analysis_of_Medical_Case_Reports> [Consulta: 10 d'abril de 2019] 
LABOV, William (1997): Narrative Analysis: Oral Versions of Personal Experience, Seattle: University of Washington Press.

LABOV, William i Joshua WALETZKY (1967): «Narrative Analysis: Oral Versions of Personal Experience», en June HeLm (ed.): AES Essays on the Verbal and Visual Arts. Proceedings of the 1966 Annual Spring Meeting. American Ethnological Society, Seattle: American Ethnological Society, p. 12-44.

LAMUELA, Xavier (2004): «Instal·lació o establiment? Encara sobre els objectius de la promoció lingüística», Caplletra, 37, p. 215-242.

LÁszló, János (2008): The Science of Stories: An Introduction to Narrative Psychology, Londres/Nova York: Routledge.

LETHBRIDGE, Stefanie i Jarmila MILDORF (2004): Basics of English Studies: An Introductory Course for Students of Literary Studies in English, Universitats de Tübingen, Stuttgart i Freiburg. $<$ http://www2.anglistik.unifreiburg.de/intranet/englishbasics/Discourse01.htm - storydisc> [Consulta: 16 de novembre de 2018]

LOLAS, Fernando (2015): Fundamentos para una teoría de la medicina, Madrid/Londres/Nova York: Niram Art.

lópez Aramburo, M. A; Claver Criado, M.; Gutiérrez Mínguez, E.; Arroyo Muñoz, J. L.; Espiga Santamaría, F. J.; Gómez lópez, A.; Marcos Díaz, J.; Alcalde Delgado, F. i Andreu GARCíA, A. (1989): «Quiste multilocular renal: consideraciones clínico-patológicas», Actas Urológicas Españolas, 13, p. 1-9.

MACIÁN, Cecili (2013): La construcción discursiva de la profesión podológica: aplicación al análisis de un corpus de revistas especializadas (tesi doctoral), Universitat Jaume I.

MaingueneaU, Dominique (1999): Términos claves del análisis del discurso, Buenos Aires: Nueva Visión. 
Maingueneau, Dominique (2009): Análisis de textos de communicación, Buenos Aires, Nueva Visión.

Maingueneau, Dominique i Vicent Salvador (1995): Elements de lingüística per al discurs literari, València: Tàndem Edicions.

Margolin, Uri (2005): «Character», en David Herman, Manfred JAHn i Marie-Laure Ryan (eds.) (2005): Routledge Encyclopedia of Narrative Theory, Abingdon/Nova York: Routledge.

MARINI, Maria Giulia (2015): Narrative Medicine: Bridging the Gap between EvidenceBased Care and Medical Humanities, Nova York: Springer.

Martín-MARTín, Pedro (2003-2004): "Genre and Discourse Community», ES: Revista de Filología Inglesa, 25, p. 153-166.

MARTIN, James Robert (1984): «Language, Register and Genre», en Frances CHRISTIE (ed.): Children Writing. Reader, Geelong, Victoria: Deakin University Press, p. 21-29.

MASSIMINI, Marcello i Giulio Tononı (2018): Sizing up Consciousness: Towards an Objective Measure of the Capacity for Experience, Oxford: Oxford University Press.

Mattingly, Cheryl i Linda C. Garro (eds.) (2000): Narrative and the Cultural Construction of IIIness and Healing, Berkeley/Londres: University of California Press.

MaURAnen, Anna (1993): Cultural Differences in Academic Rhetoric, Frankfurt del Main: Peter Lang.

Mayoral, Marina (ed.) (1990): El personaje novelesco, Madrid: Cátedra/Ministerio de Cultura.

McAdams, Dan P., Ruthellen Josselson i Amia LIEBLICH (eds.) (2001): Turns in the Road: Narrative Studies of Lives in Transition, Washington: American Psychological Association. 
Medeiros Parente, Raphael Câmara, Marco Aurélio Pinho De Oliveira i Roger Keller Celeste (2010): "Case Reports and Case Series in the Era of Evidence - Based Medicine», Brazilian Journal of Videoendoscopic Surgery, 3(2), p. 63-66.

Meister, Jan Christoph (2014): «Narratology» en Peter HüHN et al. (eds): The Living Handbook of Narratology, Hamburg: Hamburg University Press. < https://www.Ihn.unihamburg.de/> [Consulta: 2 de juny de 2017]

MilleR, Carolyn R. (1984): "Genre as Social Action», Quarterly Journal of Speech, 70(2), p. 151-167.

Monroe, William Frank, Warren Lee Holleman i Marsha Cline Holleman (1992): «Is There a Person in This Case?», Literature and Medicine, 11(1), p. 45-63.

MonTALT, Vicent (2004): «El català com a llengua de traducció cientificotècnica i la planificació lingüística», en Joan Andreu, Lluís MeSeguer, Vicent PITARCH i Vicent Salvador (eds.): La llengua i la literatura: història i actualitat, Castelló de la Plana: Institut d'Estudis Catalans/Universitat Jaume I, p. 103-113.

Montalt, Vicent i Isabel García-Izquierdo (2016): «Exploring the Links Between the Oral and the Written in Patient-Doctor Communication», en Pilar OrdóñEZ-LóPEZ i Nuria Edo-MarzÁ (eds.): Medical Discourse in Professional, Academic and Popular Settings, Bristol: Multilingual Matters, p. 103-124.

Montalt, Vicent i Maria GonzÁlez-Davies (2014): Medical Translation Step by Step: Learning by Drafting (Translation Practices Explained), Nova York/Oxon: Routledge.

Montero Martínez, Silvia (2003): Estructuración conceptual y formalización terminográfica de frasemas en el subdominio de la oncología (tesi doctoral), Universidad de Valladolid.

MONTGOMERY HUNTER, Kathryn (1991): Doctors' Stories: The Narrative Structure of Medical Knowledge, Princeton: Princeton University Press.

Montgomery, Martin (2007): The Discourse of Broadcast News: A Linguistic Approach, Londres: Routledge. 
MORAlES, Óscar Alberto (2010): Los géneros escritos de la odontología hispanoamericana. Estructura retórica y estrategias de atenuación en artículos de investigación, casos clínicos y artículos de revisión (tesi doctoral), Universitat Pompeu Fabra.

Morales, Óscar Alberto, Daniel CAssany, Ernesto Ilich Marín-Altuve i Carolina GonZÁlEZ-PEÑA (2007): «El discurso escrito de la Odontología: análisis retórico discursivo de casos clínicos hispanos (1999-2005)", MedULA: Revista de la Facultad de Medicina, 16(2), p. 75-82.

Morel SANTASUSAGNA, Jordi (2001): L'aprenentatge de coneixement especialitzat a través de l'anàlisi d'alguns conceptes del dret de família (tesi doctoral), Institut Universitari de Lingüística Aplicada, Universitat Pompeu Fabra.

MuÑoz DAGUA, Clarena (2010): «El rol de la metáfora léxica en la divulgación de la ciencia», Tabula Rasa: Revista de humanidades, 13, p. 273-292.

MuÑOz TORRES, Carlos Arturo (2011): Análisis contrastivo y traductológico de textos médicos (inglés-español). El género caso clínico (tesi doctoral), Universitat Autònoma de Barcelona.

Neely, J. Gail, Ron J. Karni, Brian Nussenbaum, Randal C. Paniello, Patrick L. Fraley, Eric W. WANG i Jason T. RICH (2008): «Practical Guide to Understanding the Value of Case Reports», Otolaryngology-Head and Neck Surgery, 138, p. 261-264.

Nemoto, Hiroyuki (2011): The Management of Intercultural Academic Interaction: Student Exchanges between Japanese and Australian Universities, Newcastle: Cambridge Scholars Publishing.

NiederHoff, Burkhard (2013): «Focalization», en Peter HüHN et al. (eds): The Living Handbook of Narratology, Hamburg: Hamburg University Press. <https://www.Ihn.unihamburg.de/> [Consulta: 18 de maig de 2017] 
Niederhoff, Burkhard (2013): «Perspective - Point of View», en Peter HüHN et al. (eds): The Living Handbook of Narratology, Hamburg: Hamburg University Press. <https://www.Ihn.uni-hamburg.de/> [Consulta: 14 de juny de 2017]

NISSEN, Trygve i Rolf WYNN (2012): «The Recent History of the Clinical Case Report: A Narrative Review», Journal of the Royal Society of Medicine, 3(87), p. 1-5. <https://www.ncbi.nlm.nih.gov/pmc/articles/PMC3545337/> [Consulta: 13 de setembre de 2017]

OCHS, Elinor (2000): «Narrativa», en Teun VAN DIJk (ed.): El discurso como estructura y como proceso, Buenos Aires: Gedisa, p. 271-304.

OfrI, Danielle (2017): What Patients Say, What Doctors Hear, Boston: Beacon Press [llibre electrònic].

Oliver del Olmo, Sonia (2005): Análisis contrastivo español/inglés de la atenuación retórica en el discurso médico: el artículo de investigación y el caso clínico (tesi doctoral), Universitat Jaume $\mathbf{l}$.

ORganització Mundial de LA SALUt (2005): «Glaring Inequalities for People with Mental Disorders Addressed in New WHO Effort». <http://www.who.int/mediacentre/news/notes/2005/np14/en/index.html> [Consulta: 22 d'abril de 2018]

PALTRIDGE, Brian (1994): «Genre and Text-Type and the Language Learning Classroom», ELT Journal, 50(3), p. 237-243.

Paltridge, Brian (1997): Genre, Frames and Writing in Research Settings. Pragmatics and Beyond, Amsterdam: John Benjamins.

Patsopoulos, Nikolaos, Apostolos A. Analatos i John P. IOANnidis (2005): «Relative Citation Impact of Various Study Designs in the Health Sciences», JAMA, 293(19), p. 2362-2366. 
Pérez HeRnÁndez, Chantal (2000): Explotación de los córpora textuales informatizados para la creación de bases de datos terminológicas (tesi doctoral), Universidad de Málaga.

Pimentel Luz, Aurora (1995): «Teoría narrativa», en Esther Cohen (ed.): Aproximaciones. Lecturas del texto, Ciutat de Mèxic: Universidad Nacional Autónoma de México, p. 257-287

Posteguillo Gómez, Santiago i Jordi Piqué-Angordans (2007): «El lenguaje de las ciencias médicas: comunicación escrita», en Enrique AlCARAZ VARó, José MATEO MARTínez i Francisco Yus RAmos (coords.): Las lenguas profesionales y académicas, Barcelona: Ariel, p. 167-181.

POTTER, Jonathan (1996): Representing Reality: Discourse, Rhetoric and Social Construction, Londres: Sage.

PŘIDALovÁ, Marie (1998): «Proč je moderní smrt tabu?», Sociologický Časopis/Czech Sociological Review, 34(3), p. 347-361.

PRINCE, Gerald (2012): «Récit minimal et narrativité», en Sabrinelle BEDRANE, Françoise REVAZ et Michel VIEGNES (eds.): Le récit minimal: Du minime au minimalisme. Littérature, arts, médias, París: Presses Sorbonne Nouvelle, p. 23-32.

QuiRogA, Horacio (1992): "La retórica del cuento», en Cuentos escogidos, Caracas: Biblioteca Ayacucho, p. 92-94.

ReVAZ, Françoise (1997): Les textes d'action, París: Klincksieck.

REVAZ, Françoise (2009): Introduction à la narratologie: Action et narration, Louvainla-Neuve: De Boeck-Duculot.

RICceUR, Paul (1983): Temps et récit, volum 1, París: Seuil.

RICceUR, Paul (1986): Du texte à l'action. Essais d'herméneutique, volum 2, París: Seuil. 
Ryan, Marie-Laure (2005): «Narrative», en David HeRMAN, Manfred JaHN i Marie-Laure RYAN (eds.) (2005): Routledge Encyclopedia of Narrative Theory, Abingdon/Nova York: Routledge.

SACKS, Harvey (1995): Lectures on Conversation, volums I i II, Oxford: Blackwell.

SACKS, Oliver (1987a): The Man Who Mistook His Wife for a Hat and Other Clinical Tales, Nova York: Perennial Library.

SACKS, Oliver (1987b): «Dr. Oliver Sacks», en Jonathan CotT (ed.): Visions and Voices, Nova York: Dolphin/Doubleday, p. 37-49.

SACKS, Oliver (1999): L'home que va confondre la seva dona amb un barret (traducció de Margarida Trias), Barcelona: Proa.

SAFIR, Margery Arented (2014): Storytelling in Science and Literature, Lewisburg: Bucknell University Press.

SAGER, Juan C. (1993): Curso práctico sobre el procesamiento en terminología, Madrid: Fundación Germán Sánchez Ruipérez.

Salager-Meyer, Françoise (1994): "Hedges and Textual Communicative Function in Medical English Written Discourse», English for Specific Purposes, 13(2), p. 149-171.

Salager-Meyer, Françoise, Gérard Defives, Cathy Jensen i María de Filipis (1989): «Principal Component Analysis and Medical English Discourse: An Investigation into Genre Analysis», System, 17(1), 21-34.

SALVADOR, Vicent (2000): «Portal: Discurs científic i comunicació social», Anuari de I'Agrupació Borrianenca de Cultura: Revista de Recerca Humanística i Científica, 11, p. 511.

SALVADOR, Vicent (2004): "La difusió social dels sabers científics: pràctiques i comunitats discursives", en Joan Andreu, Lluís Meseguer, Vicent Pitarch i Vicent Salvador (eds.): La llengua i la literatura: història i actualitat, Castelló de la Plana: Institut d'Estudis Catalans/Universitat Jaume I, p. 97-101. 
SAlVADOR, Vicent (2008): "Metàfores i coneixement», Escola Catalana, 450, p. 8-9. <http://repositori.uji.es/xmlui/bitstream/handle/10234/18018/29393.pdf?sequence=1 \&isAllowed $=y>$ [Consulta: 12 d'octubre de 2017]

SALVADOR, Vicent (2009): “'Saps què vull dir?' Reflexions sobre la pragmàtica de les definicions», en Montserrat Veyrat Rigat i Enrique Serra Alegre (eds.): La lingüística como reto epistemológico y como acción social, Madrid: Arco Libros, Vol. II, p. 721-733. <http://cei.udc.es/uploads/archivos/files/[11] Pragmatica de la defin icion.pdf> [Consulta: 27 de desembre de 2018]

SALVADOR, Vicent (2010): "L'eufemisme, entre la retòrica i la política», en Maria Josep Marín, Llum Bracho, Josep À. Mas i Anna I. Montesinos (eds.): Discurs polític i identitats (trans)nacionals, València: Universitat de València, p. 133-160.

SALVADOR, Vicent (2011): «Paraula i cultura de la salut: indagacions de lingüística mèdica», Caplletra, 50, p. 89-106.

SALVADOR, Vicent (2015a): "Un nuevo modelo de discurso biográfico», en Enric Balaguer, Maria Jesús Francés i Vicent Vidal (eds.): Aproximació a l'altre: Biografies, semblances $i$ retrats / An Approach to the Other: Biographies, Resemblances and Portraits, Amsterdam: John Benjamins, p. 9-16.

SALVADOR, Vicent (2015b): «Autorrelato e identidades profesionales: Sobre autobiografías de científicos y médicos", Annali di Ca' Foscari. Serie Occidentale, 49, p. $57-74$.

SALVADOR, Vicent (2016): «The Clinical Case Report as a Discourse Genre in the Context of Professional Training», en Pilar Ordóñez-LóPEZ i Nuria Edo-MARZÁ (eds.): Medical Discourse in Professional, Academic and Popular Settings, Bristol: Multilingual Matters, p. 31-54.

SALVADOR, Vicent (2017): «El proyecto 'Lenguaje y cultura de la salud'», en Ana María Cestero Mancera i María Eugenia Olimpio de Oliveira Silva (eds.): Investigaciones actuales en Lingüística. Vol. IV: Sobre el discurso, Alacalá de Henares: Universidad de Alcalá. 
SALVADOR, Vicent (2018a): "L'assaig com a gènere: un territori de frontera», SCRIPTA: Revista Internacional de Literatura i Cultura Medieval i Moderna, 12, p. 71-85.

SALVADOR, Vicent (2018b): «Sobre el coneixement analògic. La metàfora en el discurs de la biotecnologia», Mètode, 97, p. 73-77.

SALVADOR, Vicent i Cecili MACIÁN (2014): «Relato, voces y audiencias en el género “caso clínico"», en I Simposium EDiSO, Universidad de Sevilla. Abstract disponible en: < http://edisoportal.org/65-simposium-ediso-2014?start=84>

SAlVADOR, Vicent i Vicent Montalt (2013): «Literatura i casos clínics: anàlisi d'alguns relats d'Oliver Sacks», en VII Simposi Internacional de Literatura Autobiogràfica: biografies i retrats en la literatura catalana del segle XX, Universitat d'Alacant. [07 de novembre de 2013]

SAlVAdOR, Vicent, Cecili Macián i Maria Josep Marín (2013): "La construcción de las profesiones sanitarias a través de las revistas especializadas», Discurso \& Sociedad, 7(1), p. 73-96.

SÁNCHEZ MARTOS, Jesús (2008): «Influencia de los medios de comunicación en la salud de la población», en Ubaldo CuestA, Aitor UgarTe i Tania MenÉndez (eds.): Comunicación y salud. Avance en modelos y estrategias de intervención, Madrid: Editorial Complutense, p. 77-97.

SAns SABRAfen, Jordi (2004): L'evolució de l'ús del català en medicina a Catalunya durant el segle xx: el llarg camí d'una bella i expressiva història, Barcelona: Institut d’Estudis Catalans. Secció de Ciències Biològiques.

SAPIÑA, Lucía (2015, 3 de setembre): "Entrevista a Maurizio Gotti», Mètode. <https://metode.cat/noticies/entrevistes/entrevista-a-maurizio-gotti.html> [Consulta: 24 de març de 2018]

SEGEN, Joseph C. (2011): Segen's Medical Dictionary. <https://medicaldictionary.thefreedictionary.com/Narrative+Medicine> [Consulta: 24 d'octubre de 2018] 
SHOWALTER, Elaine (1992): «On hysterical narrative», Narrative, 1, p. 24-35.

Sketch EngIne (2019): Language Corpus Management and Query System. <https://www.sketchengine.eu/> [Consulta: febrer de 2019]

SMITH, Richard i Nataly Kelly (2012): "Global Attempts to Avoid Talking Directly about Death and Dying», BMJ Opinion, 16 d'agost. <http://blogs.bmj.com/bmj/2012/08/16/richard-smith-and-nataly-kelly-globalattempts-to-avoid-talking-directly-about-death-and-dying/> [Consulta: 3 de gener de 2018]

SNow, Charles Percy (2001 [1959]): The Two Cultures, Cambridge: Cambridge University Press.

SONTAG, Susan (1990): Illness as Metaphor and AIDS and Its Metaphors, Nova York: Picador.

SPENCE, Donald (1982): Narrative Truth as Historical Truth, Nova York: Norton.

SWALES, John (1990): Genre Analysis: English in Academic and Research Settings, Cambridge: Cambrige University Press.

SWALES, John M. (1998): Other Floors, Other Voices: A Textography of a Small University Building, Mahwah, NJ: Erlbaum.

TAAVITSAINEN, Irma (2011): "Medical Case Reports and Scientific Thought-Styles», Revista de Lenguas para Fines Específicos, 17, p. 75-98.

TaAvitsainen, Irma i Päivi Pahta (eds.) (2004): Medical and Scientific Writing in Late Medieval English, Cambridge: Cambridge University Press.

TAJER, Carlos (2012): "Metáforas para pensar la medicina», Revista Argentina de Cardiología, 80(6), p. 496-504. $<$ http://www.scielo.org.ar/scielo.php?script=sci_arttext\&pid=S1850374820120006000 19\&Ing=es\&t|ng=es> [Consulta: 8 de gener de 2018] 
TAY, Dennis (2017): "Using Metaphor in Healthcare: Mental Health», en Elena SEMINO ¡ Zsófia DEMJÉn (eds.): The Routledge Handbook of Metaphor and Language, Abingdon: Routledge.

Termcat: Centre de Terminologia (2019): Cercaterm, Barcelona: Termcat. <http://www.termcat.cat/> [Consulta: 18 de gener de 2019]

THORNBORROW, Joanna i Jennifer COATES (2005): «The Sociolinguistics of Narrative: Identity, Performance, Culture», en Joanna Thornborrow i Jennifer CoATES (eds.): The Sociolinguistics of Narrative, Amsterdam: John Benjamins, p. 1-16.

TITZMANN, Michael (2003). «The Systematic Place of Narratology in Literary Theory and Textual Theory», en Tom KINDT i Hans-Harald MülleR (eds.): What Is Narratology? Questions and Answers Regarding the Status of a Theory, Berlin: De Gruyter, p. 175-204.

TOOLAN, Michael (2001): Narrative: A Critical Linguistic Introduction, Londres: Routledge.

TOOLAN, Michael (2009): Narrative Progression in the Short Story: A Corpus Stylistic Approach, Amsterdam/Filadèlfia: John Benjamins.

TOOLAN, Michael (2016): Making Sense of Narrative Text: Situation, Repetition, and Picturing in the Reading of Short Stories, Amsterdam: John Benjamins.

URIBARRI, Iris (2004): «La descripción científica y el caso clínico», Oftalmológica Santa Lucia, 3(3), p. 95-104.

VAN DIJK, Teun A. (2003): «Specialized Discourse and Knowledge. A Case Study of the Discourse of Modern Genetics», Cadernos de Estudos Lingüísticos, 44, p. 21-56.

Van Peer, Willie i Seymour Chatman (2001): New Perspectives on Narrative Perspective, Nova York: State University of New York Press.

VANDENBROUCKE, Jan P. (1999): «Case Reports in an Evidence-based World», Journal of the Royal Society of Medicine, 92(4), p. 159-163. 
Venes, Donald (2009): Taber's Cyclopedic Medical Dictionary, Filadèlfia: F. A. Davis Company.

Walter, Tony (1991): «Modern Death: Taboo or Not Taboo?», Sociology, 25(2), p. 293-310.

WANG, Yuh-Jen i Han-Hwa Hu (2013): «Sudden Death After Medullary Infarction - A Case Report», Kaohsiung Journal of Medical Sciences, 29, p. 578-581.

Wardle, Jon i Eric Roseen (2014): «Integrative Medicine Case Reports: A Clinicians' Guide to Publication», Advances in Integrative Medicine, 1, p. 144-147

WENGER, Étienne (1998): Communities of Practice: Learning, Meaning, and Identity, Cambridge: Cambridge University Press.

Wenger, Étienne, Richard McDermott i William SNyder (2002): Cultivating Communities of Practice: A Guide to Managing Knowledge, Boston: Harvard Business School Press.

Widdershoven, Guy (1993): "The Story of Life: Hermeneutic Perspectives on the Relationship between Narrative and Life History», en Ruthellen H. JOSSELSON i Amia LIEBLICH (eds.): The narrative study of lives, Londres: Sage, p. 1-20.

WILCE, James M. (2009): «Medical Discourse», Annual Review of Anthropology, 38, p. 199-215. <https://doi.org/10.1146/annurev-anthro-091908-164450> [Consulta: 14 de juny de 2018]

ZABIELSKA, Magdalena (2014): Searching for the Patient's Presence in Medical Case Reports, Bern: Peter Lang.

ZabielSkA, Magdalena i Magda Żelazowska (2015): «Disease Entities in Case Reports from Otolaryngology from the Perspective of Polish, English and Russian Translation Studies», en Barbara BorkowsKa-KęPSKA, Grzegorz Gwóźdź i Piotr MAMEt (eds.): LSP Perspectives. Dąbrowa Górnicza: Wydawnictwo Naukowe Wyższa Szkoła Biznesu w Dąbrowie Górniczej, p. 173-185. 
ZabielSkA, Magdalena i Magda ŻelazowsKa (2016): «Difficulties and Translation Techniques in Polish-English-Russian Doctor-Patient Communication on the Basis of Otolaryngology from the Perspective of the Translator/Interpreter», en Marek KUźNIAK, Bożena Rozwadowska i Michał Szawerna (eds.): From Motion to Emotion: Aspects of Physical and Cultural Embodiment in Language, Frankfurt del Main: Peter Lang, p. 175190.

ZabielSkA, Magdalena i Magda ŻelaZowska (2017): «A New Variety of Medical Case Reporting as a Tool in ESP Teaching as Well as in Medical Training and Professional Development», Glottodidactica: An International Journal of Applied Linguistics, XLIV(1), p. 183-194. 



\section{ANNEX I: TAULA DE CODIS DEL CORPUS UTILITZAT}

\section{Casos clínics acadèmics en català}

\section{Revista Mèdica Internacional sobre la Síndrome de Down}

- 1.CAT_Down: Disfàgia d'origen central en un home amb síndrome de Down

- 2.CAT_Down: Variant de Dandy-Walker associada a síndrome de Down

- 3.CAT_Down: Síndrome mieloproliferativa transitòria en un nadó amb síndrome de Down

- 4.CAT_Down: Síndrome de Moyamoya associat amb la síndrome de Down. Troballes clíniques i radiològiques

- 5.CAT_Down: Síndrome de Down i encefalitis de Hashimoto

- 6.CAT_Down: Sexualitat i síndrome de Down

- 7.CAT_Down: Síndrome de Down amb anomalia de l'orella interna: és adequat l'implant coclear?

- 8.CAT_Down: Regressió en adults joves amb la síndrome de Down. Revisió de tres casos

- 9.CAT_Down: Matrimoni i reproducció en una dona amb síndrome de Down

- 10.CAT_Down: Discussió i revisió de la bibliografia a partir del cas d'un home jove amb síndrome de Down i trombosi venosa cerebral

Neurologia Catalana (Butlletí de la Societat Catalana de Neurologia)

- 11.CAT_Neurologia: Pacient amb oligoartritis, polineuropatia i clínica abdominal 
- 12.CAT_Neurologia: Baró de 83 anys que ingressa per a estudi de deteriorament cognitiu d'un mes d'evolució

- 13.CAT_Neurologia: Episodis paroxístics d'hemicós dret

- 14.CAT_Neurologia: Lesions disseminades en tronc i medul·la

- 15.CAT_Neurologia: Impotència funcional d'extremitats d'instauració llargament progressiva

- 16.CAT_Neurologia: Disminució del nivell de consciència i anèmia

- 17.CAT_Neurologia: Dolor muscular d'extremitats inferiors rebel al tractament habitual

- 18.CAT_Neurologia: Lesió temporal esquerre de ràpida progressió

- 19.CAT_Neurologia: Síndrome amnèsica d'instauració progressiva

- 20.CAT_Neurologia: Encefalitis límbica en pacient amb trasplantament al-logènic de moll d'ós

- 21.CAT_Neurologia: Sense títol (El racó del resident)

- 22.CAT_Neurologia: Un cas de tetraparèsia progressiva en pacient jove

- 23.CAT_Neurologia: Sense títol (El racó del resident)

- 24.CAT_Neurologia: Sense títol (Repte en neuroimatge)

- 25.CAT_Neurologia: Sense títol (El racó del resident)

- 26.CAT_Neurologia: Sense títol (Repte en neuroimatge)

- 27.CAT_Neurologia: Sense títol (Repte en neuroimatge)

- 28.CAT_Neurologia: Dona de 65 anys amb parestèsies i debilitat

- 29.CAT_Neurologia: Home de 62 anys amb parèsia d'extremitat superior dreta

- 30.CAT_Neurologia: Sense títol (Repte en neuroimatge)

\section{Desenvolupa: la Revista d'Atenció Precoç}

- 31.CAT_Atenció_precoç: Història d'una nena que jugava a construir-se a si mateixa. Desenvolupament de la identitat corporal d'una nena amb trastorn de l'espectre de l'autisme a través d'una psicoteràpia psicomotriu

- 32.CAT_Atenció_precoç: De la fortalesa buida a la casa compartida: Una experiència de treball grupal amb nens TEA en petita infància 
- 33.CAT_Atenció_precoç: El procés de simbolització en un cas de depressió preautística

- 34.CAT_Atenció_precoç: Cas clínic: L'abordatge logopèdic en un cas de microsomia hemifacial en el marc de l'atenció precoç

- 35.CAT_Atenció_precoç: Cas Clínic. La importància del treball en xarxa: pensament i perseverança

\section{Casos clínics acadèmics en castellà}

\section{Revista de Neurología}

- 1.ESP_Neurología_A: Alteraciones del lenguaje en la cerebelitis aguda: más allá de la disarria

- 2.ESP_Neurología_A: Bromocriptina: ¿podría ser la cura para el mutismo acinético posquirúrgico?

- 3.ESP_Neurología_A: Neurofibromatosis de tipo 2 con inicio en la edad pediátrica: identicación de los primeros signos y síntomas

- 4.ESP_Neurología_A: Alteraciones reversibles en la neuroimagen asociadas al tratamiento con vigabatrina en lactantes con espasmos epilépticos

- 5.ESP_Neurología_A: Demencia rápidamente progresiva y parkinsonismo asociados a múltiples fístulas arteriovenosas durales

- 6.ESP_Neurología_A: Presentación inusual de un tic convulsivo doloroso

- 7.ESP_Neurología_A: Síndrome de Kleine-Levin: diagnóstico diferencial en los síndromes encefalíticos recurrentes del adolescente

- 8.ESP_Neurología_A: Entrenamiento de las señales corticales a través de un sistema BMI-EEG, evolución e intervención. A propósito de un caso

Revista Científica de la Sociedad Española de Enfermería Neurológica

- 9.ESP_Enfermería: Caso clínico: síndrome de Von Hippel-Lindau, una visión desde enfermería

- 10.ESP_Enfermería: Síndrome de Mowat-Wilson: historia de vida de la fortaleza de una madre 
- 11.ESP_Enfermería: Encefalitis anti-NMDA y enfermería alta

- 12.ESP_Enfermería: Hipotermia terapéutica en el ictus isquémico agudo

- 13.ESP_Enfermería: Tengo daño cerebral: relato biográfico de un accidente

- 14.ESP_Enfermería: Caso clínico: enfermedad de Marchiafava Bignami

- 15.ESP_Enfermería: Plan de cuidados de un paciente con encefalopatía anóxica

- 16.ESP_Enfermería: Prosopagnosia, la discapacidad para reconocer una cara conocida

Adolescere. Revista de Formación Continuada de la Sociedad Española de Medicina de la Adolescencia

- 17.ESP_Adolescencia: Conflictos familiares

- 18.ESP_Adolescencia: Dolor abdominal persistente

- 19.ESP_Adolescencia: Vómitos persistentes

- 20.ESP_Adolescencia: Adolescente con anorexia nerviosa

- 21.ESP_Adolescencia: Cefalea y sensación de giro de objetos: una combinación olvidada

- 22.ESP_Adolescencia: Mal rendimiento escolar

- 23.ESP_Adolescencia: Trastornos de sueño. Síndrome de Retraso de Fase (SRF)

- 24.ESP_Adolescencia: Ansiedad

\section{Revista Electrónica de PortalesMedicos.com (psiquiatría)}

- 25.ESP_Psiquiatría: Alicia en el país de las maravillas

- 26.ESP_Psiquiatría: Síndrome de Tourette. Caso clínico

- 27.ESP_Psiquiatría: Presentación caso clínico. Depresión

- 28.ESP_Psiquiatría: Psicosis lúpica. Presentación de un caso

- 29.ESP_Psiquiatría: ¿Psicosis o trastorno de personalidad?

- 30.ESP_Psiquiatría: Presentación caso clínico. Trastorno obsesivo compulsivo

- 31.ESP_Psiquiatría: Caso clínico. Trastornos del espectro autista o esquizofrenia infantil. Un diagnóstico controvertido.

- 32.ESP_Psiquiatría: Caso clínico. Anorexia nerviosa 
Revista Electrónica de PortalesMedicos.com (neurología)

- 33.ESP_Neurología_B: Caso clínico. Cuando menos te lo esperas

- 34.ESP_Neurología_B: Caso clínico. Doctora icreo que la veo doble!

- 35.ESP_Neurología_B: Caso clínico. Una demencia como otra cualquiera

- 36.ESP_Neurología_B: Caso clínico. Un mareo de tantos

- 37.ESP_Neurología_B: Caso clínico. Embolia paradójica

- 38.ESP_Neurología_B: Neuropatía compresiva bilateral del ciático poplíteo externo. Jugando con un ordenador

- 39.ESP_Neurología_B: Caso clínico: miopatía mitocondrial

- 40.ESP_Neurología_B: Craneofaringioma infantil. Reporte de un caso

\section{Casos clínics acadèmics en anglès}

Czech and Slovak Neurology and Neurosurgery

- 1.ENG_Neurology_A: Significant Brain Oedema in Unruptured Brain Arteriovenous Malformation - A Case Report

- 2.ENG_Neurology_A: Successful Treatment of Meningoencephalitis due to Cryptococcus gattii with Ommaya Reservoir and Intrathecal Injection of Amphotericin B - A Case Report

- 3.ENG_Neurology_A: Differential Diagnosis of Bithalamic and Pallidal Hypointensity - A Case of HEXB Mutation

- 4.ENG_Neurology_A: A Patient Homozygous for the E200K Mutation from a Family of the Slovak Cluster of Genetic Creutzfeldt-Jakob Disease

- 5.ENG_Neurology_A: Anterior Ischemic Optic Neuropathy and Branch Retinal Artery Occlusion after Transcatheter Closure of Foramen Ovale - A Case Report

- 6.ENG_Neurology_A: Paroxysmal Kinesigenic Dystonia as a Primomanifestation of Multiple Sclerosis - A Case Report

- 7.ENG_Neurology_A: Spinal Gossypiboma 20 years after Lumbar Discectomy - A Case Report

- 8.ENG_Neurology_A: Early Rotation of Intrathecal Baclofen Pump - A Case Report 
Case Reports in Neurological Medicine

- 9.ENG_Neurology_B: Improvement and Neuroplasticity after Combined Rehabilitation to Forced Grasping

- 10.ENG_Neurology_B: Differential Diagnosis and Management of Incomplete LockedIn Syndrome after Traumatic Brain Injury

- 11.ENG_Neurology_B: Homonymous Superior Quadrantanopia due to ErdheimChester Disease with Asymptomatic Pituitary Involvement

- 12.ENG_Neurology_B: Chronic Lymphocytic Inflammation with Pontine Perivascular Enhancement Responsive to Steroids, with Cranial and Caudal Extension

- 13.ENG_Neurology_B: Uncommon Etiology for Seizure: Cerebral Hyperperfusion Syndrome

- 14.ENG_Neurology_B: Impaired Emotion Recognition after Left Hemispheric Stroke: A Case Report and Brief Review of the Literature

- 15.ENG_Neurology_B: Chronic Neuropsychological Sequelae in a Patient with Nontumorous Anti-NMDA-Receptor Encephalitis

- 16.ENG_Neurology_B: SSRI Facilitated Crack Dancing

\section{Case Reports in Psychiatry}

- 17.ENG_Psychiatry: "Being with a Buddha": A Case Report of Methoxetamine Use in a United States Veteran with PTSD

- 18.ENG_Psychiatry: Pseudologia Fantastica in the Emergency Department: A Case Report and Review of the Literature

- 19.ENG_Psychiatry: A Case of Sporadic Creutzfeldt-Jakob Disease Presenting as Conversion Disorder

- 20.ENG_Psychiatry: A Case of Persistent Generalized Retrograde Autobiographical Amnesia Subsequent to the Great East Japan Earthquake in 2011

- 21.ENG_Psychiatry: Psychopathology Related to Energy Drinks: A Psychosis Case Report

- 22.ENG_Psychiatry: Cotard's Syndrome in a Patient with Schizophrenia: Case Report and Review of the Literature

- 23.ENG_Psychiatry: A Case Report on Management of Father Daughter Incest with Schizophrenia 
- 24.ENG_Psychiatry: Alagille Syndrome: A Case Report Highlighting Dysmorphic Facies, Chronic Illness, and Depression

Frontiers in Psychology

- 25.ENG_Psychology: Novel Metaphors Comprehension in a Child with HighFunctioning Autism Spectrum Disorder: A Study on Assessment and Treatment

- 26.ENG_Psychology: Psychotherapy with a 3-Year-Old Child: The Role of Play in the Unfolding Process

- 27.ENG_Psychology: Metacognitive Therapy for Comorbid Anxiety Disorders: A Case Study

- 28.ENG_Psychology: A Novel Technique for Improving Bodily Experience in a Nonoperable Super-Super Obesity Case

- 29.ENG_Psychology: "A Child's Nightmare. Mum Comes and Comforts Her Child." Attachment Evaluation as a Guide in the Assessment and Treatment in a Clinical Case Study

- 30.ENG_Psychology: A Clinical Case Study of the Use of Ecological Momentary Assessment in Obsessive Compulsive Disorder

- 31.ENG_Psychology: Use of the Adult Attachment Projective Picture System in Psychodynamic Psychotherapy with a Severely Traumatized Patient

- 32.ENG_Psychology: Training Communication Abilities in Rett Syndrome through Reading and Writing

Case Reports in Neurology

- 33.ENG_Neurology_C: Favourable Outcome in a 33-Year-Old Female with Acute Haemorrhagic Leukoencephalitis

- 34.ENG_Neurology_C: Acute Intravenous Calcium Antagonist for Suspected Hemiplegic Migraine - A Case Story

- 35.ENG_Neurology_C: Chronic Autoimmune Meningoencephalitis and Periodic Fever Syndrome Treated with Anakinra 
- 36.ENG_Neurology_C: Internal Carotid Artery Occlusion in Systemic Lupus Erythematosus as a Potential Mimicker of Multiple Sclerosis

- 37.ENG_Neurology_C: Early Thrombectomy of a Proximal Middle Cerebral Artery Occlusion Leading to Complete Recovery with No Infarct

- 38.ENG_Neurology_C: Multisystem Disease, Including Eosinophilia and Progressive Hyper-Creatine-Kinase-Emia over 10 Years, Suggests Mitochondrial Disorder

- 39.ENG_Neurology_C: Pure Amorphagnosia without Tactile Object Agnosia

- 40.ENG_Neurology_C: Tumors Presenting as Multiple Cranial Nerve Palsies

\section{Contes clínics}

Oliver SACKS: The Man Who Mistook His Wife for a Hat and Other Clinical Tales

- A.LIT_Sacks: Preface

- B.LIT_Sacks: Introduction. Part one: Losses

- 1.LIT_Sacks: The Man Who Mistook His Wife for a Hat

- 2.LIT_Sacks: The Lost Mariner

- 3.LIT_Sacks: The Disembodied Lady

- 4.LIT_Sacks: The Man Who Fell out of Bed

- 5.LIT_Sacks: Hands

- 6.LIT_Sacks: Phantoms

- 7.LIT_Sacks: On the Level

- 8.LIT_Sacks: Eyes Right!

- 9.LIT_Sacks: The President's Speech

- C.LIT_Sacks: Introduction. Part two: Excesses

- 10.LIT_Sacks: Witty Ticcy Ray

- 11.LIT_Sacks: Cupid's Disease

- 12.LIT_Sacks: A Matter of Identity

- 13.LIT_Sacks: Yes, Father-Sister

- D.LIT_Sacks: Introduction. Part three: Transports

- 14.LIT_Sacks: The Possessed

- 15.LIT_Sacks: Reminiscence 
- 16.LIT_Sacks: Incontinent Nostalgia

- 17.LIT_Sacks: A Passage to India

- 18.LIT_Sacks: The Dog Beneath the Skin

- 19.LIT_Sacks: Murder

- 20.LIT_Sacks: The Visions of Hildegard

- E.LIT_Sacks: Introduction. Part four: The World of the Simple

- 21.LIT_Sacks: Rebecca

- 22.LIT_Sacks: A Walking Grove

- 23.LIT_Sacks: The Twins

- 24.LIT_Sacks: The Autist Artist

Allan Ropper i Brian David Burrell: Reaching Down the Rabbit Hole: Extraordinary Journeys into the Human Brain

- A.LIT_Ropper: Introduction: The Queen

- 1.LIT_Ropper: Six Improbable Things Before Breakfast. Arrivals, departures, and delays on the ward

- 2.LIT_Ropper: Like a Hole in the Head. Where baseball and neurology converge in a game-saving, over-the-shoulder catch

- 3.LIT_Ropper: The State of Confusion. Two characters in search of a neurologist

- 4.LIT_Ropper: My Man Godfrey. A poor sort of memory that only works backwards

- 5.LIT_Ropper: What Seems to Be the Problem? A politically incorrect guide to malingering, shamming, and hysteria

- 6.LIT_Ropper: Do No Harm. A walking time bomb tests the limits of good sense

- 7.LIT_Ropper: A Story Is Worth a Thousand Pictures. Nine songs of innocence and experience

- 8.LIT_Ropper: Endgame. Facing down Lou Gehrig's disease

- 9.LIT_Ropper: The Examined Life. What it takes to survive a motor-neuron death sentence

- 10.LIT_Ropper: The Curse of the Werewolf. On the front lines in the battle against Dr. Parkinson's disease

- 11.LIT_Ropper: For the Want of a Nail. A hard-knock lesson on the way to the morgue

- 12.LIT_Ropper: The Eyes Have It. When is somebody not dead yet? 
- 13.LIT_Ropper: Boats Against the Current. Based on a true story

- B.LIT_Ropper: Acknowledgments

IRVIN D. YALOM: Love's Executioner and Other Tales of Psychotherapy

- A.LIT_Yalom: Acknowledgments

- B.LIT_Yalom: Prologue

- 1.LIT_Yalom: Love's Executioner

- 2.LIT_Yalom: "If Rape Were Legal..."

- 3.LIT_Yalom: "The Wrong One Died"

- 4.LIT_Yalom: Fat Lady

- 5.LIT_Yalom: "I Never Thought It Would Happen to Me"

- 6.LIT_Yalom: "Do Not Go Gentle"

- 7.LIT_Yalom: Two Smiles

- 8.LIT_Yalom: Three Unopened Letters

- 9.LIT_Yalom: Therapeutic Monogamy

- 10.LIT_Yalom: In Search of the Dreamer

- C.LIT_Yalom: Afterword

Randy Frost i Gall Steketee: Stuff: Compulsive Hoarding and the Meaning of Things

- A.LIT_Frost: Dead Body in the Collyer Mansion: A Prologue to Hoarding

- 1.LIT_Frost: Piles upon Piles: The Story of Hoarding - Irene

- 2.LIT_Frost: We Are What We Own: Owning, Collecting, and Hoarding

- 3.LIT_Frost: Amazing Junk: The Pleasures of Hoarding

- 4.LIT_Frost: Bunkers and Cocoons: Playing It Safe

- 5.LIT_Frost: A Fragment of Me: Identity and Attachment

- 6.LIT_Frost: Rescue: Saving Animals from a Life on the Streets

- 7.LIT_Frost: A River of Opportunities

- 8.LIT_Frost: Avoiding the Agony

- 9.LIT_Frost: You Haven't Got a Clue

- 10.LIT_Frost: A Tree with Too Many Branches: Genetics and the Brain

- 11.LIT_Frost: A Pack Rat in the Family

- 12.LIT_Frost: But It's Mine! Hoarding in Children 
- 13.LIT_Frost: Having, Being, and Hoarding

- B.LIT_Frost: Acknowledgments 



\section{ANNEX II: REFERÈNCIES BIBLIOGRÀFIQUES DEL CORPUS}

\section{Casos clínics acadèmics}

- 1.CAT_Down

ZÁRATE, N. i D. RodRÍGuez (2001): «Disfàgia d'origen central en un home amb síndrome de Down», Revista Mèdica Internacional sobre la Síndrome de Down, 5(1), p. 7-9.

- 2.CAT_Down

ROQUER, J. (2003): «Variant de Dandy-Walker associada a síndrome de Down», Revista Mèdica Internacional sobre la Síndrome de Down, 7(1), p. 6-9.

- 3.CAT_Down

Tuset, E., S. Rives, T. Toll, I. Alcorta, M. Pérez, i J. Estella (2004): «Síndrome mieloproliferativa transitòria en un nadó amb síndrome de Down», Revista Mèdica Internacional sobre la Síndrome de Down, 8(1), p. 8-12.

- 4.CAT_Down

Nascimento, A., R. Navarro, J. Colomer, F. Gómez i T. Sola (2006): «Síndrome de Moyamoya associat amb la síndrome de Down. Troballes clíniques i radiològiques», Revista Mèdica Internacional sobre la Síndrome de Down, 10(3), p. 41-44. 
Abeledo, A., C. E. Valera, P. Poo, C. I. Ortez, A. Nascimento i P. Casano (2010): "Síndrome de Down i encefalitis de Hashimoto», Revista Mèdica Internacional sobre la Síndrome de Down, 14(1), p. 10-13.

- 6.CAT_Down

Garvía Peñuelas, B. (2010): "Sexualitat i síndrome de Down», Revista Mèdica Internacional sobre la Síndrome de Down», 14(3), p. 47-49.

- 7.CAT_Down

EyzaWiah, H., A. Suraya i A. Asma (2013): «Síndrome de Down amb anomalia de l'orella interna: és adequat l'implant coclear?», Revista Mèdica Internacional sobre la Síndrome de Down, 17(2), p. 25-28.

- 8.CAT_Down

Garvíal, B. i B. Benejam (2014): «Regressió en adults joves amb la síndrome de Down. Revisió de tres casos», Revista Mèdica Internacional sobre la Síndrome de Down, 18(3), p. $43-46$.

- 9.CAT_Down

AzeVedo Moreira, L.M. i L. Damasceno Espirito SAnto (2013): «Matrimoni i reproducció en una dona amb síndrome de Down», Revista Mèdica Internacional sobre la Síndrome de Down, 17(3), p. 39-42.

- 10.CAT_Down

Garzón Ruiz, J., E. Fajardo-Picó, J. Aguilar-García, C. Ruiz-Guerrero, R.M. Miranda Matilla i M.A. IribarRen-Marín (2011): «Discussió i revisió de la bibliografia a partir del cas d'un home jove amb síndrome de Down i trombosi venosa cerebral», Revista Mèdica Internacional sobre la Síndrome de Down, 15(3), p. 37-40. 
- 11.CAT_Neurologia

Servei de Neurologia. Hospital Parc Taulí, Sabadell (2006): «Pacient amb oligoartritis, polineuropatia i clínica abdominal», Neurologia Catalana, 1, p. 11.

Grup de Residents del Servei de Neurologia, Hospital de la Santa Creu i Sant Pau, Barcelona (2007): «Resposta al cas clínic anterior», Neurologia Catalana, 2, p. 6-7.

- 12.CAT_Neurologia

HospitAl Verge de LA CINTA, Tortosa (2007): «Baró de 83 anys que ingressa per a estudi de deteriorament cognitiu d'un mes d'evolució», Neurologia Catalana, 2, p. 8-9.

Servei de Neurologia, Hospital Univeristari de Girona Doctor Josep Trueta (2007): «Resposta al cas clínic anterior», Neurologia Catalana, 3, p. 6-8.

- 13.CAT_Neurologia

Servel de Neurologia, Hospital Universitari de Bellvitge, L'Hospitalet del Llobregat (2007): «Episodis paroxístics d’hemicós dret», Neurologia Catalana, 4, p. 3-4.

Servel de Neurologia, Hospital Universitari de Bellvitge, L'Hospitalet del Llobregat (2008): «Resposta cas clínic», Neurologia Catalana, 5, p. 4.

Llufriu S., S. Amaro i Víctor Obach (2008): «Discussió cas clínic anterior», Neurologia Catalana, 5, p. 5-8.

- 14.CAT_Neurologia

SePÚlVedA VÁzquez, M. (2008): «Lesions disseminades en tronc i medul·la», Neurologia Catalana, 6, p. 7-8.

Pagola J., I. Pareés, A. Massot, A. Sierra, R. Ribosa, D. Salat, J. Durà i A. Flores (2008): «Lesions disseminades en tronc i medul·la. Discussió», Neurologia Catalana, 7, p. 5-8. 
- 15.CAT_Neurologia

Martínez PiñeIro, A. (2009): «Impotència funcional d'extremitats d'instauració llargament progressiva», Neurologia Catalana, 9, p. 8-9.

Batiste, D. M. (2009): «Resposta al cas clínic», Neurologia Catalana, 9, p. 16-18.

Martínez, A. (2010): «Resposta al cas clínic: diagnòstic», Neurologia Catalana, 10, p. 12.

- 16.CAT_Neurologia

VIDAL, A. i A. MARTíneZ-DomeÑo (2010): «Disminució del nivell de consciència i anèmia», Neurologia Catalana, 10, p. 12-13.

Servel de Neurologia, Hospital Universitari Doctor Josep Trueta, Girona (2010): «Resposta al cas clínic», Neurologia Catalana, 11, p. 17.

- 17.CAT_Neurologia

MAÑÉ, A., E. Ripoll i Ò. PARdina (2010): «Dolor muscular d'extremitats inferiors rebel al tractament habitual», Neurologia Catalana, 12, p. 9.

MAÑÉ, A., E. RIPOll i Ò. PARDINA (2011): «Dolor muscular d'extremitats inferiors rebel al tractament habitual. Resolució del cas clínic», Neurologia Catalana, 13, p. 8.

- 18.CAT_Neurologia

ACEITUNo, A. i N. MAS (2011): «Lesió temporal esquerre de ràpida progressió», Neurologia Catalana, 14, p. 14-15.

Planellas, L. i E. Munteis (2011): «Lesió temporal esquerre de ràpida progressió. Resposta al cas clínic», Neurologia Catalana, 15, p. 10-11.

- 19.CAT_Neurologia

GIL-VILLAR, M. P. i F. Purroy (2012): «Síndrome amnèsica d'instauració progressiva», Neurologia Catalana, 16, p. 16. 
GiL-Villar, M. P. i F. Purroy (2012): «Discussió del cas d'una pacient de 46 anys amb quadre subagut de trastorn amnèsic i posterior síndrome febril associada a meningitis asèptica», Neurologia Catalana, 17, p. 15.

Cobo Calvo, Á., C. Izquierdo Gracia i S. Martínez-Yélamos (2012): «Discussió del cas», Neurologia Catalana, 18, p. 20-22.

- 20.CAT_Neurologia

Marín, J., E. Martinez-Lizana, E. Morenas, P. Munuera i J.Pagonabarraga (2012): «Encefalitis límbica en pacient amb trasplantament al·logènic de moll d'ós», Neurologia Catalana, 18, p. 22.

HeRVÀs, M. i J. Estela (2013): «Discussió del cas d'una pacient de 63 anys amb quadre d'encefalitis límbica post-trasplant al-logènic de moll d'os», Neurologia Catalana, 19, p. 20.

Marín, J., E. Martinez-Lizana, E. Morenas, P. Munuera i J.Pagonabarraga (2013): «Resolució del cas», Neurologia Catalana, 19, p. 21-22.

- 21.CAT_Neurologia

Gómez, A. i E. Cuadrado (2013): "Sense títol (El racó del resident)», Neurologia Catalana, 20, p. 19.

Aller-Alvarez, J.S., A. Pluma-Sanjurjo, H. Bejr-Kasem, N. Rodriguez-Villatoro i M. TORRES (2014): «Resposta al cas», Neurologia Catalana, 22, p. 11-12.

Gómez, A. i E. Cuadrado (2014): « Discussió i resolució del cas», Neurologia Catalana, 22, p. $12-13$

- 22.CAT_Neurologia

Coll Presa, C., A. Cots foraster, F. Marquez Daniel, M. Ferrandiz Mach i C. Van Eendenburg (2014): «Un cas de tetraparèsia progressiva en pacient jove», Neurologia Catalana, 24, p. 14-15. 
González Mingot, C., Gil Villar, M. P., J. Molina i F. Purroy Garcia (2015): «Resposta al cas "Un cas de tetraparèsia progressiva en pacient jove“», Neurologia Catalana, 25, p. 19-21.

- 23.CAT_Neurologia

RUIz JULIÁN, M. (2015): «Sense títol (El racó del resident)», Neurologia Catalana, 26, p. 34.

Gómez-Galván, J. B. (2015): «Discussió del cas», Neurologia Catalana, 27, p. 44.

RUIz JuLIÁN, M. (2015): «Resolució del cas », Neurologia Catalana, 27, p. 45.

- 24.CAT_Neurologia

Pagonabarraga Mora, J. (2015): "Sense títol (Repte en neuroimatge)», Neurologia Catalana, 27, p. 55.

Pagonabarraga Mora, J. (2016): "Solució al repte en neuroimatge del butlletí 27», Neurologia Catalana, 28, p. 52.

- 25.CAT_Neurologia

Falgàs Martínez, N. (2016): "Sense títol (Repte en neuroimatge)», Neurologia Catalana, 28, p. 37.

Pagonabarraga Mora, J. (2016): "Solució al repte en neuroimatge del butlletí 27», Neurologia Catalana, 28, p. 52.

Falgàs Martínez, N. (2016): «Resolució del cas clínic del butlletí n28 de l’SCN», Neurologia Catalana, 29, p. 46.

- 26.CAT_Neurologia

BLANCO, Y. (2016): «Sense títol (El racó del resident)», Neurologia Catalana, 28, p. 51.

Canento, T. (2016): «Discussió del cas», Neurologia Catalana, 29, p. 45. 
BlANCO, Y. (2016): "Solució al repte en neuroimatge del butlletí 28», Neurologia Catalana, 29, p. 58.

- 27.CAT_Neurologia

Graus, F. i D. Escudero (2016): "Sense títol (Repte en neuroimatge)», Neurologia Catalana, 29, p. 57.

Graus, F. i D. Escudero (2016): «Solució al repte en neuroimatge del butlletí 29», Neurologia Catalana, 30, p. 47.

- 28.CAT_Neurologia

CIURANS, J. (2016): "Dona de 65 anys amb parestèsies i debilitat», Neurologia Catalana, 30, p. 37-39.

Zabalza de Torres, A. i P. Ceballos Cerrajería (2016): «Discussió del cas», Neurologia Catalana, 31, p. 67-69.

Ciurans, J. (2016): «Ressolució del cas», Neurologia Catalana, 31, p. 70-72.

- 29.CAT_Neurologia

Serra Martínez, M. i C. Avellaneda Gómez (2017): «Home de 62 anys amb parèsia d'extremitat superior dreta», Neurologia Catalana, 32, p. 46-47.

Fayos, F. i C. Painous (2017): «Discussió del cas. Home de 62 anys amb parèsia d'extremitat superior dreta», Neurologia Catalana, 33, p. 52-53.

Serra Martínez, M. i C. Avellaneda Gómez (2017): «Resolució del cas. Home de 62 anys amb parèsia d'extremitat superior dreta», Neurologia Catalana, 33, p. 54-55.

- 30.CAT_Neurologia

Pérez-Dueñas, B., M. Rebollo, J.Muchart, D. Ortigoza i B. Azua (2016): «Sense títol (Repte en neuroimatge)», Neurologia Catalana, 30, p. 46. 
Pérez-Dueñas, B., M. Rebollo, J.Muchart, D. Ortigoza i B. Azua (2016): «Solució al repte en neuroimatge del butlletí 30», Neurologia Catalana, 31, p. 81.

- 31.CAT_Atenció_precoç

Henrich Zannier, M. i À. Morral SubirÀ (2018): «Història d'una nena que jugava a construir-se a si mateixa. Desenvolupament de la identitat corporal d'una nena amb trastorn de l'espectre de l'autisme a través d'una psicoteràpia psicomotriu», Desenvolupa: la Revista d'Atenció Precoç. <http://www.desenvolupa.net/esl/Ultimosarticulos/Historia-d-una-nena-que-jugava-a-construir-se-a-si-mateixa-MelaniaHenrich-Zannier-Angels-Morral-Subira-02-2018-Nuevo> [Consulta: 21 d'agost de 2018]

- 32.CAT_Atenció_precoç

Sala i Garcia, G. i M. Álvarez Blanco (2017): "De la fortalesa buida a la casa compartida: Una experiència de treball grupal amb nens TEA en petita infància», Desenvolupa: la Revista d'Atenció Precoç. <http://www.desenvolupa.net/Ultimsarticles/De-la-fortalesa-buida-a-la-casa-compartida-Una-experiencia-de-treball-grupalamb-nens-TEA-en-petita-infancia.-Gemma-Sala-i-Garcia-Maria-Alvarez-Blanco-072017-Nou> [Consulta: 21 d'agost de 2018]

- 33.CAT_Atenció_precoç

QueSADA PÀMPOLS, M. (2016): «El procés de simbolització en un cas de depressió preautística», Desenvolupa: la Revista d’Atenció Precoç, 10, p. 1-10. $<$ http://www.desenvolupa.net/Ultims-articles/El-proces-de-simbolitzacio-en-un-casde-depressio-preautistica-Merce-Quesada-Pampols-10-2016-Nou> [Consulta: 21 d'agost de 2018] 
- 34.CAT_Atenció_precoç

Pàmies i Fabregat, C. i C. Filló Papiol (2010): «Cas clínic: L'abordatge logopèdic en un cas de microsomia hemifacial en el marc de l'atenció precoç», Desenvolupa: la Revista d'Atenció Precoç, 31, p. 135-146 <http://www.desenvolupa.net/UltimsNumeros/Numero-31-2010/Cas-clinic-L-abordatge-logopedic-en-un-cas-demicrosomia-hemifacial-en-el-marc-de-l-atencio-precoc-Carme-Pamies-i-Fabregat> [Consulta: 21 d'agost de 2018]

- 35.CAT_Atenció_precoç

FerRANDO, R. (2007): «Cas Clínic. La importància del treball en xarxa: pensament i perseverança», Desenvolupa: la Revista d'Atenció Precoç, 28, p. 137-143. <http://www.desenvolupa.net/Ultims-Numeros/Numero-28-2007/Cas-Clinic.-Laimportancia-del-treball-en-xarxa-pensament-i-perseveranca-Roser-Ferrando> [Consulta: 21 d'agost de 2018]

- 1.ESP_Neurología_A

Barragán-Martínez, D., N. Núñez-Enamorado, M. Berenguer-Potenciano, N. VílloraMorcillo, A. Martínez de Aragón, A. Camacho-Salas (2017): «Alteraciones del lenguaje en la cerebelitis aguda: más allá de la disarria», Revista de Neurología, 64(1), p. 27-30. <https://doi.org/10.33588/rn.6401.2016327> [Consulta: 15 de juny de 2017]

- 2.ESP_Neurología_A

Arévalo-Sáenz, A., M. Pedrosa-Sánchez i R. García de Sola (2017): «Bromocriptina: ¿podría ser la cura para el mutismo acinético posquirúrgico?», Revista de Neurología, 64(2), p. 70-74. <https://doi.org/10.33588/rn.6402.2016430> [Consulta: 15 de juny de 2017] 
Hinojosa-Mateo, C. M., J. A. Reche-Sainz, A. Hernández-Núñez, M. Ramos-López, A. ArpaFernández i D. NATERA-De Benito (2017): «Neurofibromatosis de tipo 2 con inicio en la edad pediátrica: identicación de los primeros signos y síntomas?», Revista de Neurología, 64(3), p. 119-124. <https://doi.org/10.33588/rn.6403.2016355> [Consulta: 15 de juny de 2017]

- 4.ESP_Neurología_A

Fernández-García, M. A., J. J. García-Peñas, h. Gómez-Martín, I. Pérez-Sebastián, e. García-Esparza i S. SiRvent-Cerdá (2017): «Alteraciones reversibles en la neuroimagen asociadas al tratamiento con vigabatrina en lactantes con espasmos epilépticos?», Revista de Neurología, 64(4), p. 169-174. <https://doi.org/10.33588/rn.6404.2016157> [Consulta: 15 de juny de 2017]

- 5.ESP_Neurología_A

Mejía, P., L. M. Piedra i X. Merchán-Del Hierro (2017): «Demencia rápidamente progresiva y parkinsonismo asociados a múltiples fístulas arteriovenosas durales?», Revista de Neurología, 64(5), p. 214-218. <https://doi.org/10.33588/rn.6405.2016387> [Consulta: 15 de juny de 2017]

- 6.ESP_Neurología_A

Romano-Feinholz, S., M. P. Medina, F. E. Nares-López, J. L. Soto-Hernández i R. RevueltaGutiéRREZ (2017): Presentación inusual de un tic convulsivo doloroso?», Revista de Neurología, 64(6), p. 264-266. <https://doi.org/10.33588/rn.6406.2016434> [Consulta: 15 de juny de 2017]

- 7.ESP_Neurología_A

Duat-Rodríguez, A., I. Martínez-Albaladejo, I. Pérez-Sebastián, V. Cantarín-Extremera, A. Hedrera-Fernández i J. J. García-Peñas (2017): «Síndrome de Kleine-Levin: diagnóstico diferencial en los síndromes encefalíticos recurrentes del adolescente?», 64(7), p. 313318. <https://doi.org/10.33588/rn.6407.2016495> [Consulta: 15 de juny de 2017] 
- 8.ESP_Neurología_A

Monge-Pereira, E., I. Casatorres Pérez-Higueras, P. Fernández-González, J. IbáñezPereda, J. I. Serrano i F. Molina-Rueda (2017): «Entrenamiento de las señales corticales a través de un sistema BMI-EEG, evolución e intervención. A propósito de un caso?», Revista de Neurología, 64(8), p. 362-366. <https://doi.org/10.33588/rn.6408.2016443> [Consulta: 15 de juny de 2017]

- 9.ESP_Enfermería

Casero-Alcázar, M., M. C. Díaz-García i F. Paredes-Fernández (2017): «Caso clínico: síndrome de Von Hippel-Lindau, una visión desde enfermería», Revista Científica de la Sociedad Española de Enfermería Neurológica, 45(C), p. 24-29. <https://doi.org/10.1016/j.sedene.2016.09.001> [Consulta: 18 de juny de 2017]

- 10.ESP_Enfermería

Alba-MARTín, R. (2016): «Síndrome de Mowat-Wilson: historia de vida de la fortaleza de una madre», Revista Científica de la Sociedad Española de Enfermería Neurológica, 44(C), p. 25-30. <https://doi.org/10.1016/j.sedene.2016.06.002> [Consulta: 18 de juny de 2017]

- 11.ESP_Enfermería

Rodríguez Vicente, Y. i C. GARRIDo Segovia (2016): «Encefalitis anti-NMDA y enfermería alta», Revista Científica de la Sociedad Española de Enfermería Neurológica, 43(C), p. 2329. <https://doi.org/10.1016/j.sedene.2015.12.003> [Consulta: 18 de juny de 2017]

- 12.ESP_Enfermería

Sanjuan Menendez, E., O. Miñarro Agüero, M. G. Dalmases Casulleras, K. E. Santana Roman i P. GIRON EsPOt (2015): «Hipotermia terapéutica en el ictus isquémico agudo», Revista Científica de la Sociedad Española de Enfermería Neurológica, 42(1), p. 29-33. <https://doi.org/10.1016/j.sedene.2015.05.003> [Consulta: 18 de juny de 2017] 
- 13.ESP_Enfermería

Alba-MARTín, R. (2015): «Tengo daño cerebral: relato biográfico de un accidente», Revista Científica de la Sociedad Española de Enfermería Neurológica, 42(1), p. 20-24. <https://doi.org/10.1016/j.sedene.2015.04.003> [Consulta: 18 de juny de 2017]

- 14.ESP_Enfermería

Munné díaz, C., A. Pacheu Ramirez, M. Grau Solà, M. Torreño Sánchez i M. lleixà SARDANONS (2015): "Caso clínico: enfermedad de Marchiafava Bignami», Revista Científica de la Sociedad Española de Enfermería Neurológica, 41(1), p. 22-26. <https://doi.org/10.1016/j.sedene.2015.03.001> [Consulta: 18 de juny de 2017]

- 15.ESP_Enfermería

Lendinez Mesa, A., M. Casero Alcazar i A. S. Fernandes Ribeiro (2014): «Plan de cuidados de un paciente con encefalopatía anóxica», Revista Científica de la Sociedad Española de Enfermería Neurológica, $\quad 39(1), \quad$ p. $29-33$. <https://doi.org/10.1016/j.sedene.2014.01.001> [Consulta: 18 de juny de 2017]

- 16.ESP_Enfermería

González Ablanedo, M. R., M. I. Curto Prada, M. L. Gómez Gómez i R. Molero Gómez (2013): «Prosopagnosia, la discapacidad para reconocer una cara conocida», Revista Científica de la Sociedad Española de Enfermería Neurológica, 38(1), p. 53-59. <https://doi.org/10.1016/j.sedene.2013.10.002> [Consulta: 18 de juny de 2017]

- 17.ESP_Adolescencia

Rodríguez Molinero, L. (2017): «Conflictos familiares», Adolescere. Revista de Formación Continuada de la Sociedad Española de Medicina de la Adolescencia, V(1), p. 85-88. $\quad<$ https://www.adolescenciasema.org/caso-clinico-conflictos-familiares-lrodriguez-molinero-adolescere-2017-v-1-85-88/> [Consulta: 20 de juliol de 2017] 
- 18.ESP_Adolescencia

González Gómez, B., M.I. Hidalgo Vicario i C. Casanova Garcia (2016): «Dolor abdominal persistente», Adolescere. Revista de Formación Continuada de la Sociedad Española de Medicina de la Adolescencia, IV(3), p. 61-66. $<$ https://www.adolescenciasema.org/caso-clinico-dolor-abdominal-persistente-bgonzalez-gomez-m-i-hidalgo-vicario-c-casanova-garcia-adolescere-2016-iv-3-61-67/> [Consulta: 20 de juliol de 2017]

\section{- 19.ESP Adolescencia}

Perkal Rug, G. (2016): «Vómitos persistentes», Adolescere. Revista de Formación Continuada de la Sociedad Española de Medicina de la Adolescencia, IV(1), p. 59-62. < https://www.adolescenciasema.org/caso-clinico-vomitos-persistentes-g-perkal-rugadolescere-2016-iv-1-59-63/> [Consulta: 20 de juliol de 2017]

- 20.ESP_Adolescencia

Casas Rivero, J., F. Guerrero Alzola i M. A. Salmerón Ruiz (2015): «Adolescente con anorexia nerviosa», Adolescere. Revista de Formación Continuada de la Sociedad Española de Medicina de la Adolescencia, III(1), p. 74-81. <https://www.adolescenciasema.org/adolescente-con-anorexia-nerviosa-j-casasrivero-f-guerrero-alzola-m-a-salmeron-ruiz-caso-clinico-adolescere-2015-iii-1-74-81/> [Consulta: 20 de juliol de 2017]

- 21.ESP_Adolescencia

Gómez-Andrés, D. i I. Pulido-Valdeolivas (2015): "Cefalea y sensación de giro de objetos: una combinación olvidada», Adolescere. Revista de Formación Continuada de la Sociedad Española de Medicina de la Adolescencia, III(3), p. 60-65. <https://www.adolescenciasema.org/caso-clinico-cefalea-y-sensacion-de-giro-deobjetos-una-combinacion-olvidada-d-gomez-andres-i-pulido-valdeolivas-adolescere2015-iii-3-60-65/> [Consulta: 20 de juliol de 2017] 
- 22.ESP_Adolescencia

Rodriguez Molinero, L. (2015): «Mal rendimiento escolar», Adolescere. Revista de Formación Continuada de la Sociedad Española de Medicina de la Adolescencia, III(2), p. 46-53. <https://www.adolescenciasema.org/mal-rendimiento-escolar/> [Consulta: 20 de juliol de 2017]

- 23.ESP_Adolescencia

Merino Andreu, M. i A. Martínez Bermejo (2013): «Trastornos de sueño. Síndrome de Retraso de Fase (SRF)», Adolescere. Revista de Formación Continuada de la Sociedad Española de Medicina de la Adolescencia, I(2), p. 76-84. <https://www.adolescenciasema.org/caso-clinico-trastornos-de-sueno-sindrome-deretraso-de-fase-srf-m-merino-andreu-et-al-revista-adolescere-2013-i-2-76-84/> [Consulta: 20 de juliol de 2017]

- 24.ESP_Adolescencia

Rodrigo Alfageme, M. i R. Hernández Guillén (2013): "Ansiedad», Adolescere. Revista de Formación Continuada de la Sociedad Española de Medicina de la Adolescencia, XXII(1), p. 36-41. <https://www.adolescenciasema.org/caso-clinico-ansiedad-mrodrigo-alfageme-et-al-adolescere-2013-i-1-36-41/> [Consulta: 20 de juliol de 2017]

- 25.ESP_Psiquiatría

Herrería Herrera, R., E. Ruiz Casuso i V. Palacios Pérez (2017): «Alicia en el país de las maravillas», Revista Electrónica PortalesMedicos.com. <https://www.revistaportalesmedicos.com/revista-medica/alicia-pais-las-maravillas/> [Consulta: 28 de setembre de 2018]

- 26.ESP_Psiquiatría

Antúnez Torres, L. B., Y. M. TorRes LeÓn i J. E. Pérez DíAz (2017): «Síndrome de Tourette. Caso clínico", Revista Electrónica PortalesMedicos.com. < https://www.revistaportalesmedicos.com/revista-medica/sindrome-tourette-caso-clinico/> [Consulta: 28 de setembre de 2018] 
- 27.ESP_Psiquiatría

JIMÉnez CuAdRA, E. (2013): «Presentación caso clínico. Depresión», Revista Electrónica PortalesMedicos.com. $\quad<$ https://www.revista-portalesmedicos.com/revistamedica/presentacion-caso-clinico-depresion/> [Consulta: 28 de setembre de 2018]

- 28.ESP_Psiquiatría

Calderón Chongo, Á. A. i R. Barreto Castro (2013): «Psicosis lúpica. Presentación de un caso", Revista Electrónica PortalesMedicos.com. < https://www.revistaportalesmedicos.com/revista-medica/psicosis-lupica-caso-clinico/> [Consulta: 28 de setembre de 2018]

- 29.ESP_Psiquiatría

Álvarez Montoya, A. M. (2012): «¿Psicosis o trastorno de personalidad?», Revista ElectrónicaPortalesMedicos.com.

< https://www.portalesmedicos.com/publicaciones/articles/4980/1/Psicosis-otrastorno-de-personalidad.html> [Consulta: 28 de setembre de 2018]

- 30.ESP_Psiquiatría

JimÉnEz CuAdRA, E. (2012): «Presentación caso clínico. Trastorno obsesivo compulsivo", Revista Electrónica PortalesMedicos.com. < https://www.portalesmedicos.com/publicaciones/articles/4835/1/Presentacion-casoclinico-Trastorno-obsesivo-compulsivo.html> [Consulta: 28 de setembre de 2018]

- 31.ESP_Psiquiatría

SÁnCHEZ LORENZO, I. (2012): «Caso clínico. Trastornos del espectro autista o esquizofrenia infantil. Un diagnóstico controvertido», Revista Electrónica PortalesMedicos.com.

<https://www.portalesmedicos.com/publicaciones/articles/4903/1/Caso-clinicoTrastornos-del-espectro-autista-o-esquizofrenia-infantil-Un-diagnosticocontrovertido.html> [Consulta: 28 de setembre de 2018] 
- 32.ESP_Psiquiatría

Jiménez Cuadra, E. (2012): "Caso clínico. Anorexia nerviosa», Revista Electrónica PortalesMedicos.com.

<https://www.portalesmedicos.com/publicaciones/articles/4122/1/Caso-clinico-

Anorexia-nerviosa.html> [Consulta: 28 de setembre de 2018]

- 33.ESP_Neurología_B

Conde Muñoz, B., V. Llamazares Muñoz i M. Á. Muñoz Muñoz (2017): «Caso clínico. Cuando menos te lo esperas», Revista Electrónica PortalesMedicos.com. $<$ https://www.revista-portalesmedicos.com/revista-medica/caso-clinico-cuando-

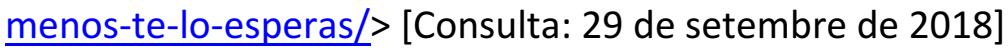

- 34.ESP_Neurología_B

Conde Muñoz, B., V. Llamazares Muñoz i M. Á. Muñoz Muñoz (2017): «Caso clínico. Doctora ¡creo que la veo doble!», Revista Electrónica PortalesMedicos.com. <https://www.revista-portalesmedicos.com/revista-medica/caso-clinico-veo-doble/> [Consulta: 29 de setembre de 2018]

- 35.ESP_Neurología_B

Conde Muñoz, B., V. Llamazares Muñoz i M. Á. Muñoz Muñoz (2017): «Caso clínico. Una demencia como otra cualquiera», Revista Electrónica PortalesMedicos.com. <https://www.revista-portalesmedicos.com/revista-medica/caso-clinico-demencia/> [Consulta: 29 de setembre de 2018]

- 36.ESP_Neurología_B

Conde Muñoz, B., V. Llamazares Muñoz i M. Á. Muñoz Muñoz (2017): «Caso clínico. Un mareo de tantos», Revista Electrónica PortalesMedicos.com. <https://www.revistaportalesmedicos.com/revista-medica/caso-clinico-mareo-tantos/> [Consulta: 30 de setembre de 2018] 
- 37.ESP_Neurología_B

Conde Muñoz, B., V. Llamazares Muñoz i M. Á. Muñoz Muñoz (2017): «Caso clínico. Embolia paradójica», Revista Electrónica PortalesMedicos.com. < https://www.revistaportalesmedicos.com/revista-medica/caso-clinico-embolia-paradojica/> [Consulta: 30 de setembre de 2018]

- 38.ESP_Neurología_B

Peris Giner J. F., J. Fernández Campillo, J. C. Medina Álvarez, E. Cardona García, R. Vela Yebra i M. A. Méndez Miralles (2016): «Neuropatía compresiva bilateral del ciático poplíteo externo. Jugando con un ordenador», Revista Electrónica PortalesMedicos.com. $\quad<$ https://www.revista-portalesmedicos.com/revistamedica/neuropatia-compresiva-ciatico-popliteo-externo-jugando-ordenador/> [Consulta: 30 de setembre de 2018]

- 39.ESP_Neurología_B

CID SÁNCHEZ, A. B. (2016): "Caso clínico: miopatía mitocondrial», Revista Electrónica PortalesMedicos.com. <https://www.revista-portalesmedicos.com/revistamedica/caso-clinico-miopatia-mitocondrial/> [Consulta: 30 de setembre de 2018]

- 40.ESP_Neurología_B

Ramos, O., Á. Alirio, L. Camacaro, L. Moreno i L. García (2014): «Craneofaringioma infantil. Reporte de un caso", Revista Electrónica PortalesMedicos.com. <https://www.revista-portalesmedicos.com/revista-medica/craneofaringioma-infantilcaso-clinico/> [Consulta: 30 de setembre de 2018]

- 1.ENG_Neurology_A

HANUŠKA, J. i J. KLENER (2017): «Significant Brain Oedema in Unruptured Brain Arteriovenous Malformation - A Case Report», Czech and Slovak Neurology and Neurosurgery, 80/113(3), p. 350-352. <https://doi.org/10.14735/amcsnn2017350> [Consulta: 16 de juny de 2017] 
- 2.ENG_Neurology_A

Chang-Hua, Ch., W. Shao-Hung, Y. Hua-Cheng, W. Wang-Fu, Ch. Wei Liang, Y. Yung-Jen, CH. YU-MIN i H. CHIEH-CHEN (2017): «Successful Treatment of Meningoencephalitis Due to Cryptococcus Gattii with Ommaya Reservoir and Intrathecal Injection of Amphotericin B -A Case Report», Czech and Slovak Neurology and Neurosurgery, 80/113(3), p. 337-342. <https://doi.org/10.14735/amcsnn2017337> [Consulta: 16 de juny de 2017]

- 3.ENG_Neurology_A

Akçakaya, N. H., Ö. Özdemır, F. G. GökçAY, S. A. U. İ̧̧eRı i Z. YapıCI (2017): «Differential Diagnosis of Bithalamic and Pallidal Hypointensity - A Case of HEXB Mutation", Czech and Slovak Neurology and Neurosurgery, 80/113(3), p. 343-345. <https://doi.org/10.14735/amcsnn2017343> [Consulta: 16 de juny de 2017]

- 4.ENG_Neurology_A

Mitrova, E., D. Slivarichova-Zakova, D. Kosorinova, M. Stelzer, S. Koscova, B. Berndtova i R. JUNAS (2016): «A Patient Homozygous for the E200K Mutation from a Family of the Slovak Cluster of Genetic Creutzfeldt-Jakob Disease», Czech and Slovak Neurology and Neurosurgery, 79/112(3), p. 336-342. <https://doi.org/10.14735/amcsnn2016336> [Consulta: 16 de juny de 2017]

- 5.ENG_Neurology_A

Stepanov, A., J. Studnicka, L. Hejsek, N. Jiraskova, R. Herzig, P. Rozsival i M. Valis (2016): «Anterior Ischemic Optic Neuropathy and Branch Retinal Artery Occlusion after Transcatheter Closure of Foramen Ovale - A Case Report», Czech and Slovak Neurology and Neurosurgery, 79/112(4), p. 458-462. <https://doi.org/10.14735/amcsnn2016458> [Consulta: 16 de juny de 2017] 
- 6.ENG_Neurology_A

NeCPÁL, J. (2016): «Paroxysmal Kinesigenic Dystonia as a Primomanifestation of Multiple Sclerosis - A Case Report», Czech and Slovak Neurology and Neurosurgery, 79/112(5), p. 601-603. <https://doi.org/10.14735/amcsnn2016601> [Consulta: 16 de juny de 2017]

- 7.ENG_Neurology_A

Opšenák, R., B. Kolarovszki, M. Benčo, R. Richterová i P. Snopko (2016): «Spinal Gossypiboma 20 Years after Lumbar Discectomy - A Case Report», Czech and Slovak Neurology and Neurosurgery, 79/112(6), p. 715-718. <http://www.csnn.eu/en/czechslovak-neurology-article/spinal-gos-sypiboma-20-years-after-lumbar-discectomy-acase-report-59494> [Consulta: 16 de juny de 2017]

- 8.ENG_Neurology_A

Stetkarova, I. i L. MencL (2015): «Early Rotation of Intrathecal Baclofen Pump - A Case Report», Czech and Slovak Neurology and Neurosurgery, 78/111(6), p. 705-708. <http://www.csnn.eu/en/czech-slovak-neurology-article/early-rotation-of-intrathecalbaclofen-pump-a-case-report-56578> [Consulta: 16 de juny de 2017]

- 9.ENG_Neurology_B

Arima, M., A. Ogata, K. KaWAhiRa i M. Shimodozono (2017): «Improvement and Neuroplasticity after Combined Rehabilitation to Forced Grasping», Case Reports in Neurological Medicine. <http://dx.doi.org/10.1155/2017/1028390> [Consulta: 23 de març de 2017]

- 10.ENG_Neurology_B

Surdyke, L., J. Fernandez, H. Foster i P. Spigel (2017): «Differential Diagnosis and Management of Incomplete Locked-In Syndrome after Traumatic Brain Injury», Case Reports in Neurological Medicine. <https://doi.org/10.1155/2017/6167052> [Consulta: 11 d'octubre de 2017] 
- 11.ENG_Neurology_B

Ridha Amer, R., S. Mohammed Qubaiban i E. Abdulkarim Bakhsh (2017): «Homonymous Superior Quadrantanopia due to Erdheim-Chester Disease with Asymptomatic Pituitary Involvement», Case Reports in Neurological Medicine. <https://doi.org/10.1155/2017/2807461> [Consulta: 2 d'agost de 2017]

- 12.ENG_Neurology_B

Mubasher, M., A. Sukik, A. H. El Beltagi i A. Rahil (2017): «Chronic Lymphocytic Inflammation with Pontine Perivascular Enhancement Responsive to Steroids, with Cranial and Caudal Extension», Case Reports in Neurological Medicine. <https://doi.org/10.1155/2017/2593096> [Consulta: 16 de novembre de 2017]

- 13.ENG_Neurology_B

Kurukumbi, M., A. Truong i N. Pirsaharkhiz (2017): «Uncommon Etiology for Seizure: Cerebral Hyperperfusion Syndrome», Case Reports in Neurological Medicine. <https://doi.org/10.1155/2017/7965758> [Consulta: 14 de setembre de 2017]

- 14.ENG_Neurology_B

Aben, H. P., Y.D. Reijmer, J. M. A. Visser-Meily, J. M. Spikman, G. J. Biessels, P. L. M. de Kort i PROCRAS Study Group (2017): «Impaired Emotion Recognition after Left Hemispheric Stroke: A Case Report and Brief Review of the Literature», Case Reports in Neurological Medicine. <https://doi.org/10.1155/2017/1045039> [Consulta: 11 d'octubre de 2017]

- 15.ENG_Neurology_B

Han, D. Y., L.M. Koehl, A. Patel, Z. Zhou, S.Phillips i S. Kapoo (2017): «Chronic Neuropsychological Sequelae in a Patient with Nontumorous Anti-NMDA-Receptor Encephalitis», Case Reports in Neurological Medicine. <https://doi.org/10.1155/2017/5675732> [Consulta: 11 d'octubre de 2017] 
- 16.ENG_Neurology_B

Doobay, R., L. Sun, A. Shah, P. Masuta i Z. Shepherd (2017): «SSRI Facilitated Crack Dancing», Case Reports in Neurological Medicine. <https://doi.org/10.1155/2017/4318450> [Consulta: 11 d'octubre de 2017]

- 17.ENG_Psychiatry

Striebel, J. M., E. E. Nelson i R. K. Kalapatapu (2017): “"Being with a Buddha”: A Case Report of Methoxetamine Use in a United States Veteran with PTSD», Case Reports in Psychiatry. <https://doi.org/10.1155/2017/2319094> [Consulta: 15 d'octubre de 2017]

- 18.ENG_Psychiatry

Thom, R., P. Teslyar i R. Friedman (2017): «Pseudologia Fantastica in the Emergency Department: A Case Report and Review of the Literature», Case Reports in Psychiatry. <https://doi.org/10.1155/2017/8961256> [Consulta: 15 d'octubre de 2017]

- 19.ENG_Psychiatry

Yegya-Raman, N., R.Aziz, D. Schneider, A. TobiA, M. Leitch i O. Nwobi (2017): «A Case of Sporadic Creutzfeldt-Jakob Disease Presenting as Conversion Disorder», Case Reports in Psychiatry. <https://doi.org/10.1155/2017/2735329> [Consulta: 15 d'octubre de 2017]

- 20.ENG_Psychiatry

OdAGAKI, Y. (2017): «A Case of Persistent Generalized Retrograde Autobiographical Amnesia Subsequent to the Great East Japan Earthquake in 2011», Case Reports in Psychiatry. <https://doi.org/10.1155/2017/5173605> [Consulta: 15 d'octubre de 2017]

- 21.ENG_Psychiatry

Hernandez-Huerta, D., M. Martin-Larregola, J. Gomez-Arnau, J. Correas-Lauffer i H. DolengeVICH-Segal (2017): «Psychopathology Related to Energy Drinks: A Psychosis Case Report», Case Reports in Psychiatry. <https://doi.org/10.1155/2017/5094608> [Consulta: 15 d'octubre de 2017] 
- 22.ENG_Psychiatry

Huarcaya-Victoria, J., M. Ledesma-Gastañadui i M. Huete-Cordova (2016): «Cotard's Syndrome in a Patient with Schizophrenia: Case Report and Review of the Literature», Case Reports in Psychiatry. <http://dx.doi.org/10.1155/2016/6968409> [Consulta: 15 d'octubre de 2017]

- 23.ENG_Psychiatry

RASHID SORON, T. (2016): «A Case Report on Management of Father Daughter Incest with Schizophrenia», Case Reports in Psychiatry. <http://dx.doi.org/10.1155/2016/4010187> [Consulta: 15 d'octubre de 2017]

- 24.ENG_Psychiatry

Bresnahan, J. J., Z. A. Winthrop, R. Salman i S. Majeed (2016): «Alagille Syndrome: A Case Report Highlighting Dysmorphic Facies, Chronic Illness, and Depression», Case Reports in Psychiatry. <http://dx.doi.org/10.1155/2016/1657691> [Consulta: 15 d'octubre de 2017]

- 25.ENG_Psychology

Melogno, S., M. A. Pinto i M. Orsolini (2017): «Novel Metaphors Comprehension in a Child with High-Functioning Autism Spectrum Disorder: A Study on Assessment and $\begin{array}{llll}\text { Treatment», } \quad \text { Frontiers } & \text { P:2004. }\end{array}$ <https://doi.org/10.3389/fpsyg.2016.02004> [Consulta: 19 d'octubre de 2017]

- 26.ENG_Psychology

SALCUNI, S., D. DI RISO, D. MABILIA i A. LIS (2017): «Psychotherapy with a 3-Year-Old Child: The Role of Play in the Unfolding Process», Frontiers in Psychology, 7:2021. <https://doi.org/10.3389/fpsyg.2016.02021> [Consulta: 19 d'octubre de 2017] 
- 27.ENG_Psychology

Johnson, S. U. i A. Hoffart (2016): «Metacognitive Therapy for Comorbid Anxiety Disorders: A Case Study», Frontiers in Psychology, 7:1515. <https://doi.org/10.3389/fpsyg.2016.01515> [Consulta: 19 d'octubre de 2017]

- 28.ENG_Psychology

Serino, S., F. Scarpina, A. Keizer, E. Pedroli, A. Dakanalis, G. Castelnuovo, A. Chirico, M. NovelLI, S. Gaudio i G. Riva (2016): «A Novel Technique for Improving Bodily Experience in a Non-operable Super-Super Obesity Case», Frontiers in Psychology, 7:837. <https://doi.org/10.3389/fpsyg.2016.00837> [Consulta: 19 d'octubre de 2017]

- 29.ENG_Psychology

SalCunI, S., D. DI Riso, D. MabiliA i A. LIS (2014): “"A Child’s Nightmare. Mum Comes and Comforts Her Child." Attachment Evaluation as a Guide in the Assessment and Treatment in a Clinical Case Study», Frontiers in Psychology, 5:912. <https://doi.org/10.3389/fpsyg.2014.00912> [Consulta: 19 d'octubre de 2017]

- 30.ENG_Psychology

Tilley, P. J. M. i C. S. Rees (2014): «A Clinical Case Study of the Use of Ecological Momentary Assessment in Obsessive Compulsive Disorder", Frontiers in Psychology, 5:339. <https://doi.org/10.3389/fpsyg.2014.00339> [Consulta: 20 d'octubre de 2017]

- 31.ENG_Psychology

George, C. i A. Buchreim (2014): "Use of the Adult Attachment Projective Picture System in Psychodynamic Psychotherapy with a Severely Traumatized Patient», Frontiers in Psychology, 5:865. <https://doi.org/10.3389/fpsyg.2014.00865> [Consulta: 20 d'octubre de 2017] 
- 32.ENG_Psychology

Fabio, R. A., I. Castelli, A. Marchetti i A. Antonietti (2013): «Training Communication Abilities in Rett Syndrome through Reading and Writing", Frontiers in Psychology, 4:911. <https://doi.org/10.3389/fpsyg.2013.00911> [Consulta: 20 d'octubre de 2017]

- 33.ENG_Neurology_C

Solis, W. G., S. E. Waller, A. K. Harris, E. Sugo, M. A. Hansen i J. Lechner-Scott (2017): «Favourable Outcome in a 33-Year-Old Female with Acute Haemorrhagic Leukoencephalitis», Case Reports in Neurology, 9, p. 106-113. <https://doi.org/10.1159/000472706> [Consulta: 3 de novembre de 2017]

- 34.ENG_Neurology_C

Lützhøft Rath, Ch., J. He, M. M. Nordling I T. Wienecke (2017): «Acute Intravenous Calcium Antagonist for Suspected Hemiplegic Migraine - A Case Story», Case Reports in Neurology, 9, p. 98-105. <https://doi.org/10.1159/000474934> [Consulta: 3 de novembre de 2017]

- 35.ENG_Neurology_C

NovRoskI, A.-R. i K. J. BALDWIN (2017): «Chronic Autoimmune Meningoencephalitis and Periodic Fever Syndrome Treated with Anakinra», Case Reports in Neurology, 9, p. 9197. <https://doi.org/10.1159/000472147> [Consulta: 3 de novembre de 2017]

- 36.ENG_Neurology_C

Sato, K., M.Kanzakı, Y. Ubara i Y.Uesaka (2017): «Internal Carotid Artery Occlusion in Systemic Lupus Erythematosus as a Potential Mimicker of Multiple Sclerosis», Case Reports in Neurology, 9, p. 86-90. <https://doi.org/10.1159/000471793> [Consulta: 3 de novembre de 2017] 
- 37.ENG_Neurology_C

Myren-Svelstad, S., T. A. Hammer i T. T. Idicula (2017): «Early Thrombectomy of a Proximal Middle Cerebral Artery Occlusion Leading to Complete Recovery with No Infarct», Case Reports in Neurology, 9, p. 76-80. <https://doi.org/10.1159/000468922> [Consulta: 3 de novembre de 2017]

- 38.ENG_Neurology_C

Finsterer, J. i J. Huber (2017): «Multisystem Disease, Including Eosinophilia and Progressive Hyper-Creatine-Kinase-Emia over 10 Years, Suggests Mitochondrial Disorder", Case Reports in Neurology, 9, p. 69-75. <https://doi.org/10.1159/000466686> [Consulta: 3 de novembre de 2017]

- 39.ENG_Neurology_C

Kubota, S., M. Yamada, H. Satoh, A. Satoh i M. Tsujihata (2017): «Pure Amorphagnosia without Tactile Object Agnosia», Case Reports in Neurology, 9, p. 62-68. <https://doi.org/10.1159/000466684> [Consulta: 3 de novembre de 2017]

- 40.ENG_Neurology_C

Kumar, K., R. Ahmed, B. Bajantri, A. Singh, H. Abbas, E. Dejesus, R. Raheel Khan, M. Niazi i S. ChILIMURI (2017): «Tumors Presenting as Multiple Cranial Nerve Palsies», Case Reports in Neurology, 9, p. 54-61. <https://doi.org/10.1159/000456538> [Consulta: 3 de novembre de 2017]

\section{Contes clínics}

SACKS, Oliver (2014 [1985]): The Man Who Mistook His Wife for a Hat and Other Clinical Tales, Londres: Picador [llibre electrònic].

Ropper, Allan i Brian David Burrell (2014): Reaching Down the Rabbit Hole: Extraordinary Journeys into the Human Brain, Londres: St. Martin's Press [llibre electrònic]. 
YALOM, Irvin D. (2013 [1989]): Love's Executioner and Other Tales of Psychotherapy Londres: Penguin [llibre electrònic].

Frost, Randy i Gail SteKetee (2010): Stuff: Compulsive Hoarding and the Meaning of Things, Nova York: Houghton Mifflin Harcourt [llibre electrònic]. 

